SZEGEDI TUDOMÁNYEGYETEM, BÖLCSÉSZETTUDOMÁNYI KAR

TÖRTÉNELEMTUDOMÁNYI DOKTORI ISKOLA, MODERNKOR DOKTORI ALPROGRAM

\title{
Plébánia és társadalom
}

\author{
A római katolikus alsópapság és a laikus templomszolgák \\ társadalmi szerepe Csongrádon a 19. század második felében \\ Doktori (Ph.D) értekezés
}

Szerző: Fábiánné Gyöngyössy Orsolya

Témavezető: Prof. Barna Gábor tanszékvezető egyetemi tanár, MTA-SZTE Vallási Kultúrakutató Csoport 


\section{TARTALOM}

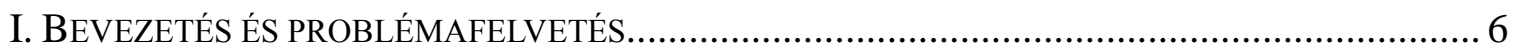

1. A kutatási téma körvonalazása..........................................6 6

2. Az értekezés felépítése, cél és hipotézis............................... 9

3. Módszer, terep és források.......................................... 14

4. Köszönetnyilvánítás................................................ 18

II. AZ ALSÓPAPSÁG ÉS A LAIKUS ASSZISZTENCIA SZEREPÉNEK KUTATÁSA NYUGAT-

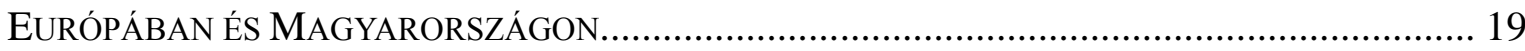

III. CSONGRÁD EGYHÁZ- ÉS TÁRSADALOMTÖRTÉNETE A 18-19. SZÁZADBAN...................... 29

1. Rövid plébánia- és településtörténet...................................................................29

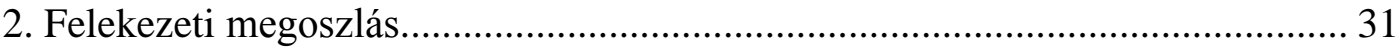

3. Ferencesek, jezsuita szerzetesek hatása.............................................................. 34

4. Lelkiség és társadalom. A csongrádi hívek a 19. század derekán.........................36

\section{AlsóPAPSÁG}

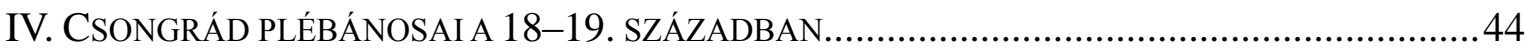

1. A plébánosok jogai, ,kötelmei” és járandóságai az életrajzok tükrében............. 44

2. Hegyi Antal: a 19. század utolsó csongrádi plébánosának arcképvázlata............ 55

3. A megyéspüspök, a kegyúr, és a település elöljárósága.....................................59

V. ÖNKÉP ÉS HIVATÁS. A NÉP KÖZÖTT ÉLÖ LELKIPÁSZTOR.................................................... 66

1. Tisztelet, bizalom és az egyházias szokások................................................. 67

2. A plébános és hívek „organikus egysége”. A védelmező atya alakja................... 70

3. A papság lokális integrációja és a mindennapi élet irányítása...........................75

4. Papság és közösségszervezés: vallási társulatok.............................................. 78

5. Néhány szó az ,ideálkép-problémáról””........................................................... 82

5.1. Szerep és személyiség. Az ideálkép törésvonalai................................. 84

5.2. Visszacsatolás: a csongrádi hívek reakciói......................................... 88 


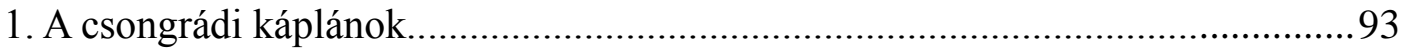

2. A káplánok javadalmai, kötelezettségei, világi és egyházi tisztségei.................. 95

2.1. Általános javadalmak..........................................................................95

2.2. Misézés, szentségek kiszolgáltatása.............................................. 96

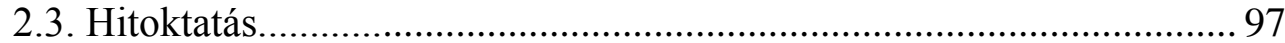

2.4. Hivatali adminisztráció....................................................................... 99

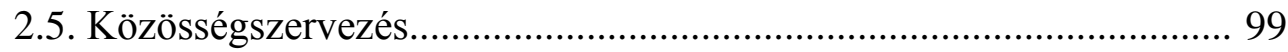

2.6. Közélet, politika és tisztségviselés....................................................101

3. Capellani expositi: a filiák önállóságának záloga............................................103

4. Az egyenrangúságról és feladatmegosztásról.................................................106

5. Kolduló ferences atyák: hierarchia és határvonalak.........................................107

6. Káplánok és plébánosok: a kapcsolatrendszer módozatai.................................109

6.1. Kölcsönös elvárások váza: a ,jó pap” és a ,jó káplán” sziluettje ....110

6.2. Támadás és támogatás. Néhány mondat a szélsőségekről...................114

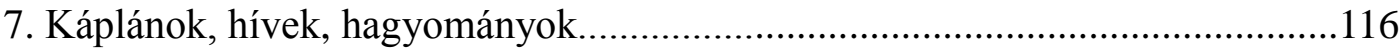

8. A káplánok funkciója, helye és szerepe a plébániai hierarchiában..............118

\section{LAIKUS TEMPLOMSZOLGÁK}

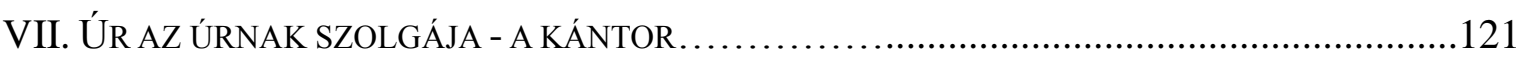

1. A „kántorizálás” intézménye Csongrádon......................................................123

1.1. A kántor megválasztása, kinevezése, elbocsájtása.............................123

1.2. Hivatali kötelességek, stoláris jövedelmek. A halotti búcsúztatók

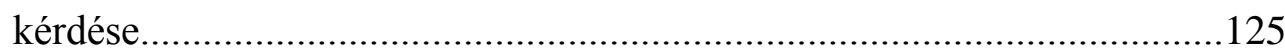

1.3. Csongrádi kántorok a 18-19. században.........................................131

1.4. Néhány szó a szuflensekről és fullajtárokról....................................133

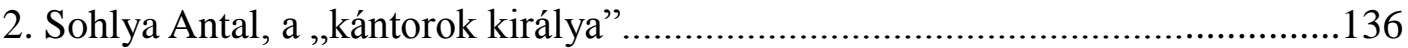

2.1. Sohlya Antal életútja és a kántori hivatal sorsa Csongrádon a 19. század végén.

2.2. A kántor mint politikus és közéleti személyiség.................................140

2.3. Az iskolai énekoktatás útjai. Sohlya az iskolaszéki tanácsban............143

2.4. Költő, író, ének- és orgonamester. A müvészkedő kántor alakja.........145 
3. A kántor és a papság: viszonyok és elvárások. 151

3.1.,Ha az igazság elleni harcban elbukom: örömest bukom el!” Az Alvinczy-Sohlya ügy, 1867-68 152

3.2. Pozicionáltság a beszédfordulatokban. 153

3.3. A fegyelmezés eszközei: kommunikációs protokoll az önérzet határain innen és túl. 155

4. A nép választottja - a nép képviselöje? 159

4.1. „Az én címem a népnél”..... 160

4.2. Példamutatás, népnyúzás. A plébános közbenjár. 162

4.3. Plébános és kántora a hívek perspektívájában. .163

5. Akire ,sok szem figyel”. 164

VIII. A SZOKÁSJOG EREJE: HARANGOZÓK ÉS SEKRESTYÉSEK. 167

1. A harangozók jövedelmi viszonyai, feladatai. 167

2. Csongrád-Belsőváros 172

3. Csongrád-Külsőváros 173

3.1. A Keviczky-éra alkonya. 173

3.2. Szőke János pályája. 176

3.3. Palási Lajos balszerencséje. 176

4. A szokásjog kérdésének margójára. .179

IX. POZÍCIÓ ÉS CENTRALIZÁCIÓ: A KURÁTOR. 180

1. Csongrád-Belsőváros 181

2. Csongrád-Külsőváros 182

3. Bába Szabó Rókus, a jámbor polihisztor. 183

4. Egy „méltó tanítvány”. 186

5. Gondolatok egy kiüresedett pozícióról 189

\section{EGYÉB EGYHÁZKÖZELI ASSZISZTENCIA}

X. „HIVATAL” A HIVATAL ÁRNYÉKÁBAN: A TEMETŐCSŐSZ ESETE A DÉKÁNYASSZONNYAL....191

XI. A CSONGRÁDI REFORMÁTUS BÁBA KÜZDELMEI. .193 


\section{AZ ALSÓPAPSÁG ÉS A LAIKUS TEMPLOMSZOLGÁK SZEREPÉNEK ÁTALAKULÁSA. CSONGRÁd TÁRSADALMA A 19-20. SZÁZAD FORDULÓJÁN}

XII. TÁRSADALMI RÉTEGZŐDÉS ÉS VALLÁSGYAKORLÁS A 19. SZÁZAD VÉGÉN..............200

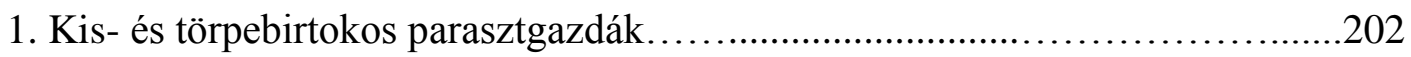

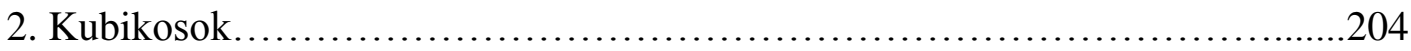

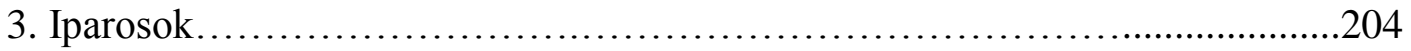

4. Önkormányzati tisztviselök.............................................205

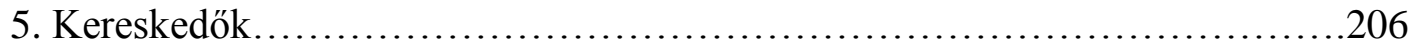

6. Templomszolgák...................................................206

7. Az ,intelligentzia".................................................208

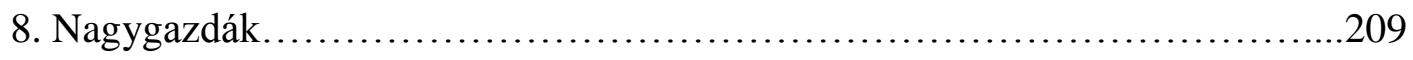

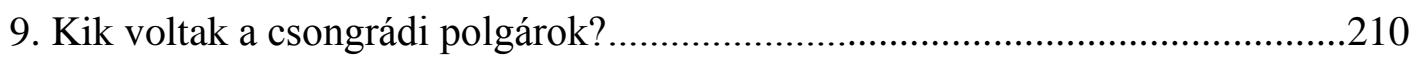

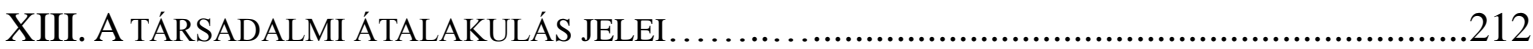

1. Születési és halálozási arányok..........................................212

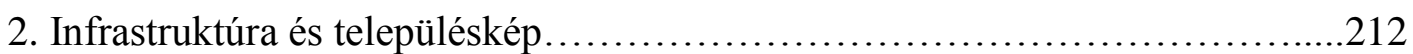

3. Korjelenségek....................................................213

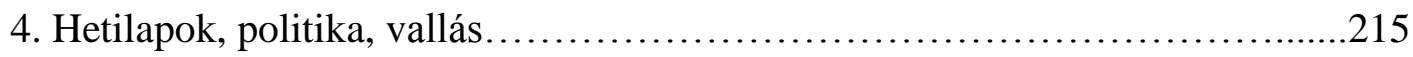

5. Papság és polgári pereskedés.......................................217

6. Szekularizáció és vallási társulatok.......................................219

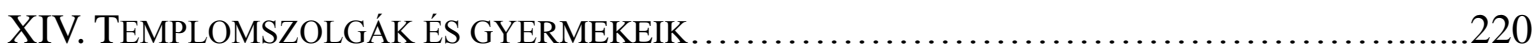

1. Új arcok, új éra. A személycsere szükségszerüsége......................221

2. Hivatás és kreativitás. Az innovatív, különc templomszolgák..................2222

3. A kapcsolatok és kiemelkedés módozatai..........................................222

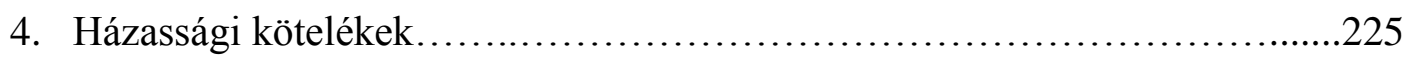

5. A laikus templomszolgák társadalmi szerepének változásáról..............226

XV. SZEMÉLYEK ÉS SZEREPEK, ÉRTÉKRENDEK ÉS TÁRSADALMI RÉTEGEK............................227

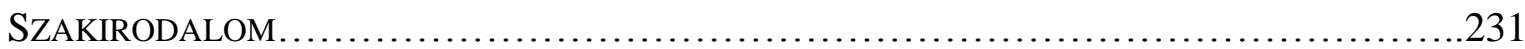

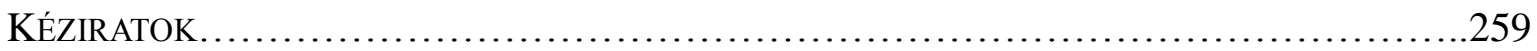

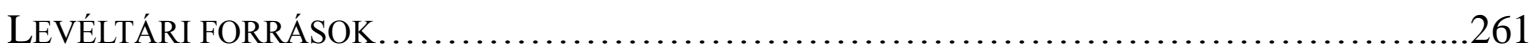

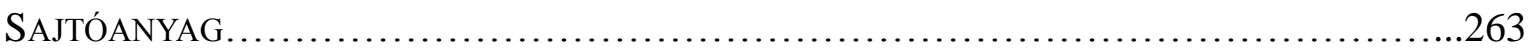




\section{BEVEZETÉS ÉS PROBLÉMAFELVETÉS}

\section{A kutatási téma körvonalazása}

A lelkipásztorkodó papok biblikus elöképeken nyugvó, ugyanakkor az adott történelmi körülményektöl elválaszthatatlan, összetett szerepet töltöttek be a 18-19. századi plébániaközösségek életében. ${ }^{1}$ Értelmiségi lelki vezetőként hatással voltak a helyi kultúra, a közmüvelődés, a kollektív valláserkölcsi értékrend, olykor a közéleti-politikai élet formálódására is. Hivatásuk sajátos jellegéből adódóan csak bizonyos időt töltöttek egy adott településen, ám ez idő alatt személyiségük, képességeik, törekvéseik és kezdeményezéseik alapvetően meghatározták a vallási élet hangsúlyait. Általánosságban a papság volt évszázadokon keresztül a magyar társadalom legjelentősebb tudatformáló rétege. $^{2}$

Az alsópapság munkáját laikus segítők egészítették és egészítik ki, akik jól körülhatárolt, szabályozott hagyományokon nyugvó feladatokat láttak el: gondoskodtak a plébánia, a templom, az oltárok, szent edények, liturgikus textíliák karbantartásáról, liturgiához előkészítéséről; harangozásról; egyházi zeneszolgálatról; felelősséget vállaltak a templompénztár kezeléséért, stb. Szükebb értelemben a laikus templomszolgák ${ }^{3}$ közé sorolhatjuk a kántort, a harangozókat és sekrestyéseket, illetve az egyházfit (kurátor). A szükségkeresztelést végző bábákat és a temetőcsőszt célravezetőbbnek tartom egyéb, egyházközeli asszisztenciaként jelölni. Bár tágabb értelemben ők is a laikus templomszolgák ernyőfogalma alá tartoznak, értekezésemben kevesebb hangsúllyal foglalkozom velük. Ök azok a világi tisztségviselők, kiknek elsődleges, gyakorlati feladatai - mint a temető őrzése vagy a gyermekek világra segítése - nem az egyházhoz

\footnotetext{
1 A bevezetőben rögzített megállapítások római katolikus plébánosokra vonatkoznak, és a kutatás meghatározott időkeretei között halmozottan érvényesek (1850-1902).

${ }^{2}$ Csorba 2002. 442.

${ }^{3}$ A fogalom - ebben a formában - egyetlen lexikonban sem taláható meg. Tágabb értelmezésben laikus templomszolgáknak nevezhetjük azokat a liturgikus szolgálatban segédkező vagy gyakorlati egyházközeli funkciókat ellátó világi tisztségviselőket, akik eltérő képzettségük, feladataik, javadalmazásuk és tekintélyük okán a plébániai hierarchia különböző fokain állnak. Hoss József munkájában ők a lelkipásztorok világi segítöi (Hoss 1948. 60). Bárth János a kultusz irányitói, segítői fejezetcím alatt sorolja fel a székelyvarsági egyházi tisztségviselőket. A kántor és a harangozó után Bárth a ministránsokat, énekvezetőket és társulati vezetőket tárgyalja (Bárth 2006. 103). Későbbi kiadású csíkszentgyörgyi kötetében a megyés mester és társai címszó alatt találjuk a kántort (ú. n. megyés mestert) segédkántort és a harangozó-sekrestyést (Bárth 2012. 357). A 19. századi kihallgatási jegyzőkönyvek tanulsága szerint a kifejezés csongrádi népnyelvi szinonimája, vagyis a templomszolgák átfogó megnevezése az egyházfi volt. A továbbiakban a laikus templomszolgák kifejezést szükebb értelmében, vagyis a kántorra, a harangozó és sekrestyésre valamint a kurátorra értve használom.
} 
kötődtek, munkájuk sajátos jellege miatt mégis kapcsolatban álltak a plébániával. A csongrádi temetőcsőszt a plébános bízta meg a szolgálattal, ugyanakkor kizárólag stoláris javadalmakban részesült, és csak a sírhelyek kiváltása ügyében kereste fel a lelkipásztort. A bábaasszonyokat a plébános előtt tett eskü, a szükségkeresztelés fontossága és a szokásjog által megkövetelt keresztelési asszisztencia kötötte az egyházhoz. Öket obstetrix vagy

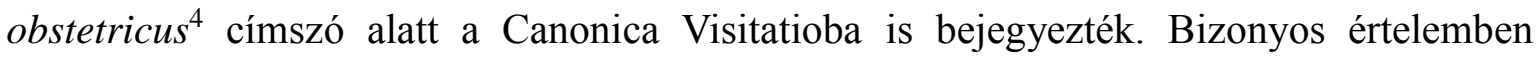
egyházközeli asszisztenciaként tekinthetünk a közösségszervezési feladatokkal megbízott világi társulati vezetőkre és a liturgikus szolgálatban segédkező ministránsokra is. Ez utóbbi szerepek az adott személy identitásának kisebb részét képezték, önkéntes tevékenységükért fizetség nem járt. Vonatkozó források hiányában a társulati vezetőkre és a ministránsokra nem szentelhettem külön fejezetet.

A papság (plébános, káplánok és szerzetes-lelkipásztorok), a laikus templomszolgák és az egyházközeli asszisztencia kicsi, de hierarchizált, tagolt közösséget alkotott. A helyi egyházszervezet élén a latinos mủveltségü plébános állt, aki tekintélyével, tudásával és befolyásával a település meghatározó személyiségei közé tartozott. Idegen származása miatt rendszerint hosszú évek teltek el, mire kiismerte a helyi viszonyokat, hagyományokat és elvárásokat. Míg a plébánosok és segédlelkészek jöttek-mentek, a templomszolgák akár évtizedeken keresztül háborítatlanul örizhették pozíciójukat.

A laikus tisztségviselők - a község által alkalmazott okleveles bábákat és a kántort kivéve - a helyi társadalom gyermekei voltak. A hagyományokat nem csak jól ismerték, de élték, megélték, hisz benne nevelkedtek. Rajtuk keresztül az újonnan hivatalba lépő plébánosok is hitelesen tájékozódhattak a helyi szokásokról. A hivatalos egyházi és a népi kultúra peremterületén lévő laikus templomszolgák - sajátos „mediátori” helyzetük miatt különösen érzékenyen reagálhattak a népi szokásjog és az egyházkormányzati gyakorlat közé ékelődő problémákra, kérdésekre.

A klérus és laikus egyházi tisztségviselők sorsa, magatartása, személye élénken foglalkoztatta a közvéleményt, az életükben bekövetkezett változások valóságos szenzációnak számítottak. Ennek oka sajátos társadalmi szerepükben keresendő.

Társadalmi szerepen „egy egyéntől a közösség részéről elvárt cselekvésmódok összességét értjük", 5 vagyis azoknak az elvárásoknak a halmazát, melyek bizonyos társadalmi státuszokhoz, pozíciókhoz kötődnek. Ezekkel az elvárásokkal, a „hogyan illik

\footnotetext{
${ }^{4}$ Az egyházlátogatási jegyzökönyvekben előfordulhatnak helytelenül ragozott latin kifejezések, akárcsak a hímnemủ végződésủ obstetricus esetében.

${ }^{5}$ Tomka 1997. 64.
} 
viselkednie egy papnak/kántornak/harangozónak stb.” kérdésével az egyén is tisztában van, és amint ezekhez igazítja magatartását, szerephordozóvá válik. A társadalmi szerep megélése, felvállalása az egyéniség egyfajta alárendelődését követeli meg, ennek megfelelően az alsópapság és a templomszolgák erkölcsi-morális súlyú feladatszerepe is őszinte azonosulást igényel. Magatartásukat, mindennapi tetteiket a szerepazonosság sikerének vagy sikertelenségének tükrében értékeli a közösség.

A társadalmi szerepekkel kapcsolatos elvárások lassabban, nehézkesebben változnak, mint a társadalom struktúrája. Mondhatnánk úgy is, hogy állandó „késésben” vannak. A klérustól és laikus egyházi tisztségviselőktől elvárt társadalmi szerep jóformán sértetlenül megőrződött a rendiségből a polgári társadalom felé vezető úton.

A vizsgált település, Csongrád társadalomfejlődésének sajátosságát a lakosok egységes római katolikus vallása, a kisbirtokos földmüvelő többség és a színmagyar etnikuma adta. ${ }^{6}$ Az 1850 és 1900 közötti időszakban a közösség mind lélekszámát, felépítését, vagyoni és foglalkozásbeli eloszlását tekintve jelentősen átalakult. Ugyanakkor a plébános szava, befolyása legalább olyan súllyal esett latba, mint a rendiség korában, és a templomszolgák élete pedig még mindig kiszámíthatóbbnak tünt az átlagosnál. ${ }^{7}$

Forrásaink szerint a csongrádiak többnyire meg voltak elégedve papjaik munkájával. Nem csoda, hisz a kegyúr, a nagykárolyi Károlyi család feje mindig a váci egyházmegye legmüveltebb és legtapasztaltabb papjai közül választotta ki Csongrád plébánosát. Nem volt ez másként 1886-ban sem, amikor a megyéspüspök ajánlása nyomán Hegyi Antalra esett a választás. Hegyi Antal - bár figyelemre méltó váci hivatali karrier állt mögötte - mind emberi természetét, mind céljait, eszközeit és vezetési stratégiáját tekintve atipikus volt. A csongrádi laikus templomszolgák helyzetének radikális megváltozása is Hegyi plébános múködési idejére tehető.

A csongrádi alsópapság, a laikus templomszolgák és az egyházközeli asszisztencia között Mátyus János (1802-1827), Alvinczy Ferenc (1865-1875) majd Hegyi Antal (18861902) plébánossága idején támadtak konfliktusok. Mátyus János jóformán állandóan hadilábon állt káplánjaival, egyikükkel még lövöldözésbe is keveredett a plébánián. ${ }^{8} \mathrm{~A}$ Mátyus plébánoshoz köthető esetekben inkább eldurvult személyi ellentétekről, mintsem a hivatáshoz, hivatalteljesítéshez köthető konfliktusokról beszélhetünk. Egészen más volt a

\footnotetext{
${ }^{6}$ A korabeli Csongrád pontos társadalmi, etnikai és felekezeti mutatóit lásd a III. fejezetben.

${ }^{7}$ Ennek oka az állandó, biztos javadalmazás volt. Bár ők is rendelkeztek csekély termö- és szőlőfölddel, tanultak mesterségeket, megélhetésük elsődleges forrása az egyháztól kapott javadalom maradt.

${ }^{8}$ Tari 1977. 25.
} 
helyzet Alvinczy Ferenc plébános és Sohlya Antal kántor vitás ügyében, melynek forráspontján a plébániai hierarchia rögzítése, az elvárások és kötelességek letisztázása állt. ${ }^{9}$ Hegyi Antal idejére, úgy tünik, látványosan felhalmozódtak az egyes egyházi hivatalokhoz kötődő problémák. 1886-ban az új plébános elsőként a harangozók és sekrestyések apáról fiúra öröklődő pályáját tette „szabaddá”, majd a gazdasági centralizáció érdekében az egyházfi megbízatását névlegessé; a református bábát vallási okokra hivatkozva eltiltotta a római katolikus gyerekek keresztelési asszisztenciájától, majd a korábbi temetőcsősz helyére saját bizalmasát emelte be.

A század végére feltorlódott változásokról kutatásom elején úgy vélekedtem, hogy a szerepelvárások változásának egyik következményével állok szemben. Hisz ugyanebben az időszakban lendült mozgásba, vált egyre nyitottabbá és differenciáltabbá Csongrád társadalma, így könnyen feltételezhető, hogy a formálódó belviszonyok hatására a templomszolgák szerepének átértékelése is elkezdődött. Időközben kiderült, hogy jóval összetettebb problémáról van szó.

\section{Az értekezés felépítése, cél és hipotézis}

Az értekezés tartalmilag öt fó részre: problémaalkotó és elemző jellegü felvezetésre, a csongrádi alsópapság, a laikus templomszolgák és az egyéb egyházközeli asszisztencia helyzetének adatfeltáró bemutatására, illetve egy összegzésre tagolódik. A felvezetés tartalmazza egyrészt az alsópapság és a templomszolgák magyarországi és nemzetközi kutatástörténetét (I-II. fejezet), majd Csongrád rövid egyház- és társadalomtörténetét a plébánia újjászervezésétől a 19. század derekáig (III. fejezet). A felekezeti viszonyoknak, a szerzetes-lelkipásztorok munkájának, illetve a kor általános lelkiségi állapotának bemutatására külön alfejezeteket szenteltem. Ennek oka, hogy a római katolikus többség, mint történelmileg kialakult helyi sajátosság, valamint a ferences szerzetesek jelenléte alapjaiban formálta a csongrádi hívek önképét és gondolkodásmódját. A csongrádi nép 1850-60-as évekbeli állapotának leírása kiindulópontként szolgál a pár évtizeddel későbbi változások megértéséhez.

Az alsópapsággal foglalkozó egység a 18-19. századi csongrádi plébánosok személyének, javadalmainak, kötelességeinek leírásával kezdődik (IV. fejezet). Ezt követi a plébános egyházi feljebbvalójának (megyéspüspök) illetve világi „,vezetőségi partnereinek”

\footnotetext{
${ }^{9}$ Az Alvinczy-Sohlya ügy részleteit később külön fejezetben tárgyalom (VII/3.1.)
} 
(kegyúr, helyi elöljáróság) kötelezettségeit, hivatali viszonyrendszerük sajátosságait bemutató fejezet. Hegyi Antal kiemelését azért tartottam célszerünek, mert az értekezés egészét áthatja az elődeinek hagyományaitól eltérő, újszerü ám mégis folytatás nélküli örökséget hagyó plébános alakja. Kutatásom elején óvakodtam attól, hogy a csongrádi plébánia történetének Hegyi Antal nevével fémjelzett, több szempontból is „rendellenesnek” nevezhető korszakát állítsam a középpontba. Ám rá kellett jönnöm, hogy e konfliktusokkal terhelt papi életút tanulságai olyan értékes kérdéseket, tanulságokat hoznak felszínre, melyek egy „rendes” plébános idejében többnyire meg sem fogalmazódnak.

Az V. (önkép és hivatás) fejezetben a csongrádi plébánosok társadalmi szerepének bemutatására és elemzésére vállalkozom az alsópapság és a hívek perspektívájából. Arra keresem a választ, hogy változott-e a 19. század második felében a plébános szerepének megítélése Csongrádon? Milyen tulajdonságok alapján ítéltek valakit „jó papnak”, ki számított a lelkipásztori eszménnyel összeférhetetlennek? Változott-e a 19. század végére és ha igen, hogyan - a normaszegö pappal szemben alkalmazott közösségi szankciók tárháza?

A kisebb-nagyobb konfliktusokat, rendkívüli élethelyzeteket felsorakoztató esettanulmányokon keresztül a gyakorlati lelkipásztorkodás kevésbé kiemelt területei és mindennapi problémái (újítás és hagyománytisztelet, szakrális védelmező szerep, erkölcsi élet és vallásos közösségszervezés) tárulnak elénk. Ennek oka, hogy a csongrádi plébánosok az alapvető lelkipásztori teendők többségét - mint a hitoktatás, misézés, gyóntatás, betegellátás, stb. - jellemzően káplánjaikra bízták.

A VI. fejezet címeként választott kérdés (paptársak vagy szolgák?) ugyan a plébános-káplán viszonyt állítja középpontba, forrásaim jóval árnyaltabb problémáról; a káplánok szerepének „félreérthetőségéről”, jog- és illetékességi körük letisztázatlanságáról árulkodnak. Bizonyos, hogy a csongrádi segédlelkészek öndefiniálási próbálkozásait sorozatos összetüzések kísérték. Míg a kántor kollegiális szemlélettel közelített (volna) a segédlelkészek felé, a ferences szerzetesnek pont az önkényes utasításokat osztogató káplánokkal szemben kellett védelmeznie autonómiáját. „Alulról” és „,fölülről” is nyitott tehát a kérdés: milyen elvek mentén zajlott a csongrádi segédlelkészek helyének kijelölése a plébániai hierarchiában? Miként definiálták saját szerepüket, és hogyan értékelte mindezt környezetük: vagyis a plébános, a szerzetesek, a templomszolgák és a hívek? Milyen 
változások történtek a káplánok szerepkörét illetően a század utolsó évtizedeiben? ${ }^{10}$

A templomszolgák helyzetét tárgyaló egység a kántor, vagyis a legképzettebb laikus egyházi tisztségviselő helyzetének körülírásával kezdődik (VII. fejezet). 1860-tól egészen 1902-ig Csongrádon Sohlya Antal volt „A kántor úr”, így életútját, tevékenységét, a helyi társadalomban betöltött szerepét kiemelt hangsúllyal tárgyalom. Sohlya kántor a Csongrádon töltött 40 esztendő alatt figyelemre méltó sokoldalúságról tett tanúbizonyságot: egyszerre volt énekmüvész, énekszerző és komponista; politizáló közéleti személyiség; énektanár, szakíró, költő és szőlősgazda. Tehetségéhez kellő önérzet is társult, így a fejezet kulcsproblémája is javarészt Sohlya kántor emberi természetéből eredeztethető. Az éneklész ${ }^{11}$ ugyanis megkísérelte társadalmilag egyenrangú, „művelt emberek társaságaként" szemlélni a csongrádi plébánia papi közösségét, melynek következményeiről az 1867-68-as Alvinczy-Sohlya ügy kapcsán olvashatunk.

Kérdésünk tehát, hogy miként látta a plébániai hierarchián belül elfoglalt helyét, szerepét a csongrádi kántor, és hogyan tekintett rá a plébános? Hogyan értékelte az alsópapság és a kántor egymással szemben tanúsított viselkedését a csongrádi hívő nép? Mi lett a sorsa a kántor által kezdeményezett, újfajta magatartásmódnak?

Csongrádon a harangozói és sekrestyési hivatal sosem vált ketté, sőt: a település kegyurasága alatt álló, belsővárosi Szent Rókus-templomban időnként az egyházfi szerepkörével olvadt össze. Értekezésemben ugyan kitérek a belsővárosi laikus egyházi tisztségviselőkre, a középpontban a külsővárosi Nagyboldogasszony-plébániatemplom szolgái állnak (VIII. fejezet). Ennek oka, hogy a belsővárosi templom a Külsőváros filiájaként nem tartott fenn papot, paplakot, kántort sem alkalmazott, csupán harangozó és sekrestyést illetve kurátort. A csongrádi egyházi élet „szíve” a 18. század végétől a Nagyboldogasszony-templom volt.

A templom elkészültétől, vagyis az 1760-as évektől kezdve a Keviczky család tagjai örökölték apáról fiúra a külsővárosi harangozói és sekrestyési tisztséget. A hagyományt egyedül a szokásjog tartotta életben, hisz a templom első plébánosával kötött szóbeli egyezséget (miszerint addig viselheti a család a hivatalt, míg az a „tisztességben megmarad”) írásban sosem erősítették meg. Ez az állapot Hegyi Antal plébános érkezéséig állt fenn, aki Keviczky György elbocsátásával szabaddá tette a tisztséget. A fejezeten belül

\footnotetext{
${ }^{10}$ Értekezésemben a káplánokról szóló fejezet annyiban különbözik a többitőll, hogy a plébánián töltött szolgálati idő rövidsége miatt eltekintettem a jellegzetes személyek, karakterek kiemelésétől, hisz hatásuk a plébániai élet egészére nézve nem, vagy nehezen mérhető.

${ }^{11} \mathrm{Az}$ éneklész kifejezést a továbbiakban a kántor szinonímájaként használom.
} 
többek között arra keresem a választ, hogy milyen sajátos szerepet töltöttek be a harangozók és sekrestyések a plébánia rendjében? Milyen célok motiválták a plébánost a változások véghezvitelére? Hogyan reagált a csongrádi hívők közössége a harangozói tisztségben bekövetkezett személyi változásokra, az évszázados szokásjog semmissé tételére? Mi lett Keviczky György hivatali utódainak sorsa?

Mivel a csongrádi kurátor a kántorral illetve a haragozó és sekrestyéssel ellentétben munkájáért csak jelképes összeget kapott, esetében inkább tiszteletbeli-bizalmi pozícióról beszélhetünk. A IX. fejezet központi alakja, Bába Szabó Rókus 50 esztendőn keresztül felügyelte a csongrád-külsővárosi templomi kiadások és bevételek rendjét. Bába Szabó bátran nevezhető egyfajta polihisztornak: a vőfélykedés és versírás mellett helytörténeti fontosságú feljegyzéseket készített, foglalkozott földméréssel és szőlőműveléssel, közéleti tisztségeket vállalt, felügyelte a katonák besorozását stb. Kurátori munkájáról egészen az 1880-as évek végéig nem maradt fenn forrásanyag. Csak a váci megyéspüspöknek címzett levelében, melyet elbocsátása után írt, illetve egy Hegyi plébánossal kapcsolatos szentszéki vallomásban nyilatkozik hivataláról. Sorsa számos motívumában megegyezik Keviczky Györgyével, így a felmerülő kérdések is hasonlóak: Milyen okok vezettek a csongrádi kurátori szerepkör „kiüresedéséhez”, névlegessé válásához majd felszabadításához? Milyen irányítási stratégia megvalósulásának útjában állt Bába Szabó Rókus?

A laikus templomszolgáktól elkülönítve tárgyalom az egyéb egyházközeli asszisztencia esettanulmányait. A csongrádi temetőcsősz és a plébános viszonyáról a rózsafüzér társulatot vezető dékányasszonnyal ${ }^{12}$ kialakult különös helyzet okán szerzünk tudomást (X. fejezet). 1892-ben ugyanis a dékányasszony közölte a frissen hivatalába lépett temetőcsősszel, hogy a plébános szóbeli engedélye nyomán igényt tart a temetőben művelt földterület felére. A csősz éveken keresztül nem merte megkérdezni, hogy Hegyi Antal plébános valóban megengedte-e Vajdovics asszonynak a szokatlan haszonvételt. Mire utalhat ez a helyzet: vajon a temetőcsősz a sajátjánál „előkelőbb” pozíciónak tartotta a rózsafüzér társulati vezetőét, kinek kérdés nélkül hajolni lehet az adott szavára? Hogyan értékelte a szituációt, közbelépett-e a plébános? Mi módon szolgálhatta Kókai Mihály temetőcsősz elbocsátása Hegyi plébános centralizálási törekvéseinek ügyét?

A korábbiaktól egészen eltérő jellegü problémát vet fel a más vallású bábaasszonyok keresztelési asszisztenciájának kérdése (XI. fejezet). Hegyi plébános és a

\footnotetext{
${ }^{12}$ A dékány vagy dékányasszony megnevezés a céhes élet hatását mutatja, mely a 18 század végén kezdett formálódni Csongrádon. A 19. század közepétől szintén dékányasszonynak nevezték a Rózsafüzér társulat vezető asszonyát. Vö. Barna 2011. 392.
} 
református szülésznő, Magdits Gáspárné konfliktusa egy téves anyakönyvi bejegyzéssel kezdődött, végül országos méretü botránnyá nőtte ki magát. Kérdésünk, hogy miként válhatott egy alapvetően vallási színezetü konfliktus társadalmi kérdéssé? Vagyis: hogyan használhatták fel Hegyi Antal politikai ellenfelei Magditsné ügyét a plébános ellenében? Milyen hosszú távú következményekkel járt az eset Hegyi Antal társadalmi megítélésére nézve?

Az értekezés összefoglaló egységeiben (XII-XV. fejezetek) a csongrádi plébánosok, kiemelten Hegyi Antal szerepvállalását elemzem a társadalmi átalakulás időszakában és folyamatában. Elsőként a századvégi hitéleti állapotok körülírására teszek kísérletet, ám a korábbiaktól eltérően az egyes vagyoni és foglalkozási csoportokat elkülönülten tárgyalom. Így látszólag engedek azon korabeli sajtótermékek sugallatának, melyek a társadalmi rétegek eltávolodása és az összefogás hiánya felett lamentálnak. Forrásaim statikus „rétegkezelése” ellenére igyekszem kihangsúlyozni a társadalmi differenciálódással együtt fokozódó átjárhatóságot, mely némiképp ellentmond az oly sokat emlegetett elszigetelödés jelenségének. Részletes társadalomtörténeti elemzésére terjedelmi okokból nem vállalkozhattam, így az olvasónak meg kell elégednie egy nagyvonalú, vázlatos helyzetképpel.

Kérdésem, hogy vajon milyen irányba változott az egyes vagyoni és foglalkozási csoportok viszonya az aktív vallásgyakorláshoz és a katolikus egyházhoz Csongrádon a 19. század második felében? Melyek voltak Csongrádon a paraszti polgárosodás tünetei és milyen szerepet töltött be az egyház a változások idején? Hátráltatta, avagy segítette és felügyelte a plébános az átalakulás rendjét? Beszélhetünk-e az egyház katalizátor szerepéről a paraszti polgárosulás perspektívájában?

A 19. századi csongrádi alsópapság viszonya a népi kultúrához forrásaimból alig körvonalazható; látszólag érdektelenek voltak a népi vallásosság megnyilvánulásai iránt, nem jegyezték le és nem is ágáltak ellenük. A nép „babonás szokásai” ellenében nem a plébánosok, hanem a 19. század végi liberális sajtó szállt síkra; ezzel a jelenséggel a csongrádi parasztság vallásos életével kapcsolatban foglalkozom.

A templomszolgák társadalmi szerepének, sajátos pozíciójának meghatározásában segít, ha a leszármazottak pályáját, házassági és rokoni kapcsolatait is nyomon követjük. Vajon mennyiben határozta meg az utódok életpályáját a szülők mintája, milyen szellemi örökséget képviseltek és vittek tovább a templomszolgák gyermekei? Milyen presztízse volt az egyházhoz közeli tisztségeknek a csongrádi társadalomban, és milyen utak, 
lehetőségek nyíltak meg a leszármazottak előtt?

Értekezésem középpontjában tehát az alsópapság, a laikus templomszolgák és az egyházközeli asszisztencia társadalmi szerepének változásai állnak a 19. század második felében. Hipotézisem szerint a csongrádi társadalom átstruktúrálódásával párhuzamosan az egyes szerepek megítélése is változáson mehetett keresztül, az átalakulást befolyásoló tendenciák megértéséhez pedig egyedi konfliktusok tanulmányozásán keresztül vezet az út.

3. Módszer, terep és források

Csongrád és szükebb környéke vallásilag homogén területnek számít, ahol a magyar ajkú római katolikusok aránya a 19. században 98-99\% körül mozgott. Így a plébániaközösség - a tanyák és a filiák lakosságát is beleértve - jóformán egyenlő volt a közigazgatási településsel. Felekezeti alapú nézeteltérésekre csak nyomokban, a 19. század utolsó évtizedeiben akadt példa.

Kutatásom fókuszába az 1850-1902 közötti időszakot helyeztem. Izgalmas és ellentmondásos korszak ez, melyet a rendi örökségtől szabadulni vágyó csongrádi parasztpolgárság útkeresési kísérletei jellemeznek. Ekkoriban alakultak az első vallási társulatok, polgári egyletek, a Kaszinó, az olvasókörök; megindult az élénk politikai érdeklődés, mely a helyi klérust és a templomszolgákat sem hagyta érintetlenül. Bár elemzésem a 19. század második felére koncentrál, ahol forrásaim lehetővé teszik, kísérletet teszek a vizsgált korszakot megelőző helyzetkép felvázolására. Ezen „engedmény” megtétele a leíró fejezetek összeállításakor (plébániatörténet, az egyes tisztségek története) kikerülhetetlennek bizonyult. Az önkép és hivatás fejezet két atipikus egyénisége, Mátyus János és Hegyi Antal csongrádi plébánosi ideje közt is több, mint hatvan esztendő telt el. Az 1810-20-as években ténykedő Mátyus János konfliktusainak bemutatásával Hegyi Antal későbbi normaszegéseit próbálom értelmezési keretbe ágyazni, a jó és rossz papról alkotott kép esetleges változásaihoz viszonypontot adni.

Az 1902-es záró időhatárt annak helytörténeti jelentősége miatt választottam. 1902 Hegyi Antal plébános amerikai emigrációjának és Sohlya Antal fökántor halálának éve. Bába Szabó Rókus egyházfi ekkoriban tünik el forrásainkból, Keviczky György harangozó és sekrestyés alig pár esztendővel korábban hunyt el. A 19. század végi csongrádi közélet emblematikus figurái voltak ők; Hegyi plébános 15 esztendeig, Sohlya Antal kántor és Bába Szabó Rókus fél évszázadon keresztül, míg a Keviczky család 120 évig szolgálta a 
plébániaközösséget. 1902-re a nevükkel fémjelzett korszak lezártnak tekinthető. ${ }^{13}$

Kutatásaim középpontban az alsópapság és a laikus templomszolgák hivatalához kötődő társadalmi szerepelvárások és a szerephordozó egyén(ek) állnak egy lokális közösségben. Ezek a hagyomány szabta minták értelemszerüen hatnak az egyén viselkedésére, hatnak a valóságra. Az ideális és reális viszonyának feltárása csak sokoldalú, változatos történeti források bevonásával és átfogó társadalmi helyzetelemzéssel kísérelhető meg. Így bár témám a pasztorálteológia, az egyházjog és az egyháztörténelem számára is kínál megközelítési lehetőségeket, a kutatási módszer és a szemléletmód történeti antropológiai jellegü. ${ }^{14}$ A történeti antropológia képviselői - hozzám hasonlóan elengedhetetlenül szükségesnek tartják a körülmények pontos letisztázását, a jelenségek hátteréül szolgáló kulturális, gazdasági és főként társadalmi állapotok felmérését. A korabeli csongrádi társadalom ilyen értelemben az a közeg, melynek értékrendjéhez, normáihoz a vizsgált tisztségviselők viszonyulnak és igazodnak. A cselekvő egyén döntései és válaszreakciói is ebben a környezetben nyernek értelmet. ${ }^{15}$

Munkámban a történeti antropológiától nehezen elválasztható mikrotörténelem két jellegzetes motívuma is kimutatható. Az egyik a Hegyi Antal plébános példáján tetten érhető, Edoardo Grendi nevével fémjelzett kivételesen normális koncepciója. Az elmélet szerint az atipikus - vagy statisztikai reprezentativitással ellentétes - jelenségek nyomán a társadalmi valóság olyan mélyrétegei tárulhatnak fel, melyek a konfliktus hiányában rejtve maradnának. ${ }^{16}$ A 19. század utolsó csongrádi plébánosa után ránk maradt terjedelmes forrásanyag értékes dokumentumgyüjteménye a papi normaszegés mintázatainak.

Mivel az értekezés egyes fejezetei mind a résztémát, mind a tér- és időbeli meghatározottságokat tekintve leszúkítettek, így a léptékváltás gondolata is logikus közelségbe kerül. A léptékváltás hidat próbál verni a mikrotól a makró, az egyeditől az általános felé oly módon, hogy a mikroszintü jelenségek egyre sűrübb leírásával a társadalmi valóság szövedékét rekonstruálja. ${ }^{17}$ A csongrádi egyházi és egyházközeli

13 A Hegyi Antalt követő Porubszky József plébános már a korábban kevés szerepet játszó ifjúságpasztorációra (Mária Kongregációra, KALÁSZ, KALOT mozgalmakra) helyezte a hangsúlyt. Lásd. Kovácsik 2010. Ugyan Hegyi Antal később visszatért Csongrádra, nyugdíjas éveinek részletes elemzése túlnyúlik kitüzött célomon.

${ }^{14}$ Peter Burke szerint onnan lehet megismerni a történeti antropológia képviselöit, hogy a kis közösségek vizsgálata során elsősorban a társadalmi interakciókra összpontosítanak. Burke 2000. 19. Az irányzat óriási jelentőséget tulajdonít annak a közvetlen kulturális és társadalmi közegnek, ahol bizonyos jelenségek, jelenség-együttesek létrejönnek. A témában lásd még: Hofer (szerk.) 1984.

15 Sebők 2000. 8; Apor 2006. 454.

16 Szíjártó M. 2006. 513.

17 A kultúra tehát - Clifford Geertz nyomán - olyan szövedék, melynek egyedi jelei összefüggő jelentésrendszert alkotnak. Apor 2006. 458. 
tisztségviselők kisebb-nagyobb konfliktusait olyan jelenségek halmazaként kezeltem, melyek önmagukon túlmutató kulturális és hagyományalapú összefüggésekre világítanak rá. Így jelen értekezés esettanulmányok füzéreként is szemlélhető, mely szélesebb társadalmi kontextusba ágyazva történeti antropológiai elemzéssé, mozaikokból összeállított képpé teljesedik ki.

A történeti antropológiai megközelítés forrásaim jellege miatt is eredményre vezető választásnak bizonyult. Országos méretü összehasonlítást azonban - referenciaanyag hiányában - aligha végezhettem. Erösen támaszkodtam a Váci Püspöki és Káptalani Levéltárban található, Csongrádra vonatkozó plébániai anyagra (Acta Parochiarum) illetve a 18-19. században Csongrádon szolgáló plébánosok személyes irataira (Acta Privatorum). A Püspöki Szentszéki iratok közül az Acta Privatorumokban elhelyezett kihallgatási jegyzőkönyv-másolatokat használtam fel. A kéziratos latin nyelvű anyag feldolgozásához alapszintü latin ismeretem nem bizonyult elegendőnek, ám Földvári Katalin (DE) személyében szakértő segítségre leltem. A csongrádi Nagyboldogasszony Plébánia irattárában az anyakönyvek, Canonica Visitatiok ${ }^{18}$ és a Historia Domus ${ }^{19}$ mellett vegyes iratanyag állt rendelkezésemre. Csongrád tanácsülési jegyzőkönyveit, az iskolaszéki iratokat az MNL CsML Csongrádi Fióklevéltárában volt szerencsém átvizsgálni. A csongrádi Csemegi Károly Könyvtár és Tari László Múzeum történeti és néprajzi adattárában lévő anyag feldolgozása nyomán a kántorokkal és a csongrádi népélettel kapcsolatos meglátásaim egészültek ki. Nagy hasznomra volt a szegedi Somogyi Károly Könyvtár, a Váci Püspöki Könyvtár illetve a SZTE-BTK Néprajzi és Kulturális Antropológiai tanszékének régi könyv gyüjteménye. A csongrádi vonatkozású sajtóanyag áttekintése a Csemegi Károly Könyvtár digitalizálási pályázatának köszönhetően jelentősen leegyszerüsödött.

Forrásaim tehát túlnyomórészt egyházi jellegűek: a váci megyéspüspökhöz címzett levelek, egyházlátogatási jegyzőkönyvek, szentszéki kihallgatási jegyzőkönyvek, ritkábban újságcikkek, képviselőtestületi jegyzőkönyvek, magánemberek visszaemlékezései (Szántai

\footnotetext{
${ }^{18}$ Canonica Visitatio: lat. „egyházlátogatás”, a plébániák ellenőrzése. Magyarországon a 12. századtól vannak adataink a püspök vagy föesperesek által írt jegyzőkönyvekre, melyek kérdőpontjait a püspök állította össze. Menetét, gyakoriságát a trienti zsinat (1545-63) szabályozta. Tomisa 2002. Csongrádon az 1715, 1726, 1745, 1761, 1781, 1828 és 1842. években zajlott egyházlátogatás. Az 1781, 1828 és 1842. évi jegyzőkönyv másolata a csongrádi Nagyboldogasszony Plébániahivatal irattárában lelhető fel, a korábbi anyagok elvesztek. A 19. század második feléböl egyedül a Schuszter Konstantin püspök által 1890-ben végzett Visitatio Paterna áll rendelkezésünkre. Ld. Váci Püspöki és Káptalani Levéltár, Vác (Továbbiakban: VPL) Vis. Pat.

${ }^{19}$ Historia Domus: 'háztörténet', az egyes plébániák lelkipásztorai által vezetett kéziratos könyv, melyben a helyi történéseket, jelentős eseményeket rögzítik. A váci egyházmegyében az 1770-es évektől tették kötelezővé a latin nyelvü Historia Domusok vezetését.
} 
Kiss Mihály, Váry Gellért stb). Mivel témámmal a kutatók ezidáig esetlegesen foglalkoztak, a felhasznált magyar és európai szakirodalmakból főként elemzési szempontokat kölcsönözhettem. A hivatkozott könyveket 2010 nyarán, egy két hetes londoni könyvtári kutatás során tanulmányoztam át a Warburg Institut, az Open University és a Folklore Society könyvtárában. Az értekezés kutatástörténeti fejezetének gerincét az itt beszerzett kötetek képezik.

Forrásaim jellegéből adódóan szükségesnek tartom felhívni a figyelmet néhány alapvető problémára. A vizsgált kéziratos anyag döntő többsége konfliktusok nyomán keletkezett panaszlevél. Sajátos, egyoldalú szándékkal íródtak, így értékítélet hozatalra csábítják az olvasót: óvatlan, naiv kezelésük pedig jelentősen torzíthatja az elemzést. ${ }^{20}$ Mindezek tükrében igyekeztem azokra a tényszerü pontokra helyezni a hangsúlyt, melyek a konfliktus okait tárják fel és a probléma megértését segítik elő. A konfliktusok vizsgálata témám szempontjából alapvető fontosságú, hisz látványossá teszik a norma és normaszegés közt húzódó, érzékeny határvonalakat. ${ }^{21}$

További problémaként merült fel a kutatás erős forráshoz kötöttsége. A vizsgált időszakban ugyan tetemesen javult a fennmaradt történeti források aránya, a kutató többször is szembesülni kényszerült egyes ügyek fragmentum-mivoltával. Vagy az eset előzményei, vagy a lezáró végkifejlet hiányzik: a probléma kiderül, de a megoldás már a múlt homályába vész. Nem volt ritka, hogy míg az eset kibontakozását a váci levéltárban követtem nyomon, a záró akkordokkal már a csongrádi plébániahivatalban talált levelekben szembesültem.

Értekezésem a 19. század végi csongrádi plébánosok és templomszolgák sajátos viszonyát illetve a helyi társadalomban betöltött szerepét elemző, történeti antropológiai jellegü esettanulmány. Mivel hasonló munka korábban nem látott napvilágot, a csongrádi helyzet általánosítása, megnyugtató elhelyezése a korabeli állapotok között most még aligha lehetséges.

\footnotetext{
${ }^{20}$ Hasonló problémákkal szembesült Timothy Tackett a 18. századi francia alsópapságra vonatkozó források vizsgálata során. Tackett 1977. 7.

${ }^{21}$ Bednárik 2013. 223.
} 


\section{Köszönetnyilvánítás}

Munkámhoz állandó szakmai támogatást és segítséget nyújtott témavezetőm, Prof. Barna Gábor egyetemi tanár.

Az értekezés VI; VIII; IX; X. fejezetei az OTKA NK 81502 Vallás, egyén, társadalom projekt támogatásával jöttek létre. A Sohlya Antal kántorra vonatkozó részt (VII. fejezet) a Magyar Müvészeti Akadémia „fiatal müvészeti ösztöndíjának” köszönhetően dolgoztam ki.

A kutatás évei során számos önzetlen segítőm akadt, kiknek türelmét, segítségét ez úton is hálásan köszönöm. Közülük név szerint említve Laczkó István, Salamon László, Janes Zoltán plébános urakat; Tóth Roland atyát és Kovácsikné Gonda Anna kántorasszonyt (Nagyboldogasszony Plébániahivatal, Csongrád); Petrik Heroldot, Papanek Ferencet, Gyenes Lászlónét és Varga-Kohári Máriát (Váci Püspöki és Káptalani Levéltár és Könyvtár, Vác); Georgiades Ildikót és Kádasné Szabó Mártát (MNL CsML Csongrádi fióklevéltára, Csongrád); Szücs Juditot, Ujszászi Róbertet és Fodor Pétert (Csemegi Károly Könyvtár és Tari László Múzeum, Csongrád); Pintér Gábort (egyháztörténész) és Hajduné Földvári Katalint (néprajzkutató). A Szegedi Tudományegyetem Néprajzi és Kulturális Antropológiai tanszékének munkatársai állandó bíztatásukkal nélkülözhetetlen segítséget nyújtottak. Családom, barátaim türelme és támogatása nélkül munkám nem jöhetett volna létre. 


\section{AZ ALSÓPAPSÁG ÉS A LAIKUS ASSZISZTENCIA SZEREPÉNEK KUTATÁSA}

\section{NYUGAT-EURÓPÁBAN ÉS MAGYARORSZÁGON}

A következő fejezetben a teljesség igénye nélkül tekintem át a téma legfontosabb kutatóit, megközelítési módjait, sorra véve a hatást keltő, kikerülhetetlen munkákat. A szerteágazó szakirodalom rendszerezését a kiemelkedő kulcstémák középpontba állításával kíséreltem meg. A laikus templomszolgák kutatásának külhoni párhuzamairól csak esetleges, elszórt adatok állnak rendelkezésre, így e tekintetben meg kell elégednünk a hozzáférhető hazai próbálkozások áttekintésével. ${ }^{22}$

Az alsópapság társadalom- és mentalitástörténeti vizsgálata Franciaországban vette kezdetét az 1960-70-es években. ${ }^{23}$ Az első, vonatkozó tanulmányok vagy egyházmegyei statisztikai adatokat közöltek, vagy a hívő nép perspektívájából rekonstruálták egy-egy vicariat 16-18. századi történetét. A nép között élő papság leírása is az átfogó egyháztörténeti munkákon belül kapott helyet. ${ }^{24}$ Mintaadó előzményként szokták emlegetni Louis Perouas három kiadást megért monográfiáját, melyben a rochelle-i egyházmegye 17-18. századi általános helyzetét írja körül. ${ }^{25}$

A franciák által elkezdett utat az Alltagsgeschichte német kutatói, majd az olaszok és a skandinávok folytatták az 1980-90-es években. Az ekkoriban született tanulmányok többsége a trienti zsinat (1545-63) következményeit, vagyis az alsópapság és a hagyományos népi kultúra viszonyának átalakulását, a papság elitizálódásának hatásait próbálta meg tetten érni. Köztük Werner Freitag, aki kora újkori Mária zarándoklatok apropóján vizsgálta a hívek és az egyre képzettebb plébánosok konfliktusokkal terhelt viszonyát. ${ }^{26}$ Gerard Rooijakkers a fonóbéli mulatságok tilalmazásának példáján mutatta be a papság és a népi kultúra „elszakadásának” folyamatát, a hivatalos (elit) és népi

\footnotetext{
${ }^{22}$ Fontosnak tartom kiemelni a J. W. Sheils és Diana Wood által szerkesztett The Ministry: Clerical and Lay címü kötetet, mely a Studies in Church History 26. tematikus számaként látott napvilágot 1989-ben. Az értekezések időkerete a 4. századtól a 20. század végéig kiterjed, és egészen Angliától Malajziáig találunk benne esettanulmányokat a laikus templomszolgák témájában. Az átlagosan 10-15 oldal terjedelmü íások mindegyike szük kérdéskörre koncentrál, leíró jellegủ vagy csak felvillant egy-egy megválaszolandó kérdést (pl. az ellenreformáció kihívásai, a laikus asszisztenciáról alkotott elképzelések változásai). Sheils-Wood eds. 1989.

${ }^{23}$ A korabeli francia kutatások irányáról és helyzetéről szóló beszámolót olasz nyelven Carla Russo állította össze. Russo az Annales iskola mintaadó szerepét - e sorok írójához hasonlóan - kiemelkedő fontosságúnak tartja. V.ö. Russo 1972.

${ }^{24}$ V.ö. Delumeau 1971.

${ }^{25}$ Perouas 1964. Kitünő példa még a mindennapi vallásosság és az alsópapság vizsgálatára a Karoling korból: Riché 1973. (Németül: Die Welt der Karolinger. Stuttgart, 1981).

${ }^{26}$ Freitag 1991. Szélesebb látókörü, a teljes kora újkort átöltelö munkái: Freitag, Werner 1998; 2002. További, alapvető megállapításokat tett a papság és a népi kultúra viszonyáról a kora újkori Németországban: Dülmen 1989.
} 
vallásosság közti kulturális szakadék megszületését a 16-17. századi dél-Hollandiában. ${ }^{27}$ Az 1980-90-es években Rainer Beck elemezte társadalomtörténeti szempontból a falvakban élő lelkipásztorok és a hívek átalakuló kölcsönviszonyát. Beck würzburgi kollégája, Wolfgang Brückner ellenében hangsúlyozza, hogy a falu nem passzív befogadó közeg, hisz maga is állít elvárásokat, kész hagyományrendszert papjai elé. Kritikáját lokális esettanulmányok, konfliktusok elemzése nyomán fogalmazta meg. ${ }^{28}$

Angolszász területeken az Annales iskola mintájára formálódó történeti antropológia égisze alatt születtek az első, vonatkozó elemzések. Ezek a munkák is konfliktuselemzések, de nem az új papi eszmény és a népi kultúra viszonyának kérdését, hanem a papság rendkívüli helyzetekben tanúsított magatartását mutatják be. A Theodore Zeldin által szerkesztett Conflicts in French Society címü kötet több szerzője 19. századi egyházellenes megmozdulásokat állít a középpontba. Külön figyelemre méltó Roger Magraw itt megjelent értekezése a falusi lelkipásztorok nehézségeiről Franciaországban. ${ }^{29}$ A tengeren túli társadalomtörténészek közül Bernard Singer fordult érdeklődéssel a 19. századi francia alsópapság felé. Singer elsősorban a közösség vezető egyéniségei, vagyis a polgármester, a tanár és a pap nézeteltéréseinek tükrében vizsgálta az egyház helyét és szerepét a helyi társadalomban. Külön figyelemre méltó a vidéki plébánosról alkotott sztereotípiák összegzésére tett kísérlete. ${ }^{30}$ Donald A. Spaeth munkája Salisbury egyházmegye alsópapságának konfliktusait tárja fel a restaurációtól 1740-ig. A munka számos erénye mellett azért is kiemelkedő, mert a szerző az esettanulmányok nyomán határozottan rácáfol a népi és hivatalos egyházi kultúrát szembeállító elméletekre. ${ }^{31}$ Timothy Tackett a 18. század végi Franciaországból hoz példákat arra, amikor a plébános kénytelen alávetni magát néphagyomány erejének és kiszolgálni a helyi színezetü szakrális-mágikus igényeket. $^{32}$

A kezdetben főként egyházlátogatási jegyzőkönyvekre, püspöki szentszéki iratokra támaszkodó kutatások az 1980-as évek végén új, korábban nem használt források bevonásával árnyalódtak. A francia mikro- és mentalitástörténeti kutatások hatása érhető tetten Alan Macfarlane munkáján, aki egy 17. századi lelkész, Ralph Josselin naplóját dolgozta fel. A lelkész életútját, érzelmeit, világnézetét és emberi kapcsolatait bemutató mü

\footnotetext{
${ }^{27}$ Rooijakkers 1989.

${ }^{28}$ Beck 1990; 1988.

${ }^{29}$ Zeldin (ed.) 1970. Magraw 1970.

${ }^{30}$ Singer 1983.

${ }^{31}$ Spaeth 2000.

32 Tackett 1977.
} 
célja a hétköznapi élet történeti szempontú megragadása volt. ${ }^{33}$ Ugyan Macfarlane-t bevallottan inspirálta oxfordi tanára, Keith Thomas munkássága, Thomas alapmüve a témában csak egy esztendővel később látott napvilágot. ${ }^{34}$

A magyar vallási néprajz elsősorban a németországi kutatásokból merített mintát és inspirációt. ${ }^{35}$ A német-orientáltságnak történeti alapokon nyugvó létjogosultsága van, gondoljunk a népi vallásosság jelenségeinek nagyfokú hasonlóságára, vagy a német céhek és vallási társulatok (Bruderschaften) történelmi mintaadó szerepére. A nyugat-európai kutatók vonatkozó eredményei azért tanulságosak számunkra, mert a trienti zsinat hatása közel egy évszázaddal korábban éreztette hatását, mint nálunk. Így igen hasonló folyamatok zajlottak le a klérus és a nép kapcsolatát, az új papkép kialakulását tekintve a 16-17. századi német, francia vagy holland területen, mint a török kiüzése utáni Magyarországon.

Az alsópapság a magyarországi vallási néprajz történetében egészen a közelmúltig nem fogalmazódott meg önálló kutatási területként. A két világháború közötti Magyarországon elsőként a református és római katolikus szerzetes-lelkipásztorok egyháztörténeti írásait, mindenek előtt a pannonhalmi iskola kutató egyéniségeit (Karsai Géza, Radó Polikárp, Csóka Lajos) érdemes kiemelnünk. A plébániatörténetírás módszertanát kidolgozó Vanyó Tihamér ${ }^{36}$ tanulmányai a Pannonhalmi Szemlében és a Szekfü Gyula nevével fémjelzett Regnumban, a kor legszínvonalasabb egyháztörténeti évkönyvében jelentek meg. ${ }^{37}$ Ekkorra már napvilágot láttak az első, valóban színvonalas plébániatörténeti írások. ${ }^{38}$ Mohl Adolf, miután az őskortól a 20. század elejéig összefoglalta Tata egyháztörténetét, külön fejezetet szentelt a helyi szokásoknak, majd függelékben közölte papi elődei, a segédlelkészek majd a kántortanítók életrajzát. Hoss József püspöki helytartó harminc esztendővel később hasonló szempontok szerint írta meg a kaposvária plébánia történetét, kiegészítve a harangozókról, sekrestyésekről és

\footnotetext{
${ }^{33}$ Macfarlane 1970.

${ }^{34}$ Thomas 1971.

35 Elég csak Schwartz Elemér problémafelvető írására gondolnunk az Ethnographia hasábjain, melyben Joseph Weigert mockersdorfi plébános „Religiöse Volkskunde” című munkájára hivatkozva próbálta felhívni a papság figyelmét a népi kultúra vizsgálatának fontosságára. Schwartz 1928.

36 A plébániatörténeti írások elengedhetetlen része az alsópapság tevékenységének feltárása, így Vanyó munkássága fontos tudománytörténeti elöképnek tekinthető. Vanyó 1937; 1940-41.

37 Bálint Sándor tudomása szerint először a sárospataki Református Hittudományi Akadémián, Ujszászy Kálmán és Szabó Zoltán kezdeményezésére ismerték el a vallásos népélet tanulmányozásának fontosságát a modern lelkipásztorképzésben. Öket követte a pannonhalmi bencés föiskola majd a gyöngyösi ferences teológusok, köztük Dám Ince, illetve a Budapesti Központi Papnevelő Intézet tanárai, nevesül Galla Ferenc és Juhász Péter. Bálint 1987.19.

${ }^{38}$ Mohl 1909.
} 
kurátoroktól szóló fejezetekkel. ${ }^{39}$

A magyar történészek mindeközben egyre határozottabban fordultak a politizáló papság és a papok 1848-49-es szabadságharcban betöltött szerepének kérdései felé. ${ }^{40}$ Hermann Egyed premontrei szerzetes tanár munkáját napjainkban Zakar Péter és Sarnyai Csaba Máté kutatásai teljesítik be. ${ }^{41}$

A „falu és papja” problémakör Bálint Sándor munkáiban körvonalazódott elsőként. ${ }^{42}$ Ö volt az, aki konkrét példákkal támasztotta alá a papság kultúraközvetítő szerepét, vizsgálta a szegedi nép papsággal, templommal és egyházszolgákkal kapcsolatos szólásait, naiv babonáit, „a papunk”-hoz való viszony évszázados beidegződéseit. ${ }^{43}$ Bálint Sándor álláspontja szerint a jozefinizmus szellemében nevelt alsópapság túlnyomó többségben elutasítóan és érzéketlenül kezelte a nép vallásos áhítatának sajátos megnyilvánulásait.

Az 1980-as években készült kutatástörténeti összefoglalók és irányadónak szánt munkák az egyház és népi vallásosság viszonyának minél teljesebb feltárását szorgalmazták anélkül, hogy konkrétan megnevezték volna az alsópapság vizsgálatának szükségességét. ${ }^{44}$ Ugyan Bartha Elek könyvében már külön fejezet foglalkozott a komlóskai lelkipásztorok közösségi szerepvállalásával, ${ }^{45}$ az egyes települések alsópapságára és a laikus templomszolgákra vonatkozó adatok még mindig a plébániatörténeti írásokban kaptak helyet. Ezek a munkák jellemzően a Canonica Visitatiok adatait és az eleven szájhagyományt vették alapul. ${ }^{46}$ Számos példát találunk a METEM Egyháztörténeti Munkacsoportjának kiadványaiban. ${ }^{47}$

Ami a nagyobb néprajzi összefoglalókat illeti, 1990-ben Bárth János a Magyar Néprajz VII. (Folklór) kötetében „a kultuszt irányító és szervező személyek” címszó alatt értekezett az alsópapság helyéről és szerepéről a népi kultúrában. Írásában külön kitért a plébánost segítő templomszolgákra. A Magyar Néprajz „Társadalom” kötetében Jávor Kata

\footnotetext{
${ }^{39}$ Hoss 1948.

${ }^{40}$ Hermann 1932; Meszlényi 1928.

${ }^{41}$ Zakar 1999; Sarnyai 2001; 2002. Említésre érdemes forrásközlő kiadvány a Dunántúlról: Hermann István 1998.

42 Bálint 2009/a. [1944].

${ }^{43}$ Bálint 1938. 15. 45; 1980. 337; 1981/a. 22; 1981/b. 89; 2009/b. 165.

${ }^{44}$ A magyarországi vallási néprajzi kutatások múltjáról, irányáról és kilátásairól hasznos összefoglalásokat találunk a következő szerzőktől: Tüskés 1986; Bálint 1987; Baumgartner 1987; Brückner 1987; Barna 1990; Tüskés - Knapp 2001.

${ }^{45}$ Bartha 1980.

${ }^{46}$ Kisházi-Kovács 2008.

${ }^{47}$ A munkacsoport kutatási programjáról készült összefoglalást lásd: Horváth 1993. A számos próbálkozás közül mind színvonalában, mind terjedelmében kiemelkedő Katus László áttekintése a szegvári plébánia történetéről. Katus 1994.
} 
tekintette át a plébános és a hívek viszonyának jellemzőit. ${ }^{48} \mathrm{Az}$ ezredforduló előtt megjelent vallási néprajzi munkák közül kiemelkedik Székely László kötete, melyben Csík megye nevezetes katolikus lelkipásztorait vette számba megkapó érzékletességgel. ${ }^{49}$

Az alsópapság módszeres vizsgálata Magyarországon Canonica Visitatok és plébániai iratok alapján vette kezdetét. Ennek oka, hogy a papság életadataira vonatkozó dokumentumok (Acta Personalia) hiányosan maradtak fenn - ha fennmaradtak egyáltalán. Előnye, hogy az azonos forrástípusok felhasználásával a tanulmányok adatai könnyen összevethetőek. Tomisa Ilona néprajzkutató-egyháztörténész vonatkozó írásaiban egyházlátogatási jegyzőkönyvek alapján körvonalazta az alsópapság helyzetét a 17-18. századi Magyarországon. Az általa gondozott vizitáció-kiadások előszavaiban és egyéb munkáiban az alsópapság kutatásához nélkülözhetetlen tudnivalóknak, mint a történelmi körülmények felvázolásának és az alapvető fogalmak letisztázásának szándéka tükröződik. Szinte rendhagyó módon a laikus templomszolgáknak is hagy helyet. ${ }^{50}$

A 2000-es évek második felében szociálantropológiai beállítottságú egyháztörténészek, történészek körében támadt érdeklődés az alsópapság irányában. Ez a „feleszmélés” részben a kutatói érdeklődés hiánya keltette ür egyre nyomasztóbb terhéhez, másrészt a konfesszionalizáció elméletének adaptációs kísérleteihez kötődik.

A konfesszionalizáció fogalmának atyja Wolfgang Reinhard és Heinz Schilling. Lényege, hogy elveti a korábbi évtizedekben meggyökeresedett reformációellenreformáció sémát, vagyis a katolikus ellenreformációt nem védekező reakcióként, hanem reformfolyamatként értelmezi. ${ }^{51}$ A konfesszionalizáció elméletét Fazekas István, Molnár Antal majd Mihalik Béla Vilmos kísérelte meg átültetni magyar viszonylatokba győri, váci és egri egyházmegyei kutatások apropóján. ${ }^{52}$

Napjainkban a tudományos érdekelődés területe a plébániahálózat újjászervezésének időszakára, vagyis a 17-18. századra koncentrálódik. Dénesi Tamás és Fazekas István munkái alapján képet kaphatunk az észak- és nyugat-dunántúli egyházmegyék papságának életkörülményeiről, pályaképéről, mindennapi nehézségeikről, melyekkel a soknyelvű és nemzetiségü, vegyes vallású településeken müködve

\footnotetext{
48 Bárth János 1990; Jávor 2000.

49 Székely 1995.

${ }^{50}$ Tomisa 1992; 1997/a; 1997/b; 2002.

${ }^{51}$ Az elmélet alapvetéseit Magyarországon elsőként Tusor Péter, a kritikákat Kálmán Gábor összegezte. A konfesszonalizáció elméletéről bővebben lásd: Mihalik 2012.

${ }^{52}$ Fazekas 1993; Molnár Antal 2004/a; 2005; Mihalik 2012.
} 
szembesültek. $^{53}$ Munkájukon felbuzdulva Gőzsy Zoltán és Varga Szabolcs a pécsi egyházmegye hasonló bemutatását tüzte ki célul. Érdeklődésük középpontjában a plébániák anyagi infrastruktúrájának, személyi állományának újjászerveződése áll a török kiűzése után. ${ }^{54}$ Mind a magyarországi, mind a nyugat-európai és amerikai kutatástörténeti előképekből egyértelmüen kimutatható a 19. századi állapotok vizsgálatának hiánya.

A néprajzkutatók közül napjainkban Barna Gábor, Bárth János és Bárth Dániel kutatásai irányadóak a témában. Barna Gábor az elmúlt évtizedekben több helytörténészt és egyetemi hallgatót bíztatott eredményesen az elhanyagolt területek vizsgálatára. ${ }^{55}$ Bárth János székelyföldi kutatásai kapcsán foglalkozik a plébánosok és templomszolgák tevékenységével. Újabban Székelyvarság és Csíkszentgyörgy településekről tette közzé a 19-20. századi plébánosok és templomszolgák adatait, bemutatva a helyi népéletre gyakorolt hatásukat (pl. mezőgazdasági innovációk) és a hívek viszonyulását. ${ }^{56}$ Gondozásában jelent meg Szakál Veronika forrásközlése a gelencei plébánosok időjárásfeljegyzéseirôl. ${ }^{57}$ Bárth Dániel 2003-ban a Cumania hasábjain elevenítette fel Szloboda Mátyás küllődi káplán hadakozását a katolikus délszláv leányok Úrnapi szőlőőrzésének szokása ellen, melyet a segédlelkész az erkölcsi bünök melegágyaként értékelt. A falu és a pap viszályának összetett okait Bárth széles társadalmi kontextusba ágyazva elemzi. ${ }^{58}$ Doktori értekezésében az esküvővel, keresztelővel és asszonyavatással összefüggésben hangsúlyozza az alsópapság kulcsfontosságú szerepét az egyházias néphagyományok alakításában. ${ }^{59} 2012$ tavaszán Bárth Dániel konferenciát hívott össze az ELTE Folklore tanszékén, mely az alsópapság fiatal kutatóit ültette egy asztalhoz. Az egy évvel később megjelent kötet elején a szerkesztő összegzi az európai kutatástörténeti elözményeket, elsősorban a 18. századra vonatkoztatva. ${ }^{60}$ Témám szempontjából kiemelendő Muntagné Tabajdi Zsuzsanna írása, aki a váci egyházmegyei papság felekezetközi konfliktusait elemzi a 17-18. században. ${ }^{61}$ Bednárik János tanulmánya mind időben, mind jellegében rokonságban áll jelen disszertáció bizonyos fejezeteivel; Bacsák Imre plébános karaktere számos vonásában hasonlít Hegyi Antaléhoz. ${ }^{62}$

\footnotetext{
${ }^{53}$ Dénesi 2006; 2009.

54 Gözsy-Varga 2009.

${ }^{55}$ Katus 1994; Józsa 2009; Kovács 2010. (kézirat); Kocsis 2012. (kézirat)

56 Bárth János 2006.

${ }^{57}$ Szakál 2011.

58 Bárth Dániel 2003.

${ }^{59}$ Bárth Dániel 2005.

${ }^{60}$ Bárth Dániel 2013.

${ }^{61}$ Muntagné Tabajdi 2013.

${ }^{62}$ Bednárik 2013.
} 
Kikerülhetetlennek tartom megemlíteni Kiss Réka 2011-ben megjelent doktori disszertációját, melynek témája az egyházfegyelmezés gyakorlata a Küküllői Református Egyházmegyében. ${ }^{63}$ Forrásai elsősorban 17-18. századi zsinati bírósági testületek protocollumai illetve egyházlátogatási jegyzőkönyvek voltak. Írásában a norma és praxis kérdéskörét, a törvényekben rögzített viselkedésminták betartatását, az egyházi elvárások és a falu erkölcsi normáinak viszonyát vizsgálja, különös hangsúllyal a fegyelmezési módok időbeli változásaira. Ugyan sem az időkeret, sem a vizsgált felekezet nem egyezik a jelen tanulmányban foglaltakkal, Kiss Réka megközelítései módja, sajátos meglátásai e sorok szerzőjére is termékenyítően hatottak.

A templomszolgák kérdése Magyarországon hiányos, egyenetlenül feltárt területnek számít. Barna Gábor a Mezey kántorcsalád vizsgálatával adott új lendületet a kántorkutatásoknak, mely korábban csak a halotti búcsúztatókkal összefüggésben tarthatott számot a kutatók érdeklődésére. Bartha Elek és Kríza Ildikó nyomán ${ }^{64}$ még a 2000-es években is történtek kísérletek a halotti búcsúztatók új szempontú vizsgálatára. ${ }^{65} \mathrm{~A}$ kántorok tevékenységének egyoldalú megközelítését, nevezetesen a temetkezési szokásokban játszott szerepük túlhangsúlyozását Beszédes Valéria is felismerte. Beszédes kezdeményezésére a Kiss Lajos Néprajzi Társaság 1997 októberében szervezett, tematikus konferenciáján a térség kántorairól tartottak beszámolót a Bácska és Bánát kutató muzeológusai. A változó színvonalú tanulmányoknak elsősorban szimbolikus jelentősége van, a vállalkozás egyfajta kísérletnek tekinthető. ${ }^{66}$

A kántorok összetett közösségi szerepvállalásáról elsőként tehát Barna Gábor tollából születtek valódi tudományos értékkel bíró tanulmányok. Barna Gábor vonatkozó munkáiban a Mezey kántordinasztia énekeinek kultúrtörténeti hatását vizsgálja. Ezek az énekek azért jelentősek, mert részben megőrizték koruk élő énekgyakorlatát, ugyanakkor új elemekkel is bővítették a Dél-Alföld vallásos énekkultúráját. ${ }^{67}$ A zenetudósok közül Bárdos Kornél és Dobszay László szentelt figyelmet a kántorok énekszerző tevékenységének. ${ }^{68}$

\footnotetext{
${ }^{63}$ Kiss 2011.

${ }^{64}$ A témában született korai, irányadó írások: Kriza 1993; Bartha 1995. Bartha Elek egy korábbi munkájában a görög katolikus Komlóska település és papjának viszonyáról is értekezett. Bartha 1980.

${ }^{65}$ A kutatók többnyire a 20. század elején-közepén alkotó kántorok halotti énekszerző tevékenységét vizsgálják. Lásd: Adorjáni 2006; Jelen sorok írója Knapek Dezső csanyteleki kántor halotti búcsúztatóinak példáján hívta fel a figyelmet a nyomtatásban megjelenő kántori segédkönyvek hatására. Gyöngyössy 2010/a.

A kántorokat a licenciátusok utódaként vizsgálja Sávai János. Sávai 1997.

${ }^{66}$ Beszédes (szerk.) 1998.

${ }^{67}$ A témában megjelent számos értekezés közül lásd: Barna 1984; 1998/a; 2011.

${ }^{68}$ Bárdos 1990; Dobszay 1995.
} 
A templomszolgák iránti tudományos érdeklődés a kántorok tematikus vizsgálatával jóformán lezártnak tekinthető. Bárth János talán az egyetlen, aki a vallási élet elemzése során részletesen kitér a laikus templomszolgák feladataira, személyére, kultúraformáló és közvetítő szerepükre egy vizsgált közösségben. ${ }^{69}$ A harangozókról, sekrestyésekről elsősorban a harangok és harangozási szokások kapcsán értekeznek a népélet kutatói, gyakran ugyanazon megállapításokat ismételve. ${ }^{70} \mathrm{Az}$ egyházfi szerepe a plébániakutatások okán merül fel, ám csak elvétve kap a kérdés külön fejezetet a templomok pénzkezelése ürügyén. ${ }^{71}$

Gyakorlati lelkipásztorkodástani tankönyvekben találunk egyházi szerzők tollából javaslatokat arra, hogyan célszerü a plébánosnak viszonyulnia saját háza népéhez. ${ }^{72}$ Ezek az írások tanácsadó szándékkal születtek, ugyanakkor az életből vett példák miatt értékes forrásként szolgálnak a templomszolgák munka és jogosultsági körének, mindennapi problémáinak megismeréséhez. Valódi különlegesség az egyetlen, sekrestyéseknek és harangozóknak szánt, gyakorlati instrukciókkal ellátott kiadvány Pogonyi Bernát plébános tollából. ${ }^{73} \mathrm{Az}$ igényeket mutatja, hogy a 1896-os állami ünnepségek ürügyén kiadott munka első kiadásának 700 példánya egy év leforgása alatt elfogyott. A lelkipásztorkodási tankönyvekhez hasonlóan kiaknázatlan forrásnak számítanak a papok által írt önéletírások, visszaemlékezések, pályaképek. Ezek száma igen csekély, szerzőjük gyakran ismeretlen; ugyanakkor életszerű képet festenek a 19-20. századi lelkipásztorkodó papok mindennapjairól, a templomszolgákhoz és híveikhez való viszonyáról. ${ }^{74}$

Munkám az elöképek tükrében újdonságot jelent mind a választott időkeretet, mind a kutatás speciális területét tekintve. A vállalkozásomhoz legközelebb álló munkák - mint Dénesi Tamás vagy Fazekas István tanulmányai - kivétel nélkül egyházmegyei szintü, átfogó keresztmetszetek, melyek a 18. század végével lezáródnak. A témában végzett, szük területre - konkrétan egy adott plébániaközösségre - koncentrálódó „mélymerítés” gyakorlatilag példa nélküli.

További eltérést jelent a korábbi kutatásokhoz képest, hogy az általam vizsgált

\footnotetext{
69 Bárth János 2006. 103-115; 2012. 357-380. Dénesi Tamás disszertációjában érintőlegesen foglalkozik a kérdéssel Dénesi 2006. (kézirat) 90-94.

70 Példaként lásd. Bálint 1980; Barna 2000. Kisházi-Kovács László írásában Kreminger Antal szegedi plébános és harangozójának konfliktusa nyomán kerülnek értékes adatok felszínre a 19. századi Szegedbelvárosi harangozó választásával, bérezésével, feladataival kapcsolatban. Kisházi-Kovács 2008. Református településről hoz vonatkozó példákat: Koppány 1985.

${ }^{71}$ Gyetvai 1987. 327.

${ }^{72}$ Dubois 1870. 360-367; Kerschbaumer 1872. 235-240; Schüch 1872. 590.

${ }^{73}$ Pogonyi 1908.

${ }^{74}$ N. N.1880; Gyürky 1881; Solymosi é.n. (kézirat).
} 
időszakban a váci püspök nem végzett kánoni vizitációt, így csak az előzmények körvonalazásánál vehettem hasznát ennek az értékes forrástípusnak, mely a korábbi kutatások törzsalapját képezte. Ugyanakkor az 1890 szeptemberében készített Visitatio Paterna tömörsége ellenére is tanulságos keresztmetszetet nyújt a csongrádi plébániai élet müködéséröl. ${ }^{75}$

Végezetül, a csongrádi plébánia históriájának bemutatása előtt néhány mondatban kitérek a csongrádi egyházi élet kutatásának történetére. Csongrád múltbéli vallási életéről az 1990-es évekig csak nagyobb, egyházmegyei szintü összefoglalók és sematizmusok nyomán kaphattunk töredékes képet. ${ }^{76}$ A későbbiekben napvilágot látott történeti munkák közül Molnár Antal tanulmányait érdemes kiemelnünk. ${ }^{77} \mathrm{~A}$ váci egyházmegye alsópapságának, köztük 18. századi csongrádi plébánosok könyvállományának összetételéről Holl Béla emlékkönyvében tájékozódhatunk. Holl kimutatásaihoz ugyan nem készített értelmező összegzést, a tényadatok alapján releváns következtetések vonhatóak le a korabeli papság műveltségéröl. ${ }^{78}$

Csongrádon a kitünő forrásadottságok és az időnként fellángoló lelkesedés ellenére a mai napig nem készült helytörténeti monográfia. Az 1970-es években Tari László szerkesztésében olyan forrásértékü publikációk láttak napvilágot, melyekben visszaemlékezések, kéziratos feljegyzések nyomán tárul fel Csongrád és a plébánia története. ${ }^{79}$ Váry Gellért, csongrádi születésű piarista pap visszaemlékezéseit reprint kiadásban, jegyzetekkel ellátva adták közre 1974-ben. ${ }^{80}$ Erdélyi Péter, Gát László, Licsicsányi István, Sebestyén István helytörténészek áttekintő, ismeretterjesztő munkáikban, várostörténeti-kronológiai összeállításaikban kisebb-nagyobb hangsúllyal tárgyalják az egyházi élet működésének kérdéseit. ${ }^{81}$ Ezek az írások föként az MNL CsML Csongrádi Fióklevéltárában található történeti iratokra támaszkodnak.

Csongrád egyházi élete önálló témaként helyi, megyei és országos szintü napilapokban, folyóiratokban bukkant fel afféle érdekességként, Bodnár József, Hegyi Antal majd Szedlacsek István plébános jóvoltából. ${ }^{82}$ A Szegedi Hírmondóban rendszeresen jelentek meg írásos beszámolók csongrádi egyházi ünnepekről, eseményekről,

\footnotetext{
75 VPL Vis. Pat. 1890.

${ }^{76}$ Schematismus cleri dioecesis Vaciensis in annum a Christo nato [...]; Chobot I. 1915; II. 1917; Zsilinszky 1898; Rajz 1943; Bánk (szerk.) 1970; Varga Lajos 1997; Patkóné Kéringer 1997; Török-Legeza 2001.

${ }^{77}$ Molnár Antal 2001; 2004/b.

${ }^{78}$ Holl 2000.

79 Tari 1977.

${ }^{80}$ Váry 1974.

${ }^{81}$ Erdélyi Péter 1998; Gát 2006; Sebestyén 2002; Licsicsányi 2011.

82 Bodnár 1864; Hegyi 1894; Szedlacsek 1924.
} 
leggyakrabban Szappanos János tanító tollából. Hogy Csongrád általános egyháztörténete mégsem ismeretlen a tudomány számára, az Dudás Lajos helytörténész munkásságának köszönhető. Dudás helyben hozzáférhető források (Historia Domus, plébániai iratok, helyi és megyei sajtóanyagok) alapján állította össze tanulmányait, melyek 1994-től az Oppidum Csongrád helytörténeti évkönyv hasábjain láttak napvilágot. Ezek az áttekintések az Árpád-kortól a 20. század közepéig tartalmazzák a csongrádi egyházszervezettel kapcsolatos, alapvető tudnivalókat. ${ }^{83}$

Ugyan Csongrádon minden időben jelentős volt a római katolikus többség, a más vallásúak egyházi élete is számot tartott a kutatói érdeklődésre. A csongrádi zsidóságról Majzik Zsanett, a reformátusokról Ekecsi Erzsébet készített szakdolgozatot, míg Bereznai Zsuzsanna az adventistákról tett közzé értekezést. ${ }^{84}$

A csongrádi plébániákhoz, plébánosokhoz közvetlenül kapcsolódó írások száma csekély annak ellenére, hogy a templomok szertartásrendje, a piroskavárosi templom és a ferencesek története viszonylag korán került a kutatói érdeklődés homlokterébe. ${ }^{85}$ Hegyi Antal plébános személye Erdélyi Péter és Tánczos Roland figyelmét is felkeltette. Míg Erdélyi Péter Hegyi plébános amerikai emigrációjának emlékeit tette közzé, Tánczos a nevezett plébános politikai tevékenységének tanulságait vette számba. ${ }^{86}$ Legújabban Kovácsik Antal tekintette át Porubszky József plébános csongrádi működésének tanulságait. ${ }^{87} \mathrm{~A}$ céhek vallási megnyilvánulásaival, a plébániához kötődő vallási társulatok kérdésével e sorok írója foglalkozott. ${ }^{88}$ Egyházszolgákkal kapcsolatban mindösszesen egyetlen munka született: Dudás Lajos 2001-ben a kezdetektől a 20. század végéig vette sorra Csongrád kántorait. ${ }^{89} \mathrm{~A}$ jelenlegi munka egyik célja tehát, hogy enyhítse a hiányzó csongrádi plébániatörténeti írás keltette ürt, egyben rendszerbe foglalja és kiegészítse a korábbi kutatások eredményeit, hogy helytörténeti írásként is hasznosítható legyen.

\footnotetext{
${ }^{83}$ Dudás 1996; 1997; 1998; 1999/a; 2000.

${ }^{84}$ Majzik 2009. (kézirat); Ekecsi 1999. (kézirat); Bereznai 1989/b.

${ }^{85}$ Gacsári Kiss 1983; Dudás 1999-2000.

${ }^{86}$ Erdélyi Péter 1993; Tánczos 2006.

${ }^{87}$ Kovácsik 2010.

${ }^{88}$ Gyöngyössy 2010/c.

${ }^{89}$ Dudás 2001.
} 


\section{CSONGRÁD EGYHÁZ- ÉS TÁRSADALOMTÖRTÉNETE A 18-19. SZÁZADBAN}

1. Rövid plébánia- és településtörténet

Csongrád a 18. század elején erősen falusias jellegü, lassan gyarapodó település volt. Területe még alig jelentett többet a vízzel körülölelt Belsővárosnál, szívében a meszelt falú, Nagyboldogasszony tiszteletére szentelt (mai Szent Rókus) templommal. A templom 1722-ben épült fel, 18 évvel az első „török utáni” plébános, Goricsánszky Mihály érkezése után. $^{90}$ Goricsánszky 1704-1706 között még egy apró, Szent Istvánról nevezett nádkápolnában misézett, melyet később fából készítettek el. A kápolna a következő években többször a tűz martalékává vált, így a plébános szabadtéri oltárnál volt kénytelen misézni. ${ }^{91}$ Schlick Lipót adományozott egy korábban katonai raktárként működő épületet az egyháznak, hogy templommá alakíthassák át.

A római katolikus plébános mellett ekkoriban a szegedi és kecskeméti rendház ferencesei látták el a csongrádi hívek és a filiák lakóinak (Algyő, Csány, Ellés, Felgyő, Tés, Újfalu $^{92}$ ) lelki gondozását; kiszolgáltatták a szentségeket, miséztek, prédikáltak. ${ }^{93} \mathrm{~A}$ Kerekárok bejáratánál őrködő Nepomuki Szent János szobor a megkésett barokk lelkiség jelenlétéről tanúskodott. A későbbi barokk plébániatemplom helyén ekkor még temető állt, közepén a dühöngő gugahalál (1738-39-es pestisjárvány) emlékét hirdető Szent Rókus kápolnával.

A Tisza túlpartján, egészen Kunszentmártonig náddal tarkított, végeláthatatlan lápos-mocsaras rengeteg nyújtózkodott, a folyón hajómalmok és halászhajók sorjáztak. A határban ekkor még nyomai sem mutatkoztak a későbbi kiterjedt tanyavilágnak. A halászó, pásztorkodó, szőlő- és földműveléssel foglalkozó csongrádi jobbágyság 1709 után a nagykárolyi Károlyi grófoknak fizette a taksát, ám a közterhek folyamatos növekedése miatt több nehéz sorsú család inkább Szegedre és Temes megyébe indult új hazát keresni. ${ }^{94}$

A 18. század második felében a település erőteljes észak-nyugati irányú

\footnotetext{
${ }^{90}$ Palugyay Imre átvette a korai váci egyházmegyei sematizmusok azon téves információját, mely szerint Csongrád 1673 óta plébániával rendelkezö település lett volna. Palugyay 1855. 477.

${ }^{91}$ Licsicsányi 2011. 15.

${ }^{92}$ Patkóné Kéringer 1997. 33.

${ }^{93}$ 1734-ben a kalocsai érsek határozta meg a ferencesek koldulási területeit. A kecskeméti ferencesek később, kb. a 18. század közepétől gyüjthettek Csongrádon. A páterek koldulási engedélyt vittek magukkal, melyet be kellett mutatniuk a helyi plébánosnak. Péterné Fehér 2009. 52.

${ }^{94}$ Herceg 1980. 61; A grófi család kezdetben jelentős kedvezményeket adott a kis lélekszámú település lakóinak. 1756-ig mérsékelt adó ellenében müvelhették a földet, de bérelhették a kocsmákat, mészárszékeket, a pálinkafözés és a halászat jogát. 1722 és 1750 között viszont 300 forintról 4500-ra emelkedett az adó mértéke. Erdélyi Péter 1998. 6-7.
} 
terjeszkedésnek indult. A lakóházak körülfogták a régi temetőt, melynek helyén az 1762-es esztendőben Fábián István plébános gróf Károlyi Antal földesúrral összefogva új templom építésébe kezdett. ${ }^{95}$ A Károlyi család és a csongrádi hívek adakozásából két évtized alatt fejezték be a mennybe fölvett Boldogasszony tiszteletének szentelt, klasszicizáló barokk stílusú „külsővárosi” templomot. Az időközben lebontott Szent Rókus kápolna berendezése és dedikációja a mai Szent Rókus-templomra hagyományozódott, mely 1784 után filiaként müködött.

Vintze Gergely plébánossága idején (1734-1757) Csongrád föesperesi székhellyé lépett elö. ${ }^{96}$ A Historia Domust Vincze István plébános kezdte el vezetni 1774-ben, melyben egészen 1704-ig visszanyúlva ismertette a plébániaközösség történetét.

Az 1770-es években a plébániatemplom közelében épült fel a mai városháza előde, az uradalmi gazdaság irodaháza. Nem sokkal később már sörház, mészárszék, kocsma és két vendégfogadó (Szarvas, Fehér ló) működéséről tanúskodnak a források. ${ }^{97}$ Kanyó András plébános összeírása szerint 1783-ban Csongrád kb. 5700 lakosa közül mindössze ezerszázan éltek a Belsővárosban (Oppidum vetus), a többség már ekkoriban a külsővárosi Nagyboldogasszony-templom és a Tisza által közrefogott területen építette fel otthonát. ${ }^{98}$

A településkép a 19. század közepéig nem mutatott jelentős változást. Határai a mai Dob, Fohász, Szép, Kereszt és Zrínyi utcáig terjedtek, a temető a településen kívül esett. Herkeváros még libalegelő volt, a Nagyrétet a Tisza vize nyaldosta. 1850-ben elkészült a római katolikus felekezeti iskola 2 fiú és 1 leány osztállyal, öt esztendővel később kijelölték az első tanyai iskolákat. ${ }^{99}$ A piactér a Nagytemplom közelében terült el, közepén az 1869-ben emelt Szentháromság szoborcsoporttal. Felgyő irányában, a város délnyugati szélén állt a híres Kaparás csárda, vele szemben az uraság serfőző háza. Ugyan a városszépítészeti bizottmány 1862-ben kísérletet tett az utcák kiegyenesítésére és a járdavonaltól beljebb eső házak előkertesítésére, az utcanevek kifüggesztése és az utcánkénti házszámozás még tervbe sem volt véve, a villanyvilágítással egyetemben. ${ }^{100}$ Csak a köznép ajkán éltek az egyes utakat, településrészeket jelölő megkülönböztetések. A

\footnotetext{
95 Dudás 1999/a. 18; Licsicsányi 2011. 18. Ekkoriban volt esedékes a napjainkban is használt temető kijelölése a várostól kellő távolságra, egy libalegelőnek használt homokdombon.

96 1835-ben a csongrádi esperesi kerületbe tartozott Abony, Jánoshida, Tápiógyörgye, Rékas, Tápiószele, Törtel, Újszász település, míg a csongrádi papokat a hódmezővásárhelyi esperes felügyelte. Patkóné Kéringer 1997. 91.

${ }^{97}$ Kruzslicz 1988. 37.

${ }^{98}$ Nagyboldogasszony Plébánia Irattára, Csongrád (továbbiakban: NPI) Historia Domus, Csongrád I. kötet, Kanyó András plébános népszámlálási adatai.

${ }^{99}$ Licsicsányi 2011. 25.

100 Dudás 2003. 97.
} 
kövezetlen köztereken sáros idöben fapallókon egyensúlyoztak a csongrádiak, a kisebb közökben libák, malacok legelésztek. ${ }^{101}$ Hegyi Antal plébános kezdeményezésére a Nagyboldogasszony-templom környéke mentesült először az állatok garázdálkodásától az 1880-as évek végén.

A nagygazda-polgárházakat jellemzően az 1850-60-as években kezdték el építeni, ám a csongrádi házak többsége még mindig sárból és fonott vesszőből készült, tetejét szalma vagy zsúpfedél borította. A középületek felhúzása ugyanebben az időszakban vette kezdetét. ${ }^{102}$ 1861-ben a település rendezett tanácsú városi rangra emelkedett, ám az ezzel járó megnövekedett terheket már nem bírta el. Csongrád így 1865-től hivatalosan nagyközségnek számított, és az is maradt még fél évszázadon keresztül. ${ }^{103}$

A folyószabályozást követően Csongrádot súlyos árvizek veszélyeztették. Az 1876os gátszakadás után az alig pár éve elindított tanítóképző intézetet Kiskunfélegyházára helyezték. Ezek az események súlyos sebeket ejtettek a csongrádi nép öntudatán, ugyanakkor a végletekig korbácsolták a gyors felzárkózás vágyát. A század második felében sorra alakultak a vallási társulatok, polgári egyletek, jótékonysági körök. Megnyitotta kapuit a Kaszinó, mely „arra van hivatva, hogy az intelligens embereket magába egyesítse és egy olyan jogi személyt alkosson, amely a derék színmagyar alföldi városnak szellemi életét irányítsa s kezdeményező legyen minden téren, ahol kulturális tekintetekről szó lehet". ${ }^{104}$ Egymást érték a díszes bálak, a politizálási kedv megugrott, vagyis: látszólag épült a polgári világ. A település lélekszáma a 19. század utolsó három évtizedében 7-8000 fővel ugrott meg: 1902-ben már közel 24.000 lakost számoltak össze. ${ }^{105}$

\section{Felekezeti megoszlás}

Csongrádot a 18. század végéig kizárólag római katolikusok lakták. Az első izraelita családok valamikor az 1790-es évek tájékán érkeztek a településre. A csongrádi zsidó hitközség 19. századi története egy dinamikusan fejlődő rétegközösség képét tárja elénk,

\footnotetext{
101 „Ha az ember a nagy utczáról belép a mellék utczába szörnyű valóságra ébredünk (sic!) akkor, ha látjuk, mint legelnek a tehenek és egyéb szarvas marhák az utczán, mint turkálják a szőke és fekete süldő malaczok a kövezetek mellékét. Itt egy kecske, amott egy birka szaggatja élvezettel az élőfák lombjait.” Csongrádi Lap, 1898. július 10. VIII. évf. 28. szám, 3. old.

${ }^{102}$ Füzesi é.n. (kézirat). 150-151.

${ }^{103}$ Exterda 1979. 252-253.

${ }^{104}$ Tiszavidék, 1908. április 12. XIX. évf. 15. szám, 3. old.

${ }^{105}$ Csongrádi Újság, 1903. október 25. I. évf. 1. szám, 1. old.
} 
mely mindössze száz év alatt jelentős politikai és gazdasági befolyásra tett szert a térségben. Az 1808/09. évi türelmi adó jegyzék szerint Csongrádon akkoriban 4 zsidó család élt, míg a hitközségi tagok száma az egész megyét tekintve mindösszesen 32 főt tett ki. Füzesi Péter a 19. század második évtizedében hat családot említ. ${ }^{106}$ A csekély létszám nem volt akadálya a Chevra Kadisa temetkezési egylet korai megalapításának (1806). ${ }^{107}$

1828-ra a csongrádi lakosok száma majdnem megkétszereződött (11.319 fő). Ekkor a kimutatásokban 25 zsidó, két görögkeleti és egy evangélikus családot tüntettek fel. ${ }^{108}$ Tíz évvel később a türelmi adót fizető családok száma még mindig 24 volt. ${ }^{109}$ Míg a szomszédos Szentesen azt is megtiltották a zsidóknak, hogy belterületen házat vásároljanak, Csongrád tucatjával fogadta azokat a családokat, akik 1848-ban a Nyitra megyei Ürményről felkerekedve kerestek új lakhelyet maguknak. Az ily módon felszaporodott csongrádi izraelita hitközség ekkoriban rendszeresítette az anyakönyvvezetést, közgyüléseiken jegyzőkönyvet vezettek. ${ }^{110}$

Az első csongrádi rabbi neve 1860 táján bukkan fel a forrásokban. Ekkorra már befejezték az impozáns zsinagóga építését (1854), mely a mai Csemegi Károly utca 7. lakóház helyén állt. ${ }^{111}$ A csongrádi zsidók többsége a 19. század végén kiskereskedelemből kereste kenyerét, ám sikeres jogtudor, újságíró, orvos, mérnök, ügyvéd és jegyző is került ki közülük.

Bár a Tisza túlpartján fekvő Szentes lakosai már a török időkben áttértek Kálvin hitére, Csongrád környékén hosszú ideig csak hírmondóként találunk néhány „erre tévedt” helvét hitvallású családot. ${ }^{112}$ A 18. század közepétől elszórt adatok vannak rá, hogy a környéken prédikáló református atyák egy-egy gyermeket megkereszteltek. ${ }^{113}$ Kanyó András plébános 1783-85-ös összeírásában viszont azt látjuk, hogy a település térségében számba vett 61 helvét hitvallású mindegyike Tésen élt. ${ }^{114}$ 1828-ban egyetlen evangélikus (lutheránus) család lakott a városban, ${ }^{115}$ számuk a század második felére 56 főre

\footnotetext{
${ }^{106}$ Füzesi 1960. (kézirat) 189.

${ }^{107}$ Ujváry 1929. 184.

${ }^{108}$ Barta 1980. 198.

${ }^{109}$ Dudás Lajos adataira hivatkozik: Majzik 2009. (kézirat)

${ }^{110}$ Gát 2006. 152.

${ }^{111}$ Az 1860-70-es években Nobel József, Hilbrun Jakab majd Weisz Lázár volt a csongrádi rabbinátus lelki vezetője. A század végén kiemelkedő jelentőségü Büchler Márton főrabbi alakja.

${ }^{112}$ Helvét hitvallású: A reformáció kálvini ágát képviselő protestáns felekezet. Dienes 2008.74.

113 1764. május 30-án Varga Katalint frater Cyprián, 1774. február 2-án Bálint Jánost Pater Paulus, 1775. június 15-én Konkoly Annát Gonday Pál református vallású keresztelte meg. NPI Születési anyakönyvek, 1764, 1774, 1775.

${ }^{114}$ Dudás 1999/a. 24.

${ }^{115}$ A protestánt egyház lutheri elveket valló ágát ágostainak is nevezték. Dienes 2008.120; Barta 1980. 198.
} 
növekedett.

A reformáció kálvini ágát képviselő első családok beköltözése a városba valamikor a 19. század derekára tehető. Lendvai Lajos helvét hitvallású uradalmi ügyvéd és katolikus felesége, Draskovits Jozefa gyermekét 1849-ben a Schönvizner (Réti) János orvos és Draskovits Rozália tartotta keresztvíz alá. ${ }^{116}$ Az 1850-es évektől találkozunk Csajági József református nemes és a lutheránus Hering József könyvkötő nevével. ${ }^{117}$ A kiegyezést követő években a Csongrád belterületén élő 16.772 római katolikus mellett 517 zsidó, 56 ágostai, 9 helvén és 2 görög katolikus lelket vett számba a csongrádi plébános. A dohánykertész és juhász-pásztor népességü uradalmi majorságban, Föll-Győ (Felgyő major) filiában az 527 katolikus mellett 27 fö helvét hitvallásút találunk. ${ }^{118}$

Bár a nehézkes kezdeteket a 19. század folyamán nem követte látványos kiteljesedés, a Csongrádon élő protestánsok a közismert, vagyonosabb réteghez tartoztak, tisztes polgári foglalkozásokat üztek. 1895-ben a csongrádi föszolgabíró és a szolgabíró is református vallású volt, akárcsak a községi alorvos, Borsos János. ${ }^{119}$ Borsos fia, Imre így emlékezett vissza az 1890-es évekbeli állapotokra: „A város 99 százaléka katolikus volt. Édesapám, Szomodi Antal késesmester és Bagossy József kereskedő képezték Csongrádon a református egyházat. Ök hárman felkérték Vannay Ferenc rajztanárt a református vallás oktatására, és ezért kapott szüleinktől havi 5 forintot. Mindössze ketten voltunk tanítványai: Szomodi Pista és én." ${ }^{120}$ Vannay Ferenc tehetséges festő is volt, így Hegyi Antal plébános tőle rendelte meg a Nagyboldogasszony-templomban ma is látható Mária Mennybemenetele (1894) és Szent Anna (1896) oltárképeket. ${ }^{121}$

A csongrádi protestánsok eleinte csak Szentesen hallgathattak istentiszteletet. A 1920. század fordulóján viszont már a Központi Elemi Iskolában ${ }^{122}$ vagy a Polgári Leányiskolában ${ }^{123}$ mondott prédikációt Futó Zoltán és Gerőc Lajos szentesi lelkész, nagyobb ünnepeken Pap Lajos körlelkész. ${ }^{124}$ A csongrádi református fiókegyházat hivatalosan 1904. október 31-én alakították meg a polgári leányiskola rajztermében. ${ }^{125}$

\footnotetext{
${ }^{116}$ NPI Születési anyakönyvek, 1849. február 14.

${ }^{117}$ NPI Születési anyakönyvek.

${ }^{118}$ NPI Historia Domus, Csongrád I. kötet, 113.

${ }^{119}$ Csongrádi Közlöny, 1895. november 16. II. évfolyam 51. szám, 3. old.

120 Jánosi 1983. 70.

121 Váci Püspöki és Káptalani Levéltár, Acta Parochiarum Csongrád. (Továbbiakban: VPL APar. Cs.) 1898. augusztus 27. Püspöki szentszéki kihallgatási jegyzőkönyv, Vannay Ferenc vallomása.

${ }^{122}$ Ma: Nagyboldogasszony Római Katolikus Általános Iskola

${ }^{123}$ Ma: Ének-Zenei Általános Iskola

${ }^{124}$ Csongrádi Újság, 1903. december 20. I. évf. 9. szám, 3. old; Csongrádi Újság, 1904. október 23. II. évf. 43. szám, 2. old.

${ }^{125}$ Csongrádi Újság, 1904. október 30. II. évf. 44. szám, 2. old.
} 
3. Ferencesek, jezsuita szerzetesek hatása

A kecskeméti, kisebb számban a szegedi rendházból érkező ferences atyák a csongrádi plébánosok állandó segítői, a hívek önfeláldozó pásztorai voltak. Egyszerü életvitelükkel már a török időkben elnyerték a nép rokonszenvét, és ez a kötődés a 19. század folyamán tovább erősödött.

A kecskeméti szalvatoriánus rendház főnöke ${ }^{126}$ állandóan biztosította legalább egy kolduló barát jelenlétét Csongrádon, aki prokurátor minőségben ${ }^{127}$ a tanyák között és a filiákon munkálkodott a templomtól távol élő nép lelki üdvéért: gyóntatott, temetett, keresztelt, utolsó kenetet adott fel, a plébános külön kérésére misézett és prédikált. A 19. század közepétől hitoktatói minőségben is feltünt. ${ }^{128}$

A ferences barát a csongrádiak jó szívére bízta fennmaradásának ügyét: ételalamizsnát gyüjtött, ideiglenes szállást a tanyai népek biztosítottak számára. 1850 után már jellemzően a plébánián étkezett. Az 1860-as években a hívek misealapítványi pénzéből már kisebb ház bérlésére is futotta. ${ }^{129}$ A 19. századból két ferences atya, az árva megyei szlovák származású Czibulka Kristóf és Darók Konstantin nevét emelhetjük ki. Czibulka Kristóf az 1830-as évektől kezdve állandó segítője volt a csongrádi papságnak. A szerzetes kezdetben Kovács Gergely nagygazda házánál lakott, majd az 1850-es évektől házat bérelt Csongrádon. 1858-ban felkérték tanyai iskolai hitoktatónak, melyet Czibulka díjmentesen elvállalt. Czibulka „magániskolája”, ahol tanítványait többek között latin nyelvre is oktatta, az akkori csongrádi felfogás szerint a „legfelsőbb tudományos fórum” volt a településen. Nem tudott tökéletesen magyarul, így többször került mulatságos, félreérthető helyzetbe. ${ }^{130}$

A ferences atyák tevékenységének hatására Csongrádon már a 18. század közepén ott találjuk a Seraficus Szent Ferenc kordás társulatot, mely mind anyagilag, mind

\footnotetext{
126 Szalvatoriánusok, obszervánsok (Strictioris observatiae): Az olaszországból kiinduló irányzat célja a Szent Ferenc által rögzített regulákhoz való, szigorú visszatérés volt. A mozgalom a 14. században jelent meg Magyarországon. 1517-ben, a Capitulum Generalissimum nyomán történt meg a salvatoriánusok és marianusok (konventuálisok) kettéválása. Az obszervánsok eleinte föként az ország déli vidékein alapítottak kolostorokat. Hunyadi János kormányzó majd fia, Mátyás erőteljesen támogatta törekvéseiket. Mályusz 2007. 272; M. Kat. Lex. XII. 543.

127 Prokurátor: A latin procurator (helytartó) szóból. Kisebb koldulási és pasztorálási területért felelős szerzetes. M. Kat. Lex. IV. 751.

${ }^{128}$ Magyar Nemzeti Levéltár Csongrád Megyei Levéltára, Csongrádi Fióklevéltára V.B.42. Csongrád Város, 1865-1872-ig Nagyközség Tanácsának iratai. Tanácsülési jegyzőkönyvek (Továbbiakban: MNL CsML CsL V.B. 42.a) 1858. január 22. jk. 40. sz.

${ }^{129}$ VPL APar. Cs. 1868. december 24. Mátray Rafael levele a váci püspökhöz.

${ }^{130}$ Váry 1974. 26-28; 201-203; MNL CsML CsL V.B. 42.a. 1858. január 22. jk. 40. sz.
} 
irányítását tekintve független volt a csongrádi plébániától. ${ }^{131}$ II. József feloszlató rendelete után a Harmadrend csak a 19. század második felében alakul újjá Csongrádon. Az alig pár tagot számláló jámbor egyesület 1895-ben a rózsafüzér társulattal közösen készíttette el Szent Domonkos és Szent Ferenc életnagyságú szobrát. ${ }^{132}$ A ferences gyökerü rendi kultuszok közül a 18-19. század folyamán Szent Ferenc és Szent Anna, később Szent Antal tisztelete vált kiemelkedővé Csongrádon.

A ferencesek mellett a vándor jezsuita prédikátorok, később a népmissziós körutak újították meg a csongrádi hívek lelki életét. Forrásaink arról tanúskodnak, hogy a 18. században nem mindenhol látták szívesen a világ végét hirdető prédikátorokat. 1759-ben egy Páter Péntek nevezetű jezsuita szerzetest utasított ki Berinkey Márton csongrádi plébános, aki viszont Szentesen kedvező fogadtatásra lelt. Sőt: „,a csongrádiak seregestül oda mentek, és mindnyájan szemeikkel látták, hogy beretvákkal vagdalta a maga hátát, és a jövendőket mind megmondotta". ${ }^{133}$

A helyi egyházszervezet megerősödése után kevésbé volt jellemző a jezsuita papok jelenléte a térségben. A 19. század utolsó évtizedeiben a népmissziós atyák csoportosan járták a településeket, hogy hitükben erösítsék és lelki megújulásra buzdítsák a jámbor katolikusokat. Csongrádon az 1889-es, január 30-tól február 14-ig tartó misszióról maradt fenn pontos leírás. Ekkor három jézustársasági atya (Flódung József, Mladonicki Ferenc, Hippich István) vezette a missziót, melynek során naponta három misét és szentbeszédeket tartottak. Hegyi Antal plébános beszámolója szerint az atyák hatására 12 ezer iskolás gyermek és számos felnőtt gyónt meg, „köztük igen sok úgynevezett régi gyónó, kik hosszú idő óta nem járultak a töredelem szentségéhez. Több vadházasságban élő pár is fölhasználta a kegyelem napjait és töredelmes gyónás után törvényes házasságra lépett. A három utolsó nap a betegeket látogatták meg a fáradhatatlan atyák, nagy lelki haszonnal". ${ }^{134}$ A gyóntatások hajnali négytől este hétig folyamatosak voltak, a prédikációk a hallgatók neme és életkora szerint különböztek. A két hetes misszió emlékére a csongrádiak keresztet állította a főoltár mellé, melyen aranyozott betűkkel tüntették fel a jeles dátumot. A misszió költségét, az atyák ellátását és tiszteletdíját részben a helyi

\footnotetext{
${ }^{131}$ A kecskeméti ferencesek 1756-ban alakították meg világiak számára a harmadrendet. 1782-ben II. József feloszlata őket, és csak 90 év után szerveződtek újjá. Péterné Fehér 2009. 42. A csongrádi kongregáció és a plébános közti konfliktusról a későbbiekben értekezünk. V.ö. VPL APar. Cs. 1767. december 24. A Seraficus Szt. Ferenc kordás társulat jegyzőkönyve. Bálint Sándor azt feltételezi, hogy a csongrádi kordás társulatot is a szegedi ferencesek irányították. Bálint 1974. 117.

${ }^{132}$ Csongrádi Közlöny, 1895. március 10. II. évf. 10. szám, 3. old.

133 Tari 1977.

${ }^{134}$ VPL APar. Cs. Hegyi Antal beszámolója, kitépett lapok a csongrádi Historia Domusból. 149.
} 
plébánia, részben a hívők közadakozása biztosította.

A misszió lelki hatásai a plébánost sem hagyták érintetlenül: a jezsuita atyák érkezésének híre már elegendő erőt adott Hegyi Antalnak ahhoz, hogy a váci püspöki székkel elmérgesedett viszonyát rendezve „,a béke szálait ujból felvegye”. ${ }^{135}$ Később, 1905-ből szerzünk tudomást a jezsuita atyák újabb csongrádi missziójáról, mely hasonlóképpen zajlott, mint 1889-ben.

4. Lelkiség és társadalom. A csongrádi hívek a 19. század derekán

Csongrád a 18. század elejétől a nagykárolyi Károlyi grófok birtoka volt. A tagosítást követően az egykori földesúri család a plébániatemplom kegyuraként kötődött a településhez. A csongrádi egész telkes jobbágyok számát Fényes Elek 1851-ben 400-ra becsülte. ${ }^{136}$ Palugyay Endre a Csongrádhoz tartozó pusztákkal együtt 1271 házszámról ad tudósítást. A családfők közül 6 „urasági” (uradalmi) jobbágy, 360 telkes jobbágy, 878 keresztény vallású zsellér, 16 zsidó zsellér. A telkes jobbágyokat tekintve 22 család gazdálkodott 2 egész teleknél nagyobb területen, 1-től 2 teleknagyságig összesen 127. Legnagyobb számban tehát házatlan zselléreket és egy sessionál kisebb területet müvelő jobbágyokat találunk a 19. század közepén Csongrádon. ${ }^{137}$

A rendiség korából megörökölt adottságok a tagosítást követően nem változtak; az 1860-as években Csongrád társadalmának zömét még mindig a 0-5 és 5-10 holdas törpeés kisbirtokosok, illetve a föld nélküli szegények, majorsági cselédek alkották. Ahogy Váry Gellért írja: ők voltak Csongrád népe ${ }^{138}$.

A csongrádi tanyai lakosság a Dél-Alföld többi mezővárosához hasonlóan a 19. század végére gyarapodott fel. Az 1770-es években még mérföldeket lehetett bejárni anélkül, hogy egy állandóan lakott tanya felbukkant volna a környéken. ${ }^{139}$ Az 1786-89-es, II. József-féle kataszteri felmérés idején Csongrád külterületén 318 szállást találtak, ám ezeket csak a nagyobb nyári földmunkák idején használták ideiglenes lakóhelyül. ${ }^{140} \mathrm{~A}$ tagosítással párhuzamosan a tanyásodás is lendületet vett; a 19. század közepétől egyre

\footnotetext{
${ }^{135}$ Váci Püspöki és Káptalani Levéltár, Acta Pivatorum (továbbiakban: VPL APriv.) Hegyi Antal, 1889. január 4. Hegyi Antal levele a váci Egyházmegyei Hatósághoz.

${ }^{136}$ Fényes 1851. I.225.

${ }^{137}$ Palugyay 1855. 476-477.

${ }^{138}$ Váry 1974.86.

${ }^{139}$ Zsilinszky 1898. 295.

${ }^{140}$ Kruzslicz 1988. 36.
} 
több adat áll rendelkezésünkre állandóan lakott tanyákról. ${ }^{141}$ A századforduló környékén a csongrádi lakosok egyharmada külterületen élt. A tanyai iskolák felállítása 1855-ben vette kezdetét, összesen 13 iskola létesült. ${ }^{142}$ A káplánok olykor kihelyezett szentmiséket tartottak a szegényesen berendezett tantermekben, nagyobb ünnepek előtt az iskola tanítója vezette az imaórákat. Az iskolák melletti haranglábak és keresztek költségeinek fedezésére Virter Lajos plébános szervezett gyűjtést a polgármester kérésére. ${ }^{143}$ A ritka lelkipásztori jelenlét okán kitermelődő szakrális népi önellátás vagy önszerveződés jelensége ${ }^{144}$ a csongrádi forrásokban alig érhető tetten. Tény, hogy a téli imádkozó esték, a Lourdes-i ájtatosság, a Szent Család-járás, a betlehemezés szokása jóval hamarabb kopott ki az anyatelepülésről, mint a tanyákról.

A halászó, földművelő és állattartó lakosság vallási életének sajátos részét képezte a különböző termény- és jószágpatrónusok tisztelete. ${ }^{145}$ A 19 . század második felére jóformán minden foglalkozási réteg megtalálta a maga speciális védőszentjét. A csongrádi szőlősgazdák 1856-ban Szent Urbán (Orbán) szobrot készíttettek a haleszi szőlők közé, ahol minden év május 25-én búcsúra gyültek össze. A szőlöbeli gazdáknál szervezettebb keretekre utalnak a csongrádi juhász- és pásztorsereg fennmaradt tárgyi emlékei. Egy 1881-ben készült inventárium szerint a juhászok társulata saját templomi lobogóval rendelkezett. ${ }^{146}$ Festett-faragott perselyük feltehetően 19. század eleje óta díszíti a Szent Rókus-templomot. 1820-ban közadakozásból készült a település határán kívül eső Szent Vendel homokkő szobor.

Nepomuki Szent János nem tekinthető kizárólag a halásznép rétegszentjének. Csongrádon az első Nepomuki szobor a vízzel körülvett Belsőváros bejáratánál állt. Az készítés pontos dátumát nem ismerjük, legkorábbi említése 1783-ból származik. Minden valószínűség szerint ez volt a Csongrád első köztéri szobra. Az ábrázolt szent csongrádi kultuszáról egyetlen feljegyzés maradt fenn, mely arról tanúskodik, hogy napját (május 16.) díszes körmenettel, búcsúval ünnepelték meg, legendáját a csongrádi hívek énekelve

\footnotetext{
${ }^{141}$ 1842. november 26-án, egy Julis nevű kisleány neve mellé a következő megjegyzés kerül a születési anyakönyvben: „Tanya alatt találtatott, kitétettvén Sváb Lörincz tanyája alatt.” NPI Születési anyakönyvek, 1842.

142 Gyovai B. 1989. 186.

${ }^{143}$ Magyar Nemzeti Levéltár Csongrád Megyei Levéltára, Csongrádi Fióklevéltára XV. 33. Iratmásolatok XVIII-XX. sz. (Továbbiakban: MNL CsML CsL Iratmásolatok) 1855. szeptember 5.

${ }^{144}$ Bálint 1980. 321.

${ }^{145}$ A szentek tiszteletéröl Csongrádon bővebben lásd. Gyöngyössy 2010/b.

${ }^{146}$ Egy 1881-ben készült inventáriumban találunk utalást a 100 forint értékü ,juhász társulati zöld lobogó”-ra, mely a budapesti Kriszta és Leitner cégnél készült. V.ö. VPL APar. Cs. 1881. Edelényi János plébános beiktatásakor készült inventárium.
} 
elevenítették fel. ${ }^{147}$ A 19. században a szentnek három szobra állt a határban: kettő a Tisza partján, egy a Belsőváros bejáratánál. A Nagyboldogasszony-templomban a 18. század végén olajképpel ellátott kőoltárt emeltek a vízen járók védőszentjének. A templom homlokzati oromfülkéjében szintén Nepomuki Szent János szobra található.

A település a 18-19. század folyamán sokat szenvedett a különböző járványoktól (pestis 1738-39, kolera 1831, 1893), árvizektől (kiemelkedően az 1866, 1876 és 1888 években), szárazságtól (1862, 1866); a jószágokat gyakran tizedelték különböző betegségek, föleg a száj- és körömfájás. ${ }^{148} \mathrm{Az}$ 1738-ben dúló pestisjárvány vagy gugahalál a csongrádi lakosok közel egyharmadát elpusztította. Vintze Gergely plébános az Oltáriszentséget hordozva körmenetet tartott a település körül, majd a lakosok fogadalmat tettek, hogy Szent Rókus pestistől óvó szent ünnepét mindig különös pompával fogják megtartani, ha a patrónus megmenti őket a pusztulástól. A csongrádiak tisztelete Szent Rókus iránt a 18-19. század folyamán töretlen maradt. ${ }^{149}$

A csongrádi nagygazdák olyan egykori, nagyobb telkes jobbágyok voltak, akik az 1850-es évektől kezdve az örökváltság jelzálog alá vett földjeit bérelték. 1858-tól a bérlők ezeket a területeket felvásárolhatták, így vagyonosodásuk felgyorsult. A frissen kialakuló nagygazdarend a következő évtizedekben a település irányítását is meghatározta. ${ }^{150} \mathrm{~A}$ több száz holdas csongrádi nagygazdák életmódja, mentalitása, viselete az 1850-60-as években alig különbözött a kis- és törpebirtokos parasztokétól. ${ }^{151}$ A legfontosabb különbség a cselédek, summások tartása és az ökrös szekér volt.

A vagyoni vagy rangbéli emelkedés az életmódváltozás nyomásával is együtt járt. Világos elképzelések éltek arról, hogy bizonyos rangon felül mit és miként kell enni, inni, felölteni, hogyan kell viselkedni. Kókai István bíróvá választása után már nem „illett” szalonnát és zöldpaprikát reggeliznie, viszont hivataltársai lelkesen ajánlgatták neki a kávézás szokásának felvételét. Bíró uram lelkiismeretesen megpróbálkozott a kávéfőzéssel, ám a rántásként elkészített, kőkemény kávébab nem nyerte el tetszését. ${ }^{152} \mathrm{~A}$ „csongrádi parasztnábobként” emlegetett Bagi Józsefről tucatszámra jegyeztek fel olyan anekdotákat,

\footnotetext{
147 „Ide korábban búcsút vezettek, körmenetben vonulva énekelték a szent tragédiáját. A csónakon felvonuló halászok koszorút dobtak a Tiszába." Hiv. Dudás 1989. 230.

${ }^{148}$ V.ö. Tari 1977.

${ }^{149}$ Szent Rókus csongrádi tiszteletéről bővebben lásd: Gyöngyössy 2010/b.

${ }^{150}$ Sebestyén 1998. 79.

${ }^{151}$ Ahogy Bagi Józsefről feljegyezték: „Ö rajta sem viseletében, sem táplálékában semmit sem változtatott a nagy vagyona. Az egyszerü tarhonya levest csak úgy ette, mint az ő legutolsó bérese. [...] A háza sem mutatta, hogy Csongrád leggazdagabb emberének a lakása [...]” Váry 1974. 129-130.

152 Váry 1974. 96.
} 
melyek az úri attitüd felvételének nehézségeiről árulkodnak. ${ }^{153}$ A csongrádi nagygazdák istenfélő ember módjára jól tudták, mivel tartoznak a Teremtőnek. Bőkezű adományaik nyomán folyton szépült a templom, szaporodtak a határban a szobrok és a keresztek. Példaként említve Csányi Forgó István állattartó csongrádi nagygazdát, aki 1857-ben egy Szent Vendelt ábrázoló fogadalmi képet festetett a plébániatemplom számára. ${ }^{154}$

Csongrádon Mária Terézia országlása idején szilárdult meg egy szük, ám annál öntudatosabb iparos-kézműves réteg. ${ }^{155}$ 1850-ben Palugyay Endre 66 szűcsöt, 61 takácsot, 59 ácsot, molnárt és kőmüvest, 44 csizmadiát, 35 szabót, 27 kovácsot és kerékgyártót, 24 lakatost, asztalost és bodnárt vett lajstromba, akik 7 céhen belül munkálkodtak. ${ }^{156}$ Bár működésük példátlanul gazdag vallási motívumokban, a céhek elsősorban szakmai érdekvédelmi szervezetek voltak, melyek a kor általános lelkiségének megfelelően szoros kapcsolatban álltak a helyi plébániával és a plébánossal. A céh patrónusának képével ellátott zászlókat csak a céhtagok temetésén és nagyobb körmeneteken használták. ${ }^{157}$ Ezek egészen a 19. század végéig a Nagyboldogasszony-templom első és hátsó traktusában ékeskedtek. ${ }^{158}$ A csongrádi céhek vallásgyakorlásáról a megyei és országos sajtó elszórt tudósításaiból alkothatunk képet. A Katholikus Néplap 1862. márciusi számából kiderül, hogy a farsang utolsó három napján tartott szentségimádáson a céhek felváltva jelentek meg. ${ }^{159}$ Három évvel később a Szegedi Híradó tudósít a bodnár céh zászlószentelési ünnepélyéről, melynek alkalmával a céhtagok örömzenével keresték fel szeretett plébánosukat. ${ }^{160}$

A csongrádi zsidó kereskedők a 19. század második felében jóformán egyedüliként uralták a füszer- és kelmepiacot, a magyar konkurenciák rövid müködés után szinte kivétel nélkül bezárni kényszerültek. 1850-ben Csongrádon 14 kereskedőről van tudomásunk, ám felekezeti megoszlásukról forrásunk hallgat. ${ }^{161}$ A csongrádi zsidók többsége látványosan törekedett arra, hogy életmódja, mentalitása közelítsen a magyarokéhoz. Sváb Jakab, egykori gyürükereskedőből lett milliomos gyermekeit magyaros csengésű nevekre

\footnotetext{
${ }^{153}$ Példaként lásd. Labádi 2004. 67-68.

${ }^{154}$ Szent Vendel jószágpatrónus csongrádi tiszteletéröl bővebben lásd: Gyöngyössy 2011/a; 2011/b.

155 A csongrádi céhek történeti áttekintését részleteiben lásd: Gyöngyössy 2010/c.

156 Palugyay 1855. 476-477.

157 Bizonyos, hogy a céhes temetések minden időben nagy pompával zajlottak Csongrádon. Mátyus János plébános ellen a 19. század elején merült fel a vád, miszerint egyedül a céhtagok díszes temetését volt hajlandó személyesen végezni, és csak céhes miséket celebrált. VPL APriv. Mátyus János, 1823. május 10. Csongrád város bírájának levele a váci püspökhöz.

${ }^{158}$ A csongrádi céhzászlókról részletesen lásd: Gyöngyössy 2013/a.

${ }^{159}$ Dudás 1998. 105.

${ }^{160}$ Dudás 1998. 105.

${ }^{161}$ Palugyay 1955. 476-477.
} 
kereszteltette, lányát - aki később meg is keresztelkedett - katolikus fiúhoz adta feleségül. ${ }^{162}$ A katolikus szokásokat tiszteletben tartották, sajátos módon meg is ülték. Erről a törekvésről tanúskodik egy 1862-böl fennmaradt újsághír, mely a nagyszombati föltámadási körmenetről számol be: „Harminc zászlót, tíz keresztet, a Szent Szűz szobrát, s a koronatársulat jelvényét vitték a körmeneteken. Tarackok durrogtak, a templom körüli köz és magánházakat, még az izraelitákét is kivilágították."163

A nagygazdák, kis- és törpebirtokos földmüvelök, idénymunkások, majorsági cselédek életmódjától, mentalitásától egyre határozottabban különültek el az ún. tisztes osztálybeliek. A községi elöljárók száma a század derekán alig 20 föt tett ki. ${ }^{164}$ A Bach korszak hivatalnokai - egyetlen Beamter kivételével - mind magyarok voltak. Mivel a kérdéses adóügyi hivatalnok egy szót sem tudott magyarul, nem is érintkezett senkivel, így a nép csak Nemszólok Marciként emlegette. ${ }^{165}$ A csongrádi kaputosok ${ }^{166}$ a szomszédos Kiskunfélegyházával ellentétben nem éltek kiemelkedő jómódban. Kádár Henrik jegyzőnek, későbbi rangos megyei tisztviselőnek volt egy háza, némi földje, szőlője és a fizetése. ${ }^{167} 1850-1861$ között a tisztviselök hétköznapi viselete a keménykalap, pantallós nadrág és a frakk volt, ünnepnapokon viszont zsinóros díszruhát vettek fel. ${ }^{168}$

A csongrádi tanult értelmiségi réteg, korabeli szóhasználatban intelligenczia aránya még az 1850-es években is igen csekély volt. 1828-ban Csongrád 11.319 lakosa között mindössze hat értelmiségit találunk. Foglalkozásukat forrásunk nem jelöli. ${ }^{169}$ Váry Gellért leírása szerint a környező nagyobb településekkel ellentétben a csongrádi tanult értelmiségiek egytől egyig idegen származású beköltözők voltak. „Ennek tán az egyik oka, hogy a törzsökös csongorádi embereknek a csongorádi mondás szerint nem igen volt kedvük sohasem tizenkét iskolát kitanulni." ${ }^{170}$ Sokatmondó adat, hogy a mindössze öt esztendeig működő csongrádi tanítóképző intézet 74 növendékéből mindössze 7 tanuló volt helybéli születésü. ${ }^{171}$

\footnotetext{
162 Váry 1974. 133.

${ }^{163}$ Idők Tanúja, 1862. április 23. Hivatkozik rá: Dudás 1999/a. 105.

164 Az 1850-es években a következő hivatalok léteztek Csongrádon: polgármester, főjegyző, aljegyző, kapitány, 5 tanácsnok, ügyész, pénztárnok, mérnök, számvevö, orvos, katonai biztos, írnok, városi gazda és gyakornok.

165 Váry 1974. 126.

166 Kaput: Eredetileg katonaköpeny, a 19. században már hosszú, kabát-szerü férfiviselet. Kaputosoknak az efféle polgárias viseletü értelmiségieket, hivatalnokokat nevezték.

167 Váry 1974. 126.

168 Váry 1974. 53.

${ }^{169}$ Barta 1980. 198.

${ }^{170}$ Váry 1974. 136.

${ }^{171}$ Gát 1982. 174.
} 
Hogy milyen elképzelése volt egy tanítónőnek a képzettségéhez méltó, tisztes életmódról, arról világos képet kaphatunk Pehm Mária 1867-es keletkezésü leveléből. A tanítónő majdnem két esztendőn keresztül nem kapott fizetést, így fokozatosan feladni kényszerült kényelmes életét. Mint írja, cselédjét télvíz idején elküldte, húslevest már régóta nem evett, ruházata elrongyolódott és kalap, kesztyü nélkül, kendővel bekötött fejjel kénytelen járni, ,mint bár mely szegény sorsú mesteremberné”. ${ }^{172}$ Hogy fenn bírja tartani magát, külön kézimunka órákat tartott az úri- és a parasztleánykáknak.

Ami a csongrádi elemi iskolai képzést illeti, 1850-ben egy római katolikus iskolában, 4 tanító felügyelete alatt müködött fiúk számára kettő, leányoknak egy osztály. A fiú osztályokba ekkoriban 366 fő, a leányokéba 273 fő járt. ${ }^{173}$ A módosabb szülök szívesebben járatták magántanítóhoz gyermekeiket, mintsem a zsúfolt iskolában, a parasztgyerekek közé kelljen szorulniuk. „Minthogy talán magam voltam száznál is több mezítlábas és gatyás gyerek közt kaputos és pantallós, a jövő évre édesapám egy magán tanuló helyre adott, ahová már Léni néném úgy is járt."174 - emlékezett vissza Meister patikus fia, Váry Gellért az 1840-es évek végére. 1850-ben a helyi értelmiségiek és nagygazdák egy része úgy vélte, nem árt, ha gyermekeik németül is megtanulnak. Bene Lajos egykori szolgabíró két német nevelőt hozatott Csongrádra, akik szorgosan oktatták a jobbmódú gyerekeket. Ez az állapot azonban csak egy esztendeig tartott, a nevelők ismeretlen okból visszamentek Pestre. Aki a helyben elérhető „legmagasabb tudományos fórumon" akarta gyermeke elméjét palléroztatni, az Czibulka Kristóf ferences atyához küldte latint tanulni. ${ }^{175}$ Csongrádon a fiúk részére 1873-tól, leányoknak 1899 után vált lehetővé a polgári iskolai képzés.

A csongrádiak „valódi” nemesnek csupán az egykori földesúri-kegyúri család tagjait ismerték, akik még lakóépülettel sem rendelkeztek a településen, látogatásuk pedig valódi szenzációnak számított. Az anyakönyvekben feltüntetett nobilitások társadalmi súlya a településen nem értékelhető. Fekete János nemes 1846-ban íródott végrendelete közepes jómódban élő családról tesz tanúbizonyságot; elosztásra került egy határbéli telek, szántóföld, egy városi ház, szőlőföld és egy ló kocsival. ${ }^{176}$

Ami a 19. század közepén egységesen fogta össze a csongrádi szegényeket és gazdagokat, müvelteket és írástudatlanokat az az érzelmes, elkötelezett vallásgyakorlás,

\footnotetext{
172 VPL APar. Cs. 1867. június 15. Pehm Mária tanítónő levele a váci püspökhöz.

173 Palugyay 1855. 477.

174 Váry 1974. 198-199.

175 Váry 1974. 201.

${ }^{176}$ MNL CsML CsL Cs. V.B. 42.e.
} 
mely nem volt mentes a szélsőségektől sem. Váry Gellért ironikusan emlékezett meg a Bach korszak csongrádi bírójának, Kókai Istvánnak különös vallási szokásairól, aki Nagyböjtben még a haját is zsír helyett vajjal kenegette. ${ }^{177}$ A Csongrádi Lap elevenítette fel azokat az időket, amikor a csongrádiak egész Nagyhéten kalap és kendő nélkül jártak, a nagyboldogasszonyi búcsút pedig nagyságrendekkel többen látogatták. ${ }^{178}$

177 Váry 1974. 95.

${ }^{178}$ Csongrádi Lap, 1897. május 9. VII. évf. 18. szám, 3. old. 
AlsóPAPSÁG 


\section{CSONGRÁD PLÉBÁNOSAI A 18-19. SZÁZADBAN}

\section{A plébánosok jogai, „kötelmei” és járandóságai az életrajzok tükrében}

A török időkben a Duna-Tisza köze a „Három város” (Cegléd, Kecskemét, Nagykőrös) kivételével jóformán elnéptelenedett, a lakosok többsége Luther és Kálvin vallását követte. A megmaradt katolikus szórványokat a kecskeméti, szécsényi, gyöngyösi és a szegedi ferencesek látogatták. ${ }^{179}$ Ugyan a bécsi Pázmáneum, a római Collegium GermanicoHungaricum valamint a nagyszombati Stephaneum is képezett néhány kispapot a váci egyházmegye számára, a lelkipásztorkodó alsópapság siralmas körülményei és a javadalmazás esetlegessége miatt számuk döbbenetesen alacsony volt. ${ }^{180}$ Tarnóczy Mátyás püspök (1650-1655) sajnálattal írta Lippay György hercegprímásnak, hogy képtelen kispapokat küldeni a nagyszombati szeminárium részére, az egész egyházmegyében pedig mindösszesen öt lelkipásztort találni. Az 1675-ben tartott garamszentbenedeki egyházmegyei gyülésen még mindig csupán kilenc pap és ugyanennyi licenciátus jelent meg. A papok közül ketten, az ordo nélküli szárazpapok ${ }^{181}$ közül tizenhatan maradtak távol. ${ }^{182}$ Erre a kihívásra a Felvidékre száműzött váci püspökök nem tudtak méltó feleletet adni. Pongrácz György (1669-1676), Dvornikovits Mihály (1689-1705) és Kollonits Zsigmond (1708-1716) már lépéseket tett a papnevelés fellendítéséért, de csak a 18. század püspökei, jelesül Althann Frigyes, Althann Károly és Migazzy Kristóf intézkedései hoztak tényleges változást. ${ }^{183}$

Csongrádot a török sereg kegyetlenkedésekkel kísért kivonulása (1686) hosszú időre visszavetette a fejlődésben. A menekülő lakosság a Tisza túlpartján lévő nádas-

\footnotetext{
${ }^{179}$ Patkóné Kéringer 1997.12.

${ }^{180}$ Pongrácz György váci püspök eképpen jellemezte a lelkipásztorok helyzetét 17. században: „Helyzetük nem irigylésre méltó [...] ha még a papok létszáma meg is engedné, hogy a licenciátusok helyét betöltsék, a legtöbb helységbe a törökök, az eretnekek, föképp az elégtelen anyagi dotáció miatt - nem menne felszentelt pap plébánosnak." Juhász 1921. 87. Az első váci egyházmegyei növendék 1668-ban kezdte tanulmányait a római német-magyar intézetben, de az egész 18. század folyamán mindössze két növendéket neveltek a váci egyházmegye szolgálatára. Nagyszombatban a 17. századi váci püspökök több ezer forintos alapítványokat tettek a kispapok képzésére. Mihályfi 1896. 233-234.

181 Licenciátus (félpap, szárazpap): Licenciával, vagyis egyházi tevékenységre jogosító engedéllyel rendelkező világi személy. Az 1689. évi baranyai megyegyülés összefoglalása szerint feladata a keresztelés, esketés, az utolsó kenet szentségének kiszolgáltatása, temetés, prédikációk és könyörgések tartása, lelki oktatás és a körmenetek rendezése volt. A 18. században a paphiány megszűnésekor e fontos intézmény elveszítette jelentőségét, a vallásos néphagyomány azonban a mai napig megörizte egyes elemeit a szentemberek, szentasszonyok személyében. A témáról bővebben lásd: Juhász 1921.

182 Török-Legeza 2001. 30. Ezen a gyülésen végül nem jelent meg a csongrádi Horváth Mihály, pedig az „Informatio” név szerint is megemlékezik róla és a többi licenciátusról. Mezősi 1939. 17.

${ }^{183}$ Bánk (szerk.) 1970; Chobot I. 1915; Forró 2000; Mezősi 1939.
} 
mocsaras lápon keresett menedéket, onnan nézték végig, ahogy a település és vele minden vagyonuk a földdel válik egyenlővé. Ekkor tűnt el Böld falu is a térképről; lakosságát a török legyilkolta vagy elhurcolta. ${ }^{184}$ A „lábadozás” évei lassan teltek.

Dvornikovits Mihály váci püspök 1700-ban visszaállította a székesegyházi káptalant és intézkedett arról is, hogy az Alföld megmaradt, nagyobb településeire kerüljön egy felszentelt plébános. Így Csongrád harminc esztendővel a török gyászos emlékü kivonulása után végre saját lelkipásztort kapott, aki 1704-ben érkezett a településre Goricsánszky László személyében.

A településnek nem volt temploma, így Goricsánszky egy aprócska, Szent Istvánról nevezett nádkápolnában misézett a Tisza partján. A kápolna helyére 1706-ban kőoszlopokkal megerősített, deszka-oldalú zsindelytetős építményt emeltek, melyet ahányszor újjáépítettek, annyiszor vált a tủz martalékává. ${ }^{185}$ Goricsánszky plébánosról sem végzettségére, sem javadalmazására vonatkozóan nem rendelkezünk adatokkal. Nincs ez másként a többi, 18. századi csongrádi plébánossal sem, kiknek életére, önfeláldozó munkásságának részleteire - az elveszett korai Canonica Visitatiok és hiányzó, vagy erősen hiányos Acta Personaliak miatt - homályt borítottak az évszázadok.

1712-ben már Decsi Mihály szolgált a településen, aki Hatvanból került Csongrádra, és mindössze pár hónapos ottlét után elhalálozott. Helyére még ugyanebben az évben Szentmiklósi Gábor Ferenc érkezett. A plébániatörténet mindössze annyit jegyez fel müködéséről, hogy „,megelégedett avval a fizetéssel, melyet előde élvezett”. ${ }^{186}$ Szentmiklósi hét éves csongrádi plébánossága után Tóalmásra majd Turára került. ${ }^{187} \mathrm{Az}$ állandó templom kérdése csak a negyedik plébános, Szegedi Mátyás idejében oldódott meg, aki 1719-től 1729-ig pasztorálta a csongrádi híveket. Az ő idejében épült fel a már említett, katonai raktárból átalakított Nagyboldogasszony (mai Szent Rókus) templom. Berkes András váci prépost 1726-ban végezte az első hivatalos egyházlátogatást Csongrádon. ${ }^{188}$ Szegediről tudjuk, hogy elődéhez hasonlóan még életében elkerült Csongrádról és Vácszentlászlón folytatta hivatását. ${ }^{189}$

Ábrahámi Pál (1729-1734) öt év csongrádi plébánosság után ugyancsak

\footnotetext{
${ }^{184}$ Erdélyi Péter 1998.

${ }^{185}$ Chobot I.1915. 24; Dudás 1999/a. 9.

${ }^{186}$ Csongrádi Közlöny, 1894. október 7. I. évf. 30. szám, 3. old.

${ }^{187}$ Chobot II.1917. 928.

${ }^{188}$ Csongrádi Közlöny, 1894. október 7. I. évf. 30. szám, 3. old.

${ }^{189}$ Chobot II.1917. 926.
} 
Vácszentlászlóra került, ahol 1740-ben elhalálozott. ${ }^{190}$ A Csongrádi Közlönyben közzétett plébániatörténetben igen szükszavúan „valami Ábrahám nevü pap”-ként szerepel, csongrádi működését 1732-ben lezártnak tekintik. ${ }^{191}$

Ugyan az első csongrádi plébánosokról alig maradt fenn adat, a 18. század közepétől forrásaink egyértelművé teszik, hogy csupa kitűnő kvalitású, jól képzett vezető került a csongrádi plébánia élére.

A csongrádi főesperesi kerület megszervezésére és a második egyházlátogatásra Althann M. Károly váci püspök kezdeményezésére, Vintze Gergely plébános idejében került sor. ${ }^{192}$ Vintze közvetlenül pappá szentelése után került Csongrádra került, itt is halt meg 1757-ben. Az 1738-as pestisjárvány idején Szent Rókus pártfogásába ajánlotta a csongrádiakat, a betegeket ő maga gondozta. ${ }^{193}$ Határozott kormányzásának, példamutató egyéniségének köszönhetően főesperessé léptették elő. Javadalmainak listáját Némethy György föesperes utasítására írták össze 1754-ben. Eszerint a csongrádi plébánosnak a 18. század közepén szántóföldet, 18 Frt értékü fát és 1000 kéve füteni való nádat biztosított a település. Emellett járt neki búza fejében évi 125 forint, 16 icce ${ }^{194}$ vaj, 1 mázsa hús ára, 20 font faggyú, 2 mázsa só, 2 hízott disznó, 100 fej káposzta vagy ezek ára. A disznóvágások után évi 8,21 forint, az ünnepi hús (nyelv) értékesítéséből 1 forint, tizenhatodból ${ }^{195} 27$ forint. A hívőktől fejenként évi 50 dénárt, keresztelésért egy kenyeret, tyúkot és 13 dénárt, gyermekágyas anya avatásáért 7,1 Frt-ot, temetésért 15 Frt-ot, koledáért (házszentelés) 6 Frt-ot szedhetett stólaként ${ }^{196}$ a plébános. Állandó bevételei így összesen évi 399,50 forintot tettek ki. ${ }^{197}$

Vintze plébános halála után a váci születésű Berinkey Márton került Esterházy

\footnotetext{
${ }^{190}$ Chobot II.1917. 673

${ }^{191}$ Csongrádi Közlöny, 1894. október 7. I. évf. 30. szám, 3. old.

192 Dudás 1999/a. 15. Föesperesség: Az egyházmegye föesperes felügyelete alatt álló, több esperességből (25) álló része.

${ }^{193}$ Tari 1977. 11. „A Historia Domus szerint igen dicséretesen müködött és kiváló egyéniség volt”. Csongrádi Közlöny, 1894. október 7. I. évf. 30. szám, 3. old.

${ }^{194}$ Icce (két messzely): 0,8484 liter

195 Tizenhatod: Az alsópapság (plébániák) a püspöktől eleinte megkapta a beszedett decima egynegyedét (quarta), majd ezt a hányadot később egytizenhatodra (sedecima) mérsékelték. M. Kat. Lex. XII. 2009. 345.

${ }^{196}$ Stóla: Jelentheti egyrészt a papság liturgikus viseletének részét, ám ebben a kontextusban temetés, esketés és keresztelés után a hívek által biztosított anyagi juttatásról van szó. Stólát a plébános, a kántor és a harangozó kaphatott. Mértékét az egyházlátogatási jegyzőkönyvekben és a laikus templomszolgák fogadószerződésében rögzítették. Hagyományosan a fizetést biztosító képviselötestülettel egyeztető megyéspüspök hagyta jóvá. A Katolikus Lexikon és Magyar Katolikus Lexikon kizárólag a plébánosra vonatkoztatva tárgyalja a stóla kérdését. M. Kat. Lex. XII. 2007. 362; Kat. Lex. IV. 1933. 450.

197 Dudás 1999/a. 16. Forrása: Szentesi Levéltár Csongrád Vármegye Nemesi Közgyülésének iratai 1753. dec. 4.
} 
Károly püspök jóvoltából, mintegy jutalomként a csongrádi plébánia élére. ${ }^{198}$ Berinkey előbb nőtincsi majd alsónémedii plébános volt. Ö tiltotta ki 1759-ben Csongrádról Páter Péntek jezsuita atyát, aki a közelgő világvégét szándékozott önostorozással demonstrálni a látványosságra fogékony nép előtt. ${ }^{199}$ Ekkoriban a település már túllépte az ősi Belsőváros határait, a lakosság örvendetesen gyarapodott, és a Nagyboldogasszonynak szentelt kis templom már szükösnek bizonyult. Minden bizonnyal Berinkey idejében indultak el az egyeztetések gróf Károlyi Antal földesúr és kegyúrral egy új templom építése ügyében, ám a gyakorlati megvalósítás már a hivatali utódra maradt. Berinkey fóesperest a mai Szent Rókus-templomban, a szentélyhez közel helyezték végső nyugalomra 1762. február 26án. ${ }^{200}$

Fábián István László a nagyszombati általános szemináriumból kikerülve előbb szegvári majd cibakházi plébános lett, innen került 1762 elején Csongrádra. Nevéhez füződik a mind méreteiben, mind kivitelezésében nagyszabásúra tervezett Nagyboldogasszony-templom alapkövének letétele. ${ }^{201}$ Fábián atya rövid, mindössze hat esztendei csongrádi plébánossága idejét - a templomépítés gyakorlati gondjai mellett - a Seraficus Szent Ferenc kordás társulat elöljáróival kialakult konfliktus keserítette meg. A nézeteltérés a plébániára vitetett egyesületi láda okán alakult ki. ${ }^{202} \mathrm{Az}$ ügy részleteivel Muntagné Tabajdi Zsuzsanna is foglalkozott tanulmányában. ${ }^{203}$ Fábián plébános 1768-ban Romhányra majd Vácra került, utóbbi helyen székesegyházi kanonok és szemináriumi rektorhelyettes lett. ${ }^{204}$ 1768-ban a csongrádi születésű Vintze István került a csongrádi plébániaközösség élére.

Vintze a római Collegium Germanicumban végezte tanulmányait. Széles látókörü, magas végzettségü pap volt. Csongrádra kerülése után egy évvel készült el a Nagyboldogasszony-templom, melynek Szent Anna oltáránál ő mondta az első szentmisét 1789-ben. Mivel a templommal párhuzamosan új plébániaépület is készült, a plébános immáron kiköltözhetett a 18. század eleje óta paplakként funkcionáló, mai Szent Rókus tér 4. szám alatt álló házból. Migazzi Kristóf püspök olyannyira becsülte jeles papját, hogy 1774-ban kihelyezett papi gyülést tartott Csongrádon. Vintze Istvánt 40 esztendős korában,

\footnotetext{
${ }^{198}$ Tari 1977. 11.

${ }^{199}$ Tari 1977. 12

${ }^{200}$ Chobot II.1917. 696.

${ }^{201}$ Chobot II.1917. 739.

${ }^{202}$ A konfliktusról később még értekezünk. V.ö. VPL APar. Cs. Seraficus Szent Ferenc társulat jegyzőkönyve 1767.

${ }^{203}$ Muntagné Tabajdi 2013. 145-146.

${ }^{204}$ Chobot II.1917. 739.
} 
Csongrádon érte a halál. ${ }^{205}$

Vintze plébánost 1778-ban Tóth Tamás követte. Tóth atya volt az első olyan csongrádi plébános, aki korábban káplánként is szolgált a településen. Az ő idejében jelentősen szépült, gyarapodott az új templom berendezése: mutációs orgonát, katedrát, márvány alapzatú keresztelőkutat, monstranciát és ezüst kelyheket szerzett. Miután Tóth Tamás a szomszédos Kiskunfélegyházára került, egyre erősödtek a panaszhangok, miszerint a fiatal plébános elméjében megháborodott: egy szentmise alatt kétszer mutatja fel a szentostyát, a szentelő szertartások során elemi hibákat vét. 1793-ban a váci, majd az egri irgalmasrendi kórházba szállították. ${ }^{206}$ 1781-ben már Kanyó András a csongrádi hívek lelki atyja.

Kanyó András személyében ismét egy szép emlékü, nagy formátumú pap került a településre. A tápiószelei születésű Kanyó csongrádi plébánosként érte el hivatása csúcsát: 1792 után kerületi föesperes és váci címzetes kanonok, majd megyei táblabíró lett. Halála előtt pár évvel a király székesegyházi kanonokká nevezte ki. ${ }^{207}$ Kanyó nevéhez kötődik az első népszámlálás Csongrádon, melynek eredményeit a Historia Domus első kötetébe jegyezte le. Ebben az 1783-85 között készült felmérésben nem csak a település és a filiák felekezeti eloszlásáról, a lakosok foglalkozásáról alkothatunk képet, de a plébánia lakói is név szerint említésre kerülnek. Eszerint a csongrádi plébánián élt egy káplán, a plébános két unokahúga (16 és 9 évesek), egy szakácsnő és két szolgáló leány (48, 17 és 16 évesek), egy szolgalegény (13 éves), egy 10 esztendős örökbe fogadott leányka és egy 20 esztendős kocsis legény. ${ }^{208} \mathrm{Az}$ összeírás szerint a filiákkal együtt Csongrád lakossága 1785-ben 6915 fő volt, ebből 61 fő református, kik Tésen éltek. ${ }^{209}$ Kanyó András példamutató buzgalommal szépítette, gyarapította a templomot. Az új harangra gyüjtés alkalmával mondott lelkesítő beszédét a Historia Domusba is bejegyezte. ${ }^{210}$ Kanyót sajátos körülmények között érte a halál: „A nagytemplomnál levő nagy kü körösztöt fölszentelte július 11-én 1802-ben. Másnap föl is ment Váczra de útjában meghalt, és Nagy Abonyban fekszik halva [...]. Meghalt 1802-ben, de nincs meghalva, mert él a tudománytul és

\footnotetext{
205 Chobot II.1917. 965.

${ }^{206}$ Chobot II.1917. 949; Tari 1977. 12; VPL APriv. Tóth Tamás, 1792. szept. 22. A kiskunfélegyházi tanács levele a váci püspökhöz.

${ }^{207}$ Chobot II.1917. 790.

208 NPI Historia Domus I. kötet, Csongrád, 180-321. A plébániai személyzet neve a későbbiekben csak elvétve maradt fenn forrásainkban. Ami bizonyos, hogy 1896-ban Forgó István volt a „parochiai kocsis”. Csongrádi Lap, 1896. március 8. VI. évf. 10. szám, 3. old.

${ }^{209}$ Dudás 1999/a. 24.

${ }^{210}$ NPI Historia Domus I. kötet, Csongrád,
} 
buzgóságtul és a kegyességtül és példáktul.”211 Kanyó Andrást, a művelt, tudós papot sokáig siratta a csongrádi nép. Ö vált állandó hivatkozási alappá akkor, amikor hivatali utódával, Mátyus Jánossal szemben panaszok merültek fel.

A domonyi születésű Mátyus János a szomszédos Csépáról került Csongrádra, mégpedig többszöri protezsálás után, „nagyságos Stösszel József a jászok és kunok fő kapitányának, nem különben Melzek János akkori főnótáriusnak barátságos kérésire, Gróf Károlyi József által". ${ }^{212}$ Fogadószerződése szerint a csongrádi plébánosnak és successorainak $^{213}$ negyedévente készpénzben lefizetendő 1200 Frt, 1000 kéve nád, 18 öl fa. Mindezért cserébe nem szedhet külön stóladíjat a hívektől. Ebbe nem tartozik bele a temetés, libera $^{214}$, impositio $^{215}$, a pluviálés szolgálattétel ${ }^{216}$, prédikációs mise és az esketés. Amennyiben nagyon megfogyna vagy szaporodna a lakosság, a tanácsbeliek nyitottságukat fejezték ki a feltételek változtatására. A szerződést 1804. július 17-én írta alá Mátyus János, a fơbíró és a csongrádi tanácsbeliek.

A csongrádi hívek és Mátyus János kapcsolatát állandó konfliktusok terhelték. Sorra születtek a fájdalmas panaszlevelek, melyek a plébános „paphoz nem illő” magatartásáról számoltak be. Vádolták többek között pénzéhséggel, a szegények iránti könyörület hiányával, a misékről való késéssel, ünnepek feltörésével ${ }^{217}$. A hívek kétségbeesetten fakadtak ki a váci püspöknek: ,annyira van már a nép között a dolog, hogy

\footnotetext{
211 Tari 1977. 13.

212 Tari 1977.13.

${ }^{213}$ Successor (lat.): utód, jogutód.

${ }^{214}$ Libera (lat.): „megszabadulni”. Korábbi századokban a holttest tényleges vagy jelképes (ld. tumba) jelenlétében végzett templomi gyászmise záró szertartása, mely egyben a temetés kezdete volt. A szertartás nevét az ilyenkor szokásos Libera me, Domine, de morte aeterna (Szabadíts meg, Uram, az örök haláltól) kezdetű énekből veszi. Sohlya Antal kántor fennmaradt tanítóképezdei jegyzeteiben a következő magyarázatot találjuk: „Így nevezendő azon szomorú szt. szertartás, mely a gyászmise végén az oltár közvetlen a szentélyben fölállított ravatal - castrum doloris - mellett végeztetik". Sohlya 1857. (kézirat) 190; Kat. Lex. III. 1932. 195; M. Kat. Lex. VII. 2002. 844.

${ }^{215}$ Impositio / Ritus impositionis ad thumbam (lat.): koporsóba tétel. A temetés előtti nap délutánján esedékes rövid szertartás, melynek lényege hogy a holttestet a pap és a kántor érkezése előtt - vagy távozásuk után - a gyászos háznál koporsóba helyezik. A pap szenteltvízzel meghinti a testet és a koporsót, míg a kántor a Circumdederunt me (Körülvettek engem a halál kínjai) kezdetü éneket énekli. A nem kötelező szertartásnak több változata is élt a 19. században. Csongrádról annyit tudunk meg Sohlya Antal kántor jegyzetei nyomán, hogy a szegényebbek csak ritkán vették igénybe a kántor vagy pap jelenlétét. Sohlya 1857. (kézirat) 39; Gyöngyössy 2010/d. 62.

${ }^{216}$ Pluviálé (lat.): pluvia, vagyis „eső” szóból származik. Elöl nyitott liturgikus ruha, palást, melyet a 18-19. században díszes csattal fogtak össze. Ha a pap a temetésen ilyen fekete színü, gazdagon hímzett pluviálét viselt, a stoláris díjak is magasabbak voltak. M. Kat. Lex. X. 1018.

217 VPL APriv. Mátyus János. Ünnep feltörése: Táj-jellegü kifejezés. Lényegét tekintve azonos az ünneprontással, melyet Bálint Sándor az ünnep keresztény méltóságának mulatozással való megszentségtelenítése, illetőleg a templomozás elmulasztásának büntetéseként jellemzett. Bálint 1998. 228. Ünnep feltörése alatt azt az esetet értették a 19. századi csongrádiak, amikor valaki szándékosan nem vette figyelembe az adott egyházi ünnephez kapcsolódó tilalmakat. Egyfajta normaszegésről van szó, melynek következményei az egész közösségre kiterjedhettek, pl. elverhette a jég a határt.
} 
ha [Mátyus János] még tovább is közöttünk marad, mind Lutheránusokká válunk". ${ }^{218}$ Nádasdy Ferenc püspök 1825-ben felfüggesztette, két esztendővel később lemondatta Mátyust a csongrádi plébánia éléről, aki szülőhelyére, Domonyba vonult vissza. ${ }^{219}$

Mátyus távozása után a csongrádi hívek maguk kerestek papot maguknak: ki is választották az akkor Kiskundorozsmán szolgáló Szabó Lászlót, aki korábban négy éven keresztül káplánkodott Csongrádon. Szabó ekkorra több évtizede Dorozsmán élt: gazdagon felszerelte a templomot, új toronysisakot csináltatott, hívei őszintén kedvelték. Kitünő egyéniségnek ígérkezett ahhoz, hogy ott folytassa a csongrádi plébániaközösség lelki vezetését, ahol Kanyó András 1802-ben örökül hagyta.

Szabó László atya Csongrádra helyezése érdekében a hívek könyörgő levelet írtak a Károlyi család fejének. Mivel a kegyúrnak éppen nem volt saját jelöltje, az óhaj akadálytalanul teljesülhetett. Szabó László javadalmai elődéhez hasonlóak voltak, ám a pénznem változása miatt pontosításra szorultak. Az új csongrádi plébános évente 1000 váltó forintra ${ }^{220}, 90$ öl $^{221}$ tiszán túli réti kaszáló használatára és 30 öl réti füre tarthatott számot. A település további 120x120 öl réti kaszálót adott a plébánosnak „olly feltétel mellett, hogy fentebb említett Fő Tiszt. Plebánus urunk nyárban ugyan és szikkadt időkben, városunkban esendő halottankat gyalog, télben pedig és sáros napokban, a halottas ház által rendeltetett kotsikon, mind maga, ha személyesen végezedni, mind pedig Tiszt. Segédje által egész a temetőig ki kísértettni Úri igérete és kötelessége szerént ne terheltessen". ${ }^{222}$ Szabó 13 esztendőt töltött Csongrádon a hívek megelégedésével kísérve. 1830-ban kerületi esperes és szentszéki kanonok lett, 1838-ban csúthi címzetes prépost. A „tudós férfiút és jeles szónokot” Csongrádon érte a halál 1840. áprilisában. ${ }^{223}$

A 45 esztendős Jancsovich József Mogyoródról került a Tisza-parti településre. Életútja rendkívül kalandos volt: az 1830-as években Jobbágyiban kis híjján felkoncolta az urak ellen feltüzelt nép. ${ }^{224}$ Ezek után került Mogyoródra, majd 1840-ben „Méltóságos Gróf Károlyi István földes urunk Eö nagysága mint Szentegyházunk pártfogója választásánál fogva”, Nádasdy Ferenc váci püspök jóváhagyásával Csongrádra. Jancsovich plébános

\footnotetext{
${ }^{218}$ VPL APriv. Mátyus János, 1823. július 10. Gyarmati Mihály közrendủ vallomása.

${ }^{219}$ Chobot II. 1917. 839.

${ }^{220}$ Váltó forint: 60 váltókrajcár értékü pénz. A váltóforint kifejezés annyit tesz, hogy nem nemesfémben, hanem papírpénzben vagy réz váltópénzben számolták az összeget. Tulajdonképpen ugyanezt jelenti a pengö és a pengőkrajcár kifejezés is. A továbbiakban jelölése: Vfrt. Ujszászi Róbert szíves közlése.

${ }^{221}$ Öl: A bécsi öl hivatalosan 1972-ig használt hosszmértékegység volt Magyarországon. Értéke kb. 1,8964 méter.

${ }^{222}$ MNL CsML CsL Iratmásolatok, 106.

${ }^{223}$ Chobot II.1917. 921.

${ }^{224}$ Chobot II.1917. 781.
} 
fizetése elődeihez hasonlóan évi 1000 frt volt, melyet szokás szerint Szent Mihály napjától kezdődően, negyed évi részletekben kapott kézhez a településtől. Ebben benne foglaltatott a párbér $^{225}$, stóla, sedecima ${ }^{226}$, továbbá mindaz, ami az érvényes (1828) Canonica Visitatioban rögzítve volt; úgy mint gabona, só, hús, bor, faggyú, őrletés, nád, tüzifa, ölfa és széna járandóság. A Szabó László idejében kiadott réti legelőt továbbra is meghagyták azzal a megjegyzéssel, hogy ősszel az egész rét a lakosok marháinak és sertéseinek legelőjéül szolgál, és ez alól a plébániai rét sem kivétel. Azt a tiszántúli káposzta- és kenderföldet is megkapta, melynek hasznát hivatali elöde élvezte, továbbá évente 21 öl fát, amit a község szállított a plébániára. Lábas jószágait a közlegelöre ő is beengedhette. A lakosok - ahogy az korábban is szokásban volt - külön fizettek a pluviálés temetés, koporsóba tétel, requiem ${ }^{227}$, libera és a halotti prédikáció után. Cserében a plébános az év minden napján köteles volt reggel 6 órakor kis misét szolgáltatni a munkába indulóknak. Továbbá a „belső városról a halottak papi kíséret mellett fognak vitetni mind száraz, mind sáros útban a parochialis templom elötti előtti keresztig, a városnak pedig többi résziről száraz útban a temetőig, sáros útban csak a város széléig, azonban ha kotsi rendeltetik, mindenkor a temetöig papi kísérettel ejtődjön a halottaknak kivitele a városnak minden részeiböl". ${ }^{228}$ Jancsovich már az első évben kellemetlen konfliktusba keveredett Böhm Rozália izraelita bábával. Az asszony ugyanis feltétlenül részt akart venni a karjai közt született katolikus csecsemők keresztelőjén, ám a plébános nem engedte be a templomba. ${ }^{229}$ Jancsovich nem sokáig vezette a csongrádi plébániát: 1844. júniusában hirtelen elhalálozott. ${ }^{230}$

Szegvárról érkezett a csongrádi plébánia élére az 56 esztendős Banó Mihály, aki táblabírói címmel is rendelkezett. ${ }^{231}$ Banó plébános szilárd erkölcsi karakterként őrződött meg az emlékezetben. Az elbeszélések szerint, amikor 1849-ben gróf Thun tábornok - a

\footnotetext{
225 Párbér: Az 1723-as országgyülésen a földesurak jobbágyaikra hárították a papok ellátásának költségeit, így keletkezett a párbér. Lényege, hogy a plébános házaspáronként meghatározott termény vagy pénzbeli juttatást kapott. Mértékét Csongrádon a Canonica Visitatioban szabályozták. Ld. Tomisa 1997/b. 171.

${ }^{226}$ Sedecima: Tizenhatod (ld. fent!)

${ }^{227}$ Requiemes mise: lat. „nyugodalom”. A trienti zsinat után így nevezték az elhunyt lelki üdvéért, fekete papi ornátusban végzett gyászmisét. A requiemes mise a szertartás introitus vagyis kezdő könyörgésének első szaváról kapta nevét: Requiem in aeternam dona eis Domine (Örök nyugodalmat adj, Uram). Definícióját eképpen olvashatjuk Sohlya Antal kántor jegyzeteiben: „Így neveztetik általában azon gyász nagy vagy kis szt. mise, mely nevét onnan vette, hogy az éneklész énekében először e szót mondja el 'Requiem' s mely egy, vagy több elhunyt hívekért, vagy az összes megholtakért az élök $\mathrm{s}$ holtak Istenének engesztelésül fölajánltatik.” Sohlya 1857. (kézirat) 124; M. Kat. Lex. XI. 2006. 574.

${ }^{228}$ MNL CsML CsL Iratmásolatok, 106.

${ }^{229}$ A csongrádi izraelita bábákról bővebben egy korábbi tanulmányomban értekezem. Ld. Gyöngyössy 2014/c.

${ }^{230}$ Chobot II. 1917. 781.

${ }^{231}$ Táblabiró: Olyan tiszteletbeli állás, mely a közügyek terén aktív kiválóságoknak járt. Dudás 1999/b. 3.
} 
Csongrádra küldött osztrák katonák felkoncolását megbosszulandó - porrá akarta égetni a települést, a plébános az Oltáriszentséget kezében tartva járult a tábornok elé, hogy kegyelemért esedezzen. ${ }^{232}$ Érdemeit hivatali utóda a Historia Domusban is megörökítette. A csongrádiak szeretett plébánosa 1850. májusában hunyta le szemét. ${ }^{233}$ Az üresedésben lévő plébánia élére gróf Károlyi István „az alattvalók oktatásában buzgólkodó és szilárd törekvésü lelkipásztort nagyon tisztelendő Virter Lajos urat” nevezte ki. ${ }^{234}$

Virter Lajos érdemeinek felsorolása külön értekezést tenne ki, így a teljesség igénye nélkül vázoljuk ennek a jeles tudós papnak a karakterét. Csongrádra kerülése előtt a váci püspöki líceum tanára, majd kókai plébános volt. Határozott, ugyanakkor előzékeny, szeretetre méltó viselkedésével hamar kivívta a köztiszteletet. 1853-ban bonyodalma támadt a világi hatóságokkal, amikor kilenc, betyárság vádjával kivégzett embert egyházi temetésben részesített. ${ }^{235}$ Virter csongrádi plébánosságának utolsó évében a kedvezőtlen időjárás miatt komoly ínség ütötte fel a fejét. A szenvedő csongrádi híveknek nyújtott önfeláldozó segítségének híre a Királyi Helytartótanácsig jutott, ahonnan erkölcsi információt kértek Virterről. A váci püspök elragadtatással ecsetelte papja érdemeit. ${ }^{236}$ Egy esztendővel később maga a király nevezte ki a váci Szent Mihály plébánia élére, de még a későbbiekben is vissza-visszatért Csongrádra, ha békítésre vagy józan beszédre volt szükség.

Müveltség kérdésében Alvinczy Ferenc sem maradt el hivatali elöde mögött. Alvinczyt gróf Károlyi István nevezte ki csongrádi plébánosnak 1854-ben. Már váci papnövendék korában kitűnt rendkívüli nyelvérzékével, írói tehetségével. Többször is írt cikkeket országos katolikus és tanügyi folyóiratokba, közben francia nyelvü műveket fordított. Alvinczy plébános - központi intézkedések hatására - már magyarul vezette a

\footnotetext{
232 Tari 1977. 21.

${ }^{233}$ Chobot II.1917. 687.

${ }^{234}$ VPL APriv. Virter Lajos, 1850. július 28. Gr. Károlyi Sándor levele.

${ }^{235}$ VPL APriv. Virter Lajos, 1853. április 20. Virter Lajos levele a váci püspökhöz.

236 „Virter Lajos hittudor tudományosan mívelt, szelíd erkölcsű fedhetetlen életü lelkész, ki kitünő buzgalommal, ernyedtelen fáradtsággal szent hivatásának él, sőt annak magát feláldozza, ki tevékeny közremunkálása által az iskolai oktatást, mint a keresztény és polgári nevelésnek fötényezőjét Csongrádon virágzásra hozta. Ki mindent legnagyobb készséggel felkarol, mi által híveinek szellemi s anyagi jóvoltát emelheti. Ki azokat szóval, tettel és példájával minden jóra s szépre serkenti, és abban legédesebb örömét találja, ha munkássága által minél több jót tehet - és azért ő, ki üdvös működésével a kedves, mívelt és szelid társalgást összekötni szokta, nem csak híveinek, hanem az egész környéknek bizalmát, szeretetét, őszinte böcsületét bírja, ő a váczmegyei papságnak egyik legszebb gyöngye. Én Virter Lajos urat, tekintvén jeles érdemeit, régen kanonokságra legalázatosabban ajánlottam volna, és ettől csak az tartóztatott, hogy ő neki anyagilag ne ártsak. Akár ezen férfiunak fedhetetlen életét, szilárd jellemét, míveltségét, hivatalbeli képességét és buzgalmát, akár rendíthetetlen hüségét felséges urunk és királyunk, őszinte ragaszkodását szentegyházunk és hazánk iránt figyelemre veszem, őt olyannak ismerem, ki legjobb sikerrel a legkitünőbb egyházi s polgári hivatalra alkalmaztatni lehetne.” VPL APriv. Virter Lajos, 1864. május 8. A váci püspök levele a Királyi Helytartótanácshoz.
} 
Historia Domust, egyben összegezte a korábban benne foglaltakat. Egykori 48-as honvédként általános közmegbecsülést élvezett. ${ }^{237}$ Alvinczy élénken érdeklödött a homeopátia iránt, betegek gyógyításával is foglalkozott. ${ }^{238}$ Hívei elsősorban a „,betegek gyógyító atyjaként” emlékeztek rá. ${ }^{239}$ Ö volt az első csongrádi plébános, aki országgyülési képviselőválasztáson jelöltként indult. 1868-ban összetűzésbe került Sohlya Antal főkántorral, melynek tanulságait a későbbiekben ismertetjük. Alvinczyt 1869-ben a hódmezővásárhelyi kerületi esperessé, 1871-ben tinnyei címzetes apáttá nevezték ki. Csongrádon halt meg 1874. december 29.-én. ${ }^{240}$ Egy 1875-ből fennmaradt kimutatás szerint a csongrádi plébánia két és fél havi kiadása (január 1 és február 19 között, vagyis az új plébános kinevezésééig) 206 Frt. 7 krajcár volt, mely magába foglalta három káplán fizetését, élelmezését és fütését, továbbá az Alvinczy temetésére érkező 16 papi vendég élelmezését és bolti számláját. ${ }^{241}$

A jeles szónok hírében álló Szvoboda (később: Szabad) József, egykori papneveldei kormányzó, egyházmegyei levéltáros és szentszéki jegyzőnek gróf Károlyi István adományozta a csongrádi plébánosi széket. Kinevezésével egy időben a váci püspöktől kerületi esperesi címet kapott. ${ }^{242}$ Szvoboda csongrádi plébánossága idején számos csapás érte a települést. A rossz emlékü 1876-os árvíz után a település jelentős része romokban hevert, a plébános saját költségén építtette újjá a megrongálódott plébániai tanyaépületeket. Az árvízveszély miatt Csongrádról a szomszédos Kiskunfélegyházára helyezték az alföld első Királyi Tanítóképző intézetét, majd kis idő múlva a település lemondott rendezett tanácsú városi rangjáról. Szvoboda plébános a közhangulat csitítására fényes szentbeszédekkel vigasztalta híveit. Később egy újságcikkben így emlékeztek meg róla: „szeretetre méltó modorával és kitűnő szónoki tehetségével úgy városunk intelligens közönségét, mint a nép minden rétegét teljesen megnyerte és lekötelezte személyisége iránt”. ${ }^{243}$ A kitűnő társasági ember hírében álló Szvoboda plébános elégtelennek találta csongrádi javadalmazásával, így 1881-ben Szentmártonkátára kérte át magát. ${ }^{244}$ Halála

\footnotetext{
237 „Alvinczy Ferenc volt az, aki az 1848-49-iki szabadságharc kitörése alkalmával papi talárját a honvéd attilával cserélte föl. Mint közhonvéd lépett be a magyar hadseregbe s végig küzdötte hösiesen a szabadságharczot”. Csongrádi Közlöny, 1894. október 7. I. évf. 30. szám, 3. old.

${ }^{238}$ VPL APar. Cs. 1868. február 12. Alvinczy Ferenc és káplánjainak levele a váci püspökhöz.

${ }^{239}$ Alvinczy ,atyja, gyógyítója volt a népnek, soha sem hazudott, még akkor sem, mikor fellépett, mint képviselőjelölt" Csongrádi Lap, 1892. január 1. II. évf. 1. szám, 1. old.

${ }^{240}$ Chobot II. 1917. 676-677.

${ }^{241}$ VPL APar. Cs. 1875. március 26. Vághegyi Ágoston esperes által aláírt elszámolás.

${ }^{242}$ Chobot II. 1917. 918.

${ }^{243}$ Csongrádi Lap, 1892. január 1. II. évf. 1. szám, 1. old.

${ }^{244}$ Chobot II. 1917. 918. Szabad József életét a későbbiekben is válogatott természeti csapások keserítették meg. Miután 1891-ben Szentmártonkátáról Püspökhatvanba helyezték, a település kétharmad része leégett.
} 
évében a Csongrádi Közlöny is megemlékezett róla. ${ }^{245}$

Az 52 esztendős Edelényi (korábban: Ebszt) János derekegyházi lelkészből lett csongrádi plébános. Ünnepélyes beiktatásáról a Szentesi Lap is beszámolt: „A derék új lelkész ünnepélyes fogadtatása f. hó 6.-án volt. A templomban ritkán tapasztalt számban sereglettek össze a hívek, és 'Isten hozott új lelkipásztorunk!' megható alkalmi énekkel fogadták az új lelkészt. 12.-én a városi elöljáróság tisztelgett nála, és Mészáros Károly tolmácsolta a hatóság jókívánalmait. Mi is gratulálunk e valóban méltán kiérdemelt kitüntetéshez.”246 A „,szelid, igazságos, politikai harcoktól tartózkodó”247 Edelényi csongrádi plébánossága idejét a káplánokkal való szüntelen hadakozása keserítette meg. Míg a plébános a segédlelkészek politikai lázításairól, ${ }^{248}$ a káplánok Edelényi erkölcsi esendőségéről, a hívek iránt tanúsított méltánytalan viselkedéséről panaszkodtak a váci püspöknek. ${ }^{249}$ Edelényi János mindössze négy évi csongrádi müködés után, 1886. szeptember 28.-án halálozott el.

Összességében megállapítható, hogy a Canonica Visitatio és a település elöljáróival kötött szerződések tisztes megélhetést biztosítottak a csongrádi plébánosoknak. A plébánia állandó vagyona részben a községtől, részben a kegyúrtól kapott ingatlanokból állt, a plébániai földek helye csak a 19. század végén, a tagosítás lezárultával rögzült. Ehhez társult a végrendelet vagy ajándékozás útján kapott vagyon. ${ }^{250}$

Mivel a csongrádi Nagyboldogasszony-plébániatemplom a nagykárolyi Károlyi család kegyurasága alatt állt, üresedés esetén a püspök írta ki a pályázatot, ám a végső döntés a kegyúr hatáskörébe tartozott. Látható, hogy a település lelki vezetőjéül csakis nagyobb tapasztalattal rendelkező, legalább 40 esztendős papot választott a gróf Károlyi család feje. Csekély kivételtől eltekintve Csongrád plébánosai a váci egyházmegye

Csongrádi Közlöny, 1896. április 19. III. évf. 16. szám, 3. old.

${ }^{245}$ Csongrádi Közlöny, 1896. április 19. III. évf. 16. szám, 3. old.

${ }^{246}$ Szentesi Lap, 1882. február 18. XII. évf. 7. szám, 3. old.

${ }^{247}$ Csongrádi Lap, 1892. január 1. II. évf. 1. szám, 1. old.

248 „Ugyanis a három káplán úr sehogy sem birt az úri osztálylyal barátkozni, sőt avval szünet nélkül feszült ne mondjam - ellenséges viszonyban áll. Ezen viszony különösen a közel lefolyt országgyülési képviselő választás alatt vált az úri osztályra elviselhetetlenné a mennyiben Bakó és Somogyi a szavadelvü párt ellen mindenféle illetlen - sőt veszedelmes kortesfogásokkal lázították a szegény népet, mely lázítás oroszlány része személyem ellen is volt irányozva nem csak, hanem úgyszólván életemet is veszélyeztette. Mert a választási szavazás alatt, midőn a csatárpárti nép legjobban nyugtalankodott, Bakó tisztelendő úr iszonytató néptömeg közt karonfogva vezette Csatárt ablakom elé, hol öt Somogyi L. úr örömteljesen fogadta, itt Csatár képviselő jelölt ellenem irányozta tüzes dictióját a néphez, mely után behozták Csatárt a parochia épületébe, a hová a fellázított nép nagy része betódult, engem szidalmazva, hogy a szabadelvü pártra szavaztam." VPL APriv. Edelényi János, 1884. július 1. Edelényi János levele a váci püspökhöz.

249 A káplánok többek közt Edelényi mohó pénzéhségét, hivatali teendőinek hanyagolását valamint a plébános és a szakácsnő túlzott bizalmaskodását, közbotrányt okozó közös kocsikázásait fájlalták. VPL APriv. Edelényi János, 1884. augusztus 14. Bakó István káplán levele a váci püspökhöz.

${ }^{250}$ Dudás 1998. 114. 
legkiválóbb tudós papjai közül kerültek ki. Nem volt ez másként a 19. század utolsó csongrádi plébánosa, Hegyi Antal esetében sem, ő viszont egy elődeitől eltérő, merően újfajta paptípust testesített meg.

2. Hegyi Antal: a 19. század utolsó csongrádi plébánosának arcképvázlata

Hegyi Antal jeles történelmi események forgatagában, 1848. szeptember 9.-én született Hódmezővásárhelyen. Egy homályos, Hegyi által összeállított újsághír arra utal, hogy édesapja kontrás volt az egyik vásárhelyi bandában ${ }^{251}$, szülei állandó anyagi nehézségekkel küzdöttek. A tehetséges fiú a középiskolákat szülőhelyén, a teológiát viszont már Vácott végezte, 1872 augusztusában szentelték pappá. Fiatal káplánként hosszabb-rövidebb időt töltött Alsónémediben, Nagykőrösön és Kecskeméten. Kecskeméti káplánkodása idején értesülünk arról, hogy Hegyi ,a néphez politicai irányú lázító beszédeket tart”. ${ }^{252}$ A segédlelkész hiába cáfolta a vádakat, 1875-ben mégis Hódmezővásárhelyre helyezték át. A Hódmezővásárhelyen töltött idő alatt Hegyi Antal érdeklődésének másik jellegzetessége rajzolódott ki, ez pedig a vallási társulatok és a vallási közösségszervezés iránt tanúsított, fokozott érdeklődés. Nevéhez füződik a hódmezővásárhelyi Jézus Szíve társulat útnak indítása és felvirágoztatása.

1876-ban Hegyi visszakerült Vácra, ahol ígéretes karrier várt az intelligens, ugyanakkor szokatlanul lobbanékony természetü fiatal papra. Felsorolni is hosszú, Hegyi hányféle minőségben szolgálta a váci egyházmegyét. Kezdetben a váci papnevelő intézet tanulmányi felügyelöje, valamint az erkölcs- és lelkipásztorkodástan helyettes tanára volt. 1879-ben ugyanebben az intézményben lelki igazgató, 1880-ban gimnáziumi helyettes tanár lett. Két év múlva már szentszéki jegyzö, egyházmegyei levéltáros és könyvtáros. 1885-ben, az általa igen tisztelt és szeretett Peitler Antal megyéspüspök halála évében már püspöki titkár majd irodaigazgató, segédtanfelügyelő és szentszéki tanácsos. ${ }^{253}$

Mikor 1886-ban a megüresedett csongrádi plébánia élére a püspökhelyettes elöterjesztette a lehetséges jelölteket, Hegyi Antal neve mellé a következő megjegyzést füzte: „Mindezen jelzett sokoldalú hivatali körben, ritka képzettséget s fáradni nem tudó ügybuzgalmat tanúsítván, egyúttal szilárdjellemü s tiszta lélek szerinti papi hivatásáról

\footnotetext{
${ }^{251}$ Tiszavidék, 1893. szeptember 3. IV. évf. 36. szám, 3. old.

${ }^{252}$ VPL APriv. Hegyi Antal, 1875. A kecskeméti egyháztanács elnökének dátum nélküli levele a váci püspökhöz.

${ }^{253}$ Chobot II.1917. 766.
} 
kétségtelen bizonyságot nyujtván nyugodt lelkiismerettel állíthatom, miszerint (ha) Nagyméltóságod őt kegyesen pártfogolni méltóztatik, a csongrádi kath. hívekre nézve Isten áldása leend e kitűnő buzgalmú egyházi férfiú." ${ }^{254}$ Az előzékeny ajánlás fogékony fülekre talált, így gróf Károlyi Sándor választása Hegyi Antalra esett. A választással egy időben a némedi és ócsai hívek is könyörgő leveleket írtak azért, hogy Csongrád helyett hozzájuk nevezzék ki Hegyit plébánosnak. ${ }^{255}$ Ünnepélyes beiktatását hivatali előde, Virter Lajos végezte 1887. augusztusában. ${ }^{256}$

Az új lelkipásztor igen hamar tanúbizonyságát tette a rekommendációban is kiemelt jellembeli szilárdságnak. Már Csongrádra kerülése évében megtiltotta Magdits Gáspárné református szülésznőnek, hogy asszisztáljon a római katolikus gyermekek keresztelőjén. ${ }^{257}$ Bírósági ügybe keveredett, amikor a nagy múltú Keviczky famíliát - kik akkoriban már 120 esztendeje töltötték be a harangozói és sekrestyési tisztséget Csongrádon megfosztotta hivatalától. ${ }^{258}$ A hívekkel szemben tanúsított olykor erőszakos, türelmetlen magatartása ellenére kétségtelen, hogy a csongrádi templom Hegyi Antal idejében látványosan szépült, gazdagodott: a berendezés folyamatosan gyarapodott, megújult, a plébániaközösség harangot vásárolt, felépült a bokrosi Jézus Szíve kápolna. Ö volt az, aki először próbálta fásítani, tisztán tartatni a templomot és környékét.

Hegyi plébános kemény jelleme és magával ragadó, szuggesztív retorikája erősen megosztotta a hívek közösségét. Voltak, akik vakon követték az „aranyszájú” prédikátort, de szép számmal akadnak olyanok is, akik azonnali elhelyezését követelték. Politikai ambíciói óriási zavart okoztak a plébániaközösségben. Valóságos állóháború alakult ki, amikor Hegyi átvette a Tiszavidék szerkesztését (1892-től), majd 1894-ben útjára indította saját hetilapját, a Csongrádi Közlönyt. Cikkeiben ellenzéki nézeteit taglalta és folyamatosan kritizálta a Csongrádi Lap álláspontját. A válasz természetesen nem maradt el: a plébános vitás pénzügyei, emberi természetének esendőségei az ellenlábas sajtó állandó témái maradtak.

Az Éder János által szerkesztett Csongrádi Lap cikkeinek javát Hegyi plébános nézeteinek szenvedélyes cáfolása tette ki. Éder János 1891-től 1915-ig volt a lap főszerkesztője. Édesapja ügyvéd, nemzetőr őrnagy és Csongrád országgyűlési képviselője, míg édesanyja Csemegi Charlotta a neves jogtudós, Csemegi Károly családjának

\footnotetext{
${ }^{254}$ VPL APar. Cs. 1886. A váci püspök levele gr. Károlyi Sándorhoz.

${ }^{255}$ VPL APriv. Hegyi Antal, 1885. június 30. A némedi és ócsai hívek levele a váci püspökhöz.

256 Tánczos 2006. 59.

${ }^{257}$ VPL APar. Cs. Historia Domus. Hegyi Antal kitépett lapjai 144-145. (1888.)

${ }^{258}$ VPL APriv. Hegyi Antal, 1888. november 6. Hegyi Antal levele a kerületi espereshez.
} 
leszármazottja volt. Éder Erdészeti akadémiára járt, később Budapesten is szerzett diplomát. Az iskolák befejezése után 1883-tól 1913-ig a polgári fiúiskola tanáraként, 1913-1919 között az intézmény igazgatójaként tevékenykedett. Éder János meggyőződéses szocialista és a szegedi szabadkőmüves páholy tagja volt. Ha mindehhez hozzávesszük édesanyja zsidó származását, világossá válnak a plébánossal kölcsönösen táplált ellenszenv összetett okai. ${ }^{259}$ A lap általánosságban liberális, enyhén szocialistaellenzéki hangvételű volt, a cikkírók között több szabadkőművest is találunk. ${ }^{260}$

Hegyi Antal Csongrádi Közlönyének indulása után a sajtóperek szinte mindennaposak voltak, Hegyi a Szegedi Királyi Járásbíróság rendszeres „vendége” lett. 1897-ben a nyomdát súlyos adósságok miatt bezárták. Hegyi Antal politikai tevékenysége Tánczos Rolandnak is felkeltette az érdeklődését, aki 2006-ban hosszabb tanulmányt szentelt „Csongrád harcos plébánosa” ellentmondásos politikai és közéleti szereplésének. ${ }^{261}$

Hegyi Antal és Schuszter Konstantin megyéspüspök viszonya az 1880-as évek végén kezdett elmérgesedni. Az első, komolyabb konfliktus Bozsó Mátyás káplán Csongrádra helyezésének terve miatt alakult ki; Hegyi ugyanis nem volt hajlandó a kétes hírű Bozsót káplánjaként fogadni. Engedetlensége miatt Vácra idézték kihallgatásra, ám a csongrádi plébános különböző okokra hivatkozva nem jelent meg a tárgyalásokon. Az ügy következménye elsőfokú fegyelmi büntetés lett. Hegyi plébános felháborodott levelek sorozatában bizonygatta az ítélethozó váci püspöki széknek, hogy a büntetés jogtalan, megbánást pedig továbbra sem tanúsított. ${ }^{262}$ Ettől kezdve a megyéspüspök és Hegyi Antal viszonya egyre keserübbé vált, egymást érték a bántalmak és megbocsájtások. A végső következmények az 1890-es évek végén érték utol a csongrádi plébánost.

Részben a Csongrádi Lap „tényfeltáró” cikkei miatt az 1890-es években rohamosan fogyni kezdett Hegyi Antal körül a levegő. A biel-i és winterthur-i plébánosoktól kapott miseintenciók összegével ${ }^{263}$ ugyanis - nyugták híján - képtelen volt elszámolni, így csongrádi plébánossága utolsó évei a támadással egybekötött haragos önvédelemről

\footnotetext{
${ }^{259}$ Dudás 1985. 89.

${ }^{260}$ Dudás 2004.

261 Tánczos 2006.

${ }^{262}$ VPL APriv. Hegyi Antal, 1888. augusztus 3. Hegyi Antal levele a váci püspökhöz.

${ }^{263}$ Részlet a Hegyi Antal ügyét tárgyaló váci szentszéki ülés jegyzőkönyvéből: „Biel-ből és Winterthurból 7 év alatt püspöki engedély nélkül mintegy 104 ezer szent misét vett át kiosztás végett, melyekről számolni nem akar és levelében kijelenti, hogy nem is tud rendszeres kimutatással szolgálni”. VPL APriv. Hegyi Antal, 1894. október 10. Püspöki szentszéki ülés jegyzőkönyve.
} 
szóltak. ${ }^{264}$ Hegyi plébános ekkor - immáron sokadjára - püspökével szemben is engedetlenségi perbe keveredett, mely az országos sajtó érdeklődését is kiváltotta. ${ }^{265}$ Közben folyamatosan ágált a polgári házasságkötés bevezetése és a zsidók recepciója ellen. 1898-ban felfüggesztették a plébánosi müködéstől, helyére ideiglenes adminisztrátorként az egykori csongrádi káplánt, Droppa Mihályt nevezték ki. ${ }^{266}$ Válaszul a budapesti Márián György nyomdájában Hegyi Antal megjelentette sok vitát kiváltó Legyen világosság! Böjti prédikáczio helyett önvédelmére irta és kézirat gyanánt kiadja Hegyi Antal, hivatalától és javadalmától felfüggesztett csongrádi plébános címü munkáját. A kivizsgálás során a röpiratot súlyosbító körülményként vizsgálta a püspöki szék. ${ }^{267}$

Hegyi Antal halmozódó egyházi és polgári peres ügyeinek sora 1902-ben érte el a türéshatárt: büntetése immáron három havi letöltendő szabadságvesztéssé bővült. Miután a csongrádi plébános sikertelenül próbálta az igazságügyi miniszter és Ferenc József kegyelmét kieszközölni, 1902. november 5-én elhagyta Csongrádot, és Budapesten, majd Hamburgon keresztül meg sem állt New Yorkig. Míg otthon körözés alatt állt és ingóságait elárverezték, Clevelandban átvette a Magyarok Vasárnapja szerkesztését, majd Fairport ${ }^{268}$ plébánosává nevezték ki. Hegyi életében kiegyensúlyozott évek következtek: az itthoni sajtóban ért vádakra kintről válaszolt, a Magyarok Vasárnapjában sorra jelentette meg az emigrációjához vezető körülményeket ecsetelő, önvédelmi írásokat. A Csongrádi Lap és a Csongrádi Újság ugyan már jó ideje „,erkölcsi halottként” emlegette Hegyit, időnkét rövid élcekkel tartották ébren a lakosság emlékezetét. ${ }^{269}$

1906-ban Hegyi Antal - szándékai szerint ideiglenesen - visszatért Magyarországra, hogy pénzt gyüjtsön egy amerikai magyar árvaház javára. Nemes céljai azonban nem hatották meg a hatóságokat, így Hegyit nyomban a szegedi törvényszék elé citálták. Öt hónapi fogházbüntetés után a hátrahagyott amerikai közösség és a csongrádiak kérvényei, hivatalos küldöttségei eredménnyel jártak, így Hegyi Antal 1906.

\footnotetext{
264 „Én belölem már sem a börtön, sem a bitófa nem csinál más embert, mint a minőnek az Isten megteremtett. Azért megvetem ezt az üldözésekkel teljes, nyomorult földi életet, és ha kényszerítenek, elmegyek a végletekig barátaimmal együtt: de a mik történni fognak, a ki hallja, mind a két füle megcsendül belé." VPL APriv. Hegyi Antal, 1895. december 9. Hegyi Antal levele a váci Egyházmegyei Hatósághoz.

${ }^{265}$ A megyéspüspök 1889. január 6-án megbocsájtotta Hegyi engedetlenségét, ám mivel magatartása ezek után is támadó maradt, 1893. februárjában a hercegprímás nyílt rosszallását is kiváltotta.

${ }^{266}$ Csongrádi Lap, 1898. január 23. VIII. évf. 4. szám, 3. old.

${ }^{267}$ VPL APriv. Hegyi Antal, 1898. augusztus 31. A váci szentszéki ülés jegyzőkönyve.

${ }^{268}$ Fairport kb. 300 fönyi lakossága föként Zemplén és Ung megyéből kivándorolt magyarokból állt. Rajtuk kívül tótok, angolok és oroszországból kivándorolt finnek is éltek a településen. Tánczos 2006. 72.

${ }^{269}$ „Meszelik a templom tornyát, készítik az állványokat körül, minek nem egy bámulója akad. Egy jóképü menyecske is a bámulók közé keveredik s amint áhítattal emeli fel szemeit a toronyra, igaz meggyőződésböl mondja: 'Haza jön már Hegyi Antal, azért meszelik a tornyot, nehogy piszkosan találja, félnek tőle, mert megint kisepri az egész városházát."'Csongrádi Újság, 1904. július 17. II. évf. 29. szám, 3. old.
} 
novemberében királyi kegyelemmel szabadulhatott.

Az egykori plébános visszaköltözött Csongrádra, ahol átvette az általa alapított Keresztény Fogyasztási Szövetkezet, később a Keresztény Gőzmalom Rt. igazgatását. 1911 és 1919 között Csongrád föbírája volt. ${ }^{270}$ A misézésen kívül más papi funkciót nem látott el. 1919 után nyugdíjba vonult, súlyos anyagi gondjaiban a frissen hivatalába lépő Hanauer Á. István megyéspüspök segítette ki. 1922. szeptemberében még ünnepélyes szentmisével ülték meg papi müködése 50. évfordulóját. Hegyi Antalt magányosan, 1923. július 9-én, 75 éves korában érte a halál. ${ }^{271}$

\section{A megyéspüspök, a kegyúr és a település elöljárósága}

Mielőtt rátérnénk az alsópapság és a laikus templomszolgák szerepének feltárására Csongrád társadalmában, elkerülhetetlen, hogy ne szenteljünk néhány bekezdést a plébános tevékenységét „felülről” meghatározó személyekre és fórumokra.

A megyéspüspök az egyházmegyéjében müködő plébánosok vezető lelkipásztora. Mátyus János kivételével - ő ugyanis az egri egyházmegyéből érkezett Csongrádra - a 19. századi csongrádi plébánosokat a mindenkori váci püspök szentelte fel hivatására. A felszentelés során a papjelölt „atyjaként” ismeri el megyéspüspökét, a köteles tisztelet és engedelmesség esküje a ceremónia kulcsfontosságú része. Ahogy Miltényi Gyula váci szentszéki tiszti ügyész egyik levelében megfogalmazta: az engedelmesség erénye nélkül nem képzelhető el a papi élet, hisz fegyelem kell ahhoz, hogy kormányozható legyen az egyházmegye. $^{272}$

A felszentelés mellett a plébániák irányításának joga is a megyéspüspöktől származott. Csongrád esetében a kegyúri család kívánságait mindig előzékenyen figyelembe vették. Ha a kegyúrnak nem volt kiválasztottja, a megyéspüspök állította össze az alkalmasnak ítélt jelöltek listáját, majd továbbította a Károlyiak felé kiválasztásra. ${ }^{273} \mathrm{Az}$ ajánlások elkészítéséhez a püspöknek alapsan ismernie kellett papjai képességeit, erényeit, gyengeségeit. A személyes ismerettség kiépítésének és a kapcsolat fenntartásának egyik útja a püspöki látogatás vagy kánoni vizitáció volt. Ugyan az 1822-es pozsonyi nemzeti zsinaton kimondták, hogy a püspökök kötelesek évente egyházmegyei zsinatot tartani és

\footnotetext{
${ }^{270}$ Sebestyén 2002. 83-84.

271 Tánczos 2006. 74.

272 VPL APriv. Hegyi Antal, 1888. december 2. Dr. Miltényi Gyula összefoglalója a váci püspöki székhez.

${ }^{273}$ Sárközy 1915. 84-85.
} 
legalább kétévente felkeresni a plébániákat, a gyakorlat egészen mást mutatott. ${ }^{274}$ Hasonló funkciója volt a püspöki bérmáló körutaknak, melyek során az egyházmegye föpásztorát a település és a plébános együtt látták vendégül. A püspök egyszerủ átutazása sem mehetett végbe különleges ceremónia nélkül. ${ }^{275}$

A kapcsolattartás kevésbé közvetlen módja a levélváltás volt. A megyéspüspök felé határozott céllal, többnyire kérés, panasz vagy köszönet ürügyén fordultak papjai. A panaszlevelek jellemzően helyi konfliktusokról számolnak be, melyekkel kapcsolatban a megyés föpásztor állásfoglalását kérték. A káplánok áthelyezési kérelmei is a püspökhöz kerültek. A levelek általában az alázatos fiúi bizalom jegyében fogalmazódtak. Ahogy Kovács Antal kecskeméti segédlelkész dispozíciós kérelmében olvashatjuk: „Isten után kegyelmes Püspök Atyám jósága az, hová menekülni tudok."276 A püspöki válaszlevelek mindig tegeződve íródtak.

A papság fegyelmi ügyeiben a megyéspüspök a kerületi esperesen és a Püspöki Szentszéki Bíróságon (korabeli szóhasználatban: Szentszék) keresztül ítélkezett. ${ }^{277}$ Ennek megfelelően a plébános legközvetlenebb feljebbvalója a megyéspüspök által delegált (átruházott) hatalommal felruházott kerületi esperes volt. A kerületi esperes feladata, hogy esperesi kerületében összehangolja a papság munkáját, felügyelje a templom és a liturgia rendjét, a plébániákat évente legalább egyszer látogassa végig. ${ }^{278}$ Ö az, aki a papság fegyelmi ügyeiben kihallgatásokat, helyszíni szemléket tarthat. Vizsgált időszakunkban a csongrádi plébánosok a hódmezővásárhelyi esperes felügyelete alá tartoztak. ${ }^{279}$

A püspök tehát elsőként a kerületi esperest kérte fel, hogy tartson helyszíni szemlét és hallgassa ki az ügyben érintetteket. Az esperes jelentése nyomán a megyéspüspöknek

\footnotetext{
${ }^{274}$ Sárközy 1915. 108.

275 „Méltóságos Jung János felszentelt püspök úr folyó hó 18-án délután Csépáról Csanyra menet, városunkon keresztül utazott. Hegyi Antal helybeli plébános fogadta öt és meghívása folytán harangzúgás közt rövid látogatást tett előbb a fellobogózott plébániai templomban aztán pedig a papi lakban, hol szívélyes búcsút vett a csépai kísérettől. Rövid pihenés után pedig ugyancsak Hegyi Antal kíséretében folytatta útját Csanyra, közben azonban még a plébániai tanyára is betért, megtekinteni az ottani gazdaságot." Csongrádi Közlöny, 1894. május 27. I. évf. 11. szám, 4. old.

${ }^{276}$ VPL APriv. Hegyi Antal, 1875. január 18. Kovács Antal levele a váci püspökhöz.

277 A trienti zsinat nyomán összehívott 1638-as tartományi zsinaton rendelték el Magyarországon az egyházmegyei bíróságok felállítását. Sárközy 1915.103.

${ }^{278}$ Sárközy 1915. 63.

${ }^{279}$ Új liturgikus ruhák, kisebb templomi tárgyak megáldásával a püspököt, a 19. század végén már inkább az esperest bízták meg. Az 1870-es években Szvoboda József csongrádi lelkész még a „,szent olajok küldönye által" továbbította Vácra a konszekrálásra váró csengőt, kelyhet és cibóriumot VPL APar. Cs. 1875. március 23. Szvoboda József levele a váci Egyházmegyei Hatósághoz. Hegyi Antal az 1880-as években viszont már több levelében is jelezte, hogy amennyiben az esperes a zord időjárás vagy egyéb akadályoztató körülmény folytán nem tudna Csongrádra jönni, püspöki engedéllyel szívesen vállalja az új szerzemények megáldását. VPL APar. Cs. 1888. május 15. Hegyi Antal levele a váci Egyházmegyei Hatóság hoz; VPL APar. Cs. 1890. augusztus 21. Hegyi Antal levele a váci Egyházmegyei Hatósághoz.
} 
joga volt azonnali döntést hozni, vagy a püspöki székre bízni az ügy további felderítését. A püspöki szék a püspök vagy helyettesének (vicarius) elnöklete alatt, a püspöktöl kinevezett ülnökökből, jegyzőből és ügyészből állt. A polgári házasságkötés törvényi bevezetése előtt (1894. XXXI: tc.) házassági ügyekben is a püspöki szék hozott döntést. 1894 után csak szorosan vett egyházi ügyek (causae mere spirituales) tartoztak a hatósághoz. A püspöki szék által hozott ítéletet a kerületi esperes felé is továbbították, aki komolyabb ügyekben maga olvasta fel a plébánosnak.

A papok világi bíróság előtti számonkérése a 19. század végén kezdett elterjedni, jellemzően laikusokat is érintő „polgári” ügyekben (becsületsértés, rágalmazás stb). Az Egyházmegyei Hatóság a 19. században az egyes plébániák által letétbe helyezett, nagyobb összegek fölött is felügyeleti jogot gyakorolt, kiadásukról a plébános külön kérésére hoztak döntést. $^{280}$

A fennmaradt levelek nyomán úgy tünik, hogy Csongrád plébánosai többnyire kiegyensúlyozott viszonyt ápoltak a megyéspüspökkel. Hegyi Antal és Schuszter Konstantin (1886-1899-ig váci püspök) kapcsolata viszont atipikus volt. A több mint tíz esztendeig elhúzódó, fordulatokban gazdag Hegyi-Schuszter konfliktus az ellentétes politikai nézetek, a csongrádi plébános szokatlanul lobbanékony természete valamint Konstantin püspök fegyelmezett pénzkezelési stratégiája miatt mérgesedett el.

Hegyi Antal közismerten jó viszonyban állt Schuszter püspök elődjével, Peitler Antallal (1859-1885), aki Hegyi plébánoshoz hasonlóan óriási összegeket áldozott templomi berendezések megújítására, új templomok építésére, kegyes alapítványokra. A nagylelkü felajánlásoknak azonban meg lett a következménye: Peitler halála után az egyházmegye pénzügyi helyzete megingott, ezért egy esztendeig nem választottak új püspököt. Schuszter Konstantin azonban szigorú ellenőrzés alatt tartotta egyházmegyéje pénzügyeit, és papjaitól is hasonló fegyelmezettséget várt el. Ez a hozzáállás viszont Hegyi Antaltól teljesen idegen volt, és a püspöki levelekből plébánosi jogainak korlátozását vélte kiolvasni. Szimbolikus gesztusnak tekinthető, hogy Hegyi Antal 1899-ben nem a nemrégiben elhunyt megyéspüspök, hanem Peitler Antal arcképét festette meg és helyezte ki a csongrádi plébánián. ${ }^{281}$

\footnotetext{
280 „A mult évben a Ftdő Egyházmegyei Hatóság kegyes engedélye folytán sikerült beszereznem a legszükségesebb templomi ruhákat.” VPL APar. Cs. 1889. május 6. Hegyi Antal levele a váci Egyházmegyei Hatósághoz.

${ }^{281}$ Tiszavidék, 1890. október 26. I. évf. 35. szám, 3. old.
} 
Míg a plébános és püspöke kapcsolata afféle ,,atyai-fiúi” viszonyként értékelhető, a kegyúrral $^{282}$ szemben már jóval hivatalosabb, világiasabb attitűd nyilvánult meg. A kegyúrnak a praesentatio (bemutatás) joga ${ }^{283}$ alapján beleszólása volt a plébános kiválasztásának folyamatába. ${ }^{284}$ Forrásaink szerint a kegyúr bemutatási joga elsőbbséget élvezett a megyéspüspök akaratánál ${ }^{285}$, és a csongrádi lakosok óhajai is ritkán befolyásolták a Károlyiakat. ${ }^{286}$

A templom felújításának költségei mindig a kegyurat terhelték. Ezzel kapcsolatban a plébános az uradalmi tiszttartó felé jelezte az igényeket. A tiszttartó helyszíni szemlén mérte fel a kérés jogosultságát, majd a Károlyi család felé továbbította észrevételeit egy előzetes kivitelezési javaslat kíséretében. Mivel az inspector célja a kegyúr tárcájának lehetőség szerinti megkímélése volt, a felújítások előtt kikérték Vác állásfoglalását, lehetséges volna-e a templomi pénztárból is áldozni a szent cél javára? ${ }^{287}$ A kegyúr és a plébános együttmüködése tehát gyakorlatias kérdések közös megoldásában merült ki. A kegyúr jogköre megkövetelte a rendszeres kapcsolattartást a mindenkori megyéspüspökkel, akivel félhivatalos, majdhogynem baráti hangvételü levelezést folytattak.

Hegyi Antal plébános több levelében és újságcikkében is utal arra, hogy igencsak kevesli a Károlyiak adományait. ${ }^{288}$ 1894-ben nyílt konfliktusra is sor került, melynek középpontjában a templom megrongálódott tetőszerkezete állt. Hegyi Antal először Körmendy Zsigmond uradalmi tiszttartónál jelezte a problémát, ám a panasztételnek ,a tiszttartó úr ismert fukarságánál fogva” ${ }^{289}$ nem volt foganatja. A plébános ezután a grófnak írt jelentést, egyben megyéspüspökét is felkérte, hogy hasson a kegyúrra. A gróf október

\footnotetext{
${ }^{282}$ Kegyuraság: A földesúri hatalomtól független, pápai vagy királyi adományozású privilégium. A kegyúr biztosította a plébániai ingatlanokat és földeket, építtette és javíttatta a templomot. Üresedés esetén javaslatot tehetett a megyéspüspöknek az utód személyére nézve. Tomisa 1997/b. 171.

283 Janes 2012. 16. (kézirat)

${ }^{284}$ VPL APar. Cs. 1875. február 12. A váci püspök levele gr. Károlyi Istvánhoz; VPL APar. Cs. 1882. január 9. A váci püspök levele gr. Károlyi Sándorhoz; VPL APar. Cs. 1886. november 8. A váci püspök levele gr. Károlyi Sándorhoz.

285 „Bajcsy Gábor, a téli csongrádi választáskor bebörtönzött csongrádi káplán [...] ki van nevezve Derekegyházára plébánossá. Elképzelhetjük, hogy milyen savanyú arccal írta alá ezt a kinevezést Schuszter Konstantin. De hát a kegyelmes úr nem térhetett ki előle, mert gróf Károlyi Sándor és László itt a kegyúr, és ezek Apponyi ajánlata folytán feltétlen ragaszkodtak a kinevezéshez." Szentesi Lap, 1892. október 16. XX. évf. 121. szám, 2. old.

${ }^{286}$ 1882-ben, mikor a hívők szívhez szóló kérvényt nyújtottak be kedves segédlelkészük, Csajka Lajos érdekében, gr. Károlyi Sándor mégis Edelényi János mellett döntött. VPL APar. Cs. 1882. január 9. A váci püspök levele gr. Károlyi Sándorhoz.

${ }^{287}$ VPL APar. Cs. 1823. július 11. Már Ferenc uradalmi tiszttartó levele a váci székeskáptalanhoz.

288 „A mi pedig kegyurunk nagylelküségét illeti, bizony el kell ismerni Ő Excellentiájáról mindaddig, míg tỏle valamire garast nem kérnek [...] miért legyen Károlyi Sándor gróf nagylelkü a csongrádi nép egyházi terheit hordozni, mikor is többé nem az ő jobbágysága?" VPL APar. Cs. 1890. december 8. Hegyi Antal levele a váci Egyházmegyei Hatóság felé.

${ }^{289}$ VPL APar. Cs. 1894. szeptember 10. Hegyi Antal levele a váci Egyházmegyei Hatósághoz.
} 
elején levéllel kereste fel Konstantin püspököt, melyben leszögezte, hogy az aktuálissá vált tetőzsindelyezés munkálatok benne vannak az éves költségvetésben, így ,akadálytalanul foganatosítva is lesznek, a mi még akkor is megtörtént volna, ha sem a csongrádi plébános úr sem Nagyméltóságod e részben hozzám nem fordultak volna is". ${ }^{290}$ Még meg sem száradt a festék a Csongrádi Közlöny új számán - melyben Hegyi Antal gyászos hangvételü cikkben emlékezett meg a rogyadozó templom sorsáról -, a gróf munkásai már el is kezdték a tetőzet zsindelyezési munkálatait. Az október 28-i számban már az alázatos köszönő sorokat olvashatjuk. ${ }^{291}$

A csongrádi plébános és a templom kegyurának kapcsolata két évvel később ismét viharossá vált. A részletekről ismét a sajtóból értesülünk. 1896 őszén Hegyi plébános a Nagyboldogasszony-templom kibővítésének szükségességét kezdte hangoztatni, és egy nagy volumenü kivitelezési tervvel áll elö. Mivel a megyéspüspök a legutóbbi csongrádi látogatása alkalmával nem győződött meg a kérés szükségességéről, azt javasolta Hegyi Antalnak, forduljon közvetlenül a kegyúrhoz. Károlyi Sándor viszont a plébános terve helyett saját ötlettel állt elő, és bővítés helyett egy másik templom építését vetette fel. A csongrádi plébános így értékelte a történteket: „Tehát a kegyelmes föpásztor még csak a közvetítésre sem vállalkozott! Így aztán könnyü püspöknek lenni, ha a legéletbevágóbb kérdések megoldását kegyesen elhárítja magától. Károlyi Sándor gróf kegyúr pedig azon nagyúri elutasításban részesített bennünket, hogy ha ő templomot akar építtetni, tud ő ahhoz terveket és költségvetést készíttetni. No, hát ezt a fejedelmi kegyességet is hálásan köszönjük, hisz rendkívüli lelki épülésére szolgálhat Csongrád város 22 ezer lelket számláló kath. közösségének, ha így bánnak vele, kik hivatva volnának a tiszavidéki katholikusság ezen védbástyájának erősítésére." 292

Hegyi Antal valójában a plébániaközösség kettészakadásától, egy azonos jogokkal rendelkező másik plébános jelenlététől tartott. A történet vége túlnyúlik Hegyi csongrádi müködésén: a 20. század elején a kegyúr tervei szerint épült fel a piroskavárosi Szent József templom.

Csongrád elöljárósága a 19. század végéig kizárólag római katolikusokból állt. A tisztségviselők családjukkal együtt templomba jártak, a szentélyben külön ülőpad illette meg őket. 1865 után egy központi rendelkezés szerint vasár- és ünnepnapok délelőttjein a

\footnotetext{
${ }^{290}$ VPL APar. Cs. 1894. október 4. gr. Károlyi Sándor levele a váci püspökhöz.

${ }^{291}$ Csongrádi Közlöny, 1894. október 28. I. évf. 33. szám, 3. old.

${ }^{292}$ Csongrádi Közlöny, 1896. szeptember 6. III. évf. 36. szám, 3. old.
} 
hivatalok zárva tartottak azért, hogy az ügyintézők templomba tudjanak menni. ${ }^{293}$ Nagyobb állami évfordulókon, emlékünnepeken tartott szentmisékre a plébániahivatal külön meghívót küldött az ipartestületnek, az iskoláknak és a csongrádi képviselőknek. ${ }^{294} 1893$ ban az újonnan megválasztott elöljáróság arra kérte a plébánost, hogy „ünnepélyes Veni Sanctével kezdhesse meg hivatalnokoskodását, illetve testületileg vehessen részt vasár- és ünnepnapokon az isteni szolgálaton". 295

A plébános javadalmainak megállapítása a püspök és a település egyezkedése nyomán, a Canonica Visitatioban rögzített feltételek szerint történt. A fizetséget a pasztorálási terület nagysága, a káplánok száma és a plébános feladatainak függvényében határozták meg. Csongrád település kielégítő, de nem kiemelkedő javadalmat biztosított papjainak, melyet Szent Mihály napjától számolva, negyedévi részletekben utaltak ki számukra.

A 19. század második felében a csongrádi plébánost különböző helyi érdekü bizottságokba is beválasztották, egy-egy szociális vagy társadalmi kérdés felelősévé tették meg. Ilyen volt az időszakosan felállított árvízi védbizottság vagy a járványügyi bizottság. ${ }^{296} \mathrm{Az}$ elöljáróság alkalmi kérésekkel, például bitófára ítélt bűnösök utolsó gyónásának elvégeztetésével is felkereste a lelkipásztort.

A 19. század végén a polgári anyakönyvezés nyomán kialakuló országos méretü kultúrharc egészen új megvilágításba helyezte a plébánia, mint adminisztratív hivatal és a település kapcsolatát. A változásra Hegyi Antal plébánossága idején került sor, aki a „polgári párosodás” lázas ellenharcosaként ${ }^{297}$ az anyakönyvvezetői hivatal létjogosultságát sem ismerte el. A Csongrádi Közlönyben sorozatban jelentek meg cikkek a polgári anyakönyvezés illetve Piroska János anyakönyvvezető személye ellenében. A plébános a gyakorlatban sem óhajtott együttmüködni az illetékes hivatalokkal. ${ }^{298}$ Hegyi Antal cikkeinek ellensúlyozására a Csongrádi Lap ironikus karcokkal idézte fel, hogy míg a türelmetlen, indulatos plébánoshoz félve mer bekopogtatni bárki, addig az

\footnotetext{
${ }^{293}$ Dudás 1998. 116.

${ }^{294}$ Csongrádi Lap, 1898. szeptember 18. VIII. évf. 38. szám, 2. old.

295 Tiszavidék, 1893. június 25. IV. évf. 26. szám, 3. old.

296 Tiszavidék, 1893. december 17. IV. évf. 51. szám, 3. old.

${ }^{297}$ Tiszavidék, 1893. január 8. IV. évf. 2. szám, 3. old.

298 „A haláleset felvételével megbízott Csongrád községi hivatalos közegek több ízben tett panasza szerint nevezett plébános úr általában nem respektálja, mint anyakönyvvezető a fennálló törvényes intézkedéseket és nem csak magán felek, de hivatalos megkeresésekre is kedélyhangulata szerint számtalan esetben megtagadja az anyakönyvi kivonatok kiadását, s úgy magán feleket, mint hivatalos közegeket a hozzá intézett kérelem megtagadása mellett szobájából kiutasít." VPL APriv. Hegyi Antal, 1892. április 2. A csongrádi járási szolgabíró levele a váci püspökhöz.
} 
anyakönyvvezetőnél ,,a szegény emberre is van az uraknak gondjuk”. 299

A püspök, a kegyúr, a település és a plébános kapcsolata több ponton, szorosan összefonódik. A Nagyboldogasszony-templom felújítása a kegyúr és a püspök, a templomtér rendezése a település, a temető és a Szent Rókus-templom ${ }^{300}$ ügyei a püspök és a település, a plébános személye a kegyúr és a püspök közös döntésének függvénye volt. ${ }^{301}$ A három, tényleges döntési potenciállal rendelkező fórum ütközőpontjában a helyi plébános állt. Az esetek többségében ő volt a kérdésfeltevő, a tanácsért vagy segítségért folyamodó fél. Ám ugyanez fordítva is igaz: ha a püspöknek, kegyúrnak vagy a településnek voltak tervei a csongrádi plébánia tulajdonaival, elsőként a plébános véleményét kérték ki.

A plébános - sok egyéb funkciója mellett - a plébánia javainak őre, elsődleges felelöse. ${ }^{302}$ A hiányosságok észrevétele és jelzése mellett a plébániaközösség vagyonán esett sérelmek kivizsgálása is az ő feladata. Akárki okozott kárt ezen értékekben, a plébános nyomban intézkedett a helyreállítás ügyében. 1881-ben a temetőben felállított Justin-féle kőfeszület rongálódott meg a település alkalmazottainak gondatlanságából. Az árvízi védekezéshez szükséges fát ugyanis a temetőből vágták ki, és az egyik fa összeroncsolta a keresztet. A település az árvíz után vaspántokat vasaltatott a feszület köré, ám ez a megoldás nem bizonyult tartósnak. Tíz esztendővel később az adományozó Justin család vállalta a teljes helyrehozatalt. ${ }^{303}$ Hasonló eset történt 1888-ban, amikor Károlyi Sándor gróf szegvári kompját az áradata a böldi révnél felállított Nepomuki Szent János szoborhoz sodorta, és a szobor megsérült. A kegyúr vállalta a pótlást, ám határozott kérése volt, hogy az új szobrot már a gáton kívül állítsák fel. ${ }^{304}$

\footnotetext{
${ }^{299}$ Csongrádi Lap, 1895. október 27. V. évf. 44. szám, 3. old.

300 A 18. század végétől a belsővárosi Szent Rókus filiális templom kegyura a település volt. A felújítási munkálatokról, az egyházfi valamint a harangozók és sekrestyések személyéről a helyi közgyülés hozott döntést.

${ }^{301}$ A 19. század második felében felmerülő, komolyabb vitákban a Vallás- és Közoktatásügyi Minisztérium, a Belügyminisztérium és a hercegprímás állásfoglalását kérték a felek.

302 „Van szerencsém tisztelettel megjegyezni, hogy plébánosi eskümnél fogva természetes őre s kezelője lévén a csongrádi egyház vagyonának, kötelességem azt oly módon gyümölcsöztetni, melyen több hasznot hajthat [...] gyenge állású egyházamnak. VPL APar. Cs. 1891. május 27. Hegyi Antal levele a váci Egyházmegyei Hatósághoz.

${ }^{303}$ VPL APar. Cs. 1890. október 27. Hegyi Antal levele a váci Egyházmegyei Hatósághoz.

${ }^{304}$ VPL APar. Cs. 1888. Hegyi Antal bejegyzése a Historia Domus kitépett lapjain 146-147; Tiszavidék, 1890. március 2. I. évf. 1. szám, 3. old; VPL APar. Cs. 1891. június 1. Hegyi Antal levele a váci Egyházmegyei Hatósághoz. A témáról lásd: Gyöngyössy 2010/b. 15.
} 


\section{V. ÖNKÉP ÉS HIVATÁS.}

\section{A NÉP KÖZÖTT ÉLŐ LELKIPÁSZTOR}

A lelkipásztorkodó alsópapság képzése a 18. század végétől Magyarország minden egyházmegyében szervezett keretek között, szakértő tanárok és lelki vezetők segítségével történt. A szemináriumok zárt, fegyelmezett világában a felsőfokú latinos müveltség és a liturgia elsajátítása mellett a növendékek egyfajta sajátos identitást is magukévá tettek.

Ez a szemináriumi identitás szigorúan biblikus alapokon nyugszik. ${ }^{305}$ Lényege, hogy az Egyház fö célkitüzése, vagyis a rábízott lelkek örök üdvösségre vezetése kiválasztott vezetőkre van bízva. A papi hivatásra maga Jézus Krisztus „hívja meg” az egyéneket (Jn 15,16; Zsid 5,4), akik belső késztetésüknek engedve vállalják a hívekért végzett szolgálat terheit és örömeit. A pap maga is a hívek közül kerül ki (Zsid 5,1), ugyanakkor a hármas hatalomban ${ }^{306}$ való részesedés okán kiválasztott, így magasan a hívők „fölé” emelkedik. Ahogy Varga János lejegyezte: „Igazából Isten és emberek közt van a [pap] helye! Nemcsak hivatásánál, hanem méltóságánál fogva is 'közvetítő' Isten és ember között." 307 A kormányzói, tanítói és szentségi hatalom mellett egyedül a papok részesednek Jézus bűnbocsátó erejében (Jn 20,22-23), mely a holtak feltámasztásánál is nagyobb tett ${ }^{308}$, így az angyaloknál előkelőbbek. ${ }^{309}$ Ezért is nevezik őket „alter Christusnak", vagyis Krisztus másának.

A papi rend méltóságteljes hivatal, így a hívekénél jóval rendezettebb életet kíván. Ezért tilalmas a szerencsejáték, vadászat, túlzott italfogyasztás, táncvigalmakon való részvétel és világi hivatalok viselése, vagyis olyan cselekedetek, melyeket az Egyház „a bün kizárásával a világiaknak megenged, de a papoknak nem”. ${ }^{310}$ Ugyanakkor alapvető követelmény a szeplőtelenség (coelibátus), józan mértékletesség, adakozókészség, szerény ruházkodás és a tudományos életben való jártasság. A papságot sajátos ruházata is megkülönbözteti a hívektől, melyet már Kálmán I. törvénykönyve gondosan körülírt. ${ }^{311}$

\footnotetext{
${ }^{305}$ A „papkép” mindenre kiterjedő, elemző bemutatása nem célunk, így csupán a leglényegesebb vonásokat kiemelve, általánosságban körvonalazom a jelenséget. Megállapításaim a II. Vatikáni Zsinat elötti szemléletmódot igyekeznek visszaadni.

${ }^{306}$ A kormányzói, tanítói és szentségi hatalom a jézusi hármas tisztségében való részesedést jelenti. Sárközy 1915. 14.

307 Varga János 1941. 158.

308 „A pap sokkal nagyobbat tesz, mint aki halottakat támaszt, mert ö a föloldozás által a holt lelket örökké tartó élettel ajándékozza meg." Gyenis 1927. 26.

${ }^{309}$ A hagyomány Assisi Szent Ferenchez köti azt a mondást, miszerint ha egyszerre találkozna egy pappal és egy angyallal, a papot köszöntené elsőként. Gyenis 1927. 15.

${ }^{310}$ Sárközy 1915. 4.

${ }^{311}$ Sárközy 1915. 36.
} 
Hegyi Antal 1893-ban a Tiszavidék hasábjain egy, a papi hivatás mellett érvelö, a szentség felvételére buzdító írást tett közzé. A papi életpályát olyan „díszes, előkelő” állásként jellemezte, melynek legfőbb előnye, hogy „biztos és független pálya is, a hol a törekvő tehetség előrehaladásában nincs kegyelemre és pártfogókra utalva, hanem lelkének erejével és szellemének szabadságával kivívhatja magának a legelőkelőbb méltóságokat" . ${ }^{312}$ Szintén a protekció nélküli elörehaladás vonzerejét emelte ki a Csongrádi Közlönyben három esztendővel később megjelent tárcájában. ${ }^{313}$ Hegyi Antal arra is figyelmeztette olvasóit, hogy a szentségben való részesedés eltörölhetetlen, így aki megválik a pályától „csak utálat és megvetés tárgya lehet az emberek szemeiben”. 314

A továbbaikban azt vizsgáljuk meg, miként hatott az imént körvonalazott papkép a plébános és hívei kapcsolatára, hogyan értékelte, jelölte ki saját szerepét a plébános a plébániaközösségben? Mi különböztette meg a 19. századi csongrádi hívek számára a ,jó papot” a „rossz paptól’? Változtak-e a fő elvárások a 19. század folyamán? Hogyan fejezték ki a hívek rosszallásukat a normaszegő pap irányába? A konfliktusok elemzése nyomán az alsópapság helyi társadalomban betöltött szerepének megértéséhez kerülhetünk közelebb.

\section{Tisztelet, bizalom és az egyházias szokások}

A pap karakteres és tisztán körvonalazható szereptudatát tovább erősítette az a sajátos viszonyulásmód, melyet lelkipásztori munkája során a hívek részéről tapasztalt nap mint nap.

A helyi alsópapság minden időben megkülönböztetett tiszteletben részesült: kalaplevéve köszöntötték őket az utcán, kezet csókoltak nekik. A Csongráddal szomszédos csépai lakosok 1799-ben ezt ,illő kötelességbeli tiszteletnek”315 nevezték. Ahogy 1889-ben Zöld Antal néptanító egyik levelében fogalmazta: „ez az ember [t.i. a plébános] Csongrádon a legfőbb tiszteletre méltó egyéniség”. ${ }^{316}$ A plébános megnevezése a csongrádi nép ajkán a plebános úr volt, ám mivel nem egyedüli papként élt a plébánián, a

\footnotetext{
312 Tiszavidék, 1893. szeptember 24. IV. évf. 39. szám, 2. old.

313 „A papi pályát ajánljuk is mindazon tanulók figyelmébe, kik hivatást éreznek magukban az egyházi élet iránt. Mert míg más magasabb életpályán protekció nélkül alig lehet boldogulni: addig a papi pálya protekció nélkül is nyitva van a legszegényebb ember gyermeke részére.” Csongrádi Közlöny, 1896. augusztus 30. III. évf. 35. szám, 3. old.

${ }^{314}$ Tiszavidék, 1893. szeptember 24. IV. évf. 39. szám, 2. old.

${ }^{315}$ VPL APar. Cs. 1799. január 15. A csépai lakosok levele a váci püspökhöz.

${ }^{316}$ VPL APriv. Hegyi Antal, 1889. február 21. Zöld Antal levele a váci püspökhöz.
} 
káplánoktól való megkülönböztetés végett ő volt a föpap ${ }^{317}$, fö úr $^{318}$, föatya ${ }^{319}$ vagy öreg $\operatorname{pap}^{320}$.

Isten szavának hírnökét ${ }^{321}$ feltétlen bizalom övezte. A kihallgatási jegyzőkönyvek tanulsága szerint az írástudatlan parasztemberek fenntartások nélkül hallgattak szavára, adományaikról, misealapítványaikról nem kértek írásos igazolást. „Ilyenkor [t.i. mikor adománygyüjtésre szólított fel a plébános] bizony nagyon adakoztunk, mert minden szava bizony szent volt, és azt gondoltuk, hogy ő saját jövedelmét is az utolsóig az Isten dicsőségére áldozza, tehát mi is szívesen tettük.” ${ }^{322}$ „Hegyi Antal plébános úr akart nekem adni róla írást [nyugtát], de nem fogadtam el, mert bíztam benne, mint főatyámban.”323

A plébános befolyásával a világi elöljárók is tisztában voltak. Nem csoda, hogy a település elöljárósága oly nagy jelentőséget tulajdonított a templomi prédikáció tartalmának. Példaként hozom fel Hegyi Antal sokat támadott kijelentését azzal kapcsolatban, hogy nem becsületes ember és asszony az, aki a csongrádi Szentháromság téren felállított mechanikai müszínházba beengedi a gyermekét. ${ }^{324}$ Hegyi plébános kijelentése kiváltotta a település elöljáróságának rosszallását, melyet belső fórumokon, testületi üléseken is megvitattak.

Tekintély és bizalom együttese befolyással, hatalommal jár, az elismert hatalom pedig a plébánia eredményes kormányzásának szükségszerü eszköze. Ám ez sem elegendő ahhoz, hogy a lelkipásztor egykönnyen felülírjon vagy megváltoztasson évszázados szokásokat, hiedelmeket. Bálint Sándor hívta fel a figyelmet arra, hogy az egyházi tudományossággal áthatott lelkipásztori tilalmak fájdalmas disszonanciát keltenek a nép körében. ${ }^{325}$ Úgy vélte, hogy a lelkipásztorkodó alsópapság többségében idegenkedve viszonyul a népi vallásosság jelenségeihez, tilalmazza, esetleg csendesen megtűri azokat.

Hogy a felvilágosult papság-felvilágosulatlan nép ellentétpárjának felállítása mégsem problémamentes, arra az életből vett példák figyelmeztetnek. Mikor Mátyus János csongrádi plébános fülébe jutott, hogy egy gyászoló család az elhunytnak nem óhajt requiemes szentmisét szolgáltatni, figyelmeztette őket: csúfosan meg fogják bánni

317 „Vidékünkön a káplános plébánosokat is főpapoknak nevezik”. VPL APar. Cs. 1867. Sohlya Antal dátum nélküli levele a váci püspökhöz.

${ }^{318}$ VPL APriv. Hegyi Antal, 1898. augusztus 22-26. Máté János vallomása.

${ }^{319}$ VPL APriv. Hegyi Antal, 1898. augusztus 22-26. Lantosné Roza Ilona vallomása.

${ }^{320}$ VPL APriv. Hegyi Antal, 1898. augusztus 22-26. Ornyikné Nyilas Viktória vallomása.

${ }^{321}$ Bálint 2009/a. 165.

322 VPL APriv. Hegyi Antal, 1898. augusztus 22-26. Tari Luca vallomása.

323 VPL APriv. Hegyi Antal, 1898. augusztus 22-26. Lantosné Roza Ilona vallomása.

${ }^{324}$ NPI 1889. Gétzi János nyomtatásban megjelent nyílt levele. Schwartz Sándor nyomdájából.

325 Bálint 2009/a. 146. Tower Vilmos illemkódexében a tapintatos rá/átnevelés előnyeire figyelmeztette paptársait. Tower 1940. 89. 
döntésüket, „mikor a Haza járó Lélek a zsákot az ajtóhoz támogattya, a Konyhába a Fazekakat le-támogattya, a vagy le rakja". ${ }^{326} \mathrm{Az}$ említett fenyegetés lehet pusztán a néplélek működését jól ismerő plébános retorikai frázisa, a meggyőzés alternatív eszköztárának része. Ugyanakkor az is elképzelhető, hogy a hazajáró lélek hite - annak általános elfogadottsága miatt - a nép között élö lelkipásztor világképét sem hagyta érintetlenül. Ám ha a plébános a katolikus egyház tanaiba beilleszthetetlen hiedelmekre hivatkozik, akarva-akaratlanul is megerösíti, legitimálja azokat.

Csongrádi forrásaink olyan jellegzetes helyi szokások, ünnepi elemek meglétéről tanúskodnak, melyeket a papság változtatások nélkül elfogadott. Ezek a kisebb-nagyobb területi eltérések a liturgikus gyakorlat egységesítésének hiánya miatt alakulhattak ki, és a lokális adottságokhoz idomulnak. Ilyen ájtatos szokás volt Csongrádon a két templom közötti szent menet ${ }^{327}$ vagy a Szent Márk-napi Mindenszentek-litánia sajátos éneklése ${ }^{328}$. Helyi előzmény nélküli új szokásokat csak az alsópapság kezdeményezésére, az egyházmegye jóváhagyását elnyerve, valamilyen határozott lelkiségi céllal vezethettek be. A honosítás a lelkipásztor személyes felügyelete mellett, elöre meghatározott keretek között valósulhatott meg. 1897-ben Hegyi Antal a szocialista nézetek és nazarénus tanok rohamos terjedése ellenében vezette be a 40 órás szentségimádást. ${ }^{329}$ Miután az eseményt kihirdette a vasárnapi nagymisén, a tervezett szentségimádás rendjét írott formában is kifüggesztette a templom ajtajaira. A csongrádi plébános káplánjaival együtt vett részt az imaalkalmon; óránként miséztek és térdepelve végezték a szentségimádást. ${ }^{330}$ A 40 órás imádság alatt az ájtatos társulatok tagjai a papok mellett asszisztáltak. Szintén Hegyi Antal vezette be a Hétfájdalmú Szüz ünnepén (szeptember 15.) végzett körmenetet a temetői kálváriához. Droppa Károly adminisztrátor 1898-ban megjegyezte, hogy a szokás már el

\footnotetext{
${ }^{326}$ VPL APriv. Mátyus János, 1823. május 10. Csongrád város bírájának levele a váci püspöki székhez.

327 „Csongrádon az ugynevezett Belvárosból a Külvárosba a népegyházhoz ezen nagy napon [húsvétkor], valamint pünkösd napján is szt. menet tartatik, melyet lelkésszel vagy anélkül a segédlelkész tart, $s$ úgy irányozván elindulását, hogy e szt. menet épen a nagy szt. mise kezdete előtt pár perczel érjen a népegyház elé, hol a kereszt előtt egy 'Miatyánkot's 'Üdvözlégy' imádkozása után a szt. menet a néphez csatlakozik. És épen e rendben megy vissza szt. mise után. Jövet énekeltetik a Mindenszentek letenyéje, menet pedig a húsvéti 'Föltámadt Krisztus e napon' ének. És midőn a szt. menet vissza ér a belvárosi templomhoz, ott szintén imádkozik a néppel a segédlelkész egy 'Miatyánk's 'Üdvözlégy'-et s vége a szertartásnak is". Sohlya 1857. (kézirat) 232.

328 „Nem lehet még e letenye [Mindenszentek litánia] éneklésénél egy szép szokást érintetlenül hagynom, mely ugyan csak Csongrádon dívik, s mit más helyt nem tapasztaltam. Mely is az, hogy minden szakasz szentek eléneklése után az éneklész előéneklése után a nép által teljes, megható, s mérföldre elhalló hangon énekeltetik, t.i. 'esedezzetek, a mi Urunk Jézusnál, Mi kegyes Megváltónknál. Ne tekintse a mi büneinket, hallgassa meg buzgó kérésünket, nagy irgalmasságából.'Vagy: 'Hogy adjon szép esőket'”. Sohlya 1857. (kézirat) 237-238.

${ }^{329}$ VPL APar. Cs. 1897. április 2. Hegyi Antal levele a váci Egyházmegyei Hatósághoz.

${ }^{330}$ VPL APar. Cs. 1897. február 17. Hegyi Antal levele a váci Egyházmegyei Hatósághoz.
} 
nem hagyható, mert a nép „,most már nagyon megkívánja”. 331

A helyi alsópapságot tehát „alanyi jogon” megilleti a hívek általános tisztelete és bizalma. Tekintélyének okán megnyilatkozásai, tettei értékelés alá esnek, kezdeményezéseinek széles körü visszhangja támad. Legmaradandóbb hatást mégis a példamutatás erejével tud elérni; Hegyi Antal például kitünő szervező egyéniség hírében állt, aki tisztában volt a személyes jelenlét erejével, mely az új szokások vagy új ájtatos társulatok megalakításához, sikeres müködéséhez jóformán elengedhetetlen. Az általa bevezetett szokások mind meggyökeresedtek, a nép Hegyi plébános távozása után is fenntartotta őket.

2. A plébános és hívek „organikus egysége”. A védelmező atya alakja

Levéltári forrásaink illetve Hegyi Antal sajtócikkeinek szóhasználata egyértelműen arra utal, hogy a plébános „sajátjaként” tekintett a hívek közösségére, kiknek sorsában maradéktalanul osztozik. ${ }^{332}$ A híveim ${ }^{333}$, gondjaimra bízottak ${ }^{334}$, népem ${ }^{335}$ megnevezéseken kívül aligha találunk egyéb jelzőt. Ez az organikus szemlélet a papi hivatás sajátos természetéből fakad.

Lényege, hogy a plébános a hívek testi és lelki jólétéért folyó küzdelemben compassiót vállal a közösséggel: sérelmük az ő személyes sérelmével egyenlő. Ez a viszonyulásmód aligha választható: a nép részéről alapvető elvárásként jelenik meg. ${ }^{336}$ Mikor 1867-ben Alvinczy Ferenc a túl magas stóladíjakat követelő kántor ellenében emelte fel szavát, eképpen körvonalazta hivatása lényegét: „Aztán, midőn az ínség, most rövid idő alatt már két ízban zsarolta, sanyargatta az alföldi népet: kik iparkodtak ezt leginkább enyhíteni, kik szereztek több anyagi, pénzbeli segélyt, mint a plébánosok?! [...] Ha az inség sanyargatja a népet: akkor védheti a plébános az ő híveit, de ha egy kántor zsarolja azokat, akkor 'csitt!', 'hallgass!' a neve, nemde? Legyen bizonyos Sohlya [kántor] úr, hogy a csongrádi plébános soha, semmi ügyben nem fogja elhagyni híveit, ha hozzá igazságos

\footnotetext{
${ }^{331}$ NPI 1898. április 8. Droppa Károly levele a váci Egyházmegyei Hatósághoz.

${ }^{332}$ Hegyi plébános az 1888 -as árvíz után a váci püspöktől kért segítséget: „Méltóztassák egyuttal tisztelettel vett parancsának teljesítését megfelelő eszközök által lehetővé is tenni, mert az Úr Istennel nem szállhatok itéletre, hogy miért sujtott le atyai keze népemmel együtt a föld poráig." VPL APriv. Hegyi Antal, 1888. május 14. Hegyi Antal levele a váci Egyházmegyei Hatósághoz.

${ }^{333}$ VPL APar. Cs. 1867. november 12. Alvinczy Ferenc és káplánjainak levele a váci püspökhöz.

${ }^{334}$ VPL APriv. Hegyi Antal, 1892. május 10. Hegyi Antal levele a váci Egyházmegyei Hatósághoz.

${ }^{335}$ VPL APriv. Hegyi Antal, 1888. május 14. Hegyi Antal levele a váci Egyházmegyei Hatósághoz.

336 „Lelkiatyát óhajtunk, kegyelmes [püspök] úr: Lelkiatyát, ki nem csak czímből, hanem érzésböl is legyen lelkiatyánk, ki velünk érezzen.” VPL APriv. Hegyi Antal, 1889. Gétzi János nyílt levele. Schwartz nyomdájából.
} 
panasszal járulnak."337

Az előbbi megállapítás fordítva is érvényes. A hívek közösségére, mint a plébánossal sorsközösséget vállaló homogén „védelmi tömbre” való hivatkozás Hegyi Antal retorikájának állandó eleme volt. Mikor a csongrádi plébános viszonya a váci püspöki székkel Bajcsy Gábor káplán elhelyezése miatt elmérgesedett, az esetet a plébániaközösség egésze elleni offenzívaként értékelte. Válaszában ,a népen esett sérelem” 338 megtorlását helyezte kilátásba, mely nem csak joga, de plébánosi kötelessége egyben: „ügyemet és népemet fogom védelmezni bárki ellen utolsó lehelletemig, s elviszem föllebbezésemet az apostoli Szentszékig ha éppen térden állva kell is csusznom Rómáig", 339

A szokatlanul merész hangnem miatt Hegyi Antal később írásos elnézést kért. A Szentszéki elnök a felmentő iratban elöadta, hogy a csongrádi plébánost „eljárásában nem a felsőbbség iránti tisztelet $\mathrm{s}$ köteles engedelmesség felmondása, hanem inkább a hívei lelki üdvéről túlfeszített gyöngédséggel gondoskodó lelkipásztor rosszul felfogott kötelességérzete, tehát tévhit, balvélemény vezérelte". ${ }^{400}$ 1898-ban, mikor Hegyi felfüggesztésének híre az országos sajtóba is bekerült, továbbra is tartózkodott attól, hogy az esetet szigorúan önmagára vonatkoztatott magánügyként kezelje. ${ }^{341}$

A plébános ellen irányuló morális „támadások” idején hangsúlyozott egységnek mint retorikai fordulatnak egyfajta védelmező, erkölcsi felmentő ereje van. A népi gondolkodásmód ezt az egységet ösztönösen felvállalja, hisz meggyőződése szerint a plébános egy személyben képviseli az egész plébániaközösséget. A vállalás elutasítása csak a pap személyisége és a papságtól elvárt, sztereotip magatartásminta nyilvánvaló összeférhetetlensége miatt történhetett meg. Hegyi Antal plébánost híveinek egy része támogatta, más része elutasította; a „csongrádi nép” egységes tömbként való kezelése mindenesetre komoly elvi akadályokba ütközik. Míg Alvinczy plébános a kántor temetési

\footnotetext{
${ }^{337}$ VPL APar. Cs. 1867. november 12. Alvinczy Ferenc és káplánjainak levele a váci püspökhöz.

338 „A hol híveim lelki jóléte és üdvéröl van szó, lehetetlen hallgatnom, mert mint lelki pásztornak alkalmazkodnom kell azon megdönthetetlen egyházi elvhez: 'salus animarum suprema lex esto'". [A lelkek java a legföbb törvény] VPL APriv. Hegyi Antal, 1894. február 14. Hegyi Antal levele a váci Egyházmegyei Hatósághoz.

${ }^{339}$ VPL APriv. Hegyi Antal, 1894. szeptember 30. Hegyi Antal levele a váci Egyházmegyei Hatósághoz.

340 VPL APriv. Hegyi Antal, 1888. június 30. A szentszéki elnök jelentése Hegyi Antal ügyében. Jegyzőkönyvi kivonat.

${ }^{341}$ „A Ftdő Szentszék ítélkezése által oly súlyos méltatlanság esett meg rajtam, s vérig felháborította jobb sorsra érdemes szegény híveimet, melyhez fogható alig történt Magyarországon [...] nem a népszerüsödés a feladatom, hanem a kesergő híveimnek a megnyugtatása, kötelességemben állott a hozott fegyelmi itéletek szabálytalanságát az előadott okokkal kimutatni” VPL APriv. Hegyi Antal, 1898. január 23. Hegyi Antal levele a váci Egyházmegyei Hatósághoz.
} 
stólájának korlátozásával egyértelmủen hívei életének megkönnyítéséért cselekedett, addig Hegyi Antal esetében az egyéni és közösségi érdekek szétválasztásának problémájával szembesülünk.

A továbbiakban azokat a fenyegető egzisztenciális krízishelyzeteket vesszük számba, amikor a plébános szakrális hatalmát vagy tekintélyét felhasználva igyekezett megóvni híveit az olyan tényleges (nem pusztán retorikai) veszélyektől, mint a járványok, erőszak vagy természeti katasztrófák.

Bálint Sándor megállapítása szerint a nép vallásos világképét a képzelet, érzelem, és egyéb irracionális hajlamok alakítják. ${ }^{342}$ Ez a világkép Isten felszentelt képviselőinek, a papoknak olyan szakrális erőt tulajdonít, mely képes arra, hogy elhárítsa a közösséget fenyegető tényleges veszélyeket. A papok rendkívüli képességeibe vetett hit az ótestamentumi Áron föpap történetére vezethető vissza, aki imádságával mentette meg népét a pusztító veszedelemtől. ${ }^{343}$ Alapja, hogy a katasztrófák sosem a véletlen szülöttei: rajtuk keresztül maga a Mindenható fejezi ki nemtetszését; bünbánatot követel, és a közösség lelki megtisztulásának szükségességére figyelmeztet. Ki más lenne képes kieszközölni az engesztelő bocsánatot, mint a közösség lelki vezetője? ${ }^{344}$

Az első csongrádi plébános, kinek hősies jelleméről különös kegyelettel emlékeznek meg forrásaink, Vintze Gergely volt. Az ő csongrádi müködése idején (1738) tört ki a pusztító gugahalál. A pestis egy esztendő leforgása alatt 726 áldozatot követelt, a betegeket maga a plébános gondozta. ${ }^{345}$ Egy alkalommal, mikor az életükért és szeretteikért reszkető csongrádi hívek a templomba gyültek szentmisére, Vintze plébános prédikációjában felszólította elkeseredett híveit, hogy ajánlják magukat Szent Rókus pártfogásába, és tegyenek fogadalmat egy kápolna építésére. Az összegyült nép eleget tett lelkipásztora kérésének, majd az Oltáriszentséget tartó Vintze plébános vezetésével körmenetet tartottak a Belsőváros körül. A pestis hamarosan megszünt, és a csongrádiak nem feledkeztek meg fogadalmukról: a mai Nagyboldogasszony Általános Iskola helyén kápolnát emeltek a szent tiszteletére, napját pedig kiemelt fogadalmi ünneppé tették meg. ${ }^{346}$

\footnotetext{
${ }^{342}$ Bálint 2009/b. 143.

${ }^{343}$ Móz. IV. 16,42-48.

${ }^{344}$ Ez a gondolatkör a 20. századba is átmenekítődött: Gyenis András 1927-ben paptársairól, mint „új Áronokról” beszél: „Amint régen, úgy ma is elhárítják az igazságos büntetést és Isten nem hajtja végre a csapást, amellyel fenyegetőzött a szolgája által bemutatott áldozat iránti tiszteletből és szeretetből." Gyenis 1927. 20.

${ }^{345}$ Csongrádi Közlöny, 1894. október 7. I. évf. 30. szám, 3. old.

${ }^{346}$ Tari 1977.11.
} 
Papok gyógyító tevékenységére Csongrádon a 19. század második felében, a homeopátia elterjedésével találunk adatokat. Alvinczy Ferencről jegyezték fel, hogy „mint homeopata számtalan egyénnek mentette meg életét kor és valláskülönbség nélkül”. ${ }^{347}$ A plébános egyik levelében röviden megemlékezett a kántor fiának, Sóhlya Gyulának meggyógyításáról és az alkalmazott vizsgálati módszerről: „A plébános kikérdezte a fiút és anyját a betegség okáról [...] miután a plébános a fiu gyomrát és üterét megtapogatta, nyelvét, szemét megnézte: észrevette, hogy itt gyomorterhelésből származott gyomorláz (febris gastrica) van. Ez ellen adott neki orvosságot, s hogy nem csalódott, mutatja az, hogy kevés nap mulva a sekrestye előtt egészségesen látta a fiút." ${ }^{\text {¡4 }}$ Az 1893-as kolerajárvány idején Varga Mihály káplán gyógyította a betegeket annak ellenére, hogy ekkorra már kielégítő orvosi ügyelet müködött a településen. Varga sikeres gyógyításairól a Tiszavidék is beszámolt. ${ }^{349}$ Egyik éjszaka ismét két beteghez hívták utolsó gyóntatásra, kiknek Varga gyógyszert is vitt a plébániáról. Reggelre mindkét kezeltje meghalt, és mivel a kolerás betegeket elmulasztotta előző nap bejelenteni a hatóságoknak, a csongrádi főszolgabíró 50 Frt pénzbírságra ítélte az atyát. ${ }^{350}$

Banó Mihály plébános nem égi-természeti, sokkal inkább földi hatalmasságok ellenében kényszerült kiállni híveiért. A történetnek több változata maradt fenn. 1849-ben a Kiskunfélegyházán állomásozó Thun gróf felderítő csapatokat küldött Csongrádra. A megérkező osztrák katonák zaklatni kezdték a nemzeti színű szalagot, gombos mentét viselő lakosokat. Egyes forrásaink szerint emiatt, mások szerint Kossuth ellenállásra buzdító levele okán ragadtak fegyvert a csongrádiak, és néhány katonát örökre ott is marasztaltak. A felböszült Thun tábornok parancsba adta, hogy a települést a földdel kell egyenlővé tenni. A kétségbeesett csongrádiak egy része a templomba menekült, ahonnan Banó plébános Draskovits István polgárral „templomi szentség lobogó alatt”351 - más források szerint az Oltáriszentséggel kezében - az osztrák parancsnok elé sietett, és kérlelni kezdte, hogy változtassa meg ítéletét. A parancsnok a büntetést végül néhány órányi szabad rablásra és gyújtogatásra változtatta.

Csongrádon a 18-19. század folyamán nem volt hiány válogatott természeti csapásokban. A csongrádi plébános 1866-ban a következő bejegyzést hagyta örökül a

\footnotetext{
${ }^{347}$ Csongrádi Lap. 1892. január 1. II. évfolyam, 1. szám, 1. old.

348 VPL APar. Cs. 1867. november 12. Alvinczy Ferenc és káplánjainak levele a váci püspökhöz.

349 „A héten történt, hogy Oláh Balázs a putriban rosszul lett, gyógyszert a plébániáról vitetett, melynek használata mellett miután öt Varga Mihály gyógykezelö káplán úr személyesen is fölkereste, csak hamar jobban lett." Tiszavidék, 1893. szeptember 3. IV. évf. 36. szám, 3. old.

350 Tiszavidék. 1894. január 21. V. évf. 3. szám, 3. old.

${ }^{351}$ Csongrádi Lap, 1899. augusztus 6. IX. évf. 32. szám, 1-2. old.
} 
Historia Domusban: „Szerencsétlen év! Háború - kolera - árvíz - marhavész! Fagy aszály - ínség!” 352 A legkomolyabb károkat az árvizek okozták. A Tisza szabályozását követően egymást érték a kisebb-nagyobb árvizek, mígnem 1876-ban a folyó elöntötte a települést. ${ }^{353}$ A Csongrádi Újság cikkírója bibliai hasonlattal élve emlékezett vissza ezekre az időkre: „Mintha Szodoma és Gomora sorsára jutottunk volna, legnagyobb ellenségünk, a szép szőke, de veszedelmes Tiszával folytattunk élethalál harcot.”354 1888-ban ismét komoly veszély elé nézett a település. Hegyi Antal plébános jelentésében írja, hogy már csak a Jóisten őrködő kegyelmében és Jézus Szentséges Szívében bízik. ${ }^{355}$ Csongrád végül megmenekült a víz betörésétöl. Ennek emlékére Hegyi plébános Jézus Szívének ünnepét a csongrádiak fogadalmi ünnepévé emelte. ${ }^{356}$

Hogy a nép milyen kiemelt jelentőséget tulajdonított plébánosa krízishelyzetekben tanusított cselekedeteinek, tisztán mutatja az az eset, amikor Hegyi plébános a víz betörésétől való félelemben a belsővárosi templomból kimenekítette az Oltáriszentséget. A hívek kétségbeeséssel vették tudomásul a hírt: „hangos zokogásban tört ki az utcák népe, hogy már csakugyan elvesz a város, mert a Belsővárosból már az Oltáriszentséget is elviszik". ${ }^{357}$ A hívek a racionális indíttatású, preventív tettből fátumot véltek kiolvasni. Úgy tartották, hogy lelki vezetőjük az égi hatalmak szándékát ismerve csalhatatlanul látja a település sorsát.

Forrásaink tükrében Hegyi Antal elődeinél racionálisabb gondolkodású, tettrekész papként tünik fel. Nem csoda, hisz a 19. század második felében már lehetősége volt arra, hogy központilag támogatott, szervezett segítséget nyújthasson, mentőstratégiát dolgozzon ki. Szakrális funkciója újfajta, mondhatni „polgárias” vonásokkal egészül ki. Miközben az árvízi védbizottság elnökeként a gátak megerősítésének elvén dolgozott, engesztelő imaórákat tartott és Jézus Szívének kegyelmébe ajánlotta a fenyegetett közösséget. Mindez a plébános hagyományos társadalmi szerepének kibővülését, egyben bizonyos mértékü átalakulását jelzi.

\footnotetext{
352 NPI, Historia Domus I. kötet, 109. old.

353 Tari 1977. 30.

${ }^{354}$ Csongrádi Újság, 1905. április 23. III. évf. 17. szám, 4. old.

${ }^{355}$ VPL APriv. Hegyi Antal, 1888. március 31. Hegyi Antal levele a váci püspökhöz.

${ }^{356}$ Csongrádi Közlöny, 1895. június 16. II. évf. 24. szám, 3. old.

357 VPL APar. Cs. 1888. Hegyi Antal dátum nélküli bejegyzései a csongrádi Historia Domus kitépett lapjain. 109.
} 
A plébános és híveinek kapcsolatát a mürokonsági kapcsolatok, tiszteletbeli felkérések mélyíthették el. A kiemelkedően egyházpártoló családok, módosabb nagygazdák nem ritkán egy helyi papot kértek fel keresztszülőnek vagy esküvői násznagynak. Az 1816-ban született Pigler László keresztapja Bogyay Ferenc segédlelkész volt ${ }^{358}$, Piroska János csongrádi festőmüvész édesapjának keresztlevelén pedig Straub Ferenc káplán neve szerepel keresztapaként ${ }^{359}$. Sohlya Máriát, Gyula főjegyző leányát - aki a főkántor unokája is egyben - Hegyi Antal plébános tartotta keresztvíz alá. ${ }^{360}$ Az 1860-as években Alvinczy Ferenc megbetegedése miatt Straub Viktor káplánt kérte fel a Borbás család násznagynak. ${ }^{361}$ Szvoboda Ferenc iskolaszéki elnök ${ }^{362}$ leányának esküvőjén Hegyi plébános volt a násznagy, míg a szertartást Csapó János segédlelkész celebrálta. ${ }^{363} \mathrm{~A}$ felvázolt esetek a papok helyi társadalmi beilleszkedésének bizonyítékai. Egy ilyen felkérés - a papi hivatás önmagában vett presztízsértéke mellett - a pap személyiségének szóló, gesztusértékü visszajelzésnek is tekinthető.

A lelkipásztor elsősorban nem a szokásrendszer passzív kiszolgálója és fenntartója, hanem annak aktív meghatározója volt. Egészen a polgári házasságkötés bevezetéséig az egyház volt az egyetlen szervezet, mely saját törvényei szerint határozta meg például a házasulandó felekkel szembeni elvárásokat. Kiss Réka szavait idézve: a papok „nem csak a nyilvános, közösségi vallási élet helyi vezetői, hanem egyben a vallási és társadalmi normarendszer lokális szintü közvetítői is voltak". ${ }^{364}$

Mivel az egyház alaptörvényei az emberi élet fordulóit illetően erősen szabályozottak, az egyedi esetek elbírálásában az alsópapság korlátozott döntési joggal rendelkezett. Kérdéses házassági, erkölcsi ügyekben a püspöki székhez fordultak tanácsért. Hegyi Antal plébános a 19. század végén, pontosan a polgári házasságkötés előviharaiban szigorította meg a jegyesek beíratkozásának rendjét. Ifj. Lászlóffy László földbirtokost

\footnotetext{
${ }^{358}$ NPI Születési anyakönyvek, 1816. szeptember 16.

${ }^{359}$ A keresztlevél a CsKK Tari László Múzeum „Piroska János” c. időszaki kiállításán volt megtekinthető 2012. őszén. Adatai: Piroska János született: 1866. november 8. Keresztelték: 1866. november 9. Keresztatya: Straub Ferencz káplán.

${ }^{360}$ NPI 1894. március 12. Sohlya Gyula föjegyző levele a váci püspökhöz.

${ }^{361}$ VPL APar. Cs. 1867. november 12. Alvinczy Ferenc és káplánjainak levele a váci püspökhöz.

362 A csongrádi egyházi iskolákat 1869-ben községi iskolákká szervezték át, melyek irányításával az iskolaszék lett megbízva. Az iskolaszékben a plébános, a kántor és az egyházfi is tisztségviselő volt. Dudás 1985. 182.

${ }^{363}$ Csongrádi Közlöny, 1896. május 17. III. évf. 20. szám, 4. old.

${ }^{364}$ Kiss 2011. 146.
} 
azért nem jegyezte be a házasulandók közé, mert menyasszonya luteránus volt. ${ }^{365}$

Hogy megakadályozza a jegyesek házasság előtti szétválását - melyet Csongrád esetében igen gyakorinak ítélt - Hegyi plébános csak a násznagy jelenlétében jegyezte be őket a hirdetőkönyvbe ${ }^{366}$, szétválás esetén kárpótlási bírságra ítélte a visszalépő felet. Egy ilyen ügy, mely végül a plébános polgári peres elmarasztalásához vezetett ${ }^{367}$ teljes terjedelmében ránk maradt. Bertus Rókus napszámos a váci püspökhöz címzett levelében panaszolta, hogy miután jegyet váltott Samu Julianna leánnyal, „köztünk felmerült okok miatt" a legény visszaküldte a jegykendőt. Mikor azonban pár hónappal később Pusztai Franciskával óhajtott volna beíratkozni, a plébános 30 forintos kártérítés kifizetésére szólította fel a legényt, melyet elhagyott menyasszonyának kellett kifizetnie. A vagyontalan legény igen sokallta a kiszabott összeget, ezért a váci püspökhöz fordult igazságtételért. ${ }^{368}$ Mikor a püspök kérdőre vonta a csongrádi plébánost, Hegyi válaszában életszerủen ecsetelte a szegény hajadont a gazdagabbért elhagyó ifjú históriáját, aki volt menyasszonyáról valótlan betegséget állítva csapódott leánytól leányig. A plébános az elhagyott jegyes fájdalmának kárpótlásaként hajtotta be az összeget a legényen: „A szegény árvákat a mai igazságszolgáltatásban nem igen védelmezi más, mint a jó Isten! S így mint Isten szolgája kötelességemnek tekintettem ezen védtelen árva leányt [...] becsületének gonosz megtámadója ellen a törvényes eszközökkel megvédeni."369

Az erkölcsi ügyekben ítélt pénzbírság kivetése Hegyi Antaltól korántsem volt idegen módszer. 1888-ban egy csongrádi asszony azzal kereste fel plébánosát, hogy férje rendszeresen megveri, ráadásul összeállt egy „megesett nőszeméllyel”. A pap beidézte a férjet, aki a verések okaként neje részeges természetét jelölte meg, az említett „,megesett nőszemély” pedig csupán szolgálója, nem ágyasa. Hegyi Antal a püspöki szék felé továbbította az ügyet, ám levelében nem mulasztotta el megemlíteni, hogy ezidáig az általa beterjesztett 20 házassági ügy közül csak egyet bírált el a jeles tanács. A lassú ügyintézés pedig óriási károkat okoz az amúgy is ingatag talajon álló erkölcsiségnek. ${ }^{370}$ Hegyi

\footnotetext{
${ }^{365}$ VPL APriv. Hegyi Antal, 1892. március 14. A csongrádi lakosok levele a hercegprímáshoz.

366 „Ezen rendszabályhoz azért ragaszkodom, mert ide jövetelemkor a jegyesek semmi komolyságot nem tulajdonítottak a beíratkozásnak, legalábbis fele elvált közülük." VPL APriv. Hegyi Antal, 1894. július 10. Hegyi Antal levele a váci Egyházmegyei Hatósághoz.

${ }^{367}$ VPL APriv. Hegyi Antal, 1892. március 14. A csongrádi lakosok levele a hercegprímáshoz.

${ }^{368}$ VPL APriv. Hegyi Antal, 1891. Bertus Rókus napszámos dátum nélküli levele a váci püspökhöz.

${ }^{369}$ VPL APriv. Hegyi Antal, 1891. január 28. Hegyi Antal levele a váci Egyházmegyei Hatósághoz.

370 „Nem mulaszthatom el azonban Ftdő Szentszék figyelmébe ajánlani, hogy az a huza-vona eljárás, melyet a Ftdő Szentszék a házassági perekben, értem sommás perekben általában tanusít épen nem vezet jó eredményre, sőt csak istápot nyújt az erkölcstelenségre, mikor a felek azt tapasztalják, hogy szabad a vásár, a plébános fölterjesztésének semmi eredménye, a bünösnek haja szála sem görbül meg." VPL APriv. Hegyi Antal, 1888. október 25. Hegyi Antal levele a váci Egyházmegyei Hatósághoz.
} 
plébános az ügyintézés radikális felgyorsítását javasolta, melynek következményeként „egészen más alakot öltenének az erkölcsi állapotok, mert a bünös félre tartási költségek alakjában akárhányszor rá lehetne húzni a vizes lepedőt s méltóztassék meghinni, hogy ez a zsebben való érvágás jobban hat mindennemü kapaczitálásnál". ${ }^{371}$ A pénzbírság mellett Hegyi Antal nem ódzkodott az erkölcsi bünösök kiprédikálásától sem. A 19. század végén már a sajtó útján is hangot adott nemtetszésének azért, hogy a közösségi nyomást kieszközölje. ${ }^{372}$

A csongrádi plébános legendás szigorával valódi hatást próbált elérni, példát kívánt statuálni. Történt egyszer, hogy egy öngyilkos ügyében a plébános nem látta igazoltnak a beszámíthatatlanság kritériumát, így csak az öngyilkosok parcellájában engedélyezte a temetést. A rokonok fellázadtak a döntés ellen, és a település elöljáróságán keresztül, rendőri felügyelettel temették el halottukat a „rendes halottak” sorába. Az eset híre a váci püspökhöz és a belügyminiszterhez is eljutott. A püspöki állásfoglalás Hegyi Antalnak adott igazat, kinek becsületében és a hívek vallásos érzületében komoly kárt okozott a telemetési engedélyt kiállító elöljáróság. ${ }^{373}$

A 19. század végének polgári perekkel tarkított idején is elmondható, hogy a plébános a hívek erkölcsi életének illetékes őrzője maradt, kinek véleményét kérték és segítségére számítottak. A pap a magánügyeikben hozzá forduló hívek panaszát kivizsgálta, majd az érintett feleket a plébániára hívatta elbeszélgetésre. Ha szép szóval nem tudta megbékíteni a vitás feleket, az eset leírását a püspöki szék felé továbbította. A püspöki szék illetékességét ugyanakkor Hegyi Antal több levelében is megkérdőjelezte, és a hívei közt élő lelkipásztor egyedüli kompetenciáját hangsúlyozta: „A plébános ugyanis megtesz a béke helyreállítására minden kísérletezést, mert ez lelkiismeretbeli kötelessége is, s a hol ő nem boldogul, ott hiába való minden kísérletezés, mert hívei nevéhez nálánál senki sincs közelebb s rajtuk jobban senki sem uralkodhatik."374

\footnotetext{
${ }^{371}$ VPL APriv. Hegyi Antal, 1888. október 25. Hegyi Antal levele a váci Egyházmegyei Hatósághoz. 372, ,Nyílt levél] Az iskolaszékhez. Valigurszki Júlia helybeli tanítónő hónapok óta különválva él férjétöl a nélkül, hogy akár kibékülne, akár váló pert indítana. Kérdezzük tehát a tisztelt iskolaszéket, hogy összeegyeztethetőnek tartja-e ezen nyilvános botrányt a tan és nevelés ügy érdekeivel, hogy annak megszüntetése iránt hatásköriböl kifolyólag mindez ideig nem intézkedett?” Tiszavidék, 1893. január 15. IV. évf. 3. szám, 3. old

${ }^{373}$ VPL APriv. Hegyi Antal, 1892. január 11. A váci püspök levele a belügyminiszterhez.

${ }^{374}$ VPL APriv. Hegyi Antal, 1888. október 25. Hegyi Antal levele a váci Egyházmegyei Hatósághoz.
} 
4. Papság és közösségszervezés: vallási társulatok

Az ájtatos társulatok - sajátos lelkiségi céljaik mellett - hatékony eszközei voltak a plébániaközösség több ezer főt magába foglaló, vegyes kötődésű tagjainak csoportosítására, a közösség átláthatóbbá tételére. A társulatok jellemzően a közösség legvallásosabb tagjait fogták össze, akik a világi és az egyházi elöljáró (plébános vagy káplán) felügyelete mellett végezték a megszabott ájtatosságokat, miközben adományokat biztosítottak a templom javára, szobrokat készíttettek, nagyobb ünnepeken oltárt díszítettek. Tower Vilmos azért tartja fontosnak a társulatok ügyét, mert „egyesületek révén könnyebben lehet a nép gondolkozását átalakítani, a lelkületet átgyúrni [...] az egyesületben a pap a néppel való bánásmód lélektanát is megtanulja, amelyet sem könyvből, sem tanfolyamokból nem meríthet". 375

A csongrádi jámbor társulatok történetének kezdete körülbelül a 18. század közepéig nyúlik vissza. A legelső kezdeményezés a Seraficus Szt. Ferenc Kordás Társulat lehetett, mely 1767-ben már „régóta” müködött. Az élő és elhunyt tagok számára szentmisét szolgáltattak, ez utóbbi időpontját újhold vasárnapján hirdették ki a templomban, „hogy annál nagyobb gyülekezettel és buzgósággal jelen lehessenek a Congregatiosok" ${ }^{376}$ A ferences atyák által életben tartott egyesület független volt a csongrádi plébániától és a plébánostól. 1767-ban, amikor a plébános a korábbi szokásoktól eltérően a plébániára hozatta a társulat pénzét tartalmazó egyesületi ládát, a két vezető laikus tisztségviselö, Deák István atya és Csenky Györgyné mater valóságos hadjáratot indított a láda visszaszerzéséért. ${ }^{377}$ A konfliktust a társulat ügyeibe beavatkozó lelkipásztori döntés robbantotta ki. A kordások minden áron igyekeztek megtartani egyesületi autonómiájukat, és csupán a liturgikus szolgálatok ürügyén (misemondatás, temetés stb.) kívántak érintkezésbe lépni a plébánossal.

A II. József idejében feloszlatott kordás társulatot hosszú évtizedekig nem követte hasonló kezdeményezés. Majd csak 1858-ban, amikor is Virter Lajos plébános megalapítja a csongrádi Élő Rózsafüzér társulatot. Megnevezése a későbbi forrásokban következetlen; említik szentolvasó, olvasó, Mária vagy rózsafüzér imacsoportként is. A társulat hamar népszerü lett a Szüzanyát különös gyöngédséggel tisztelő csongrádi hívek körében. A

\footnotetext{
375 Tower 1940. 160.

${ }^{376}$ VPL APar. Cs. Seraficus Szent Ferenc társulat jegyzőkönyve 1767.

377 VPL APar. Cs. Seraficus Szent Ferenc társulat jegyzőkönyve 1767. Lásd még: Muntagné Tabajdi 2013. 145.
} 
társulat mindössze négy éves müködés után 66 imakoszorút, vagyis 990 aktív tagot mondhatott magáénak. ${ }^{378}$ Hegyi Antal közbenjárására a rózsafüzér koszorúkat 1894-ben a győri anyatársulathoz csatolták, így a csongrádi tagokra is az archiconfraternitas egységes szabályzata vált érvényessé. A bekebelezési okiratot Kanda István kanonok, az egyházmegyei ájtatos társulatok központi igazgatója hagyta jóvá még 1887 márciusában. ${ }^{379}$ A megújult keretek közt müködő rózsafüzér társulat könyvét 1896-ban már Hegyi plébános saját nyomdájában adták ki. ${ }^{380}$ A 19. század utolsó évtizedeiben a csongrádi rózsafüzér társulatok világi elöljárója Gyovai Döme István kisbirtokos volt. A világi elöljárókat mindig a társulat tagjai választották meg, így a plébánosnak sem az elöljáró személyébe, de még esetleges leváltása ügyébe sem volt beleszólási joga. ${ }^{381}$ Gyovai Döme jegyzőkönyvben rögzített vallomása szerint a társulat az 1880-90-es években Szent Domonkos életnagyságú szobrára (200 Frt), Szent Antal azonos méretű szobrára (113 Frt), a Lourdes-i oltárra helyezendő, tizenöt tizedes nagyolvasóra (16 Frt) gyüjtött jelentősebb adományt. $^{382}$

Hegyi Antal tehetséges vezető egyéniség volt; korán felismerte a társulatokban rejlő társadalmi erőt, mely biztosíthatta saját pozíciójának megerősítését, a közvélemény bizonyos szintű kézben tartását. Csongrádra érkezésének első percétől fogva szigorú felügyelete alatt tartotta az Olvasótársulat sorsát. 1894-ben elérte, hogy a győri anyatársulat hivatalosan is kinevezze a helyi egyesület teljes jogú igazgatójává. ${ }^{383}$ Éberen őrködött afölött, hogy felügyeleti joga kizárólagos és csorbítatlan legyen. Káplánjaiban sosem bízott annyira, hogy megossza velük a vezetési feladatokat, így 1884 után a csongrádi segédlelkészeknek vajmi kevés köze volt a vallási társulatokhoz. Mikor 1899ben úgy tűnt, hogy Hegyi Antalt végleg felfüggesztik csongrádi hivatalából, Droppa Károlyt nevezték ki helyettesének. Hegyi plébános azonban pár hónap leforgása után váratlanul visszatért Csongrádra és nyomban felülbírálta a távollétében bekövetkezett változásokat. Felháborodásának oka két szobor felállítása volt, melyeket maga

\footnotetext{
378 Dudás Lajos valószínüsíti, hogy 1858 elött is müködtek Csongrádon „egyházi egyesületek”, de a forrásoknak nyomuk veszett. Dudás 1998. 105; Barna 2011; 1998/b.

379 NPI 1887. március 20. Kanda István levele Hegyi Antalhoz. A győri anyatársulatról kunszentmártoni példán lásd. Barna 2011; 1998/b.

380 „Élö Rózsafüzér” társulati imakönyv a csongrádi szent olvasó társulat tagjainak használatára. A Ft. Egyházmegyei Hatóság engedelmével kiadja: A társulat elöljárósága. Csongrádi Közlöny nyomdája, 1896. Csemegi Károly Könyvtár és Tari László Múzeum (Továbbiakban: CsKK TLM) Néprajzi Adattár 94-2008.1

${ }^{381}$ NPI 1894. július 10. Hegyi Antal levele a váci Egyházmegyei Hatósághoz.

${ }^{382}$ VPL APriv. Hegyi Antal, 1898. augusztus 26-27. Szentszéki kihallgatási jegyzökönyv. Gyovai Döme István vallomása.

${ }^{383}$ CsKK TLM Néprajzi Adattár 94-2008.1. 15-16. A társulati kézikönyvben megtaláljuk a kinevező okirat kivonatát.
} 
szándékozott a templomban elhelyezni. ${ }^{384}$ Droppa Károly a támadásokra reagálva azt hangsúlyozta, hogy a plébánia átvételekor a társulatok teljes jogú vezetőjévé is előlépett, így nem csak joga: kötelessége volt a laikus egyesületeket érintő, folyamatban lévő ügyek intézése. Mivel a kérdéses Szent Antal szobor felállításához és szenteléséhez Droppa püspöki engedélyt kért és kapott, Hegyi Antal panasza határozott elutasításra talált.

Pár évvel a csongrádi rózsafüzér társulat megalakulása után, 1863-ban Korber Antal káplán vezetésével hagyták jóvá az Oltáregylet müködését. ${ }^{385} \mathrm{Az}$ egyesület adománygyüjtéssel biztosította a templomi szerelvények feljavítását, cseréjét, miközben rendszeres szentségimádásokat tartanak az Oltáriszentség tiszteletére. 1897-ben az egylet már Hegyi Antal felügyelete alá tartozott, kéréseiket is a plébános közvetítette az Egyházmegyei Hatóság felé. ${ }^{386}$ A társulat fénykora azonban túlnyúlik a 20. század első évtizedeire, amikor is Porubszky József plébános, a Szentségimádó Papok egyházmegyei igazgatója csongrádi munkásságát az Oltáriszentség dicsőségére ajánlotta fel, és személyesen vette kézbe a társulat irányítását. ${ }^{387}$ A Nagyboldogasszony Plébániahivatal irattárában fennmaradt, Porubszky plébános idejéből származó tagnévsorban kb. 370 nevet találunk. A társulat nem hagyott teret a társadalmi elkülönülésnek: a módos Bagi, Bozó, Draskovits, Faragó, Forgó, Herke, Máté, Szarka és Tari úrhölgyek mellett Csongrád szegényeit is megtaláljuk a listán. ${ }^{388}$

Csongrádon a következő jelentős fordulatra Edelényi János idejében kerül sor, aki a püspöki buzdító körlevelek hatására kezdeményezte a Jézus Szive társulat megalapítását. A kezdetben csekély népszerüségnek örvendő társulat még Edelényi idejében Jézus és Mária

\footnotetext{
${ }^{384}$ A következő levél 1899 februárjában kelt az Egyházmegyei Hatóságnak címezve: „Főtisztelendő Egyházmegyei Hatóság! Az itteni élő rózsafüzér társulat 1897. évi [...] elnökletem alatt tartott közgyülése elhatározta, hogy [...] mintegy 150 frtnyi költséggel Szent Antal szobrot fog létesíteni olly célból, hogy annak jövedelmeiböl az elhagyatott, gyámol nélküli házi szegényeket szent Antal kenyerével segélyezze. Droppa Károly administratornak ugyan fogalma se volt arról, hogy mire való ez a szobor, de azért [...], vállalkozott a felfüggesztésem ideje alatt megérkezett szobor fölállítására. [...] A ftö. Egyházmegyei hatóság félrevezetésével, a szent rózsafüzér társulat kárára készíttetett, hogy ugy mondjam, egy oly buta munkát, mely általános megbotránkozására szolgált a csongrádi népnek. [...] A szobrot 1-ör nem oda állíttatta a hova szánva volt, 2-or pedig mert egy oly tudatlan kőmívesre bízta ezt a munkát, ki életében sem állított fel szobrot, vagy keresztet, és [...] mégis a csatolmányok szerint 27 frtot utalt ki a társulat pénztárából, a mihez pedig nem volt egyáltalán semmi joga, mivel a györi anyatársulat által nem volt meghatalmazva az itteni rózsafüzér társulat vezetésére. Az egész szobrot aztán át kellett helyeztetnem oda, a hová szánva volt, de ez a munka szakértő ember kezében már csak 19frt. 45 Kr.ba került. A társulat ez évi jan. 1-én tartott közgyülése aztán Döme István társulati elöljáróval akarta megtéríttetni a jogtalan elharácsolt 27 frtot, de mivel szerintem ez kiadásnak okozója Droppa Károly administrátor volt, a társulat megbízásából alázatosan felkérem a Ftő. Egyházmegyei Hatóságot, hogy ővele méltóztassék ezen összeget visszafizettetni” VPL APar. Cs. 1899. február 28. Hegyi Antal levele a váci Egyházmegyei Hatóságnak.

385 Dudás 1998. 105.

${ }^{386}$ VPL APriv. Hegyi Antal, 1897. április 2. Hegyi Antal levele a váci Egyházmegyei Hatóságnak.

387 VPL APar. Cs. 1902. december 18. Porubszky József levele a váci püspöknek.

${ }^{388}$ Hasonló tapasztalatait rögzítette kunszentmártoni példák alapján Barna 2011.
} 
Szívét ábrázoló képeket hozatott Prágából, majd Jézus Szíve szobrot Tirolból. ${ }^{389}$ A kultusz 1886 után, Hegyi Antal színre lépésével vált kiemelkedő jelentőségűvé Csongrádon.

Hegyi Antal már segédlelkészi évei alatt kiemelkedő harcosa volt Jézus Szíve ügyének, melynek ékes bizonyítéka a kecskeméti egylet megalapítása. A kecskeméti Jézus Szent Szive Egylet 1875-ben már több mint 2000 tagot számlált. Nyári vasárnap délutánokon a templomban, télen magánházaknál tartották az ájtatosságokat. Ezeken az alkalmakon, mint Hegyi írja: „valahányszor csak tehettem, személyesen megjelentem, soha nem mulasztván el ily alkalomkor néhány buzdító szóban az összesereglett néphez tanítást intézni”. ${ }^{390}$ Nagyobb Mária ünnepeken az akkori kecskeméti káplán körmeneteket vezetett a szőlők közti Mária kápolnához, és a tagok kérésére - Tárkányi Béla műve ${ }^{391}$ alapján társulati imakönyvet állított össze. Hegyi leveléből kiderül az is, hogy bár csupán aligazgatói minőségben foglalkozott a társulattal, a plébános feladatait is átvette. ${ }^{392}$

Az „aranyszájú papként” is emlegetett Hegyi Antal lelkesítő szózatai valósággal lázba hozták a csongrádi híveket, akik egyre bőkezübben adakoztak a csongrádi Jézus Szent Szíve társulat céljaira. A befolyt adományokból és tagdíjakból már a müködés első évében lobogót csináltattak, a templomban Jézus Szíve szobrot emeltek. Hegyi Antal sajtótudósítása szerint a társulat alig négy évvel az újjáalakulást követően 8000 tagúra duzzadt. ${ }^{393}$ Hegyi feljegyzéseiből az is kiderül, hogy ebben az időben heti három alkalommal gyültek össze a Szent Szív tagok, hogy a társulati imádságokat a plébánossal közösen begyakorolják. A Jézus Szíve kultusz megkoronázásaként a csongrádi hívek egy 1500 kilogramm súlyú harangot készíttettek a Szent Szív tiszteletére. A harang megcsendítésért járó összeget Hegyi külön kezelte és a társulat fenntartására fordította. 1895-ben Bokros pusztán felszentelték az apró Jézus szíve kápolnát, négy évvel később a társulat teveszőr damaszt lobogókat és arannyal hímzett vörös miseruhát vásárolt a templom számára.

Hegyi Antal néhány esztendő leforgása alatt a kor színvonalának megfelelő szervezettségi szintre emelte a csongrádi társulatokat. Az 1890-es évek végén a politikai „ellensajtó” azzal vádolta a lelkipásztort, hogy azért fektet kiemelt hangsúlyt a társulatok ügyére, hogy kellő társadalmi bázist teremtsen politikai céljai megvalósításához és anyagi

\footnotetext{
${ }^{389}$ NPI Historia Domus, I. kötet

${ }^{390}$ VPL APriv. Hegyi Antal, 1875. január 19. Hegyi Antal levele a váci püspöknek.

391 Tárkányi Béla: Jézus Szent Szivének imádása. Szent István Társulat, Eger, 1853.

392 „Eddig, részben elfoglaltsága miatt is, vajmi kevés gondja lévén az Apát ő nagyságának e társulatra, a beiratkozó tagokat én vettem fel." VPL APriv. Hegyi Antal, 1875. január 19. Hegyi Antal levele a váci püspöknek.

${ }^{393}$ Dudás 1998. 105.
} 
hasznot húzzon az egyletekből. ${ }^{394}$ Bizonyos, hogy a társulatok közvetlen felügyeletével, a személyes példamutatással a plébános tömegeket tudott megszólítani. A társulati szobrok, lobogók, harangok a közös áldozathozatal gyümölcsöző eszméjét hirdették, ugyanakkor a plébános „szimpátiatőkéjét” is jelentősen növelték.

\section{Néhány szó az „ideálkép-problémáról”}

A fenti esettanulmányokat látva joggal merül fel a kérdés: mégis milyen volt a csongrádi hívek elképzelése a ,jó papról’? Melyek voltak azok a visszatérő fogalmak, melyekkel körülírták a lelkipásztori eszménynek megfelelő lelkiatya karakterét?

A rendelkezésre álló levéltári- és sajtóforrásokban többnyire általános fogalmakkal operáló „erénylistával” találkozunk. A jó pap valódi atya, pásztor, aki a lelkek őreként tereli, legelteti nyáját. ${ }^{395}$ Jó pásztor és a lelkek orvosa, akiről a hívek „,a jó erköltsöt, az egyenes lelkűséget, az istenfélelmet elképzelik”. ${ }^{396}$ Emberi példája „béketűrésre, szeretetre, reményre" ösztönzi a híveket. ${ }^{397}$ Ahogy a csongrádi lakosok Vaszary Kolos hercegprímáshoz írt levelében olvashatjuk: „aki benned [t.i. a Jóistenbe] vetett bizalmunkat jó példájával öregbítené s megtanítana arra, hogyha e földön mindent elvesztettünk, de ha Istenfélők, jámborok, becsületesek vagyunk, akkor e rövid földi lét után megmarad számunkra egy biztos, örökké való boldogság". ${ }^{398}$ A jó pap tehát a földi nehézségek elviselésére, az anyagi javakon való felülemelkedésre tanítja híveit.

1889-ben Gétzi János csongrádi lakos nyílt levelében egy lelkeket müvelö atyáért áhítozik: „Lelkiatyát óhajtunk [...] ki lelkünket müvelje; lelkiatyát, ki szívünket nemesítse s minden jóra hajlandó lelkünket a mennyekre érdemessé tegye; lelkiatyát, ki vallásosságra, erényre, kitartásra, szeretetre, becsülés és becsületre tanítson, s akkor mi is engedelmes, hü fiai leszünk." ${ }^{399}$ A jó pap nem csak kiváló lelki vezető, de szorgalmas „templomgondnok” is, akinek a „gondos, istápoló keze nyomán” megszépül a templom és környéke. ${ }^{400}$ A paphoz illő viselkedés jele pedig a „békés [...], előzékeny, udvarias

\footnotetext{
394 „Ez az ember képes mindenféle szent társulatokat szervezni azért, hogy azokból anyagi hasznot húzhasson". Csongrádi Lap, 1892. január 1. II. évf. 1. szám, 2. old.

395 VPL APriv. Hegyi Antal, 1892. március 14. A csongrádi lakosok levele a hercegprímáshoz.

396 VPL APriv. Hegyi Antal, 1889. február 21. Zöld Antal néptanító levele a váci püspökhöz.

${ }^{397}$ VPL APriv. Hegyi Antal, 1892. március 14. A csongrádi lakosok levele a hercegprímáshoz.

398 VPL APriv. Hegyi Antal, 1892. március 14. A csongrádi lakosok levele a hercegprímáshoz.

${ }^{399}$ VPL APriv. Hegyi Antal, 1889. Gétzi János nyílt levele. Schwartz nyomdájából.

${ }^{400}$ VPL APriv. Hegyi Antal, 1892. március 19. Eszes Mátyás levele a hercegprímáshoz.
} 
magaviselet". 401

Ritkán hangsúlyozott szempont, hogy a közösség lelki vezetője számára aligha létezik tabula rasa; természetszerüen kapcsolódik be a lokális hagyomány és emlékezet láncolatába. Visszacsatolási pontokkal, hivatali elődeire vonatkoztatott emlékezeti sémákkal, reflexiókkal és hasonlításokkal kell szembesülnie, illetve ezeket kezelnie. Feladatköre, a pasztoráció igényelt területe hátrahagyott elődei „örökségétől” is függ. Mikor Mátyus János csongrádi plébános ellenében Takács Jakab földmủves vallomást tett, hivatali elődének gyakorlatához viszonyította lelkipásztorát: „Idegenek vagyunk tőlle mindnyájjan, mert abból a jó regulából melly megboldogúlt Fő tisztelendő Kanyó úr alatt volt, semmi sincs többé."402

Csongrádról a későbbiekben egy sajtócikk áll rendelkezésünkre, mely Virter Lajostól kezdve sorra veszi Hegyi Antal hivatali elődeit, illetve azok kiváló tulajdonságait. A célzatos, szembesítési szándékkal született cikk hitelességének kiértékelése nem feladatunk: az ideális lelkipásztor nyomában járó elme számra azonban kikerülhetetlen, értékes forrás. Virter Lajosról, a tudós lelkipásztor a csongrádi hívek „,igazi édes atyja volt”, kinek áldásos tevékenységére a legnagyobb hálával és elismeréssel emlékeztek vissza. Jellemszilárd egyéniségként „,inkább kész lett volna nyelvét tövéböl kiszakítani, mint száján egy hazug szót kiereszteni”. ${ }^{403}$ Alvinczy Ferencet, a „gyógyító atyát” igen korán érte a halál, mely „elragadta hálás hívei köréből”, ám a csongrádiak a legmélyebb kegyelettel emlékeznek rá. ${ }^{404}$ Utódáról, Szabad (Szvoboda) Józsefröl kiderül, hogy szeretetre méltó modorú, kedélyes társasági ember és kitünő szónoki tehetségü pap volt, aki Csongrád minden társadalmi rétegét lekötelezte személyisége iránt. Edelényi János szelíd, igazságszerető és barátságos természete miatt érdemelte ki a hívek bizalmát, így „ő valóban, igazi pap volt". ${ }^{405}$ Három hónappal később a Csongrádi Lap ismét a papi elődöket hozta fel példaként: „Hegyi plébános úr elődei olyanok voltak, akiket valóban tisztelt minden polgár valláskülönbség nélkül, kik nem törődtek híveik politikai meggyőződésével, de annál inkább rajta voltak, hogy a vallásosságban, a keresztényi erényekben: a türelem, jámborság, szerénység és szelídségben példát mutassanak a híveknek. Vagyis: a szó szoros

\footnotetext{
401 Tiszavidék, 1890. március 22. I. évf. 12. szám, 3. old. Borszörcsöki Egressy László postamester nyílt levele.

402 VPL APriv. Mátyus János, 1823. július 10. Takács Jakab vallomása.

${ }^{403}$ Csongrádi Lap, 1895. december 15. V. évf. 51. szám, 1. old.

${ }^{404}$ Csongrádi Lap, 1895. december 15. V. évf. 51. szám, 1. old.

${ }^{405}$ Csongrádi Lap, 1895. december 15. V. évf. 51. szám, 1. old.
} 
értelemben igazi lelkipásztorai voltak híveiknek."406

A Csongrádi Lap által felvázolt előképek - az állítások valóságalapjától függetlenül - tapasztalati alapú viszonymérce mellé állították Hegyi Antalt. A számon kért tulajdonságok, melyekkel hivatali elődei maradéktalanul rendelkeztek, megfelelni látszanak a korábban felvázolt általános fogalmakkal övezett ideálképnek. Ez az ideálkép azonban rugalmas, simulékony alaptermészetet követel, mely nem hagy teret a személyiség egyedi vonásainak.

\subsection{Szerep és személyiség. Az ideálkép törésvonalai}

A papsággal szemben támasztott elvárások akkor jelennek meg forrásainkban, amikor az ideálkép megsérül, és a hívek a - jogos vagy jogtalan - csalódásból fakadó kívánságaikat, vágyaikat igyekeznek szavakba önteni. Ebben az alfejezben az ideálkép „törésvonalai” mentén kísérlem meg meghatározni a személyes vonások azon körét, melyeket a csongrádi hívek nem tartottak a papi jellemmel összeegyeztethetőnek. Távol álljon tőlem a régmúlt emberi esendőségeinek szenzációhajhász taglalása: az ideális papi karakterhez nem illeszthető tulajdonságok körét forrásaim igazságértékétől elvonatkoztatva kivonatolom.

A csongrádi panaszlevelekben használt általános kifogások magyarázatra szorulnak. 1799-ben a szomszédos csépai hívek arra kérték a váci püspököt, hogy plébánosuk „bokrossan öszve tódult törvénytelen tselekedetétül és üldözéseitül menté tenni méltóztasson". ${ }^{407}$ Attól féltek a jámbor csépaiak, hogy a plébános elítélendő viselkedése a nép erkölcsi és lelkiségi állapotán is nyomot hagy. A nevezett lelkipásztor, Mátyus János Csépáról Csongrádra került plébánosnak. Takács Jakab csongrádi földműves pár esztendővel később eképpen vallott lelkipásztora ellenében: „Szabad ő végette [t.i. a plébános végett] a káromkodás, paráználkodás, házasságtörés, erőszakoskodás, innepi munka sat". ${ }^{408}$

A papok ellen felhozott, gyakran konkrét eseteket felemlítő bünlajstromban olyan sérelmes pontokat találunk, mint a hívekkel való durva bánásmód (fizikai és verbális erőszak), gorombaság, káromkodásra hajló természet. ${ }^{409}$ A paptársakkal szemben tanúsított

\footnotetext{
406 Csongrádi Lap, 1896. február 23. VI. évf. 8. szám, 1. old.

${ }^{407}$ VPL APriv. Mátyus János, 1799. január 15. A csépai lakosok levele a váci püspökhöz.

${ }^{408}$ VPL APriv. Mátyus János, 1823. július 10. Takács Jakab vallomása.

409 Csongrádi Közlöny, 1894. március 4. I. évf. 1. szám, 1-2. old. „Hegyi Antal inkább zsandár strázsamesternek, mint Rom. Katholikus plébánosnak való.” Csongrádi Lap, 1892. január 1. II. évf. 1. szám, 2. old.
} 
lelketlen magatartást a hívek különös megbotránkozással kísérték figyelemmel, hisz a plébános és káplánjai közösségétől a felebaráti szeretet élő példájának megvalósulását várták. Az ünnepek közbotrányt okozó, látványos feltörését, ${ }^{410}$ a káplánokra bízott ünnepi misézést, a szentségek kiszolgáltatásának akadozását is bosszúsággal szemlélték, esetenként nyilvánvaló provokációként értékelték. ${ }^{411}$ Ugyanez vonatkozik a kolduló szegények elutasítására ${ }^{412}$, vagy a plébánia szakácsnőjével való, túlzott bizalmaskodásra. ${ }^{413}$

A hívek számára előnytelen adottságokról, a javító szándékú intézkedések hiányáról is megemlékeznek forrásaink. 1823-ban Makai János csongrádi lakos vallomásában olvashattjuk, hogy bár öt pap is van Csongrádon, a plébános mégis csak napi két szentmise tartását engedélyezi. Ennek következménye, hogy a templom zsúfolásig tele van, így valaki mindig elájul. ${ }^{414}$ A plébános ráadásul rendszeresen késéssel kezdi a misét, így „némellyek Szt. Misének hallgatása nélkül, vagy bosszuságból, vagy sürgősebb Dolgaik végett a Szt. Egyházból kilépni kéntelenek”, 415 „,Szegényebb gyermekeink és a gúnyátlan szegényebb Sorsú emberek addig is még Ftdő Plébános Úr béjön a templomba majd lefagynak". ${ }^{416}$ A hitoktatás elmaradása különösen fájdalmasan érintette a keresztény szülőket. ${ }^{417}$

A lelkipásztora müveltségére, tudására büszke plébániaközösség népe azt is észrevette, ha a plébános latin tudása nem kielégítő, vagy nem készült fel kellőképpen az ünnepi prédikációra. A Csongrádi Lap 1895-ben azon élcelődött egyik cikkében, hogy Hegyi Antal ,a latinul írt evangéliumot belgául olvassa”. 418

Anyagi természetü esendőségek közé sorolható a Canonica Visitatioban foglaltaktól

\footnotetext{
410 „Éppen indulóban volt már a Processió, a Zászlók kint voltak a nép pedig számos mint a tenger, midőn a Plébános Úr tanyájáról haza jövén négy lovú kotsijával a nép között keresztül hajtott, és alig ért be kapuján már indult a Processzió, ezen végett a nép igen zúgolódott.” VPL APriv. Mátyus János, 1823. július 10. Gyarmai Mihály vallomása.

4111823 májusában a csongrádi bíró arról panaszkodott a váci püspöki széknek, hogy a csongrádi plébános nem vett részt a húsvéti feltámadási ünnepen, áldozócsütörtökön kenyeret süttetett a plébánián, és ha megfizették, még nagyböjt idején is megeskette a párokat. Ha úgy hozta kedve, hazaküldte a keresztelésre hozzá vitt gyermekeket és két asszony utolsó gyónás nélkül halt meg azért, mert a káplánok éppen nem tartózkodtak a plébánián, a plébános pedig nem volt hajlandó házukhoz kimenni. VPL APriv. Mátyus János, 1823. május 10. Csongrád város bírájának levele a váci püspökhöz.

${ }^{412}$ Csongrádi Közlöny, 1894. március 4. I. évf. 1. szám, 1-2. old.

${ }^{413}$ VPL APriv. Mátyus János, 1807. november 3. A csongrádi lakosok levele a váci püspökhöz.

${ }^{414}$ VPL APriv. Mátyus János, 1823. július 10. Makai András vallomása.

${ }^{415}$ VPL APriv. Mátyus János, 1823. május 10. Csongrád város bírájának levele a váci püspökhöz.

${ }^{416}$ VPL Apriv. Mátyus János, 1823. május 10. Csongrád város bírájának levele a váci püspökhöz.

417 „A nevendékekre nézve lelki tanítás nem tartatik, a Religióbéli oktatásokban nyilván tsökkenyést szenvednek s azon szerént nevelkednek." VPL APriv. Mátyus János, 1823. május 10. Csongrád város bírájának levele a váci püspökhöz.

${ }^{418}$ Csongrádi Lap, 1895. június 2. V. évf. 23. szám, 2. old.
} 
eltérő stóladíj szedése, a fösvénység, kapzsiság. ${ }^{419}$ Tower Vilmos illemtankönyvében említi, hogy a világ a papok egy bünén sem ütközik meg annyira, mint mohó pénzvágyán. ${ }^{420}$ A 19. század második felében a hivatali kötelességek megtagadása (pl. anyakönyvi kivonat kiszolgáltatása) is szerepel a panaszok között. ${ }^{421}$

A „rossz papról” alkotott elképzelések köre Hegyi Antal plébánossága idején új elemekkel bővült. Ennek oka, hogy Hegyi plébános elődeinél markánsabban vállalta fel a közéletiséget: politizált, korteskedett, hírlapot szerkesztett. Szokatlan magatartása miatt híveinek egy része nem tartotta hagyományos értelemben vett, ,igazi lelkipásztornak”.

Politizáló papokkal pedig már Hegyi Antal színre lépése előtt találkozhattak a csongrádiak: 1886-ban Edelényi János plébános káplánjai ellen Csemegi Antal polgármester írt panaszlevelet a váci püspöknek. A polgármester állítása szerint a plébánia teljes papi személyzete felelős azért, hogy Csatár Zsigmond országgyülési képviselő előző évi megválasztásakor Csongrádon felborult a közrend. A káplánok ugyanis - a kántorral és az egyházfival karöltve - politikai célú gyüléseket szerveztek, a templomban kétes tartalmú beszédeket tartottak. Csemegi szerint a lázítás rossz fényt vetett a kormányra, a helyi elöljáróságra és a polgármesterre, ezért a csongrádi papság azonnali kivizsgálását kérelmezte. A polgármester később ugyan elismerte a plébános politikai semlegességét, a két káplán ellenében tett feljelentését az alispánon keresztül a belügyminisztériumba is eljuttatta. ${ }^{422} \mathrm{~A}$ segédlelkészek sorsáról forrásaink hallgatnak, az eset mégis jelzi az elöljáróság ellenszenvét a helyi papság politikai tevékenységével kapcsolatban.

Hegyi Antal az 1891-92-es képviselőválasztások idején a helyi sajtóban és röpiratok útján igyekezett legitimálni szokatlanul határozott politikai ambícióit. Célja Csongrád kormánypárti képviselőjének, Szivák Imrének megbuktatása volt, melyet az ellenlábas Hock János támogatásával próbált elérni. Hegyi nem válogatott a propagandisztikus eszközökben: gyüléseket szervezett, kortes beszédeket tartott, házról házra járva agitált Hock mellett. Egyes források szerint még a templomi katedráról is Szivák Imre ellenében szónokolt, ám ezeket a vádakat Hegyi Antal mindvégig tagadta. ${ }^{423}$

A csongrádi bíró és a jegyző meglepetten szemlélte a plébános példátlan aktivitását. Konstantin püspökhöz írt levelük őszinte ijedelemről árulkodik. A tisztségviselök

\footnotetext{
419 „A plébánus úr egyet [a pusztakengyeli szerencsétlenségben] elhunyt munkások közül díjtalanul el nem temetett." VPL APriv. Hegyi Antal, 1892. március 14. A csongrádi lakosok levele a hercegprímáshoz.

${ }^{420}$ Tower 1904. 160. Állitását csak erösítik az efféle, nép körében terjedő gúnynevek, mint a „parochia szent hasa" Csongrádi Lap, 1895. december 22. V. évf. 52. szám, 2. old.

${ }^{421}$ Csongrádi Közlöny, 1894. május 27. I. évf. 11. szám, 3. old.

${ }^{422}$ VPL APar. Cs. 1876. február 18. Lichtner Gáspár esperes levele a váci püspökhöz.

${ }^{423}$ VPL APriv. Hegyi Antal, 1892. január 2. A váci püspök levele Hegyi Antalhoz.
} 
argumentációja szerint ugyanis egy plébános feladata a nép erkölcsi, és nem politikai vezetése; Hegyi viselkedése tehát „nem paphoz illő”, így az eset azonnali közbelépést igényel. ${ }^{424} \mathrm{~A}$ váci püspök a történtekre reagálva hosszú, atyai levelet írt a csongrádi plébánosnak, melyben főpásztori állásfoglalását fejtette ki. ${ }^{425}$

A püspök elismerte, hogy a polgári szabadságjogok gyakorlása a közterhek viselésében osztozó papságnak is kijár, ám a papi hivatás méltóságának megőrzését minden múlandó politikai konstrukció támogatásánál fontosabbnak tartotta. Konstantin püspök így mértékletességre intette Hegyi Antalt, egyúttal szigorúan eltiltotta a szószéki politizálástól, a nyílt szervezkedésektől és házaló agitációtól. ${ }^{426}$ Hegyi plébános válaszlevelében leszögezte, hogy politikai ellenfelét az egyház ellenfelének tekinti, így kötelességének érzi - akár a püspöki rendreutasítással ellenkezve is - harcba szállni Szivák megbuktatása érdekében. ${ }^{427}$

Hegyi Antal aktív politikai-közéleti tevékenységét tehát sem a váci megyéspüspök, sem a helyi elöljáróság nem tartotta a papi hivatással összeegyeztethetőnek. Egy, a „csongrádi lakosok” által aláírt panaszlevél szerint a plébános politizálása miatt az „ellenségeskedés, gyülölet, elkeseredés, harag, bosszú és erkölcstelenség magvai” szóródtak szét a plébániaközösségben. ${ }^{428}$ A Csongrádi Lap pedig egyenesen Hegyi Antal plébánost hibáztatta azért, hogy ,a csongrádi nép erkölcsileg lejtőre került”. ${ }^{429}$

A Csongrádi Lap rendszeresen szembesítette Hegyi Antal plébánost a hívek vélt

\footnotetext{
${ }^{424}$, A pap, kinek minden párton felül kell állania, korcsmában közönséges politikai agitátorként müködni nem átall.” VPL APriv. Hegyi Antal, 1891. december 30. A csongrádi elöljáróság levele a váci püspökhöz. Egy hónappal később báró Podmaniczky Frigyes is hangot adott rosszallásának: „Csongrádon a politikai helyzet a r. kath. Papság s különösen Hegyi Antal plébános féktelen izgatásai folytán válságossá lett [...] a minek következményei ismét - az egyház szempontjából is - beláthatatlanok.” VPL APriv. Hegyi Antal, 1892. január 8. Báró Podmaniczky Frigyes levele a váci püspökhöz.

${ }^{425}$ Schuszter Konstantin szerint, ha a papok a választások idején szavazatukkal támogatják a trón, a hon és az egyház céljainak megvalósulását, és alkalmanként tanácsot adnak a politikai kérdésekben hozzájuk forduló híveknek, az támogatandó és elismerésre méltó. Ugyanakkor „azon sajátszerủ állás és hivatásnál fogva, melyet a lelkipásztor a hívek között - mint a béke angyala s az egyesség hirdetöje és terjesztöje - elfoglal és betölt, egyházi férfiú $[\ldots]$ kénytelen megmaradni bizonyos korlátok között $[\ldots]$ nem vihet vezérszerepet semmiféle politikai pártnak érdekében sem" VPL APriv. Hegyi Antal, 1892. január 2. A váci püspök levele Hegyi Antalhoz.

${ }^{426}$ Hogy figyelmeztetésének kellö nyomatékot adjon, magához hívatta Hegyi Antal fő politikai támaszát, Bajcsy Gábor káplánt, és többé nem engedte vissza Csongrádra. VPL APriv. Hegyi Antal, 1892. január 20. A váci püspök levele Bajcsy Gábor káplánhoz.

${ }^{427}$ „Abban semmiféle tényező által nem engedem polgári szabadságomat korlátozni, hogy egyházam nyílt ellenségét [...] a képviselői mandatum birtokából kibuktassam” VPL APriv. Hegyi Antal, 1892. január 5. Hegyi Antal levele a váci Egyházmegyei Hatósághoz.

${ }^{428}$ VPL APriv. Hegyi Antal, 1892. március 14. A csongrádi lakosok levele a hercegprímáshoz.

${ }^{429}$ „A csongrádi ember lényegében egészen megváltozott: tisztességet nem ismer, a törvényeknek nem engedelmeskedik; felebbvalóit, elöljáróit kigunyolja; ur-gyülölő. Akár van rá oka, akár nincs. Irigy annyira, hogy a tisztességes gunyát viselö hivatalnokra is görbe szemmel néz: mert azt hiszi, hogy az ő verejtékén, az ő zsírján szerezte.” Csongrádi Lap, 1899. október 29. IX. évf. 44. szám, 3. old.
} 
vagy valós elvárásaival. 1896. májusában hosszabb cikk értekezett arról, hogy egy jó pap nem politizál, hanem megmarad hívei lelki életének ápolásánál: „[bárcsak] egy jámbor, istenfélő, szelíd, türelmes plébánost választhatnánk be. Olyat, aki a hívőkkel nem gorombáskodik, aki nem kortes vezért: hanem lelkipásztor lenne; aki nem kortes beszédek tartására: hanem az Isten igéjének hirdetésére használná fel [...] szelidlelkü lelkiatyára van szükség" ${ }^{430}$ A jó plébános tehát a politika megosztó erejét felülírva a béke megtestesítője, a társadalmi egyetértés záloga. ${ }^{431}$ A morális síkon kissé felülemelkedve érdemes újra felidéznünk, hogy a Szivák Imre pártját fogó Csongrádi Lapnak nagyon is gyakorlatias érdekei füződtek ahhoz, hogy Hegyi Antalt visszaszorítsák a plébánia falai közé.

Az imént felsorolt példák alapján megállapítható, hogy a súlyosabb „,papi bűnök” közé, mint a gyakorlati lelkipásztorkodás kiemelt területein tapasztalt kötelességmulasztás (gyóntatás hanyagolása, szentmisék késéssel tartása) vagy az erkölcsi-morális példamutatás hiánya (pénzéhség, nőkkel való érintkezés) a 19. század végén a túlzott politikai-közéleti szerepvállalás lépett. Hegyi Antal azáltal, hogy a társulati tagokat és a laikus templomszolgákat is bevonta az agitációba, hogy prédikációiba politikai tartalmat füzött, papi szerepének és személyes meggyőződéseinek ellentmondásaiba keveredett, melyet környezete sem hagyott szó nélkül.

A ,paphoz nem illő” motívumok köre a csongrádi példák nyomán korántsem teljes. Célunk nem egy minden részletet kimerítő bünlajstrom összeállítása, hanem a forrásaink alapján körvonalazódó „lelki helyzetkép” megragadása, a lelkipásztor iránt támasztott elvárásrendszer elemeinek felvázolása volt.

\subsection{Visszacsatolás: a csongrádi hívek reakciói}

Az alsópapság viselkedését, tetteit, döntéseit állandó értékelő aktus övezi, a hívek panaszos vagy dicsérő szólamú levelei pedig az adott magatartásminta elfogadottságáról adnak számot.

A váci püspöknek küldött panaszlevelek előzményének tekinthetjük a hívek közt szájról-szájra terjedő, szállóige-szerü formulákat. Az utolsó kenet feladására káplánjait küldő plébánosra mondták a csongrádi asszonyok, hogy „könnyebb volna, úgy mond a

\footnotetext{
${ }^{430}$ Csongrádi Lap, 1896. május 24. VI. évf. 21. szám, 2. old.

431 „Békebírája lesz a békétlenkedőknek, ki fogja egyenlíteni az egyenetlenséget, ki fogja békíteni az ellenségeskedőket, és így meg fogja szüntetni a nép és az értelmiség közt dúló ádáz harczot” Csongrádi Lap, 1893. február 26. III. évf. 9. szám, 1-2. old.
} 
sárkányt a lyukából kiolvasni, mint a Fő Tisztelendő Urat a házából”. ${ }^{432}$ A következő lépcsőfok a plébános írásos bepanaszolása volt a megyéspüspöknél.

A csongrádi hívek csak olyan kiemelt alkalmakkor találkozhattak a megyéspüspökkel, mint a bérmálkozás vagy a kánoni vizitáció - hacsak ez utóbbi esetben nem a kerületi esperest küldte el maga helyett. A hívekben kialakult elképzelés a püspökről tehát jóformán érintetlen a tapasztalattól. A püspök az elérhetetlen távolságokban élö, igazságszerető, bölcs főatya, aki nem csak meghallgatja, de legjobb szándéka szerint meg is segíti a hozzá „orcza pirulló szerénységgel” folyamodó fiait. ${ }^{433}$ A püspökhöz címzett levelek tárgya vagy a plébános egy konkrét cselekedetének bírálata, vagy a teljes személyiség elutasítása. ${ }^{434}$

A „népbotrányt” mint retorikai fordulatot célzatosan, nyomatékosításként használják forrásainkban, jelezve a papság tekintélyét veszélyeztető ügy súlyosságát. ${ }^{435} \mathrm{~A}$ megdöbbent közösség lélekrajzának leírása a panaszlevelek fajsúlyos része: „a nép igen zúgolódott”, 436 „a hívő nép egy része oktalanul káromkodik, másrésze pedig sír szíve fájdalmában” ${ }^{437}$ „,bizony megunták azt [ti. a plébánost] a csongrádiak” ${ }^{438} \mathrm{Nem}$ ritka, hogy a levél írója a fokozás szándékával szó szerint idézi a panaszos fohászokat: „némellyek: 'bár tsak az Isten elvinné', mások: 'bár tsak az ördög vinné', egyebek pedig: 'bár tsak jobb lelki pásztort kapnánk"' ${ }^{439}$ A legkomolyabb, szinte fenyegetésszerű formulák valódi kétségbeesésről tanúskodnak: ,,annyira van már a nép között a dolog, hogy ha (a plébános) még tovább is közöttünk marad, mind Lutheránusokká válunk."440

A panaszlevelekkel párhuzamosan terjedt a plébánossal szemben tanúsított passzív rezisztencia: „számtalanon vagyunk, kik kénytelenek vagyunk a kegyelet szent érzelmeit visszafojtani szívünkben”, ${ }^{441}$ „kénytelenítve vagyunk a Rom. Kath. Anyaszentegyházat

\footnotetext{
${ }^{432}$ VPL APriv. Mátyus János, 1823. július 10. Miskoltzi Pál vallomása.

${ }^{433}$ VPL APriv. Mátyus János, 1799. január 15. A csépai lakosok levele a váci püspökhöz.

434 „88-ban a temető rendezése is mennyire nem volt ínyére némely polgároknak s úgy panaszolták be a plébánost Schuszter püspöknél, mint a temető feldúlóját.” Tiszavidék, 1894. március 11. V. évf. 10. szám, 3. old.

${ }^{435}$ „[A csongrádi plébános] elítélése nemcsak ő reá háramlik, hanem szégyenfolt lesz a papi osztályra is.” Csongrádi Lap, 1898. július 10. VIII. évf. 28. szám, 3. old. „Halasztást nem tür az ügy, a nélkül, hogy a katolicizmusnak érzékeny kárára ne történne”. VPL APriv. Hegyi Antal, 1889. Gétzi János nyílt levele, Schwartz nyomdájából.

${ }^{436}$ VPL APriv. Mátyus János, 1823. július 10. Gyarmati Mihály vallomása

${ }^{437}$ VPL APriv. Hegyi Antal, 1894. március 4. A csongrádi káplánok levele a váci püspökhöz.

${ }^{438}$ VPL APriv. Mátyus János, 1823. július 10. Mészáros Imre vallomása.

${ }^{439}$ VPL APriv. Mátyus János, 1823. július 10. Urgasz József vallomása.

${ }^{440}$ VPL APriv. Mátyus János, 1823. július 10. Gyarmati Mihály vallomása

${ }^{441}$ Csongrádi Közlöny, 1894. május 27. I. évf. 11. szám, 3. old.
} 
kerülni”. ${ }^{442}$ A szentmiséken részt vevő hívek száma hanyatlásnak indul, főleg a távolabbi filiák lakosai nem vállalják a hosszadalmas utat. ${ }^{443} \mathrm{Az}$ utolsó kenetre szoruló, súlyos betegek „képessek volnának gyonás nélkül meghalni, mint sem T. Plébános Úrnak gyónni", ${ }^{444}$

Az érzelmes hangvételü levelekből a közösség erkölcsi rendjének féltése rajzolódik ki. 1799-ben a szomszédos csépai lakosok azért ragadtak pennát Mátyus János, későbbi csongrádi plébános ellen, mert attól tartottak, hogy a köszönésüket nem fogadó plébános miatt a lakosok előbb-utóbb elhagyják a régi, szép üdvözlő formulát. ${ }^{445}$ A plébános felelössége a közerkölcsi állapotokat tekintve halmozott, így a hívek a rendelkezésükre álló eszközökkel igyekeztek nyomást gyakorolni rá, hogy példájával a ,paphoz illő” elvárásokat tükrözze vissza. Kiss Réka a Küküllői Református Egyházmegyei források alapján megállapította, hogy míg a 17. században a papokkal szemben inkább gazdasági jellegü retorziókat alkalmaztak (pl. közmunka és adómegtagadás), addig a 18. században már egészen más jellegü ellenállást tanúsítottak a hívek (nem mentek el a templomba, nem fogadták el az úrvacsorát). ${ }^{446}$ A 19 . századi csongrádi forrásokban a közösségi elégedetlenség kizárólag a vallásgyakorlás hanyatlásán mutatkozott meg.

A kérdőre vont plébánosok reakciója a püspök irányában kivétel nélkül védekező, hárító, nem ritkán magukat a panaszosokat jelölik meg a közbotrányt keltő esetek okozójaként. Hegyi Antal „tudatlan beavatkozóként” ír kritikusairól, akik „okosabbak akarnak lenni, még a szorosan vett egyházi ügyekben is, mint tulajdon vezetőjük”. 447 Ugyanebben a forrásban ,apagyilkosnak” nevezi bepanaszolóit. 1893-ban a sorozatos támadásoknak kitett Hegyi Antal baljós ködbe burkolja a csongrádi plébániai állást, mely saját jövőjét is fátumként determinálja: „,az utóbbi félszázad alatt a csongrádi plébánosok ötven éves korukig vagy megszöktek, vagy elhaltak Csongrádról. S bizony a lélekölő, szakadatlan munka mellett a mostani plébános sem ígérhet más sorsot magának". 448

A csongrádi híveknek tehát határozott elképzelései voltak a „valódi, jó lelkipásztor” jellemrajzáról. Az erősen sztereotipizált vágyak föbb motívumai tapasztalati alapúak, hisz a

\footnotetext{
${ }^{442}$ VPL APriv. Hegyi Antal, 1889. Gétzi János nyílt levele, Schwartz nyomdájából.

${ }^{443}$ VPL APriv. Mátyus János, 1799. január 15. A csépai lakosok levele a váci püspökhöz.

${ }^{444}$ VPL APriv. Mátyus János, 1799. január 15. A csépai lakosok levele a váci püspökhöz.

445 „Mellybül a botránkoztatás utánn tsak még az ne származzon Tdő Plébános Úr után a Hívek között, hogy azon Anyaszentegyháznak béhozott szép szokását, Dicsértessék Jézus Sz. nevének említését elhagyják.” VPL APriv. Mátyus János, 1799. január 15. A csépai lakosok levele a váci püspökhöz.

${ }^{446}$ Kiss 2011. 193.

447 Tiszavidék, 1890. május 11. I. évf. 11. szám, 3. old.

448 Tiszavidék, 1893. augusztus 6. IV. évf. 32. szám, 3. old.
} 
papi elődök magatartásának egyes vonásait idézik vissza. A „visszavágyott” karakterek és az el nem fogadott személyiségek pedig árnyalatlanul szélsőséges ellentétpárokká rendeződnek. Ezt tapasztalhatjuk Kanyó András és Mátyus János, a század második felében Virter Lajos és Hegyi Antal esetében. A hívek tehát nem az ismeretlen szemináriumi normákhoz, hanem egy megélt, de elmúlt „aranykor” papi ideáljához igazították a plébános társadalmi szerepéröl alkotott elvárásaikat.

\section{PAPTÁRSAK VAGY SZOLGÁK?}

\section{A KISEGÍTÖ LELKÉSZKEDÉS RENDSZERE}

A kisegítő lelkészkedés rendszere óriási késéssel kezdett kiépülni a szervezetében szétzilált, paphiánytól szenvedő, hódoltság utáni váci egyházmegyében. ${ }^{449}$ Althann Mihály Frigyes (1718-1734) alighogy magára öltötte a püspöki ornátust, nyomban meg is alapította a váci szemináriumot. Itt eleinte a káptalan tagjai oktatták a papi életre készülőket, ezt a tisztet később domonkos atyák látták el. Voltaképpen a tanító domonkos és kegyesrendi szerzetesek váci letelepedése volt az egyházmegye rekatolizációjának kulcseseménye. Az ideiglenes papneveldében végzett munkájuk hatására 1717-ben már 32 állandó plébános müködött szerte a Duna-Tisza közén. ${ }^{450}$

Bár Althann és nagyméltóságú utódai komoly erőfeszítéseket tettek a Szeminárium bővítésére, a vándorló ferences atyákra, a licenciátus intézményére még a 18. század közepén is nagy szükség mutatkozott. Althann Frigyest 1734-ben testvéröccse, Károly követte a püspöki székben, aki 1750-ben a piaristákra bízta a szeminaristák oktatásának feladatát. Az új püspök a papképzés átszervezése mellett a plébániák számának növelésével próbálta kivezetni egyházmegyéjét a bénultságból. ${ }^{451}$ Fáradozásainak eredményeként közel 40 filiával és plébániával, számos új és újjáépített templommal gyarapodott a váci egyházmegye.

Az egyházmegye „,aranykora” Migazzi Kristóf idejére tehető, aki 1785-ben már egy jól müködő egyházszervezetet hagyott maga után. A püspök Borromei Szent Károly papnevelési rendszerét alkalmazva megkövetelte a kispapoktól, hogy magyarul, németül és

\footnotetext{
449 A váci egyházmegye 1544-1686-ig volt a török kezén. Mivel a mindenkori váci püspök ezidő alatt a Felvidék különböző városaiban lakott, a papszentelés feladatát sem tudta ellátni, így a lelkipásztorok száma eröteljes csökkenésnek indult. Szarka 1947; Molnár Antal 2001.

${ }^{450}$ Chobot II. 1917. 619. Ez a szám több mint kétszerese a húsz évvel korábbi adatoknak: Bendő István püspöki helynök 1697-ben végzett vizitációja során 12 papot talált a váci egyházmegye 22 plébániáján. Török-Legeza 2001. 33; Mezösi 1939.

451 Patkóné Kéringer 1997. 14; A váci szeminárium történetéről bővebben lásd: Varga Lajos 2004. (kézirat).
} 
„tótul” is tudjanak beszélni. ${ }^{452}$ 1780-ban elkészült az új, nagyobb befogadóképességü szeminárium épülete, ám mindössze három éves müködés után az intézmény bezárni kényszerült. II. József 1783-ban ugyanis elrendelte az egyházmegyei papképző intézetek felszámolását. ${ }^{453}$ A 26 váci papnövendéket a Pozsonyban székelő Központi Szemináriumba irányították. Az államosított „kísérleti papnevelés” következményeként a váci szeminaristák kétharmada a felszentelés előtt elhagyta az intézetet. ${ }^{454}$

Hogy Migazzi püspök erőfeszítései a királyi rendelkezések ellenére sem voltak terméketlenek, mutatja, hogy halála idején (1803) a nagyobb településeknek már saját plébániája és temploma volt, a papképzés adatai pedig megnyugtatóan alakultak. ${ }^{455}$ Mivel a plébániák számának növekedése már nem állt arányban a papképzés növekvő ütemével, immáron lehetőség nyílt a frissen felszentelt papok számára, hogy működésük első éveiben káplánként, tapasztalt lelkipásztor mellett ismerkedjenek a plébánia irányításának gyakorlatával. A kisegítő lelkészkedés rendszerének kiépülését az Alföld 18. századi újranépesedése és a filiák szaporodása is szükségessé tette. ${ }^{456}$

A latin cappellanus szó kezdetben a kis kápolnában miséző lelkiatyát jelentette. A 18. századi szóhasználatban a káplán már olyan frissen, néhány éve vagy évtizede felszentelt áldozópap, aki püspöki utasításra, az adott település vezetésével megbízott lelkipásztor felügyelete mellett segédkezik. ${ }^{457}$ Gaith és Patzner 1892-es kiadású lelkipásztori lexikona szerint a capellani locales (vagyis helyi káplánok) jogaikat és kötelességeiket tekintve egyenrangúak a plébánossal, csupán illetményeik alacsonyabbak. $^{458}$ A káplán és plébánosa viszonyát elemző szócikkben a szerzők megerősítik, hogy „egyházi rendre nézve mindkettő egyenlö, tehát a plébános káplánját úgy tekintse, mint társát". 459

A segédlelkészek feladataköre a helyettesítésre és megbízásra (potestas delegata et vicaria) korlátozódik, vagyis amit a plébános maga kíván elvégezni, azt a káplán már nem teheti meg. ${ }^{460}$ A kisegítő lelkész nem egyenlő a helyettes lelkésszel vagy plébániai adminisztrátorral (helyettessel). Míg a helyettes lelkész a plébánossal egyenlő jogokkal

\footnotetext{
452 Forró 2000. 26.

${ }^{453}$ Mihályfi 1896. 235.

454 Török-Legeza 2001. 38.

455 1785-ben 85 müködő plébánia és 80-nál is több filia volt a váci egyházmegyében. Varga Lajos 1997. 6.

456 1808-ben a váci egyházmegyében 108 plébániát találunk, a katolikus hívek száma viszont 352.618 fő volt. Varga Lajos 1997. 7.

${ }^{457}$ M. Kat. Lex. VI. 2001. 146.

${ }^{458}$ Gaith-Patzner 1892. 165.

${ }^{459}$ Gaith-Patzner 1892. 304.

${ }^{460}$ Gaith-Patzner 1892. 335.
} 
rendelkezik, a káplánok függő viszonyban állnak, nem jogosultak önálló döntéshozatalra. ${ }^{461}$ Káplánokra elsősorban nagyobb lélekszámú, filiával rendelkező egyházközségekben, munkájában akadályozott idős, vagy beteg plébános mellett van szükség a liturgikus szolgálat gördülékenysége érdekében. A kisegítő lelkészkedés intézménye a protestáns egyházakban is elterjedt.

A káplán megnevezése a csongrádi anyakönyvekben caplanus, cooperator loci, vagy rövidítve capl, cooper, capell. A szomszédos csépai lakosok 1799-ben keltezett, választékos hangú levelében: Pater Cooperator. ${ }^{462}$ A csongrádi filialista tési kertészek 1815-ös kérelmében a Plebánus Úr Tisztelendö segédére történik utalás. ${ }^{463}$ Csongrádon 1836 októberétől, a Matriculák magyar nyelvü vezetését követően találkozunk a káplán, gyakrabban káplány megnevezéssel.

Jelen fejezetben a rendelkezésre álló források alapján körvonalazom a gyakran váltakozó, „maguk után különösebb emléket nemigen hagyó”464 káplánok alakját, szerepét a 19. század végi csongrádi plébániaközösség életében. Különös figyelmet szentelek a plébánossal, a ferences atyákkal és a laikus templomszolgákkal kialakult konfliktushelyzetek tanulságaira, melyek a segédlelkészek helyére, szerepére világítanak rá a plébániai hierarchia rendjében.

\section{A csongrádi káplánok}

A török idők után újraszervezett csongrádi plébánia első vezetői (1704-től) ötven éven keresztül jóformán egyedül, gyönge javadalmazás mellett, egy szerény deszkatemplomban látták el a hívek lelki gondozását. Állandó segítőik a kecskeméti és szegedi konvent által kirendelt ferences barátok voltak. ${ }^{465}$ Csongrád lélekszáma a Károlyi grófok adókedvezményeinek hatására 1723-ban jelentősen megnövekedett, így a plébános teendői

\footnotetext{
461 Révai XI. 1914. 220-221. Administrator interimalis (ideiglenes lelkészhelyettes): „Oly világi vagy szerzetes papok, a kik valamely plébánia megüresedése alkalmával az új plébános kinevezéséig a püspök által rendeltetnek ki a plébániai hivatal vitelére. [...] b) a kik a plébánost annak távollétében helyettesítik." Gaith-Patzner 1892. 2. Tanulmányomban a káplán, káplánatya, kisegitő lelkész és segédlelkész kifejezéseket szinonímaként használom.

${ }^{462}$ VPL APriv. Mátyus János, 1799. január 15. A csépai lakosok levele a váci püspökhöz.

${ }^{463}$ VPL APar. Cs. 1815. július 2. A tési kertészek levele a váci püspökhöz.

${ }^{464}$ Váry 1974. 26.

465 A hódoltság korában Csongrád és környéke a Szeged-alsóvárosi kolostor körzetébe tartozott. A 18-19. században viszont már jelentősen több kecskeméti illetőségü szerzetes fordult meg a környéken, mint szegedi. Ennek oka, hogy az 1823-45 közötti püspöki vizitáció eredményeiből okulva Roskoványi Ágoston püspök 1854-ben négy missziós körzetet szervezett, melyek vezetését a szolnoki és kecskeméti ferences rendházakra bízta. Az intézkedés következményeként Csongrád a kecskeméti rendház körzetébe került. V.ö. NPI Születési anyakönyvek, Varga Lajos 1997. 7; Bálint 1983. 26.
} 
is megszaporodtak. Az első káplán, Molnár Mihály 1758-ban érkezett a településre. ${ }^{466}$

A segédlelkészek hagyomány szerint 1-3 évet töltöttek állomáshelyükön, ez Csongrádon sem volt másként. Az anyakönyvek arról tanúskodnak, hogy a váltásokra jellemzően az őszi és tavaszi hónapokban került sor.

A csongrádi kápláni állások száma 1809-ben egyről háromra emelkedett. Az igény tartósságát mutatja, hogy az 1854-ben épített új csongrádi plébániaépület már három tágas káplánszobával rendelkezett. ${ }^{467}$ Időközben az egyházmegyei papnevelés ügye is átalakult, korszerüsödött; Roskoványi Ágoston (1851-1859) megyéspüspök négy évre emelte a kispapok képzési idejét. ${ }^{468}$

A 19. század folyamán a csongrádi segédlelkészek száma változatlan maradt. Kedvezőtlen fordulatra akkor került sor, amikor Bajcsy Gábor csongrádi káplánt 1892-ben a megyéspüspök Vácra hívatta, és túlzott politikai aktivitása okán azonnali elzárásra ítélte. Hegyi Antal így három helyett két káplánnal látta el a liturgikus teendőket. Hegyi plébános ugyan 1892 és 1898 között többször is kérte a megyéspüspököt, hogy küldjön neki harmadik segédlelkészt, felterjesztései nem találtak megértésre. A káplán hiányát Schneider György nyugalmazott áldozár felkérésével, illetve az egy lelkész egy napon celebrálható miséinek számszerü emelésével igyekezett enyhíteni. ${ }^{469} 1888$ nyarára a helyzet látszólag tarthatatlanná vált: „ha sokszor ismételt kérésem daczára a baj a legrövidebb idő alatt nem orvosoltatik, egyik templomot a hívek legnagyobb botrányára be kell záratnom". ${ }^{470}$ Hegyi Antal panaszos levelei ellenére majd csak Porubszky József és Thury Károly atya sikeres váci diplomáciájának köszönhetően emelik a csongrádi segédlelkészek számát öt före. ${ }^{471}$

\footnotetext{
466 NPI Canonica Visitatio 1828. Dudás Lajos helytörténész szerint csak 1771-től müködtek a csongrádi plébánosok mellett segédlelkészek. V.ö. Dudás 1999/a.

${ }^{467}$ VPL APar. Cs, 1854. augusztus 15. A váci püspök levele gróf Károlyi Istvánhoz.

${ }^{468}$ Forró 2000. 31.

${ }^{469}$ VPL APriv. Hegyi Antal, 1894. szeptember 30; 1899. január 19; illetve: 1898 október 7. Hegyi Antal levelei a váci püspökhöz. Lásd még: Tiszavidék 1893. január 22. IV. évf. 4. szám, 3. old. A Hegyi által kért engedélyt Binatio-nak nevezzük. Jelentése: „Az egyházi jog szerint csupán karácsony ünnepén van megengedve ugyanazon nap egynél többször bemutatni a sz. miseáldozatot.” Különleges okok, amikor napi több szentmise tartható: „2) Ha egy lelkész több plébánia élére van állítva.” Ha más pap nem áll rendelkezésére, joga és kötelessége a lelkipásztornak 2-3 alkalommal is misézni. Önhatalmúlag viszont erröl nem ítélkezhet: a püspök jóváhagyására van szükség, aki felülbírálja a binatio indokoltságát. Gaith-Patzner 1893. 54-55.

${ }^{470}$ VPL APriv. Hegyi Antal, 1888. július 23. Hegyi Antal levele a váci Egyházmegyei Hatósághoz.

${ }^{471}$ Dudás 2000. 89.
} 
2. A káplánok javadalmai, kötelezettségei, világi és egyházi tisztségei

\section{1. Általános javadalmak}

A segédlelkészek pénz és természetbeli fizetségének biztosítása a plébános feladata volt. A járandósággal összefüggő feladatok köre a lelkipásztori müködés minden gyakorlati aspektusát lefedte, ám önálló döntéshozatalra nem adott feljogosítást. ${ }^{472}$

A csongrádi káplánok állandó lakhelye a plébánia épületében volt, ahol együtt étkeztek a plébánossal és a kolduló ferences atyával. ${ }^{473}$ Sem élelemre, sem tüzifára nem kellett gondot fordítaniuk. ${ }^{474} \mathrm{~A}$ minden hónap végén kézhez kapott pénzbeli juttatást a Canonica Visitatio alapján számolták ki. 1784-ben egy csongrádi káplán éves fizetése 60 rhénes forintot tett ki. ${ }^{475} \mathrm{Az}$ 1870-es évek közepén ez az összeg havi 10 forint volt. ${ }^{476}$ 1898-ban a csongrádi plébánia vezetésével meghatalmazott adminisztrátor évente fejenként 105 forintot adhatott káplánjainak. Önmagára és a két segédlelkész eltartására évi 900 forintot fordíthatott. ${ }^{477} \mathrm{~A}$ beteg káplánok ápolási költségeit is a plébánosnak kellett elöteremtenie. ${ }^{478}$ A váci püspöki hivatal nem kis döbbenettel fogadta Hegyi Antal 1888-ban keltezett felterjesztését, melyben súlyos beteg segédlelkésze „tartási díjának” megtérítését kérte. $^{479}$

A csongrádi állomáshely összességében kielégítő anyagi hátteret biztosított a káplánok számára. Pozsár Endre 1888-ban írt levelében arra kérte a váci püspököt, hogy szándéka ellenére ne mozdítsa el Csongrádról a gyengébben javadalmazó

\footnotetext{
472 „A róm. kath. segédlelkészek, miként mindenütt, úgy Csongrádon is, az akadályozott plébánost az összes lelkészi teendőkben csak helyettesítik és kisegítik; ezért mindenben az ő utasítása szerint járnak el." Csongrádi Újság, 1911. január 15. IX. évf. 3. szám, 3. old. Kopeczky József káplán nyílt levele.

${ }^{473}$ A csongrádi káplánok 1894-ben pontosan a plébániai étkeztetés és a kosztpénz összegének szabályozása ügyében keresték fel a váci püspököt. VPL APriv. Hegyi Antal, 1894. március 4. A csongrádi káplánok levele a váci püspökhöz.

${ }^{474}$ A lelkészek minimális jövedelmét meghatározó kongrua bevezetése előtt a segédlelkészek ellátását illetően a következő szempontok voltak megszívlelendők: „A meghatározott fizetésen felül (a segédlelkész) a plébánostól rangjához illő ellátást, jelesen tisztességes lakást, élelmezést, továbbá szolgálatot, fütést, világítást és mosást követelhet; tulságos követelésnek azonban nincsen helye.” Gaith-Patzner 1892. 305.

${ }^{475}$ NPI 1784. május 25. A Föl-Gyövi, Csanyi, Tési és Fehér-tói kertészek levele a váci püspökhöz. A rhénes, másképp rhénusi, rajnai vagy német forint hatvan krajcárt érő, német ezüstforint volt.

${ }^{476}$ Ekkoriban már osztrák értékü, tízes alapú pénzrendszer volt érvényben. Egy osztrák értékủ forint értéke 100 krajcár volt.

${ }^{477}$ VPL APriv. Hegyi Antal, 1898. január 19. Püspöki szentszéki ülés jegyzökönyve.

478 „A káplány mint munkatárs a dijra is érdemes, evégett kötelessége a plébánosnak öt illő ellátásban részesíteni, betegségében gyámolítan.” Schüch 1872. 584.

479 „Tekintettel arra, hogy teljesen szokatlan, sőt példátlan, hogy plébános ily czimen igényt támasszon (kérése) elutasítandó” VPL APriv. Hegyi Antal, 1888. október 16. Püspöki leirat.
} 
Kiskunmajsára. ${ }^{480}$

\subsection{Misézés, szentségek kiszolgáltatása}

A misék számát és a misézés rendjét Csongrádon a plébános osztotta fel a káplánok között. ${ }^{481}$ A vezető lelkipásztor jellemzően a vasárnapi „tízórás” nagymisén prédikált, a filiákra csak kivételes esetekben (pl. templombúcsú alkalmával) látogatott el. Olykor nagyobb ünnepi misék celebrálását is valamelyik káplánjára bízta. Mátyus János plébános idejében kizárólag a céhek rendelt miséit végezte a helyi főpásztor - ezt azonban sosem bízta segédlelkészeire. ${ }^{482}$ Alapítványi misék után a káplánok (a kántorral és a harangozóval egyetemben) előleg formájában kapták vonatkozó illetményüket. ${ }^{483}$ A plébános saját belátása szerint el is tilthatta segédlelkészeit a misézéstől. ${ }^{484}$

Újszülött gyermekek keresztelésére a 19. század elején reggel hat órakor vagy fél nyolckor, a század második felében már a fél hétkor kezdődő misén vagy azt megelőzően került sor. ${ }^{485} \mathrm{Az}$ anyakönyvek tanulsága szerint a 19. század közepén jellemzően a káplánok, kisebb részben a ferences atyák szolgáltatták ki az első szentséget. A plébániát irányító lelkipásztor csak kifejezett kérésre keresztelte személyesen a módosabb szülők esetleg a laikus templomszolgák gyermekeit. ${ }^{486}$ A jegyesek oktatása és az esketések lebonyolítása ugyancsak a káplánok feladatai közé tartozott, ám erre minden esetben engedélyt kellett kérniük a plébánostól. ${ }^{487}$

$\mathrm{Az}$ adott héten esedékes temetéseket a soros vagy hetes káplány végezte. ${ }^{488} \mathrm{~A}$ káplánok külön temetési stólát nem szedhettek. A Canonica Visitatioban rögzített díjak a

\footnotetext{
${ }^{480}$ VPL APar. Cs. 1888. február 20. Pozsár Endre káplán levele a váci püspökhöz.

${ }^{481}$ Példaként említve: 1894-ben vasárnaponként Schneider György fél hétkor, Droppa Károly nyolc órakor, Hegyi Antal plébános 10 órakor misézett a Nagyboldogasszony-templomban. Ezzel párhuzamosan Varga Mihály káplán misézett fél kilenctől a Szent Rókus filiában. VPL APriv. Hegyi Antal, 1894. március 4. A csongrádi káplánok levele a váci püspökhöz. Ugyanakkor tudomásunk van arról, hogy Kecskeméten az 1870es években az ún. számadó káplány osztotta fel a misézés rendjét. VPL APriv. Hegyi Antal, 1875. január 19. Hegyi Antal levele a váci püspökhöz.

${ }^{482}$ VPL APriv. Mátyus János, 1823. július 10. Makai András vallomása.

${ }^{483}$ VPL APriv. Hegyi Antal, 1888. január 9. Hegyi Antal levele a váci Egyházmegyei Hatósághoz.

${ }^{484}$ Ahogyan az történt 1894-ben Schneider György, majd 1899-ben Felber István esetében. VPL APriv. Hegyi Antal, 1894. március 4. Hegyi Antal levele a váci püspökhöz. Illetve: Csongrádi Lap 1899. október 29. IX. évf. 44. szám, 3. old.

${ }^{485}$ VPL APar. Cs. 1841. szeptember 9. Jancsovics József levele a váci püspökhöz.

${ }^{486}$ A csongrádi lakosok panaszosan jelentik 1825-ben a váci püspöknek, hogy Mátyus János lelkipásztor elfoglaltságai okán - hazaküldi a keresztelésre hozzá vitt gyermekeket. VPL APriv. Mátyus János 1825. május 4. A csongrádi bíró levele a váci püspökhöz.

${ }^{487}$ Gaith-Patzner 1892. 335.

488 VPL APar. Cs. 1867. november 12. Alvinczy Ferenc levele a váci püspökhöz.
} 
helyi lelkipásztort illették, ám az összeget saját belátása szerint utólag megoszthatta. ${ }^{489}$ Mátyus János plébános az 1820-30-as években a kántor énekes halotti búcsúztatójának végighallgatásáért 1 forint várakozópénzt kért a hívektől, melynek felét a temetést végző káplánnak adta. ${ }^{490}$ Egy 1867-ből származó adat szerint nagygazdák halottas prédikációja után 5 forint járt a temető káplánnak. ${ }^{491} \mathrm{~A}$ temetésen használt halotti gyertyákat a gyászos felek hagyomány szerint a templomnak ajándékozták. A viaszgyertyákat a káplánok juttatták a plébános kezéhez, aki túladott rajta, és az összeget a templom pénztárához adta. ${ }^{492}$ A plébános távollétében a káplánok vezették a temetői jövedelmek jegyzékét, rendezték a sírhelyek kiváltásának ügyét. ${ }^{493}$ A temetést végző atyához esős időben, avagy a siralmas ház nagyobb távolsága esetén a gyászos felek kocsit, ún. bejárót küldtek. Ha a gyászos ház utcája járhatatlan volt, a hívek az egyik sarki szomszéd házához vitték a halottat, hogy a temető káplán ruházatában, az egyházi felszerelésekben ne essen kár. ${ }^{494} \mathrm{~A}$ 19. század végén halott beszenteléséért 20 krajcárt, pluviálés (de nem énekes) halotti kis mise után 50 krajcárt kaptak a káplánok. ${ }^{495}$ A további, általános lelkészi teendők között kiemelkedő a gyóntatás és a betegek kenetének feladása, ám ezek a segédlelkészek javadalmazástól mentes feladatai közé tartoztak.

\subsection{Hitoktatás}

Mikor az 1868. és 1876. évi XXVIII. törvénycikkek lehetővé tették az egyházi iskolák községivé alakítását, a csongrádi elemi iskolák mindegyike elhagyta a felekezeti jelleget. ${ }^{496}$ Alig két évvel az átalakulást követően azt olvashatjuk a váci megyéspüspök helynökének jelentésében, hogy a csongrádi plébánosok nem gondoskodnak kellően a katolikus gyerekek valláserkölcsi oktatásáról. ${ }^{497}$ A jelentés hatására a püspök arra utasította a csongrádi plébánost, hogy sürgősen alakítsa át a káplánok feladatainak rendjét.

\footnotetext{
489 „A csongrádi segédlelkészek semmiféle stóladíjat nem szednek. Ez miként mindenütt, úgy Csongrádon is, csak a plébánost illeti.” Csongrádi Újság, 1911. január 15. IX. évf. 3. szám, 3. old.

${ }^{490}$ 1824-ben a csongrádi bíróhoz érkezett panaszok miatt a helyi vezetőség tiltani igyekezett a szokást. VPL APriv. Mátyus János, 1824. július 10. Kováts Ferenc káplán vallomása.

${ }^{491}$ VPL APar. Cs. 1867. november 12. Alvinczy Ferenc levele a váci püspökhöz.

${ }^{492}$ VPL APriv. Hegyi Antal, 1894. március 4. A csongrádi káplánok levele a váci püspökhöz.

${ }^{493}$ VPL APriv. Hegyi Antal, 1898. augusztus 22-26. Püspöki szentszéki kihallgatási jegyzökönyv kivonata.

494 „A piroskavárosiak és annál inkább a munkástelepiek pedig a régi jogszokás szerint tartoznak úgy a betegellátáshoz, mint a temetésekhez kocsit adni, vagy ha nem adnak, halottjukat a városba behozni." Csongrádi Újság, 1911. január 15. IX. évf. 3. szám, 3. old.

${ }^{495}$ VPL APriv. Hegyi Antal, 1894. március 4. A csongrádi káplánok levele a váci püspökhöz.

${ }^{496}$ Karácsonyi 1985. 321. A csongrádi iskolák 1869-ben alakultak községi intézményekké, felügyeletüket eztán az iskolaszék látta el. Sebestyén 2002.31.

${ }^{497}$ NPI 1870. november 18. A püspöki helynök levele a váci püspökhöz.
} 
A csongrádi elemi iskolás gyermekek hitoktatása így az 1870-es évektől kezdve a segédlelkészek feladatai közé tartozott. Szokásos napja a szerda és szombat volt. ${ }^{498}$ A hitelemző órák fontosságát mutatja, hogy ezekhez a kötött időpontokhoz igazították a megbízott segédlelkészek egyéb parochiális teendőit. Peitler Antal majd Schuszter Konstantin váci püspökök körlevelei is ezt a szemléletmódot támogatták. ${ }^{499}$ A hitelemző káplánokkal az iskolaszék külön szerződést kötött, melynek egyházi elnöki székében a mindenkori helyi plébános vagy annak helyettese ült. ${ }^{500}$

A polgári fiúiskolában már olyan lelkészek tanítottak, akik a váci püspöktől ideiglenes felmentést kaptak a lelkipásztori teendők alól. Ezek a fiatal papok minden idejüket az oktatásnak szentelték, csak a tanári fizetésből éltek, így függetlenek maradhattak a helyi plébániától. Ilyen jeles hitoktató volt a század utolsó felében Márk Balázs, aki kilenc évig tanította a hittan mellett a latin és német nyelveket. Álláshelyének terhei azonban felörölték egészségét ${ }^{501}$, így a megyéspüspök felmentette a hitoktatás alól és Ceglédre helyezte káplánnak.

Márk Balázs helyére az iskolaszék nem igényelt új, teljes állású hitoktatót, inkább Varga Mihály és Droppa Károly helybeli segédlelkészeket kérte fel a feladat elvégzésére. Az iskolaszék kérelmét a váci püspök jóváhagyta. Alig egy évvel később Hegyi Antal plébános, aki az iskolaszék alelnöki címét is birtokolta, személyes ellentétek miatt megkísérelte kimozdítani káplánjait a hitelemzői pozícióból. A tanfelügyelő a következöképpen reagált a plébános kérésére: „mi nem Ft. [fötisztelendö] úrral, hanem Droppa és Varga urakkal szerződtünk, ha ők megteszik a kötelességöket, akkor nincs szavunk".502 A plébános a visszautasítást követően (1894) lemondott iskolaszéki tisztségéröl. Varga és Droppa káplánok távozásával ismét teljes állású hitoktató lelkészt találunk a polgári fiúiskola kötelékeiben. ${ }^{503}$

\footnotetext{
${ }^{498}$ VPL APar. Cs. 1867. november 12. Alvinczy Ferenc levele a váci püspökhöz.

${ }^{499}$ V.ö. VPL Circ. 1782-1950.

${ }^{500}$ Gaith-Patzner 1892. 189.

501 „A lélekölő munka alatt egészségi állapota a mult évben már nagyon megrendült. A gyorsan alkalmazott orvosi segély és fürdőkúra azonban visszaállította egészségét, mindazáltal tanácsosabbnak látta nagyobb bajnak pályaválasztás által elejét venni s ezért mondott le állásáról.” Tiszavidék, 1893. július 23. IV. évf. 30. szám, 3. old.

${ }^{502}$ VPL APriv. Hegyi Antal, 1894. február 10. Varga Mihály káplán levele a váci szentszék titkárához.

${ }^{503}$ Csongrádi Lap, 1898. február 6. VII. évf. 6. szám, 3. old. Ekkoriban Drexler Antal látta el a hittan, német és latin nyelv oktatásával járó kötelezettségeket.
} 


\subsection{Hivatali adminisztráció}

A lelkészi hivatal adminisztrációja, vagyis a keresztelendők, házasulandók, halottak adatainak rözítése a plébános hatáskörébe tartozott ${ }^{504}$, aki az anyakönyvek fáradtságos másolásáért külön javadalmat biztosíthatott káplánjai számára. Az efféle „privát megbízások" kívül estek a Canonica Visitatio szabályozási körén, az összeg szabad egyezkedés tárgyát képezte. Hegyi Antal plébános 1894-ben íródott levelében jelezte a váci püspöki szék felé, hogy káplánjai egy árva polgári iskolás fiúra bízták az anyakönyvek másolását, aki számtalan hibát ejtett. Hegyi ebből kifolyólag megvonta káplánjaitól az irodai kisegítő teendők utáni járandóságot. ${ }^{505}$

A plébános távollétében az általa szóban megbízott segédlelkészek teljes jogú helyettesként vezették a plébániaközösség adminisztrációját. A gyűjtési felhívásokat követően a káplánok is jogosultak voltak az adományok beszedésére, a templom felújítási munkálataira kötött szerződéseken tanúként szerepeltek, vitás esetekben (pl. templomi perselyek feltörésének ügye) pedig ellenőrző tanúként látjuk őket viszont. ${ }^{506}$

\subsection{Közösségszervezés}

Egy korábbi fejezetben részletesen vázoltam a csongrádi plébánosok közösségszervező tevékenységét, most a káplánok szerepével vetek számot. Listánk rövid és elgondolkodtató: Csongrádon az egyetlen, káplán által vezetett vallási társulat a 19. században az Oltáregylet volt. A társulatvezető Korber Antal segédlelkész csongrádi működéséről, az Oltáregylet alapításának körülményeiről nem maradt hátra feljegyés. A század utolsó éveiben pedig Csapó János káplán intézkedett annak érdekében, hogy Csongrádon is megalakulhasson a Katolikus Kör, ám a káplán semmilyen tisztséget nem vállalt benne. ${ }^{507} \mathrm{~A}$ szerény adatok nem a káplánok motivációjának vagy kreativitásának

\footnotetext{
${ }^{504}$ Ugyanakkor Hódmezővásárhelyen az 1860-as években az egyik káplán volt örökösen megbízva az iroda vezetésével. Tiszavidék 1893. augusztus 13. IV. évf. 33. szám, 3. old.

${ }^{505}$ VPL APriv. Hegyi Antal, 1894. július 10. Hegyi Antal levele a váci püspöki székhez.

${ }^{506}$ Források: VPL APriv. Hegyi Antal, 1898. augusztus 22-26. jegyzőkönyv, Máté János vallomása; VPL APar. Cs. 1889. január 31. Bakos Károly orgonakészítő szerződése; VPL APriv. Hegyi Antal, 1898. október 30. Hegyi Antal levele a váci püspökhöz.

${ }^{507}$ A magyarországi Katolikus Körök közvetlen mintájául a német Katolikus Nagygyülések (Katholikentag) szolgáltak. Hatásukra jött létre a hitbuzgalmi, társadalmi és kulturális szervezeteket összefogó Katholikus Körök Szövetsége. Gergely 1999. 124. Szükséges tehát különbséget tennünk a tisztán lelkiségi és karitatív célzattal létrejött társulatok (Jézus Szíve, Rózsafüzér társulat stb.) illetve a katolikus érdekérvényesítést előtérbe helyező, társadalmi céllal létrejött egyesületek és körök között, melyek felépítésüket tekintve szoros
} 
hiányát, inkább hivatali leterheltségüket és a plébánosok óvatosságát mutatják.

A korlátozások egy lehetséges okára Schüch Ignác 1872-ben megjelent lelkipásztori kézikönyve világít rá: „Különösen fontosabb dolgokban újításokat a plébános engedelme és jóváhagyása nélkül elhirtelenkedve semmiképp ne tegyenek, mivel a felelősség nem a káplányt, hanem a plébánost terheli." ${ }^{\circ 08}$ Ugyanezt a tanácsot találjuk később Tower Vilmos írásában: „Káplán ne alapítson egyesületet a plébános tudta és beleegyezése nélkül, mert áthelyeztetésével az egyesület is haldokolni kezd [...] A káplán ne tekintse az egyesületet a plébános elleni hadjárat egyik erődítésének" ${ }^{509}$.

A 19. századi csongrádi plébánosok közül egyedül Hegyi Antal esetében bizonyított, hogy tudatosan tartotta távol káplánjait a vallási társulatoktól. Hegyi Antal célja ugyanis egy szigorúan centralizált plébániaszervezet volt, mely kizárta a káplánok komolyabb közösségi szerepvállalásának lehetőségét. A plébános tehát saját kezében tartotta a társulatok irányítását, és csupán bizalmasának, Csapó Jánosnak engedélyezett némi önálló mozgásteret, hogy híveket toborozzon a Katolikus Kör számára.

Csapó János a káplánok közt egyedüliként kapott jogosultságot a plébános nevében végzett agitációra. A jelenség hátterében nagyfokú bizalmat és őszinte eszmei azonosulást kell feltételeznünk. Sperling Béla segédlelkész vallomását olvasva árnyaltabbá válnak a bizalmas munkakapcsolat okai: „[Csapónak] nemcsak bérmaatyja Hegyi, hanem nevelő atyja is, ki protestáns vallásról áttérését elősegítette $\mathrm{s}$ áttérése után a szemináriumba felvétette, $\mathrm{s}$ tanulási ideje alatt anyagilag is támogatta s itt Csongrádon is többször volt nála a szünidők alatt, mint vendég." 510

A csongrádi káplánok tehát alapvető plébániai feladatok ellátásával „tehermentesítették” a plébánost, de a vallási közösségszervezés kulcspozícióira már nem tarthattak igényt. A jelenség oka egyrészt a társulatok stabil, kiegyensúlyozott müködésére való törekvés, mely egy állandó lelki vezető felügyeletét igényli. Másrészt oka a már említett társadalmi potenciál, a társulatokban rejlő társadalmi erő, melynek gyakorlati működésére Hegyi plébános kapcsán még ki fogunk térni.

rokonságban állnak a 19. század végi „polgári egyesületekkel”. A csongrádi polgári egyesületekről bővebben lásd. Gyöngyössy 2014/a.

508 Schüch 1872. 584-585.

509 Tower 1940. 173-181.

${ }^{510}$ Csongrádi Lap, 1898. május 29. VIII. évf. 22. szám, 2. old. 


\subsection{Közélet, politika és tisztségviselés}

Mivel a csongrádi plébános fizetését a település biztosította, Csongrád elöljárósága és a segédlelkészek csak meghatározott ügyekben kerültek kapcsolatba egymással. Az elöljárók esetleges kívánságait a plébánoson keresztül bonyolították le. Erre példa 1859-ből Siprikó Kiss István rabló ügye, aki mellé ,a halálra leendő ájtatos végellátáshoz” segédlelkészt kért a település. ${ }^{511}$ Közvetlen érintkezési pont akkor alakult ki, amikor a polgári iskolai hitoktatói feladatok ellátása ürügyén az iskolaszék egyezségre lépett a segédlelkészekkel. Ugyan a megállapodás a plébános tudtával jött létre, a hitoktatói pozíció anyagilag elkülönült, független munkaviszonyt jelentett az iskolaszék és a káplánok között. ${ }^{512}$

A csongrádi káplánok a helyi közélet meghatározó személyiségei közé tartoztak. A különböző polgári egyesületek, körök egymással versengve igyekeztek tagjaik közt tudni a segédlelkészeket; csatlakozásra, felszólalásokra, gyakran vezető tisztségek betöltésére kérték fel őket. Az országgyülési képviselőválasztások idején ezek a törekvések látványosan felerősödtek. Bajcsy Gábor káplán levelében a következő vallomást olvashatjuk: „Mindenféle bizottságba be akartak választani s különféle tisztségeket akartak rám ruházni a választások alatt, de én az ilyen kitüntetéseket mind visszautasítottam, azokat elfogadni megtagadtam." 513

A helyi elöljáróság éber figyelemmel kísérte a segédlelkészek politikai aktivitását, és a kedvezőtlennek ítélt „elhajlás” legkisebb jelére panaszt tettek a plébánosnál. 1862-ben az alispán a következő levéllel kereste fel Virter Lajos plébánost: „Több helyütt tapasztaltam, hogy némely lelkészek, segédlelkészek és tanítók, a kormány ellen ellenséges indulattal viseltetnek, és izgatásokat tesznek. Bizodalmasan felhívom Uraságodat, hogyha a járásban ilyen esetek lesznek, nékem azonnal bejelenteni szíveskedjék."514 Csongrádon a 19. század második felében egyre sűrüsödtek az efféle gyanúperek. A két legkiemelkedőbb periódus Csatár Zsigmond majd Hock János országgyülési képviselővé választásának időszaka volt.

1876-ban a hódmezővásárhelyi kerületi esperes rendszeres vendége lett a csongrádi plébániának. A kivizsgálások sorozatát Csemegi Károly polgármester kétségbeesett levele indította el, aki szerint ,az itteni plébánia összes papi személyzete kisebb-nagyobb

\footnotetext{
${ }^{511}$ NPI Szolgabírói iratok, 1067/1859.; Dudás Lajos 1998. 116.

512 VPL APriv. Hegyi Antal, 1894. február 10. Varga Mihály káplán levele a váci püspöki szentszék titkárához.

${ }^{513}$ VPL APriv. Hegyi Antal, 1892. d.n. Bajcsy Gábor káplán levele a váci püspökhöz.

${ }^{514}$ Dudás 1998. 116.
} 
mérvben részt vesz a város nyugalmát és a társadalmi rendet veszélyeztető üzelmekben, különösen pedig Horváth János káplán úr". ${ }^{515}$ Az ok a polgármester riválisának, Csatár Zsigmondnak növekvő népszerüsége volt, akit Csemegi szerint a helyi káplánok nyilvánosan támogattak. A kivizsgálással megbízott Lichtner Gáspár kerületi esperes azonban felmentette a gyanúsított segédlelkészeket a vádak alól, majd békítő levelet írt a csongrádi polgármesternek.

Hegyi Antal plébánossága idején a teljes magyar közélet a várakozás forrongásában, az alsópapság jelentős része a 48-as eszmék büvöletében élt. A Csongrádi Lap 1896-ban kiemelten foglalkozott a váci egyházmegyében politikai korteskedéssel vádolt néppárti lelkészek viselt dolgaival. Januárban Kiskundorozsmáról jött a hír, hogy „a káplán a községben néppárti indítványokat osztogat a hívek között, hogy a hecc-káplánok és mágnások e pártjának propagandát csináljon, és amellett szítja a felekezeti gyülölséget is". 516 Pár hónappal később Járvás József, egykori csongrádi segédlelkész szerencsétlen kecskeméti politizálásáról értesülünk. ${ }^{517}$ A riasztó példák kiemelésével, a politizáló papság kudarcainak taglalásával a Csongrádi Lap Hegyi Antal plébános pozícióját próbálta gyengíteni.

Bizonyos, hogy Hegyi Antal politikai nézetei erőteljes hatást gyakoroltak a felügyelete alatt ténykedő, fiatal lelkészekre. Négy káplánról is tudjuk, hogy határozott agitációt folytattak Hock János képviselőjelölt sikeréért. A Csongrádi Lap ironikus hangnemben közölte le Csapó János és Krezsák Géza állítólagos „kidobásának” esetét a csongrádi választóhelyiségből. ${ }^{518} \mathrm{Az}$ alsópapságot kompromittáló cikkekre a Tiszavidékben majd a Csongrádi Közlönyben érkezett válasz Hegyi Antal tollából.

Az 1896-os országgyülési képviselőválasztások esete azért különbözik a korábbi évek példáitól, mert - bár a káplánok korábban is könnyen belesodródtak a helyi politikai mozgalmakba - a plébános szerepe ezidáig feddhetetlen maradt, és az esetleges kivizsgálások is egyedül a segédlelkészeket érintették. A Csongrádi Lap a plébános holdudvarában agitáló segédlelkészeket a nem túl megtisztelő heccz-káplán, illetve a pap fullajtárja ${ }^{519}$ kifejezésekkel illette.

\footnotetext{
${ }^{515}$ VPL APar. Cs. 1876. február 18. Lichtner Gáspár kerületi esperes levele a váci püspökhöz.

516 Csongrádi Lap, 1896. január 6. VI. évf. 1. szám, 2. old.

${ }^{517}$ Csongrádi Lap, 1896. november 15. VI. évf. 47. szám, 3. old.

${ }^{518}$ Csongrádi Lap, 1896. június 28. VI. évf. 26. szám, 2. old.

519 Csongrádi Lap, 1892. január 1. II. évf. 1. szám, 2. old. Fullajtár: Csongrádon a segéd-orgonista megnevezése volt. Eredeti jelentése: „kikáltó, küldönc”.
} 
3. Capellani expositi ${ }^{520}$ : a filiák önállóságának záloga

Mivel az anyatelepülés ellátása is elegendő feladatot rótt a csongrádi lelkészekre, a távol eső filiákra már kevesebb figyelem jutott. A plébános igen ritka vendég volt a leányegyházakban. Bába Szabó Rókus egyházfi verses krónikájában megemlékezik arról az „ismeretlen” csongrádi plébánosról ${ }^{521}$, akivel az elbocsátott felgyői dohánykertészek már nem találkozhattak:

Ismeretlen lelki atyánk,

Ki csak nemrég jöttél hozzánk,

Szárnyad alá nem juthattunk,

Fájdalom hogy meg kell válnunk. ${ }^{522}$

A plébános helyett a Plebánus úr Tisztelendö Segédei ${ }^{523}$ és a kolduló barátok látogatták a leányegyházak népét. Forrásaink arról tanúskodnak, hogy az anyaközségtől eltérően nem alakult ki mélyebb, személyes kötődés a filiák lakói és a periodikusan változó, miséken, temetéseken vagy búcsú idején felbukkanó segédlelkészek között. A vélt vagy valós mellőzöttség tudata, az elmélyültebb lelki életre való éhség a filiák meghatározó alapérzésévé vált. A helyzet orvoslására helyi kezdeményezésekkel igyekeztek megoldást találni. A csongrádi plébánossal és a váci püspökkel folytatott egyezkedések tétje nem kevesebb, mint egy káplán teljes vagy részleges „kisajátítása” volt. A vallási különbségeken felül emelkedő anyagi áldozatok, ${ }^{524}$ az újra és újra előterjesztett alázatos kérelmek híven tükrözik a községek elszántságát.

A 19. században a csongrádi plébános felügyelete alá Algyő (1760) Újfalu (1784) és Csány (Csanytelek, 1806) leválása után négy filia (Föll-Gyö/Felgyő, Ellés/Ellésmonostor, Teés/Magyartés és a csongrád-belsővárosi Szent Rókus-templom)

\footnotetext{
520 Capellani expositi: „Azon papok, kik a püspök beleegyeztével valamely fiókegyháznál (expositura) laknak, s ott a plébános nevében gyakorolják a lelkipásztorkodást; a jövedelem és az anyakönyvek vezetése a plébánost illeti." Gaith-Patzner 1982. 245.

${ }^{521}$ Alvinczy Ferenc 1865-től 1875-ig volt Csongrád plébános, valószínűleg őrá történik utalás.

522 Ld. Felgyeö községének több mint egy százados fönállása utáni elpusztitása emlékére 1866-ban. Hozzáadva katona búcsúzása szüleitől. írta: Bába Rókus csongrádi lakos. Kiadja Simon János Gyulán, 1866. Nyomatott Dobay Jánosnál.

${ }^{523}$ VPL APar. Cs. 1815. július 2. A tési kertészek levele a váci püspökhöz.

524 Tés református lakosai is aláírták a saját katolikus lelkészért folyamodó kérvényeket. Ld. VPL APar. Cs. 1815. július 2. A tési kertészek levele a váci püspökhöz.
} 
tartozott. ${ }^{525}$ A plébános helyzetét nehezítette, hogy Ellés és Tés a Tisza túlpartjára esett. Az utak minden irányban elviselhetetlenül rosszak, a tiszai átkelés rendkívül veszélyes volt. Az újszülöttek többségét vagy egy arra járó ferences atyával kereszteltették meg, vagy bábakeresztségben $^{526}$ részesítették. Felgyő és Ellés lakosai csak Csongrád földjébe temethették halottaikat, míg a saját temetővel rendelkező Tésen és Felgyőn a lelkipásztor mellett a kántor is köteles volt közremüködni a végtisztességeken. A távoli községekhez kapcsolódó liturgikus „kötelmek” teljesítése mind a filiák, mind az egyházi személyzet részéröl kérdésekbe, nehézségekbe ütközött.

A legkorábbi fennmaradt panaszlevelet 1784-ben vetették papírra a 'Föl-Gyövi', csanyi, tési és fehértói kertész filialisták, akik „lelküknek bővebb gondviselésére és vigasztalása" érdekében saját, csak a nevezett településeket ellátó káplánt kértek a váci püspöktől. A felterjesztés szerint a kertészek magukra vállalnák a pap évi 60 Rhénes forintból álló fizetését, illetve a lakosokra eső évi 1 forintos párbért, annak beszedésével együtt. ${ }^{527}$ Kérelmük nem járt sikerrel, így azt 1804-ben és 1806-ban is megismételték. Az elutasítás tulajdonképpeni oka, hogy egy bizonyos fokú önállósággal rendelkező segédlelkész (kihelyezett lelkész vagy capellani expositi) könnyen az anyaközségtől való elszakadás útjára terelhette a leányegyházakat. A kérelem szellemisége tehát alapvetően ellenkezett a mindenkori csongrádi plébános érdekeivel.

Sikerrel járt viszont a csongrád-belsővárosi Szent Rókus-templomhoz tartozó lakosok kívánsága, akik 1808-ban „a népnek szaporodása, úgy nemkülönben a Belső Városi lakosok között nem kevés számmal található, s utolsó aggott özvegységbe lépett Keresztény Atyámfiainak, a Külső Városban levő Szentegyházunknak távolléte végett a lelki buzgó ájtatosságban történhető hátramaradások"528 ürügyén folyamodtak saját káplánért. Kérésük annyiban különbözött az 1784-es felterjesztéstől, hogy láthatóan nem kívánták „kiszakítani” a káplánt a plébánia kötelékeiből. A megegyezés csupán a harmadik káplán feladatkörének kibővítéséről szólt, mely a csongrádi plébános felügyeletével és engedélyével köttethetett meg. A belsővárosi lakosok évi 300 rhénus forintot, három öl

\footnotetext{
525 Patkóné Kéringer 1997. 33.

526 A száraz-, bába-, házi- vagy János keresztségnek is nevezett rövid szertartás paphiányos történelmi időkben, nehezen megközelíthető helyeken (tanya, hegyvidék, téli időszakban stb.) volt különösen gyakori. Az elvégzés helyes módjáról a helyi plébános oktatta ki és eskette fel a bábaasszonyokat. Ha a gyermek életben maradt, a keresztszülők kötelesek voltak vele a pap elé járulni, aki a szenteltvíz elhagyásával, csupán krizmával véglegesítette a szentségben. A Rituale Strigoniense és a Pázmány-féle nagyszombati zsinat (1629) is megerősíti, hogy háznál keresztelni csak végszükségben lehet. Bárth Dániel 2005. 148; Deáky 1996. 94; Deáky - Krász 2005. 279; Mihályfi 1926. 47.

${ }^{527}$ NPI 1784. május 25. A Föl-Gyövi, Csanyi, Tési és Fehér-tói kertészek levele a váci püspökhöz.

${ }^{528}$ NPI 1808. november 1. A csongrád-belsővárosi Szent Rókus-templom híveinek levele a váci püspökhöz.
} 
tűzifát, ötszáz kéve füteni való nádat kínáltak fel a segédlelkésznek. Ezért cserében az esztendő minden napján szentmisét, Húsvét, Pünkösd és Karácsony első napján, Úrnapján és Nagyboldogasszony ünnepén énekes misét, lelki tanítást és délutáni litániát, szombatonként a három belsővárosi iskolai osztályban hitoktatást kértek. Az ajánlatot a harmadik káplán személyének változása esetén változatlanul fenntartották. ${ }^{529}$

A belsővárosiakat ismét a „Lelki Dolgok szertartásaikban mind eddig tökélletes lekötelezéssel nem lévén meg vigasztalt" 530 tésiek követték, akik 1815-ben négy pontból álló kérelmet terjesztettek a váci püspök elé. A kérelem fel sem vetette az önálló lelkipásztor ötletét, ugyanakkor reális és szerénynek mondható megoldást kínált a fennálló hitéleti problémák javítására. A csongrádi plébániatemplom távolsága miatt elsőként azt javasolták, hogy a tési határban felállított keresztnél Pongrác napi szentmise, „ájtatos Processio, szív indító Tanítással Lelki Atya által végeztessen, az ottan meg jelenő Híveknek Lelki épülésekre, mind az köztünk Lakos Reformata valláson levők, kik az illy ájtatosságkor számossan meg jelennek, oktatásokra". 531 A második pont szerint a tési kertészek a papi funkciók akadálytalan ellátása érdekében vállalták volna a lelkész és a kántor biztonságos fuvarozását. Ez a kritérium a filia örökös gondja maradt annak ellenére, hogy 1788 óta királyi rendelet kötelezte a filiális egyházak híveit a pap és a kántor szállítására. ${ }^{532}$ Az utolsó pontban a leányegyház lakosai fogadalmat tettek a párbér „annak ideibe szorgalmatos lefizetésére". 533

Fell-Gyö vagy másképp Felgyeő uradalmi majorság, juhász és kertész község alapításától kezdve ${ }^{534}$ egészen a dohánykertészek szerződésének felbontásáig (1866, más források szerint 1872) a csongrádi plébános fennhatósága alá tartozott. A filia 19. századi vallási életéről szokatlan forrásból, Bába Szabó Rókus kiadott verses króikájából értesülünk, melyet 1866-ban vetett papírra a csongrádi kurátor. ${ }^{535}$ Az írás szerint Felgyő község rendelkezett haranggal, egy Szent István király tiszteletére dedikált kis kápolnával, valamint jól müködő rózsafüzér társulattal. A kápolnának nevezett kis imaházat az 1830-as évek végén rendezték be, hogy ne kelljen Csongrádra szekerezni misét hallgatni. Az

\footnotetext{
${ }^{529}$ NPI 1808. november 1. A csongrád-belsővárosi Szent Rókus-templom híveinek levele a váci püspökhöz.

${ }^{530}$ VPL APar. Cs. 1815. július 2. A tési kertész lakosok levele a váci püspökhöz.

${ }^{531}$ VPL APar. Cs. 1815. július 2. A tési kertész lakosok levele a váci püspökhöz.

${ }^{532}$ Gaith-Patzner 1892. 130.

${ }^{533}$ VPL APar. Cs. 1815. július 2. A tési kertész lakosok levele a váci püspökhöz.

534 Első említése egy 1763-64-es összeírásból származik. Innentől kezdve a felgyőiek 10-30 évre szóló szerződéseket kötöttek a Károlyi grófokkal. Ezeket a szerződéseket később folyamatosan megújították.

535 Bába Szabó Rókus személyéről egy későbbi fejezetben értekezünk. Ld. egyházfi/kurátor. A históriás énekek stílusát idéző alkotást Katona Imre elemezte. Katona 1976-77.
} 
épületet 1879-ben bontották le, helyére gróf Károlyi Sándor kőkeresztet állíttatott. ${ }^{536} \mathrm{~A}$ felgyőiek az 1840-es években ${ }^{537}$, továbbá 1872 és 1897 között Csongrádon földelték el halottaikat. ${ }^{538}$ A Vidre-torokban fekvő öreg temetőt 1872 elött, majd 1897 és 1964 között használhatták az egykori dohánykertészek és felgyői pusztákon élő tanyai lakosok.

Hogy a váci püspök nem volt érzéketlen a filiák kívánságára, mutatja, hogy a 19. század végén Csongrád-Belsővárosban minden alkalommal ugyanaz a segédlelkész gyóntatott és misézett, Csany pedig 1787-től kezdve önálló káplánsággal bírt, mígnem 1804-ben ténylegesen elszakadt Csongrádtól. ${ }^{539}$ Katona Imre - a Bába Rókus-féle versezetet alapul véve, helytelenül - úgy vélte, hogy a felgyői dohánykertészeknek saját plébánosa vagy kihelyezett káplánja volt. ${ }^{540}$

Az anyakönyvi bejegyzések arra engednek következtetni, hogy a legfrissebben kinevezett káplán nagyobb gyakorisággal járt a nehezen megközelíthető leányegyházakba, mint régebb óta szolgáló társai. Ezek a korai nehézségek a beilleszkedési szakasz részét képezték, és a segédlelkész kitartását, elszántságát tették próbára.

\section{Az egyenrangúságról és feladatmegosztásról}

A segédlelkészek feladatkörének arányos megosztása a plébániai élet mindenkori, nyugtalanító forráspontja, a plébános bölcs belátásának és diplomáciai képességének próbaköve volt. Míg az azonos fizetésért azonos funkciót betöltő segédlelkészek arányos bánásmódot vártak, a mindennapi gyakorlat bizonyos funkciók átcsoportosításának kényszerét hozta magával.

Csongrádon a 19. század második felében már általános volt az úgynevezett számadó káplány kijelölése. A tisztség kiosztása a plébános személyes hatáskörébe tartozott. A választás során latba esett a káplán életkora, talpraesettsége, az adott plébánián eltöltött idő hossza és a plébánossal való, kiegyensúlyozott munkaviszony. Ha csupán ez utóbbi tényező emelte bizalmi pozícióba a számadót, az ügy rendszerint panaszlevelekbe torkollt, és a hátrányt szenvedett segédlelkészek a megyéspüspökhöz fordultak

\footnotetext{
${ }^{536}$ VPL APar. Cs. 1842. május 31. A felgyői kertészek levele a váci püspökhöz.

${ }^{537}$ VPL APar. Cs. 1842. június 2. Kmeth Lajos kántor levele a váci püspökhöz.

${ }^{538}$ VPL APar. Cs. 1897. március 30. Hegyi Antal levele a váci püspökhöz.

539 Patkóné Kéringer 1997. 31.

540 Mint írja: a felgyői dohánykertészek kiköltöztetése olyan hirtelen történt, hogy még ,az általuk fogadott papot sem tudták értesíteni”. Katona 1976-77.
} 
jogorvoslatért. ${ }^{541}$ Hegyi Antal kecskeméti káplánévei alatt került hasonló helyzetbe. A megyéspüspöknek címzett levelében hivatalkörének átlépésével vádolta meg akkori plébánosát: „bár távol állok bármely ily értelemben veendő lépéstől, plébánosomnak azon jogát, hogy egyik káplánnak a másik rovására praerogativákat [előjog] osztogasson, soha el nem ismerem, mert ezt csak püspököm teheti, kinek engedelmességet fogadtam". 542

A számadó káplán jogkörének kiterjedtsége szintén a plébános belátásán múlott. Míg Kecskeméten a számadó szabadon oszthatta be társai misézési rendjét ${ }^{543}$, Csongrádon mindez nem volt jellemző. A csongrádi számadó legfontosabb feladata a plébánia havi bevételeinek számon tartása volt. Az elszámolást a hónapok első napján juttatta a plébános kezéhez. ${ }^{544}$ Csapó János számadó káplán 1898-ban jegyzőkönyvezett vallomásából kiderül, hogy feladatai közé tartozott még az anyakönyvi kivonatok kiadása, a halotti- és mise bejelentések felvétele, illetve a sírhelyek kijelölése. A jelzett bevételekröl külön naplót vezetett, melyet hetente bemutatott Hegyi Antal plébánosnak. ${ }^{545}$

A számadó káplán intézménye nem elöírt és nem kötelező, inkább egyfajta szükséghelyzet (a plébános elfoglaltsága, leterheltsége) hívta életre. Ugyan a pozíció megosztó erejü „bizalmi helyet” jelölt ki a számadónak, a plébános kellő empátiával, diplomáciai érzékkel elejét vehette a paptársak elégedetlenségének.

Egészen eltérö jellegü a hetes vagy soros káplány tisztsége, mely periodikusan cserélődött a három csongrádi segédlelkész között. A soros káplán feladata az adott hétre eső temetések lebonyolítása volt, a fennmaradó, egyéb plébániai munkákat addig paptársai osztották fel maguk között. 1867-ben Alvinczy Ferenc plébános arra kérte Peitler Antal váci püspököt, hogy amennyiben hetes káplánjának hitoktatói kötelességei is volnának, a többi segédlelkész között is feloszthassák a temetéseket. ${ }^{546}$

5. Kolduló ferences atyák: hierarchia és határvonalak

A 19. századi csongrádi plébánosok törekedtek minél szorosabb ellenőrzésük alá vonni a kecskeméti konvent által kirendelt ferenceseket azzal a céllal, hogy a káplánok munkáját

\footnotetext{
541 Így történt az 1880-as években Csapó János számadó káplán esetében, aki a csongrádi plébános ,,jobb keze" és bérma keresztfia volt. v.ö. NPI 1897. december 9. Hegyi Antal levele a váci Egyházmegyei Hatósághoz.

542 VPL APriv. Hegyi Antal, 1875. január 19. Hegyi Antal levele a váci püspökhöz.

${ }^{543}$ VPL APriv. Hegyi Antal, 1875. január 19. Hegyi Antal levele a váci püspökhöz.

${ }^{544}$ VPL APriv. Hegyi Antal, 1894. március 4. Csongrádi káplánok levele a váci püspökhöz.

${ }^{545}$ VPL APriv. Hegyi Antal, 1898. augusztus 27. Püspöki szentszéki vizsgálóbiztos jegyzőkönyve.

546 VPL APar. Cs. 1867. november 12. Alvinczy Ferenc plébános levele a váci püspökhöz.
} 
irányított módon egészítsék ki. Ennek egyik módja a napi étkezés biztosítása volt, melyért cserébe a prokurátor eleget tett a plébános kisebb-nagyobb kéréseinek. Az 1830-40-es években Czibulka Kristóf ferences barát ugyan Kovács Gergely parasztgazda házánál lakott, ebédelni és vacsorázni már a plébániára járt. ${ }^{547}$

Mátray Rafael ferences atya 1868-ból származó levele már a plébániai munkába való, szorosabb bekapcsolódásról tanúskodik. A szerzetes eképpen összegezte feladatait: „gyakran a Káplány Urak helyett a belsővárosi templomba eljárok misézni, a főtiszt. Plébános úr felszólítása következtében a nagy böjti conciokkal [itt: prédikáció] szinte megtiszteltettem, a tanyai iskolákban a cathecheticai [hitoktatói] hivatallal ruháztattam fel, és a Főtiszt. Plébános Úr felhatalmazása folytán - amint hajdanában, úgy most is - midőn egyes betegek bizalma megtiszteli a szerzetes atyát, gyóntatni elmén". 548

A ferences atya bevonása a plébánia életébe a hierarchia és illetékességi határok kérdését is felszínre hozta. Mátray Rafael levele szerint a csongrádi káplánok nem tekintették egyenrangú paptársnak a ,szerzetes monachust” és maguk is többlet feladatokkal terhelték meg. Az első ránk maradt konfliktus írásos emléke 1868-ból származik. Amikor a káplánok a szentírás-magyarázat mindennapi feladatával akarták megbízni Mátray barátot, az atya visszautasította a felkérést, mondván: „időszerint hetekről hetekre, kívül a pusztában tanyáról tanyára járván kéregetek, az ügybuzgósága szerint meg nem felelhetek a várakozásoknak". ${ }^{549}$ A ferences atya szerint a segédlelkészek bosszúsak azért, mert a plébános felhatalmazásával ő is jogosulttá vált az utolsó kenet szentségének kiszolgáltatására, így egyre népszerübbé vált a csongrádi hívek körében. A szerzetes atya arra kérte a váci püspököt, hogy a hasonló esetek elkerülése érdekében vonja őt a plébános kizárólagos rendelkezése alá: „különben bekövetkezhetnék, hogy ők [a segédlelkészek] ámbátor teljes számmal levén minden terhet az én vállaimra raknának". 550

A következő híradás káplánok és ferences atya közti nézeteltérésről 1894-ből származik. Forrásaink alapján kiderül, hogy Kovács Kálmán ferences szerzetest a váci püspök eltiltotta a működésétől azért, mert a vádak szerint egy nővel élt egy fedél alatt. A Csongrádi Lap közlése szerint Hegyi Antal plébános a püspöki felfüggesztés ellenére misézni engedte Csongrádon a szerzetest, sőt, fizetést is biztosított számára. ${ }^{551}$ Varga Mihály káplán felháborodását fejezte ki azért, mert a „botrányos életü” Kovács atya

\footnotetext{
${ }^{547}$ Váry 1974. 26.

548 VPL APar. Cs. 1868. december 24. Mátray Rafael barát levele a váci püspökhöz.

${ }^{549}$ VPL APar. Cs. 1868. december 24. Mátray Rafael barát levele a váci püspökhöz.

${ }^{550}$ VPL APar. Cs. 1868. december 24. Mátray Rafael barát levele a váci püspökhöz.

${ }^{551}$ Csongrádi Közlöny, 1894. március 4. I. évf. 1. szám, 1-2. old.
} 
szabadon müködhetett a környéken. ${ }^{552}$ Az ügy kivizsgálására küldött Csávolszky József kerületi esperes felmentette Hegyi Antalt a szerzetes támogatásának vádja alól. A vizsgálóbiztos a következő jelentést terjesztette a váci püspök elé: „A káplánok felgerjedése onnan ered, hogy a plébános némely functiot a nevezett szerzetessel végeztetett annak idejében s a káplánok accidencióját, és amennyiben többször prédikált a plébános helyett, népszerüségét is veszélyessé tette, ezért állást foglaltak, hogy ezt nem türik tovább, minek kijelentése után a plébános több kedvezményt elvont tőlük s az irodai dolgokra sem használta őket." 553

A ferences barát tehát olyan kisegítő paptárs, aki gvardiánja ${ }^{554}$ megbízásából végzi kolduló tevékenységét, anyagilag függetlenül attól a plébániától, melynek segítségére van. A helyi papság munkarendjébe csak a plébános akarata vonhatja be, melynek mértéke személyes egyezkedésük és a gvardián engedélyének függvénye. A gvardián, rendje érdekeinek és a kihelyezett szerzetes eredeti feladatainak összevetésével mérlegeli a feladatkör kiszélesítésének feltételeit. A feladatok átvállalásával a szerzetesek egyre változatosabban érintkeznek a hívekkel, miközben népszerüségük is növekszik. Nem csodálkozhatunk azon, hogy a mindenkori csongrádi segédlelkészek bizalmatlanul szemlélték az efféle változásokat. Miközben feladataik némiképp csökkentek, a rivalizálás légköre is időröl-időre begyürüzött a plébánia falai közé.

\section{Káplánok és plébánosok: a kapcsolatrendszer módozatai}

A soron következő alfejezetben arra keresem a választ, hogy miként valósult meg a káplánok és a plébános együttműködése a 19. század végi Csongrádon? Hogyan járultak hozzá a káplánok a plébánia kiegyensúlyozott müködéséhez? Hogyan segítette, illetve akadályozta a személyes viszony minősége a plébániaközösség sikeres irányítását?

\footnotetext{
552 „Hát az igaz volna, hogy a barát itt marad és tovább fungál, mert neki senki sem parancsol? Vagy talán a második verzió az igaz: hogy azért szabad neki fungálni, mert a püspök ellenére a prímás a suspensio [felfüggesztés] alól fölmentette?" VPL APriv. Hegyi Antal, 1894. február 10. Varga Mihály káplán levele a váci szentszéki titkárához.

${ }^{553}$ VPL APriv. Hegyi Antal, 1894. március 10. Csávolszky József jelentése a váci püspökhöz. Hegyi Antal az általa kiadott „Legyen világosság” c. röpirat 43. pontjában eképpen kommentálta a történteket: „Kovács Kálmán Szent Ferencz rendi szerzetest magam makacs influenza miatt szolgálatképtelen lévén két hónapon keresztül provincziáléjának engedelmével kisegítöül ideiglenes plébániám körébe fogadtam, s ettől az agilis fiatalembertől, kit a nép csakhamar megkedvelt, különösen Varga Mihály a népszerüségét féltette.” Csongrádi Lap, 1898. március 27. VIII. évf. 13. szám, 3. old.

${ }^{554}$ Gvardián: Ferences rendházfönök. Péterné Fehér 2009. 35.
} 


\subsection{A kölcsönös elvárások váza: A ,jó pap” és a ,jó káplán” sziluettje}

A plébánosnak és a segédlelkészeknek egyaránt meg volt az elképzelése arról, hogyan illik viselkednie a másik félnek. Hogy felvázolhassuk a ,jó pap” és a ,jó káplán” tulajdonságait, ismét a panaszlevelekre kell támaszkodnunk. Elsőként azt vizsgálom meg, miféle adottságok tették jó vagy rossz munkatárssá a segédlelkészt a plébános szemszögéből? Milyen konkrét esetekben kellett a csongrádi plébánosnak közbeavatkoznia, fegyelmezési eszközhöz nyúlnia?

„Állásomnál fogva mindenkitől, tehát annál inkább azoktól, kik az én kenyeremet eszik, jogosan megvárhatom, hogy elöttem tisztességesen viselkedjenek" ${ }^{\text {} 555}$ - vetette papírra 1894-ben a káplánok helyes magaviseletéről alkotott meglátásait Hegyi Antal. A köteles tisztelet mellé a plébános céljainak elfogadása, a szófogadás, csendesség igénye párosult. ${ }^{556}$ A káplánoknak ahhoz az eszméhez kellett igazítaniuk viselkedésüket, miszerint a plébánosnak ,mindig igaza van”. 557

A plébánost elsődleges felelösség terhelte azért, hogy káplánjai viselkedése és erkölcse kifogástalan legyen. ${ }^{558}$ A szóbeli figyelmeztetéseken, megfeddéseken túl csak súlyosabb erkölcsi vétségek kerültek írásos formában a váci püspök elé. Edelényi János plébános 1884-ben keletkezett levele szerint egyik káplánja indokolatlanul hosszú „kirándulásokat” tett a szőlők közé. Arra gyanakodott, hogy asszony van a dologban. ${ }^{559}$ A plébános - miután szavai hasztalannak mutatkoztak - a püspöki szentszéket hívta segítségül.

A káplánok szerelmi provokációja felett nem csak a plébános, de a közerkölcs is éberen őrködött. Az alábbi eset szintén Hegyi Antal plébánossága idején esett meg: „Különös módját eszelte ki néhány leányzó az ismeretség kötésének, ugyanis: 3 Kros okmánybélyeggel ellátott leveleket küldözgetnek a fiatal urakhoz, melyek egy némely helybeli nő photographált arczképét tartalmazzák. Az arczképhez gyakran levelet is mellékelnek a következő tartalommal: 'Én téged nagyon szeretlek'. Különösen kiszemelték

\footnotetext{
${ }^{555}$ VPL APriv. Hegyi Antal, 1894. január 31. Hegyi Antal levele a váci Egyházmegyei Hatósághoz. ${ }^{556}$ VPL APriv. Hegyi Antal, 1894. január 31. Hegyi Antal levele a váci Egyházmegyei Hatósághoz.

${ }^{557}$ Az önálló döntéshozatal feladásának józan magyarázatát adja kézikönyvében Schüch Ignác: „a felelősség nem a káplányt, hanem a plébánost terheli." Schüch 1872. 585. Gaith és Patzner is megerösíti Schüch megállapításait, miszerint „a plébánost illeti Isten előtt a felelősség, ezért a káplán a lelkipásztori teendőket illetőleg a plébános intézkedéseihez alkalmazkodjék, annak jogaiba ne avatkozzék; ujitásokat önkényüleg ne eszközöljön”. Gaith-Patzner 1892. 304.

558 „A plébános a káplán hivatalos müködésére és erkölcsi viseletére felügyel, a hanyagot jóakaratúlag inteni, a járatlanokat tanácsával segíteni stb. sz. kötelessége.” Gaith-Patzner 1892. 305.

${ }^{559}$ VPL APriv. Edelényi János, 1884. augusztus 28. Edelényi János levele a váci püspökhöz.
} 
a helybeli rom. cath. Káplán urakat, kik naponként részesülnek ilyen kitüntetésben. Ezek az arczképes levelek inkább beválnának arczátlan leveleknek: mert ez az eljárás nagyon elszomorító erkölcsi romlottságra mutat." 560

Hegyi Antal plébános 1896-ban a következő, különös kérdéssel kereste fel a váci Egyházmegyei Hatóságot: „Megengedhetőnek $\mathrm{s}$ a papi állás komolyságával és tisztességével összeegyeztethetőnek találja-e azt a Ftdő. Egyházmegyei Hatóság, ha egy pap, mondjuk valamely káplán, nyílt figyelmeztetés ellenére, vegyes férfi és női, sőt, idegen városbeliek és nem katholikusok társaságában, nőkkel, papi talárban végig táncolja egy lakodalmas háznál, hol cigányok húzzák a talp alá valót, a napnak egy bizonyos részét, teszem: dél után két órától este tízig?"561 A plébános - káplánja megnevezése nélkül hosszasan bosszankodott a reverenda megszégyenítése felett. A szabad kedvű segédlelkészt a plébános dorgálása sem hatotta meg: „Miután az illetőt hasztalan figyelmeztettem előre, hogy ily nemü botrány elkerülése végett ne menjen talárban a lakodalmas házhoz, sőt mikor táncra perdült, segédtársait is hasztalan küldöttem hozzá, hogy ha már táncol, mit részemről civil ruhában sem helyeslek paptól, legalább a reverendát vegye le."562

Ezek a nyilvánosság előtt zajló ügyek hosszú távon befolyásolhatták a helybeli papság megítélését, így a mindenkori csongrádi plébánosok igyekeztek átfogóan tájékozódni a segédlelkészek viselt dolgairól.

A káplánok elképzelése a ,jó plébánosról” szintén a panaszlevelek sérelmes pontjain keresztül tapintható ki. Bakó István csongrádi káplán 1884-ben keltezett levelében aggodalmasan írja, hogy a plébános kutyának nevezi segédlelkészeit, és számos egyéb jelét adja annak, hogy nem tekinti őket egyenrangú paptársnak. ${ }^{563}$ A hivatali alárendeltség hangsúlyozása mellett a káplánok túlzott leterhelése szerepel a panaszok között. ${ }^{564}$ Bakó

\footnotetext{
${ }^{560}$ Csongrádi Lap, 1896. március 15. VI. évf. 11. szám, 3. old.

${ }^{561}$ VPL APar. Cs. 1896. augusztus 29. Hegyi Antal levele a váci Egyházmegyei Hatósághoz.

562 VPL APar. Cs. 1896. augusztus 29. Hegyi Antal levele a váci Egyházmegyei Hatósághoz.

563 „Plébános úr soha nem tartotta kötelességének, hogy ebben [t.i. a gyóntatásban] segédkezzék a káplányoknak, mint fő és illetékes lelkipásztor [...] mondván: 'azért fizetem a káplányokat, a kutyákat' miszerint mindent végezzenek.” VPL APriv. Edelényi János, 1884. augusztus 3. Bakó István káplán levele a váci püspökhöz. A plébános helyes hozzáállását Schüch Ignác eképpen foglalja össze: „Egyébiránt a plébános káplányával mint áldozárral bánjék: ne legyen magatartása irányában büszke; ne éreztesse vele alárendelt helyzetét; tanusítson iránta kellő tisztelete s rajta legyen, hogy a háznép is tisztelje öt." Schüch 1872. 585. [kiemelés: Gy. O.]

${ }^{564}$ Hogy menyire általános problémáról van szó, mutatja a korabeli segédkönyvekben és lexikonokban található figyelmeztetések lankadatlan sora: „Minthogy a káplány munkatárs, a lelkészkedés minden kötelmeit ne halmozza a plébános káplányára, hanem legyen plébános ne csak címre, hanem müködésre nézve is.” Schüch 1872. 585. „A plébániai teendőket maguk között barátságosan és igazságosan osszák meg; a plébános ne toljon minden terhet a káplánra, $\mathrm{s}$ a káplán ne vonakodjék különösen az öregebb és betegebb plébánosnak minden egyházi működésben lehetőleg és szívesen segítségére lenni.” Gaith-Patzner 1892. 304. [kiemelések: Gy. O.]
} 
István szerint a csongrádi plébános egyenesen „irtózik” a templomtól, hisz minden szentmisét a káplánok celebrálnak. ${ }^{565}$

A levél második pontjában Bakó káplán a szentbeszéd igényességét, lélekmüvelő mélységét hiányolja: „Igaz, hogy nagybőjti időszak hat vasárnapján tartott hat szónoklatot, de a hívek közbotrányára s legnagyobb gúnykacajára eme 6 alkalommal Vajda Sámuel múlt századbeli 'Jézus élettörténete' I.ső kötetéből szóról szóra betüről betüre olvasta a kenetes igéket." ${ }^{566}$ A hívek iránti tiszteletlenség további jele a magas stóladíjak szedése és a nép sértő gúnyolása, melyet Bakó káplán nem tartott plébánoshoz méltónak. ${ }^{567}$

A káplánok számára a segédlelkészi évek meghatározó jelentőségüek voltak. A plébános viselkedése, egyházfegyelmezési stratégiája mintaként szolgálhatott számukra, melyet belátásuk szerint utasítottak el, avagy követni, utánozni igyekeztek. A gyakorlati évek fontosságát Schüch Ignác sem mulasztja el hangsúlyozni: „Fiatal lelkészek későbbi magaviselete sok esetben azon befolyástól függ, melyet első lelkipásztori elöljáróik gyakoroltak reájok." ${ }^{568} 1884$-ben a helytelen lelkipásztori példát látva ${ }^{569}$ eképpen fakad ki a csongrádi Bakó segédlelkész: „Különös égi csudaszerü lelkierő kell ily körülmények között az ott müködő papnak, hogy nemes érzelmekkel bíró lelke az életben ily - a fiatal években szerzett erényei után ily szomorú valóságban látva maga előtt az életet önmagával meg ne hasonodjék. Alig tudván összeegyeztetni a botrányos papi életet, mely türetik azzal, a minőre növendék korában neveltetett. [...] Ily körülmények között a káplán a vezető principálistól csak rendetlenséget és lelkiismeretlenséget tanulhatott volna." 570 Mikor Csávolszky József esperes 1894-ben a csongrádi káplánok elhelyezésére tett javaslatot, fő indokként az alázatosság gyakorlásának lehetetlenségét jelölte meg; a vezető lelkipásztor túlontúl magabiztos természete megítélése szerint helytelen mintát közvetített a fiatal papok felé. ${ }^{571}$

Mind a segédlelkészek, mind a hívek elvárták plébánosuktól a kicsinyes konfliktusokon felülemelkedő, krisztusi megbocsátó természetet. 1894-ben Hegyi Antal és káplánjai közt a személyi ellentétek tragikusan elmélyültek. A plébános nem volt hajlandó

\footnotetext{
${ }^{565}$ VPL APriv. Edelényi János, 1884. augusztus 3. Bakó István káplán levele a váci püspökhöz. ${ }^{566}$ VPL APriv. Edelényi János, 1884. augusztus 3. Bakó István káplán levele a váci püspökhöz. 567 „Némely esetben négyszeres illetéket is fizettet a felekkel, kiket 'bagázs' néven czimezget” VPL APriv. Edelényi János, 1884. augusztus 3. Bakó István káplán levele a váci püspökhöz.

${ }^{568}$ Schüch Ignác 1872. 585.

569 Bakó segédlelkész felháborodásának fő oka a plébános és házvezetőnőjének gyanúsan bizalmas viszonya volt. VPL APriv. Edelényi János, 1884. augusztus 3. Bakó István káplán levele a váci püspökhöz.

570 VPL APriv. Edelényi János, 1884. augusztus 3. Bakó István káplán levele a váci püspökhöz.

571 „A káplán urak önérzete az alázatosság erényének rovására igen nagy kifejlődésnek indult, $\mathrm{s}$ a plébános úr szokatlanul bátor fellépése nem jó iskola az önérzet túltengése ellen.” VPL APriv. Hegyi Antal, 1894. március 10. Csávolszky József levele a váci püspökhöz.
} 
egy asztalnál étkezni a segédlelkészekkel, és a „papokhoz illő békülés” legkisebb jelét sem mutatta. A káplánok a váci Egyházmegyei Hatóság felé is jelezték Hegyi Antal elfogadhatatlannak ítélt magatartását. ${ }^{572}$

Az egyetlen eszköz, mellyel a káplánok kifejezhették elégedetlenségüket, az a kollektív engedetlenség volt. 1894-ben Hegyi Antal felháborodottan közölte a püspöki szentszékkel, hogy káplánjai az együttmüködést megtagadták, és nyíltan összefogtak azért, hogy őt a plébánia éléről elűzzék. ${ }^{573} \mathrm{~A}$ váci szentszék helytelenítését fejezte ki azért, mert a csongrádi káplánok „egymással szövetkezve paptársuk és közvetlen fönökük ellen kihívólag állást foglaltak s vele feleseltek." 574

A segédlelkészekkel hadilábon álló plébános a megyéspüspöknél kérelmezhette a káplánok elhelyezését. Hegyi plébános különösen tartott az egyházmegye egyik legtehetségesebb fiatal papjának, Varga Mihálynak közkedveltségétől, aki azokban az időben csongrádi segédlelkészként tevékenykedett. Hegyi és Varga kezdeti egyetértésének okát hasonló természetükben kell keresni, ám viszonyuk két év elteltével olyannyira megromlott, hogy a kialakult helyzet komolyan akadályozta a mindennapi feladatok ellátását. A váci püspök végül jobbnak látta a káplánt elhelyezni Csongrádról. Hegyi plébános a segédlelkészek demoralizáltságára hivatkozva sürgette az intézkedés mihamarabbi végrehajtását. ${ }^{575}$

A helyes lelkipásztori magatartás alapmintái azonos mértékben vonatkoztak a plébánosra és káplánokra; ám egymás iránti elvárásaikat a plébániai hierarchiájában betöltött, eltérő helyzetük árnyalta. A „főnök és paptárs” plébános engedelmességet, míg a segédlelkészek az egyenrangúság minél teljesebb megvalósulását, legalábbis annak látszatát igényelték. A plébánia kiegyensúlyozott működéséhez az elvárások kölcsönös felismerésére és tiszteletben tartására volt szükség. Ennek tükrében a plébános és segédlelkészeinek személyes habitusa, összeférhetősége válik kulcskérdéssé.

\footnotetext{
572 VPL APriv. Hegyi Antal, 1894. március 4. A csongrádi káplánok levele a váci püspökhöz.

${ }^{573}$ NPI 1894. szeptember 30. Hegyi Antal levele a váci püspöki székhez.

574 VPL APriv. Hegyi Antal, 1894. március 14. Püspöki szentszéki ülés jegyzökönyvének kivonata. Ahogy Hegyi Antal írja: „A hivatali teendőkben való engedelmességet [káplánjaim] megtagadták. Minek folytán a lelkiek ellátásában a legnagyobb zavar és botrány állott be, s én azokért semmi felelősséget nem vállalok." VPL APriv. Hegyi Antal, 1894. március 7. Hegyi Antal levele a váci Egyházmegyei Hatósághoz. [kiemelés: Gy. O.]

575 „Kérnem kell ezt kiváltképpen híveim érdekében, mert a hol a gyónók száma az iskolás gyermekekkel együtt megközelíti a tizenkét ezret a húsvéti időben, nem lehet a gyónókat kitenni annak a veszélynek, hogy a lelkiatyák kedvetlensége és türelmetlensége miatt érvénytelen húsvéti gyónást végezzenek." VPL APriv. Hegyi Antal, 1894. február 14. Hegyi Antal levele a váci Egyházmegyei Hatósághoz.
} 
A kisebb-nagyobb, tartós vagy időszaki konfliktusoktól mentes plébániai élet képe: utópia. Ez különösen igaz az olyan településeken, ahol több lelkipásztor munkáját, eltérő habitusát kellett a plébánosnak életközösséggé hangolnia. A panaszlevelek, az időnként felcsapó elégedetlenség természetesnek tekinthető, mely „egészséges” mértékben nem akadályozza a plébánia müködését. Léteznek azonban olyan helyzetek, amikor az együttmüködés ellehetetlenül, és csak személycserével küszöbölhető ki a „templom bezárásának” rémképe. ${ }^{576}$

A csongrádi plébániaközösség kritikus időszakai tisztán körvonalazhatóak. A fennmaradt jegyzőkönyvek szerint 1825-ben a csongrádi plébános és káplánjai között ismeretlen okból lövöldözés alakult ki, és csak a káplánok elhelyezése vetett véget az áldatlan állapotoknak. ${ }^{577}$ 1887-ben Edelényi János keveredett súlyos, politikai alapú nézeteltérésbe segédlelkészeivel. A panaszos levelek sorát a megyéspüspök ismét diszpozícióval oldotta el. A harmadik, egyben legtovább elhúzódó periódus Hegyi Antal csongrádi plébánossága idején, 1886 és 1902 között regisztrálható. 1888-ban Hegyi plébános megakadályozta Bozsó Mátyás majsai káplán Csongrádra helyezését, mondván: „alig van hely az egyházmegyében, a hol csupán csak nevének említése is félelmet ne idézne elő a jámbor lelkekben". ${ }^{578}$ A nevezett káplán Csongrádra kerülése esetén Hegyi kilátásba helyezte plébániája elhagyását. ${ }^{579}$ Varga Mihály ellen már 1893-ban elindult a panaszhadjárat, melynek csak a nevezett káplán elhelyezése vetett véget. ${ }^{580}$ Miután 1894 ben Schneider György áldozárt rendőrrel vitette ki a templomból, Hegyi mindhárom káplánja követelni kezdte a plébános püspöki szentszék elé állítását. ${ }^{581}$

A helyi papság konfliktusainak híre minden más eseményt elhomályosított. Így nem csodálkozhatunk azon, hogy az efféle történések a paraszti feljegyzésekben is helyet kaptak az „év fő eseményei” között. ${ }^{582}$ A 19. század végén már a helyi sajtó is nyomon

\footnotetext{
576 „Ha sokszor ismételt kérésem daczára a baj a legrövidebb idő alatt nem orvosoltatik, egyik templomot a hívek legnagyobb botrányára be kell záratnom.” VPL APriv. Hegyi Antal 1888. július 23. Hegyi Antal levele a váci Egyházmegyei Hatósághoz.

577 VPL APriv. Mátyus János, 1825. szeptember 13. Püspöki szentszéki jegyzőkönyv kivonata.

578 VPL APriv. Hegyi Antal, 1888. július 23. Hegyi Antal levele a váci Egyházmegyei Hatósághoz.

${ }^{579}$ VPL APriv. Hegyi Antal, 1888. május 22. Hegyi Antal levele a váci Egyházmegyei Hatósághoz.

${ }^{580}$ A Hegyi-Varga konfliktus okait az előző fejezetben már érintőlegesen vázoltam.

${ }^{581}$ VPL APriv. Hegyi Antal, 1894. március 4. A csongrádi káplánok levele a váci Egyházmegyei Hatósághoz. Schneider György ellen az volt a kifogás, hogy Hegyi Antal engedélye nélkül misézett a Nagyboldogasszonytemplomban.

582 „1825. esztendőben augusztus 18-án Mátyus János öspörös úr megverekedett Rózembertzki káplánnal. Melyért Mátyus János öspörös úr Vácra citáltatott és ott is maradt.” Tari 1977. 25.
} 
követte a lelkészek ügyes-bajos dolgait.

A vitás felek rendszerint a váci püspök kegyelmére bízták az egyenetlenségek feloldását. A káplánok ugyanis nagyobb beletörödéssel fogadták a püspöki ítéletet, mint közvetlen helyi felettesük rendelkezéseit, kihez „csupán” testvér-papi viszony füzte őket, nem pedig felesküdött engedelmesség. Hegyi Antal kecskeméti káplánkodása idején keletkezett levelében ezt olvashatjuk: „Amit Nagyméltóságod igazságos ítélete reám mér, a tiszta bűntudat legédesebb megnyugvásával fogadom, mert Nagyméltóságoddal szemben csak egy kötelességet ismerek, t.i. feltétlenül engedelmeskedni atyai akaratának." 583

A hiteles lelkipásztori munkát ellehetetlenítő konfliktushelyzetek mellett érdemes felelevenítenünk a szokatlanul szoros együttmüködés példáit. A paptársak között kialakuló rokonszenv és elvi egyetértés direkt megnyilvánulásait a helyi sajtóban is nyomon követhetjük. Hegyi Antal plébános minden alkalmat megragadott arra, hogy kedvelt káplánjai „hőstetteit” sajtó útján közzé tegye. Mikor 1896 januárjában Drexler Antal hitoktató és Krezsák Géza segédlelkész egy idős földművest mentett ki a Tiszából, Hegyi Antal érdekfeszítő leírással emlékezett meg az eseményről. ${ }^{584}$ Még ugyanezen év novemberében Sperling Béla káplán vadászokat megszégyenítő bátorsággal vaddisznót lőtt a mámai réten. Az eset részleteiről, a fiatal pap lélekjelenlétéről hosszú cikk jelent meg a Csongrádi Közlönyben ${ }^{585}$ és a Csongrádi Lapban. ${ }^{586}$ Nagyvonalú gesztusokra a közvélemény szemétől rejtve is akadt példa. Hegyi Antal plébános és Varga Mihály káplán kezdeti rokonszenvét mutatja, hogy a plébános jelentős összeggel segítette a fiatal lelkész „Borus napok” címü könyvének háromszori kiadását. ${ }^{587}$

Hegyi Antal esetében a kedvelt paptársak diszpozíciójával szembeni ellenállás illetve bizonyos káplánok privilegizálása nem csak a szimpátia függvénye volt. Mivel a fent jelzett esetek kivétel nélkül Hegyi plébános politikai aktivitásának csúcsidejéből származnak, joggal feltételezhető, hogy a támogatások nyomán kölcsönös előnyök fakadtak. Hegyi plébános ugyanis mind az országgyülési képviselőválasztások, mind a polgári házasságkötés elleni propaganda idején nagyban támaszkodott segédlelkészei

\footnotetext{
${ }^{583}$ VPL APriv. Hegyi Antal, 1875. január 19. Hegyi Antal levele a váci püspökhöz.

584 „De mire a két lelkész a veszély helyére érkezett, a hullámok az öreget a merigetőtől már oly távolra sodorták, hogy puszta kézzel nem lehetett elérni, azontúl közel is volt a végkimerüléshez, mert a kezében lévő vederrel csak nehezen bírta magát fentartani. Többször víz alá merült $\mathrm{s}$ nagyokat ivott a jeges hullámokból. Az utolsó percben mégis sikerült a két lelkésznek egy rudat előkeríteni, melyet egyikük sietve benyújtott a jeges partról lefelé haladó öregnek, a másik pedig ennek kezét fogta erősen, ne hogy a fuldokló valamikép öt is magával rántsa." Csongrádi Közlöny, 1896. január 5. III. évf. 1. szám 1. old; Csongrádi Lap, 1896. január 6. VI. évf. 1. szám, 3. old.

${ }^{585}$ Csongrádi Közlöny, 1896. november 15. III. évf. 46. szám, 4. old.

${ }^{586}$ Csongrádi Lap, 1896. november 15. VI. évf. 47. szám, 3. old.

${ }^{587}$ VPL APriv. Hegyi Antal, 1894. július 10. Hegyi Antal levele a váci Egyházmegyei Hatósághoz.
} 
határozott fellépésére. Csapó János a polgári házasságkötés törvényének szabálytalan betartása miatt többször került a szegedi ítélőtábla elé. Bajcsy Gábor káplán pedig - Hegyi közvetlen hatására - olyan eröteljes agitációba kezdett, hogy a megyéspüspök Vácra citálta, és többé nem engedte vissza Csongrádra.

7. Káplánok, hívek, hagyományok ${ }^{588}$

A plébános viszonylagos állandósága mellett a segédlelkészek átmeneti jelenségként kísérték a csongrádiak életútjának jelentős fordulóit, szervezték hitéletét. Megbízásuk ideje gyakran arra sem volt elég, hogy nevüket helyes formában őrizze meg az emlékezet. A káplán vezetéknevének idegenszerű hangzása számtalan „tapogatózó” megnevezést eredményezett, így lett pl. Rosenbergből egy kéziratos paraszti feljegyzésben Rózembertzki. ${ }^{589} \mathrm{Ez}$ a jelenség korántsem szokatlan, gondoljunk az idegen hangzású szentek neveinek megkapóan színes népi változataira. ${ }^{590}$ Gyakoribb ennél a segédlelkész testi vagy jellembeli sajátosságain alapuló ragadványnév keletkezése. Szántai Kiss Mihály szitaszövő mester kéziratos visszaemlékezésében széles palettáját találjuk a 19-20. századi csongrádi gúnyneveknek ${ }^{591}$. A köznyelv alkotó kedve előtt a papi személyzet sem élvezett felmentést. Sperling Béla 1898-ban szokatlan hajszíne miatt érdemelte ki a veres ${ }^{592}$ vagy vörös káplány ${ }^{593}$ elnevezést. Megjegyzendő, hogy az 1830-as években a csongrádi származású Csemegi Károly, későbbi jogtudós „,minthogy akkori időben a papság még az egyéneknek bővében volt”, vörös hajszíne miatt nem lehetett lelkipásztor. ${ }^{594}$ Járvás Józsefet „kicsiny termete és szelíd, barátságos viselkedése miatt”595 a csongrádiak kis Járvásnak nevezték.

A keresztelők, esketések, temetések lebonyolítása, szentmisék celebrálása, utolsó kenet kiszolgálása, gyóntatás, a filiák lakosainak lelki ellátása Csongrádon túlnyomórészt a káplánok feladata volt. ${ }^{596}$ Egyszerü, alázatos viselkedésükkel hamar rokonszenvet válthattak ki a hívek körében. Nem egyszer előfordult, hogy a hívek szeretett káplánjuk

\footnotetext{
${ }^{588}$ A témáról bővebben lásd: Gyöngyössy 2014/b.

589 Tari 1977. 15.

590 Az idősebb csanytelekiek a templom névadó szentjét, Nepomuki Szent Jánost Nepomucinus Jánosként emlegetik. A formula alapja a latinosan ejtett Nepomucenus lehetett. Saját gyüjtés adatai, 2007.

591 Szántai Kiss 1972. (kézirat) 59-60.

${ }^{592}$ VPL APriv. Hegyi Antal, 1898 augusztus 22-26. Domonkos Lajos kihallgatásának jegyzőkönyve.

${ }^{593}$ Szentesi Lap, 1898. május 6. XXVII. évf. 53. sz. 4. old.

594 Váry 1974. 145-146.

595 Csongrádi Lap, 1896. november 15. VI. évf. 47. szám, 3. old.

${ }^{596}$ Ahogy Szántai Kiss Mihály visszaemlékezésében olvashatjuk: „Hegyi sose szokott kimenni egy beteghez sem, mindig a káplánjait szokta küldeni gyóntatásra.” Szántai Kiss 1972. (kézirat) 53.
} 
plébánosi pozícióba emelését kérték a váci püspöknél. Az efféle kérvényekhez hosszú aláírási íveket mellékeltek. ${ }^{597}$ A káplánokat olykor keresztszülőnek vagy esküvői násznagynak is felkérték a módosabb csongrádi parasztpolgárok. Az így kialakuló mürokonsági kapcsolatok egy életre megszilárdíthatták az érintett segédlelkészek csongrádi kötődéseit. ${ }^{598}$

Káplánok és hívek érintkezési alkalmai közt sajátos helyen áll a gyógykezelés kérdése. Az 1893-as kolerajárvány idejéből maradt ránk az alábbi, tanulságos újságcikk: „A héten történt, hogy Oláh Balázs a putriban rosszul lett, gyógyszert a plébániáról vitetett, melynek használata mellett, miután őt Varga Mihály gyógykezelő káplán úr személyesen is fölkereste, csak hamar jobban lett." ${ }^{599}$ Varga káplán tevékenysége valóságos szenzációnak számított. Nem csoda, hisz megannyi szent életének meghatározó vonása volt a járvány veszélyeivel mit sem törődő, önzetlen beteggondozás.

A káplánok életének fő eseményei, akárcsak elhelyeztetésük és megérkezésük híre kifogyhatatlan téma volt, melyet a közvélemény állandó érdeklődése kísért. A helyi sajtó minden kiszivárgott mozzanatról, családi tragédiáról kéretlen beszámolót adott közre. ${ }^{600} \mathrm{~A}$ 19-20. század fordulóján divatossá vált, hogy a váratlanul disponált segédlelkészek az újságokban vettek búcsút híveiktől. ${ }^{601} \mathrm{Az}$ áthelyezések híre mellett a sajtó a káplánok későbbi sorsáról is beszámolt. ${ }^{602}$

A csongrádi közvélemény fokozott figyelemmel kísérte a segédlelkészek életét, kis túlzással mondhatni „minden lépését”. Az eltévelyedés legkisebb jelére érzékeny levelekben reagáltak. A váci püspökhöz címzett panaszlevelek sorát az újságokban közzé tett nyílt levelek apasztották. Egy tanulságos példa 1895-ből azt mutatja, hogyan vette át az Egyházmegyei Hatóság funkcióját egy helyi lap szerkesztői hivatala: „Krigler S. szabó mester, kórházi gondnok panaszt emelt lapunk szerkesztőségénél egyik róm. kath. segédlelkész ellen, (kinek nevét elhallgatjuk) hogy a gyóntatószékből 11 éves kis leányához oly kérdést intézett, minőt csak bordélyházakban szoktak intézni a

\footnotetext{
${ }^{597}$ Példaként említve Hegyi Antal esetét, akit Csongrádra helyezése előtt az alsónémedi és ócsai hívek is tárt karokkal vártak volna vissza. VPL APriv. Hegyi Antal, 1885. június 30. Hegyi Antal levele a váci püspökhöz. ${ }^{598} \mathrm{Az}$ ide vonatkozó példákat az V/3. fejezetben már közöltem.

${ }^{599}$ Tiszavidék, 1893. szeptember 3. IV. évf. 36. szám, 3. old.

${ }^{600}$ Példa erre Drexler Antal hitoktató káplán testvérének halálhíre. Csongrádi Közlöny, 1895. december 29. II. évf. 53. szám, 2. old.

${ }^{601}$ A gazdag anyagból álljon itt példaként Krezsák Géza mintaszerü búcsúzása: „Csongrádról történt áthelyeztetésem alkalmából mindazon jó barátaim és ismerőseim, kiktől személyesen el nem köszönhettem, valamint Csongrád város mélyen tisztelt közönsége, nagyra becsült szeretetükért ez úton fogadják bucsuüdvözletemet. Csongrád 1890. okt. 1. kitünő tisztelettel: Krezsák Géza sk. káplán.” Csongrádi Közlöny, 1896. október 4. III. évf. 40. szám, 4. old.

${ }^{602}$ Csongrádi Közlöny, 1895. június 2. II. évf. 22. szám, 3. old.
} 
legelvetemültebb hölgyekhez."603

A káplánok szerepe a népéletben akkor vált kulcsfontosságúvá, amikor a vezető lelkipásztor és hívei viszonya kiegyensúlyozatlan, a plébános megítélése megosztó, ellentmondásos volt. Példaként ránk maradt a Csongráddal szomszédos csépai lakosok 1799-böl származó levele, melyben arról vallanak, hogy közülük többen utolsó szentség nélkül halnának el, ha nem volnának káplánok a településen. Ugyanis többen nem hajlandóak a vezető lelkipásztortól (Mátyus János, későbbi csongrádi plébánostól) elfogadni a végső útravalót, annak kérdéses életvitele miatt. ${ }^{604}$

\section{A káplánok funkciója, helye és szerepe a plébániai hierarchiában}

A segédlelkészek elsődleges feladata a „paptárs és főnök" ${ }^{605}$ irányítási stratégiájának kiismerése, elsajátítása volt, hogy az alapelveket magukévá téve a plébános meghosszabbított kezeként müködhessenek a közösségben. A rendszer hagyományosan egyirányúnak tünteti fel magát, ám bizonyos esetekben a segédlelkészek is befolyásolhatták, kiegészíthették plébánosuk terveit. Csekély számú, ám annál szemléletesebb példákaként említhetőek az új vallási társulatok. Az Oltáregylethez hasonló kezdeményezések akkor találtak elfogadásra, amennyiben beleilleszkedtek a hosszútávú plébániairányítási tervek sorába.

A népes csongrádi egyházközség sorsának egy kézben tartása határozott központi akaratot igényelt. Amennyiben ezzel az akarattal a káplánok bármilyen oknál fogva nem tudtak azonosulni, az a mindennapi lelkipásztorkodás szintjén is komoly fennakadásokat okozhatott. A paptársak munkakapcsolatának minősége javarészt ezen az azonosuláson állt, vagy bukott. A sikeres plébániakormányzat tehát nagyban függött az alkalmazott stratégia elfogadható, általános jellegétől, illetve a plébános és a kisegítő papi személyzet diplomáciai érzékétől, lelki alkatától; vagyis olyan személyes faktoroktól, melyekkel tudományos értekezés keretei között magabiztosan számolni aligha lehet.

Hegyi Antal Csongrádra érkezése után a segédlelkészek politikai aktivitása látványosan megnőtt. Ennek oka, hogy az ellenzéki országgyülési képviselőjelölt győzelemre jutattásához a plébánosnak szüksége volt káplánjai együttmüködésére is. Hegyi Antal tehát nem csak „elnézte” a segédlelkészek agitációs tevékenységét, hanem

\footnotetext{
${ }^{603}$ Csongrádi Lap, 1893. január 22. III. évf. 4. szám, 3. old.

${ }^{604}$ VPL APriv. Mátyus János, 1799. január 15. A csépai lakosok levele a váci püspökhöz.

${ }^{605}$ VPL APriv. Hegyi Antal, 1894. március 14. Püspöki szentszéki ülés jegyzőkönyvének kivonata.
} 
lelkesítette, bíztatta őket. A csongrádi káplánok így a 19. század utolsó évtizedeiben nem csak egyházi, de világ kérdésekben is igyekeztek a plébánost támogatni, hozzá hasonulni. A helyi alsópapság nem csak politikai kérdésekben nyílt meg a világi szféra felé: Hegyi Antal a belső ellentéteket is előszeretettel terelte a polgári törvényhozás ítélőszéke elé. A plébános és a káplánok polgári peres ügyeinek tanulságaira a későbbiekben még visszatérünk.

Kitől lehet parancsot elfogadni, ki adhat utasítást kinek? A segédlelkészek illetékességi köre, a plébániai hierarchiában betöltött helye nem mindig volt letisztázott. A ferences szerzetest afféle „rendszeren kívüli kisegítőnek” tekintették, és a plébánossal való egyeztetés nélkül próbálták irányítani, utasítgatni. A ferences atya viszont egyedül a plébánost tekintette valódi döntéshozónak, így a segédlelkészek ellenében panaszt tett a váci püspöknél. A képet tovább árnyalja a soron következő fejezet, melyben a kántor mint „legrangosabb” laikus templomszolga - a segédlelkészekkel egyenrangú félként határozta meg önmagát. Ennek megfelelően a káplánok kéréseit a kántor rendszeresen felülbírálta; ez a habitus vezetett többek közt 1867-ben a nevezetes Alvinczy-Sohlya konfliktushoz. 
LAIKUS TEMPLOMSZOLGÁK 
Templomszolgákon azokat a laikus egyházi tisztségviselöket értjük, akik közvetlenül a plébániatemplomhoz, illetve a filiákhoz kötődően végzik és végezték munkájukat, vagyis: a kántor, a harangozó és sekrestyés valamint az egyházfi (kurátor). Közülük egyedül a kántori tisztség igényelt külön képzettséget. Egy kántor akár az egész országot bejárhatta állomáshelyről állomáshelyre vándorolva, így a legmobilabb laikus egyházközeli rétegnek tekinthető. A harangozó és sekrestyésnek valamint az egyházfinak helyi születésü, köztiszteletben álló férfinak kellett lennie, akinek jámborságáról, feddhetetlen erkölcsi életéről a közösség már meggyőződött. A kántor látványosan többre becsülte magát a többi templomszolgánál. Méltán kifejezte helyzetét, hogy a papi személyzet után egyedül neki járt az „úr” megnevezés.

A következőkben a csongrádi laikus templomszolgák életét, hivataluk sorsát és történetét veszem sorra azzal a szándékkal, hogy helyük és szerepük kitapinthatóvá váljon a plébánia hierarchiájában és a helyi társadalomban. Az időszakosan fellángoló konfliktusok nyomán elsősorban a papsághoz füződő viszony sajátosságai tárulnak fel.

\section{VII. ÚR AZ ÚRNAK SZOLGÁJA - A KÁNTOR}

A kántor szó az olasz cantare (énekelni) igéből származik, és a liturgikus ének- és zeneszolgálat hivatalosan megbízott, világi vezetőjét értjük alatta. ${ }^{606} \mathrm{~A}$ Csongráddal szomszédos Csépa községben keletkezett egyik panaszlevélben a Cantor megnevezéssel találkozunk. ${ }^{607}$ Mivel a kántorságra a 20. század közepéig csak a tanítói pályával együtt lehetett képesítést szerezni, hivatalos forrásokban a mester vagy kántortanitó volt az általánosan használt formula. ${ }^{608}$ Sohlya Antal csongrádi kántor egyik levelében számba vette a csongrádi hívek ajkán élő megszólításokat: kántor úr, kánturam, nemzetes úr, teens uram, fönök úr ${ }^{609}$, uram bátyám, barátom sat. ${ }^{610} \mathrm{~A}$ tiszteletadás a kántor feleségének is kijárt, akit a csongrádiak ifiasszony, nemzetes asszony, nagyasszony, nénémasszony, teens asszony vagy kántorné asszony néven neveztek az 1860-as években. ${ }^{611}$ Szintén Sohlya

\footnotetext{
${ }^{606}$ Kat. Lex. II. 1931. 489; M. Kat. Lex. VI. 2001. 135. Tágabb értelemben ,jelenti mindazokat, akik részt vesznek a liturgikus énekben (cantores), szoros értelemben énekvezető, előénekes." ${ }^{607}$ VPL APriv. Kanyó András, 1799. január 15. A csépai lakosok levele a váci püspökhöz.

608 1818-ban Szepeshelyen, 1828-ban Egerben állították fel a kántori mesterképző intézetet, ám a kántorságot csak a tanítói képesítés mellett lehetett megszerezni. A falusi és kisvárosi kántorok egészen 1948-ig jellemzően tanítói feladatot is elláttak. Koudela 1936. 18; M. Kat. Lex. VI. 2001. 135.

${ }^{609}$ Sohlya Antal megjegyzi: „t.i. a kántorsegédektől így hallják”

${ }^{610}$ VPL APar. Cs. 1867. Sohlya Antal dátum nélküli levele a váci püspökhöz.

${ }^{611}$ VPL APar. Cs. 1867. Sohlya Antal dátum nélküli levele a váci püspökhöz.
} 
Antal írásaiban találjuk az éneklész és a lelkész szavak után képzett orgonász ${ }^{612}$ illetve éneklészorgonász ${ }^{613}$ kifejezéseket.

A kántor a plébános legrangosabb világi ,alkalmazottja” volt; írni-olvasni magyarul, olykor latinul is tudott, értett a kottás zenei játékhoz. ${ }^{614}$ Esetenként egyéb (gyakran iparos) szakmával is rendelkezett, ám a kántori pályát felvéve korábbi mesterségét elhagyta. Csongrádon a 18. században - a Károlyi kegyúr kívánsága nyomán csak helyi illetőségü személyek tarthattak számot a tisztségre. A 19. századi kántorok viszont már idegen földről kerültek a csongrádi plébániára. A kántor - tekintélyéből kifolyólag - nem osztozott a ,gyüttmentek” általános megítélésében: jeles közéletipolitikai tisztségeket vállalt, akár polgári egyletet (pl. 48-as Népkör) alapíthatott és vezethetett.

A kántorok ellenőrzése és irányítása a mindenkori plébános és káplánjai hatáskörébe tartozott. Ugyan a papsághoz hasonlóan idegen földről terelte hivatalába az élet, a kántor szolgálati ideje rendszerint túlnyúlt feljebbvalói müködési idején. Az éneklész a nép között élt: közvetlenül tapasztalta ki a helyi szokások természetét, hely- és emberismeretének kiszélesítésére állandó lehetősége adódott. ${ }^{615}$ A tudásnak ezen fajtájára egy papi személy körülményesebb módon tudott szert tenni, így nem csodálkozhatunk azon, ha a kántor bizonyos kérdésekben kompetensebbnek érezte magát plébánosánál.

A soron következő fejezetben a kántor saját társadalmi szerepéről alkotott elképzelését vizsgáljuk meg a 19. század második felében. Az elemzés középpontjában Sohlya Antal áll, aki 1860-tól egészen a 19. század végéig Csongrád föéneklésze volt. Amellett hogy jelentős írói-müvészi vénával rendelkezett, de nem állt tőle távol a közéleti szereplés sem. Így bátran állítható, hogy „Sohlya bácsi” emblematikus, meghatározó figurája volt Csongrád 19. századi egyházi és világi-társadalmi életének.

\footnotetext{
612 Sohlya 1857. (kézirat) 58.

613 Sohlya 1857. (kézirat) 91.

${ }^{614}$ A kántor - múvészi hajlamainak engedve - olykor saját szerzeményeket komponált, melyre számolatlanul találunk lenyügöző példákat a kunszentmártoni Mezey család, esetenként éppen a csongrádi Sohlya Antal repertoárjában.

${ }^{615}$ Bárth János 1990. 356. A nép körében élő és müködő kántor nem csak magaviseleti és erkölcsi példa, de egy falu énekismeretének, éneklési módjának, bizonyos vallási szokások rendjének is meghatározója volt.
} 


\section{A „kántorizálás” intézménye Csongrádon}

\subsection{A kántor megválasztása, kinevezése, elbocsájtása}

Csongrádon az első, szilárd alapanyagú templom elkészültével (1722) határozott igény merült fel egy orgonista és mester ${ }^{616}$ alkalmazására. A hívek a kegyúr közbenjárásával kerítettek kántort a szerény kis orgona mellé, ám az első csongrádi éneklésznek még a neve sem maradt fenn a forrásokban.

Csongrádon a 18. század elején a templomi énekszolgálatra megbízott személy kinevezéséhez szükség volt a kegyúr-földesúr és a megyéspüspök jóváhagyására. Az alkalmassági vizsgára az egyházközség tagjai közül ideiglenesen kijelölt „bírák” jelenlétében került sor. A jelöltek származása ekkoriban kiemelkedő fontosságú volt. Ahogy a Károlyi földesúr egyik levelében olvasható: „ugyis jobb s illendőbb is magatok felekezetit tartani, mint sem külső idegent bé fogadni s annak fizetni".617 Ennek megfelelően az alkalmas személyek köre meglehetősen szük lehetett. A kiválasztott kántortanító szerződését évente újították meg.

1736. március 6-án a csongrádi bírák és lakosok panaszos levéllel keresték fel a megyei tiszttartó hivatalt. Vincze Gergely csongrádi plébános ugyanis a mindszenti búcsú alkalmával egy makói illetőségü, Horvát nevezetü egyént bízott meg azzal, hogy a csongrádi származású Lénárt János mellőzésével legyen a csongrádiak új orgonistája. Az orgonista-jelölt Advent idején meg is érkezett, és a „Kistemplomban”618 sort is kerítettek a meghallgatására. A bírák ugyan kezet adtak az új orgonistának, ám ezzel csupán a plébános szándékát kívánták elismerni. Mivel az egyezség nem volt hivatalos, a csongrádiak eleinte passzívan szemlélték az eseményeket: „mivel nékünk mind egy, akár egyik akár másik légyen, csak az isteni szolgálatban fogyatkozás ne essék, és a Mgos Földes Urunk Eö Egzcennetiájának akarattyával ne ellenkezzék". ${ }^{619}$

Mikor azonban a plébános kijelentette, hogy az orgonista választásának joga egyedül őt illeti, a csongrádi bírák nyomban pennát ragadtak, hogy értesítsék gróf Károlyi Sándor földesúr- és kegyurat. Károlyi ugyanis korábban azt a döntést hozta, hogy a

\footnotetext{
616 Orgonista és mester: A kántor megnevezése a 18. századi forrásokban, mely arra utal, hogy az egyházi énekszolgálat mellett tanítói tisztséget is betöltött.

${ }^{617}$ VPL APar. Cs. 1736. Gr. Károlyi Sándor dátum nélküli levele a csongrádi bírákhoz és jobbágyokhoz.

${ }^{618}$ Vagy az akkori Szent Rókus kápolnáról van szó, mely a mai Nagyboldogasszony Katolikus Általános Iskola helyén állt, vagy a mai Szent Rókus - akkoriban Nagyboldogasszony - templomról.

${ }^{619}$ VPL APar. Cs. 1736. március 6. A csongrádi bírák és lakosok levele a Károlyi Sándor kegyúrhoz.
} 
település az előző évi orgonista szerződését köteles meghosszabbítani. A kegyúr akaratának megfelelően a csongrádiak végül nem küldtek fogatot Horvát elé6 ${ }^{620}$, így Vincze plébános máshonnan kényszerült kocsit fogadni az orgonista elhozatalára. A felháborodott plébános Vácott tett panaszt a csongrádiakra, melynek következményeként sem a korábbi, sem az új orgonista nem került beiktatásra.

Gróf Károlyi Sándort őszintén meghatotta a csongrádiak engedelmessége. Dátum nélküli levelében arról biztosította a lakosokat, hogy a plébános kellő rendreutasítása levél útján már megtörtént: „mivel ottan magamnál töb Földes Urat nem ismérek lenni, s meg sem engedem, hogy valaki disponállyon akaratom ellen". ${ }^{621}$ Ugyanakkor szigorúan meghagyta, hogy idegen származású orgonistát továbbra se engedjenek maguk közé. Ha mindez a plébános makacssága miatt nem volna lehetséges, tagadják meg az orgonista járandóságainak kifizetését. Vincze plébános levele sem váratott magára: latin nyelvü jelentésében hosszasan ecsetelte Lénárt János alkalmatlanságának okait. Károlyi Sándor válaszul megfeddte a plébánost azért, mert későn szólt a nevezett kifogásokról. Ugyanakkor lelkére kötötte, hogy a jövöben semmi esetre se intézkedjék önhatalmúan, bármilyen kényes is legyen az ügy természete. ${ }^{622}$ Hogy végül kit erősítettek meg a kántori pozícióban, arról forrásaink hallgatnak.

A 19. században a kántor személyének kiválasztása már a kántor fizetését biztosító helyi képviselőtestület hatásköre volt, az éneklészek pedig „idegenböl” érkeztek Csongrádra. ${ }^{623} \mathrm{Az}$ elöljáróság a kántorválasztás jogát a csongrádi plébániaközösség képviselőjeként gyakorolta, ennek megfelelően csak a katolikus tagok szavazhattak. ${ }^{624} \mathrm{~A}$ püspöknek jogában állt a választás megismétlését kérni vagy a kántorjelöltet elutasítani. A 19. század második felében rendszerint az illetékes kerületi esperes képviselte a püspököt, aki jelentést tett a választás körülményeiről. A kántorválasztás folyamatába a plébánosnak nem volt beleszólása, az alkalmatlannak tetsző éneklészt azonban elmozdíthatta állásából. ${ }^{625}$ A plébánosnak ez a joga azonban - forrásaink tanúsága szerint - a

\footnotetext{
620 „Amintis hogy mi magunkat tellyességgel kívántuk, kívánnyuk is életünk fogytáig mindenekben kötelességünk tenni eő Excellentiájja parancsolattyának és akarattyának alkalmaztatni és tartani magunkat, akár el sem mentünk az orgonistáért, és meg fogadásárul is parancsolatunk lévén eő Excellentiáját ubi per omnia renunciáltuk, s ellene mondottunk.” VPL APar. Cs. 1736. március 6. A csongrádi bírák és lakosok levele a Consistoriumhoz.

${ }^{621}$ VPL APar. Cs. 1736. Gr. Károlyi Sándor levele a csongrádi bírákhoz és jobbágyokhoz.

${ }^{622}$ VPL APar. Cs. 1736. április 14. Gr. Károlyi Sándor levele Vincze Gergely plébánoshoz.

623 VPL APar. Cs. 1894. július 29. Hegyi Antal levele a váci Egyházmegyei Hatósághoz. A 19. század közepén Kmeth Lajos és Sohlya Antal kántorok „máshonnani” származását Váry Gellért is megemlíti. Váry 1974. 140.

${ }^{624}$ VPL APar. Cs. 1894. július 31. A váci püspök levele Hegyi Antalhoz.

${ }^{625}$ Ahogy erre Alvinczy Ferenc plébános több levelében is utalt: jogában állna „,egy szavával” elhelyeztetni
} 
gyakorlatban nem érvényesült. Amikor 1867-ben Alvinczy Ferenc plébános és Sohlya Antal kántor között valóságos ,állóháború” tört ki, a vezető lelkipásztor 50 oldalra rúgó panaszlevele sem volt elég ahhoz, hogy kántorát a váci püspök felfüggessze. ${ }^{626}$ A kántor elbocsátásának ,jogáról” Hegyi Antal plébános 1897 júliusában hivatalosan is lemondott. Akkoriban Hornyik Károly, a lebénult Sohlya Antal veje helyettesítette az öreg föéneklészt. Hegyi plébános ugyan alkalmatlannak találta a helyettes kántort a pozíció betöltésére, elbocsátani mégsem merte, mondván: „előre is látom, hogy akkor darázsfészekbe nyúlok [...] ezen oknál fogva tehát, még a jelen súlyos helyzetben sem akarok plébánosi jogommal a helyettesítést illetőleg élni”, ${ }^{627}$ Ennek ellenére 1898-ban felröppent a sajtóhír, miszerint Hegyi Antal felmondott Hornyik Károlynak. Hogy Hornyik végül mégis megmaradt a tisztségben, annak az az oka, hogy hivatására a helyi elöljáróság nevezte ki, így egyedül ők voltak jogosultak az elmozdítására is. ${ }^{628}$

Kmeth Lajos 1828-ban keltezett kántori szerződésébe belefoglalták: amennyiben nem elégedettek a szolgálataival, azt negyed évvel az elbocsátása elött tudomására hozzák. Ugyanez vonatkozott arra az esetre, ha a kántor szándékozná elhagyni Csongrádot. ${ }^{629} \mathrm{~A}$ csongrádi kántorok a 18-19. század folyamán gyakorlatilag kinevezésüktől halálukig látták el az éneklészi szolgálatot.

\subsection{Hivatali kötelességek, stoláris jövedelmek. A halotti búcsúztatók kérdése}

Dudás Lajos helytörténész meglátása szerint a csongrádi kántori hivatal tisztes megélhetést biztosított az éneklészek számára. ${ }^{630}$ Ennek ellenére a kántor jövedelmének kérdése időrőlidőre napirendre került hol a méltatlankodó plébános, hol az elégedetlen kántor vagy a hívek kezdeményezésére. 1758-ban a csongrádi lakosok azt jelentették a Tekintetes Vármegyének, hogy „galibánk légyen kántorunk miatt”. ${ }^{631}$ Az éneklész által követelt évi 100 forintos fizetést a község ugyanis nem tudta biztosítani, így a tanácstalan csongrádiak a vármegyéhez fordultak igazságtételért.

70 esztendővel később, 1842-ben Kmeth Lajos, akkori csongrádi fóéneklész levéllel kereste fel gr. Nádasdy Ferenc váci püspököt, hogy fizetésének javítását

\footnotetext{
kántorát. VPL APar. Cs. 1867. november 12. Alvinczy Ferenc és káplánjainak levele a váci püspökhöz. ${ }^{626}$ VPL APar. Cs. 1867. november 12. Alvinczy Ferenc és káplánjainak levele a váci püspökhöz.

${ }^{627}$ VPL APar. Cs. 1897. július 8. Hegyi Antal levele a váci Egyházmegyei Hatósához.

${ }^{628}$ Csongrádi Lap, 1898. október 23. VIII. évf. 43. szám, 2. old.

${ }^{629}$ MNL CsML CsL Iratmásolatok, 15.

${ }^{630}$ Dudás 2001. 67.

${ }^{631}$ VPL APar. Cs. 1758. február 6. A csongrádi bírák és tanácstagok levele a Tekintetes Nemes Vármegyéhez.
} 
kérelmezze. Kmeth Lajos a következő, Canonica Visitatioba is belefoglalt javadalmakról számolt be: évi 300 váltóforint, 3 öl tüzifa, 300 kéve „füteni való réti gaz”, egy darab kenderföld és a kántori lakás használati joga. ${ }^{632}$ Ehhez járult még a földesúr jóvoltából fél házteleknyi föld és két kaszáló. Jövedelmének „ingadozó” részét a temetések és halotti búcsúztatók tették ki, melyek összege „öreg mind kicsiny halotti temetésekről különbség nélkül 15 Vfrt. búcsúztatásért bizonytalanul 1 Vfrt.-tól 10 Vforintig”. 633

Az állandó javadalmazásért cserébe Kmeth Lajos köteles volt a két csongrádi templomban napi három szentmise alatt orgonálni, litániákat vezetni, sátoros ünnepeken a belsővárosi népet a Szent Rókus-templomból a Nagyboldogasszony-templomig vezetni, majd mise végeztével visszakísérni. ${ }^{634}$ A bonyodalmak akkor kezdődtek, amikor a frissen kinevezett Jancsovich József plébános újabb feladatokkal bízta meg a kántort. Bevezette ugyanis, hogy ünnepnapokon három helyett négy misét, vasár- és ünnepnapokon valamint Nagypéntek délutánján asperges éneklést ${ }^{635}$ is vezessen. Kmeth Lajos azt is sérelmezte, hogy a Tisza túlpartján lévő tésiekhez is köteles volt „vízen, sáron mint jégen a legnagyobb veszélek között is" temetésre menni, cserében viszont semmilyen juttatást nem kapott. Ugyanakkor a két kántorsegéd részére saját fizetéséből kellett évi 170 forintot, kosztot, szállást, mosást, fütést és gyertyát biztosítania. ${ }^{636}$

Kmeth kántor 1857-ben nyújtott be újabb fizetésemelési kérelmet a megyéspüspök felé. A kérelem kivizsgálására összeálló papi, szolgabírói és községi helyhatóság 1857. szeptember 28-án érkezett Csongrádra. Miután sorra vették a panaszokat, a következő

\footnotetext{
${ }^{632}$ 1769-ben a plébánia elkészültével párhuzamosan (1854) épült fel a kántor és a harangozó szolgálati lakása a mai Templom utcában. A kántori lak kútjának építésére Mátyus János plébános idejében, 1822-ben kerül sor. 1850-ben újították fel a kidőlt kerítést. Váry Gellért, csongrádi származású piarista szerzetes említi, hogy a korábbi Sárkány utcát a 19. század közepén Kántor utcának nevezték. Ez az az út, „,mely a templom farától a kántori lakás előtt a Tiszára visz". VPL APar. Cs. 1822. szeptember 8. Edelényi János határozata; ForgóForgó 1987. 37; Váry 1974. 15.

${ }^{633}$ VPL APar. Cs. 1842. június 2. Kmeth Lajos kántor levele a váci püspökhöz. Az említett jobbágytelek Györi András és Keki József telke között helyezkedett el. A legelöről további 40 forintot, a kenderföldből (melyet elmulasztott a levélben megemlíteni) 100 öl hosszú és 6 öl széles részt, továbbá 12 öl tüzifát és ugyanennyi nádat kapott. A stóladíjak közül kifelejtette a templomi kihirdetések után járó 20 váltó forintot. Ld. NPI Canonica Visitatio 1828. De Cantorum. Ugyanebben az időben az Óbecsén szolgáló Mezey János a községtől 200 Forint juttatást, mellé 1000 kéve nádat kapott, stólaként a jegyesek és házasok kihirdetésére 45 krajcárt, avatásért 10 krajcárt, temetésekre 12-30 krajcárt. Barna 2009. 444.

${ }^{634}$ MNL CsML CsL Iratmásolatok. Az 1761-es Canonica Visitatiohoz csatolt fogadószerződés másolata 1828-ból.

${ }^{635}$ Asperges: A latin 'aspergere' (meghinteni) szóból. A szenteltvíz hintésére szolgáló alkalmatosság az aspergile vagy aspergillum (szenteltvíz-hintő pálca) és az aspersorium (hordozható szenteltvíz-tartó). Használata a lelki megtisztulás és bünbánat fontosságát, a keresztséget és a szentséget hivatott jelképezni. Jellegzetes kísérő éneke az Asperges me Domine hyssopo et mundabor kezdetü, 50. antifóna (Zsolt. 50). Fordítása: „Hints meg engem, Uram, izsóppal, és megtisztulok.” Az idézett panaszos levél szerzője ezen antifona éneklésére céloz. M. Kat. Lex. I. 2004. 457.

${ }^{636}$ VPL APar. Cs. 1842. június 2. Kmeth Lajos kántor levele a váci püspökhöz.
} 
fizetési javaslatot nyújtották be a községnek: egyszerü temetések után 15 váltóforintnak megfelelően 6 pengő; halotti búcsúztatókban a megnevezett személyek párjától 24 p. krajcár; énekes gyászmiséért és Liberáért a korábbi 1 Vfrt. helyett 30 p. krajcár; koporsóba tételért ${ }^{637}$ a korábbi 2 Vfrt. helyett 1 pengő forint járjon a kántornak. ${ }^{638}$

Kmeth Lajos több ponton kifogásolta az új díjazási rendszert. Az egyszerü temetésért járó fizetséget, mely a „szegény csongrádi nép körében a leggyakoribb”, rendkívül alacsonynak találta. A halotti búcsúztatókkal kapcsolatban azt sérelmezte, hogy „az éneknek fejezete, vagyis a befejezése és bezárása a leglényegesebb éneklészi teher $\mathrm{s}$ épen e fáradságért semmi dijj nem határoztatott". ${ }^{639}$ Továbbá felrótta a bírálóknak, hogy Liberás gyászmise tetszés szerint rendelhető, az adott család belátásától függ, hogy igényt tart-e rá vagy sem. Ugyanez mondható el a koporsóba tételről, mely „,csak a nagyszerü, s így igen ritkán előforduló temetéseknél van gyakorlatban". ${ }^{640}$ A kántor javaslata szerint az egyszerü temetések díját ne 6, hanem 15 pengőben, egyszerü „öregtemetésekét” 30 pengő krajcárban határozzák meg. A halotti búcsúztatókat illetően jobbnak látta volna, ha egy búcsúztató díját legfeljebb 4 pengő krajcárban határozzák meg, viszont „,nagyszerü, pompásabb temetéseknél" a díjazás szabad egyezkedés tárgyát képezhetné. A levél írója 30 éves kántori szolgálatára hivatkozva kérte, hogy a püspök jó szívvel fogadja kérelmét. ${ }^{641}$ Alázatos levele azonban Vácott nem talált megértésre.

Kmeth Lajos ezek után a Császári- és Királyi Budai Helyhatósághoz nyújtotta be javaslatait, melynek hatására a helyhatóság leiratot küldött a megyére, melyet a megye rendelet formájában közvetített a csongrádi elöljáróság felé. Az elöljáróság óriási felháborodással vette kézbe a kántor fizetésemelési folyamodványát. Válaszként cirkalmas levélben összegezték korábban tett engedményeiket. ${ }^{642}$ A tanulságos eset a csongrádi kántor stoláris javadalmainak változatos forrásait, egyben Kmeth Lajos fontosabb feladatainak körét is megmutatja.

A kántor javadalmainak kiegészítéséül szolgáló, alapítványi misékért járó díj az 1860-as évektől a 19-20. század fordulójáig nem változott. Ekkoriban egy alapítványi

\footnotetext{
${ }^{637}$ Koporsóba tétel: Latin nevén Impositio, vagy Ritus impositionis ad thumbam. Magyarázatát 1. fent. ${ }^{638}$ VPL APar. Cs. 1857. október 6. Kmeth Lajos kántor levele a váci püspökhöz.

${ }^{639}$ VPL APar. Cs. 1857. október 6. Kmeth Lajos kántor levele a váci püspökhöz.

${ }^{640}$ VPL APar. Cs. 1857. október 6. Kmeth Lajos kántor levele a váci püspökhöz.

${ }^{641}$ VPL APar. Cs. 1857. október 6. Kmeth Lajos kántor levele a váci püspökhöz.

${ }^{642}$ Eszerint 1857 áprilisában a kántor fizetését 300 váltó forintról a jobb árfolyamértékủ pengőre emelték fel, a házasulandó párok hirdetési cédulájának másolási díját 20 váltókrajcárról 10 pengő krajcárra, a Requiemes miseszolgálat, a Libera és koporsóbeszentelés árát 1 Vfrt.-ról egyégesen $30 \mathrm{p}$. krajcárra változtatták. A halotti búcsúztatók taksája a Helyhatósági Tanács javaslatát érvényesítve páronként 24 krajcár maradhatott. Az egyszerü temetésekért járó 6 pengő krajcárt azonban továbbra sem állt módukban megemelni. VPL APar. Cs. 1857. október 23. Csongrád községi választmányi ülés jegyzőkönyvi kivonata.
} 
misékért - függetlenül attól, hogy hány pap celebrálta - 42 krajcár, Liberáért újabb 42 krajcár járt a kántornak. ${ }^{643}$

Az éneklész stoláris jövedelmeinek átgondolására mindig az új kántor hivatalba lépésének idején került sor. Ennek okát Schuster Konstantin váci püspök világosan megjelölte: „,a kántori illeték szabályozására most lesz a legalkalmasabb időpont, mikor az állomás üresedésben lesz - minthogy a már megválasztott Kántor kétoldalú szerződése még bajok előfordultával sem oldható fel a szerződtető fél részéről”. ${ }^{644}$ Sohlya Antal 1860. április 1-jén érvénybe lépő szerződésében a stoláris javadalmak már osztrák krajcár és forint értékben voltak megadva, ${ }^{645}$ számszerüsítve a következőképpen:

Házassági hirdető levelek: $20 \mathrm{Kr}^{646}$

Temetések: 15 Kr. (szegényektől, akik polgármesteri bizonyítvánnyal rendelkeznek, ez a díj nem követelhető)

Énekes gyászmise (Requiem) Liberával: $84 \mathrm{Kr}$.

Énekes gyászmise Liberával, koporsó kitétel nélkül: $42 \mathrm{Kr}$.

Koporsóba tétel (Impositio): $42 \mathrm{Kr}$.

Temetési búcsúztató, a stoláris $15 \mathrm{Kr}$-on kívül:

Kiskorú halottnál (5-10 éves) 50 Kr-tól 2 Frtig

Öreg halottnál: 8-15 versszak között 1 Frt-tól 4 Frt-ig

Név szerinti búcsúztatásért: 8-15 versszak között 1 Frt-tól 3 Frt-ig

Öreg halottnál: 10-20 versszak között 2 Frt-tól 8 Frt-ig

Rendkívüli, határozatlan mennyiségü verses búcsúztatás szabad egyezkedés tárgya, díja 8 Frt-tól 20 Frt-ig terjedhet. ${ }^{647}$

\footnotetext{
${ }^{643}$ VPL APriv. Hegyi Antal, 1898. augusztus 22-26. Püspöki szentszéki kihallgatási jegyzőkönyv. Hornyik Károly vallomása. Ugyanitt Droppa Károly adminisztrátor vallomásában megjegyzi, hogy ,itt [t.i. Csongrádon] minden három papos mise Liberával van. Tehát úgy látszik liberás miséért jár ez a $84 \mathrm{Kr}$. Ezen illetményét [a kántor] napról napra kapja."

${ }^{644}$ VPL APar. Cs. 1894. július 31. A váci püspök levele Hegyi Antalhoz.

${ }^{645}$ 1858-ig egy forint 60 krajcárra oszlott, innentől kezdve vezették be az osztrák értékủ forintot, ami már decimális, tehát 1:100 arányú volt. Ujszászi Róbert szíves közlése.

${ }^{646}$ Alvinczy Ferenc plébános levelében írta, hogy a házassági hirdető cédulák másolásáért, a hirdetési lista összeállításáért a helybeli lakostól 20 krajcárt, „idegentől” 40 krajcárt kérhetett el a kántor. A plébános ez alapján hirdette ki litánia alkalmával a házasulandókat. A plébános ugyanakkor nem mulasztotta el megjegyezni, hogy ez afféle „ferde szokás”, mely még a Canonica Visitatioba is bekerült. VPL APar. Cs. 1867. november 12. Alvinczy Ferenc és káplánjainak levele a váci püspökhöz.

${ }^{647}$ VPL APar. Cs. 1867. évben, Sohlya Antal nyomtatásban megjelent röpirata szerint. A röpirat csak a nevezett javadalmakra tér ki.
} 
Mindezek mellett a csongrádi kántor köteles volt minden szombati litánia után ének-oktatást tartani az iskolás gyermekeknek, továbbá a szentmise énekeit a szertartások előtt a hívekkel begyakoroltatni.

A kántori szerződésbe foglalt „kötelmek” tetemes részét a halott mellett végzett szolgálatok tették ki. Legnagyobb kihívást szemmel láthatóan a halotti búcsúztatók díjának meghatározása jelentette. ${ }^{648}$

Halotti búcsúztatók körüli anomáliáról elöször 1823-ban találunk adatot Csongrádról. Mikor Mátyus János plébános megtudta, hogy egy gyermek halott részére énekes búcsúztatót és a nagy harang kongatását is megrendelték, ám Requiemet (gyászmisét) nem óhajtott a család szolgáltatni, haragját a halottbejelentést végző édesapára zúdította. ${ }^{649}$ Ugyanezen plébános temetésenként 1 forint ún. várakozópénzt kért a hozzátartozóktól azért, hogy a temetésen végig várja a kántor búcsúztató énekét. ${ }^{650} \mathrm{~A}$ papság részéröl a díjazás ellenőrizhetetlensége, a versezetek alacsony színvonala és a müfaj bosszantó „életképessége” volt a búcsúztatók iránti ellenszenv elmélyülésének oka. ${ }^{651}$

1867-ben Alvinczy Ferenc plébános erőteljes kirohanás intézett Sohlya Antal kántor búcsúztatási gyakorlata ellen. A kántor és a plébános közötti konfliktus ugyan nem a búcsúztatók ürügyén robban ki, de a kántor elleni vádak sarkalatos pontját képezte. $\mathrm{A}$ plébános beszámolója szerint Csongrádon az ingyenes szegénytemetések, másképp karinges temetése $k^{652}$ is ritkán múltak el a „drága, de rosz, füzfán termett, hitbeli hibáktól piszkos, együgyüeket ámító, a kántor privát bosszuállásának tért adó ostoba halotti búcsúztató nélkül”. ${ }^{653}$ A szokás meggyökeresedésének okát Alvinczy a kántor

\footnotetext{
${ }^{648}$ Halotti búcsúztató: Az elhunyt hozzátartozói által megrendelt, és a kántor által személyre szabottan készített (vagy összeállított), kötött versformájú, ismert egyházi ének dallamára előadott halotti versezet, mely többnyire tartalmazza az elhunyt hozzátartozóinak nevét vagy a rokonsági fok jelölését. Sohlya Antal csongrádi kántor eképpen definiálta a halotti búcsúztatókat: „Bucsuztatónak szorosan csak azt lehet neveznünk, melyben az elhunyt nevében, $\mathrm{s}$ helyette az éneklész az elhunyt vérsége $\mathrm{s}$ barátaitól búcsút vészen." Sohlya 1857. (kézirat) 394. A halotti búcsúztatók történetéről, müfaji jellemzőiről egy korábbi munkámban már értekeztem. Lásd: Gyöngyössy 2010/a. A kántorok minden időben elégedetlenek voltak stoláris jövedelmeikkel, így a 19. század folyamán nem voltak ritkák az efféle sirámok: „Nekem egyenesen e búcsúztatókból kell élnem [...] s ha ezt elveszik maguknak a lelkész urak, akkor mehetek én nőmmel, anyámmal s gyerekeimmel koldulni” VPL APar. Cs. 1867. Sohlya Antal dátum nélküli levele a váci püspökhöz.

${ }^{649}$ Méltatlankodásának oka, hogy Reqiemes gyászmiséért külön díjazás járt volna a papnak. VPL APriv. Mátyus János, 1823. május 10. Csongrád város bírájának levele a váci püspökhöz.

${ }^{650}$ VPL APriv. Mátyus János, 1823. július 10. Kováts Ferenc káplán vallomása.

${ }^{651}$ V.ö. Gyöngyössy 2010/e.

${ }^{652}$ Karing: Latinul superpelliceum vagy rochettum. Fehér színủ liturgikus ruha, mely a 10. század végén alakult ki az albából. A 17. század óta csipkével díszítik. Karinges temetésnek nevezi a népnyelv, amikor a pap karinget visel a szertartáson, mellőzve a fekete miseruhát. M. Kat. Lex. VI. 2001. 206.

${ }^{653}$ VPL APar. Cs. 1867. november 12. Alvinczy Ferenc és káplánjainak levele a váci püspökhöz.
} 
magatartására vezette vissza: „Ha halottbejelentés után a kántorhoz küldöm őket, a hideg kezdi rázni a híveket és igen sokszor azt mondják 'Jaj! Csak ahhoz a nyúzóhoz ne kellene menni! - 'Miért?' - 'Alig lehet vele megalkudnunk. [...]' - 'De hát mit panaszkodnak? Ki kényszeríti kendteket, hogy illyen ollyan bucsuztatót rendeljenek, ha kell a czifra bucsuztató, hát fizessenek a kántornak!' És ekkor már nagyon furcsa dolgokat beszélnek a hívek, hogy mit csinál a kántor, ha nem búcsúztatnak" ${ }^{654}$ Ha nem kértek búcsúztatót, vagy nem fizették meg kellően szolgálatait, a kántor éneklés helyett „csak mormogott”, vagy el sem jött a temetésre. ${ }^{655}$

Huszonhárom esztendővel később Csongrád új plébánosa, Hegyi Antal - a temetések után befolyó pénzek egyenlőtlenségét sérelmezve - valóságos támadást indított Sohlya Antal és a csongrádi nép „cinkos hiúsága” ellen. Hegyi plébános levelében számszerủen sorolta elő a halotti búcsúztatás anyagi vonatkozásait: ,a nép maga táplálja a lábra kapott rossz szokást, csakhogy hiúsága ki legyen elégítve, s neve legalább ezen utolsó alkalommal a világ előtt ki legyen kiáltva. Így történik aztán, hogy pl. karinges temetéseknél a plébános nem kap semmit, mert az ő stólája meg van váltva az évi 1680 Frt. tiszteletdíjjal, a temetést végző segédlelkész kap 20 Krt csizmakoptatás czimén, a kántor pedig egymaga 5-6 Frt. jutalomban részesül a semmit mondó búcsúztatók után, s ezért a papnak órahosszáig dideregnie kell a hidegben. A 3 papos temetéseknél a 3 pap a templommal együtt kap 18 Frt 70 Krt, a kántor egymaga 20-25 Frt, néha többet is, mert a búcsúztató szabad alku tárgya csak azért, hogy a kaptafaszerű búcsúztató formába a bemondott neveket - legtöbbször bosszantó nyakatekertséggel - belegyüri”. ${ }^{656}$ Hegyi plébános levelében arra kérte a váci Egyházmegyei Hatóságot, hogy a szegény, karinges temetéseken tiltsa meg a halotti búcsúztatók éneklését. Hisz „,a hol nem telik a néptől garas a szentmisére és templompénztár javára, ott ne legyen keresnivalója a hiábavaló búcsúztatóknak sem, hanem mondjon a helyett a kántor valamely könyörgő egyházi éneket, mely többet használ Isten előtt a léleknek tíz összetákolt búcsúztatónál”. ${ }^{657}$

Ahol a halotti búcsúztatók után járó fizetség a kántor és a gyászos család „magánügye”, vagyis szabad egyezkedés tárgya maradt, ott a díjszabás kérdése körül

${ }^{654}$ VPL APar. Cs. 1867. november 12. Alvinczy Ferenc és káplánjainak levele a váci püspökhöz.

655 Gyánti Ágnes esete, lásd. VPL APar. Cs. 1867. november 12. Alvinczy Ferenc és káplánjainak levele a váci püspökhöz. Évtizedekkel később Hegyi Antal plébános tollából hasonló panaszok jutottak el a váci püspöki szentszékhez: „A ki jogosulatlan illetményeket szed, az nem más mint a kántor, a ki annyira viszi ezt az üzérkedést, hogy ha valaki temetések és misék alkalmával csak a rendes illetményeket fizeti be, valóságos botrány, a hogyan énekel." VPL APar. Cs. 1891. február 28. Hegyi Antal levele a váci Egyházmegyei Hatósághoz.

${ }^{656}$ VPL APar. Cs. 1891. január 30. Hegyi Antal levele a váci Egyházmegyei Hatósághoz.

${ }^{657}$ VPL APar. Cs. 1891. január 30. Hegyi Antal levele a váci Egyházmegyei Hatósághoz. 
fellángoló anomáliák az éneklész és plébánosa kapcsolatára is árnyékot vetettek. Mikor Sohlya Antal és Alvinczy Ferenc plébános között felütötte fejét az egyenetlenség, a kántor jobbnak látta a „rágalmak elkerülése végett” röplapon terjeszteni a stoláris javadalmak listáját. Segédei napokon keresztül osztogatták az utcán Sohlya díjszabás-jegyzékét. ${ }^{658}$

A díjszabás mellett a halotti búcsúztatók milyensége is állandó vita tárgyát képezte. Egy-egy balul elsült ének híre akár évtizedekkel is túlélte alkotóját, rosszabb esetben nyomtatott formában is megörökítette az emlékezet. A Csongrádi Lap eképpen emlékezett meg az öreg Sohlya kántor búcsúztatói gyakorlatáról:

Tejfel, turó, vaj, iró,

Sohlya tata nagy író;

Tüz-, víz-, gyász- és baleset,

Ö írja meg, hogy esett. ${ }^{659}$

1.3. Csongrádi kántorok a 18-19. században

Dudás Lajos helytörténész 2001-ben az Oppidum Csongrád hasábjain egy teljes tanulmányt szentelt a csongrádi kántoroknak. ${ }^{660}$ Forrásai azonban csak 1761-ig engedték vissza az időben, és elsősorban a 19-20. századi kántorok álltak érdeklődése középpontjában.

A legkorábbi orgonista és mester, kinek neve forrásainkban fennmaradt, a már említett csongrádi illetőségű Lénárt János, akit 1736-ban a makói származású, Horvát vezetéknevü kántor követett a tisztségben. ${ }^{661}$ Néhány évtizeddel később, az 1761-ik évi Canonica Visitatio a kántor személyére is kitér. A forrás szerint ekkoriban az 54 esztendős Tóth Imre látta el a tanítói és kántori (Ludimagister et Cantor) teendőket Csongrádon, kinek szolgálatairól és magaviseletéről a plébános elégedetten nyilatkozott. ${ }^{662}$

Bába Szabó Rókus egyházfi feljegyzéseiben maradt ránk Faragó János csongrádi

\footnotetext{
${ }^{658}$ VPL APar. Cs. 1867. november 12. Alvinczy Ferenc és káplánjainak levele a váci püspökhöz.

${ }^{659}$ Csongrádi Lap. 1892. január 17. II. évf. 3. szám, 3. old. Ugyanebben a cikkben az idős kántor köré valóságos hálót szőnek iróniából, melynek alapja egy közszájon terjedő, félresikerült halotti búcsúztató: „De leginkább az esett rosszul az öregnek, hogy supplensével, Sántha Jánossal, a nemesség kivívása reményében előre megfestette az ősi címert [...]. A pajzs jobb felén hárompapos temetést ábrázoló kép $\mathrm{s}$ az Öreg úr búcsúztatóiból a magyar költészet öröklő remeke: „Midőn a vízbe fulladtál, jaj be sokat ihattál”. Tudvalevőleg az öregúr ezt a búcsúztatót zengette el egy 16 éves vízbe fúlt leányzó ravatalánál. Erre a versére még máig is büszke." ${ }^{660}$ Dudás 2001.

${ }^{661}$ VPL APar. Cs. 1736. március 6. A csongrádi bírák és lakosok levele a Consistoriumhoz.

${ }^{662}$ MNL CsML CsL Iratmásolatok, 106.
} 
kántor emléke, akiről a Bába Szabó tudni vélte, hogy 1798-ban hunyt el. ${ }^{663}$ Faragó neve már az 1784-ben Kanyó András plébános által végzett népszámlálás idején is felbukkant. A bejegyzés szerint a csongrádi éneklész akkoriban 53 éves volt, feleségével, Galbáss Juliannával három gyermeket neveltek. Háztartásukban két szolga neve is fel volt tüntetve. ${ }^{664}$

A már említett 1761-ik évi Canonica Visitatio folytatásaként vezetett iratköteg végéhez Kmeth Lajos csongrádi éneklész 1828-ban aláírt fogadószerződését csatolták, melyet 1842-ben újítottak meg a korábbi feltételek szerint. ${ }^{665}$ Kmeth Lajos kántortanító 1801-ben született, ismeretlen helyen. Gimnáziumot végzett, ahol latinul és németül is tanult. Három éves Nagykőrösi működés után került Csongrádra. Az 1842-es kánoni vizitációs jegyzőkönyv szerint jó erkölcsű, vallásos férfi, emellett egészséges és erős testalkatú volt. Mivel Csongrádon elegendő tanító müködött, így a kántornak már nem kellett tanítania. Az orgonán megfelelően játszott (apte pulsat organum), a világi énekeket mellőzte. ${ }^{666}$

Kmeth Lajos első felesége, Bauersax Anna 43 éves korában, 1845 szeptemberében hunyt el. ${ }^{667} \mathrm{~A}$ töredékben fennmaradt megemlékezésekből az derül ki, hogy a jólelkü kántor oly sokaknak adott kölcsön, hogy élete utolsó éveiben súlyos anyagi gondokkal küzdött. Kmeth Lajos sírjának szomorú sorsára Hegyi Antal plébános hívta fel a figyelmet a Tiszavidék hasábjain. ${ }^{668}$ Kmeth második felesége, a harangozó és sekrestyés családból származó Keviczky Márta 1859. novemberében levéllel kereste fel a csongrádi elöljáróságot, hogy nehéz anyagi helyzetére és férje 31 éves kántori szolgálatára való tekintettel még egy évig ne hirdessék meg a kántori állást Csongrádon. Ezidő alatt a kántori javadalmak élvezése fejében az özvegy két alkalmas segéd tartását vállalta. A Tanács a kérelmet elfogadta, így az állást csak 1860. Szent Mihály napján hirdették meg. ${ }^{669}$ Hogy az özvegy és gyermekei végül Csongrádon maradtak-e vagy sem, arról nincs

\footnotetext{
663 Tari 1977. 13.

${ }^{664}$ NPI Historia Domus I. kötet, 205.

${ }^{665}$ MNL CsML CsL Iratmásolatok, 106.

${ }^{666}$ NPI Canonica Visitatio, De Cantorum. 1842.

${ }^{667}$ Dudás Lajos 2001. 70.

668 „Oh bár akadna olyan ember is, ki a néhai Kmeth Lajos kántorról is megemlékeznék, kinek sírját - hogy hol van - már csak emlékezetből ismerjük, mint hogy a kis fenyőfa kereszt is rég megsemmisült sírjánál. Kmeth Lajos nem csak minden jövedelmét, de a neje 10.000 frt. hozományát is mind a barátságnak áldozta fel elannyira, hogy a szemfödele még nincs kifizetve, és még is ma már jeltelen sírban nyugszik. Nem kötelesség, de a szívesség parancsolja, hogy a jeltelen sírt jelezzétek meg ti, kik annyi szívességével éltetek az elhunytnak." Tiszavidék, 1894. november 11. V. évf. 45. szám, 3. old.

${ }^{669}$ MNL CsML CsL V.B. 42. a. 1859. november 7. jk. 288. sz. Kmeth özvegyének esete nem egyedi: az 1872-ben elhunyt kunszentmártoni kántor felesége a férj halálát követő évben a kántori lakban maradhatott. Barna 2009. 450.
} 
tudomásunk. Ami bizonyos, hogy Kmeth Lajos fiai, József és István tanyai tanítók lettek Csongrád környékén, ám az 1858-59-es években más községekben is pályázatokat nyújtottak be ${ }^{670}$ Kmeth Lajos kántor anyagi ügyei még 1868-ban is napirenden voltak. ${ }^{671}$

A 19. század második felét egyetlen kántor, Sohlya Antal neve fémjelzi, kiről a későbbiekben részletes életrajzot és leírást közlünk.

\subsection{Néhány szó a szuflensekről és fullajtárokról}

Ahhoz, hogy a csongrádi fóéneklész a fogadószerződésben foglalt kötelességeinek maradéktalanul eleget tudjon tenni, énekelni és orgonálni tudó segédek tartására kényszerült. A kántorsegéd népies neve Szegeden suplenc ${ }^{672}$, Csongrádon szuflens ${ }^{673}$ vagy kis kántor ${ }^{674}$ volt. Hivatalos iratokban és a sajtóban megnevezésük kántorsegéd, supplens $^{675}$ vagy aléneklész ${ }^{676}$. Számuk Csongrádon egytől háromig terjedhetett. Két segéd tartása a filiák miatt elengedhetetlennek bizonyult, három csak a fókántor hosszas betegsége vagy súlyos járvány idején vált kötelezővé. ${ }^{677}$ Csongrádon kántori segédlet nélkül még a legszerényebb végtisztesség is elképzelhetetlen volt: ezeken az ún. „ötgarasos” vagy „karinges” temetéseken kizárólag segédek asszisztáltak. ${ }^{678} \mathrm{~A}$ kántorsegédek fogadásának feltételei csak a század végére változtak meg: 1896-ban a segédek éves fizetése teljes ellátással 180 forint, ellátás nélkül 400 Frt volt. ${ }^{679}$

A supplensek kiválasztása a 19. század végéig a főkántor egyedüli joga volt, elbocsátásukról is ő döntött. A plébánosnak gyakran arról sem volt tudomása, pontosan kik, és hány segéd müködik a kántor kezei alatt. ${ }^{680}$ Alvinczy Ferenc eképpen összegezte a

\footnotetext{
${ }^{670}$ MNL CsML CsL V.B. 42. a. 1856. szept. 9. ülés, 429. sz. és 432. sz. határozatok.

${ }^{671}$ MNL CSML CSL V.B. 42. a. 1868. július 3. 388. sz. határozat.

672 Bálint 1983. 97.

${ }^{673}$ VPL APar. Cs. 1868. február 4. Gyánti Ágnes vallomásában eképpen panaszkodott a főkántorra: „Még a 15 krajczárt sem adta vissza, holott sem ő (nem jelent meg a temetésen), de még csak egy gyerek szuflenst sem küldött."

${ }^{674}$ Megemlítve a Tiszavidék közleményében, Faragó Mihály temetése kapcsán. Lásd: Tiszavidék, 1894. december 16. V. évf. 50. szám, 3. old. Illetve Sohlya Antal nyugdíjazási ügyében: Csongrádi Közlöny, 1894. augusztus 12. I. évf. 22. szám, 3. old.

${ }^{675}$ Csongrádi Lap, 1892. január 17. II. évf. 3. szám, 4. old.

676 VPL APar. Cs. 1868. január 9. Skultéty József vallomása. Megjegyzendő, hogy sem a Katolikus Lexikon, sem a Magyar Katolikus Lexikon nem emlékezik meg a kántorsegédekről.

677 VPL APar. Cs. 1867. Sohlya Antal dátum nélküli levele a váci püspökhöz. Ugyanebben a forrásban a csongrádi kántor arról panaszkodik, hogy a plébános elvárja tőle a három segéd tartását csupán azért, mert neki is három káplánja van.

${ }^{678}$ VPL APar. Cs. 1867. Sohlya Antal dátum nélküli levele a váci püspökhöz.

${ }^{679}$ VPL APar. Cs. 1896. november 17. Jegyzőkönyvi kivonat képviselőtestületi ülésről, Csongrád.

680 „A plébános, aki a temetéseket elrendeli, sohasem tudhatja bizonyosan: mikor van meg a rendes két segéd, mikor nincs? [...] Itt a kántorsegédek csak úgy jönnek mennek, s ismét jönnek mennek a plébános híre tudta
} 
csongrádi helyzetképet: „Vajjon van-e a papnak joga megnézni, kivel megy temetni és ki van a kóruson miséje alatt - vagy pedig nincs? [...] mert különben a kántor az ő kis kutyáját is elküldhetné a pappal temetni. [...] Vajjon kellett-e a mostani csongrádi papok miatt [a fóéneklésznek] csak egy segédet is elküldenie? Pedig nagyon tudja, hogy milly furcsa népségek megfordulnak nála". 681

A kántorsegédek neve esetlegesen maradt fenn - ha fennmaradt egyáltalán - a forrásokban. 1842-ben mindössze annyi derül ki, hogy Kmeth Lajos kántornak két segéd részére kellett évi 170 forintot, kosztot, szállást, mosást, fütést és gyertyát biztosítania. ${ }^{68}$ Tette ezt annak ellenére, hogy fogadószerződése szerint csupán egy supplens tartására volt kötelezhető. ${ }^{63}$ Még Kmeth Lajos kántorsága idején, 1853-ban hat méteres szárnnyal bővítették ki a csongrádi kántorlakot, melyet a segédek részére különítettek el. ${ }^{684} \mathrm{Az}$ új hajlék első lakója Kovacsics Béla volt, aki 1853-tól elemi leányiskolai tanítóként müködött ${ }^{685}$, majd az 1860-as évek közepétől csépai főkántor lett. ${ }^{686} 1867-68$-ból az idős Skultéti (vagy Skultéty) József és Oláh Lázár neve maradt ránk. Skultétiről annyit tudunk meg, hogy idős ember volt, aki a Belsővárosban lakott, így sokáig tartott mire a plébániára besétált. ${ }^{687}$ 1869-ben Skultétit tanítónak nevezte ki az iskolaszék. ${ }^{688}$ Oláh Lázár 1867-ben belsővárosi elemi iskolai tanító lett. ${ }^{689}$

1870-71-ben segédkántorként müködött Sohlya Antal mellett a későbbi polgári iskolai igazgató - Sohlya jövendőbeli veje - , Farkas Béla. ${ }^{60}$ Nem tudni, hogy Vogel Ignác kántortanító ebben az időben kizárólag tanításból élt, vagy supplensként is müködött

nélkül.” VPL APar. Cs. 1867. november 12. Alvinczy Ferenc levele a váci püspökhöz.

${ }^{681}$ VPL APar. Cs. 1867. november 12. Alvinczy Ferenc levele a váci püspökhöz. A helyi főpásztor egyik legkellemetlenebb emléke ezekről a „furcsa népségekről” egy rühes segéd esete, akivel temetések alkalmával közös kocsira kényszerült ülni.

${ }^{682}$ VPL APar. Cs. 1842. június 2. Kmeth Lajos kántor levele a váci püspökhöz.

683 „Melly szolgálatokat, minthogy maga a nevezett kántor úr nem teljesíthetné, azért köteleztetik egy alkalmas suplenset, a ki a fennt előhozott ájtatos szolgálatokban segédet [...] lehessen állandóul tartani” MNL CsML CsL Iratmásolatok, 106.

${ }^{684}$ Dudás 2001. 68.

${ }^{685}$ Forgó-Forgó 1987. 73.

${ }^{686}$ VPL APar. Cs. 1867. november 12. Sohlya Antal levele a váci püspökhöz.

${ }^{687}$ VPL APar. Cs. 1868. február 28. Kevitzky György vallomása.

${ }^{688}$ MNL CsML CsL Csongrád Város, 1865-1872-ig és 1880-1923-ig Nagyközség Községi Iskolaszékének, 1897-től Állami Elemi és Polgári Iskolai Gondnokságának iratai V. B. 79. (Továbbiakban: MNL CsML CsL V. B. 79.) 1869. október 24. jk. 35. sz. határozat.

${ }^{689}$ VPL APar. Cs. 1867. november 12. Alvinczy Ferenc levele a váci püspökhöz. Oláh Lázárral kapcsolatban Szántai Kiss Mihály említi, hogy tudomása szerint ő volt Csongrád második diplomás tanítója, aki híres volt szép kézírásáról és rajztudásáról. V.ö. Szántai Kiss 1972. (kézirat)

${ }^{690}$ MNL CsML CsL V. B. 79. 1871. július 6. jk. 242. sz. határozat. Farkas Béla (1847-1913) a Hont vármegyei Kisbéren született, 1871-től kezdve Csongrádon élt. A polgári fiúiskolában igen hamar igazgatói tisztségbe került, és egészen 1913-as nyugdíjazásáig vezette az intézményt. Lásd: Füzesi é.n. (kézirat) 229. 
Sohlya Antal mellett. ${ }^{691}$ Szentkereszty Tivadarnak, a későbbi gerendási kántortanítónak is csupán tanítói müködése bizonyítható. ${ }^{692}$ Ö volt az, aki a Szentesi Lapban méltató sorokkal emlékezett meg Sohlya Antal 50 éves kántori szolgálatáról. ${ }^{693}$ Fölföldy Mihály „képezdevégzett kántorsegédet” viszont már segédkántori minőségből emelte az iskolaszék 1880-ban javadalmazás nélküli, kisegítő tanítói állásba. ${ }^{694}$ 1892-ben történik említés egy Sántha János nevezetű supplensről, majd 1894-ben Khírer (vagy Kirer) József okleveles segédkántorról, aki kérelmet nyújtott be egy elemi iskolai tanítói állás elnyerése érdekében. Az állást meg is kapta. ${ }^{695}$ Khírer Józsefet egy év múlva Kiszombor község kántorává választották meg. Ám csongrádi kapcsolatai nem szakadtak meg: alig egy esztendő múlva Sohlya fooéneklész egyik leányunokáját vette feleségül. ${ }^{696}$ 1898-ban értesülünk a Kiskunmajsán kántorizáló Schwarz Alajos, egykori csongrádi supplens és jeles zongoratanár haláláról. ${ }^{697}$

A segédkántori tisztség tehát gyakornokoskodást, legfeljebb egy-két esztendeig tartó hivatalviselést jelentett; afféle „,ugródeszka” volt a főkántori vagy tanítói állás elérése elött.

Forrásaink többnyire név nélkül emlékeznek meg a kántorsegédekkel kapcsolatos problémákról. Ezek között első helyen áll a képzetlenség, a túlzottan fiatal kor és a pontatlanság, vagyis az át nem érzett felelősség. 1868 januárjában Szepesi József csongrádi faragóács a szomszédos csépai kántort hívta el édesapja temetésére énekelni. Sohlya Antal főéneklész távollétében ugyanis az a nevezetlen csongrádi supplens asszisztált volna a szertartáson, akiről az elhunyt nem a leghízelgőbb véleményen volt. ${ }^{698}$ A név szerint is ismert csongrádi kántorsegédek kántortanítói képesítéssel rendelkeztek, így hamarosan vagy az egyik elemi iskola tantestületében, vagy egy község választott főéneklészeként folytatták pályájukat. Hegyi Antal plébános 1896-ban elérte, hogy a kántorsegéd választása pályázati hirdetés útján, ne a kántor és supplens egyezkedése folytán történjen meg. Innentől kezdve a fóéneklész által megfelelőnek tartott két-három jelentkező közül a

\footnotetext{
${ }^{691}$ MNL CsML CsL V. B. 79. 1874. július 18. jk. 183. sz. határozat.

692 Tiszavidék, 1893. szeptember 3. IV. évf. 36. szám, 3. old.

${ }^{693}$ Hivatkozik rá: Labádi 2008. 101.

${ }^{694}$ MNL CsML CsL V. B. 79. 1880. február 22. jk. 166. sz. határozat.

${ }^{695}$ MNL CsML CsL V. B. 79. 1894. január 14. jk. 68. sz. határozat.

${ }^{696}$ Csongrádi Közlöny, 1895. február 24. II. évf. 8. szám, 3. old. Khírer 1912-ben már szentesi fökántorként jelentette meg A szentesi róm. kath. buzgó hívek ajkán élő egyházi népénekek gyüjteménye...(Untermüller Ernő gyorssajtója, Szentes) címü munkáját. Ld. Barna 2009. 454.

${ }^{697}$ Csongrádi Lap, 1898. január 16. VIII. évf. 3. szám, 3. old.

698 „Apám meghagyta, hogy a csongrádi kántor segédet, ama rendetlen életü, czégéres kórhelyt, kit gonoszságáért már más honnan kicsaptak a kántorságból, be ne eresszem az ő temetésénél énekelni." VPL APar. Cs. 1868. január 14. Szepesi József vallomása.
} 
plébános joga lett kiválasztani a legalkalmasabbat. A plébános immáron elbocsátásukba is beleszólhatott. ${ }^{699}$

Vizsgált időszakunkban az orgona müködtetéséhez a kántornak szüksége volt fújtatóra, szegedi népi nevén kalkantistára ${ }^{700}$, csongrádiasan fullajtárra. Sohlya Antal csongrádi főkántor jegyzeteiben szerepel az orgonafúvónyomász kifejezés ${ }^{701}$, ám hivatalos iratokban az orgonanyomót használták ${ }^{702}$. 1880-ban a frissen megválasztott Mezey Márton kunszentmártoni kántor szerződésében az orgonafúvó nyomó megnevezést találjuk. ${ }^{703}$

Mivel a fújtató munkája nem igényelt különösebb szakértelmet, csak némi odafigyelést, így jellemzően a harangozó és sekrestyés vagy egyéb, laikus alkalmi segítők asszisztáltak a kántor munkájához. Sohlya Antal jegyzeteiben a fullajtár kitanításának szükségességéről is értekezik, mondván: „nehogy rendetlen nyomás által mind a fuvók s orgona romoljanak, mind az istentisztelet zavartassék”. ${ }^{704}$ 1878-ban a csongrád-belsővárosi Szent Rókus-templom harangozója, Bernáth Ferenc évi 8 forint kiegészítő juttatást kapott „orgona nyomási illeték” jogcímen. ${ }^{705}$ A külsővárosi templomban ugyanezért a munkáért, ugyanebben az időszakban 31 forint járt. ${ }^{706}$ A kaposvári orgonanyomó fizetése ugyanekkor 18 forint 12 krajcár volt. ${ }^{707}$ Kunszentmártonban a plébános is beleszólt, hogy kit alkalmazhat a kántor fújtatóként. Javadalmazását igen méltányosan, évi 50 osztrák értékü forintban állapították meg, melyet a község biztosított számára. ${ }^{708}$

\section{Sohlya Antal, a „kántorok királya”}

Kmeth Lajos halálával a csongrádi kántori állás ismét betöltésre várt, ám a meghirdetésre csak egy esztendővel később került sor. Az üresedés iránt óriási volt az érdeklődés, végül a 40 pályázó közül Sohlya Antal nagyváradi főkántor került ki győztesen. 1860 őszétől a századfordulóig Csongrádon „Sohlya bácsi” neve egyet jelentett a kántor fogalmával. Korának emblematikus figurája volt ő, vitathatatlan írói és éneklészi tehetséggel, politikai ambíciókkal és kissé ellentmondásos emberi természettel megáldva. A következőkben a

\footnotetext{
${ }^{699}$ VPL APar. Cs. 1896. november 17. Jegyzőkönyvi kivonat képviselőtestületi ülésről, Csongrád.

${ }^{700}$ Bálint 1983. 97.

${ }^{701}$ Sohlya 1857. (kézirat) 348.

702 Kaposváron a népnyelv is orgonanyomóként emlegette. Hoss 1948. 64.

${ }^{703}$ Barna 2009. 449.

704 Sohlya 1857. (kézirat)

705 MNL CsML CsL V.B.72. Csongrád Város, 1880-1923-ig Nagyközség Tanácsának iratai, Tanácsülési jegyzőkönyvek. (Továbbiakban: MNL CsML CsL V.B.72.) 1877. Templomi számadási okmányok.

${ }^{706}$ VPL APar. Cs. 1878. június 8. Szvoboda József levele a váci püspökhöz.

${ }^{707}$ Hoss 1948. 64.

708 Barna 2009. 449.
} 
kántor és a hívek, a kántor és a többi egyházszolga valamint a kántor és hivatali felettesei viszonyát elemezzük, Sohlya Antal példáján.

2.1. Sohlya Antal életútja és a kántori hivatal sorsa Csongrádon a 19. század végén

1821. július 20-án Sohlya Antal kiskunmajsai juhásznak és Kozák-Nagy Erzsébetnek fiúgyermeke született, aki édesapja nevét kapta a keresztségben. A szerény anyagi lehetőségek ellenére a tehetséges fiú a kőmüves szakma mellett két gimnáziumi osztályt is kijárt. Az ifjú Sohlya Antal gyermekkorától kezdve erős elhivatottságot érzett a kántori hivatás iránt, így tizenévesen már supplens volt szülövárosában. Innen Szegedre, Csanytelekre, Szegvárra, Hódmezővásárhelyre, Makóra majd Algyőre került gyakornoknak. 1842-ben Békéscsabán tett tanképesítő vizsgát, mely ekkoriban a tanítóképző intézeti tanúsítvánnyal volt egyenértékü. A békéscsabai leányiskolában nyomban alkalmazást is nyert, de mindössze egy év után Gyulára majd Sarkadra került kántortanítónak. ${ }^{709}$ 1845-ben az éppen megüresedő nagyvárad-velencei állást pályázta meg, melyet el is nyert. Egy esztendővel később feleségül vette Vargyasi Dániel Anna kézimunka tanítónőt, akivel 43 esztendőn át éltek együtt békében.

A szabadságharc híre Nagyváradon érte a fiatal párt. Sohlya tétovázás nélkül beállt nemzetörnek. A harcokról egész életében büszkén és szívesen mesélt. ${ }^{710}$ A szabadságharc után Sohlya birodalmi alkotmány és bíráskodásról szóló előadásokat hallgatott a nagyváradi jogi akadémián. Utolsó nagyváradi éveiben, 1855 és 1860 között az egyházi ének- és szent szertartástan tanárként alkalmazták a királyi tanítóképző intézetben. Innen pályázta meg a csongrádi főkántori állást.

Sohlya a kezdetektől fogva otthonosan érezte magát a kis alföldi mezővárosban: hivatala elnyerése után három esztendővel máris szőlőterületet vásárolt az ún. Öregszőlőkben. ${ }^{711}$ Csongrádon töltött évtizedei alatt számos világi tisztséget elvállalt. Alig akadt olyan egyesület, melynek ne lett volna tagja. Ezek a pozíciók elsősorban politikai, oktatásügyi és közéleti jellegüek voltak, de Sohlya alakjától nem elválasztható a

\footnotetext{
${ }^{709}$ Dudás 2001. 70.

${ }^{710}$ Kántorizálásának 50. jubileumán a csongrádi sajtó eképpen elevenített fel egy esetet: „Róth és Filippovich táborából elfogott tisztek mintegy 40 szekéren Szegedről Szatmár felé voltak szállítandók, útközben azonban a horvátok vérengzésén felbőszült nemzetőrség ezen fegyvertelen foglyokat fel akarta konczolni, mire a nemzetőrök közül már akkor jól ismert Sohlya Antal lépett fel, mint védő angyal s meg menté a szegény foglyok életét. Mi okmánnyal van igazolva”. Tiszavidék, 1893. július 30. IV. évf. 31. szám, 2. old.

${ }^{711}$ Mód 2012. (kézirat) Az „Öregszőlők” határrész a várostól ÉNY-ra terül el. Tari László feltételezte, hogy ezen a határrészen már a török időkben is szőlőt müveltek. Váry 1974. 226.
} 
művészeti, írói és irodalmi élet, valamint a szőlészeti-borászati tevékenység sem. ${ }^{712} \mathrm{Az}$ idős kántor tisztségeinek száma egy fővárosi lap beszámolója szerint 1890 tájékán félszázra rúgott. ${ }^{713}$ A kiöregedő éneklész 1893-ban, Csongrádon ünnepelte kántorizálásának 50. évfordulóját. ${ }^{714}$

Hegyi Antal már az 1880-as évek végén próbálta rábeszélni az idős kántort, hogy vonuljon nyugdíjba. A javaslatot a két alkalmatlannak ítélt kántorsegéd ${ }^{715}$ és a főkántor hajlott kora okán szorgalmazta a plébános. ${ }^{716}$ Sohlya ugyan ígéretet tett az önkéntes nyugdíjba vonulásra, ám erre végül nem került sor. Hegyi Antal 1894 júliusában a váci Egyházmegyei Hatósághoz fordult, így próbált nyomást gyakorolni a kántorválasztás jogát birtokló helyi képviselőtestületre. Elképzelése szerint a hivatali utód terhére nyugdíjazták volna Sohlyát. A váci püspök támogatta Hegyi plébános javaslatát, ugyanakkor arra hívta fel a figyelmet, hogy az utód jövőbeli szerződésének feltételeit is érdemes volna újragondolni. ${ }^{717}$

A plébános próbálkozásait látva Sohlya Antal aláírásokat kezdett gyüjteni a belsővárosi hívek között, hogy igazolja: kántorsegédei tökéletesen ellátják szolgálatukat, és a híveknek sincs oka panaszra. ${ }^{718}$ Hegyi válaszul a Csongrádi Közlöny hasábjain olvasta kántora fejére hiányosságait. ${ }^{719}$

A csongrádi képviselőtestület már augusztus elején napirendre tűzte azt a nevezetes püspöki leiratot, mely Hegyi Antal álláspontját védte. A függetlenségi érzelmű gőzmalomés hajótulajdonos, Eszes Mátyás egy vizsgálóbizottság felállítását kérte, míg Éder János, a

\footnotetext{
${ }^{712}$ A Sohlya család szőlészeti-borászati tevékenységéről, nemesítési próbálkozásaikról lásd Mód László tanulmányait. Mód 2012; 2012 (kézirat).

713 Tiszavidék, 1893. július 30. IV. évf. 31. szám, 2. old.

${ }^{714}$ A jeles alkalomból a helyi lapok részletes életrajzzal üdvözölték. A városi ünnepély július 29. és 30.-án, két napon keresztül tartott: szombaton este az iparos dalegylet adott koncertet, a vasárnapi misét pedig az ünnepelt régi barátja, az egykori 48-as honvéd, Lehoczky József orosházi plébános celebrálta. Délben Sohlyáék házánál tartottak díszebédet, ahol a meghívott jeles közéleti személyiségek pohárköszöntőkkel méltatták a jubilánst. Tiszavidék, 1893. augusztus 13. IV. évf. 33. szám, 3. old.

715 „Két segédet ugyan tartana, de az egyik tulajdon veje: Hornyik Károly, ki asztalos mesterséget tanulván, csak nagyon keveset ért a kántorsághoz. Másik segéde meg egy fiatal gyerkőc volna, ki a mult évben végezte a képezdét s így természetes, hogy ennek sincs semmi jártassága a kántori teendőkben.” VPL APar. Cs. 1894. július 29. Hegyi Antal levele a váci Egyházmegyei Hatósághoz.

716 „Sohlya Antal helybeli kántor úr el van öregedve teljesen, fülére nem hall, látni is csak egyik szemével lát nagyon kicsit s így maga szolgálatképtelen, mert a mi funkciót végez, abban sincs köszönet.” VPL APar. Cs. 1894. július 29. Hegyi Antal levele a váci Egyházmegyei Hatósághoz.

${ }^{717}$ VPL APar. Cs. 1894. július 31. A váci püspök levele Hegyi Antalhoz.

${ }^{718}$ Csongrádi Közlöny, 1894. augusztus 12. I. évf. 22. szám, 3. old.

719 „Sohlya úr 72 évében van s látása s hallása annyira megfogyatkozott, hogy annak rendje és módja szerint nem képes elvégezni az isteni szolgálatot. Nem is igen szolgál ugyan, csak épen mikor a szükség kényszeríti, akkor is számtalanszor megtörtént, hogy vagy bele orgonál a pap énekébe, vagy nem felelt, a hol kellett volna. Mert a karzatról nem képes az oltárnál a pap ténykedését kivenni. Ezen állapoton pedig nem lehet aláirásokkal vitatkozni, azért sincs itt más teendő, mint a nép érdekében tett felsőbb intézkedésen megnyugodni." Csongrádi Közlöny, 1894. augusztus 12. I. évf. 22. szám, 3. old.
} 
Csongrádi Lap főszerkesztője csupán a két alkalmas segéd tartására kívánta emlékeztetni Sohlyát. A szavazáson végül Eszes indítványa nyert többségi támogatást. ${ }^{720}$

Mire a kivizsgáló bizottság összeállhatott volna, Sohlya Antalt agyvérzés érte, így ágyban fekvő beteg lett. ${ }^{721}$ A helyettesítéssel Sohlya vejét, Hornyik Károlyt bízták meg azzal az ígérettel, hogy haláláig gondját viseli a lebénult főéneklésznek. A főkántori állás nyilvános meghirdetését „tapintatosságból” csak Sohlya Antal halála esetén helyezték kilátásba.

A közgyülés döntésével Hornyik vállára nehezedett a csongrádi föéneklészi teendők minden súlya. Az asztalos végzettségü kántorhelyettes müködését gyenge orgonatudása és állítólagos nemtörődömsége miatt Hegyi plébános állandó rosszallással figyelte. Két esztendő elteltével a helyzet alig változott. Az öreg fökántornak közben Ilona lánya és Farkas Béla veje viselte gondját. Hegyi Antal megelégelte a helyzetet, és a következő levéllel kereste fel a váci Egyházmegyei Hatóságot: „,az öreg kántor 78 éves, és még ki tudja, hogy meddig viszi ezt az állapotát [...] és végtére sem lehet megkívánni, hogy egy 22 ezer lelket számláló plébániában családi érdekek miatt egy ilyen fontos állás évekig árvaságban sínlődjék". ${ }^{722}$ A körülményekre való tekintettel komolyan sürgetni kezdte Sohlya Antal nyugdíjazási ügyének rendezését és a főkántori állás meghirdetését: „mert most igazán olyan segédkántorunk van, ki nem képes a nép igényeinek megfelelni”. ${ }^{723}$ A püspök Ullár István kerületi esperest kérte fel, hogy tanácskozzon a csongrádi plébánossal. ${ }^{724}$ Néhány nappal később Sohlya Antal a plébános, Ilona leánya és veje jelenlétében kérelmezte nyugdíjazását, hisz a kántori lakba már nem kívánt visszatérni, a helyettes kántortól a megígért juttatásokat pedig évek óta nem kapta meg. ${ }^{725}$

Ám hiába volt Hegyi plébános erőfeszítése, az esperesi értekezlet eredményeként a korábbi kondíciókat erősítették meg. Nevezetesen: Sohlya Antal haláláig az állás csak helyettesítéssel tölthető be. A helyettes éneklész köteles 180 forint évi fizetés, mosás, teljes ellátásért, vagy évi 400 forint díjazásért, ám ellátás nélkül egy képesített segédet tartani. Ha Sohlya Antal nem kíván a kántori lakban élni, úgy a helyettes éneklész évi 500 forint ellátási díjat köteles biztosítani számára. A korábbi visszásságok elkerülése érdekében a helyettes kántor csak a plébánossal történő egyeztetést követően hagyhatja el

\footnotetext{
${ }^{720}$ Csongrádi Közlöny, 1894. szeptember 16. I. évf. 27. szám, 1. old.

${ }^{721}$ Csongrádi Közlöny, 1894. december 23. I. évf. 41. szám, 3. old.

${ }^{722}$ VPL APar. Cs. 1896. augusztus 12. Hegyi Antal levele a váci Egyházmegyei Hatósághoz.

${ }^{723}$ VPL APar. Cs. 1896. augusztus 12. Hegyi Antal levele a váci Egyházmegyei Hatósághoz.

${ }^{724}$ VPL APar. Cs. 1896. augusztus 17. A váci püspök levele Ullár István kerületi espereshez.

${ }^{725}$ VPL APar. Cs. 1896. augusztus 22. Hegyi Antal levele a váci Egyházmegyei Hatósághoz.
} 
Csongrádot. ${ }^{726}$ A novemberi képviselőtestületi ülésen ismét Hornyik Károlyt erősítették meg a tisztségben. Hegyi plébános leveleiben közben egyértelmü utalásokat tett arra, hogy a döntés hátterében Hornyik Károly sógorát, a befolyásos Sóhlya Gyula föjegyzőt feltételezi.

Fél év elteltével a kántori hivatal ügye még nem jutott nyugvópontra. Hegyi Antal plébános immáron kétségbeesetten panaszolta a váci Egyházmegyei Hatóságnak, hogy a helyettes kántor Kecskemétre költözött és csak „,vendégszerepelni jár haza”, miközben a kántori teendőket két tapasztalatlan suhancra, az idős kántort egy beteges asszony gondozására bízta. Mivel Hegyi Antal tartott attól, hogy a közvélemény ellene fordul, az Egyházmegyei Hatóságra bízta a csongrádi kántori állás ügyét. „Én ugyan nagyon sajnálom a beteg öreget, ki még mindig hiúságát találja abban, hogy ő a csongrádi főkántor, de hát így a legnagyobb elhagyatottságban sínlődik [...] hanem hát a kántorság végre nem a Sohlya család benefíciuma, s miután így az egyház és hívek igényeinek kielégítéséről gondoskodni nem lehet, más utat és módot kell kitalálni ezen igények kielégítésére nézve."727 Mikor a püspök kihallgatást rendelt el az ügyben, Hegyi váratlanul visszavonta panaszait. Az esperes ugyanis szigorúan megintette a helyettes kántort, így úgy vélte, hogy reális esély mutatkozik a közeli javulásra. ${ }^{728}$

A híres csongrádi fóéneklész állapota 1894 decemberétől egészen haláláig válságos maradt. A csongrádi sajtó időnként beszámolt arról, hogy az idős Sohlyának újból és újból feladták a betegek kenetét. ${ }^{729}$ A fóéneklész tolókocsiban ülve hallgatta meg a kántorizálásának 60. évfordulójára írt köszöntő beszédeket. A „kántorok királya” 1902. február 5-én hunyta le végleg a szemét.

\subsection{A kántor mint politikus és közéleti személyiség}

1860 után, de különösen az 1880-as évek elején olyan lehetőségek nyíltak meg a közélet és a politika terén, melyek a laikus templomszolgák hivatali elődei számára elképzelhetetlenek voltak. Ebben az időben Csongrádon is sorra alakultak a hosszabbrövidebb életü egyházi és világi egyesületek, szervezetek, polgári- és olvasókörök,

\footnotetext{
726 VPL APar. Cs. 1896. november 27. Ullár István esperes jelentése a váci püspökhöz. Csongrádi Közlöny, 1896. szeptember 6. III. évf. 36. szám. 3-4. old.

${ }^{727}$ VPL APar. Cs. 1897. július 8. Hegyi Antal levele a váci püspökhöz.

${ }^{728}$ VPL APar. Cs. 1897. szeptember 6. Ullár István jelentése a váci püspökhöz.

${ }^{729}$ Csongrádi Közlöny, 1895. október 13. II. évf. 41. szám, 3. old; Tiszavidék, 1902. február 9. XIII. évf. 6. szám, 3. old.
} 
kaszinók. Ezek a szervezetek jellemzően arra törekedtek, hogy a helyi közélet reprezentatív egyéniségeit a tagjaik közé vonják be. Valóságos harc indult az értelmiségiek, képviselők, módosabb nagygazdák és az egyházi tisztségviselők megnyeréséért.

A kántorok - és általában az egyházi személyek - aktív politikai szereplése a 19. század végén korjelenségnek tekinthető. Miután 1875-ben Horvát Döme kecskeméti képviselő az országgyülésen valóságos támadást indított a kántortanítókkal szemben, a Csongrádiak „válaszul” Csatár Zsigmond kántortanítót választották meg képviselőjükké. ${ }^{730}$ Csatárt Hegyi plébános és Sohlya Antal is támogatta. ${ }^{731}$

Mivel Sohlya Antal egész életében hü marad a 48-as eszmeiséghez, a liberális beállítottságú egyesületeket tudatosan kerülte. Összességében kevés olyan kezdeményezés volt Csongrádon, melyhez előbb-utóbb ne csatlakozott volna. Müveltsége, literáltsága okán rendszerint adminisztratív feladatokat ruháztak rá. Ahogy 1867-ben kiállított erkölcsi bizonyítványában olvashatjuk: „a közönség érdekeiben alakított csaknem valamennyi bizottmányok jegyzőjéül alkalmaztatik". ${ }^{732}$ Feltünő aktivitását a Csongrádi Lap személyeskedő hangnemben, állandó kritikával szemlélte, és sajátos módon ki is értékelte. ${ }^{733}$

Évszám megjelölése nélkül, csupán a legfontosabb közéleti és politikai tisztségeit áttekintve: Sohlya Antal tiszteletbeli városi tanácsnok, iskolaszéki főgondnok, Csongrád vármegye törvényhatósági bizottságának tagja, a Polgári Kör, Csongrád és Vidéke Takarékpénztár illetve a Keresztény Gőzmalom választmányi bizottságának illetve a közbirtokossági bizottságnak is tagja volt. Részt vett a Csongrádi Kaszinó alapításában ${ }^{734}$, ám a legtöbb energiát az általa életre hívott csongrádi 48 -as Népkörre fordította. ${ }^{735}$ Mindezek mellett olyan időszaki bizottságokba is beválasztották, mint az árvízi vészbizottság 1882-ben, vagy a vasúti bizottság. ${ }^{736}$ Tíz éven keresztül töltötte be az északi vízvédelmi föfelügyelői posztot.

Bár Sohlya Antal nem született csongrádinak, tettvágyának és egyházi hivatalának

\footnotetext{
730 Tiszavidék, 1893. szeptember 17. IV. évf. 38. szám, 3. old.

731 Csatár és Sohlya az 1850-as évek elején, Nagyváradon került ismerettségbe. Innen Csatár - Sohlya segítségével - Monospetriben nyert kántortanítói állást. Csongrádon Sohlya Antal kinevezésének évében, 1860-ban helyezkedett el mint tanító. Tiszavidék, 1893. szeptember 17. IV. évf. 38. szám, 3. old. Bensőséges viszonyukról Váry Gellért is megemlékezett. V.ö. Váry 1974. 154.

${ }^{732}$ VPL APar. Cs. 1867. november 22. Sohlya Antal erkölcsi bizonyítványa.

733 „Sohlya tata véghetetlen dicsvágyó s a legszélsőbb komikumig hivalkodó emberke.” Csongrádi Lap, 1892. január 17. II. évf. 3. szám, 3. old.

${ }^{734}$ Tiszavidék, 1893. július 30. IV. évf. 31. szám, 2. old.

${ }^{735}$ A Csongrádi 48-as Kör alapítólevelét a belügyminiszter 1877. január 18-án hagyta jóvá. MNL CsML CsL Iratmásolatok 128.

${ }^{736}$ Labádi 2000. 120.
} 
köszönhetően hamar a helyi közélet kiemelkedő alakjává vált. Ennek egyik bizonyítéka egy dualizmus korabeli emlékalbum, mely a csongrádi Tari László Múzeum gyüjteményében található. ${ }^{737}$ A nevezett albumot annak helytörténeti jelentősége miatt már több szempontból elemeztem. ${ }^{738}$ A 14 bejegyző között ott találjuk a helyi káplánokat: Varga Mihályt és Csapó Jánost, továbbá Sohlya Antal gyermekkori barátját, Lehoczky József orosházi plébánost, illetve a latin és hittan tanárként müködő fiatal papot, Márk Balázst. Az albumban többek között gimnáziumi tanár, csendőr föhadnagy és egy építész is otthagyta kézjegyét. Az ismeretlen tulajdonos tehát úgy vélte, hogy Sohlya Antal bejegyzése jól megérdemelt helyet foglal el a helyi egyházi és polgári értelmiségiek között. ${ }^{739}$

Ha nyomon követjük Sohlya Antal gyermekeinek életét, azt láthatjuk, hogy vagy házassági kapcsolataik vagy elért tisztségeik révén jelentős befolyással rendelkeztek a helyi közéletben. Fia, Sóhlya Gyula ${ }^{740}$ egészen a csongrádi föjegyzői székig vitte. Első felesége a környék egyik leggazdagabb földbirtokosának leánya, a fiatalon elhunyt Cs. Forgó Zsófia volt. ${ }^{741}$ A csongrádi főjegyző egész karrierjét végigkísérte édesapja öröksége. Megnyilatkozásainak meg kellett felelnie a „jó kántorfiútól” elvártaknak. Félreérthető lépéseit a sajtó különös részletességel elemezte. A figyelem különösen az 1890-es évek közepén koncentrálódott személyére, amikor Hegyi Antal plébánossal a viszonya megromlott. ${ }^{742}$ A bonyodalmakat csak tetőzte Sóhlya Gyula nyíltan hangoztatott vallásossága, és az a tény, hogy Hegyi Antal az ő Mária nevü gyermekének keresztapja volt. ${ }^{743}$ Sóhlya Gyula messzemenőkig tisztelte az édesapját: tulajdon fiát Antalnak nevezte

\footnotetext{
737 A Belicza József szerkesztette „Barátság tükre” emlékkönyv egy kitöltött példánya a csongrádi Csemegi Károly Könyvtár és Tari László Múzeum gyüjteményében. CsKK TLM Könyvtár 2451.

${ }^{738}$ V.ö. Gyöngyössy 2009; 2010/e.

${ }^{739}$ Gyöngyössy 2010/e.

740 Forrásaink arról tanúskodnak, hogy Sohlya Antal fia a nevét már kizárólag Sóhlya-ként írta le. Értekezésemben a neveket a forrásokban szereplő forma szerint használom.

${ }^{741}$ Forgó Zsófia halálhíréről a Tiszavidék 1893. szeptember 24-i számában olvashatunk.

${ }^{742}$ A Hegyi plébános által szerkesztett Csongrádi Közlönyben rendszeresen jelentek meg Sóhlya Gyuláról provokatív, személyeskedő közleményeket. Egy csanyteleki olvasó 1894-ben keletkezett levelében azzal vádolta a föjegyzőt, hogy a Wekerle kormány rendelkezéseit támogatja, vagyis a polgári házasságkötés ügye mellett áll. Idézem: „Azt tudjuk, hogy Sóhlya ur kántor fiu, s mint ilyen tán az egyház fillérein nevelkedett. [...] S most már értheti a tisztelt szerkesztőség, miért oly erős a halottaiból föltámadt Wekerle kormány? Mert íme, a független katholikusok, a jó kántorfiak tüntetnek mellette.” Csongrádi Közlöny, 1894. július 17. I. évf. 14. szám, 1-2. old. Ne feledkezzünk meg arról sem, hogy a korban a kántorok fiúgyermekei gyakran követték édesapjuk pályáját. Az életpálya modellnek megfelelő „örökség-reflex” egyfajta elvárásként jelent meg, mely különböző csatornákon kifejezésre is jutott.

${ }^{743}$ Mikor Hegyi Antal jelentése nyomán a váci püspök kérdőre vonta Sóhlya Gyulát „vallást sértő politikai ténykedéseivel” kapcsolatban, a csongrádi főjegyző a következő nyilatkozatot tette: „Én, Nagyméltóságú Uram, katholikus szülők gyermeke, magam s kis gyermekeimmel együtt az itt alapított Jézus Szentséges Szíve társulat tagja vagyok, mint katholikus ember kötelességemet pontosan teljesítettem, s alig pár éve csak, hogy Hegyi Antal úrral [...] éppen a többször hangoztatott visszaélések, kíméletlen támadások miatt
} 
el. ${ }^{744}$ Apja halála után a csongrádi Nagyboldogasszony-templom orgona-feljárójánál színes üvegablakot készíttetett az egykori csongrádi föéneklész emlékére.

Sohlya Ilona, a főkántor idősebbik leánya Farkas Béla elemi és polgári iskolai igazgató felesége lett, aki az 1870-es évek elején még segédkántorként müködött jövendőbeli apósa mellett. ${ }^{745}$ Sohlya Antal ennek a leányának a gondozásában élte utolsó éveit. A Sohlya család kapcsolathálója a környékbeli értelmiségiekkel kötött házasságoknak köszönhetően terebélyesedett ki. A főkántor másik leánya, Sohlya Jolán Hornyik Károly asztalossal, későbbi csongrádi helyettes kántorral lépett frigyre. ${ }^{746}$ Hornyik Károly a híres kecskeméti főjegyző és várostörténet-író Hornyik János unokaöccse volt. ${ }^{747}$ Farkas Máriát, Sohlya Antal unokáját a nagykőrösi származású Khirer József kántortanító vette nöül 1895-ben. ${ }^{748}$

Sohlya Antal gyermekeinek és unokáinak életére kimutatható hatással volt az idős főkántor befolyása és több évtizedes egyházi múltja. Egyik unokájából kántortanító lett, másik egy kántorhoz ment feleségül, míg a harmadik papi pályára lépett. Gyermekei kedvező házasságához - a kántori pálya önmagában vett presztízse mellett - minden bizonnyal hozzájárult az is, hogy a fóéneklész kilépett szokásos egyházi feladatainak körén, és nyitni kezdett a közügyek felé.

\subsection{Az iskolai énekoktatás útjai. Sohlya az iskolaszéki tanácsban}

Sohlya Antal fökántor kötelességei közé tartozott a csongrádi elemi iskolás gyermekek külön díjazás nélküli énekoktatása. ${ }^{749}$ Forrásaink szerint ez a funkció a gyakorlatban igen hézagosan valósult meg. 1867 novemberében Alvinczy Ferenc plébános jelezte a váci püspöknek, hogy a kántor több iskolában nem vizsgáztatta le énekből a gyermekeket, akik tapasztalata szerint a ,'Jaj de fáj'-on kívül nagyon keveset tudnak producalni”. ${ }^{750}$ A

meghasonlásban vagyok.” NPI 1894. március 12. Sóhlya Gyula főjegyző levele a váci püspök felé.

${ }^{744}$ Az ifjabb Sóhlya Antal a Debreceni Magyar Királyi Gazdasági Tanintézet növendéke lett a századforduló tájékán. 1900. és 1901. évből származó tanjegyzetei a csongrádi CsKK Tari László Múzeumban megtalálhatóak. Ifj. Sóhlya 1900-1901. (kézirat).

${ }^{745}$ MNL CsML CsL V.B 79.1871. július 6. jk. 242. sz. határozat.

${ }^{746}$ Tiszavidék, 1893. július 30. IV. évf. 31. szám, 2. old.

747 Tiszavidék, 1894. november 11. V. évf. 45. szám, 3. old.

${ }^{748}$ Csongrádi Lap, 1895. július 28. V. évf. 31. szám, 2. old.

${ }^{749}$ A korban a gyermekek énekoktatása a kántorok általános kötelezettségei közé tartozott. Mezey János kunszentmártoni kántor 1850-ben keltezett szerződésében ez olvasható: kötelessége „,az oskolás gyerekeket és az ifiuságot hetenként bizonyos időben, és általa választandó alkalmas helyen az éneklében tanítgatni." Barna 2009. 448.

${ }^{750}$ VPL APar. Cs. 1867. november 12. Alvinczy Ferenc levele a váci püspökhöz. 
csongrádi plébános azt is hiányolta, hogy kántora az ifjúsági miséken nem énekeltette a gyerekeket. Alvinczy panaszait megszívlelve Oláh Lázár tanító, egykori segédkántor vette kézbe a gyermekek ügyét. Amikor Oláh Lázár már az orgona elé is odaült, miközben a gyerekek énekét kísérte, a főkántor letiltotta a fiatal tanerőt a kórusról. ${ }^{751}$ A konfliktus azért tart számot érdeklődésünkre, mert Sohlya Antal válaszlevelében felsorolta azokat a zenemüveket, melyeket a gyermekeknek megtanított. ${ }^{752}$

Sohlya Antal nem csak az elemi iskolákban oktatott, de önszorgalomból kisebb dalárdát is szervezett a helyi mesterlegényekből. A dalárda müködéséröl nem maradt fenn iratanyag. Annyi bizonyos, hogy valamikor az 1860-as évek elején kisebb szerenádot adtak Alvinczy Ferenc plébánosnak, aki cserében 4 forintot adományozott a templompénztárból a dalárda javára. ${ }^{753}$ A dalárda még hosszú évekig fennállt, majd 1897-ben, immáron Hornyik Károly vezetésével alakult újjá. ${ }^{754}$

1871-ben Csongrádon kezdte meg müködését az Alföld első királyi tanítóképző intézete, melyben Sohlya az intézmény 1876-os fennállásáig az igazgatói tanács tagjai közt foglalt helyet. Az intézmény első évében énektanítással is foglalkozott. ${ }^{755}$

Kántori hivatalából kifolyólag Sohlya 1867-ig tanbizottmányi tag, majd az Eötvösféle 1868. évi XXXVIII. népoktatási törvény nyomán létrejött iskolaszék tisztségviselöje lett. ${ }^{756}$ Hivatalba kerülése után alig egy évvel máris folyamodványt nyújtott be az elöljárósághoz egy kisdedóvó intézet fölállítása érdekében. ${ }^{757}$ Ez a fajta újító, kezdeményező lelkület egészen az 1880-as évekig jellemezte Sohlyát: iskolaszéki fögondnokként és iskolalátogatóként lelkiismeretesen készítette a szükséges jelentéseket és leltárakat, vezette a számadáskönyvet, intézkedett a leromlott eszközök és az iskolai berendezés cseréjéről, javításáról, pótlásáról. 1872-ben arról értesülünk, hogy 16 szülővel

\footnotetext{
${ }^{751}$ VPL APar. Cs. 1867. november 12. Alvinczy Ferenc levele a váci püspökhöz. Az Oláh és Sohlya közti feszült viszony életük további részében is végigkísérte őket. Mikor 1883-ban Sohlya Antal elmarasztaló jelentést írt a belvárosi iskola állapotáról - ahol történetesen Oláh Lázár tanított - Oláh a jelentést igaztalannak állította be, és Sohlya iskolalátogatói megbízásának visszavonását követelte. Kérelmét az iskolaszék elutasította. MNL CsML CsL V.B. 79. 1883. december 29. jk. 251. sz. határozat.

752 „A tanonczok az Egri Énekkátét [a vizsgán] majdnem egészen tudták, s ezen kívül több istenes templomi éneket [...]. Karácsonykor is az iskolás gyerekek a templom karában 'Krisztus Jézus született' éneket Tárkányitól kettősben - duett - énekelték!". VPL APar. Cs. 1867. Sohlya Antal dátum nélküli levele a váci püspökhöz.

${ }^{753}$ VPL APar. Cs. 1867. Sohlya Antal dátum nélküli levele a váci püspökhöz.

754 Tiszavidék, 1897. március 28. VIII. évf. 13. szám, 3. old.

755 Dudás 2001. 72.

${ }^{756}$ MNL CsML CsL V.B. 42. 1863. november 21. jk. 938. határozat.

${ }^{757}$ MNL CsML CsL V.B. 49. Csongrád Város Községi Választmányának iratai (továbbiakban: MNL CsML CsL V.B. 49.) 1861. április 15. jk. 447. határozat. A Tanács támogatta az elképzelést, és a Városháza jobb oldalán lévő hátsó kamrát szabadították fel a célra.
} 
társulva magán nőneveldét állított fel. ${ }^{758}$ Év végén egy középtanoda létesítésére tett javaslatot, mellyel megalapozta a későbbi polgári fiúiskola ötletét, ahol az első tanévtől kezdve énektanári tisztséget töltött be. ${ }^{759}$ Sohlya az 1870-es évek végén, 1880-as évek elején többször is megkísérelt lemondani előbb a gondnoksági, utóbb a jegyzői tisztségről, ám az iskolaszék csak ez utóbbi visszalépését fogadta el. ${ }^{760}$ Indokként erősen megromlott egészségügyi állapotát hozta fel. Innentől kezdve aktivitása jelentősen visszaesett. Csupán a rá bízott köteles teendőket látta el, újító szándékú javaslatokat már nem tett.

\subsection{Költő, író, ének- és orgonamester. A müvészkedő kántor alakja}

Egy kántornak - hivatásából adódóan - rendelkeznie kellett bizonyos zenei érzékkel, megfelelő énekhanggal, orgonajáték tudással. Emellett a halotti búcsúztatók írásának mindennapi, gyakran igen terhes és monoton gyakorlatával verselői vénájukat is éberen kellett tartaniuk. ${ }^{761}$ Figyelemre méltó azoknak az éneklészeknek a száma, akik nem elégedtek meg kötelességeik egyszerü teljesítésével, hanem müvészi hajlamuknak engedve költészeti és zeneszerzői babérokra törtek.

A verselő-művészkedő kántorok munkássága elvétve kalandozott egyházi tematikán kívülre. A 19. század folyamán a saját szerzésű halotti búcsúztatókat és kántori segédkönyveket közre adó kántorok bizonyultak a legtermékenyebbnek. ${ }^{762}$ Ezek a müvek amellett, hogy gyakorlati segítséget nyújtottak az időhiánnyal küzdő kántortársaknak akarva-akaratlanul is alakították a halotti szertartások helyi gyakorlatát. Csongrád környékéröl Balogh János szentesi református kántor (1871) és Mezey Mór szentesi katolikus éneklész (1864), a szegedi Erdélyi Sándor (1887) a kunszentmártoni öreg Mezey János (1853), Mezey Nepomuk János (1883), valamint a kiskunfélegyházi Csima István, (1895) Ulrich Antal és testvére, Ulrich Béla (1897) összeállítását érdemes megemlítenünk.

\footnotetext{
$758 \mathrm{Az}$ intézmény két év müködés után a polgári iskolába olvadt be. MNL CsML CsL Gondnoksági iratok, 1872. június 28. jk. 333. sz. határozat; Dudás 2004. 13.

${ }^{759}$ MNL CsML CsL V.B. 42. 1872. november 12. jk. 48. sz. határozat. A csongrádi polgári fiúiskola 1873-ban nyitotta meg kapuit. Dudás 1985. 183.

${ }^{760}$ MNL CsML CsL V.B. 42. 1881. október 30. jk. 3. sz. határozat.

${ }^{761}$ Egy 20. század elején Csanytelek községben tevékenykedő kántor, Knapek Dezső munkássága kitünően példázza, hogy a csekély költői érzékkel (vagy egyszerűen csekély idővel) rendelkező éneklészek miként használták fel a kántori segédkönyvek versezeteit a halotti búcsúztatók írása során. Lásd: Gyöngyössy 2010/a.

762 A kántorkönyvek „kéziratos vagy nyomtatott gyüjtemények, melyek az egyházi év liturgikus szertartásaihoz és népi ájtatosságaihoz elöírt vagy szokásos énekeket tartalmazzák (hangjegyekkel, orgonakísérettel vagy anélkül), a szükséges magyarázatokkal a kántorok, énekvezetők számára." M. Kat. Lex. VI. 2001. 135.
} 
Ez utóbbi kiadványról a Csongrádi Közlöny is ajánlást tett. ${ }^{763}$ Az Ulrich testvérek munkája azért is kiemelkedö, mert saját búcsúztató verseiken kívül kántor édesapjuk, illetve kiskunfélegyházi, jánoshalmi, kocséri és mohorai kántorok szerzeményeiből is válogattak. A kunszentmártoni születésű Mezey István „Egyházi énektár” című munkája Zsasskovszky Ferenc elutasító bírálata miatt csak 1913-ban jelent meg. ${ }^{764}$

Sohlya Antal Csongrádra érkezésének évében került ki a nyomdából Garay Alajos pesti plébánossal és Engeszer Mátyás zenetanárral közösen szerkesztett halotti búcsúztatógyüjteménye, a Temetési gyászénekek a szokásos egyházi imák- és sz. szertartásokkal (1860). A munka több szempontból is aktuális volt, hisz egy 1859. július 8-án keltezett püspöki szentszéki végzés a „bucsuztatók közé vegyíteni szokott kérkedő, hiábavaló s néha-néha nem eléggé tisztult kitételek, ugy a módfeletti hosszadalmasság gátlására"765 elrendelte, hogy a kántorok négy-hat versszaknál hosszabb búcsúztatót nem énekelhetnek. A mü előszavában Garay plébános lesújtó hangon nyilatkozott a halotti búcsúztatók üres szellemtelenségéről. A szerzők ihletadó mintát kívántak a kántorok kezébe juttatni, hogy az egyház által is üdvösnek tartott szövegek terjedését segítsék elő. ${ }^{766}$

Sohlya Antal nagyváradi tanítóképezdei jegyzetében ${ }^{767}$ külön fejezet foglalkozik a halotti búcsúztató készítésének módszertanával. A csongrádi főéneklész ebben a kéziratban a költői érzék hiánya szülte, nevetséges poétikai erőfeszítések ellen emelte fel hangját. Az „elfajult”, költőietlen halotti búcsúztatók kigyomlálása érdekében Sohlya Antal a nyomtatott segédkönyvek forgatására serkentette a pályatársakat: „Kik azt hiszik, hogy egy búcsúztató sem tudományt, sem szakképességet nem kíván, hogy azt bárki is készíthet, azok igen csalatkoznak. Azért kik kellö tudománnyal, alapos szakismerettel, s kellö jártassággal nem bírnak ezen a nyilvános helyen eléneklendő mü készítésére, s ugy a nyelvészetnek még csak elemeit sem bírják, azok ne fogjanak hozzá, hogy ujat készítsenek, mert félő hogy ily versek kerülnek ki gyárukból: 'Oh te édes kedves Inci feleségem, / Megbocsát ha valék én már tehetetlen." ${ }^{768}$ Ugyanakkor nem mulaszthatom el megemlíteni a Csongrádi Lap tárcáit, melyek pontosan Sohlya Antal búcsúztatói gyakorlatát állították

\footnotetext{
${ }^{763}$ Csongrádi Közlöny, 1897. február 7. IV. évf. 6. szám, 4. old. Emellett országos hírüvé nőtte ki magát az egri Chilkó Sándor (1867), az esztergomi Gerley Mátyás (1890) és a szintén esztergomi Szokoly István (1896), az Ókanizsai Szerdahelyi János (1896) és a budai Vátzi János (1886) kiadványa.

${ }^{764}$ Barna 2009. 2.

${ }^{765}$ Garay-Sohlya-Engeszer 1860. VII.

766 „Némely tanítók [...] részént a templomban a néppel hangjok rendkivüli fölemelése által a dallam kellemét elnyomják, részént a templomon kívül a bucsuztatók alkalmával leginkább a mérséklet határait átlépik: atyai látogatásaimkor némely plébánián mind magam tapasztaltam, mind némelyek a kerületi papság közöl panaszt emelvén, orvoslásért esedeztek." Garay-Sohlya-Engeszer 1860. VI.

767 Sohlya 1857. (kézirat)

${ }^{768}$ Sohlya 1857. (kézirat) 355.
} 
pellengérre. $^{769}$

Az imént említett jegyzetet Nagyváradon zárta le Sohlya 1857. január 1-jén. ${ }^{770} \mathrm{Az}$ élő beszédként rögzített írás terjedelme 450 csíkos füzetbe írt oldal, 49 tanórára bontva. A tanórák témái igyekeztek a kántori állás összes területét lefedni, így szó esett többek közt az egyházi év ünnepeinek szokásairól, avatási rítusokról, az orgonálás technikájáról, a kántor helyes viselkedéséröl. A tanórák anyaga tele van gyakorlati tanácsokkal, személyes példákkal, melyeket Sohlya kántori müködése idején gyüjtött össze. Gyakran hivatkozott a Garay Alajossal és Engeszer Mátyással közösen összeállított kötetre, Fekete Ferenc segédkönyvére, Tárkányi Béla és Zsasskovszky Ferenc énektárára, Bartha Endre Müvészeti Vezér és Magyar Apolló című munkáira, Wimmer Ede pécsi karnagy énektanjára, továbbá a Zsasskovszky testvérek, Szentmihályi Mihály, Csíki (?), Szelepcsényi György, Mezey Nepomuk János, Pajer Antal és Kovács Márk műveire. ${ }^{771}$ A helyi szokásokat illetően Nagyváradról, Kiskunmajsáról, Csongrádról, Szegvárról, Gyuláról, Sarkadról, Tenkéről, Bélfenyérről, ritkán Bécsből hozott példákat, melyeket saját tapasztalatai illetve kántor ismerősei közlése alapján állított össze. Sohlya Antal tíz esztendővel később - minden bizonnyal a kiadás szándékával - Alvinczy Ferenc plébánosnak is megmutatta a kéziratot, aki lapszéljegyzetekben pontosította az olvasottakat.

1870-ben jelent meg Sohlya betoldásaival az Utmutató Kántorkönyv, melynek negyedik kiadása 1876-ban került ki a szegedi Burger Zsigmond özvegyének nyomdájából. ${ }^{772}$ A könyv alapját Fekete Ferenc, egykori szeged-alsóvárosi kántor 1818ban megjelent munkája ${ }^{773}$, illetve a Fekete kötetre nagyban támaszkodó, imént tárgyalt tanítóképezdei jegyzet szolgáltatta. Sohlya Antal a negyedik kiadáshoz írt rövid előszavában a könyv széleskörü elterjedtségére, hiánypótló hasznosságára utal. ${ }^{774}$ Sohlya

\footnotetext{
${ }^{769}$ A Csongrádi Lap. 1892. január 17. II. évf. 3. szám, 3. old.

770 Ekkoriban Sohlya a nagyváradi királyi tanítóképezdében tartott „egyházi ének és szent szertartás” néven bevezető kurzust a leendő tanítóknak és kántortanítóknak.

${ }^{771}$ Fekete 1818; Garay-Sohlya-Engeszer 1860; Kovács 1842; Mezey 1883; Szelepcsényi 1738; Szentmihályi 1797-98; Tárkányi-Zsasskovszky 1855; Wimmer 1856; Zsasskovzsky 1853. A Mayer-ként említett szerző mögött minden bizonnyal Pajer Antal plébánost érti. Bartha Endre és Csíki (?) munkáival kapcsolatban nem áll rendelkezésünkre könyvészeti információ.

772 Sohlya 1876.

${ }^{773}$ Fekete 1818. (2. bővített kiadás: 1823. Grünn Orbán, Szeged; 3. bővített kiadás: 1854; 4. kiadást Ujra átdolgozta s hangjegyekkel bővítette Sohlya Antal, 1876. Szeged). Fekete Ferenc a könyv első kiadása idején már 30 éve szolgált kántorként, a könyvet eredetileg magánhasználatra szánta. Később, mint írja: „a nálam megfordult számos kántor vagy papi renden lévők, kiknek kezeikbe akadt, vizsgálták, forgatták és bíráló figyelemre vették, mindnyájan oly ítélettel voltak, hogy közrebocsátanám, azon utmutatásokkal, melyek fáklya gyanánt szolgálnak a szertartásokban és mindeddig a kántorkönyvekből kihagyattak”. Fekete Ferenc elöszava, lásd: Sohlya 1867. IV.

774 „Ismeretes e mủ - bátran állítom - majdnem minden magyar kath. Éneklész előtt, mert szent szertartásainknál mint általános szerkönyvet használtuk, és használjuk jelenben is, s így e mủ majdnem
} 
elsősorban hangjegyezéssel, új énekek betoldásával és a nyelvi hibák korrigálásával egészítette ki Fekete Ferenc munkáját. Kántorkönyve inkább tekinthető jószándékú átdolgozásnak, mintsem önálló münek.

Sohlya Antal kisebb írásai jellemzően az iskolai ének- és zeneoktatás módszertanáról, a tanítóképző intézetek állapotáról szóltak. Cikkei olykor kimondottan politikai tartalmúak voltak. ${ }^{775}$ Külön vizsgálat tárgyát képezhetik Sohlya szőlészeti és borászati témájú írásai. Ezekben az értekezésekben egy innovatív, kísérletező kedvü egyéniség képe bontakozik ki előttünk. Miután Sohlya közzé tette a kecskeméti Miklóstelepen tett látogatásának tanulságait, maga is megpróbálkozott a peronoszpóra ellen kifejlesztett eljárásokkal - a korabeli beszámolók szerint fényes sikerrel. ${ }^{776}$

$\mathrm{Az}$ értekező, problémafejtegető írások mellett az egyházi énekköltészet is foglalkoztatta Sohlyát, bár munkássága ezen a téren közel sem olyan jelentős, mint kunszentmártoni pályatársáé, öreg Mezey Jánosé, akivel valószínüleg személyes ismerettségben állt. ${ }^{777}$ Sohlya Antal 1867-ben keletkezett levelében arról számolt be a váci püspöknek, hogy a korábban egyházmegyeileg jóváhagyott saját Énekkönyvéböl tanítja a csongrádi népet énekelni. ${ }^{778}$ A kézirat - a kántor közlése szerint - a szegedi Burger-féle könyvnyomdában várta jobb sorát. A nevezett Énekkönyv pontos tartalmáról, a kiadási szándék megvalósulásáról nincs tudomásunk.

Sohlya Antal önálló énekszerzői kísérleteinek bizonyítéka Gyula fia énekeskönyvében található, melyet IV. osztályos gimnáziumi tanulóként kezdett vezetni 1870 szeptemberében. ${ }^{779} \mathrm{Az}$ énekeskönyv kéziratos részében három Mária ének szerzője az

nélkülözhetetlen kézi- és szerkönyvünk." Sohlya 1867. V.

${ }^{775}$ Sohlya Antal olyan országos és megyei terjesztésủ lapokban publikálta vegyes tematikájú írásait, mint az Idők Tanuja, Vezér, Baloldal, Katholikus Néplap, Vasárnapi Újság, Tanügyi Lapok, Egyetértés, Magyar Újság, Független Polgár, Nagyvárad-Bihar, Szegei Híradó, Zenészeti Lapok, Munkások Újsága, Magyar Állam, Jóbarát, Népnevelők Kalauza, Nemzeti Újság, Magyarország, továbbá Csongrád és Pest megye kisebb lapjai. V.ö. Tiszavidék, 1893. július 30. IV. évf. 31. szám, 2. old. Írásait Kunfi, Anonymus, Csongrádi, Várháti stb. álneveken jelentette meg. Szentesi Lap, 1893. július 30. XXIII. évf. 90. szám, 2. old; M. Kat. Lex. XII. 2007. 193.

${ }^{776}$ A témában lásd Mód László tanulmányait: Mód 2012, 2012 (kézirat)

777 Bizonyos, hogy Sohlya Antal rendszeresen használta és tanította a csongrádiaknak Mezey János énekeit. Feljegyzései között ilyen sokatmondó sorokat olvashatunk: „Mint bizonyosan tudjuk, s öreg Mezey János volt kunszentmártoni jeles magyar éneklész szájából hallottuk, ezen ferfiú most általános szükségletre írott búcsúztatókat szándékozik sajtó alá bocsátani, melyekböl levonván kevés nyelvtani hibákat eszmebőség $\mathrm{s}$ gazdag tartalmánál, s népszerüségénél fogva ajánljuk mindazon sorsosinknak, kiknek a helyi szokások szerént e búcsúztatókra szükségök van.” Sohlya 1857. (kézirat) 357.

${ }^{778}$ VPL APar. Cs. 1867. Sohlya Antal dátum nélküli levele a váci püspökhöz.

${ }^{779}$ Az énekeskönyv elején lévő nyomtatott mü a következö: Ima és énekkönyv a középtanodai $r$. kath. ifjúság számára. Bíbornok herczeg-prímás és esztergomi érsek ő főmagassága jóváhagyásával. II. kiadás, Budán, Érczhegyi Ferencz Bizománya, 1866. Ehhez a munkához füzött üres lapokat Szilber János csongrádi könyvkötő, melyekre az ifjú Sóhlya Gyula különbféle szertartási és alkalmi énekeket jegyzett le. Ld. Sóhlya 1870. (kézirat) 
édesapa, Sohlya Antal. ${ }^{780}$ Szintén a CsKK Tari László Múzeum gyüjteményét gazdagítja Sohlya Antal gyermekkori énekeskönyve 1832-ből, melyről a gyüjtő, Juhász János feltételezte, hogy több saját szerzeményü darabot is tartalmaz. ${ }^{781}$ Bizonyos továbbá, hogy Sohlya az 1890-es években Angyali Hangzatok címen ének- és imakönyvet állított össze, melyet kántorizálásának 50. jubileumára készültek kiadni. ${ }^{782}$

A kántori énekeskönyvek és halotti búcsúztató könyvek összeállítói a 19. század végén egyre több figyelmet fordítottak a szerzőség pontos megjelölésére, egyre kevésbé kezelték „szabadon”, mintegy közköltészeti alkotásként a pályatársak munkáit. Ezen nyomtatott müvek elterjedtségének feltérképezése még szakmánk előtt álló feladat. Az Alföldön Tárkányi-Zsasskovszky 1855-ös énektára volt a kántorok nélkülözhetetlen segítője: Sohlya Antal újra és újra hivatkozott használatára, a kunszentmártoni templomi kóruson is ott találunk egy kötetet. ${ }^{783}$ Mezey István kunszentmártoni kántor hagyatékának része volt a kiskunfélegyházi Csima István Gyászénektára, mely munkáról Barna Gábor megállapította, hogy igen gazdag Mezey dallamokban. ${ }^{784}$ Említettem, hogy Sohlya Antal szívesen kölcsönzött énekeket öreg Mezey Jánostól. Az énekekre könnyedén szert tehetett a Mezey ponyvanyomtatványok megvásárlásával, melyeket a csongrádiak és nagyváradiak kedvelt búcsújáró helyén, Máriaradnán is árusítottak. Arról is van tudomásunk, hogy Mezey Nepomuk János saját, 1883-ban Szentesen kiadott énekeskönyvét szekéren hordozva népszerüsítette keresztül-kasul a Dél-Alföldön. ${ }^{785}$

A helyi egyházi vezetés többnyire fenntartással, gyanakvóan kezelte a kántorok önálló költői megnyilvánulásait. Mezey Nepomuk János énekeskönyve azért nem nyerte el kritikusa, Zsasskovszky József tetszését, mert túl sok önálló művet tartalmazott, holott a templomban csak az egyházi hatóság által jóváhagyott énekek használhatóak. ${ }^{786} \mathrm{~A}$ csongrádi főkántornak elsősorban a plébános jóváhagyását kellett elnyernie ahhoz, hogy a hívőknek új énekeket taníthasson be. Egy vitás ügy kapcsán Sohlya Antal pontosan megnevezte azokat az énekeket, melyeket a csongrádiak általa sajátítottak el. Sokatmondó tény, hogy ezek között nem találni saját szerzeményt. Szerző szerint rendezve a következő müvekről esik szó:

\footnotetext{
${ }^{780}$ Kezdetük: „Üdvözlégy, Oh, Mária...”; „Ha nincs ki nyujtson végsegélyt...”; „Irgalomnak édes Anyja...”

${ }^{781}$ Sohlya 1832. (kézirat). A feltételezés a jelöletlen énekek miatt csak igen alapos utánajárással nyerhetne bizonyítást.

782 Tiszavidék, 1893. július 30. IV. évf. 31. szám, 2. old.

783 Sohlya 1857. (kézirat) Barna 2009. 452.

${ }^{784}$ Barna 2009. 452; 459.

${ }^{785}$ Barna 2009. 453; 456.

${ }^{786}$ Az elmarasztaló kritika ellenére Mezey János 1913-ban kiadta a mủvet, Istent dicsőitő Egyházi Ének könyv címen. Barna 2009. 456.
} 


\begin{tabular}{|c|c|}
\hline Tárkányi Béla ${ }^{787}$ : & „Imádunk téged, oh, angyali kenyér” \\
\hline Mezey János ${ }^{788}$ : & „Mennyben az Úr színe alatt” \\
\hline \multirow{6}{*}{ Kovács Márk ${ }^{789}$ : } & „Most az Úrnak drága teste” \\
\hline & „Bünös lelkem nézz az égre” (újhold vasárnapján) \\
\hline & „Jézus, vérontásodnak” (böjtben) \\
\hline & „Emelnek már, Oh, élet” \\
\hline & „Áldjuk a Teremtőt” (újévre) \\
\hline & „Esünk zsámolyodhoz” (nagymise ének) \\
\hline Bayer: ${ }^{790}$ & „Nincsen aki megsegítsen” (esőért) \\
\hline Zimmermann: $:^{791}$ & „Imádunk arcra borulva” (úrfelmutatáskor) ${ }^{792}$ \\
\hline
\end{tabular}

Az 1860-as években Alvinczy Ferenc plébánost nem nyügözték le azok a külföldi zeneszerzők, akikkel Sohlya Antal próbát tett. A plébános azt írta Peitler Antal váci püspökhöz címzett levelében, hogy a csongrádi kántor olykor valóságos „macskazenét csinál” az orgonán, „czikornyásan énekel” vagyis „sybillázik”793 a kóruson. A plébános meg volt győződve arról, hogy a kántor az ő bosszantására mellőzi a megszokott egyházi zeneműveket. ${ }^{794}$ A plébános emiatt vezette be a már említett előzetes énekbemutatási kötelezettséget, melyet 1867 után az orgonamüvekre is kiterjesztett.

Sohlya Antal válaszlevelében saját Éneklészettan című munkájára hivatkozott,

\footnotetext{
787 Tárkányi-Zsasskovszky 1855.

${ }^{788}$ A Sohlya által említett „Mennyben az Úr színe alatt” címü ének helyesen: „Mennyben az úr színe előtt”. Facsimile kiadásban olvasható kottával együtt: Barna 2009. 143-144. Az egyik legelterjedtebb Mezey szerzeményről van szó, mely később több énekeskönyvbe is belekerült. A „Most az Úrnak drága teste” kezdetü ének nem található ez utóbb említett gyüjteményben.

${ }^{789}$ Kovács 1842.

${ }^{790}$ Itt Pajer Antal (1817-1881) egri egyházmegyei pap Könyörgés esőért című verséről van szó, mely 1863. június 4-én jelent meg a Katholikus Néplapban. Müvét ismeretlen zeneszerző zenésítette meg, így terjedt el az egész Alföldön. Lisztóczky 2011. 91.

791 Valószínüleg Anton Zimmermannra gondol (1741-1781), aki Batthyányi József karnagya, majd a pozsonyi Szent Márton Székesegyház orgonistája volt.

792 VPL APar. Cs. 1867. Sohlya Antal dátum nélküli levele a váci püspökhöz.

793 „A templomi ének lehet komédia a kántor úr előtt, amint hogy ő szokott is ott operázni. De előttem nem az!" VPL APar. Cs. 1868. április 16. Alvinczy Ferenc utasításai Sohlya Antalnak. Zsasskovszky József ugyanezt a kritikát fogalmazta meg a Mezey kántorok énekeivel kapcsolatban: „Ahol ezen Mezey-féle énekek kerülnek forgalomba [mint Csongrádon is - Gy. O.], ott a szegény ájtatoskodó nép kénytelen a kántor czikornyás éneklésének hallgatásával beérni.” Barna 2009. 457-458.

${ }^{794}$ VPL APar. Cs. 1867. november 12. Alvinczy Ferenc levele a váci püspökhöz. A 19. századi kántorok többségére valóban jellemző volt a modoros, világias éneklési-orgonálási stílus. „A templomok cigányos muzsika modorában harsogtak, a kántorok túlnyomó része szebbnek hitte önmaga szólóztatását, a nép éneklésre tanítása munkát, sok, nagy, kitartó és nem egyszer háládatlan munkát jelentett akkor is, így egyházi énekésünk, egy-két oázistól eltekintve, kopár, szikkadt sivatagon, szinte élettelenségben tengődött.” Koudela 1936. 19.
} 
melyben, mint írja: „nyilvánosan megrovom az Isten házában tilinkózást az orgonával, s énekkel, tehát föl sem tehető rólam e vád, mert kissé zenész lévén olykor rendes hangszaktactus menetet használok a magány énekben, bár a népénekben is lehetne itt, mint azt Nagyváradon 15 évi kántorságomban kivittem". ${ }^{795}$ A konfliktus forrása egy állítólagos felsülési botrány volt, amikor is a nép nem tudta követni kántor énekét annak szokatlan újdonsága miatt. Forrásainkból az is kiderül, hogy Haydn „Oh, Isten, szent Fölségedet” címü miséjének Sanctus tételéről volt szó, melybe a nép „kezdett bele-bele kapadozni, tehát egy helyütt ennek második részében tett terz helyett secundot mondott, az ismeretlen hang kissé consumálván, de én az eredeti hangot tartottam ki hanggal és orgonával, nehogy utóbb is hibásan énekelje a nép ezt az éneket". 796

A 19. század folyamán nincs adatunk olyan nézeteltérésre, mely a kántor mise előtti énektanítására, ének- és orgonajátékára vonatkozna. Sohlya Antal lebénulása után veje, Hornyik Károly látta el a helyettes kántori szolgálatot. Ami bizonyos, hogy Hornyik 1898 szeptemberében saját szerzeményü gyászénekkel tisztelgett Erzsébet királynő emlékének a csongrádi halotti misén. ${ }^{797}$

\section{A kántor és a papság: viszonyok és elvárások}

A csongrádi kántorok több évtizedes müködésük idején alaposan kiismerték a helyi szokásokat, embereket, helyeket és helyzeteket. A bizonyos időközönként cserélődő plébánosok ilyen jellegű tudásra aligha tudtak szert tenni. Kmeth Lajos kántor 1828 és 1859 között négy, Sohlya Antal 1860 és 1902 között öt plébános és több tucatnyi káplán mellett szolgált.

A kántorok sajátos tudásához, illetve végzettségük miatt elfoglalt „magasabb” társadalmi helyzetéhez jellegzetes öntudat párosult, mely nem ritkán félreérthető helyzeteket teremtett kántor és plébánosa között. A legtöbb konfliktus a hierarchia rögzítése és az illetékességi körök bizonytalansága okán alakult ki. Az illetékességgel kapcsolatos „határátlépési konfliktusok” tipikusak - hisz a felek egyaránt hivatkoznak bevett szokásokra és egyházi törvényekre -, ugyanakkor mélységesen szubjektívek voltak. A konfliktusok lefolyásának menete, a vitázó felek sajátos hangsúlyai szorosan összefüggtek a szimpátiával, habitussal és kompromisszum-készséggel.

\footnotetext{
${ }^{795}$ VPL APar. Cs. 1867. Sohlya Antal dátum nélküli levele a váci püspökhöz. ${ }^{796}$ VPL APar. Cs. 1867. Sohlya Antal dátum nélküli levele a váci püspökhöz.

${ }^{797}$ Csongrádi Lap, 1898. szeptember 18. VIII. évf. 38. szám, 2. old.
} 
A következő fejezetben a plébános-kántor, káplán-kántor viszony módozatait tekintjük át egy konkrét eset kapcsán. Különösen tanulságos, hogy a kántor miként próbálja a polgári értékrend elemeit felhasználva egyenrangú, művelt felek párbeszédévé transzformálni a plébánosával folytatott kommunikációt. A stratégia fogadtatásáról Alvinczy Ferenc és Sohlya Antal levelei nyomán alkotunk képet.

3.1. „Ha az igazság elleni harcban elbukom: örömest bukom el!” Az Alvinczy Sohlya ügy, 1867-68.

Sohlya Antal kántor a kiegyezés évében már hetedik esztendeje volt Csongrád fóéneklésze. A kántor pályája csúcsán állt: énektani, pedagógiai, szőlészeti és borászati témájú cikkei már megyei és országos jelentőségü sajtóorgánumokban jelentek meg. Hivatali élete azonban nyomasztó konfliktustól volt terhes: Sohlya 1867 őszén egy 50 oldalas, dátumozás nélküli levéllel kereste fel Peitler Antal váci püspököt, melyben Alvinczy Ferenc plébános és káplánjai, Szálé Viktor és Straub Ferenc „méltánytalan viselkedésére” tett panaszt. A püspök a levél másolatát a csongrádi plébánosnak továbbította, hogy érdemben tudjon reagálni a felhozott vádakrak. Alvinczy és káplánjai hasonló hosszúságú, szenvedélyes irományukban pontokba szedték a kántor panaszait, melyeket sorban a „rágalmazó” ellen fordítottak. ${ }^{798}$ A plébános válaszát követően a püspök kivizsgálást rendelt el Csongrádon, melynek levezetésével Lichtner Gáspár hódmezővásárhelyi kerületi esperest bízta meg.

A kerületi esperes 1868 februárjában tanúkihallgatást rendezett, a plébános részéről 24 tanú felsorakoztatásával. Sohlya Antal a kihallgatást olyannyira megalázónak találta, hogy engedélyt kért az esperestől az ülés elhagyására. A helyi papság végül az ügy békés rendezése mellett döntött: április 16-án egy harminc pontból álló utasítás aláírására, egyben hibáinak elismerésére szólították fel a kántort. A váci püspöki szentszék tapintatosságából több ponton is finomított, ám a felszólítás alá mégis a következő bejegyzés került: „Sohlya Antal kántor úr ezen béke ajánlatot előttünk elolvasta, de hogy magát ezen pontokhoz akarja ezentúl alkalmazni, ezt aláírni nem akarta, nyilván megmutatván, hogy eddigi hibáiról lemondani, s visszaéléseit megszüntetni nincsen szándékában.”799 A kántor még egy utolsó, keserves levélben közölte a váci püspökkel, hogy vegyes bíróság elé kívánja terjeszteni az ügyet, végül néhány napi gyötrődés után mégis aláírta a nevezett utasítást. Az Alvinczy-Sohlya ügy így hivatalos úton lezárult. A fennmaradt terjedelmes iratanyag

\footnotetext{
${ }^{798}$ VPL APar. Cs. 1868. február 27. Alvinczy Ferenc és káplánjainak levele a váci püspökhöz.

${ }^{799}$ VPL APar. Cs. 1868. április 16. Alvinczy Ferenc utasítása Sohlya Antalhoz.
} 
értékes információkkal szolgál a társadalmi szerepek mibenlétéről alkotott elképzelések megértéséhez, a hivatali alá-fölérendeltségi viszony finom hálójának feltérképezéséhez.

\subsection{Pozicionáltság a beszédfordulatokban}

Alvinczy Ferenc plébános és Sohlya Antal leveleinek célja hivatali viszonyuk újragondolása, elvárásaik letisztázása volt. A plébános számára mindez a hagyományos hierarchikus keretek között volt elképzelhetö, önmagát és káplánjait a kántor elöljáróinak nevezte. ${ }^{800}$ „Nincs még eddig semmi püspöki rendelvény, mellyel fogva a pap nem volna elöljárója a kántornak, tehát Sohlya is vagy eszközöljön ki illy rendeletet a püspökségtöl, vagy pedig engedelmességet tanusítson, midőn őt a pap valamelly hibájáért, gorombaságáért vagy visszaéléséért rendre utasítja." 801 „Azon hivatalos alárendeltségénél fogva, melyben plébánosához áll, ennek hivatalos intései $\mathrm{s}$ parancsai iránt engedelmességgel viseltessék végre." ${ }^{~} 802 \mathrm{Ez}$ a pozicionáltság a kántor részéről a papi autoritás feltétlen elfogadásával, az ágens szerepről való lemondással járt együtt.

A plébános sem a temetések ügyét, sem a plébánia mindennapjait illetően nem tekintette kompetens döntéshozónak kántorát: „szorosan a plébános utasítása szerint tartozik eljárni, s ahhoz alkalmazkodni [...] s magát a miséző pap kívánságához tartsa". 803 Ennek megfelelően hangzik el a kántor hivatali helyzetének meghatározására az alattvaló kifejezés: „[a plébános] alattvalójától, a kántortól megkívánja, hogy a kötelességét híven teljesítse". ${ }^{804}$ A plébános érvrendszerét követve konfliktus csak a pap akaratának jogtalan fölülbírálásából eredhet, így a megkövetés - mely Alvinczy plébános kívánsága is egyben - egyedül a kántorra hárul: ,azon ígéret mellett, hogy az elősoroltakat szem elől soha nem téveszti, kérje meg a plébános urat, hogy vele ki béküljön". 805

A kántor második levelében nem győzte hangsúlyozni, hogy fönöke ${ }^{806}$, a plébános iránt feltétlen elkötelezettséget érez, és nem őt, hanem azokat hibáztatja a szomorú eset miatt, kik ellene hangolták. Érzelmesen ${ }^{807}$, másszor heroikus szólamot megütve ${ }^{808}$

\footnotetext{
800 „(A kántor) az elöljárósága iránti alárendeltségről, tiszteletről és engedelmességről ne feledkezzék meg”; VPL APar. Cs. 1868. április 16. Alvinczy Ferenc utasítása Sohlya Antalhoz.

${ }^{801}$ VPL APar. Cs. 1868. április 16. Alvinczy Ferenc utasítása Sohlya Antalhoz.

${ }^{802}$ VPL APar. Cs. 1868. április 16. Alvinczy Ferenc utasítása Sohlya Antalhoz. [kiemelések: Gy. O.]

${ }^{803}$ VPL APar. Cs. 1868. április 16. Alvinczy Ferenc utasítása Sohlya Antalhoz.

${ }^{804}$ VPL APar. Cs. 1868 február 12. Alvinczy Ferenc és káplánjainak levele a váci püspökhöz.

${ }^{805}$ VPL APar. Cs. 1868. április 16. Alvinczy Ferenc utasítása Sohlya Antalhoz.

806 „Erre nézt igen helyes lenne, ha maga a n.t. Plébánus úr rendelkeznék mint fönök, $\mathrm{s}$ így sok kellemetlenség kerültetnék ki." VPL APar. Cs. 1868. Sohlya Antal dátum nélküli levele a váci püspökhöz. 807 „A főtisztelendő esperes úr előtt összetett, fölemelt kézzel kértem bocsánatot n.t. Alvinczi Ferencz urtól, s
} 
nyilatkozik kettőjük viszonyáról. Egyre szenvedélyesebb levelének végén azonban győz az önérzet, mely a következő kritikai konklúzióra fut ki: „tudtomra adatott - mintha egy negyed százados éneklészségemben meg nem tanultam volna - hogy én alárendeltje vagyok lelkész fönökömnek, de mint müvelt ember müvelt embertől más stilust ohajtottam volna még akkor is, ha csakugyan bünös volnék. Szerény nézetem szerént Isten egyháza szolgái vagyunk én is és plébánus úr is azzal a különbséggel, hogy a plébánus úr elöljáróm, de nem zsarnok uram!" $" 809$ Ezzel a hirtelen perspektívaváltással felszentelt pap és egyházi éneklész helyett két mủvelt ember áll előttünk, akik egyaránt Isten házának szolgái. Így a „kántorok királya” cím kigúnyolása és a szintén élcként használt „tekintetes Kántor úr" kifejezés ellen - mellyel a plébános alárendeltje vakmerőségét kívánta pellengérre állítani - a kántor határozottan tiltakozott. ${ }^{810}$ Sohlya Antal ezzel a meglepően önérzetes, ám kétségtelenül az önvédelem szándékától vezérelt retorikával 'közelebb húzta a papi talárt a földhöz', mely természetesen nem nyert osztatlan tetszést sem a püspök, sem a plébános részéröl. ${ }^{811}$

A kántor ugyan elismerte hivatali alárendeltségét, ám bizonyos esetekben a kántorok közötti szakmai lojalitást a plébános akaratánál erősebb hálóként tüntette fel. Kitünő példa erre az az eset, amikor egy temetésre Csépáról óhajtottak kántort hozatni a gyászos felek. Ezt a csongrádi plébános meg is engedte, ám Sohlya eképpek fakadt ki: „de elfeledte itt fötiszt. fönököm, hogy egy becsületes kántor sem fog az én beleegyezésem nélkül temetni jönni Csongrádon". 812

A plébános és a kántor hivatali viszonyánál némiképp bonyolultabb a föéneklész és a káplánok kapcsolata. Alvinczy Ferenc hosszasan sorolta azokat a ,kántori visszaéléseket”, melyeket az éneklész a plébánossal ugyan nem, de annak káplánjaival szemben megengedett magának. Ilyen a hívek előtt használt becsmérlő hangnem ${ }^{813}$, az

nem szégyenlem bevallani, hogy könnyeztem!” VPL APar. Cs. 1868. Sohlya Antal dátum nélküli levele a váci püspökhöz.

808 „Még mindig tisztelettel viseltetem azon osztályhoz, melynek becsületéért és tekintélyéért annyit harczoltam, és ellenséget is szerezve magamnak bántalmaztattam." VPL APar. Cs. 1868. Sohlya Antal dátum nélküli levele a váci püspökhöz.

${ }^{809}$ VPL APar. Cs. 1868. Sohlya Antal dátum nélküli levele a váci püspökhöz. [kiemelések: Gy. O.]

810 VPL APar. Cs. 1868. Sohlya Antal dátum nélküli levele a váci püspökhöz. Megjegyzendő, hogy a kunszentmártoni öreg Mezey Nepomuk Jánost is „kántorkirály” névvel illették. Barna 2009. 452.

${ }^{811}$ Lásd: VPL APar. Cs. 1868. április 16. Alvinczy Ferenc utasítása Sohlya Antalhoz.

812 VPL APar. Cs. 1867. november 12. Sohlya Antal levele a váci püspökhöz.

813 A kántor egy alkalommal így szólt a gyászos házhoz gyalog érkező káplánokhoz, akik a bérelt kocsi elküldése miatt vonták felelősségre: „'Halgassanak, magok nem tudják miben áll a dolog' sat. Ezen szavával nyíltan ki mutatván, hogy a Kántor Sohlya úr kevésbe veszi Elöljáró papjait." VPL APar. Cs. 1868. január 4. Nagyistók Imre kocsis nyilatkozata. [kiemelések: Gy. O.] 
illetlen viselkedés ${ }^{814}$, továbbá a misézés alatt elkövetett szabálytalankodás ${ }^{815}$. A plébános mindezt ugyanúgy értékelte, mintha a kántor vele szemben követte volna el ${ }^{816}$, hisz a káplánokat - mint a plébános akaratának keresztülvivőit - a kántornak teljes jogú elöljáróiként kell(ene) elfogadnia. Ebben a szemléletben a segédlelkészek maradéktalanul osztoztak. Mikor Bagi Erzsébet fiának temetésére nem ért oda a kántor búcsúztatni, a következő jelenet zajlott le: „a Kántortul ekkor eljött egy fiu, és a bucsuztató levelet mit Skulteti [t.i. a segédkántor] küldöt Káplány urnak ata: ez azt monta én nem vagyok Kántor és én nem bucsuztatok, és elutasítota a levelet". 817

Hogy honnan vette a kántor a bátorságot ahhoz, hogy a káplánnal kívánta felolvastatni a halotti búcsúztatót, arra Sohlya Antal maga adott választ egyik levelében: „nekem semmi bajom nincs az elüljárókkal, ha csak a káplány urakat nem érti nt. Plébánus ur ilyenekül. De én azt tartanám, hogy nekik is elüljáró a nt. Plébánus úr, de nem megfordítva". ${ }^{818}$ Ebben az árnyalatlan, kétszintű hierarchiában a segédlelkészek és a kántor egyenrangú felekké váltak.

3.3. A fegyelmezés eszközei: kommunikációs protokoll az önérzet határain innen és túl

Az egyházfegyelmezés alapja a belső rend fenntartására való törekvés, melynek fő eleme a plébános akaratával ellenkező törekvések visszaszorítása, szankcionálása. A fegyelmezési eljárás mindig kiváltja a fegyelmezett fél reakcióját, így az Alvinczy-Sohlya ügy tanulságait is kétoldalú perspektívából vizsgálhatjuk meg. Mint azt látni fogjuk, a kántor válaszaiból kibontakozó önkép az alkalmazott fegyelmezési módok létjogosultságát, a fegyelmező személyének illetékességét, autoritását kérdőjelezik meg.

A kántorral szemben alkalmazott elsődleges fegyelmezési mód a szóbeli megrovás volt. A szóbeli megrovás enyhébb módja a zárt ajtók mögött zajló megbeszélés, csak komolyabb esetekben került sor nyilvános kiprédikálásra. Sohlya Antal több levelében

\footnotetext{
814 A kántor egy temetésen nyíltan kijelentette, hogy nem hajlandó egy kocsira ülni a vele haragban álló Szálé Viktor káplánnal. VPL APar. Cs. 1868. január 4. Nagyistók Imre kocsis nyilatkozata.

815 A kántor ,a Requiem alatti, különben sem templomba való búcsúztatást az általa nem kegyelt miséző káplány elleni demonstracióul használja fel." VPL APar. Cs. 1868. április 16. Alvinczy Ferenc utasítása Sohlya Antalhoz.

${ }^{816}$ A kántor „beavatkozik, és pedig a szemtelenség határáig a temetések rendezésébe, s ha ezért valamelly káplány úr rendre utasítja őt, még neki áll följebb, és ő idézvén elő a botrányt." VPL APar. Cs. 1868 február 12. Alvinczy Ferenc és káplánjainak levele a váci püspökhöz.

${ }^{817}$ VPL APar. Cs. 1868 február 25. Bőröss Pálné Bagi Erzsébet vallomása. [kiemelések: Gy. O.]

${ }^{818}$ VPL APar. Cs. 1868. Sohlya Antal dátum nélküli levele a váci püspökhöz. [kiemelések: Gy. O.]
} 
olvashatjuk, hogy a nézeteltérések kezelésének számára egyetlen elfogadható útja a „csendes, szép” beszélgetés volt. ${ }^{819}$ Minden egyéb szankcionálási módot, vagy azok kilátásba helyezését, Sohlya igazságtalan túlkapásként értékelte. Hivatkozásul több évtizedes kántori ténykedését hozta fel, miközben szívesen utalt a lapokban róla felhozott méltatásokra ${ }^{820}$, felemlegetve a papi rend iránti lojalitását és meghatározatlan küzdelmeit, melyeket a papság érdekében kellett megvívnia ${ }^{821}$.

1867 szeptemberében egy Hajdu János nevü ifjú kereste fel a kántort azért, hogy közelgő esküvője céduláját készítse el, és juttassa a miséző káplán kezébe. A kérdéses cédula azonban elkallódott. Mise után a fiatal menyasszony sírva kereste fel a plébánost, hogy tegyen valamit az érdekükben, mert az esküvő így egy héttel is elhalasztódhat. Az esetet követő intézkedésről fájdalmas hangon számolt be a főéneklész: „Straub káplán a délesti istentisztelet végén egyházi ornátusban, az oltártól kifordulva legalább 2000 (!!!) ember előtt mondá ki, hogy ezen hirdetőt most kell fölolvasnia a kántor hanyagsága miatt, ki kötelességét nem teljesítette." ${ }^{822}$ Az elmaradt házassági hirdetőcédula esetének leírását Sohlya Antal a megyéspüspök felé továbbította, mondván: a templom ezzel a méltánytalan kiprédikálással „személyeskedés és rágalom tanyája lett”. ${ }^{823}$

A plébános és kántora közti levelezés, az írásban rögzített utasítások és az azokra érkező reakció a fegyelmezés nyomatékosabb szintjének tekinthető. 1867-ben egy cigánytemetés kapcsán indult felfokozott hangú levélváltás a káplánlak és a plébánia között. Sohlya Antal leírása szerint egy cigány család, miután drágállotta a halotti búcsúztatás tarifáját, így azt meg sem rendelte. A kérdéses temetés napján azonban egy cigányasszony kopogtatott az ajtaján, és sürgetni kezdte, hogy induljanak a végtisztességre. Miután Sohlya kántor emlékeztette őt a korábban felbomlott egyezkedésre, az asszony a plébániára sietett panaszt tenni. A cigányasszony hamarosan meg is érkezett egy levéllel. Az esetről eképpen emlékezett meg a fóéneklész: „kaptam az első levelet főtiszt.

\footnotetext{
819 „Tehát nem lehetett volna az ily ügyeket szépen egymás között pap és kántornak elintézni?” VPL APar. Cs. 1867. november 12. Sohlya Antal levele a váci püspökhöz.

${ }^{820}$ „Azt gyanitottam volna, hogy egy korhely, a hivatalát nem teljesítő, szakmáját nem értő, az egyház és a t. papság ellen vétő egyház szolgával tán történhetik valami négyszemközti rendre utasitás, de egy vallásos, hü, $\mathrm{s}$ a vallás és az egyház énekei mellett mindha küzdő $\mathrm{s}$ a nyilvánosság terén is gyenge tehetségét mérlegbe vető, mint a „Religio” egyházi lap - ha jól emlékszem 1862-ik évi egyik száma idézi [...] hivatalát értő józan kántorral, hogy ily spectaculumok történhessenek, fogalmamon kívül esett, míg az velem meg nem történt." VPL APar. Cs. 1867. november 12. Sohlya Antal levele a váci püspökhöz.

821 „Mindig hö védője valék a t. papság és ezek érdekeinek [...] mindig tisztelettel viseltetem azon osztályhoz, melynek becsületéért és tekintélyéért annyit harcoltam, és ellenségeket is szerezve magamnak bántalmaztattam.” VPL APar. Cs. 1867. november 12. Sohlya Antal levele a váci püspökhöz.

${ }^{822}$ VPL APar. Cs. 1867. november 12. Sohlya Antal levele a váci püspökhöz.

${ }^{823}$ VPL APar. Cs. 1867. november 12. Sohlya Antal levele a váci püspökhöz.
} 
főnökömtől, melyet szomorú ereklye gyanánt őrzök, hogy még unokám is lássa, miszerént mint negyed százados kiérdemült kántor ilyet is nyertem a t. papságtól hüségemért. Ezen levelet kezembe adta a cigány asszony azon világos paranccsal, hogy mindjárt olvassam el, mert én neki szolgája vagyok - t.i. a cigány asszony szolgája vagyok. Én azt mondtam neki, hogy takarodjon dolgára, majd elolvasom s íróasztalomra tévén a levelet csak azért sem olvastam el, mert a cigánynő parancsolta”. ${ }^{824}$ A plébános utasítását gyakorlatilag meg nem történtté tette a sajátos kézbesítési szituáció. A második levél Sohlya leírása szerint „egy kis összegyürt papíron” érkezett, ugyancsak a cigányasszony kézbesítésével: „főnököm [a levélben] fenyegetések közt parancsolta, hogy magam menjek temetni a cigányt $\mathrm{s}$ a cigányok előtt elcsapatásomról beszélt". ${ }^{825}$ Mindezek után a kántor a harangozót küldte a plébánoshoz azzal a szóbeli kérelemmel, hogy mentse ki a cigánytemetés alól.

A kántor négy tényezőt kifogásolt: a kommunikáció módját (írásbeli utasítás), a leírt tartalom hangnemét (parancs), a levél stílusát (gyürt papír) és a kézbesítő személyét (cigányasszony). Mikor Alvinczy Ferenc plébános tudomására jutottak Sohlya Antal kifogásai, eképpen csattant fel: „Vagy tán a plébánosnak nem is szabad kántorához írnia, azt kötelességére figyelmeztetnie?" ${ }^{26}$ Majd kijelentette, hogy viszont válaszlevelek küldését a kántor részéről nem tartja elfogadható kommunikációs módnak, hiszen „mindannyiszor hivatalos kötelessége volna személyesen eljönni”. 827 A formátumra reagálva a plébános megjegyezte, hogy a második „összegyürt kis papír” olyan levélforma, melyet baráti levelezéseknél szoktak használni: összegöngyölt cédula, négy ujjal keresztben összenyomva hogy illetéktelenek ne olvashassanak bele. ${ }^{828}$

A pontokba szedett bünlajstrom összeállítása szintén a plébános fegyelmezési eszköztárának része volt. Alvinczy Ferenc, miután látta, hogy szóbeli utasításai hasztalanok, elkezdte összeírni kántora „visszaéléseit”. ${ }^{829}$ Megjegyzendő, hogy a fegyelmezés retorikájába esetenként olyan büntetések is bekerültek, melyek gyakorlati keresztülvitele nem feltétlen tartozott a plébános hatáskörébe. Az ilyen típusú fenyegetések

\footnotetext{
${ }^{824}$ VPL APar. Cs. 1867. november 12. Sohlya Antal levele a váci püspökhöz. ${ }^{825}$ VPL APar. Cs. 1867. november 12. Sohlya Antal levele a váci püspökhöz.

826 VPL APar. Cs. 1868. február 12. Alvinczy Ferenc levele a váci püspökhöz. Alvinczy plébános nem mulasztja el az alkalmat, hogy Sohlya igényeit összefüggésbe hozza a „kántorok királya” címmel: „hanem azért korántsem fogja (a plébános) aranybetüvel pergamenre írt levelét őkirályságának vörös bársony párnán vagy ezüst tálczán térdenállva benyujtani."

${ }^{827}$ VPL APar. Cs. 1868. február 12. Alvinczy Ferenc levele a váci püspökhöz.

${ }^{828}$ VPL APar. Cs. 1868. február 12. Alvinczy Ferenc levele a váci püspökhöz.

${ }^{829}$ VPL APar. Cs. 1868. február 12. Alvinczy Ferenc levele a váci püspökhöz.
} 
jellemzően a felfüggesztést helyezték kilátásba. ${ }^{830} \mathrm{Az}$ Alvinczy-Sohlya ügy kapcsán keletkezett bünlajstrom javadalmazási kérdéseket (halotti búcsúztatók tarifája) is feszegetett, mellyel kapcsolatban a kántor nem tartotta illetékesnek plébánosát, és nem mulasztotta el erre emlékeztetni. ${ }^{831}$ Hasonló reakciót váltott ki a plébános azon felvetése, miszerint Sohlya Antal alapvető szakmai hibákat követett el bizonyos egyházi énekek müfaji meghatározása során. ${ }^{832}$

A fegyelmezés következő szintje az ítélkezésben illetékes egyházi följebbvalók (esperes, megyéspüspök, püspöki szentszék) bevonása volt. A püspök írásos, személyre szóló figyelmeztetése rendkívül hatékonynak bizonyult volt annak ellenére, hogy a megrovásokat ritkán (Csongrád esetben sohasem) követte felfüggesztés. Mindezek mellett a plébánosnak kötelessége volt évente „erkölcsi informatiot” írni kántoráról, és továbbítani a váci püspök felé. Az efféle jelentések létezéséröl csak másodlagos forrásból van tudomásunk. ${ }^{833}$

A fegyelmezés szélsőséges formája a fizikai erőszakkal való fenyegetés, vagy annak bármilyen megvalósulása volt. Sohlya Antal csak másodkézből értesült arról a felettébb homályos híresztelésről, mely szerint Straub káplán fel fogja őt pofozni, ha még egyszer azt tapasztalja, hogy nem köszön neki az utcán. ${ }^{834}$ Ugyanebben a levélben hivatkozott Sohlya Antal arra az esetre, mikor gimnazista fiát, Sóhlya Gyulát Szálé Viktor káplán ,azon ráfogással, hogy füvegét le nem vette, ezt fejéből kiütve agyba főbe verte a piacon". ${ }^{835}$ A plébános egyedül a fiú fövegének leveréséről tudott, melyet a gyerek nem vett le a templom elött, és a káplánnak sem köszönt. ${ }^{836}$

Az Alvinczy-Sohlya ügy kapcsán keletkezett iratokban a pap-kántor hivatali kapcsolat szinte minden lehetséges ütközőpontja kimutatható. Az illetékességi körök tisztázása, az alá-fölérendeltségi viszony megnyugtató rendezése mellett a fegyelmezési lehetőségek eszköztára is vizsgálhatóvá válik. Tanulságos mentalitástörténeti adalékokkal

\footnotetext{
830 „Kötelességemnek fogom tartani őt [...] visszautasítani a malteros kanálhoz, hogy dobálja sárral eredeti hivatása szerént a falat, ne a katholikus klérust!” VPL APar. Cs. 1868. április 16. Alvinczy Ferenc utasítása Sohlya Antalnak.

831 „De ha szabad mély alázattal kérdenem, mi joga van a lelkész urnak az ily pénzügyi kérdéshez, hiszen ez már csak nem egyházi ügy, kinek nehézsége van, keresse a város elöljáróságát, de igénytelen nézetem szerént igen káros itt magát hívatlan bírónak föltolni a lelkész úrnak.” VPL APar. Cs. 1867. november 12. Sohlya Antal levele a váci püspökhöz.

832 „Ezt egy kezdő ifjú kántornál alkalmazhatná n.t. Plébánus úr, de nem egy megőszült képezdei tanárnál.” VPL APar. Cs. 1867. november 12. Sohlya Antal levele a váci püspökhöz.

${ }^{833}$ VPL APar. Cs. 1868. április 16. Alvinczy Ferenc utasítása Sohlya Antalnak.

${ }^{834}$ VPL APar. Cs. 1867. november 12. Sohlya Antal levele a váci püspökhöz.

${ }^{835}$ VPL APar. Cs. 1867. november 12. Sohlya Antal levele a váci püspökhöz.

${ }^{836}$ VPL APar. Cs. 1868. február 12. Alvinczy Ferenc levele a váci püspökhöz.
} 
szolgál a panaszfélből vádlottá alakuló kántor önérzetes védekezése. Mikor Alvinczy Ferenc gúny tárgyává tette Sohlya Antal „kántor király” címét, az éneklész a keresztre feszített Jézus meghurcolásához hasonlította az esetet ${ }^{837}$ Hasonló retorikai fordulattal élve, egy pápa és egy bíboros-hercegprímás példájával védekezett, mikor a kőműves szakmába való visszaküldése került kilátásba. ${ }^{838} \mathrm{Az}$ ehhez hasonló, olykor kimondottan vakmerőnek tűnő „,bibliai összemérések” korántsem voltak ritkák a korban: a sekrestyéstől a plébánosig minden egyházhoz közel álló személy alkalmazta akkor, ha szavainak különös nyomatékot kívánt adni.

\section{A nép választottja - a nép képviselője?}

Ugyan a kántort és a plébánost egyaránt hivatásuk „kötelmei” láncolták az adott településhez, egy kántor akár haláláig is szolgálhatott egy plébániaközösséget, a plébános viszont a püspök belátásától függően változtatta állomáshelyét. Az akár több évtizedes ott tartózkodás során a helyi lakosok közé „beolvadó” kántor széleskörü hely- és emberismeretre tett szert, a szokásokról és mentalitásról nem is beszélve. Innen nyeri forrását az a sajátos identitás, mely akár hivatali elöljárója ellenében is bátran mer a „nép ítéletére” hivatkozni és „népi érdekvédőként” fellépni. Az érdekvédelem azonban ellenpólust kívánt: ez az ellenpólus pedig nem ritkán maga a plébános akarata volt. „A plébános nehezen szólalhat fel [...] mert a hiuságában sértett kántor mint a nép választottja, a hívek lázításával sok zavart csinálhat”. ${ }^{839}$ Eképpen szólalt fel a halotti búcsúztatók eltörléséért síkra szálló Veron Lajos váci zsinati titkár 1921 áprilisában. Kijelentése természetesen évtizedekkel korábban is érvényes volt. A kántor öntudatának komoly forrásáról van tehát szó; egyfajta potenciális tekintélyalapú erőről, mellyel képes volt alapjaiban formálni a közvéleményt.

Ne feledjük azonban, hogy az egyházi éneklész - hivatalából adódóan - a plébános

\footnotetext{
837 „Én számot vetettem magammal, hogy ha elhagyatnám is Méltóságodtól (a váci püspöktől) - mit bölcsessége s igazság szeretetéről föltennem nem szabad - vissza lépnék a kántorságtól, melyben fötiszt. Mendik Ágoston úr által Királynak neveztettem a Tanügyi Lapokban, mely most épen oly guny lett, mint Jézus urunk királysága Pilátus előtt, midőn már a nyilvános fölpofozás a tisztelendő urak által megígértetett, a köpözés folyik, még hátra van a korbács és keresztre feszítés, de már ezekre méltatlan leszek, $\mathrm{s}$ inkább lábbal feszíttessenek föl az első romai szentséges atyával.” VPL APar. Cs. 1867. november 12. Sohlya Antal levele a váci püspökhöz.

838 „Furcsa állítást látok itt. Mintha - ha jól emlékszem - VIik Xixtus [VI. Sixtus] romai szent atyát eredeti hivatása a sertések örzésére, Scitóvszki [Scitovszky János] bíbornok prímást pedig falusi mester apjához az iskola porba lehetne visszautasítani?!" VPL APar. Cs. 1867. november 12. Sohlya Antal levele a váci püspökhöz.

${ }^{839}$ VPL Synodus Dyocesana 1921. Veron Lajos titkár javaslatai a törvények conceptusára 1921. április.
} 
akaratának közvetítöje kellett, hogy legyen. Egyéni döntéseinek hatóköre igen szük lehetett: csak a kántorsegédek megválasztását, a hosszabb halotti búcsúztatók tarifájának megállapítását, bizonyos fokig a misén elhangzó népénekek rendjét tekintve maradt némi mozgástere. Sem a temetések, sem a misézések rendjébe nem volt beleszólása, legfeljebb javaslatokat tehetett hivatali elöljárója felé. A plébános azonban szabadon utasíthatta a kántort arra, hogy ésszerüen változtasson a korábban bevett szokásokon (pl. népénekek rendje). A kántornak ellenkezés nélkül eleget kellett tennie elöljárója óhajának. ${ }^{840}$

A következő alfejezetekben forrásaink tükrében azt vizsgáljuk meg, hogy miként érvényesülhetett, avagy fordulhatott visszájára a kántor népvédő-attitüdje, hogyan élte meg saját szürőszerepét, illetve miként értékelte a kántor és plébánosa viszonyát a hívek közössége.

4.1. „Az én címem a népnél...”841

A szakirodalomban rendszerint a kántorok közízlés-formáló, újító szerepét szokás előtérbe helyezni. ${ }^{842}$ Csongrádon az egyetlen Haydn-mise kudarcán kívül kántori kezdeményezésü újításáról nemigen tudunk beszámolni. Akadályozta ebben Sohlya Antalt egyrészt a plébánossal kialakult személyes konfliktusa, másrészt az a tény, hogy az újító szándékú intézkedésekhez a hívek rendkívül rugalmatlanul viszonyultak. Elég felidézni a halotti búcsúztatók eltörlését kijelentő, évtizedekkel későbbi váci egyházmegyei zsinati döntés hatását. ${ }^{843} \mathrm{Az}$ elégedetlenség a közvetítő-végrehajtó kántorra, kisebb mértékben a szintén közvetítő szerepet betöltő plébánosra zúdult. Másik példa: amikor Alvinczy Ferenc plébános meghagyta Sohlya Antalnak, hogy rövidítse le a szokott ünnepi népénekeket, a hívők méltatlankodását a döntést végrehajtó kántornak kellett elviselnie: „eléggé megszenvedtem most Karácsonykor a néptől, minthogy megszokott 5-6 versszak kedves népénekük helyett csak egy és két versszakot énekeltem. Nem tudván a nép a letiltást,

\footnotetext{
${ }^{840} \mathrm{Ne}$ felejtsük el, hogy a helyi szokások változtatását érintő, komolyabb döntések egyházmegyei, vagy éppen vatikáni szinten születtek. Ezekben az esetekben a plébános is csupán közvetítő szerepet töltött be.

${ }^{841}$ Sohlya Antal leveleiben a nép arctalan, egységes tömbként jelenik meg, mely nem foglalja magában az értelmiségieket. A hívők közösségének egészére a város kifejezést használja. Sohlya kántor a népre kétféle értelmezési keretben utal: a nép, akit ismer és képvisel, és a nép, aki visszaigazolja szándékainak helyességét. „Hivatkozom Csongrád város értelmisége és a népre” VPL APar. Cs. 1867. november 12. Sohlya Antal levele a váci püspökhöz.

${ }^{842}$ Ld. Barna 2009; Dobszay 1995.

${ }^{843}$ A döntésről értesítö püspöki körlevelet a váci egyházmegye összes templomában felolvasták. A katolikus hívő közönség döbbenettel fogadta a váratlan bejelentést. Többen elégedetlen morajlással, felháborodott bekiabálásokkal tiltakoztak a határozat ellen. VPL Synodus Dyocesana 1921. Marschall Endre levele a hercegprímáshoz 1921. július 6 .
} 
engem okolt és rágalmazott, pedig ime látszik, hogy nem én valék az ok". ${ }^{844}$ Ezek azok a jellegzetes helyzetek, amikor a kántor köztes, szürő-szerepe felettébb hálátlan pozíciónak bizonyult.

A nép sajátos ízlését ismerő és elfogadó, konzervatív magatartás azonban az éneklész számára tényleges (anyagi) előnyökkel járhatott. Ismét a halotti búcsúztatók eltörlése ellen vívott harcot idézem fel, melynek élén pont a katolikus kántorok álltak. Hanauer István váci megyéspüspök egyenesen a „gyermekded nép” naivitását kiszolgáló és kihasználó egyházi éneklészeket tette felelőssé azért, hogy a halotti búcsúztatok ügye még a 20. századra sem lelt nyugvópontra. Tapintatosan nem említette a búcsúztatókkal járó egyéb, anyagi természetű előnyöket. Mint írja: „a kántori állás tekintélyét is emelni akarom [...] Ne alacsonyítsa le magát falusi népénekessé, aki a nép fejletlen ízlésének hízelegve törekszik a nép kedvében járni" ${ }^{845}$

Forrásaink sajátos fajtáját képviselik azok a levelek, melyekben a kántor „a nép” egyszemélyes képviselőjeként tünteti fel magát. A „nép sérelmeinek” orvoslására tett, helyi érdekü javaslatok azt sugallják, hogy az érvelő a közakarattal megegyezően cselekszik. Jogosan áll fenn a gyanú, hogy a nép-sérelem csupán tetszetős szófordulat a kántor érvelésében, célja azonban mélységesen személyes. ${ }^{846}$

Az óhajtott közszimpátia elnyerésének kerékkötője egy fegyelmezési eljárás kínos részleteinek napvilágra kerülése lehetett. A hívekben kialakuló ítélkező benyomás félelme vezérelte Sohlya Antalt akkor is, amikor a megyéspüspök elé terjesztette kritikai meglátásait: „fötiszt. fönököm semmit nem közöl velem, ami neki nem tetszik, hanem jegyezget, s a híveknek mutogatja, olvassa s rosszalja, s így tizedik vagy huszadik szájból jő tudomásomra akarata, midőn már az egész város nyelvére jutottam". ${ }^{847}$ Mikor a káplánok egy temetésre gyalogosan érkezve a gyászoló felek előtt vonták kérdőre egy elküldött bérkocsi ügyében, ,a botrány befutá két óra alatt a várost” ${ }^{848}$ A törékeny jó hír és

\footnotetext{
${ }^{844}$ VPL APar. Cs. 1867. november 12. Sohlya Antal levele a váci püspökhöz.

${ }^{845}$ Hanauer Á. István 1929. 138. Marschall Endre kiskunmajsai kántor 1921. július 6-án kelt sorait részben anyagi indokok, részben a hagyományokhoz fokozottan ragaszkodó érzelmesség hatja át. ,[...] azonban a rendelkezés a célját el nem érheti már csak azért sem, mivel évszázados magyar népszokást akar megdönteni akkor, midőn minden más vonalon fajunk fennmaradása érdekében a népszokásokat $\mathrm{s}$ a tisztán faji népmüveltséget jelölik meg legalkalmasabbnak arra, hogy ezen célt elérni tudjuk." VPL Synodus Dyocesana 1921. július 6. Marschall Endre levele a hercegprímáshoz.

${ }^{846}$ Sohlya Antal eképpen zárja levelét: „A két káplány úr nem csak ellenem, de a szertartás és a nép ellen is elkövették [.... így, hogy] a hívek is a temérdek bántalmazásoktól mentve legyenek [...] Csongrádra higgadt, jó lelkü káplány urakat tenni mély tisztelettel esedezem kegyesen méltóztassék!" VPL APar. Cs. 1867. november 12. Sohlya Antal levele a váci püspökhöz.

${ }^{847}$ VPL APar. Cs. 1867. november 12. Sohlya Antal levele a váci püspökhöz.

${ }^{848}$ VPL APar. Cs. 1867. november 12. Sohlya Antal levele a váci püspökhöz
} 
becsület Sohlya kántor érzékeny pontja volt, hisz a közösségi szimpátia, vagyis az „igazság” elnyerése még a tényleges egyházfegyelmezési döntéseket is fordított megvilágításba helyezhette.

\subsection{Példamutatás, „népnyúzás”. A plébános közbenjár}

A kántor és a nép viszonyát illetően a plébános elsősorban példamutató magatartást várt el. Az egyházszolgák tisztelettudó, szabálykövető, vagyis minta-értékü viszonyulásmódja a plébános sikeres irányítási-fegyelmezési stratégiájának fokméröje, bizonyos értelemben a hívek fegyelmezettségének záloga volt. Az Alvinczy-Sohlya ügy kapcsán a plébános a kántori példamutatás hiányosságainak lehetséges következményeit helyezte kilátásba: „,Ne terheltessék kalapját levenni, midőn temetésen énekel, mert ama kálvinista szokás nem volt itt meg s nem akarom, hogy alattam kapjon lábra." ${ }^{849}$ Ugyancsak említésre került az „illendő beszédstílus”, a térdhajtás, a miséken való pontos megjelenés követelménye. ${ }^{850}$

A hívek és a kántor érintkezésében beálló visszásságok, egyenetlenségek orvoslása a plébános lelkiismereti kötelessége volt. A már sokat hivatkozott Alvinczy-Sohlya konfliktus kapcsán a kántor népképviseleti attitüdjének visszásságai is kiütköztek. Alvinczy Ferenc plébános leírása szerint a halotti búcsúztató magas stóladíja miatt a hívek maguk között csak „nyúzóként” emlegették kántorukat. ${ }^{851}$ Hogy a plébánost nem hagyta hidegen a hívők panasza, annak nyomát „Utasítások” című írásában találjuk meg: „A híveket a meghatározott illetéken fölül ne zsarolja, mert már a hideg leli őket, midőn mondom, hogy a kántornál is jelentsék a temetést." ${ }^{~} 52$ Emellett a plébános szóvá tette azt is, hogy a kántor lelketlenül megszidja a híveket, ha valaki csak kántor úrnak és nem teens úrnak nevezi őt. ${ }^{853}$

Alvinczy plébános leveleiből a „gondviselő plébános-atya” sziluettje bontakozik ki: „Egy jóravaló lelkipásztor nem elégszik meg azzal, hogy híveinek csupán lelki javát viselje szívén: hanem azok földi javát is iparkodik elömozdítani, azokat inségökben gyámolítani, a

\footnotetext{
${ }^{849}$ VPL APar. Cs. 1868. április 16. Alvinczy Ferenc utasítása Sohlya Antalnak. ${ }^{850}$ VPL APar. Cs. 1868. április 16. Alvinczy Ferenc utasítása Sohlya Antalnak. ${ }^{851}$ VPL APar. Cs. 1867. november 12. Alvinczy Ferenc levele a váci püspökhöz. ${ }^{852}$ VPL APar. Cs. 1868. április 16. Alvinczy Ferenc utasítása Sohlya Antalnak.

${ }^{853}$ VPL APar. Cs. 1868. április 16. Alvinczy Ferenc utasítása Sohlya Antalnak. A váci püspöki szentszék a következőképpen változtatott az idézett ponton: „A hívek irányában, midőn hivatalos ügyben nála megfordulnak, minden nemü korholástól óvakodjék." VPL APar. Cs. 1868. április 16. Körrey Ferenc és Villiger István javaslatai az „Utasítások” című írás átalakítására.
} 
zsarolások, törvénytelen huzás-vonások, nyúzások ellen tehetsége szerént védelmezni." ${ }^{854}$ A papnak tehát joga, egyben kötelessége hívei érdekében közbelépni, különösen akkor, ha egy templomszolgával szemben merülnek fel panaszok. Mikor a kántor a plébánost illetéktelennek nevezte a magánegyezkedésen alapuló pénzügyek felülbírálásában, Alvinczy Ferenc eképpen fakadt ki: „Ha az inség sanyargatja a népet: akkor védheti a plébános az ő híveit, deha egy kántor zsarolja azokat: akkor a plébánosnak 'csitt!', 'hallgass! a neve nemde? Legyen bizonyos Sohlya úr, hogy a csongrádi plébános soha, semmi ügyben sem fogja elhagyni híveit, ha hozzá igazságos panasszal járulnak." ${ }^{\circledR 55}$

\subsection{Plébános és kántora a hívek perspektívájában}

A kántor tetteit nem csak a fegyelmezésre jogosult plébános, de a hívek közössége is számon tartotta. Ha úgy vélték, hogy nem tesz eleget az egyházi feljebbvalók iránti köteles tiszteletnek, azt haladéktalanul jelentették a plébánosnak. Alvinczy Ferenc levelében számtalan utalást találunk erre a jelentés-gyakorlatra. ${ }^{856}$ A plébánostól cserében azt várták el, hogy hatékonyan és haladéktalanul utasítsa rendre a templomszolgát.

A híveket közvetlenül - akár anyagilag, egzisztenciálisan is - érintő kihágásoknál súlyosabban esett latba a papsággal szemben tanúsított tiszteletlenség. A plébános és a káplánok elöljáró-mivolta ugyanis a hívek szemében nem képezte vita tárgyát. A kántortól minden időben azt várták el, hogy méltón képviselje az egyházat, tisztelje a helyi papságot, vagyis türelmet és engedelmességet tanúsítson. Mindezek tükrében nem csodálkozhatunk azon, milyen óriási visszhangot váltottak ki azok az esetek, amikor a kántor a káplánok vagy a plébánossal szemben nyíltan kifejezte ellenszenvét.

1867-ben, egy temetést követően a kántor megtagadta, hogy egy kocsira üljön az általa nem kedvelt káplánnal. Az eset a hívek szeme láttára többször is megismétlődött, és heves felháborodást keltett. Többen bekiabálással utasították rendre a makacs egyházszolgát, miközben a káplán is nyilvános állásfoglalásra kényszerült: „Elkezdődött a beszentelés és a bucsúztatás, minek végeztével Szálé Viktor [káplán] úr mondta: 'Keresztény hívek, én ünnepélyesen kijelentem, hogy a Kántor úr meg volt kínálva a kotsival és én le nem tiltottam erről s velem most is felülhet'. Ekkor a nép zugolodott

\footnotetext{
${ }^{854}$ VPL APar. Cs. 1867. november 12. Alvinczy Ferenc levele a váci püspökhöz. ${ }^{855}$ VPL APar. Cs. 1867. november 12. Alvinczy Ferenc levele a váci püspökhöz. $856 \mathrm{Pl}$. „A hívek már előttem is kijelentették megbotránkozásukat”; „többször jöttek (a hívek) a plébánoshoz”, VPL APar. Cs. 1868. április 16. Alvinczy Ferenc utasítása Sohlya Antalnak.
} 
mondván: Íme szépen szól a Tisztelendő Úr még hívja, és a nép meg támadta a kántort mondván: most üljön fel már a Kántor a kotsira mert úgy szép egy Temetés ha a pap mellett a kántor ül. A kántor felelte: 'Nem ülök fel most mert fázik a lábom'. Mire többen feleltük: 'Mégis nem szép hogy jusztra nem akar felülni'. Különösen Németh Pál (mondogatta), 'nem azért nem akar felülni, hanem mert kevély'; Mi zugolodva mondtuk: Hogy ez illetlenség, tiszteletlenség mit a Kántor tesz, és némellyek a körül állók közül felkiáltottak, miért is nem teszik ki a kántort?" ${ }^{857}$ A bosszankodó hívek a sértett papságtól várták a megtorló intézkedéseket, különösen azért, mert a papi rend tekintélyét látták veszélybe kerülni: „Ugyan miért türik már a papok ennek a kántornak rendetlenségét [...] tudjuk mennyit bosszantja, keseríti a papságot, a plébános mégsem szól! Csak egyet szólna: tüstént csapnák ki a kántort!" ${ }^{858}$ A hívek a nyíltan kifejezett nemtetszéssel és a plébános elé terjesztett panaszokkal igyekeztek nyomást gyakorolni a vezető lelkipásztorra, hogy állítsa helyre a meglazult plébániai fegyelmet.

5. Akire mindig ,sok szem figyel”

Amint felsorolt példáinkban láthattuk, sokoldalú viszony állt fenn a kántor és a szolgálatait igénybe vevő hívek között. A kántor elvárta egyrészt a templomlátogató nép megkülönböztetett tiszteletadását, az előre-köszönést és a köszöntés helyes formuláját. ${ }^{859}$ Ugyanakkor viselkedését, megnyilvánulásait állandó kontroll alatt tartotta, hisz tisztában volt azzal, hogy cselekedeteinek súlya és mintaértéke van; letisztult elvárások kereszttüzében áll.

Sohlya Antal kéziratban maradt jegyzeteiben olyan tanácsokat találunk, melyekre egy kezdő kántornak oda kellett figyelnie akkor, ha a hívek osztatlan elismerését óhajtotta kivívni. Mint írja: a kántornak a templomi szolgálattétel idején szerényen, áhítatosan kell viselkednie, hiszen „nincs botrányosabb a nép szemében, mintha az éneklész közömbös és hidegnek látszik szent vallása iránt" ${ }^{860}$ Lehetőleg ne mosolyogjon, hanem kellő komolysággal végezze a közös imádságokat, vessen keresztet, térdeljen le, ha kell. A temetési menetben vegye le a fövegét, ne bonyolódjon magánbeszélgetésbe, és a szertartás

\footnotetext{
${ }^{857}$ VPL APar. Cs. 1868. január 4. Nagyistók Imre kocsis vallomása. ${ }^{858}$ VPL APar. Cs. 1867. november 12. Alvinczy Ferenc levele a váci püspökhöz.

${ }^{859}$ A kántor ,,az úton, ha tisztességesen köszöntik, köszöntse vissza, nehogy emiatt megrovassék. Ha magánál előbbkelővel találkozik, előzze meg köszönésével.” Sohlya 1857. (kézirat) 437.

${ }^{860}$ Sohlya 1857. (kézirat) 438.
} 
után hazafelé irányítsa lépteit, ne a kocsmába. ${ }^{861}$ Sohlya Antal arra is figyelmezteti pályatársait, hogy a méltóságteljes viselkedés a kántor hétköznapi életének részét kell képeznie. Ha a kántor névnapi, keresztelői lakomára hivatalos, éjjel 10 óránál tovább ne maradjon, ne kártyázzon, vigyázzon arra, hogy mennyi bort fogyaszt, nehogy magáról megfeledkezve trágár dalok éneklésébe csatlakozzon. A népnyelv ugyanis nem felejt: ha egy kántor egyszer az ittasság vádja alá esett, attól többé nem szabadulhat. ${ }^{862}$

A mértékletes társasági élet mellett rendkívül fontos volt a kiegyensúlyozott családi élet. A kántornak ezen a téren is követelndő mintaként illett a hívek előtt állnia. Minden tekintetben törekednie kellett a példás, keresztény családfö képének kialakítására, hisz a békétlen élet előbb vagy utóbb a hívek tudomására jutott, és megbotránkozást szült. ${ }^{863}$ Sohlya Antal eképpen összegezte jegyzeteit: „,szóval legyen az éneklész minden tetteiben a szó telljes értelmében ember, és pedig józan, szerény, engedelmes, becsületes, jámbor, vallásos, példás, emberséges, művelt, valamint hivatalában úgy házi körében de minden tettei s lépteiben is. Csak így fogja bírni mindenki szeretetét, s tiszteletét, s holta után is valamint édes övéi, úgy a jámbor hívek is még évtizedek során át is elmondják hamvai fölött: 'Nyugodjék békén. Adjon Isten örök nyugalmat lelkének"', ${ }^{864}$

A kántori hivatal tehát az élet minden területét átható életstílus, életminta: viselőjét méltóságra és példaadásra, a tudatos keresztény élet megvalósítására kötelezte. Ha ezek a feltételek nem, vagy csak részlegesen teljesültek, a hívek nem késlekedtek panaszaikat a plébános elé terjeszteni, vagy a kántort élő szóban megróni, kritizálni, szóbeszéd tárgyává tenni.

Egy 19. századi kántor hivatali élete során, településről településre szegődve változatos helyi hagyományokkal szembesült. Ennek oka, hogy még az egyes egyházmegyéken belül sem élt általános érvényü, egységes énekgyakorlat, az egyházi év ünnepeit is sajátos, helyi színek gazdagították. A hagyomány erejének nemhogy a kántor, de a plébánosok is többnyire meghajolni kényszerültek. A hagyományszabta elvárások kitapasztalása tehát a frissen hivatalba lépő éneklész elsődleges feladata volt. Sohlya Antal jegyzeteiben arra figyelmezteti „sorsosait”, hogy mind az énekek rendjét, mind az orgonajáték stílusát tekintve „tegyen akként az éneklész, amint ezt a régi helyi szokás

\footnotetext{
861 Sohlya 1857. (kézirat) 24.

862 Összességében: „soha se feledje, hogy öreá sok szem néz, tehát szüntelen komolyan s illedelmesen beszéljen" Sohlya 1857. (kézirat) 439.

863 Sohlya 1857. (kézirat) 441.

${ }^{864}$ Sohlya 1857. (kézirat) 449.
} 
ajánlja". ${ }^{865}$ Az éneklész különösen a halotti búcsúztatás során igazodjon rugalmasan - akár kisebb szabályok felrúgása árán is - a gyászos felek igényeihez. ${ }^{866}$ A halotti búcsúztatókkal kapcsolatban is helyesen cselekszik a kántor, ha a hívek által kedvelt egyházi dallamokat veszi alapul, vagyis aláveti magát a hívek ízlésének. ${ }^{867}$ A szokás ereje nagy: ám a leghagyománytartóbb közösségekben is történtek kísérletek újításokra, a nép felvilágosítására. Szintén Sohlya Antal írásában találunk bíztatást arra, hogy amint alkalma nyílik rá, a kántor emeljen szót a gyermekded, babonás népszokások ellen. ${ }^{868}$

A Sohlya Antal tanítói jegyzeteiből kibontakozó kántor egyénisége teljesen feloldódik hivatalában. A keresztény ember mintaképe, afféle példaképpé magasztosult „népfia”, aki kétségtelen tekintélye ellenére kettős elvárásrendszer ütközőpontján: a hívek és helyi néphagyományok, valamint hivatali elöljárói vigyázó horizontjában áll. Mủveltsége okán úgy is mondhatnánk, hogy „úrként szolgált urat”, egyházi tisztsége mégis olyan társadalmi megbecsülést biztosított számára, melyet ha képes volt értő módon felhasználni, gyümölcseit még gyermekei és unokái is élvezhették.

A Sohlya Antal által képviselt magatartásminta a korabeli csongrádi viszonylatok között kiemelkedően haladó szellemü volt. Az újítások, egyéni kezdeményezések bátor felvállalása - legyen szó akár a szőlő permetezéséről, a 48-as Népkör megalapításáról vagy Haydn becsempészéséről a szentmisére -, a képzettségével párosuló öntudat és a tisztelet megkövetelése egészen szokatlan volt. Társaságát a többi laikus templomszolga ellenében nem az egyszerü hívek, hanem a település elöljárói, az orvosok, ügyvédek és a káplánok között találta meg. A csongrádi hívek többsége különcként tekintett a kántorra, kinek ötleteit először megmosolyogták (ld. a permetezés mintája) majd a módosabb nagygazdák lassanként követni kezdték.

Részben befolyásos főjegyző fia, részben a ,közbotrány elkerülése” vagyis a nevével egybeforrt hivatás okán maradhatott meg még lebénulása után is hivatalában.

\footnotetext{
865 Sohlya 1857. (kézirat) 50.

866 „Ha az idő kedvezőtlen vagy a szomorú felek világosan kívánnák ebben is, hogy a szertartás minél rövidebb legyen - az esetben ez énekből is - bár szabály ellen - néhány vers elhagyhatik, $\mathrm{s}$ így 5-6 vers elég.” Sohlya 1857. (kézirat) 28. „Ha a Szt. misét szolgáltató, vagy is a megemlékező, s ugy a helyiség szokása megkívánná, hogy az éneklész a fölajánlási énekben az elhunyt neve, $\mathrm{s}$ halálának ideje megemlíttessék az éneklész által, tehát helyesen cselekszik az éneklész, ha a jó szándékú megemlékezőnek ebbeli akaratát teljesíti." Sohlya 1857. (kézirat) 125-126.

867 „Végre ajánljuk az értelmes éneklésznek, miszerént népszerü búcsúztatóit azon dallamokon énekelje, melyet a nép ismerve szeret, s igyekezzék azon dallamokra készíteni búcsúztatóit." Sohlya 1857. (kézirat) 359.

868 „De némely helyeken holmi babona is dívik, így: midőn a holttest elvitetik az udvarról, fölforgattatnak a székek, melyeken a lelkész s a gyászfelek ültek azon indokból, hogy ez által a halál a házhoz vissza ne menjen. Tehát az ily nevetséges babona ellen az illetőkkel barátságosan össze jövén szót emelhet az éneklész, igyekezvén ezt az illetőkből kiírtani, nevetségessé tévén azt.” Sohlya 1857. (kézirat) 34-35.
} 
Ugyanakkor a gyengélkedő föéneklész és az alkalmatlan helyettes kántor békétlensége, az elöljáróság ragaszkodása Hornyik Károlyhoz, illetve a plébános küzdelme a kántorválasztások kiírásáért olyan feloldhatatlannak tünő helyzetet teremtett, melynek csak az idős kántor majd helyettesének közeli halála oldhatott fel a 20. század első éveiben.

\section{A SZOKÁSJOG EREJE: HARANGOZÓK ÉS SEKRESTYÉSEK}

Forrásaink jellegéből adódóan az egyházszolgák ügyes-bajos dolgairól árnyaltabb képet kapunk, mint egyszerü hétköznapjaikról. A harangozók és sekrestyések (továbbiakban: harangozók) személyéhez is föként hivatalukkal összefüggő vitás ügyek kapcsán kerülhetünk közel. Tevékenységükről írásos nyom alig maradt fenn. Ez részben az általános kutatói érdektelenségnek, másrészt a források szükösségének tudható be. A fejezet elején sorra veszem a csongrádi bel- és külsővárosi harangozók feladatait, jövedelmét, személyét. Ezt követően a vérséghez kötődő a szokásjog erejét, a 19. század végén bekövetkező változások körülményeit vizsgálom meg a Keviczky család példáján.

1. A harangozók jövedelmi viszonyai, feladatai

A harangozói hivatal önálló megléte azokra a plébániákra jellemző, ahol a település lélekszáma indokolja a sekrestyés és harangozó feladatainak különválását. Kisebb falvakban a kántori, tanítói, harangozói és sekrestyési hivatalt rendszerint egyetlen személy töltötte be. Bizonyos, hogy amióta Csongrádnak harangjai vannak ${ }^{869}$, azóta harangozó és sekrestyései is voltak, és a funkciók szétválására sosem került sor. ${ }^{870} 1769$ után két harangozó és sekrestyést (campanista) valamint két egyházfit (aeditus) találunk Csongrádon; külön a belsővárosi Szent Rókus-templomban - melynek kegyura a település, ${ }^{871}$ és külön a külsővárosi Nagyboldogasszony-templomban, melynek kegyura a gróf Károlyi család volt. ${ }^{872}$

A harangozó megnevezés a latin campanator/campanista szó tükörfordításaként a templomszolga legfontosabb funkciójából, a harangok kezeléséből veszi eredetét, ám a feladatkör korántsem ebben merült ki. Forrásainkban találkozunk még a sekrestyés,

\footnotetext{
${ }^{869}$ A csongrádi harangokról lásd: Dudás 1997; Dudás-Köhegyi 2000.

${ }^{870}$ Kaposváron 1915-ig ugyanez volt a helyzet. Hoss. 1948. 63.

871 V.ö. Nagy 2008. (kézirat).

872 V.ö. Góg 1984. 163.
} 
harangozó, templomgondnok, egyházfi, gazda, templomgazda megnevezésekkel is. A külsővárosi Nagyboldogasszony-templomban csak a harangozó, illetve az adományok pénzkezelése okán ritkábban az egyházfi megjelölés élt. ${ }^{873}$

Amíg a Szent Rókus-templom harangozóját a kegyúri funkciót betöltő helyi elöljáróság emelte a posztra, Csongrád-Külsővárosban még az 1760-as években adta Keviczky András kezébe Kanyó András plébános a plébániatemplom kulcsát, a tisztség pedig apáról fiúra szállt. Bizonyos, hogy a csongrádi Öregszőlők között is állt egy harangláb, külön fizetett harangozóval. ${ }^{874}$ A továbbiakban csak a bel- és külsővárosi, vagyis a templomokhoz kötődő harangozókkal foglalkozunk.

Az első harangozók kinevezésének körülményeiröl nem sokat tudni. A Keviczky család hagyománya szerint Kanyó András plébános az 1760-as években a következő szavak kíséretében nevezte ki a harangozót: „mindaddig viseli a te családod a szolgálatot, míg a becsületben megmarad". ${ }^{875}$ A Külsővárosban harangozó-választásra a következő 120 esztendőben nem került sor. 1888-ban, Keviczky György elbocsátását követően Hegyi Antal plébános személyes választása nyomán Szőke János harangozót erősítette meg posztjában, melyhez a püspöki jóváhagyást is kieszközölte. Ez a lépés azonban kiváltotta a harangozói javadalmakat biztosító községi elöljáróság, illetve a kegyúri jogokat gyakorló Károlyi család ellenkezését is, kik ugyancsak érdekeltnek érezték magukat a harangozókérdésben. Szőke lemondása után (1895) a választásra már nyilvános pályázat kiírását követően, a kerületi esperes elnöklete alatt került sor.

A kántorválasztástól eltérően a harangozókat nem hallgatták meg, csupán a benyújtott pályázatokat tekintette át a testület, majd kikérték a jelölteket ismerő kurátor véleményét. Az állásra csak katolikus, helyi illetőségü, családos egyének pályázhattak. ${ }^{876}$

Mivel a harangozói tisztség nem igényelt különleges tudást, sokkal inkább

\footnotetext{
873 A fogalmak használata forrásainkban igen zavaros. Kurátornak vagy templombirónak, egyházfinak, templomgondnoknak szokás nevezni azt a pénzkezeléssel megbízott világi férfit, aki a templom gazdálkodását követi nyomon. A Hoss József-féle kaposvári plébániatörténetben az egyházfi egyértelmüen a sekrestyést jelöli. V.ö. Hoss 1948. 63. Az 1824-ik évi csongrádi Canonica Visitatioban az aeditus kifejezés fedi a templomgondnoki funkciót ellátó személyt. A kurátor szó használata a népnyelvben igen gyakori, de megtévesztő, mivel az aeditusra és a belsővárosi harangozó és sekrestyésre (a visitatioban: campanatores) egyaránt alkalmazták. Forrásaink következetlenségén átívelve a továbbiakban a „harangozó” megnevezést vesszük át, a kurátor és egyházfi kifejezéseket meghagyjuk a templomgondnoknak. Ld. Pogonyi 1908. 64; M. Kat. Lex. XI. 2006. 996.

874 1853-ban Lantos István szölöhegyi harangozó arról panaszkodik a községi elöljáróknak, hogy ugyan jogosult fizettség fejében a nagyobb gazdáktól 2, kisebbektől 1 garast követelni, csak nagyon kevesen fizetnek neki. Kéri, hogy jövedelmét - ahogy a fenti nehézségek miatt korábban is - a községi pénztárból fedezzék. A képviselők meg is szavazták az év 3 pft. értékü, csekély javadalmat. Forgó-Forgó 1987. 62. 875 VPL APriv. Hegyi Antal, 1888. október 23. Keviczky Sándor nyílt levele.

${ }^{876}$ Csongrádi Közlöny, 1895. szeptember 1. II. évf. 35. szám, 4. old.
} 
jellembeli feddhetetlenséget és praktikus készségeket, alantasabb hivatalnak számított a kántorénál; a fizetsége is fele annyi volt. ${ }^{877}$ A külsővárosi harangozók jövedelmét a Canonica Visitatio alapján biztosították a település pénztárából. ${ }^{878}$ Itt a harangozó éves jövedelme a 18. század végén és a 19. század első felében is 100 rhénes forint, 2 öl tüzifa és 300 kéve füteni való nád volt. A templomi ruhák mosásáért, vasalásáért a templompénztárból évi 24 forintot utaltak ki neki. ${ }^{879}$ A belsővárosi harangozó fizetése jóval kevesebb volt: összesen évi 50 váltó forint, egy köböl búza és 200 kéve füteni való nád. Ehhez viszont nem járt lakás, vagy külön illetékszedési jog a keresztelések vagy asszonyavatások $^{880}$ után. Amikor a mindenkori belsővárosi harangozó fizetésemelésért folyamodott, rendszerint külsővárosi pályatársa méltányosabb körülményeivel hozakodott elö. ${ }^{881}$

A külsővárosi harangozó 1855-ben a következő, szánalmat keltő sorokkal kereste fel a váci püspököt: „ősatyáim által, s már kilenczven éven keresztül e család által viselt harangozói szolgálat a boldogabb időkben megállapított csekély fizetéssel felettébb terhes, S abbóli megélhetésem nyomorusággal teljes". ${ }^{882}$ A fizetésemelési kérelem 1857-ben, Virter Lajos plébános javaslatát követően talált meghallgatásra. ${ }^{883}$ Ugyancsak 1855-ből maradt fenn Gyovai József csengettyüs (harangozósegéd) fizetésjavítás iránt folyamodó levele. Az írásból kiderül, hogy harangozó bojtár összesen évi 10 váltó forintot kapott szolgálataiért. ${ }^{884}$

23 esztendővel később a külsővárosi harangozó éves fizetése 196 váltóforint 50 krajcárra, míg a Szent Rókus-templom harangozó és templomgondnokáé 123 váltóforint 50 krajcárra rúgott. ${ }^{885} 1894-b e n$, az új belsővárosi harangozó hivatalba lépése alkalmából nyomban fizetésemelési kérelmet nyújtott be, melynek okaként a város gyarapodó

\footnotetext{
${ }^{877}$ VPL APar. Cs. 1878. június 8. Szvoboda József levele a váci püspökhöz. A harangozó „speciális tudása” a harangok megfelelő kezeléséhez kötődhetett.

878 VPL APar. Cs. 1878. június 8. Szvoboda József levele a váci püspökhöz.

${ }^{879}$ NPI Canonica Visitatio 1842; VPL APar. Cs. 1842. június 2. Keviczky András levele a váci püspökhöz.

${ }^{880}$ Asszonyavatás: Az asszonyok szülés utáni, rituális bevezetése a templomba, másképp: introductio mulieris post partum. A magyar nyelvterület egészére jellemző purifikációs szertartás, mely a nyugati és a keleti egyházban is öröklődött. Bővebben lásd: Bárth Dániel 2005.

881 Balogh Énok belsővárosi harangozó kérelme a városi közgyülési jegyzőkönyvben: „a mennyiben a külsővárosi harangozónak a város évenként ostyasütésre három öl kemény tüzifát szokott adni, [kéri, hogy] e címen neki is állapítana meg némi jutalékot, méltányosnak találtatván, ostyasütésért évi 24 frt. évi általányt állapított meg a belsővárosi harangozó részére [az elöljáróság]”. Csongrádi Közlöny, 1895. szeptember 15. II. évf. 37. szám, 3. old.

${ }^{882}$ VPL APar. Cs. 1955. június 1. Keviczky György levele a váci püspökhöz.

${ }^{883}$ VPL APar. Cs. 1857. február 27. Csongrádi Tanácsülés jegyzőkönyvi kivonata.

${ }^{884}$ VPL APar. Cs. 1857. május 6. Gyovai József levele a váci püspökhöz.

885 VPL APar. Cs. 1878. június 8. Szvoboda József levele a váci püspökhöz. A kérdéses időszakban, a Belsővárosban egyetlen személy töltötte be a harangozó és a kurátor funkcióját.
} 
lélekszámát és az egyre sűrüsödő templomi teendőket jelölte meg. Az igen jelentős, 123 forintról 200 forintra való emelést egyedül Hegyi Antal plébános támogatta, a többi képviselő elutasította. ${ }^{886} \mathrm{Az}$ élelmes harangozó még ugyanebben az évben ostyasütés fejében külön díjat harcolt ki a községi elöljáróságtól. ${ }^{887}$ 1895-ben a külsővárosi harangozói állás jövedelme - a lakáson, háztáji kerten és a szokásos egyházi illetményeken kívül - a következőképpen alalkult: évi 100 forint fizetés, 30 ft. nádváltság és 3 öl tüzifa értékü (36ft.) faváltság, ostyasütésre 6 véka búza, egyházi pénztárból a templomi ruhák mosásáért 30 frt, szappanra 12 frt. 50 kr. utólagos, negyedévi részletekben. ${ }^{888}$

A harangozó bérének számottevő része temetés, esküvő, keresztelő vagy asszonyavatás után járó, stoláris javadalom volt ${ }^{889}$, mely 1802 előtt versenként ${ }^{890}$ két krajcárt jelentett. Az 1842-es püspöki vizitációs jegyzőkönyvben azonban - Keviczky András harangozó bosszúságára - elmulasztottak rögzíteni néhány stoláris jövedelemforrást; és a településtől kapott természetbeli juttatások is kimaradtak. A helyi elöljáróság ugyanis a vizitációra hivatkozva megtiltotta a harangozónak, hogy külön díjat szedjen a harangozásért céhes miséken, esküvőkön, haldoklókért és gyermekágyas asszonyok avatása alkalmával. Ezekért a feladatért korábban versenként hat krajcárt is elkérhetett a hívektől. Keviczky András külön fájlalta, hogy a községtől kapott kaszálóját ugyancsak el akarták venni tőle.

A harangozó a panaszlevélhez csatolta nagyapjának díjszabásait. Eszerint a 18. század végétől a 19. század közepéig semmit nem változott a külsővárosi harangozó stoláris jövedelme, mely a következőképpen nézett ki: szentlélek (haldoklóért végzett) és esketés alatti harangozásért versenként 6 krajcár, énekes requiem és libera alatti szolgálatért külön-külön 30 krajcár, céhes miséért 18 krajcár, gyermekágyas asszony avatásáért 30 krajcár járt. ${ }^{891}$ A Belsővárosban csak 1855-ben engedélyezték, hogy a harangozó minden vers után 6 váltó krajcárt szedhessen. ${ }^{892}$

Csongrád elöljárói 1892-ben keltezett levelükben arról számoltak be Vaszary Kolos hercegprímásnak, hogy a plébános a Canonica Visitatio figyelmen kívül hagyásával szabad kezet engedett a külsővárosi harangozónak a stoláris díjak szedésére. Ezért „ott hol ez előtt

\footnotetext{
886 Tiszavidék, 1894. október 28. V. évf. 43. szám, 3. old.

887 Csongrádi Közlöny, 1895. szeptember 15. II. évf. 37. szám, 3. old.

${ }^{888}$ Csongrádi Közlöny, 1895. szeptember 1. II. évf. 35. szám, 4. old.

${ }^{889}$ VPL APar. Cs. 1806. március 5. A hódmezővásárhelyi uradalmi ügyintéző levele a csongrádi állapotokról.

${ }^{890}$ Vers: Egy vers Csongrádon a harangok megcsendítésének egy ’egysége'.

${ }^{891}$ VPL APar. Cs. 1844. Keviczky András dátum nélküli levele a váci püspökhöz.

${ }^{892}$ VPL APar. Cs. 1855. június 1. Bernát Ferenc levele a váci püspökhöz.
} 
rendes viszonyok között 2 frt volt fizetendő, ma 8-12 forint számíttatik fel”. ${ }^{893}$ Ha ez igaz, akkor a harangozó bizonyos esetekben háromszor többet keresett a kántornál. ${ }^{894} \mathrm{Az}$ elöljáróság levele azért is tanulságos, mert kiderül belöle, hogy a Canonica Visitatiot nem állapotfelmérő leírásként, hanem szerződésként értelmezték. Ugyanez mondható el a laikus templomszolgákról is, akik leveleikben cáfolhatatlan hivatkozási pontként utalnak a püspöki látogatási jegyzőkönyvre.

1895-ben stoláris járadék címén asszonyavatásért 6 krajcárt, délelőtti esketésért 30, délutániért 60 krt. kérhetett a külsővárosi harangozó. ${ }^{895}$ Miután elkészült a Jézus Szívének tiszteletére szentelt harang, megszólaltatásáért 2 forintot a templomnak, 30 krajcárt a harangozónak kellett adni. ${ }^{896}$ Összességében a külsővárosi harangozói állás éves jövedelme a juttatásokkal együtt 1000-1200 forintra rúgott. ${ }^{897}$ Ahogy 1904-ből visszatekintve a helyi sajtóban némi túlzással megjegyezték: „a harangozóknak nagyobb jövedelmük volt, mint akár az akkori főszolgabírónak, akár a járásbírónak”. ${ }^{898}$ Az illetmények újrarendezésére 1904-ben, Hegyi Antal plébános távozását követően került sor. A viták kereszttüzében álló harangozói jövedelmeket a kerületi esperes elnökletével összeült bizottság végül a felére csökkentette le. ${ }^{899}$

A sekrestyési feladatköröket tekintve a bel- és külsővárosi harangozó egyaránt rendelkezett saját templomkulccsal, harangozott, amikor kellett ${ }^{900}$, sütötte az ostyákat, előkészítette, tisztán tartotta, vasalta, szükség esetén megvarrta az elszakadt miseruhákat. A papság fehérneműinek mosásáért a külsővárosi harangozó külön fizetséget kapott (30 forint). ${ }^{901}$ Szentmise előtt segített a papnak öltözködnii02, meggyújtotta a gyertyákat, kihelyezte a kelyhet. Ministráns gyermekek hiányában ő szolgált az oltár mellett. ${ }^{903}$ A templomban illetlenül viselkedőket figyelmeztette, ki is vezethette. A Belsővárosban ő volt az orgonafúvó-nyomó, míg a Külsővárosban erre a feladatra külön segédet alkalmaztak. A

\footnotetext{
${ }^{893}$ VPL APriv. Hegyi Antal, 1892. március 14. Csongrád kéviselőtestületének levele a hercegprímáshoz.

${ }^{894}$ A vádpont szerint a kántor 84 krajcárt, míg a harangozó esetenként 2-3 forintot is megkapott. Csongrádi Közlöny, 1894. március 4. I. évf. 1. szám, 1-2. old.

${ }^{895}$ VPL APar. Cs. 1898. október 30. Hegyi Antal levele a váci püspökhöz.

${ }^{896}$ VPL APriv. Hegyi Antal, 1894. július 10. Hegyi Antal levele a váci Egyházmegyei Hatósághoz.

${ }^{897}$ Csongrádi Lap, 1895. szeptember 22. V. évf. 39. szám, 3. old.

898 Csongrádi Újság, 1904. november 6. II. évf. 45. szám, 1. old.

${ }^{899}$ Csongrádi Újság, 1904. november 6. II. évf. 45. szám, 1. old.

900 Minden nap reggel, délben este, misék előtt jeladásul, mise alatt úrfelmutatáskor, liberás misében úrfelmutatás után 5 percig, temetés alkalmával; processzió ha indul a községből, ha búcsúsok érkeznek; vihar elejébe, tűz, árvíz, egyéb veszedelem idején. Ld. Pogonyi 1908. 93-97.

901 VPL APriv. Hegyi Antal, 1888. november 6. Hegyi Antal levele a kerületi espereshez.

902 A csongrádi népnyelv a sekrestyét segrist-nek emlegette, a harangozó és sekrestyés fö feladatai ide kötődtek. Ld. VPL APar. Cs. 1868. február 28. Keviczky György vallomása.

${ }^{903}$ VPL APriv. Hegyi Antal, 1888. Keviczky György dátum nélküli levele a váci püspökhöz.
} 
plébános utasítására adományokat gyüjtött a hívektől. ${ }^{904} \mathrm{Az}$ utolsó kenet feladására igyekvő papot vagy ő, vagy a kántor kísérte el. A Belsővárosban ő szervezte a gyalogos búcsújárásokat Máriaradnára, Félegyháza-Szentkútra és Szegedre. Valójában mindenféle apró-cseprő ügyben, mint a rendetlenkedő gyermekek fegyelmezése, a templomban hangoskodók kivezetése vagy a templom körül legelésző állatok elhajtása lehetett rájuk számítani. ${ }^{905}$ Amikor Alvinczy Ferenc plébános és Sohlya Antal kántor nem állt szóba egymással, a harangozó közvetítette közöttük a leveleket. ${ }^{906}$

\section{Csongrád-Belsőváros}

A belsővárosi Szent Rókus-templom harangozói posztján az 1830-as években Bernát Antalt találjuk. Elődeiről ezidáig nem került elő feljegyzés. ${ }^{907}$ Fia, Bernát Ferenc az 1840es évek elején vette át apja tisztségét, és egészen 1893. december 5-én bekövetkezett haláláig ő maradt a Szent Rókus-templom sekrestyése és harangozója. ${ }^{908}$ Bernát Ferenc hivatali utóda, Balogh Énok számos jövedelemjavítási kérelmet nyújtott be a helyi elöljáróság felé, változatos sikerrel. Egy 1894-ben keletkezett levelében eképpen panaszkodott: „A templom gondnoki és sekrestyési teendőim végzése közben a harangozást - természetesen - másokkal kell teljesíttetnem." ${ }^{909}$ Segédeit saját keresetéből fizette, az ostyasütéshez és tömjén égetéséhez szükséges fát szintén a maga tüzelőjéből biztosította. Fizetésének évi 120-ról 200 forintra emelését a csongrádi elöljáróság megtagadta. ${ }^{910}$ Forrásaink alapján Balogh Énok a szokásos harangozói tennivalók mellett a kurátor funkcióját is betöltötte. ${ }^{911}$

\footnotetext{
904 „Én is gyüitöttem ezekre: öröklámpára 4 frt 30 krt, miseruhára 4 frt 40 krt, a sátorra [baldachin] 5 frt. Ezeket a pénzeket írásosan adtam át a Hegyi föt. Úrnak, mint plébánosnak.” VPL APriv. Hegyi Antal, 1898. augusztus 22-26. Palásti Lajos vallomása.

${ }^{905}$ VPL APriv. Hegyi Antal, 1894. július 10. Hegyi Antal levele a váci Egyházmegyei Hatósághoz; Csongrádi Közlöny, 1896. szeptember 27. III. évf. 39. szám, 4. old.

906 VPL APar. Cs. 1867. november 12. Sohlya Antal levele a váci püspökhöz. Hagyományosan a harangozó végezte templom és a plébánia takarítását, templomi terítők tisztítását, cseréjét, a lobogók és zászlók tisztítását, a templom virágozását, a temetési kellékek gondozását, télen ő intézte a tüzgyújtást, a templom környékének rendben tartását, kint a hó takarítását. Bővebben lásd: Pogonyi 1908.

907 VPL APriv. Mátyus János, 1826. Mátyus János dátum nélküli levele a váci püspökhöz.

908 Tiszavidék, 1893. december 17. IV. évf. 51. szám, 3. old.

${ }^{909}$ MNL CsML CsL V.B.71. 1894. október 4. Balogh Énok levele a községi elöljáróság felé.

910 MNL CsML CsL V.B. 71. 1894. október 4. Balogh Énok levele a községi elöljáróság felé. Az ostyasütéssel kapcsolatban Pogonyi Bernát leszögezi, hogy az ostya csak finom búzalisztböl és vízből állhat, továbbá igen vékonynak kell lennie. A mézeskalácsostól beszerzett ostyasütő vasat fehér viasszal kenték meg, hogy ne tapadjon bele a formába. Sütés után egy tiszta, másra nem használható gyalult deszkatáblán kellett formára vágni az ostyákat. A müveletet legalább havonta kétszer meg kellett ismételni. Ld. Pogonyi 1908. 99-100.

911 Csongrádi Közlöny, 1896. szeptember 20. III. évf. 38. szám, 4. old.
} 


\section{Csongrád-Külsőváros}

\subsection{A Keviczky-éra alkonya}

Az első csongrád-külsővárosi harangozó Keviczky András volt; a harangozói házat is az ő lakhelyeként tüntették fel a II. József-féle kataszteri felmérésen. ${ }^{912}$ Fia 52 esztendőn keresztül viselte hivatalát. 1827-től már unokáját, az ifjabb Keviczky Andrást találjuk a poszton. ${ }^{913}$ A családból elsőként ő rendelkezett szerződéssel, elődei még „szabadon éltek". 914 A Jancsovics József plébános idejében végzett (1842) kánoni látogatási jegyzőkönyv szerint András akkoriban volt 48 esztendős, felesége Csábi Rozália. Munkáját megbízhatóan és kötelességtudóan végezte. Keresete évi 110 forint, három öl fa, 300 kéve füteni való nád továbbá 6 véka gabona volt. A hívek minden versért 6 krajcárt fizettek neki. ${ }^{915}$ Keviczky András ebből a jövedelemből tartotta fenn szépen gyarapodó családját. ${ }^{916}$ András halála után (1848) annak 23 esztendős fia, György vette át a harangozóságot. ${ }^{917}$ György az asztalos mesterséget is kitanulta, az 1840-es évek derekán két esztendeig tartó vándorútra is elment. 1852-ben példás magaviseletének igazolására kért bizonyítványt a csongrádi elöljáróságtól. ${ }^{918}$ Keviczky György lelkes szőlőművelő hírében állt, szőlőjében nemesített gyümölcsfákat nevelt. Amikor Hegyi Antal plébános 1886-ban Csongrádra került, „Gyuri bácsi” már közel negyven esztendeje szolgált a Nagyboldogasszonytemplomban. ${ }^{919}$

Hogy pontosan mi történt 1888. október 23-án, reggel negyed kilenckor a

\footnotetext{
912 Kruzslicz 1988. Kruzslicz tanulmányából a harangozó neveként helytelenül Reviczky szerepel. A ritkábban Kevitzkyként feltüntetett családnevet következetesen Keviczkynek írjuk.

913 Füzesi é.n. (kézirat); VPL APar. Cs. 1844. Keviczky András dátum nélküli levele a váci püspökhöz.

9141848 elött a templomszolgák mentesek voltak az adóterhektöl és a robot kötelessége alól. VPL APar. Cs. 1842. június 2. Keviczky András levele a váci püspökhöz.

915 NPI Canonica Visitatio 1842.

916 Keviczky András gyermekei voltak: Keviczky Erzsébet szül. 1821. november 8; Keviczky Viktória szül. 1823. december 23; Keviczky György szül. 1825. április 13; Keviczky Rozál szül. 1826. november 2; Keviczky Márta szül. 1828. július 28; Keviczky Veron szül. 1831. február 2; Keviczky Franciska Márta szül. 1833. április 22; Keviczky András Ádám szül. 1835. december 23. V.ö. NPI Születési anyakönyvek.

${ }^{917}$ VPL APar. Cs. 1888. november 22. Keviczky György levele a váci püspökhöz.

${ }^{918}$ Forgó-Forgó 1987. 45.

919 Keviczky György állítása szerint családja 1888-ban már 150 éve viselte a harangozói tisztséget Csongrádon. Mivel a templom építésének ideje objektíven rácáfol erre (1769), a kijelentést akár jószándékú túlzásnak is vélhetjük. Kevesebb valószínűséggel jelentheti azt is, hogy az első Keviczky a mai Szent Rókustemplomban kezdte szolgálatát, és onnan került át az új plébániatemplomba. Esélyt hagynék annak a feltételezésnek is, hogy a harangozó egyszerúen nem volt tisztában a templom építésének idejével, és szülei, nagyszülei nagyvonalú történetei nyomán alakult ki benne a „másfél százados múlt” meggyőződése. VPL APar. Cs. 1888. november 22. Keviczky György levele a váci püspökhöz.
} 
plébániatemplom sekrestyéjében, azt csak a jelenlévő plébános és a harangozó tudhatta bizonyosan, ám ketten kétféleképpen emlékeztek az eseményekre.

A plébános a kérdéses nap reggelén miséhez készülődve a harangozót nem lelte a sekrestyében. Miután sikertelenül kereste otthonában és a családtagok közül senki nem akart a segítségére lenni, a plébános egyedül öltözködött fel és ministráns nélkül kezdett el misézni. „Csak mikor a főoltár előtti énekes mise végéhez közelgett, érkezett meg valahonnan az én harangozóm, kit mikor távolléte miatt kérdöre vontam, daczosan azt felelte, hogy a piaczon volt kukoriczát vásárolni. ${ }^{920}$ Miután viselkedése miatt megfeddte a templomszolgát, az válaszul nekitámadt, így a plébános önvédelemből arcon ütötte. ${ }^{921}$ Másik levelében Hegyi Antal azt írja, hogy a harangozó maga provokálta ki az első ütést, és csak utána támadt rá. ${ }^{922}$ Miután elvette tőle a templom kulcsait, az öreg harangozó hozzávágta: „tehet velem, amit akar, mert mégis megmutatom, hogy nem fog ki rajtam”. ${ }^{923}$

A harangozó állítása szerint csak pár percre távozott a sekrestyéböl, ezért nem találta a megérkező plébános, aki felbukkanása után nyomban rátámadt: arcon verte és fojtogatni kezdte. Ö lefejtette magáról a rátámadó lelkiatyát, majd - mintha mi sem történt volna - ministrált neki a szentmisén. A mise végén a plébános közölte vele, hogy többé nem tart igényt a szolgálataira. ${ }^{924}$

Az öreg harangozó fia, Keviczky Sándor ${ }^{925}$ csongrádi hivatali jegyző még az elbocsátás napján nyílt levelet intézett a plébánoshoz, melyet egy szentesi nyomdában sokszorosított és városszerte terjesztett. Keviczky Sándor ajánlata szerint a család megbocsájt a plébánosnak abban az esetben, ha édesapját visszahelyezi a harangozói állásba. A levél hangvétele hullámzó, a sorok rendkívüli zaklatottságról árulkodnak: „merem hinni, hogy ön mint pap és ember egyáltalán nem fog egy elaggott, szegény, élete alkonyán lévő embert kenyerétől megfosztani csupán azért, mert az ön által neki adott arczul ütésekért önnek kezeit meg nem csókolta és köszönetet nem mondott [...] végre kijelentem, hogy azért intéztem ez úton főtisztelendőségedhez kérelmemet, mert személyesen önhöz menni magamnak elég tanácsosnak nem gondoltam”. ${ }^{926}$

\footnotetext{
${ }^{920}$ VPL APriv. Hegyi Antal, 1888. november 6. Hegyi Antal levele a kerületi espereshez.

${ }^{921}$ VPL APriv. Hegyi Antal, 1890. március 17. Hegyi Antal levele a váci püspökhöz.

922 „Dorgálásomra daczos és durva felelés volt részéről a válasz. Azt mondtam tehát neki, hogy fogja be a száját és ne feleseljen velem, mert különben kap olyan nyaklevest, hogy megemlegeti, mikor a koporsóba teszik is. De ő azt vágta vissza, hogy azt szeretné ö látni! Hát a mire kíváncsi volt, megkapta négyszem közt melegiben" VPL APriv. Hegyi Antal, 1888. november 6. Hegyi Antal levele a kerületi espereshez.

${ }^{923}$ VPL APriv. Hegyi Antal, 1888. november 6. Hegyi Antal levele a kerületi espereshez.

${ }^{924}$ VPL APriv. Hegyi Antal, 1888. Keviczky György dátum nélküli levele a váci püspökhöz.

925 Született 1863. május 23. NPI Születési anyakönyvek.

${ }^{926}$ VPL APriv. Hegyi Antal, 1888. október 23. Keviczky Sándor nyílt levele.
} 
Nem csak a családot, de a teljes csongrádi közvéleményt felkavarta Keviczky György felfüggesztésének híre. Tekulics János befolyásos városi alkalmazott két havi próbaidőt próbált kieszközölni a harangozónak. Ám pár nappal később, miután ismeretlenek kővel dobták be Schimmalcsik káplán ablakát, a próbaidő terve füstbe ment. Hegyi Antal már másnap egy nyilvános helyen ,ablakbeverőnek” nevezte a Keviczky fiúkat, akik becsületsértésre hivatkozva a királyi járásbírósághoz fordultak elégtételért. ${ }^{927}$

1888. november 6-án a váci megyéspüspök felszólítására Ulár István kerületi alesperes kérdőre vonta Hegyi Antalt az esettel kapcsolatban. ${ }^{928}$ A plébános érvelése szerint, mivel az ő hivatali előde nevezte ki Keviczky György ősét harangozónak, így a mindenkori plébánosnak áll jogában a leszármazottat megfosztani hivatalától. ${ }^{929}$ Bevallása szerint már régóta fontolgatta az öreg harangozó elbocsátását, mivel anélkül járt ki a szőlőjébe, hogy távozását a plébánosnak jelentette volna. Ugyanakkor az utolsó kenetet feladó pap éjjeli kísérését módszeresen kikerülte. ${ }^{930}$ Hegyi Antal a templom és a templomi ruhák tisztaságában, rendezettségében is súlyos hiányosságokat tapasztalt, végül felhánytorgatta, hogy a papok fehérnemüjének mosását - fizetésemelés elmaradása miatt az öreg harangozó nemrég felmondta. ${ }^{931}$

Keviczky György pár héttel később keltezett levelében azt bizonygatta a váci püspöknek, hogy Hegyi Antal elődei kivétel nélkül elégedettek voltak szolgálataival, ám a mostani plébános érthetetlen ellenszenvet táplál iránta - már ha az arcon ütést az ellenszenv jeleként értelmezzük. ${ }^{932}$ Hivatkozott őseire, agg korára, menthetetlen szegénységére, közmegbecsülésére, őseinek megbecsültségére, csak ne fosszák meg a harangozóságtól. ${ }^{933}$ Schuszter Konstantin azonban Hegyi Antalnak adott igazat. A „plébánosára kezet emelő” harangozó felfüggesztését nem oldotta fel, így 1888. december 10-én a 4446. számú főpásztori határozattal Keviczky Györgyöt hivatalosan is elmozdították állásából. ${ }^{934}$

A csongrádi elöljáróság - a közvéleményen osztozva - nem értett egyet Keviczky György elbocsátásával. A harangozó kilakoltatását követelő plébános kérelmeit válasz nélkül hagyták, így Hegyi Antal a püspöknél és az alispánnál is bepanaszolta a testületet. ${ }^{935}$

\footnotetext{
927 VPL APriv. Hegyi Antal, 1888. november 6. Hegyi Antal levele a kerületi espereshez.

${ }^{928}$ VPl APriv. Hegyi Antal, 1888. november 6. Hegyi Antal levele a kerületi espereshez.

929 „A mely tényező őt betette állásába, mikor arra érdemtelennek bizonyult, az a tényező ki is tette.” VPL APriv. Hegyi Antal, 1888. november 6. Hegyi Antal levele a kerületi espereshez.

${ }^{930}$ VPL APriv. Hegyi Antal, 1888. november 6. Hegyi Antal levele a kerületi espereshez.

${ }^{931}$ VPL APriv. Hegyi Antal, 1888. november 6. Hegyi Antal levele a kerületi espereshez.

932 VPL APar. Cs. 1888. november 22. Keviczky György levele a váci püspökhöz.

${ }^{933}$ VPL APar. Cs. 1888. november 22. Keviczky György levele a váci püspökhöz.

${ }^{934}$ VPL APar. Cs. 1888. december 6. Schuszter Konstantin püspök levele Hegyi Antalhoz.

935 VPL APar. Cs. 1889. április 15. Hegyi Antal levele a váci püspökhöz.
} 
Keviczky György a belügyminisztériumi osztálytanácsoshoz írt táviratában kérte, hogy április végéig a harangozói lakban maradhasson, ugyanis mint írja: „ez időben nem tudok hová húzódni”. ${ }^{936}$ A házat végül 1889. április 30-án, csendőri beavatkozással hagyta el öreg Keviczky György és családja. ${ }^{937}$ Különösen megrendítette a közvéleményt, hogy a megalázó kilakoltatásra Nagypénteken került sor. ${ }^{938}$

Keviczky György 1898. augusztus 21 -én hunyt el. Utolsóként a családból, összesen 40 esztendőn keresztül volt a Nagyboldogasszony-templom harangozója. ${ }^{939}$ Az elbocsátás kiváltotta visszhang azonban évekig zengett a Hegyi plébánossal hadilábon álló sajtóban és a plébános elhelyezéséért küzdő hívek leveleiben. 1892-ben a csongrádi hívek egy csoportja eképpen panaszkodott Vaszary Kolos hercegprímásnak: „Keviczky Györgyöt [Hegyi Antal] vad kegyetlenséggel megverte és fojtogatta őt, szolgálatából pedig elcsapta." ${ }^{940}$ A Csongrádi Lap 1901-ben Közveszélyes örült a csongrádi parochián címmel az eset erősen torzított változatával állt elö: „[Hegyi Antal] alig hogy elfoglalta a parochiát, 2 hétre rá az öreget, ki 40 évig a templom szolgálatában állott, harangozott a templomban, a hívek szeme láttára felpofozta, kilökte, s elcsapta állásából a 70 éves aggot, aki bánatában és szégyenében pár hét mulva meghalt."941

\subsection{Szőke János pályája}

Hegyi plébános Keviczky György helyére az akkor 37 esztendős búcsúvezetőt, Szőke Jánost terjesztette elő a külsővárosi harangozói állásra. ${ }^{942}$ Választását a harangozó jelölt személyes kvalitásai indokolták: „Eddig is egyike volt ő legbuzgóbb, s általam nagyrabecsült híveimnek, jelen állásában pedig jóakarata, ügyessége, tisztaság-szeretete és szolgálatkészsége által négy hónap óta mindenkor méltónak tanusította magát a belé helyezett bizalomra." ${ }^{943} \mathrm{Az}$ új harangozót a püspöki jóváhagyást követően, április 27-én eskette fel plébánosa. ${ }^{944}$

\footnotetext{
936 VPL APar. Cs. 1889. április 15. Keviczky György távirata a helügyminiszterhez.

937 VPL APar. Cs. 1889. április 30. Alispáni levél a váci püspökhöz.

938 VPL APriv. Hegyi Antal, 1892. március 14. A csongrádi hívek levele a hercegprímáshoz.

${ }^{939}$ Csongrádi Lap, 1898. augusztus 28. VIII. évf. 35. szám, 3. old.

${ }^{940}$ VPL APriv. Hegyi Antal, 1892. március 14. A csongrádi hívek levele a hercegprímáshoz.

941 Csongrádi Lap, 1901. február 4. XI. évf. 5. szám 2. old.

942 Csongrádi Közlöny, 1894. augusztus 19. I. évf. 23. szám, 3. old. Szöke János 1856. december 14-én született Csongrádon, apja Szőke László, anyja Ács Mária. VPL APar. Cs. Szőke János keresztlevele. Szőke János 1898-ban tett vallomásából kiderül, hogy ő szervezte a csongrádiak kiskunfélegyháza-szentkúti búcsújárásait. VPL APriv. Hegyi Antal, 1898. augusztus 22-26. Szőke János vallomása.

${ }^{943}$ VPL APar. Cs. 1889. március 24. Hegyi Antal levele a váci püspökhöz.

944 VPL APar. Cs. 1889. április 15. Hegyi Antal levele a váci püspöki szentszékhez.
} 
Úgy tünik, hogy az évek során Hegyi csalódott szeretett harangozójában: „A külvárosi harangozó jó ember, de gondatlan, s e miatt állandóan a sarkában kell lenni. Biz én megkövetelem tőle, hogy pontosan végezze minden dolgát, mert azért templomszolga". ${ }^{945}$ Szőke lemondására ismeretlen okokból került sor 1895. szeptemberében. Ha hitelt adhatunk a Hegyi plébánost támadó sajtóhíreknek, ismét egy eldurvult összeszólalkozás állt a háttérben. ${ }^{946}$ A váci püspök rendelkezése nyomán Hegyi Antal tüzte ki a harangozóválasztás időpontját, melyre meghívta a kerületi esperest, a Károlyi kegyúr képviselőjét és a községi elöljárók képviselőit. Jelen volt továbbá Bába Szabó Rókus egyházi gondnok, kinek szintén kikérték a véleményét a jelöltekkel kapcsolatban. ${ }^{947}$ A 17 jelentkező közül végül a hét gyermekes, szegény sorsú földművest, Palásti Lajost terjesztették a váci püpök elé.

\subsection{Palásti Lajos balszerencséje}

Palásti Lajos ${ }^{948}$ első hivatali évei békében, eseménytelenül teltek: idősebb fiai segítettek neki a harangozásban, a kisebbek ministráltak. 1898 októberének egyik reggelén azonban Vajdovics Julianna dékányasszony az általa kezelt Mária persely ${ }^{949}$ közelében állva döbbenten hallotta, hogy egy asszony pénzt dob bele, és az bizony nem csörren, hanem koppan a persely alján. Mivel feltörésre gyanakodott, azonnal szaladt Hegyi Antalhoz, aki el is hívta Sineger Vendel lakatost, hogy vegye szemügyre a szerkezetet. A lakatos a zárat rendben találta, így álkulcsos tolvajra kezdtek gyanakodni. Miután a plébános a harangozóval és az egyik káplánjával átnézte a többi perselyt is, kiderült, hogy mindegyikben gyanúsan kevés a pénz, a Péterfillérek kulcsa pedig eltünt az irodából. ${ }^{950} \mathrm{~A}$ plébános gyanúja a harangozó segédeire terelődött, „mert ezek már egy alkalommal követtek el visszaélést az előbbeni harangozó idejében, amikor érzékenyen meg is lakoltak

\footnotetext{
${ }^{945}$ VPL APriv. Hegyi Antal, 1894. július 10. Hegyi Antal levele a váci Egyházmegyei Hatósághoz. 946 „[Hegyi Antal] másnap Balog Énok harangozónál ebédelt, vacsorált pedig Szőke János elbocsátott harangozónál kit éppen ő pofozott ki állásából.” Csongrádi Lap, 1898. március 27. VIII. évf. 13. szám, 2. old. ${ }^{947}$ Csongrádi Lap, 1895. szeptember 22. V. évf. 39. szám, 3. old; Csongrádi Közlöny, 1895. szeptember 22. II. évf. 38. szám, 4. old.

${ }^{948}$ Palásti Lajos született 1860. május 12-én. NPI Születési anyakönyvek.

${ }^{949}$ A Mária kassa a Nagyboldogasszony-templom Lourdesi oltára mellett volt elhelyezve. A rózsafüzér társulati dékányasszony, mint a persely kulcsosa havonta egyszer ürítette a perselyt. A benne talált összeget misézésre fordították. A többi perselyt az egyházfi és a számadó káplán kezelte. Csongrádi Lap, 1898. október 30. VIII. évf. 44. szám, 2. old; VPL APar. Cs. 1898. október 30. Hegyi Antal levele a váci püspökhöz.

${ }_{950}$ VPL APar. Cs. 1898. október 30. Hegyi Antal levele a váci püspökhöz.
} 
tolvajlásaikért". 951

A harangozó segédei, köztük Palásti Lajos egyik fia azt vallotta a csendőröknek, hogy látta a dékányasszonyt a perselyekben kutakodni. A legények elbeszélése alapján a hatósági nyomozás végeredménye így hangzott: „,a persely tartalmát Vajdovics Julianna nevü dékányasszony tolvajlotta el”. ${ }^{952}$ Az asszony nem sokáig ült a csongrádi községháza tömlöcében: időközben ugyanis feltünt két tanú, kiknek vallomása nyomán kiszabadulhatott. Két asztalossegéd a kérdéses nap reggelén egy térdeplő zsámolyt kárpitozott a templomban, így a saját szemükkel látták, amint a harangozó 14 esztendős fia álkulccsal nyitogatja az egyik perselyt. A plébános meggyőződése szerint atyja, a harangozó tudott az esetről. ${ }^{953}$ A templom kulcsait Palásti Lajos átadta a plébánosnak, a harangozói lakból viszont - mivel egyéb szállása nem volt - még nem költözött ki. ${ }^{954}$

Palásti a megyéspüspöknek címzett levelében továbbra is tagadta fia bünösségét, és kitartott amellett, hogy a dékányasszony keze ragadós. ${ }^{955}$ A balsorsán siránkozó Palásti helyére Hegyi Antal a település elöljáróit megkerülve egy volt gátőrt kért fel harangozónak. Hajdú János már 1895-ben megpályázta az állást, ám akkoriban nem járt sikerrel. ${ }^{956}$ A Csongrádi Lap nyomban azt firtatta, hogy valójában a dékányasszony szívügye volt az előző harangozó leváltása és állítólagos kedvesének megválasztása. ${ }^{957}$

A csongrádi jegyző és bíró a harangozó-kérdésében ismét élesen szembehelyezkedett Hegyi Antallal. Mivel a harangozó a községi pénztárból kapta fizetését, lakása is a község tulajdona, így kinevezésének is a helyi elöljárósággal együttmüködve kellett volna megtörténnie. Tiltakozásul - az 1889-es ügyhöz hasonlóan megtagadták a harangozói lak átadását és az új harangozó jövedelmének kiutalását. ${ }^{958}$

1898 novemberében ismét arról hallunk, hogy Palásti Lajost a püspök rendelkezése nyomán visszahelyezték állásába. ${ }^{959}$ 1903-ban legidősebb fia, János volt a harangozó bojtára (segédje). ${ }^{960}$ Palásti Lajos még hét éven keresztül viselte hivatalát, ám András fia miatt végül mégis lemondani kényszerült. Mint kiderült, az időközben felcseperedett legény egy cimborájával együtt előszeretettel dézsmálta a Szent Antal perselyt, a pénzt

\footnotetext{
951 VPL APar. Cs. 1898. október 30. Hegyi Antal levele a váci püspökhöz.

952 VPL APar. Cs. 1898. október 30. Csongrád község elöljáróinak levele a váci püspökhöz.

${ }^{953}$ VPL APar. Cs. 1898. október 30. Hegyi Antal levele a váci püspökhöz.

954 Csongrádi Lap, 1898. október 30. VIII. évf. 44. szám, 2. old.

955 VPL APar. Cs. 1898. november 1. Palásti Lajos egyházfi levele a váci püspökhöz.

956 Csongrádi Közlöny, 1895. szeptember 29. II. évf. 39. szám, 3. old.

957 Csongrádi Lap, 1898. október 30. VIII. évf. 44. szám, 2. old.

958 VPL APar. Cs. 1898. október 30. Csongrád község elöljáróinak levele a váci püspökhöz.

${ }^{959}$ Csongrádi Lap, 1898. november 20. VIII. évf. 47. szám, 2. old.

960 VPL APriv. Medveczky János, 1903. Medveczky János dátum nélküli levele a váci püspöki szentszékhez.
} 
pedig dorbézolásra költötték. ${ }^{961}$ Ezúttal a plébános érte tetten a tolvajokat. Palásti Lajos helyét 1905-ben Király Sándor vette át. ${ }^{962}$

\section{A szokásjog kérdésének margójára}

A csongrád-külsővárosi harangozói állás története két korszakra bontható. A templom építésétől számítva a Keviczky család vonalán öröklődött a hivatás, közel 120 esztendőn keresztül. Keviczky György 1889-ben igen hasonló körülmények között élt, azonos feladatkört látott el, mint 1769-ben élt dédöregapja. A família a harangozói állás egyedüli és biztos örököseként élt a harangozói lakban, legfőbb gondjuk a kereset időnkénti megemelése és korábbi javaik megtartása volt.

1889-ben Hegyi Antal plébános világított rá arra, hogy milyen törékeny alapokon nyugszik a leszármazási rend jogosultsága. „Nekem mindegy, akár Keviczky Györgynek, akár másnak hívják a harangozót, de rendnek és tisztaságnak kell lenni okvetlenül a templomban, evvel tartozik a harangozó." ${ }^{963}$ A hivatalvesztés kimondásával egy csapásra érvénytelenné vált az első Keviczky harangozó és az akkori plébános szóbeli megegyezése. A hivatal örökléséről, a „méltó kötelességteljesítés” kritériumairól írásos emlék sosem született, és ez a megszokáson alapuló usus a 19. század végén elégtelennek bizonyult. A varázs megtörése népmesei egyszerüségü és tragikumú, hisz a család nem halmozott fel tartalékot, nem vásárolt saját házat vagy földet arra az esetre, ha el kellene hagyniuk a harangozói házat. Az óvatosság jeleként értékelhetjük azonban Keviczky György céhes próbálkozásait, vagy fiának, Sándornak hivatalnoki ambícióit.

Egészen 1889-ig nem firtatta senki, hogy milyen jogon képez kikezdhetetlen védőburkot a Keviczky család köré a szokásjog. Nem csoda, hogy mind a közösség, mind a helyi elöljáróság döbbenettel és ellenállással fogadta Keviczky György elbocsátásának hírét. A település vezetői minden rendelkezésükre álló eszközzel akadályozták a „reform” végrehajtását: hónapokig halasztgatták a kilakoltatást, az új harangozó jövedelmét visszatartották. A plébános eképpen emlékezett vissza küzdelmeire: „Szándékomban lévén, hogy miután addig csak az volt vagy öt generáción keresztül szokásban, hogy a Keviczki családban egyszerűen csak apáról fiúra szállott a harangozóság, a szabályszerü betöltést majd az elöljárósággal egyetértőleg fogom eszközölni, erről azonban az elöljáróságnak e

\footnotetext{
${ }^{961}$ Csongrádi Újság, 1904. július 10. II. évf. 28. szám, 4. old.

962 Csongrádi Újság, 1905. április 30. III. évf. 18. szám, 2. old.

${ }^{963}$ VPL APriv. Hegyi Antal, 1888. november 6. Hegyi Antal levele a kerületi espereshez.
} 
kérdésben elfoglalt ellenséges magatartása miatt csak hamar le kellett mondanom." 964

Mi volt Hegyi Antal célja? Miért helyezkedett végül mégis szembe azzal a testülettel, kiknek támogatására számított volna? Valóban a szabályok betartása iránti elkötelezettség volt a motiváció? Ha tartjuk azt a hipotézist, miszerint Hegyi Antal egyházfegyelmezési döntéseinek hátterében jellemzően saját pozíciójának megerősítése és egy centralizált plébániai vezetés képe állt, úgy joggal feltételezhető, hogy a harangozó és sekrestyési hivatalt is egy elveihez közel álló 'stratégiai személlyel' kívánta betöltetni. Erre a plébános által elképzelt szerepre az idős harangozó, úgy tünik, nem volt alkalmas. Hegyi plébános ellentmondást nem türő, hirtelen haragú természetének éppen elegendő ok lehetett Keviczky György állítólagos „feleselése” ahhoz, hogy a szokásjogot semmibe véve és a közvéleménnyel szembeszállva keresztül vigye akaratát, és a harangozói hivatalt felszabadítsa.

Feltevésünket erősíti, miszerint Hegyi Antal az öreg Keviczky távozása után a kegyúrral és a helyi elöljárósággal mit sem törődve saját támogatói közül jelölte ki az utódot. ${ }^{965} 1889$ után viszont a harangozói állásban érdekelt felek, vagyis a település és a kegyúr is „észbe kaptak, és fokozott figyelemmel kezdték kísérni ennek az alapvetően bizalmi hivatásnak a sorsát, mely már sohasem biztosíthatta azt a nyugalmat, melyet a Keviczky család élvezett 120 esztendőn keresztül.

\section{POZÍCIÓ ÉS CENTRALIZÁCIÓ: A KURÁTOR}

A Canonica Visitatioban Aeditus vagy Curator név alatt felsorolt személyeket a csongrádi nép kurátor, templomgazda, templomgondnok vagy egyházfi néven ismerte a mindennapokban. A szakirodalomban előfordul a templomatya kifejezés is. ${ }^{966}$ A latin eredetű kurátor szó jelentése „gondnok”, „gondviselő”. Feladata a templomi kiadások és bevételek számon tartása, összesített számadások készítése, illetve a harangozói jövedelmek kiutalása volt. A pénztárkönyvi mozgásokról évente egyszer a plébános mellett a város és a kegyúr képviselőjének is számot kellet adnia. Cserében az a kitüntetés járt neki, hogy körmenetek alkalmával füstölővel a kezében vonulhatott az Oltáriszentség előtt.

\footnotetext{
${ }^{964}$ VPL APar. Cs. Hegyi Antal feljegyzései a csongrádi Historia Domus kitépett lapjain. 130. old. 1888.

965 A híres Szeged-Belvárosi plébános, Kreminger Antal idejében, az öreg harangozó nyugdíjba vonulását követően alakult ki hasonló perpatvar (1847). A szegedi esetben a város, mint kegyúr próbálta az egyház bevonása nélkül megválasztani az új harangozót, ám Kreminger plébános ellenállásán megbukott a kísérlet. Ahogy püspökhöz írt levelében leszögezte: „Excellencziád rendeletei jogot, sőt kötelességet tartalmaznak arra, hogy a plébános és alesperes megnézze, ki az ő harangozója”. Kisházi-Kovács 2008. 55-56.

${ }^{966}$ Hoss 1948. 60. Kaposvár példáján.
} 
Az igen fontos, bizalmi pozícióra a 18. században inkább iparosok, a 19. században jellemzően jómódú gazdaemberek tarthattak számot. Csongrádon külön egyházfi müködött a Belsővárosban és a Külsővárosban. ${ }^{967}$

Miután sorra vettük az írásos emlékezet által elérhető csongrádi kurátorokat, Bába Szabó Rókus példáján mutatjuk be azt az ellentmondásos helyzetet, amikor az egyházfi pozíciójával járó hatáskör a plébános centralizációs törekvéseinek útjába kerül. A fejezet célja tehát annak bemutatása, hogy milyen okok vezettek a csongrádi kurátori hivatal „kiüresedéséhez”, névlegessé válásához majd felszabadításához.

\section{Csongrád-Belsőváros}

Az írásos emlékezet által megőrzött első belsővárosi kurátort „,nem túl derék” emberként jellemezték a Canonica Visitatioban. ${ }^{968}$ Mészáros István egyházfi eredeti foglalkozását tekintve molnár volt, szolgálataiért cserébe felmentést élvezett a katonáskodás alól. A csongrádiak úgy nyilatkoztak a vizitátornak, hogy hamarosan megszabadulnak tőle. ${ }^{969} \mathrm{~A}$ Mészáros után következő belsővárosi egyházfi személye homályba vész. A funkciót az 1870-es években az írástudatlan Tari János látta el. A szükséges nyugtákat Tari egyik írniolvasni tudó gyermeke állította ki. Ö jegyezte fel a harangozó cédulákat is, vagyis hogy kinek, hány alkalommal szükséges harangozni, és ezt az írást továbbította a harangozó felé. ${ }^{970}$

A Tarit követő Gulyás József templomgondnok neve bőkezü adományai révén maradt fenn. A település első oltárképét, a mennybe fölvett Boldogasszonyt ábrázoló festményt saját pénzéből újíttatta meg, még a nevét is feltüntette a bal alsó sarokban. ${ }^{971}$ 1885-ben a Szent Rókus-templomot „egyedül Isten iránti hálából és tiszteletböl” kívülbelül helyrehozatta. ${ }^{972} \mathrm{Az}$ óriási költségekkel járó renoválást még hosszú évekig emlegették Csongrádon, különösen akkor, ha a település mint kegyúr elöljáróságát kívánták bosszantani. ${ }^{973}$ A felújítást követően Gulyás József szentségtartót (monstrancia)

\footnotetext{
967 Forrásaink a pénzkezeléssel, adománygyüjtéssel ideiglenesen megbízott harangozót és sekrestyést is egyházfiként jelölik. Csongrádi Közlöny, 1894. május 6. I. évf. 8. szám, 4. old.

968 NPI Canonica Visitatio 1842.

${ }^{969}$ NPI Canonica Visitatio 1824.

970 1876-ban például 73 alkalommal rendeltek harangozást a Szent Rókus-templomban. MNL CsML CsL Képviselötestületi iratok 1872-1949. Tari János számadása 1876.

${ }^{971}$ A festmény napjainkban a Szent Rókus-templom szentélyében található.

972 VPL APar. Cs. 1885. március 14. Gulyás József levele a váci püspökhöz.

973 „Miatta [ti. a városi elöljáróság miatt] ugyan összedölhetett volna a kisded belsővárosi templom, ha megmentésére Isten szent Fölsége nem támaszt egy jó szívű Gulyás Józsefet, ki a roskadozót sajátjából
} 
és vélumot készíttetett a Rókus templom számára, melyeket a váci püspökhöz küldött felszenteltetni. A püspök nem győzte dícsérni az egyházfi áldozatkészségét. ${ }^{974}$

1891-ben már Polyák József a Szent Rókus-templom gondnoka. ${ }^{975}$ Az öt követő Balogh Énok már sekrestyés, harangozó és egyházfi is volt egyben. ${ }^{976}$

A belsővárosi templomgondnokok egészen 1891-ig nem kaptak juttatást szolgálataikért. Hegyi Antal 1891. februárjában keltezett levelében jelezte a váci Egyházmegyei Hatóságnak, hogy jogos kérése nyomán már a Belsővárosban is évi 10 forintos fizetést kap a kurátor. ${ }^{977}$

\section{Csongrád-Külsőváros}

Elsőként az 1824-es Canonica Visitatio említi Nagy János egykori tanácstagot, mint a Nagyboldogasszony-templom gondnokát. ${ }^{978}$ Nagy János a vizitációs jegyzőköny szerint becsületes, példás életű ember volt. Szolgálataiért lakást nem kapott, kiváltságokat nem élvezett, viszont évente 10 forint fizetést biztosítottak neki. Kinevezéséről a plébános és a helyi tanács közösen döntött. Feladata a bevételeket és kiadásokat tartalmazó könyv vezetése volt. A templom ládájának egyik kulcsa nála, párja a plébánosnál volt; a szerkezetet a két kulccsal közösen lehetett felnyitni. Az elszámolásokért elsősorban a plébános tartozott felelősséggel, felülvizsgálatot a csongrádi elöljárók és az egyházmegye hivatalos küldöttei végezhettek. Nagy János segéde egy Szmatona Antal nevezetü cipész, aki évi 10 forintért cserébe a külsővárosi templom mindenese és a kántor segédje volt. A jegyzőkönyv korántsem hízelgően emlékezik meg tevékenységéről. ${ }^{979}$

Nagy János közvetlen hivatali utódáról forrásaink hallgatnak. 1863-tól már Szalkai Szabó Istvánt találjuk a tisztségen, akit a plébános és a csongrádi elöljáróság kért fel a gondnoki feladatok vállalására. Az új kurátor kezdeti lelkesedése igen hamar lelankadt. A harangok megszólaltatásáért szedett pénz kezelését és a koldusoknak szánt adományok szétosztását Szalkai Szabó igen terhesnek találta. Mint azt 1865-ben keletkezett levelében írta: hivatali kötelességei miatt egyetlen napra nem hagyhatta el házát, csak akkor, ha megbízható helyettest tudott maga helyett felmutatni. A fizetést ugyanakkor méltánytalanul

\footnotetext{
helyreállíttatta.” VPL APar. Cs. 1890. december 8. Hegyi Antal levele a váci püspökhöz.

974 VPL APar. Cs. 1885. március 21. A váci püspök levele Gulyás Józsefhez.

975 VPL APar. Cs. 1891. február 21. Hegyi Antal levele a váci Egyházmegyei Hatósághoz.

976 Csongrádi Közlöny, 1896. szeptember 20. III. évf. 38. szám, 4. old.

977 VPL APar. Cs. 1891. február 21. Hegyi Antal levele a váci Egyházmegyei Hatósághoz.

978 NPI Canonica Visitatio 1824.

979 „Vix probus” Ld. NPI Canonica Visitatio 1824.
} 
kevésnek értékelte. ${ }^{980}$ Szalkai Szabót Bába Szabó Rókus követte a tisztségben, aki 1898-ig megszakítás nélkül látta el Csongrád-Külsővárosban az egyházfi teendőit.

3. Bába Szabó Rókus, a jámbor polihisztor

Ugyan több írás is foglalkozott már Bába Szabó Rókussal, korának közismert csongrádi egyéniségével, ${ }^{981}$ születési és halálozási adatait a mai napig nem sikerült pontosan meghatározni. Valószínüleg Szabó Rókus néven anyakönyvezték 1831-ben. ${ }^{982}$ Ebben az időszakban két Szabó Rókust is bejegyeztek, feltehetően Szabó József és Berkes Rozália felgyői lakosok 1830. november 12-én született gyermekéröl van szó. Bizonyos, hogy a későbbi kurátor szívéhez igen közel állt Felgyő dohánykertész község sorsa. Amikor gróf Károlyi Sándor az 1860-as években felbontotta a kertészek szerződését és szélnek eresztette a lakosságot, Bába Szabó Rókus verses krónikában örökítette meg az eseményt. ${ }^{983}$ Az egyházfi verse 1866-ban ponyva formájában is napvilágot látott Dobay János gyulai nyomdájában, a pesti Sallay András költségén.

Valódi nehézségekbe ütközünk, ha Bába Szabó foglalkozását, társadalmi állását kívánjuk egy szóban meghatározni. 1898-ban földmívesnek vallotta magát ${ }^{984}$, Füzesi Péter paraszti földmérőként emlegette. ${ }^{985}$ Tari László harangozó és sekrestyést ${ }^{986}$, Katona Imre Felgyőre felfogadott kántort sejtett személyében. ${ }^{987}$ Tari és Katona bizonyosan tévedtek.

Bába Szabó Rókus helyi és megyei szintű egyesületi tagságainak száma figyelemre méltó, talán csak Sohlya Antal kántor dicsekedhetett ilyen színes palettával. 1892-ben az újonnan alakult Csongrád és Vidéke Takarékpénztár Rt. igazgatósági tagjai közé választották. ${ }^{988}$ 1894-ben a Csongrádi Közlöny úgy emlegette, mint városi képviselő és

\footnotetext{
980 Évente összesen 10 forint 50 krajcárt kapott mint egyházfi, ehhez járult minden hónap végén a számadás alkalmával kiutalt 42 krajcár. VPL APar. Cs. 1865. Szalkai Szabó István dátum nélküli levele a váci püspök felé.

981 Tari 1977; Katona 1976-77.

982 1898-ban 67 évesnek vallotta magát, ám a csongrádi anyakönyvekben közel és távol nem találunk Bába Rókus vagy Bába Szabó Rókus nevü gyermeket. VPL APriv. Hegyi Antal, 1898. augusztus 22-26. Bába Szabó Rókus vallomása.

983 Eredeti címe: Felgyeö községének több mint egy százados fönállása (!) utáni elpusztítása emlékére 1866ban, Hozzáadva katona búcsúzása szüleitöl. Írta: Bába Rókus csongrádi lakos, Kiadja Simon János, Gyulán, 1866. Nyomatott Dobay Jánosnál. Ld. Katona Imre 1976-77. 163.

984 VPL APriv. Hegyi Antal, 1898. augusztus 22-26. Bába Szabó Rókus vallomása.

985 „Kocsin kivitték a földre, azt felmérte bizonyos díjazásért.” Füzesi é.n. (kézirat) 201.

986 Tari 1977. 9; Váry 1974. 232. (Tari László megjegyzései).

987 Katona 1976-77. 164.

988 Labádi 2007. 85. Szentesi Lap 1892. február 26. XX. évf. 21. szám, 4. old.
} 
iskolaszéki tag. ${ }^{989}$ Az 1880-as, 90-es években ő volt felelős a katonák újoncozásáért. 1895 ben a 48-as Népkör jegyzőjének választották meg. ${ }^{990}$ Még ugyanebben az esztendőben a vármegye törvényhatósági bizottságának tagjai között találjuk. ${ }^{991}$ 1896-ban Csongrád tiszteletbeli tanácsnoka. ${ }^{992}$ A harangozó-választási bizottság tagjaként a sekrestyés személyébe is beleszólása volt. ${ }^{993}$ Egy újságcikk szerint még vőfélykedéssel is foglalkozott. ${ }^{994}$

Bába Szabó Rókus háza a mai Csemegi Károly utcában állt, az épület 1882-ben porig égett. ${ }^{995}$ A kántorhoz és harangozóhoz hasonlóan rendelkezett szőlőfölddel, ám kunyhóját a szerszámaival együtt 1893-ban felgyújtották. ${ }^{996}$ Házasságai szerencsétlenül végződtek, ahogy feljegyzéseiben írja: „ne éljenek ily szomorú napokat (maguk) mint én, mert én már fiatal napjaimban háromszor házasodtam”. 997 Egyik feleségét Magyar Annának hívták. 1853-ban arról szerzünk tudomást, hogy nőül vette a plébános baksi születésü, hajadon szakácsnőjét. ${ }^{998}$

Bába Szabó Rókus 1864-ben lett a csongrád-külsővárosi templom választott gondnoka. ${ }^{999}$ Feladatait egy 1898-ban keletkezett vallomásában írta körül. Elmondása szerint a Purgatórium és Szent József oltárok perselyeit egyedül ürítette ki minden hónap végén, míg a Mária persely tartalmát vasár- és ünnepnapokon számolta le a plébánosnak. ${ }^{1000}$ Kisebb templomi javítások alkalmával vagy fogyó eszközök (pl. gyertya) beszerzésekor ő fizette ki a mestereket és kereskedőket a sekrestyében tartott pénzből. ${ }^{1001}$ Elődeihez hasonlóan gondoskodott a szegényeknek szánt adományok szétosztárásról és számon tartotta a harangozásért befolyt összeget.

A plébániatemplom kurátoraként minden folyó adakozásba bekapcsolódott. Ha nem akadt elég önkéntes adakozó, a fennmaradó összeget kipótolta. A templompénztárba

\footnotetext{
989 Valójában az iskolaszék megalakulásától kezdve a tagja volt, ám a jegyzőkönyvek szerint csekély érdeklödést mutatott az iskolai ügyek irányába. Csongrádi Közlöny, 1894. november 18. I. évf. 36. szám, 3. old.

${ }^{990}$ Csongrádi Közlöny, 1895. február 10. II. évf. 6. szám, 4. old.

${ }^{991}$ Csongrádi Közlöny, 1895. október 20. II. évf. 42. szám, 4. old.

992 Csongrádi Lap, 1896. július 5. VI. évf. 27. szám, 2. old.

${ }^{993}$ Csongrádi Közlöny, 1895. szeptember 29. II. évf. 39. szám, 3. old.

${ }^{994}$ Csongrádi Lap, 1892. január 17. II. évf. 3. szám, 4. old.

${ }^{995}$ Füzesi é.n. (kézirat) 201.

996 Tiszavidék, 1893. július 23. IV. évf. 30. szám, 3. old.

997 Tari 1977. 24.

998 Tari 1977. 24.

${ }^{999}$ VPL APriv. Hegyi Antal, 1898. augusztus 22-26. Bába Szabó Rókus vallomása.

${ }^{1000} \mathrm{Ha}$ a perselyekben $1 \mathrm{frt} .88$ krajcárnál kevesebbet talált, nem ürítette ki. Ha a nevezett összegnél több volt benne, csak 1 frt 88 krajcárt vett el, a többit benne hagyta. VPL APriv. Hegyi Antal, 1898. augusztus 22-26. Bába Szabó Rókus vallomása.

${ }^{1001}$ Ezek rendszerint 10 forintnál kevesebb, kisebb kiadások voltak. VPL APriv. Hegyi Antal, 1898. augusztus 22-26. Bába Szabó Rókus vallomása.
} 
előttünk ismeretlen szándékkal 25 forint értékü alapítványt tett. ${ }^{1002}$ A felesége családjából származó Magyar Lajossal közösen kökeresztet építtetett a csongrádi Györfösben, egy elporladt fakereszt helyére. ${ }^{1003}$ A közösségi fontosságú gyüjtések és ügyek sikeréhez, mint a Kossuth szobor felállítása, szintén hozzájárult. ${ }^{1004}$ Hosszú éveken keresztül szervezte és vezette a csongrádiak máriaradnai zarándokútjait. A csongrádiak a 19. század végén gőzhajóval tették meg az utat Szegedig, onnan Békéscsabán át Radnáig vonatoztak. ${ }^{1005}$

Templomgondnokként módja és lehetősége volt arra, hogy a plébániai földek egy részét haszonbérbe vegye. A plébános a csekély, évi 50 forintos bérlet fejében határozott müvelési feltételeket szabott meg. Hegyi Antal 1891-ben meggondolta magát, és visszavette a két hold földet, mondván a művelést „Istenért megteszik cselédeim ingyen”, a haszon viszont így teljes egészében a templomé lesz. ${ }^{1006}$ A plébános két esztendővel később egy másik határrészben kezdett bérletbe, ám három esztendő múlva átengedte Bába Rókusnak, mert úgy találta, hogy a föld nem elég termékeny. ${ }^{1007}$ Az egyházfinak kölcsön felvételére is volt lehetősége a templom kasszájából, melyet kamatostul törlesztett vissza. ${ }^{1008}$

Bába Rókusnak komoly rálátása volt a plébánia és a település múltbéli és folyó ügyeire, állapotára. Ahogy 1898-ban keltezett levelében magáról írta: „Bába Rókus 48 év alatt a templomba mindég és mindenütt (ott) volt”. ${ }^{1009}$ Váry Gellért „,nagyon ismeretes emberként” emlékezett vissza Bába Rókusra, aki „Csongrád városának és az egyes embereknek minden legkisebb ügyét tudja”. ${ }^{1010}$ Az egyszerü paraszti nép, akik közül származott, becsülte talpraesettségéért, így gyakran kértek tőle tanácsot ügyes-bajos dolgaikban. ${ }^{1011}$ A templomgondnok írásban rögzített megnyilatkozásai figyelemre méltó értesültségről, kiváló memóriáról tanúskodnak. Legyen szó időpontokról, eseményekről, helyi szokásokról vagy mennyiségekről, Bába Szabó Rókust nem hagyta cserben az emlékezete. Csongrád kitűnő krónikása lehetett volna belőle, mint ahogy próbát is tett egyik írásában, melynek alapját a Historia Domus magyar nyelvü bejegyzései képezték.

\footnotetext{
1002 VPL APriv. Hegyi Antal, 1898. augusztus 22-26. Bába Szabó Rókus vallomása.

1003 Tiszavidék, 1893. július 23. IV. évf. 30. szám, 3. old.

1004 Csongrádi Közlöny, 1894. április 22. I. évf. 6. szám, 3. old.

1005 Csongrádi Közlöny, 1895. október 13. II. évf. 41. szám, 4. old.

1006 VPL APar. Cs. 1891. május 21. Hegyi Antal levele a váci püspökhöz.

1007 VPL APriv. Hegyi Antal, 1898. augusztus 22-26. Püspöki szentszéki jegyzőkönyv, Bába Szabó Rókus vallomása.

1008 VPL APriv. Hegyi Antal, 1898. augusztus 22-26. Püspöki szentszéki jegyzőkönyv, Bába Szabó Rókus vallomása.

${ }^{1009}$ VPL APar. Cs. 1898. november 22. Bába Szabó Rókus levele a váci püspökhöz.

1010 Váry 1974. 154.

${ }^{1011}$ Füzesi é.n. (kézirat) 201-202.
} 
Az 1853-ban keletkezett kézirat Bába Szabó Csépán lakó rokonainak, Tórus Istvánnak és feleségének íródott, és Csongrád jelesebb helytörténeti eseményeit tartalmazza. A füzet kézről-kézre járt a csongrádiak között, mígnem töredékes formában Tari László kezébe jutott. Tari a szöveget ugyan nehézkesnek, de közlésre érdemesnek tartotta, így 1977-ben több kéziratos forrással együtt megjelentette. ${ }^{1012}$

Nem tudni, hogy Bába Szabó Rókus pontosan mikor hagyott fel templomgondnoki teendőivel. Bizonyos, hogy helyén 1898-ban már egy Kürthy nevezetü asztalosmestert, Hegyi elkötelezett „rajongóját” találjuk. ${ }^{1013}$ 1904-ben már Justin Gergely viselte a posztot, aki egészen 1912-es lemondásáig volt a külsővárosi egyházfi.

\section{Egy „méltó tanítvány”}

Az 1898 előtt keletkezett helyi újságcikkek azt a benyomást keltik, hogy Hegyi Antal Bába Szabó Rókus személyében szívének kedves követőjére lelt. ${ }^{1014}$ Ha mindebböl csupán annyi igaz, hogy a kurátor csöndes együttmüködésben munkálkodott a plébános mellett, ez máris elegendő indok arra, hogy Bába Szabó a Csongrádi Lap elsőszámú célpontjai közé kerüljön. „Különös” életstílusa, vagyis a sokoldalú szellemi tevékenység (írás, verselés, vőfélykedés stb.) és a földmüvelő ősök életmintájától való eltávolodás Hegyi Antal holdudvarában bünné transzformálódott: „Teljes életében komoly munkával sosem foglalkozott. Paraszt ember létére sem az eke szarvát, sem a kaszát és kapát kezébe nem vette, hanem ugy élt meg és ugy szerzett vagyont, hogy ide oda szaladgált, mint a vizes ürge.”" ${ }^{1015}$ Bába Szabó politikai nézeteiről, annak esetleges változásairól egyéb adat nem áll rendelkezésünkre az idézett újságcikken kívül, mely jellemtelen köpönyegforgatással vádolja az egyházfit; „mint kortes és felfogadott hazudozó ússza keresztül az élet fáradalmait. [...] méltó szolgája és tanítványa Hegyi Antal plébánosnak". ${ }^{1016}$ Hasonló közléseket bőséggel találunk a Csongrádi Lap hasábjain. Ezekben olykor Róka Bába néven emlegetik az egyházfit. ${ }^{1017}$

\footnotetext{
1012 Tari 1977.

1013 Csongrádi Lap, 1898. november 6. VIII. évf. 45. szám, 2. old.

1014 „Hegyi a templom-gondnok kíséretében, kezében a kereszttel, házról-házra, tanyáról tanyára ment a választókhoz, hogy őket a keresztény hit elnyomására törekvő kormány és Szivák ellen izgassa." Labádi 2007. 88. Szentesi Lap, 1892. március 25. XX. évf. 25. szám, 1-2. old.

1015 Csongrádi Lap, 1892. január 17. II. évf. 3. szám, 4. old.

1016 Csongrádi Lap, 1892. január 17. II. évf. 3. szám, 4. old. Korábban már volt róla szó, hogy Bába Szabó Rókust a 48-as Népkör tisztségviselöjének választották meg. Az idézett cikk a Függetlenségi Párt melletti állásfoglalást megelőző időkre utal.

1017 „-Szereti-e ugyan a püspök Hegyit? - Dehogy szereti. - Nincs hát már senki, aki szeresse ezt a jó
} 
Egy hírlapi vagdalkozásokkal tủzdelt évtized után a „méltó tanítvány” és plébánosa viszonya fokozatosan elmérgesedett. 1898 áprilisában az a pletyka járta, hogy Hegyi Antal - akkoriban már felfüggesztett csongrádi plébános - elbocsátással fenyegette meg a templomgondnokot. ${ }^{1018}$ A Csongrádi Lap megszellőztette, hogy a konfliktus a misepénzek elszámolása miatt alakult ki. ${ }^{1019}$ Mivel a kurátor készségesen együttműködött a Hegyi plébános felfüggesztése idejére kinevezett adminisztrátorral, a volt plébános hütlen árulónak bélyegezte egykori bizalmasát. Az első adandó alkalommal Bába Szabó fejéhez vágta: „megálljon, majd ha visszajövök, legelsőbben is magát csapom el”. ${ }^{1020}$ Ez a jelenet csupán szerény előjátéka volt az 1898 nyarán történteknek.

A felfüggesztett plébános ellen 1898 augusztusában több, mint félszáz tanú meghallgatásával kezdett vizsgálatokba Matejka Vilmos szentszéki biztos. Az írástudatlan tanúk vallomásának rögzítésében a harangozó és az egyházfi is segédkezett, végül ők is kihallgatásra kerültek. Matejka Vilmos részletesen kifaggatta Bába Szabó Rókust a plébánia pénzügyeiröl. A válaszok korrektek és pontosak voltak, ám mikor a kisebb ügyektől - mint a temetői sírhelyek díja - távolodni kezdtek, Bába Rókus megtorpant, elbizonytalanodott. Matejka hitetlenkedésére válaszul hangzott el a vallomás: a plébánia általános bevételeiről és kiadásairól a kurátor semmit sem tud. Feladatköre a valóságban csupán a perselyek elszámolására korlátozódott. „,[A perselyeket] vasár- és ünnepnapokon rendesen felnyitottam, másokkal együtt - plébános úr jelenléte nélkül - megolvastam, az összeget czédulára írtam fel, és így a sekrestyében lévő ládába, melyben gyertyák és gyertya hulladékok is tartattak, czédulástul a pénzt betettem, a hónap végén pedig az összejött pénzt czédulákkal együtt a plébániára bevittem, hol a plébános úrnak átadtam a ki azt saját [...] kasszájába tette, vagy pedig az asztalon hagyta."1021 Csupán év végén látta, hogy a perselypénzek be vannak vezetve a „nagy könyvbe”. ${ }^{1022}$ A templomi adósságokról akkor szerzett tudomást, amikor az Egyházmegyei Hatóság lefoglalt egy nála tartott,

embert? - Dehogy nincs! Vajdovics Julcsa meg Bába Rókus” Csongrádi Lap, 1896. november 8. VI. évf. 46. szám, 3. old; Csongrádi Lap, 1892. január 17. II. évf. 3. szám, 4. old.

1018 Csongrádi Lap, 1898. április 10. VIII. évf. 15. szám, 3. old.

1019 Korábban már szó esett a Hegyi Antal plébános felfüggesztésének okaként szolgáló misepénz-botrányról. Mivel részletekbe menően nem áll módunkban az üggyel foglalkozni, csupán annyit jegyzünk meg, hogy Bába Szabó Rókus a helyettes adminisztrátor kérésére két olyan szentmise okmányt adott át, melyeket még Hegyi Antal írt alá. Hegyi Antal felháborodását az okmányok átadásának ténye váltotta ki. VPL APriv. Hegyi Antal, 1898. augusztus 22-26. Püspöki szentszéki kihallgatási jegyzőkönyv, Bába Szabó Rókus vallomása. ${ }^{1020}$ VPL APriv. Hegyi Antal, 1898. augusztus 22-26. Püspöki szentszéki kihallgatási jegyzőkönyv, Bába Szabó Rókus vallomása.

1021 VPL APriv. Hegyi Antal, 1898. augusztus 22-26. Püspöki szentszéki kihallgatási jegyzőkönyv, Bába Szabó Rókus vallomása.

1022 Nagy könyv: a templomi bevételeket és kiadásokat tartalmazó könyv. VPL APriv. Hegyi Antal, 1898. augusztus 22-26. Bába Szabó Rókus vallomása. 
kisebb összeget. ${ }^{1023}$ Mikor a vallató az év végi számadásról kérdezte, Bába Rókus őszintén így felelt: „Be hívtak, hogy írjam alá a kész iratokat, három irat volt, amit alá kellett írnom. Elémbe tették, hogy írjam alá. Miután a többi urak, a kegyurasági megbízott, a községi elöljáróság és a kerületi esperes úr már aláírták, én is aláírtam, a nélkül, hogy tudtam volna mi van benne." 1024

Ez a jámbor őszinteség kellemetlenül érintette Hegyi Antalt, hisz a váci egyházmegye általános rendszabályzata arra kötelezte a plébánost, hogy a bevételeket és kiadásokat előzetesen beszélje meg a kurátorral. ${ }^{1025}$ Ám a templomgondnok saját bevallása szerint akkor látta az új templomi szerzeményeket, amikor azok a helyükre kikerültek.

Az augusztusi vallomás után két hónappal a felfüggesztett plébános hivatalosan is visszatért Csongrádra. Első dolgai között megírta Bába Rókus elbocsátó levelét, melyet indoklással együtt tettek közzé a Csongrádi Lap első oldalán. A nevezetes ok az egyházi vagyon hűtlen kezelése, a plébániai szőlőben lévő gyümölcsfák kiásása, „ellopása” volt. A megalázó nyílt levél a kurátor családi padjának eltávolítását is kihirdette. ${ }^{1026}$ Bába Szabó Rókus ekkor pennát ragadott, hogy élete talán első és utolsó levelével felkeresse a váci püspököt.

Meglepő lehet, de az elcsapott kurátor a nevezetes levélben nem Hegyi Antalt, hanem a püspöki széki vizsgálóbiztosokat okolta helyzetéért, akik a vallomás után nem óvták meg tanújukat a következményektől. „Nó igaz azon közmondás, aki megmondja az igazat be törik a feje. Engemet 15 napon át hit alatt Matejka Vilmos mint ki küldött vizsgáló bíró kérdőre vont, és íme itt az érdem [...] és kik tették, a Papok, akik bele vittek engemet, mert követelik hogy én tudok ezt és amazt, és tehát kérdéseikre feleltem, és íme most ugy vagyok mint a ki csavart czitrom."1027 Bába Rókus a körülmények áldozataként tekintett magára, akit az esküvel szentesített őszinteség nyomása tett Hegyi Antal ellenségévé. A levél semmit nem kért, csupán közölt: a kurátor rezignáltan tudomásul vette immáron „gúnnyal és szégyennel telt” életét, majd azzal a reménnyel zárta sorait, hogy a

${ }^{1023}$ VPL APriv. Hegyi Antal, 1898. augusztus 22-26. Püspöki szentszéki kihallgatási jegyzőkönyv, Bába Szabó Rókus vallomása.

${ }^{1024}$ VPL APriv. Hegyi Antal, 1898. augusztus 22-26. Püspöki szentszéki kihallgatási jegyzökönyv, Bába Szabó Rókus vallomása.

${ }^{1025}$ VPL APriv. Hegyi Antal, 1898. augusztus 31. Püspöki szentszéki tanács jegyzőkönyvi kivonata.

1026 „A történteknél fogva kénytelen vagyok önt a kurátorságból ezennel elbocsátani és tudtára adni, hogy privát padját, melynek felállítására, mint templomgondnok kapott engedélyt, a templomból késedelem nélkül eltávolíttassa, mivel akik az egyház vagyonát pusztítani merészelik, semmikép sem tarthatnak rá igényt, hogy az egyház által bármiféle kedvezményben részesíttessenek." Csongrádi Lap, 1898. november 6. VIII. évf. 45. szám, 1. old.

1027 VPL APar. Cs. 1898. november 22. Püspöki szentszéki kihallgatási jegyzőkönyv, Bába Szabó Rókus levele a váci püspökhöz. 
temető hamarosan megszabadítja a szenvedésektől. ${ }^{1028}$

\section{Gondolatok egy kiüresedett pozícióról}

Forrásaink alapján nem lehet megállapítani, hogy Bába Szabó Rókus csak Hegyi Antal színre lépését követően vesztette el rálátását a plébánia pénzügyeire, vagy a korábbi plébánosok idejében is névleges volt funkciója. Ami bizonyos, hogy Hegyi Antal mint „főgazda” magabiztosan, komolyabb megkötések nélkül forgatta a templom vagyonát. Bába Szabó Rókust a levelein és vallomásain keresztül átsütő alázatos szerénység bénította meg abban, hogy pozíciójával járó hatáskörének érvényt szerezzen. Hegyi Antal centralizációs törekvéseinek ideális társa volt ez a csöndes kurátor, akit nem kellett „háttérbe tenni” - odatalált magától is. Valószínüleg ennek köszönhető, hogy a nehéz természetü plébános és a templomgondnok viszonya a szentszéki vizsgálódás kezdetéig ép maradt.

Bába Szabó Rókust legendás tájékozottsága, tudása tette emlékezetessé. Kitünő memóriája mellett irodalmi, történetírói próbálkozásai is figyelemre méltóak. Korának helyi jelentőségü, kiemelkedő alakjaként megkerülhetetlen azok számára, akik Csongrád 19. századi történetével kívánnak foglalkozni.

${ }^{1028}$ VPL APar. Cs. 1898. november 22. Püspöki szentszéki kihallgatási jegyzőkönyv, Bába Szabó Rókus levele a váci püspökhöz. 
EGYÉB EGYHÁZKÖZELI ASSZISZTENCIA 


\section{X. „HIVATAL” A HIVATAL ÁRNYÉKÁBAN:}

\section{A TEMETŐCSŐSZ ESETE A DÉKÁNYASSZONNYAL}

Csongrád temetőjét ${ }^{1029} 1795$-ben hasította ki a gróf Károlyi família a közlegelök közül. Ez a terület 1857-re betelt, így a mellette elterülő libalegelő felé terjeszkedett tovább. Az egyre terebélyesedő temető felügyelete, rendjének megtartása külön hivatal létrejöttét tette szükségessé. Mivel a területet a kegyúri család a katolikus egyháznak szánta ${ }^{1030}$, a csőszről való gondoskodás is az egyház feladata maradt.

A legszerényebb egyházi hivatallal a temetőcsősz dicsekedhetett. A jelölt a plébános választása nyomán nyert jogosultságot a temetőben álló kis vályogkunyhóra és a rögzített stoláris javadalmakra. Személyét tekintve sem a püspök, sem a kegyúr, de még a települési elöljáróság sem érezte érdekeltnek magát. A leginkább fizikai munkával és némi rendfenntartással járó munkakör nem igényelt képzettséget, kitételként csupán a józan, becsületes élet szerepelt. Egyszerü feladatköréből adódóan a temetőcsősz ritkán keveredett bármiféle nézeteltérésbe, az állás csekély presztízse miatt kenyerét sem kellett féltenie. Mivel a temető ekkoriban a településen kívül esett, a csősz egyfajta „társadalmon kívüli” életet élt, ami jelentősen csökkentette az állás vonzerejét. Ugyan forrásaink nem teszik lehetővé egy teljes körkép felvázolását, vizsgált időszakunkból mégis rendelkezésünkre áll Kókai Mihály temetőcsősz 1898 -ban felvett vallomása ${ }^{1031}$, aki feladatairól, keresetéről is beszámolt a vallatóbiztosnak.

Kókai Mihály a vallomás felvétele idején 39 esztendős volt, iskolába sosem járt, így írni-olvasni sem tudott. 1898-ban már hat esztendeje végezte munkáját, kinevezése vízkereszt előtt történt. Állandó fizettsége nem volt, viszont temetések alkalmával a kis harangok után 10 krajcárt, a három harang közös csendítése után 40 krajcárt kapott a gyászolóktól. Felnőtt halott sírjának ásásáért egy forint, kis halott sírjáért 50 krajcárt volt a fizetsége. A temetőben lévő, egy hold nagyságú üres területet szabadon művelhette,

\footnotetext{
${ }^{1029}$ A korábbi évszázadokban temető volt a mai Szent Rókus-templom körül, a Nagyboldogasszony-templom mögötti területen és a mai uszoda helyén. Ezeket különböző időpontokban, jellemzöen a 18. század folyamán zárták le.

${ }^{1030}$ Hiába is keresnénk adományozó okiratot: a Károlyi grófok hivatalos okmányok nélkül bocsátották az egyház rendelkezésére a területet. Ebböl komoly gondok származtak a 19. század végén, amikor is a helybéli tanácstagok egy része a temető elidegenítését és köztemetővé nyilvánítását kezdte követelni. A botrány kiváltó okát az öngyilkosok és nem katolikus halottakkal szemben tanúsított, hagyományos egyházi gyakorlat szolgálta.

${ }^{1031}$ A fejezet további részei külön jelölés nélkül a következő forrásból származnak: VPL APriv. Hegyi Antal, 1898. augusztus 22-26. Püspöki szentszéki kihallgatási jegyzőkönyv. Kókai Mihály vallomása.
} 
hasznából az első évben egyedül, később a dékányasszonnyal megosztva részesült. ${ }^{1032}$ Kókai Mihály feladatai közé tartozott a plébános utasítása nyomán a sírok kijelölése, a sírok közt legelésző libák, kecskék kihajtása. Mikor a gyászolók „féltek bemenni főt. Hegyi Antal plébános úrhoz, mert mérges volt", a temetőcsősznek fizették ki a sírhelyeket $^{1033}$, aki a plébános felé továbbította a cédulákat. Az írástudatlan temetőcsősz 16 esztendős nevelt leánya segítségével kezelte az igazolásokat. Kókai Mihály idejében ment végbe Csongrádon a nagy temetőrendezés, ahogy akkoriban emlegették: „,a kockázás”. A szerteszét heverő sírok közé Hegyi plébános utakat vágatott, körben kerítést építtetett, a fákat kivágatta, melyek hasznát a temetői utak építésére fordította. A fák eladását az egyházfi és a templomcsősz közösen bonyolította le, a pénzt a temetőcsősz kezelte.

Forrásaink egyetlen nézeteltérésől tanúskodnak, mely az élelmes rózsafüzér társulati dékányasszony miatt alakult ki. Az új csősz hivatalba lépését követően Vajdovics Julianna azzal a követeléssel állt elé, hogy Hegyi plébános beleegyezése nyomán engedje át számára a temetőben müvelt föld felét haszonvételre. Kókai Mihály nyilván tisztában volt azzal, hogy Vajdovics személyében Hegyi Antal legföbb bizalmasát tisztelheti, így jobbnak látta, ha csöndben hallgat az esetről. Hosszú évek teltek el így, mire az ügy Bába Szabó Rókus egyházfin keresztül Hegyi Antal fülébe jutott. A plébános csupán annyit jegyzett meg: „minek olyan bolond, minek adja?” Ám a temetőcsősz ,a békesség okáért” továbbra sem tagadta meg a termőföld felét a dékányasszonytól.

1898-ban, Hegyi plébános felfüggesztése idején Droppa Károly helyettes adminisztrátor észlelte az eset abszurditását. Rövid nyomozás után kiderítette, hogy még a csősz hivatalos javadalmai közt sem szerepel a müveletlen föld használatának joga. Döntése a korábbiaknál igazságosabb megoldást eredményezett: Vajdovics Juliannát, ki „az egyházban semmiféle olyan szolgálatot nem tesz, melyért neki ilyen díjazás jogosan engedélyezhető volna", ${ }^{1034}$ teljesen kizárta a használatból, a temetőcsősznek pedig meghagyta, hogy terményének harmadát a továbbiakban templompénztár javára szolgáltassa be.

A temetőcsősz hivatala a plébániától kellően távolinak, Kókai Mihály pedig kellően bátortalannak bizonyult ahhoz, hogy egy ilyen eset éveken keresztül rejtve maradjon.

\footnotetext{
1032 Évente körülbelül 30 véka búza termett a temetőben. A csongrádiak Szent Márk napján ide vonultak ki processzióval, hogy szentelt búzát vigyenek magukkal.

${ }^{1033}$ A csősz vallomása szerint rátemetés esetén, vagyis „ha odaengedik az egyik halottat a másikhoz” a sírhely ára 1 forint volt. Az első sorban, a stációk mentén egy sír 10 forintba került, a második sor már fele annyit ért. A temetői kápolnától távol eső helyekért már csak 3 forintot kellett fizetni.

${ }^{1034}$ VPL APar. Cs. 1898. július 17. Droppa Károly levele a váci püspökhöz.
} 
Ahogy Vajdovics dékányasszony vallomásában is szerepel: „,a plébános úr abba nem folyt bele, nem is tudta adott-e [terményt] vagy nem adott [a temetöcsősz]". ${ }^{1035}$ Így történhetett meg, hogy a dékányasszony hat esztendőn keresztül a helyi vezetés tudta nélkül „,csinált” egyházi javadalmat magának. Vajdovics emlékei szerint a csősz saját jószándékából engedte át a termőföldet cserébe azért, mert az asszonyság rendszeresen takarította a temetői kápolnát, mosta és vasalta az oltárterítőket, „és mutattam a temetőcsősznek, hogyan legyen minden a kápolnában". ${ }^{1036}$ A jámbor temetőcsősz még a foglalás jogosultságát sem merte megkérdezni Hegyi Antaltól annak ellenére, hogy a sírhelykiváltások ürügyén állandó érintkezésben álltak egymással. A tárgyalt eset - a szereplők mentalitását is figyelembe véve - iskolapéldája egy magát egyházközelinek érző, csupán kegyességi alapon buzgólkodó laikus társulati vezető önrendelkezésének, melyet a plébános egyenrangú felek magánkonfliktusaként értékelt. 1898-ban egy újságcikk arról számolt be, hogy Hegyi Antal elbocsátotta a csongrádi temetőcsőszt, kinek helyére Vajdovics asszony férjura került. ${ }^{1037}$

\section{A CSONGRÁDI REFORMÁTUS BÁBA KÜZDELMEI ${ }^{1038}$}

Ami a csongrádi „bábakérdést” illeti: az 1770-es évekbeli országos összeírásból kiderül, hogy 1778-ban egy Vidáts Anna nevezetü, római katolikus szülésznő müködött a településen. Vidáts Annáról tudható, hogy a felmérés évében töltötte 47. életévét, férjezett volt, Budán tette le vizsgáit és a várostól évi 100 forint juttatást kapott. ${ }^{1039}$ Pár évvel később az összeírás már két városi szülésznőről tesz említést. ${ }^{1040}$ 1800-ben a harangozó Kevitzky család egyik nőtagját is megtaláljuk az anyakönyvekben. ${ }^{1041}$

Biztos forrásunk az 1824-ben keletkezett egyházlátogatási jegyzőkönyv, mely de

\footnotetext{
1035 VPL APar. Cs. 1898. augusztus 22-26. Püspöki szentszéki kihallgatási jegyzőkönyv. Vajdovics Julianna vallomása.

${ }^{1036}$ VPL APar. Cs. 1898. augusztus 22-26. Püspöki szentszéki kihallgatási jegyzőkönyv. Vajdovics Julianna vallomása.

1037 Csongrádi Lap, 1898. november 6. VIII. évf. 45. szám, 2. old.

1038 A csongrádi bábákról két korábbi tanulmányomban részletesen értekezem. Ld. Gyöngyössy 2013/b. Böhm Rozália zsidó bábaasszony kálváriáját jelen értekezésben külön nem idézem fel, főképpen azért, mert ügye kívül esik a vizsgált időintervallumon. Az esetről részletesen lásd: Gyöngyössy 2014/c.

${ }^{1039}$ Krász 2003. 192; 1781. szeptember 17-én Vidáts Anna keresztelte Murzi Mihály gyermeket szükségben. NPI Születési Anyakönyv.

1040 Szenti 1998. 541.

${ }^{1041}$ NPI Születési Anyakönyv, 1800. szeptember 2. Nagy András keresztelését Kevitzky Katalin szolgáltatta ki. Végszükség esetén az egyházszolgák és hozzátartozóik is végeztek szükségkereszteléseket: 1748. március 4-én Szabó József kurátor (sekrestyés) keresztelte meg Bodor Katalin gyermeket. Feltételezhető, hogy a gyermeket a plébános távolléte miatt, „vészhelyzetben” keresztelte meg a sekrestyében.
} 
obstetricibus címszó alatt sorolja fel a csongrádi bábákat. Eszerint végzettséggel, „diplomával” négy szülésznő rendelkezett, további hat asszonyt a plébános ugyan felesketett és kioktatott a szükségkeresztelés rendjéröl, de csupán édesanyjuktól örökölt gyakorlati tudásuk jogán gyakorolták a hivatást. ${ }^{1042}$ Jancsovics József plébános 1841-ben keletkezett levelében számszerüen említi, hogy Csongrádon 11 bábaasszony tevékenykedik, közülük kettő oklevéllel rendelkezik. ${ }^{1043}$

A csongrádi városi szülésznő kinevezése az 1850-es években már a föjegyző feladata volt. Ilyen módon jutott hivatalához Szabó Mihályné Juhász Ágnes és Takáts Andrásné Kiss Veronika, kiknek 1852-ben keletkezett levelét a váci püspöki levéltárban őrzik. Ha hitelt adunk a szülésznők szavainak, rajtuk kívül egy izraelita és számtalan lógós (képzettség nélküli) öregasszony ténykedett a vajúdó asszonyok körül. Az első, református vallású szülésznőről az 1860-as évek közepén szerzünk tudomást.

Jelen fejezet a református szülésznő keresztelési asszisztenciájával, a templomba lépés jogával és a szükségkereszteléssel kapcsolatos kérdéseket veszi számba egy olyan közösség példáján, ahol a római katolikusok aránya 98-99\% körül mozgott. Arra keresem a választ, hogy miként próbált a református szülésznő megfelelni a népi szokásjog, az állam és az egyház sajátos, olykor egymásnak ellentmondó elvárásainak? Milyen kompromisszumok születhettek a hagyomány, a vallások szabta keretek és a megélhetési kényszer határmezsgyéjén?

Magdics Gáspárné református szülésznő 15 év kiskunmajsai szolgálat után, 1865 tájékán került Csongrádra, és egészen 1899-ben bekövetkezett haláláig a településen élt. ${ }^{1044}$ Az „okleveles” szülésznő évi 50 forint fizetséget kapott a településtől. Gáspár fia suszterként dolgozott, Kázmér pedig rostásból lett községházi alkalmazott. Magdicsné egészen 1888-ig háborítatlanul végezte munkáját, amikor is nézeteltérésbe keveredett Hegyi Antal plébánossal.

Az 1880-90-es évek fordulóján Csongrádot izgalomban tartó konfliktusról Tánczos Roland annyit jegyez meg, hogy Hegyi Antal Magdics Gáspárné szülésznőt ,ismeretlen okokból" kitiltotta a templomból, aki a helyi közgyüléshez fordult jogorvoslatért. ${ }^{1045} \mathrm{~A}$ kiváltó okokról valóban nem értesülünk a periratokban. A Historia Domus árván keringő, kitépett lapjain viszont ránk maradt egy érzelemdús visszaemlékezés Hegyi Antal

\footnotetext{
1042 NPI Canonica Visitatio 1824.

1043 VPL APriv. Jancsovics József. 1841. szeptember 9. Jancsovics József levele a váci püspökhöz.

${ }^{1044}$ Csongrádi Lap, 1899. március 5. IX. évf. 10. szám 2. old.

1045 Tánczos 2006. 60.
} 
tollából. ${ }^{1046}$

A plébános leírása szerint 1888. tavaszán a református szülésznő késve érkezett egy keresztelőre, így Schimmalcsik Ignác káplán a keresztanya bemondása alapján adott nevet Légrádi Benjámin iparos gyermekének. A bábaasszony érkezésekor már az anyakönyvi bejegyzés is megtörtént. Ekkor derült ki, hogy egyedül a bába tudott a szülők által választott keresztnévről, így követelni kezdte a bejegyzés megváltoztatását. Szóváltás támadt a káplán és a bába között, melynek következményeként Magdics Gáspárné a járásbírósághoz fordult elégtételért. ${ }^{1047}$

Mikor az eset Hegyi Antal plébános tudomására jutott, megtiltotta a bábának hogy a templom sekrestyéjébe lépjen. „De [a bába] a tilalmat nem akarta tekintetbe venni, újra meg újra betolakodott a sekrestyébe s a kereszteléseknél is jelen akart lenni minden áron. Ezért őt a sekrestyéből mindannyiszor kidobattam, a kereszteléstől pedig eltávolíttattam." 1048 A szülésznő május 21-én levéllel kereste fel a váci püspököt, a világi hatóságoknál pedig tovább bővíttette a vádlottak körét: 1888. július 10-én már Schimmalcsik káplán mellett Hegyi Antal plébános is álláspontja megvédésére kényszerült a járásbíróság előtt. Az 1888/1105 sz. alatt hozott ítélet szerint a plébánosra kivetett büntetés összege a szülésznő közel két éves keresetével volt egyenértékü. ${ }^{1049}$

A világi hatóságok elmarasztaló ítélete egyedül a becsületsértés vádpontját érintette, de nem rendelkezett (nem is tehette) a szülésznő legfájóbb panasza felől. Hegyi továbbra is kiutasította Magdicsnét a sekrestyéből, amikor gyermeket kísért volna keresztelésre, vagy gyermekágyas asszonyt avatásra. ${ }^{1050}$ A pap 1888 decemberében a járásbíróság előtt is kijelentette, hogy más szülésznőket beereszt, de a református bábát továbbra sem hajlandó. ${ }^{1051}$

Mikor a szülésznő felismerte, hogy a hatósági ítéletek nem változtatnak helyzetén, ismét a váci megyéspüspök majd Csáky Albin vallás- és közoktatásügyi minisztert elé tárta

1046 Hegyi Antal bejegyzéseit Amerikába szökése után, a 20. század első éveiben eltávolították a Háztörténetből. Az értékes forrás ezidáig rejtve volt a csongrádi helytörténészek előtt. Helye: Váci Püspöki Levéltár, Acta Parochiarum Csongrád.

${ }^{1047}$ VPL APar. Cs. Historia Domus, Hegyi Antal kitépett lapjain 144.

1048 VPL APar. Cs. Historia Domus, Hegyi Antal kitépett lapjain 144.

1049 VPL APriv. Hegyi Antal, 1889. szeptember 13. A váci püspök levele gr. Csáky Albin miniszterhez. Hegyi Antalt 110 forint, káplánját 30 forint pénzbüntetésre ítélték.

1050 „1888. évi november hó 27-én a Csongrádi R. Cath. Szentegyházban a sekrestyében avatásnál megjelentem a szokáshoz és kötelességemhez híven, s ott, Hegyi Antal plébános engem minden ok nélkül Kajtár Veron, Pintér Juliánna, Kása Jánosné Palásti Lajos, Bori Pál s Eke Pál csongrádi lakosok előtt előbb a sekrestyéből durván kiutasított, azután pedig - mert kimenni, jogomat ismerve nem akartam - tettleg megtámadott." MNL CsML CsL V.B. 71. 1889. június 1. Magdics Gáspárné felterjesztése a Királyi Járásbírósághoz. [kiemelések: Gy. O.]

${ }^{1051}$ VPL APriv Hegyi Antal, 1888. július 26. Magdics Gáspárné szülésznő levele a váci püspökhöz. 
panaszait. ${ }^{1052}$ A felfokozott hangvételü levelekből a szülésznő hivatásának hagyományos, népi szokásjog által legitimált kontúrja bontakozik ki. ${ }^{1053}$ A szülésznő állítása szerint a templomból való kitiltással meggátolták hivatása teljesítésében, vagyis megfosztották keresetétől. ${ }^{1054}$ Így „szülésznői functiojába való visszahelyezését” követelte. ${ }^{1055}$ Az érvelés háttere igen egyszerü: a várandós asszonyok ahhoz a szülésznőhöz pártoltak, aki maradéktalanul eleget tett a népi szokásjog kritériumainak, a szülés levezetésétöl, a keresztelési asszisztencián át egészen a templomi asszonyavatásig. A hagyomány a bábaasszony szolgálatait csak ezekkel a funkciókkal együttesen ismerte teljesnek, javadalmazását is ennek függvényében kapta. Ennek megfelelően a hagyományos feladatkör bármely elemének elmaradása a szülésznővel szembeni bizalmatlansághoz, „nem hivatalos hivatalvesztéshez” vezethetett.

Schuszter Konstantin megyéspüspök két levelet is írt Hegyi Antalnak, melyben arra kérte, hogy engesztelődjenek ki a bábával, és hagyja őt részt venni a keresztelőkön. Mivel a válaszok elmaradtak, a kerületi esperes személyesen kereste fel a vitás feleket 1889 . szeptember 10-én. Az esperesnek sem Hegyi Antalt, sem a bábát nem sikerült jobb belátásra bírnia. A kerületi esperes úgy vélte, hogy a bábának kellő elégtétel a plébánosra kirótt pénzbüntetés, ugyanakkor egy katolikus paptól nem várható el, hogy más vallásúakat a templomba beengedjen. Schuszter Konstantin magáévá tette esperese tanácsát, és a belügyminiszter elé a következő álláspontot terjesztette elő: „Tekintettel arra, hogy a bábák mindenütt az egyház szolgái közé soroltatnak egyházlátogatási jegyzökönyvekben a mennyiben a keresztségnél közremüködnek, és pedig utolsó helyen a harangozó után - és hogy a harangozót is önhatalmilag alkalmazzák és bocsáthatják el a plébánosok, továbbá az egyházi férfiak is, tehát amazoknak fölebbvalói, az egyházi bíróság által büntetésekkel illettetnek azért, ha egyházi férfiakat a világi bíróság előtt vádolnak. Nagyon természetszerüen magyarázható az, hogy a plébános egy oly vallású bábát, kinek felekezetéből csak 17 lélek van a városban, s ki öt közel 20.000 városbeli híve elött úgy megszégyenítette, ha nem megtorlás, de legalább is hasonló esetek ismétlődésének

1052 1873-tól a bábaképző intézetekkel és az okleveles bábák ügyeivel kapcsolatban a vallás és közoktatásügyi minisztérium volt az illetékes szerv. Hőgyes 1896. 980.

1053 MNL CsML CsL V.B. 71. 6420/1888.

1054 „Mert megfosztott hivatásom teljesítésétől s kenyér keresetemtől éltem alkonyán öreg napjaimra, s hogy miért, nem tudom, én soha nem vétettem ellene, azért fordulok tehát méltóságod kegyes színe elé alázatos kérésemmel, hogy Méltóságod vonja őt felelősségre, hogy miért akar engem ártatlanul megfosztani kenyeremtől, mert úgy hiszem nevezett foúr tudja azt, hogy nincs az a Dogmaticaba meg írva, hogy ved el a szegénytől a munkája s véres verejtékkel szerzett kenyerét." VPL APar. Cs. 1888. július. 26. Magdics Gáspárné levele a váci püspökhöz

1055 ,[Kérem,] hogy engem mint okleveles és városi szülésznőt az anyaszentegyházba és azonkívül ténykedni minden háborítás nélkül engedjen” MNL CsML CsL V. B. 71. 6420/1888. 
tekintetéből - a kath. egyház azon szabványát, mely szerint a szent dolgokban a más vallásúakkal való közösség kerülendő, szigorú jogszerüséggel alkalmazásba vevén, őt a sekrestyéből kitiltotta. Ám a diplomával jogot nyert a szülésznő a szüléseknél működhetik, de hogy a templomban is a keresztség szentségének kiszolgáltatásánál segédkeztetik-e oly személy, ki ellen egyházi fölebbvalóinak jogos kifogás, van tehát hogy elfogadható-e ő az egyház szolgálattevő személyzete közé? Szerény nézetem szerint ez a dolognak egy olynemü más oldala, amelyben illetékesen ítélni alázatos véleményem szerint csak az egyházi hatóságot illetheti. A más vallásbeli bábának egyébként sem szabad a kath. szentségnél legkisebb segédkezéssel sem lenni, és sem a gyermeket, sem más szertartási tárgyat érinteni, csakis kísérheti a keresztanyát, hogy ennek legfölebb utközben segédkezhessék." 1056

A váci püspök tehát az egyházi hatóságok rendelkezési körébe utalta a református bába kérdését, egyben plébánosa döntésének jogosságát is megerősítette. Azt a javaslatot tette az ügy feloldása érdekében, hogy a református bába kísérje el a gyermeket és a keresztanyát a templomig, ám kívül várja meg a szertartás végét. Magdicsné továbbra is a világi hatóságoknál próbált magának igazságot szerezni, de kérését ezentúl mindenhonnan elutasították, mondván: a sekrestyéből kitiltás „nem vonatkozik a szorosan vett szülésznői müködésre". ${ }^{1057}$ Arra a vádra, hogy az asszisztenciától való eltiltás miatt az asszonyok elfordultak tőle, a püspök azt válaszolta: mindez a plébánossal szemben tanúsított tiszteletlen magatartásnak köszönhető. ${ }^{1058}$

Magdics Gáspárné esete a sajtóvisszhangot tekintve kísértetiesen emlékeztet az elbocsátott Keviczky György harangozó ügyére. Évekkel később ilyen híreket olvashatunk a Csongrádi Lapban: „[Hegyi Antal] özv. Magdicsné vérig rugdosása miatt el volt ítélve súlyos testisértésért.” ${ }^{1059}$ „Özv. Magdics Gáspárné bábaaszszonyt a templomban felöklelte, megrugdosta.” ${ }^{1060}$ „A saját templomában tudniillik véresre vert egy hatvankét esztendős asszonyt.”1061 „Magdics Gáspárné bábaasszonyt is megrohanta egyszer a templomban, éppen ugy keresztélés alkalmával s felpofozta az oltár előtt a ceremóniák végzése közben, s azóta nem volt szabad a bábaasszonynak a templomba lépni.”"1062 „[Magdicsnét] - mert 'ő

\footnotetext{
1056 VPL APar. Cs. 1889. szeptember 13. a váci püspök levele gr. Csáky Albin belügyminiszterhez.

1057 MNL CsML CsL 1889. október 23. Csongrád Vármegye törvényhatóságának Szentesi közgyülésének jegyzőkönyvéből 389 sz.

${ }^{1058}$ VPL APar. Cs. 1890. január 28. A váci püspök levele gr. Csáky Albin belügyminiszterhez.

1059 Csongrádi Lap, 1895. július 12. V. évf. 25. szám, 3. old.

1060 Csongrádi Lap, 1896. január 15. VI. évf. 3. szám, 1. old.

1061 Csongrádi Lap, 1897. szeptember 4. VII. évf. 36. szám, 2-3. old.

1062 Csongrádi Lap, 1901. február 4. XI. évf. 5. szám, 2. old.
} 
[Hegyi] ellene panaszt emelt - örökre kitiltott a templomból, ki emiatt elveszte kenyerét, s nagy szegénységben halt el [...] s mikor látta, hogy mégis belép a templomba a bábaasszony, egy csecsemőt hozván ölében: annyira dühbe jött ezen, hogy agyba-föbe verte a keresztelés alkalmával." ${ }^{1063}$ Ezek az erősen túlzó és torzító állítások a Hegyi Antal elleni politikai hadjárat céljait szolgálták.

Ugyan Hegyi plébános nem a vallási toleranciájáról volt híres, Magdics Gáspárné esetét mégsem lehet pusztán felekezeti alapú konfliktusként értékelni. A református szülésznő érvrendszerében a bába hagyomány által kódolt feladatait a „hivatásos” városi alkalmazás jogi erővel hatotta át. Ennek megfelelően, ha a szokásjog által elvárt tevékenységek közül bármely részelemet akadályozták, az a teljes szülésznői tevékenység akadályozását jelentette, mely a bábát alkalmazó település érdekeit is sértette. Az egyházi és világi hatóságoknak közel három esztendőbe telt, mire feltárták az összefüggést, és határozottan állást mertek foglalni a közösség íratlan elvárásaira hivatkozó Magdicsné ellenében.

${ }^{1063}$ Csongrádi Lap, 1901. február 26. XI. évf. 7. szám, 2. old. 
AZ ALSÓPAPSÁG ÉS A LAIKUS TEMPLOMSZOLGÁK SZEREPÉNEK ÁTALAKULÁSA.

CSONGRÁD TÁRSADALMA A 19-20. SZÁZAD FORDULÓJÁN 
A korábbi fejezetekben egy-egy jellegzetes probléma mentén mutattam be a 19. századi csongrádi plébánosok és laikus templomszolgák arcképvázlatát. Az esettanulmányok nyomán olyan mélyebb összefüggések, motivációk, beidegződések, kulturálisan meghatározott magatartásminták tárultak fel, amelyek a személyi esetlegességek mellett is értékelhető képet adtak a csongrádi plébániai élet belső rendjéről. Az értekezés végéhez közeledve, egyben a vizsgálódás fókuszát kitágítva arra keresem a választ, hogy miként differenciálódott Csongrád társadalma a század utolsó évtizedeiben, melyek voltak a polgárosodás tünetei, és föként: milyen szerepet töltött be a helyi plébánia a változások idején? Miként formálódott az egyes vagyoni- és foglalkozási csoportok vallásgyakorlása, egyházhoz való viszonya? A társadalom szerkezeti átalakulásával párhuzamosan milyen értelemben beszélhetünk a klérus és a laikus templomi asszisztencia társadalmi szerepének változásáról?

\section{TÁRSADALMI RÉTEGZŐDÉS ÉS VALLÁSGYAKORLÁS A 19. SZÁZAD VÉGÉN}

A polgárosodás kísérőjeleként számon tartott társadalmi rétegződés sajátos formában jelentkezett Csongrádon. Elég, ha csak a vagyoni különbségek nézzük, ahol korábban sosem látott differenciák ütköztek ki. Az 1900-as évek elején 26 család bírt 100 hold feletti birtokkal, 52 család 50-100 holddal, 671 család 10-50 holddal, 2071 gazda mindössze 1-10 holddal. 212 személy egy holdnál is kevesebb területen gazdálkodott. ${ }^{1064} \mathrm{~A}$ vagyoni polarizálódás okát Kósa László a legelőfeltörések és ármentesítés nyomán fellendülö extenzív fejlődés fokozatos beszükülésében látja. ${ }^{1065}$

A társadalmi rétegződés a vagyoni, foglalkozási, vallási alapon szerveződő csoportok elkülönülésének irányába tartott. A század végére külön mulatóban, külön bálban szórakoztak, külön fertályon éltek a módos nagygazdák és a zsidó értelmiségiek, az iparosok, kereskedők és a kubikos bérmunkások. Az egyes településrészeken belül mereven tartotta magát az endogámia. Nem ritkán bicskázásig fajuló kakaskodások érzékeltették a határokat. A társadalmi „széthúzás” a vizsgált időszakban érte el tetőfokát. Ahogy a Csongrádi Újság cikkírója összegezte: „a földmívelő lenézi az iparost, a kereskedő elhúzódik az iparos társadalomtól, az értelmiség pedig mindkét osztálytól. Ha egy társas összejövetelt tartanak az iparosok, ott sem kereskedő, sem hivatalnok, sem a földmívelő gazdák nem vesznek részt. Viszont a gazdák összejöveteleitől távol tartják

\footnotetext{
1064 Sebestyén 2002. 16.

1065 Kósa 1998. 79.
} 
magukat az iparosok és az értelmiség”. ${ }^{1066}$

A társadalom az egyháztól várta az integráló és összekötő híd-szerep felvállalását. A templomot egyfajta kimondatlan konszenzus nyomán társadalmi ellentétektől mentes „övezetként” fogadták el. Érzékeltes példa a föként középparasztokat és nagygazdákat tömörítő 48-as Népkör zászlószentelési ünnepélye. Az alkalomra (tévedésből?) az iparosok is kaptak meghívót, így a nevezett időpontban ők is bevonultak a templomba. A Népkör egyik tisztségviselője haragosan kérdőre vonta a jeles kompániát, ám az iparosok azt felelték: katolikus létükre akkor mennek a templomba, amikor akarnak. ${ }^{1067}$

A vasárnapi misén válogatás nélkül megjelent a csongrádi katolikus közönség színe-java. Valaki mindig elájult a fullasztó tömegben ${ }^{1068}$, a kántor kénytelen volt szitkozódva furakodni a lépcsőn, hogy részt vehessen a körmeneten ${ }^{1069}$, a plébános is csak rendőri segítséggel tudott a nép közé férkőzni, amikor a szenteltvíz-hintést végezte ${ }^{1070}$. Nem véletlen, hogy a különböző vallási társulatokhoz való csatlakozás a 19. század végére afféle „presztízskérdéssé” vált.

Kegyes céljaikon túl a vallási társulatok - különösen a nők számára - a közösségivé válás első iskolái lehettek. Nem véletlen az sem, hogy a polgári egyesületekkel egy időben jelentek meg. ${ }^{1071}$ A rózsafüzér társulat utcánként szerveződött, a közeli házak lakói alkottak egy-egy imakoszorút, nemenként és korcsoportonként elkülönülve. Az imacsoportok azonban igyekeztek megmaradni a településrészek határain belül, melyek az egyes foglalkozási csoportok történelmileg kialakult határvonalai is egyben. A területi alapon szerveződő rózsafüzér imakoszorúk voltaképpen tovább mélyítették a meglévő társadalmi sáncokat. A nem területi alapú, kevésbé strukturált társulatok azonban Hegyi Antal szándéka szerint oldani próbálták a jegecesedett határvonalakat. Bizonyos, hogy a Hegyi által vezetett jámbor egyesületekben minden foglalkozási és társadalmi réteget megtalálunk, a világi vezető szerepeket pedig jellemzően kisbirtokos parasztemberek és parasztasszonyok töltötték be (pl. Gyovai Döme István, Vajdovics Julianna).

Csongrád társadalma tehát az 1850-es évekhez viszonyítva mozgásba lendült, átstrukturálódott, ezzel párhuzamosan az egyházhoz való kötődés erőssége és milyensége is differenciálódott. A továbbiakban az átrendeződés hatásait követjük nyomon, különös

\footnotetext{
1066 Csongrádi Újság, 1903. november 8. I. évf. 3. szám, 2. old.

1067 Csongrádi Újság, 1905. március 12. III. évf. 11. szám, 2. old.

1068 VPL APriv. Mátyus János, 1823. július 10. Makai András vallomása.

${ }^{1069}$ VPL Apar. Cs. 1867. Sohlya Antal kántor dátum nélküli levele a váci püspökhöz.

${ }^{1070}$ VPL Apar. Cs. 1887. Hegyi Antal dátum nélküli levele a váci püspökhöz.

${ }^{1071}$ A kérdésről bővebben lásd: Barna 2011.
} 
hangsúlyt fektetve az egyes vagyoni rétegek és foglalkozási csoportok vallásgyakorlásának sajátosságaira.

1. Kis- és törpebirtokos parasztgazdák

A település északi és nyugati irányú terjeszkedésének párhuzamos tendenciájaként kell megemlítenünk a tagosítás hatására fellendülő tanyásodási folyamatot. Az 1890-es évekre a jobbágyból tulajdonos paraszttá vált, magukat „,földmívesnek” nevező csongrádi lakosság harmada a környező tanyákon élt.

A felvilágosult korszellem azon nézetét ${ }^{1072}$, miszerint a „tudatlan nép dőre babonasága” zavartalanul virágzik a tanyavilág archaikus zárványgyürüjében, a Csongrádi Lap cikkei képviselték. Példaként álljon itt a Lap interpretációja Mészáros Mihályról, a halottlátó csépai szentemberről: „Alig néhány éve, egy csépai svihák parasztot, a ki szerintök a jövőbe olvasott, valóságos túlvilági hatalommal felruházott lénynek, szent embernek tartották. [...] Nem látták be, hogy egy ez közönséges svihák, pénzcsaló és fizetett bérencz volt; aki minden valószínüség szerint osztozott azoknak fillérein, a kikkel elhitette, hogy meghalt testvéreik, szüleik vagy gyermekeik a gyehenna lángjában kínlódnak mind az ideig, míg azokat pénzen meg nem váltják." ${ }^{1073}$ A cikkek szerint a tanya a parasztbábák, füves asszonyok, vajákos emberek világa, ahol a szellemek visszatérnek bosszút állni ${ }^{1074}$, a kukoricában lábostörő szörnyetegek élnek ${ }^{1075}$, az ördögöt a községháza tömlöcébe dughatják ${ }^{1076}$, és a hirtelen meggazdagodást a boszorkányokkal való cimborálással is lehet magyarázni ${ }^{1077}$.

Tény, hogy a 19. század végén a csongrádi parasztemberek a természeti csapások ellen még mindig föként imádsággal, szentek szobrainak állításával védekeztek, a termelési rend racionalizálásához elemi bizalmatlansággal viszonyultak. Ez a mentalitás viszont

\footnotetext{
1072 A „felvilágosult” szemléletmód egyik kiemelkedő, korabeli példája Varga János 1877-ben megjelent munkája. Az ironikus hangvételü Babonák könyvét az egyszerủ nép „okítására, gyógyítására” szánta. Ahogy a szerző megfogalmazta: „A babonaság a józan észnek megtévelyedése. Lelki betegség; mely azonban hála istennek, nem épen gyógyíthatatlan baj. Oktalan hit; amit se a tudomány, se a vallás tételeiből nem lehet igazolni." Varga János 1877. 8.

${ }^{1073}$ Csongrádi Lap, 1897. szeptember 26. VII. évf. 39. szám, 1. old.

${ }^{1074}$ Csongrádi Lap, 1899. január 22. IX. évf. 4. szám, 3. old.

${ }^{1075}$ Csongrádi Lap, 1898. július 24. VIII. évf. 30. szám, 3. old.

1076 Tiszavidék, 1893. április 23. IV. évf. 17. szám, 3. old.

1077 Tiszavidék, 1897. január 17. VIII. évf. 3. szám, 3. old. A Csongrád-bokrosi parasztság hiedelmeiről lásd Sándor Antalné kéziratban maradt gyüjtését a CsKK Tari László Múzeum Néprajzi Adattárában. Sándor 1987. (kézirat).
} 
éppen annyira jellemezte a településen élő parasztságot, mint a tanyák népét. ${ }^{1078}$

A Csongrádi Lap marasztaló cikkeinek ellenpontját a Csongrádi Közlöny képviselte. A plébános saját szerkesztésủ újságja hasábjain magasztalta a tanyai nép példamutató áldozatkészségét, akik igen jámbor, vallásos életet éltek annak ellenére, hogy szentmisét a rossz utak miatt csak nagyobb ünnepeken hallgattak. Mint írja: „,megvallva az igazat, a városiak is tanulhatnának egy kis buzgóságot attól a szegény tanyai néptől, mely az Advent alatt állandóan megtartotta a Rorátékat, Karácsony éjszakáján pedig még az éjféli misét is a fenti mód szerint". ${ }^{1079}$ A külterületen egyre-másra szaporodtak a magánadományokból emelt keresztek, szobrok, Bokrospusztán közadakozásból épült fel a Jézus Szíve kápolna. A tanyai iskoláknál engedélyt kaptak a rózsafüzér imádságra, ha káplán is jött, misére is sor került. ${ }^{1080}$

A hagyományos paraszti világ bomlása 1868 után, az Eötvös-féle népoktatási törvény hatására gyorsult fel. 1904-ben ugyan még mindig akad olyan szülő, aki „két libát többre becsült a fiánál, s fel hagyta nőni anélkül, hogy legalább írni-olvasni megtanulna", ${ }^{1081}$ ekkoriban Csongrádon már csak 470 tanköteles gyermek (kb. 15\%) nem járt elemi iskolába. A fiatalság alfabetizációjának terjedését mutatja, hogy az 1890-es években a temetőcsősz és a belsővárosi kurátor még nem, de gyermekeik már tudtak írniolvasni. Az idősebbek a századforduló táján gyakran saját életkorukat sem tudták megmondani, nemhogy a nevüket leírni. ${ }^{1082}$ A középkorosztállyal kapcsolatban Váry Gellért optimistább, szerinte ugyanis 1900-ban már „talán a legszegényebb édes anya is csongorádi szokás szerint föl tudta írni az imádságos könyvének a belső lapjára, hogy a fia mikor született, vagy bármi más olyan dolgot, a mit megjegyezni érdemes". ${ }^{1083}$ Bár az elemi iskola látogatásának morálja sokat javult, a polgári fiú és leányiskolák tanulóinak száma továbbra is alacsony maradt. ${ }^{1084}$ A Csongrádi Újság a helyi ,intelligentzia” alacsony számában látta a probléma gyökerét, a földműves lakosok pedig nem szívesen küldték föleg leánygyermekeiket - felsőbb iskolába. ${ }^{1085}$

\footnotetext{
${ }^{1078}$ Csongrádi Lap, 1898. február 13. VIII. évf. 7. szám, 3. old; Csongrádi Lap, 1898. július 24. VIII. évf. 30. szám, 3. old.

${ }^{1079}$ Csongrádi Közlöny, 1896. január 12. III. évf. 2. szám, 3. old.

1080 Gyovai B. 1989. 186.

1081 Csongrádi Újság, 1904. augusztus 20. II. évf. 34. szám, 1. old.

${ }^{1082}$ Hegyi Antal tanúinak kihallgatási jegyzökönyvében tömkelegével találkozunk ilyen megjegyzésekkel: „,́gy tartom, 66 éves”, „körülbelül 47 éves, „úgy gondolom 76 éves”. VPL APriv. Hegyi Antal, Püspöki szentszéki kihallgatási jegyzőkönyv, 1898. augusztus 22-26.

1083 Váry 1974. 183.

1084 Jánosi 1983. 74

1085 Csongrádi Újság, 1904. február 28. II. évf. 9. szám, 1. old. Csongrádon 1899-től nyílt lehetősége a módosabb leányoknak arra, hogy polgári iskolába járjanak. Dudás 1987. 88.
} 


\section{Kubikosok}

A többi Tisza-menti településhez hasonlóan Csongrádon is kitermelődött előbb a folyószabályozásnál, majd a vasútépítéseknél alkalmazott, házatlan zsellérekből lett kubikos réteg. ${ }^{1086}$ A jelentéktelen földterülettel, vagy csupán lakóhellyel rendelkező bérmunkásság az év nagy részében távol volt, csupán feleségeik és gyermekeik maradtak Csongrádon. A központtól távol eső munkástelepek ${ }^{1087}$ csak a 19. század végén olvadtak a településtestbe. A sajátos életvitel és a templomtól való távolság miatt a kubikos a legkevésbé vallásos rétegnek számított. Csongrád-Piroskaváros rendezésekor kiemelt figyelmet kapott a kubikosok „megtérítésének” szükségessége, így a településrész szívében egy jövőbeli templom számára alkalmas területet hagytak meg. A templom felépítésére, egyben a plébániaközösség megosztására a 20. század elején került sor. Vizsgált időszakunkban forrásaink nem foglalkoznak a kubikos-kérdéssel, a későbbiekben a piroskavárosi kolostor ferenceseinek feladata lesz az ottani lakosok hitéletének fellendítése.

\section{Iparosok $^{1088}$}

A javarészt kis- és középbirtokos parasztemberekből álló csongrádi társadalomban a föld állt az egyetemes értékhierarchia csúcsán. Ha lehetősége volt rá, a csongrádi paraszt gépesítés helyett a meglévő terület kiterjesztésére fordította vagyonát, hisz a társadalmi presztízs foka szorosan összefüggött a birtok nagyságával. Iparos foglalkozásra elsősorban az adta a fejét, aki nem, vagy alig rendelkezett müvelhetö földdel (lásd a zselléreket vagy a templomszolgák gyermekeit), már az édesapja is mühelyben kereste a kenyerét, vagy egyszerüen tehetséget és vonzalmat érzett valamely mesterség irányába.

Az iparosok öntudatát egészen a 19. század utolsó harmadáig a királyi privilégiummal felruházott „tekintetes czéh-hez” való tartozás adta. Ez a jellegzetes tartás, a szakmai büszkeség az Ipartestület korában is fennmaradt. A kötelező tanoncévek és a több esztendeig tartó vándorlás alatt az iparos segédek olyan világlátásra tettek szert, mely nyitottabbá tette őket az új jelenségek, a változás irányába. Ez a nyitottság olykor sajátos

1086 Katona Imre munkásságában bőven találunk a csongrádi kubikosok életére vonatkozó adatokat. Ld. Katona 1957; 1996.

${ }^{1087}$ A csongrádi munkástelepek felsorolását lásd. Dudás 2003. 95-96.

1088 A csongrádi céhek vallásgyakorlásáról, a templomi céhjelvények sorsáról néhány korábbi tanulmányomban hosszasan értekeztem. Lásd: Gyöngyössy 2010/a; 2013/a. 
ambíciókkal társult: a 19. század második felében nem volt ritkaság, hogy egy tehetséges iparos köztisztviselői pozícióba került. Az iparosok voltaképpen a hiányzó csongrádi kisés középnemesi réteg hivatalnoki helyeit töltötték fel.

Annak ellenére, hogy még sekrestyés és egyházfi is került ki közülük, az iparosok mind magánadományaikat, mind a kegyes buzgalmat tekintve messze elmaradtak a földmüvelő gazdák mögött. Hegyi Antal plébános sem tudta hitbéli alapon hatékonyan megszólítani vagy politikai céljainak támogatására bírni az iparosokat.

\section{4. Önkormányzati tisztviselők}

A 19. század második felében országos szinten általánosan elterjedtté vált a hivatalnoki pozíciók „méltóságos atyafiságokkal” való betöltése. ${ }^{1089}$ 1866-ból van adatunk arra, hogy a helyi polgármester és a szolgabíró rokonságban álltak. ${ }^{1090}$ Mivel a csongrádi nagygazdaréteg és a szabadfoglalkozású értelmiségiek számára az altisztek és köztisztviselők élete nem jelentett vonzerőt, az efféle pályákon az iparosok és templomszolgák gyermekei látták meg az elörelépés és kitörés lehetőségét. Ez a tendencia az 1860-as évek közepétől tartósnak bizonyult, és kellő öntudattal ruházta fel a szerszámot pennára cserélő hivatalnokokat. ${ }^{1091}$

A köztisztviselők templomba járását egy 1861-es főispáni leirat tette kötelezővé a térségben. A polgármester nyomban lépéseket tett egy külön padsor elkészíttetésére, melyet a Nagyboldogasszony-templom szentélyében állítottak fel. ${ }^{1092}$ 1893-ban arról szerzünk tudomást, hogy a régi szokást „újonnan felelevenítették”, így a helyi elöljárók vasár- és ünnepnapokon a 8 órai szentmisét külön padban hallgatták végig. ${ }^{1093}$

A csongrádi elöljárók állandó vitában álltak Hegyi Antal plébánossal. Hol a temető és a templomkert tulajdonjoga, hol a polgári anyakönyvezés ügyében kerekedett izzó levelezés a plébánia és a községháza között. Az ellenzéki érzelmü plébános választási korteskedése a kormányhatalmat képviselö községházi alkalmazottak ellenében is irányult. A település jegyzőjévé előlépett Sóhlya Gyula, Sohlya Antal kántor fia azt írta egyik

\footnotetext{
${ }^{1089}$ Erdei 1980/a. 406.

1090 VPL APar. Cs. 1866. május 17. Pehm Mária levele a váci püspökhöz.

1091 Pehm Mária tanárnő 1866-ban keletkezett levelében panaszkodott a városi pénztárnokra, aki szerinte „egy elbizakodott, müveletlen csizmadia, bennünket, egyháziakat ki nem állhat.” VPL APar. Cs. 1866. május 17. Pehm Mária levele a váci püspökhöz.

1092 Forgó-Forgó 1987. 50.

1093 Tiszavidék, 1893. június 25. IV. évf. 26. szám, 3. old. 1865-ben a polgármester rendelete nyomán vasár és ünnepnapokon, míg a misének vége nem lett, zárva voltak a csongrádi hivatalok. Dudás 1998. 116.
} 
levelében, hogy katolikus neveltetése és mély vallásossága ellenére valóságos „meghasonlásban van” a plébános személye miatt, kit a községházi perpatvarok nyomán volt szerencséje közelebbröl is megismerni. ${ }^{1094}$ A kötelező templomlátogatásnak a katolikus tisztviselők rendszerint eleget tettek, mégis ők tekinthetők a helyi társadalom leginkább szekularizálódott rétegének.

\section{Kereskedők}

Csongrádon a 19. század derekától kezdve a zsidó kiskereskedők felülreprezentáltsága volt jellemző. Gyermekeik többnyire szüleik üzletét vitték tovább, ritkábban értelmiségi, köztisztviselői pályák felé törekedtek. Példaként említem Lilienthal Emilt, kinek édesapja rőföskereskedő volt, az üzletet testvérbátyja vitte tovább, ő maga pedig köztisztviselővé vált. ${ }^{1095}$

Hegyi Antal plébános - kora úri középosztályára jellemzően - ellenérzéssel szemlélte a zsidó kereskedők hegemóniáját. A század utolsó éveiben meg is alapította a Keresztény Fogyasztási Szövetkezetet, melynek tagjai megfogadták, hogy csak a katolikus vallású kereskedök üzletét látogatják. A szervezet müködéséröl, a csatlakozott tagok számáról részletes adatok nem állnak rendelkezésünkre, ám puszta megléte jelzés értékű.

\section{Templomszolgák}

A laikus egyházi tisztségviselök hivataluktól, származásuktól és képzettségüktől függően eltérő társadalmi csoportokhoz érezték közel magukat. A kántorok egy szavazással egybekötött alkalmassági vizsgát követően, általában idegen közösségből érkeztek állomáshelyükre. Mezővárosokban, városokban csak kántortanítói végzettséggel lehetett fóéneklészi állásba kerülni, így a helyi müveltségi elit tagjai közé soroltattak annak ellenére, hogy jövedelmük nem érte el a vezető polgárság szintjét. ${ }^{1096}$ A betagozódás reprezentatív gesztusok nyomán szilárdult meg; az értelmiség szívesen kérte fel a kántort

1094 Mikor Hegyi Antal jelentése nyomán a váci püspök kérdőre vonta Sóhlya Gyulát „vallást sértő politikai ténykedéseivel” kapcsolatban, a csongrádi főjegyző a következő nyilatkozatot tette: „Én, Nagyméltóságú Uram, katholikus szülők gyermeke, magam s kis gyermekeimmel együtt az itt alapított Jézus Szentséges Szíve társulat tagja vagyok, mint katholikus ember kötelességemet pontosan teljesítettem, s alig pár éve csak, hogy Hegyi Antal úrral [....] éppen a többször hangoztatott visszaélések, kíméletlen támadások miatt meghasonlásban vagyok.” NPI 1894. március 12. Sóhlya Gyula főjegyző levele a váci püspökhöz.

1095 Csongrádi Lap, 1896. július 5. VI. évf. 27. szám, 2. old.

1096 Barna 2011. 359. Sohlya Antal tájékozottságát mutatja, hogy rendszeres előfizetője volt a jelentősebb, országos pedagógiai lapoknak. MNL CsML CsL Gondnoksági iratok, 1890. március 1. jk. 97. sz. határozat. 
és feleségét keresztszülőnek. A kántor gyermekeit jellemzően helyi előkelőségek ${ }^{1097}$ vagy kántortanító kollégák ${ }^{1098}$ keresztelték meg. Sohlya Antal leányunokáját, Sohlya Marikát maga Hegyi Antal plébános tartotta keresztvíz alá. ${ }^{1099}$

A kántor a harangozók és sekrestyések hivatalát már jóval alacsonyabb rangúnak tartotta. Sohlya Antal tanítóképezdei jegyzetében botránkozva említ olyan eseteket, amikor a helyi hagyomány olyan feladatok ellátását követeli meg a kántortól, melyek rá nézve „lealacsonyítóak és gyerekesek [...] már csak azért is, mert ezen szolgálatok majd nem országszerte az oltárszolgák kötelmei részben, részben pedig az egyházfi - más néven harangozóé, vagy sekrestyésé”. ${ }^{1100}$ Ide tartoznak az olyan „tettleges erőt kívánó szolgai kötelmek", mint a lámpahordozás, gyertyagyújtás, harangozás vagy éppen a csizmatisztítás. Sohlya Antal jegyzetében bosszankodva ír az efféle méltatlan elvárásokról, melyeken a kántor önerejéből nem volt képes változtatni, és csak egyházi elöljárója jóindulatában bízhatott.

A harangozók és sekrestyések már saját közösségük gyermekei voltak. A kántornál és a papoknál elmélyültebben ismerték a helyi hagyományokat és a közösséget, ám ennek a tudásnak az átvételére hivatali feljebbvalóik korlátozottan tartottak igényt. A több generációs Keviczky család esetében a gyermekek jellemzően iparos mesterségre vagy hivatalnoki pályára adták fejüket. Az egyik Keviczky-leányt Kmeth Lajos kántor vette feleségül. A harangozó és sekrestyések - a kántorral ellentétben - sosem élvezhették a megtisztelő „úr” megnevezést, elvétve kérte fel őket násznagynak vagy keresztszülőnek egy-egy földmüves vagy iparos família.

Az egyházfi bizalmi pozíciójára a gazdák közül is a legbecsületesebbek tarthattak számot. Az egyéb egyházi asszisztenciát tekintve az egyházi segédkezés ténye nem határozta meg, legfeljebb ,javította” az egyén társadalmi megítélését. Társadalmi hátterük, családi viszonyaik sokszínűek voltak, közülük egyedül a képzett bábák származtak másik településről. A legszegényebb egyházközeli tisztségviselő kétségkívül a temetőcsősz, kinek ősei jellemzően házatlan zsellérek voltak.

A templomszolgák hivatala Csongrádon irigyelt, biztos keresetü foglalkozás volt,

1097 Barna Gábor meglátása szerint Mezey János kántort az óbecsei magyar társadalom felső rétege maradéktalanul befogadta. Ennek egyik jele, hogy Mezey négy, Óbecsén született gyermekének keresztanyja Vissy Antónia, jeles helyi előkelő család leszármazottja volt. A Kunszentmártonban született Mezey Sándor Pál keresztanyja az egyik városi tekintély, Bozóky Sándor felesége lett. Barna 2009. 447.

1098 Knapek Dezső későbbi csanyteleki kántort, kinek édesapja Makláron kántortanítóskodott, 1881. január 13-án Polgári Gáspár kántortanító neje, Kapsay Júlia asszony tartott keresztvíz alá. Magyar Nemzeti Levéltár Heves Megyei Levéltára (továbbiakban: MNL HML) IV-416. 228. Maklári anyakönyv másolata.

1099 NPI 1894. március 12. Sóhlya Gyula főjegyző levele a váci püspökhöz.

${ }^{1100}$ Sohlya 1857. (kézirat) 323. 
üresedés idején egymást érték a jelentkezők. Ahogy Hegyi Antal fogalmazott újságja hasábjain: „sokan futnak, de csak egy nyerheti el a kinevezés babérját”. ${ }^{1101}$ 1892-ben Eszes Mátyás gőzmalom-tulajdonos, Hegyi Antal jó barátja azt vetette az atyja elbocsátása miatt elégedetlenkedő ifjabb Keviczky György szemére, hogy azért tiltakozik olyan hevesen, mert ő maga ,a reménylett kényelmes élettől elmaradt”. ${ }^{1102}$ Éder János lapszerkesztő az időközben felfüggesztett Hegyi Antalon élcelődve azt állította, hogy a plébános már számtalan pártfogójának felajánlotta a külső- és belsővárosi harangozói és templomgondnoki állásokat abban az esetben, ha visszasegítik őt hivatalához. A nevekkel tarkított lista végére odatüzte: „,ezek minden perczben készek, nem annyira Hegyi Antalért, mint a kurátori és harangozói állásért vért ontani”. ${ }^{1103}$

\section{Az, ,intelligentzia”}

Csongrádi szóhasználatban összefoglalóan ,intelligenciának” nevezték a polgárit vagy ennél magasabb iskolát végzett tiszti kardbojt-viselőket, jelesebb köztisztviselőket, orvosokat, polgári iskolai tanárokat, iskolaigazgatókat, ügyvédeket, akik életmód, vagyon és mentalitás tekintetében látványosan elkülönültek a számszerü többségben lévő földművesektől és mezőgazdasági bérmunkásoktól. Az ,intelligens közönség” színi előadásokra, bálakba járt, érdeklödött a település múltja, történelme, a környékbeli ásatások iránt. ${ }^{1104}$ Ha portréfestő vetődött a környékre, egymással versengve árasztották el a megrendelésekkel. ${ }^{105}$ A sok száz holdas nagygazdák gyermekei jó eséllyel kerültek diplomás pályákra, így - bár státusz szempontjából korábban sem maradtak el az intelligencia mögött -, a képzettség megszerzésével pozícióemelkedés is járt.

A klasszikus ,polgári” mentalitást és életmódot ${ }^{1106}$ ez a szük csoport közelítette meg leginkább. Eklektikus-klasszicista stílusú, egyszintes lakóépületeiket a Nagyboldogasszony-templom és a mai Szentháromság tér környékén emeltették. Ezekben a három-öt szobás lakóházakban állandó cselédeket tartottak, a férfiak Kaszinóba és Polgári Körbe jártak, míg asszonyaik a jótékonysági egyletekben jeleskedtek. A

\footnotetext{
${ }^{1101}$ Csongrádi Közlöny, 1895. szeptember 8. II. évf. 36. szám, 3. old.

1102 VPL APriv. Hegyi Antal, 1892. március 19. Eszes Mátyás levele a hercegprímáshoz.

${ }^{1103}$ Csongrádi Lap, 1898. szeptember 25. VIII. évf. 39. szám, 2. old.

${ }^{1104}$ Csongrádi Lap, 1892. május 22. II. évf. 21. szám, 3. old.

1105 Csongrádi Lap, 1898. november 20. VIII. évf. 47. szám, 2. old. Wiesner Károly festő csongrádi megrendeléseiröl.

${ }^{1106}$ Hagyományosan a három szobás lakást és a cselédtartást szokták a polgári életforma ismertetőjegyeként megemlíteni, melyet kiegészíthet a szecessziós ülögarnitúra, a szalon, házi zongora és üveges vitrinek valamint a kávéházba járás vagy a nyaralás. Ld. Hanák 1978. 462-472.
} 
polgármester, a főjegyző és szolgabíró az orvosokkal, ügyvédekkel, gyógyszerészekkel találkozgatott a Kaszinóban vagy a Magyar Király szálló kertjében, hogy egy pohár sör mellett megbeszéljék a település ügyes-bajos dolgait. ${ }^{1107}$ A többségében zsidó vallású értelmiségiek fogékonynak bizonyultak a liberális eszmék irányába, így nem csoda, hogy a képviselőtestületi üléseken rendszeresen összekülönböztek Hegyi plébánossal.

Hegyi Antalt az 1890-es években már hagyományosan „az intelligentzia gyülölőjeként" tartották számon. Réti Ferenc föszolgabíró a papi elödök és az értelmiségiek közti bensőséges kapcsolat megszakadását, az értelmiségiek elleni „lázítást” kérte számon Hegyi plébánoson, kinek hivatásánál fogva példaként kellene a nép előtt járnia a hatóság tiszteletét illetően. ${ }^{108}$ A plébános úgy vélte, semmi oka nincs tisztelni és becsülni azt a helyi intelligenciát, mely élen jár a plébános elhelyezését sürgető levelek írásában, az aláírások gyüjtésében és polgári perek kezdeményezésében. ${ }^{1109}$

\section{Nagygazdák}

Bár forrásainkban tisztes vagy előkelö polgárként emlegetik öket ${ }^{1110}$, a gabonakonjunktúra idején megtollasodott nagygazdák számára a „polgár” szó sajátos értelmezést takart. A csongrádi nagygazda-polgár nem a korabeli nagyobb városokban elterjedt, hagyományosan polgáriasnak nevezett - számára értelmezhetetlen - életmódot és mentalitást jelenítette meg, hanem a rendi-nemesi minták követésével fejezte ki a megváltozott anyagi helyzettel párosuló társadalmi emelkedést. A 100 hold feletti nagygazdák és családtagjaik a reformkori nemesekhez hasonlóan kezdtek öltözködni, viselkedni, kikapcsolódni. Ehhez az attitüdhöz esetenként erőteljes dzsentroid vonások vegyültek. ${ }^{111}$ Ahogy akkoriban emlegették: „imponáló megjelenése annak vagyon, kinél több a kiadás, mint a vagyon”. ${ }^{112}$

A nagygazdák leányai közt valóságos háború dúlt azért, hogy a divatáru

\footnotetext{
1107 Jánosi 1983. 76.

${ }^{1108}$ Csongrádi Lap, 1898. február 13. VIII. évf. 7. szám, 1. old.

1109 Tiszavidék, 1902. január 26. XIII. évf. 4. sz. 3. old.

1110 Példaként lásd Sohlya Antal írásának szóhasználatát a templomtorony históriájáról. Tiszavidék, 1894. december 16. V. évf. 50. szám, 3. old.

1111 „A kilencvenes évek hangosak voltak a jókedvtől és jóléttől. Mintha örökkévalóságnak látszott volna az élet. A lakodalmak napokig tartottak. Bagi Zsigmond harmincéves koráig ezer hold földet mulatott el, 32 párbajt vívott. [...] Zóra Fedor, Tary Jani, Tekulics Sándor, Bagi Zsiga, Kovács Henrik, Bubenik Antal mulatságaitól hangos volt a város. Gőzhajót füttettek be, és cigányzene mellett hajókáztak Szegedig meg vissza. Víg társaságok lövöldözték a kávéházak tükreit, célba löttek a díszekre, szinte ész nélkül szórták a pénzt.” Jánosi 1983. 77.

${ }^{1112}$ Labádi 2000. 134. (Szentesi Lap, 1884. augusztus 30. XIV. évf. 35. szám, 3. old.). Egyes parasztcsaládok valóban nemesi eredettel büszkélkedhettek, ám életmódjuk semmiben nem különbözött a nagygazdákétól. Jánosi 1983. 78.
} 
kereskedőktől elsőként szerezzék be a legszebb, legfinomabb anyagokat. A Csongrádi Újság cikkírója nosztalgiázva emlegette fel azokat az időket, amikor Klein Lipót üzlete 1868-ban bezárni kényszerült, mert senkinek nem kellettek a cifra nevü bécsi és párizsi kelmék. ${ }^{1113}$ A módos gazdák fiaikkal és leányaikkal is kijáratták a polgári iskolát, így ennek a generációnak a tanuláson és az úri passziók gyakorlásán kívül nem sok teendője akadt. Gyermekeiket végzettségük okán, szüleiket az állandó cselédtartás miatt sorolhatjuk a korabeli úri középosztályhoz. ${ }^{114}$ A nagygazda réteg „kinyílását” segítették a cseregyerek-cserelegény kapcsolatok. A bánsági németek családokhoz küldött fiatalok szélesebb világlátással, élő nyelvismerettel felvértezve tértek haza. ${ }^{1115}$

Ami az egyházhoz való viszonyt illeti, a nagygazdák családjában a vallásosság az értékhierarchia csúcsán maradt. ${ }^{1116} \mathrm{~A}$ vallási társulatoknak ugyanolyan lelkes tagjai voltak mint a legszegényebbek. A templom céljaira indított gyüjtéseken továbbra is nagyvonalúan adakoztak. Az egyházat kiemelten pártoló nagygazda családok kb. az 1940-es évekig saját paddal rendelkeztek a Nagyboldogasszony-templomban. Ezek a privilegizált helyet biztosító padok a plébános hozzájárulásával készülhettek el. ${ }^{117}$ Az úri kisasszonyok, feleségek egymással versengve hímezték a szebbnél szebb oltárterítőket, térdeplő párnákat. A finom holmikról Hegyi Antal plébános méltatással egybekötött cirkalmas megemlékezéseket tett közzé hetilapjában. ${ }^{1118}$

9. Kik voltak a csongrádi polgárok?

Amennyiben polgárosodáson a rendi nemesség önmenekítő újraformálódását értjük, Csongrád esetében a fogalom értelmét veszti. Ha a rendi társadalom mellett kifejlődött,

\footnotetext{
1113 Csongrádi Újság, 1904. március 13. II. évf. 9. szám, 2. old.

1114 Hanák 1978. 435.

1115 Szücs 1993.

${ }^{1116}$ A 19. század második felében a Bagi, Draskovits, Faragó, Csanyi Forgó, Máté és Tari családok ápoltak szorosabb kapcsolatot a mindenkori plébánossal, nagylelkü felajánlásokkal, alapítványokkal és hagyatékokkal támogatva az egyház céljait.

1117 Példaként említve: Edelényi János 1884-ben engedélyezte a földbirtokos Faragó Mihály nejének, hogy elzárható családi padot készíttessen a szentélyben. Kérése csupán annyi volt, hogy a pad központi elhelyezkedése okán ő kívánja megrendelni azt. Egy későbbi forrásunkban arról szerzünk tudomást, hogy Edelényi a padot saját költségén ( 24 forintért) készíttette el maga és pap vendégei számára, ám megengedte, hogy Faragó Mihályné is használhassa. A század végén Bába Szabó Rókus 16 családi pad létezéséről tudott. VPL APriv. Edelényi János, 1884. augusztus 28. Edelényi János levele a váci püspök felé; VPL APar. Cs. 1886. december 23. Inventárium Edelényi János halála után.

1118 „Draskovits Erzsike kisasszony, Draskovits Dezső úr mủvelt, kedves leánya Úrnapja alkalmából saját hímzésű, művészi két oltárvánkossal lepte meg plébániai templomunkat. [...] Habár nagyon kedvesen lepett meg minket az értékes ajándék, mégis inkább annak örvendünk, hogy intelligens családaink ifjú sarjai ekképpen gondoskodnak az Isten házáról. Húsvétkor Eszes Mariska, most pedig Draskovits Erzsike tüntette ki magát az Úr hajlékának ékesítésében.” Csongrádi Közlöny, 1895. június 16. II. évf. 24. szám, 3. old.
} 
kapitalista viszonyok mentén szerveződött rétegre gondolunk, akkor a maréknyi zsidó ügyvéddel és malomtulajdonossal be is zárult a csongrádi polgárok köre. ${ }^{1119}$ Kik voltak tehát a csongrádi polgárok a 19. század végén?

Ha a csongrádiak korabeli szóhasználatát vesszük alapul, a polgár a lakosság általános ernyőfogalmaként funkcionált, a skála a parasztpolgártól az előkelő vagy tisztes polgárig terjedt. ${ }^{1120} \mathrm{Az}$ állandó cselédeket tartó, szavazati joggal bíró tisztes polgárok viselkedésszociológiai értelemben az úri középosztályt testesítették meg, az előkelőbb hangzású $u ́ r$ megnevezést is jóval szívesebben használták. ${ }^{1121}$ Öket hívta Márkus István cívismódra polgárosuló parasztoknak. ${ }^{1122}$ Az általuk képviselt, reformkori-nemesi világot idéző attitüd tovább késleltette a feudalizmus maradványelemeinek felszívódását. A polgári ízéskultúra nyugatias vonásai idegenek, feldolgozhatatlanok voltak egy ilyen, alapvetően jobbágyparaszti mentalitású közegben, ahol a földbirtok nagyságában mérték a tekintélyt. A viseletkultúra viszont a századfordulóra meglehetősen polgárias színezetet vett: a birkabőr subát, nadrágot és a csizmát fokozatosan kiszorította a sötétkék vagy fekete lajbi, a pantalon, kaput és a harisnyával viselt topánka. A városi parasztlányok befont és felszalagozott haját a franciás konty váltotta fel, csizma és papucs helyett már harisnyát és cipöt viseltek. ${ }^{1123}$

Csongrád esetében a paraszti polgárosodás kezdetét tehát a hagyományos jobbágyparaszti életforma, viselet, világkép felbomlásával, általakulásával lehetne jellemezni, mely az élet különböző területein eltérő tempóban és intenzitással zajlott le. Mindezek elöfeltétele a jobb anyagi helyzet, az írásbeliség térnyerése és a földrajzi mobilitás fellendülése, vagyis a társadalom nyitottá válása volt. A legfontosabb feladat mégis a politizálási hajlam növekedése, a nemzet sorsával való azonosulás maradt. A telkes parasztoknak meg kellett szokniuk a gondolatot, hogy már nem csak Werbőczy népe alkotja a nemzetet. A folyamatot a polgári iskola megnyitása, illetve az örökösödések nyomán kialakuló földhiány gyorsította. Igazat kell adnunk Szücs Juditnak, aki szerint az első „valódi” csongrádi polgárok a 100 hold feletti, földmüves szülők érettségizett gyermekei közül kerültek ki az 1930-as évek tájékán. ${ }^{1124}$

\footnotetext{
1119 V.ö. Erdei 1980/a. 299-302.

1120 Tiszavidék, 1894. december 16. V. évf. 50. szám, 3. old.

${ }^{1121}$ Hanák 1978. 462.

1122 Márkus 1996.

1123 Váry 1974. 179-181.

1124 Szücs 1989; 1995.
} 
1. Születési és halálozási arányok

A születési és halálozási arányszámok párhuzamos, utóbbinak meredekebb csökkenését a szakirodalom a polgárosodás csalhatatlan jeleként határozza meg. ${ }^{1125}$ Csongrádon a 19. század utolsó évtizedeiben valóban kimutatható a halálozás fokozatos csökkenése, ám mellette stabilan tartotta magát a születésszám, akár kétszeresen is meghaladva a mortalitási arányokat. ${ }^{1126}$ Kézenfekvő részben az orvosi ellátás korszerűsödésére gondolnunk, másrészt ne feledjük, hogy katolikus településröl van szó, ahol az egy családra jutó gyermekek aránya hagyományosan magasabb volt. ${ }^{1127}$

2. Infrastruktúra, településkép

A társadalmi változásoknak keretet adó, településszintü fejlődés kerékkötője az állandó árvízi fenyegetettség, az időjárási viszonyoknak kiszolgáltatott termelési mód és az infrastrukturális fejlődés meddő akadozása volt. A villanyvilágítás a 19. században csupán ígéretes terv maradt; a sártengeren dülöngélő pallók lecserélése, az utak kövezése megkésve, nehézkesen indult el. Maguk a lakosok sem törődtek az utak tisztaságával; lábas jószágaikat az utcákra hajtották ki legelészni. ${ }^{1128}$ 1894-94-ben az alföldi traverzális műút építésével, Kiskunfélegyházától Szentes irányában épült ki az első makadám út, mely keresztül vezetett a településen. Az építkezések hatására vett lendületet az utcák kövezése, kezdetét vette a pallók felszámolása. ${ }^{1129}$

Ugyan 1888-ban átadták a Kiskunfélegyháza-Csongrád vasútvonalat, a gőzmasina rendkívül lassú és megbízhatatlan volt, nem ritkán az utasok segédkeztek a lerobbant gépezet újraindításában. Az Eszes-féle gőzfürdő három esztendő elteltével, az alacsony forgalom miatt bezárt. 1872-ben Csongrád büszkeségét, a tanítóképző intézetet árvízi fenyegetettség okán Kiskunfélegyházára helyezték, ahonnan sosem került vissza. Nem

\footnotetext{
${ }^{1125}$ Hanák 1978. 403; Gyáni-Kövér 2006. 32.

1126 Sebestyén 2003.

1127 Hanák 1978. 414.

1128 „Szörnyű valóságra ébredünk akkor, ha látjuk, mint legelnek a tehenek és egyéb szarvasmarhák az utczán, mint turkálják a szőke és fekete süldő malaczok a kövezetek mellékét; mint legelik a libák a kövér papsajtot, és mint pocsognak a kacsák falka számra a mocskos csatornákba. Itt egy kecske, amott egy birka szaggatja élvezettel az élőfák lombjait.” Csongrádi Lap, 1898. július 10. VIII. évf. 28. szám, 3. old. 1129 Jánosi 1983. 74.
} 
sokkal később rendezett tanácsú városi rangjáról lemondva a település a nagyközségek sorába került. ${ }^{1130}$

A kusza településkép első, rendezett „szigete” a római katolikus temető volt. Hegyi Antal csongrádi plébánossága második évében utakat vágatott a rendezetlenül heverő sírok közé, kutat fúratott, kerítést építtetett, árkot ásatott. A közvéleményt erőteljesen megosztó temetörendezést többen a plébános újabb eszement ötleteként könyvelték el, figyelmen kívül hagyva az intézkedés racionális vonatkozásait. ${ }^{1131}$ A következő, szimbolikus értékü változás a templomkert 1894-es fásítása, körbekerítése volt. A plébános a szószékről közölte a környéken legeltető állatok gazdáival, hogy adott esetben nem átall fegyverrel óvni a templomkert füvének épségét. Hogy mennyire nem a levegöbe beszélt, azt egy kecske és egy malac lábának ellövése után kerekedett botrány is tanúsítja. ${ }^{1132}$

\section{Korjelenségek}

A 19. század végi Csongrád lakosságának etnikai összetételét, anyanyelvét és a felekezeti arányait illetően sem tekinthető kora átlagos településének. ${ }^{1133} \mathrm{Az}$ országos szintü társadalmi problémákra adott szervezeti szintű válaszok azonban - még ha teljességgel indokolatlannak tüntek is - nem kerülték el az Alföld egyik legmagyarabb és legkatolikusabb nagyközségét. Kitünő példa erre a hit- és érdekvédelmi céllal életre hívott Katholikus Kör, melynek hiányoztak belső keletkezésü előfeltételei, a szervezet létjogosultságát adó problémák.

Csapó János csongrádi káplán már 1895 decemberében levéllel kereste fel Schuszter Konstantin püspököt, melyben támogatásáért esedezett és fővédnöknek kérte fel. Csapó levele szerint az ötlet Csongrád ,jóérzésű katolikus polgáraitól” származott, akik küldöttséggel keresték fel öt, hogy továbbítsa igényüket a püspök felé. ${ }^{1134}$ A Kör 1896. március 22-én nyerte el a belügyminisztérium jóváhagyását ${ }^{135}$, ám az agitáció már jóval korábban elkezdődött.

\footnotetext{
${ }^{1130}$ Csongrád esete nem példa nélküli: ugyanebben az időben vált nagyközséggé Kalocsa és Orosháza is.

1131 „Ö (t.i. Hegyi Antal) mindent felforgató elveinél fogva, a temetőben alig pár évvel ezelőtt eltemetett holtak sirhalmait és keresztfáit leromboltatta, hogy az ott nyugvó halottaink hamvai felett sétául szolgáló utat létesítsen. Vajjon sétakert-e a temető, vajjon élvezni, avagy szórakozást keresni járunk-e a sírkertbe, hova eddig a kegyelet vezérelt megsiratni kedveseinket, kik ott nyugosszák örök álmukat?” NPI 1889. Gétzi János nyílt levele. Nyomtatott Schwartz Sándornál.

${ }^{1132}$ Csongrádi Lap, 1899. június 11. IX. évf. 24. szám, 2. old.

1133 V.ö. Hanák 1978.

${ }^{1134}$ VPL APar. Cs. 1895. december 31. Csapó János káplán levele a váci püspökhöz.

1135 Dudás 1998. 105.
} 
Február 16-án Csapó János a plébánia épületében hívta össze a csongrádiakat, hogy meggyőzze őket az egyesület létrehozásának szükségességéröl. ${ }^{1136}$ Az előmunkálatok végrehajtására elnöknek Hegyi Antal plébánost, jegyzőnek pedig Krezsák Géza segédlelkészt választották meg. Két héttel később a Hegyi plébános által szerkesztett Csongrádi Közlöny címlapon közölte Csapó káplán cikkét, melyben az egyesület céljait körvonalazta: „Főcélunk, mint az alapszabályoknak alább közölt két paragrafusából is kitűnik: a valláserkölcsi szellem öregbítése és a felebaráti szeretet cselekedeteinek gyakorlása. [...] Egy kath. közszellemet kell teremtenünk, mely a modern pogányságot elfújja a föld színéről, s ne engedje azt, hogy hitünket, lelkünk meggyőződését úton útfélen minden pimasz bántatlanul sértegethesse, összegyüjtjük mindazokat, kiknek lelkében még ki nem aludt a keresztény érzelem, mert csak ha egyek leszünk gondolkodásmódra és akaratra, akkor lehetünk erősek és hatalmasak." ${ }^{1137}$ Erőteljes szavak ezek, melyek a „modern pogányság démona” ellenében hívják zászló alá a katolikus érzelműeket.

Miután a minisztériumi engedély lehetővé tette a hivatalos tagtoborzást, az alapító optimistán látott neki a gyülésekre alkalmas helyiség felkutatásának: „Ha a jelentkező tagok száma oly nagy lenne, hogy egy helyiség szüknek bizonyulna be fogadásukra, két helyiség fog állíttatni."1138 Májusra találtak alkalmas házat a Templom utcában, így ki is tűzték az alakuló gyűlés időpontját. A hónap végén azonban „habár számosan léptek már be eddig is [...] még sokan vannak, kik a belépés iránti óhajukat szóbelileg már nyilvánították, de elfoglaltságuk miatt még be nem íratkoztak”, ${ }^{1139}$ egy későbbi időpontra tették a Kör megnyitását, melyre hosszas halasztások után csak 1896. novemberében került sor. Mi volt az oka a késlekedésnek?

A Katolikus Kör létjogosultságának kérdése az első percétől kezdve kiváltotta a Csongrádi Lap visszhangját. A Lap 1896 márciusában kiadott cikksorozatában támadást indított a Kör által képviselt eszmeiség ellen. Az érvelés gerince szerint Csongrádon elenyésző számban élnek más felekezetűek, így a katolikus eszmék féltése teljesen indokolatlan. „Mi értelme van tehát nálunk a 'Katholikus Kör' szervezésének? Ezt épp oly szükségtelennek, pláne nevetségesnek tartjuk, mintha ugyancsak nállunk, ahol a 20.803 lélek közül egyetlen-egy sincs más nemzetiség, mint magyar, valakinek eszébe jutna magyar olvasó egyletet, vagy bármiféle magyar egyesületet állítani azért, mert

\footnotetext{
${ }^{1136}$ Csongrádi Közlöny 1896. február 23. III. évf. 8. szám, 3. old.

${ }^{1137}$ Csongrádi Közlöny, 1896. március 8. III. évf. 10. szám, 1. old.

${ }^{1138}$ Csongrádi Közlöny, 1896. március 22. III. évf. 12. szám, 3. old.

${ }^{1139}$ Csongrádi Közlöny, 1896. november 8. III. évf. 45. szám, 3. old.
} 
nemzetiségünket, nyelvünket féltené attól a néhány vásznas tóttól, akik heti vásárok alkalmával a piaczon egymás közt nem magyarul beszélnek. [...] A 'Katholikus Kör' alakítása e szerint csak arra való lesz, hogy néhány száz fanatizálható, félkegyelmü polgárnak tájékozatlanságát és észbeli korlátoltságát felhasználva, a felekezeti gyülöltséget szítsák, a polgároknak egy más iránti kölcsönös tisztelet és felebaráti szeretetet romba döntsék." ${ }^{1140}$ Csapó János sem késlekedett a válasszal, így a Csongrádi Közlöny ismét hetekig címlapon foglalkozott a Katolikus Kör kérdésével. A támadások ideig-óráig elérték céljukat: a tagfelvétel a várakozásokkal ellentétben akadozottan haladt.

Az 1885-ben megnyitott Keresztény Gőzmalom és a Keresztény Fogyasztási Szövetkezet a zsidó kereskedők ellenében hangsúlyozta a vállalkozás „keresztényi” jellegét. ${ }^{1141}$ A kortárs piarista szerzetes-író, Váry Gellért túlzásnak vélte, hogy egy malmot - akár csak egy szekeret, vagy bármi egyebet - kereszténynek vagy nem kereszténynek neveznek el. ${ }^{1142}$ A kezdeményezések élharcosa minden esetben Hegyi Antal plébános volt, aki nem csak élénk figyelemmel kísérte a Gőzmalom és a Szövetkezet sorsát, de a szervezeteken belül vezető tisztségeket is vállalt.

4. Hetilapok, politika, vallás

Az 1890 után indított első helyi-közéleti lapok jelentősen befolyásolták a csongrádi közvéleményt. ${ }^{1143}$ Borsos János orvos családjában tudjuk, hogy párhuzamosan olvasták a két ellenlábas orgánum, a Csongrádi Újság és a Tiszavidék cikkeit. ${ }^{1144}$ Ugyan még mindig csak a lakosok fele tudott írni-olvasni, a sajtóban megjelent - gyakran felettébb ellentmondásos - hírek szájról-szájra jártak.

A csongrádi sajtótermékek stílusukat és felépítésüket tekintve az országos kortendenciákat képezték le. Profiljukat az ellenzéki 48-as vagy a liberális-kormánypárti elvek tükrében alakították ki, és javarészt egymásra reflektáltak rendkívül személyeskedő hangnemben. A Csongrádi Közlöny és a Csongrádi Lap, vagyis Hegyi Antal és Éder János ökölharcának tétje a lakosság politikai nézetének alakítása, országgyülési képviselőválasztások idején a kortes hadjárat sikerre vezetése volt. A vizsgált időszakban Csatár Zsigmond (későbbi kántor) és Hock János (katolikus pap) megválasztásának esete

\footnotetext{
${ }^{1140}$ Csongrádi Lap 1896. március 1. VI. évf. 9. szám, 2. old.

${ }^{1141}$ Gát 1982. 157-158.

${ }^{1142}$ Váry 1974.

${ }^{1143}$ A csongrádi újságokról bővebben lásd: Dudás 2004.

1144 Jánosi 1983. 78.
} 
áll példaként előttünk, mely mindkét esetben a klerikális-ellenzéki erök helyi túlsúlyáról tanúskodik. ${ }^{1145}$

Hegyi plébános lapszerkesztői-újságírói tevékenysége a véleményformálás határozott szándékát mutatja, mely a hagyományos papi szerepkör kiszélesítését is jelentette. Éder János a liberális eszméknek megfelelően ${ }^{1146}$ kezelte a lapszerkesztő kollégát; kortes hadjárat idején tehát elvárta tőle, hogy felelős közéleti emberként, afféle hivatalnokként álljon ki jelöltje mellett a sajtóban, és emelt fővel viselje a politizáló állampolgároknak ,kijáró” ellenoldali hangnemet.

Hegyi Antal azonban politikai tevékenysége és papi hivatása között nehezen találta az egyensúlyt. ${ }^{1147}$ A nép sem tudott elvonatkoztatni papi mivoltjától - igaz, Hegyi Antal sem törekedett erre. ${ }^{1148} \mathrm{Az}$ ellenzék támogatásának oka ugyanis a kormány vallásellenesnek értelmezett intézkedései (polgári anyakönyvezés és házasságkötés) voltak: Hegyi plébános voltaképpen az egyház régi előjogait védte és hitvédelmi céllal kezdett politizálni.

Több forrásunk is megerősíti, hogy Hegyi plébános a templomi szószékről agitált, káplánjait, az egyházfit és a vallási társulatok tagjait is bevonta a szervezkedésekbe. ${ }^{1149} \mathrm{~A}$ képviselőválasztás valóságos „szent háborúra” kezdett hasonlítani. Mikor Réti Ferenc főszolgabíró a sajtón keresztül visszavonulásra szólította fel Hegyit, ő válaszul esküvel erősített plébánosi kinevezésére hivatkozott, mely tartósabb a főszolgabírói hivatalnál. ${ }^{1150}$ A retorikai csúcspontot azok az önvédelmi célú bibliai hasonlatok jelentik, melyekkel előszeretettel hozakodott elő politikai támadások idején. ${ }^{151}$

\footnotetext{
${ }^{1145}$ Ahogy Romsics Ignác is megjegyzi, a színkatolikus településekröl jellemzően a 48-as jelölteket küldték a parlamentbe. (Romsics 2007. 740.) Országosan az Alföldet és a Dunántúlt tartották inkább ellenzéki érzelmünek, míg a Felvidéken és Erdélyben a kormánypárt képviselöi arattak győzelmet. Csatár megválasztásának körülményeiröl bővebben lásd: Zsótérné Nemes 1989.

1146 A liberális eszme a papi hivatalt megfosztotta transzcendentális vonatkozásaitól, és a vallást afféle morálként, szellemi magatartásként értelmezte. Ld. Romsics 2007. 723.

${ }^{1147}$ Káplánjai eképpen panaszkodtak a váci püspöknek: a plébános „folytonos csavargásai miatt mi vezettük az irodát is, a sok számú gyónóval meg éppen nem szokott törődni, mert az állandó korteskedés, gyủlésezés, nemkülöben az általa szerkesztett szennylap minden idejét elfoglalja." VPL APriv. Hegyi Antal, 1894. március 4. Csongrádi káplánok levele a váci püspökhöz.

${ }^{1148}$ Álljon itt példaként egyetlen tanulságos idézet Hegyi egyik elkötelezett hódolójának tollából: „Az egyház e jeles plébánosáról azt hirdették a vármegye hívei, hogy a leggyülöltebb pap a világon. S ez a gyülölt ember kibontja Csongrádon az ellenzék zászlaját, és a tiszta hazaszeretet nevében felemeli a zászló alatt apostoli szavát, $\mathrm{s}$ megindul vele a nép, és elsepri a kormánypártot, $\mathrm{s}$ vele együtt a megdönthetetlennek hirdetett Szivákot.” Labádi 2007. (Az idézet 1892-böl származik - Szentesi Lap.)

${ }^{1149}$ Csongrádi Lap, 1892. január 1. II. évf. 1. szám, 2. old. „Nem csak a plébános és a templomatya, hanem a segédlelkészek, kántorok, Jézus Szíve Társaságbeliek, az összes olvasós és lobogóhordozó egyházfiak és leányok egymással vetélkedve üzték a fanatizálás és terrorizálás mesterkedéseit." Labádi 2007. 88. (Szentesi Lap, 1892. március 25. XX. évf. 25. szám, 1-2. old.)

${ }^{1150}$ Csongrádi Közlöny, 1895. május 5. II. évf. 18. szám, 3. old.

1151 „Nem éppen így tettek-e ellenfelei Krisztus Urunkkal, mikor a saját hazugságaikat állították fel ellene
} 
Ez a nyilvánvaló kettősség kellőképpen irritálta a politikai ellenfeleket. „Midőn püspökét gyalázza, akkor szerinte mint polgár beszél, tehát a papi törvények határán kívül érzi magát, míg ha mint polgár követ el vétket, akkor a papi talárt használja védbástyául" 1152 - írják elhelyezéséért küzdő ellenfelei. A Csongrádi Lap 1895-ben Karvaly néven külön vicclapot nyitott „Gyihe Antal, a Csigerháti Bűzlöny szerkesztőjének” bosszantására, aki hol Jézushoz, Szent Ágostonhoz vagy Keresztelő Szent Jánoshoz hasonlítja magát. ${ }^{1153}$ Hegyi Antal előtt tehát nem kevesebb feladat állt, mint a hiteles pap és hiteles állampolgár ötvözése és elfogadtatása, ám erőfeszítései felemás, támadható és kiforratlan összképhez vezettek.

\section{Papság és polgári pereskedés}

Csongrádon elsőként 1876-ban, Csatár Zsigmond képviselővé választását követően indult komolyabb vizsgálódás a helyi papság ellen. Szvoboda József káplánjait a csongrádi polgármester jelentette a váci püspöknél, mert úgy vélte, hogy a fiatal papok zártkörü gyüléseken korteskednek és lázítják a népet a helyi vezetöség ellen. Ugyan Csemegi polgármester kilátásba helyezte az ügy polgári peres útra terelését, pár hét elteltével meggondolta magát. Ahogy a kerületi esperes írta jelentésében: „A lakosság szerfölött izgatott és ki tudja mi történik, ha izgatottsága a tanúk hajhászása által még fokoztatik? Ö (Csemegi) a vallásra, mind az erkölcsiségre, de még a papságra nézve is hasznosabbnak látná, ha az én eddigi csendes vizsgálatommal az ügy további zaklatásának eleje vétetnék, és arra én is közremüködném." 1154 A kerületi esperes támogatta a szándékot, így az ügy végül nagyobb hírverés nélkül elsimult. ${ }^{1155}$

Míg elődei látványosan tartózkodtak tőle és sikeresen elkerülték a polgári peres eljárásokat, Hegyi Antal ellen tucatszámra érkeztek feljelentések többnyire fizikai bántalmazás, lázítás, becsületsértés, sajtóvétség vádjával. Az ügyeket a helyi járásbíróság és a szegedi királyi törvényszék tárgyalta. A hatóságok nem voltak tekintettel Hegyi Antal

bizonyítékul? [...] Hogy engem ne bántalmazzanak a legqualificálatlanabb módon, mikor öt, a mestert halálálig bántalmazták?" VPL APriv. Hegyi Antal, 1894. szeptember 30. Hegyi Antal levele a váci püspökhöz.

${ }^{1152}$ VPL APriv. Hegyi Antal, 1892. március 14. Csongrádi lakosok levele a hercegprímáshoz.

${ }^{1153}$ Csongrádi Lap, 1898. február 6. VIII. évf. 6. szám, 2. old. A jelenség a vizsgált korszakban általános lehetett. Mohl Adolf a tatai plébánia történetéről szóló írásában a reformátusok vádjai ellen védekező plébános is „Szent Pállal kiált fel”. Mohl 1909. 154.

${ }_{1154}$ VPL APar. Cs. 1876. február 18. A kerületi esperes levele a váci püspökhöz.

${ }^{1155}$ „Az aztán csakugyan felzavarhatná a jó lelkủ kath. hívek nyugalmát, ha ezek azt vennék észre, hogy kedvelt papjaikat, mint a minők a csongrádiak, valamely tisztviselő kellő ok nélkül háborgatná és rágalmazná.” VPL APar. Cs. 1876. február 18. A kerületi esperes levele a váci püspökhöz. 
papi mivoltára: a beidézések időpontját rendszerint valamilyen jeles egyházi ünnepre tüzték ki, ami tovább növelte az eset abszurditását. ${ }^{1156}$ Ami a leginkább megdöbbentette a csongrádi közvéleményt, az a plébános által saját paptársai ellenében indított polgári peres eljárások sora volt, mely a legliberálisabb elmék képzeletét is felülmúlta. Hegyi elsőként egyik helyettese miatt hívott rendőrt, aki a plébános engedélye nélkül misézett a templomban. Ugyan a rendőr egy ujjal sem nyúlt a lelkiatyához, a misézést félbeszakító jelenet híre még sokáig visszhangzott a csongrádi utcákon.

1898-ban a plébános saját káplánjai ellenében indított rágalmazási pert. Elsőként Sperling Béla segédlelkész állt súlyos testi fenyegetés vádjával a bírák előtt, másodszorra további három káplánnal közösen, nyilvános becsületsértés gyanújával. Hiába figyelmeztette a lépés káros erkölcsi következményeire és hiába próbálta a peren kívüli megegyezés útjára terelni Szathmáry Ödön bíró, Hegyi Antal nem állt el szándékától. ${ }^{1157} \mathrm{~A}$ papok kihallgatása mindig csütörtöki napokra esett. A kíváncsi hívek ott tolongtak a járásbíróság körül, figyelték a csudát, ahogy papjaik a törvényszék előtt vallanak. A helyi lapok részletekbe menően leközölték a papok közt dúló keresztényietlen békétlenség részleteit. A tragikus mélypontot két káplán eskü alatt tett, egymásnak ellentmondó vallomása jelentette. Droppa Károly eképpen elevenítette fel az eset következményeit: „az első pör alkalmával e városban nagy megbotránkoztatást szült, hogy Csapó másképpen vallott, mint Drexler. Figyelmeztetett a bíró a per előtt, hangsúlyozta azt, hogyha pörre visszük a dolgot, bármiképpen dől is el a pör, ez által az egyház tekintélyén súlyos csorba esik". ${ }^{1158}$

Hegyi Antal elődei a plébánián belül támadt konfliktusokat minden erejükkel igyekeztek titokban tartani és egymás között, végső esetben a váci püspök bevonásával elsimítani. Ugyan voltak a plébánia történetében kiugró esetek - például az 1820-as években Mátyus János plébános és Rosenberg káplán lövöldözése - a csongrádi papság magánkonfliktusai sosem kerültek ilyen körvonalazottan, ilyen részletesen nyilvánosságra. A perek egyik következményeként a papság képe fájdalmasan realisztikussá vált. A felismerés, hogy egy pap is tud haragot tartani és hamisan vallani, ráadásul mindezt nyíltan felvállalja, valósággal letaglózta a csongrádi közvéleményt. Éder János lapja kárörvendően taglalta az eset morális következményeit, a nép csalódott fájdalmát, a papság hagyományos imázsának talán első, valódi komoly torzulását.

\footnotetext{
1156 Csongrádi Közlöny, 1894. augusztus 19. I. évf. 23. szám, 3. old.

1157 VPl APriv. Hegyi Antal, 1898. augusztus 22-26. Püspöki szentszéki kihallgatási jegyzőkönyv. 1158 VPL APriv. Hegyi Antal, 1898. augusztus 22-26. Püspöki szentszéki kihallgatási jegyzőkönyv.
} 
6. Szekularizáció és vallási társulatok

A szekularizáció ${ }^{1159}$ Csongrádon ekkoriban még nem a hívők számának apadásában, hanem a külsőség, a reprezentáció megnövekedett fontosságában jelentkezett. Ahogy Hegyi Antal írta Csongrádra érkezése idején: „A szó szoros értelmében beteg ember hagyományát örököltem. A hitélet pangásban sínylett. A nép minden vallásosságot a külsőségekben helyezett, de a lelkiismeret tisztaságára és a szívre éppen nem látszott figyelmet fordítani." ${ }^{1160}$ A jellegzetes mentalitás ellenében Hegyi Antal a vallási társulatok fellendítésével szállt harcba. Hegyi plébános néhány esztendő leforgása alatt a kor színvonalának megfelelő szervezettségi szintre emelte a vallási társulatokat. Ö volt az első csongrádi plébános, aki káplánjait teljes mértékben kivonta az egyesületi élet szervezéséből, és csupán bizalmasának - és egyben bérmafiának, Csapó János segédlelkésznek engedélyezett némi önálló mozgásteret, hogy híveket toborozzon a Katholikus Kör számára. Az elnöki székben azonban itt is a plébánost találjuk. Ez a szervezési stratégia Hegyi Antal plébánosi müködésének utolsó éveiben hozta meg gyümölcsét.

Hegyi Antal felfüggesztését követően a plébános ártatlanságát hangoztató fórum vezéregyéniségei a rózsafüzér társulatból kerültek ki. 1898 februárjában a püspöki küldött beszédet intézett a csongrádi néphez, hogy megmagyarázza Hegyi Antal felfüggesztésének okait. A Csongrádi Lap eképpen idézi fel a történteket: „Midőn mise után felolvasták a Szent szék ítéletét, néhány elöre betreszírozott olvasós asszony közbe kiáltotta: nem igaz! Hegyi ártatlan! Erre azután moraj keletkezett a templomban, mely annyira fokozódott, hogy a 10 órai mise után a szentszéki ítélet felolvasását abba kellett hagyni." ${ }^{1161}$ A templomi kihirdetést követően a szentszéki megbízott összehívta a vallási társulatok vezetőit, hogy megmagyarázza a fefüggesztés okait. A vezetők egyöntetően azon az állásponton voltak, hogy Krisztus példáján nekik is meg kell bocsátaniuk a plébánosnak. ${ }^{1162}$

\footnotetext{
${ }^{1159}$ Szekularizáción azt a folyamatot értjük, amikor az állam és egyház erőviszonyát tekintve az állam kerül fölénybe. Mint jelenség ide sorolható a szekták népszerüsödése, a vallásgyakorlás visszahúzódása a magánszférába és a vallási közöny terjedése. Ld. Gyáni-Kövér 2006.

${ }^{1160}$ VPL APar. Cs. Hegyi Antal sorai a csongrádi Historia Domus kitépett lapjain. 1888.

${ }^{1161}$ Csongrádi Lap, 1898. február 13. VIII. évf. 7. szám, 1. old.

1162 VPL APriv. Hegyi Antal, 1898. augusztus 22-26. Püspöki szentszéki kihallgatási jegyzőkönyv, Agócs János vallomása.
} 
Szintén a Csongrádi Lap közölt iróniával fütött beszámolót Hegyi Antal márciusi visszatérésről: „Már a vasútnál mintegy 3000 főnyi fehérkendős néném asszony ${ }^{1163}$ várta az elítélt plébánost, minden némber kezében 1 szál szentelt viaszgyertyát tartott [...] Hegyi felállt a lóczára és sürü könnyhullatások között jelentette ki, hogy ártatlan. 'Krisztust is eláztatták a papok, őt is a paptársai', mondá. A sok zajos multú némber ezen kijelentésre czitrom nagyságú könnyekkel áztatta a kocsi utat. Ily módon igazolták Hegyi Antalt a sikkasztás vádja alól néném asszonyék." 1164 Júniusban arról értesít a cikkíró, hogy Hegyi plébános elhelyezése miatt a csongrád-belsővárosi lakosok nem hajlandóak részt venni az Úrnapi sátrak díszítésében, különösen az asszonyok „,reszelő-meszelő háborúra készek, s nem ünnepelnek Hegyi nélkül’. 1165

Az ,aranyszájú papként” is emlegetett Hegyi Antal meggyőző, szuggesztív retorikájával szilárd társadalmi bázist épített ki, elsősorban az asszonyok körében. Az asszonyokon keresztül pedig jó esélye volt a családfők megpuhítására, a közvélemény határozott formálására. A vallási társulatok alapításába és szervezésébe fektetett energia tehát nem pusztán lelkiségi, de jelentős társadalmi következményekkel is járt. Hegyi plébános sajátos retorikai stílusa szerencsésen találkozott a csongrádi hívek fogékonyságával a látványos és reprezentatív alkalmak, események, jelenségek iránt. A folyamatosan szépülő és gyarapodó templom, virágözönnel borított körmenetek mind a plébános szavainak igazát, szándékainak tisztaságát hivatottak igazolni.

\section{TEMPLOMSZOLGÁK ÉS GYERMEKEIK}

A papi elődöktől „megörökölt” laikus egyházi tisztségviselök elbocsátásával olyan kísérletnek lehetünk tanúi, mely a hatékony szervezeti müködés érdekében oltja ki a szokásjog erejét. A továbbiakban, mintegy összegzésként a templomszolgák leváltásának szükségszerüségéről, az egyházi tisztségviselők újító kísérleteiről és gyermekeik sorsáról értekezünk.

\footnotetext{
1163 A rózsafüzér társulati asszonyok jellegzetes „,egyenviselete” társulati tag temetésén vagy körmenet alkalmával a fehér fejkendő.

${ }^{1164}$ Csongrádi Lap, 1898. március 11. VIII. évf. 11. szám, 2. old.

1165 Csongrádi Lap, 1898. június 12. VIII. évf. 24. szám, 2. old.
} 
1. Új éra, új arcok. A személycsere szükségszerüsége

A Hegyi Antal idejében végrehajtott személycseréket hiba volna pusztán személyi ellentétekre visszavezetni. A plébános lépéseit olyan intézkedések soraként is értékelhetjük, melyek célja a plébánia hatékonyabb müködési rendjének kialakítása volt.

Hegyi plébános egy erősen centralizált plébániaszervezet létrehozásán fáradozott, melynek megvalósításában a templomszolgáknak kulcsszerepet szánt. Rendkívül fontos volt számára, hogy ki, milyen mértékben képes azonosulni céljaival. Kis túlzással azt is állíthatjuk, hogy a feltétlen elvhüség a templomszolgák legföbb erényeként lépett elö. Az „alkalmatlanak” ítélt templomszolgák eltávolításáért folytatott hadjárat már 1886-ban elkezdődött. A 40 esztendeig kitartóan szolgáló Keviczky György harangozót engedetlen pimaszság és testi bántalmazás, az 50 éve békében ténykedő Bába Szabó Rókus egyházfit „árulás” és a templomi pénzek hütlen kezelésének vádjával távolította el helyéröl. Az érintetteknek az esküvel tett vallomásokon, elkeseredett tisztázó leveleken kívül más fegyvere, egyéb bizonyítéka nem volt, így a váci püspöki szentszék a plébános állitásait fogadta el. 1898-ban a csongrádi bíró - az elbocsátott templomszolgák panaszait megelégelve - a megyéspüspökön keresztül üzente meg Hegyi Antalnak, hogy „a jövőben a község által alkalmazott egyházi tisztviselők és szolgák rendszeressé vált üldözésével hagyjon fel". 1166

A kiöregedett Sohlya kántor ellen Hegyi plébános azért nem indított (nyílt) támadást, mert joggal tartott Sóhlya Gyulától, az éneklész föjegyzővé vált fiától. A helyettes kántor, Hornyik Károly kezdeti támogatását Hegyi plébános igen hamar megbánta, a későbbiekben maga próbálta sürgetni eltávolítását. Mivel sorozatos panaszlevelei nem jártak sikerrel, egészen 1902-ig a megnyomorodott fóéneklész és az alkalmatlan helyettes viszálya árnyékolta be a csongrádi kántori hivatalt.

A csongrádi laikus egyházi tisztségviselők egyedi színezetű konfliktusai azt mutaták, hogy az új plébános érkezésével megváltozott irányítási stratégia hatásai a legközvetlenebb hivatali alárendelteken mutatkoztak meg elsőként. Ez a korábbiakban is így lehetett, de mivel a változások nem társultak politikai, közéleti indítékokkal, a konfliktusok sem voltak jellemzőek.

Hegyi Antal plébánost szemmel láthatóan motiválta egy olyan csapat képe, mely

${ }^{1166}$ VPL APar. Cs. 1898. október 30. Csongrád község elöljáróinak levele a váci püspökhöz. 
feltétel nélkül tud azonosulni céljaival. Ennek egyik jele, hogy többször is megkísérelte jogkörén túl befolyásolni az egyházszolgák megválasztását. A többszörös érdekeltség okán szándékai csak részlegesen valósultak meg, intézkedéseinek visszhangja azonban túlnőtte a tényleges eredmények horderejét.

\section{Hivatás és kreativitás. Az innovatív, különc templomszolgák}

A csongrádi templomszolgák közt feltünően sok az átlagosnál sokoldalúbb, valódi kísérletező tehetség, aki kiemelkedő eredményeket mutatott fel akár a művészetek vagy a gazdálkodás területén. Sohlya Antal kántor oktatói jegyzeteket készített, egyházi dallamokat, énekeket, tudományos és ismeretterjesztő cikkeket, kántori segédkönyvet írt. Sohlya a művészkedés mellett őszintén lelkesedett a szőlőnemesítés iránt, Csongrádon az elsők között használt permetezőszert. Szőlőskertjének nem győztek csodájára járni, így hamarosan mintakövetésre sarkallta az újításokra nyitott gazdákat. Egész életében büszke volt arra, hogy a polgári fiúiskola ötletét elsőként ő vetette fel Csongrádon. ${ }^{1167}$ Bába Szabó Rókus sokoldalú tevékenységéröl oldalakon keresztül lehetne értekezni, a paletta a vőfélykedéstől kezdve a földmérésig terjedt. Verses krónikát, helytörténeti feljegyzéseket írt. Az ilyen jellegű tevékenységet Mohay Tamás a paraszti polgárosulás csalhatatlan jeleként értékeli. ${ }^{1168}$

A kántor és az egyházfi a legmegbecsültebb laikus egyházi tisztségviselő volt; a kántor képzettsége, az egyházfi pedig vagyona okán. Vállalkozó szellemü természetük, a paraszti világtól eltávolodott, különc természetük önkéntelenül is a polgárosodás ügyvivőivé tette őket. Környezetük osztatlan bizalmatlansággal, nem ritkán gunyorosan szemlélte próbálkozásaikat. Hogy hasonló mentalitásuk ellenére miért nem egyeztek ki Hegyi Antallal, arra válasz elsősorban személyes okokban keresendő.

\section{A kapcsolatok és kiemelkedés módozatai}

Forrásaink alapján megállapítható, hogy az csongrádi laikus egyházi tisztségviselök egységesen megbecsülték, nagyra tartották az iskolázottságot. Gyermekeiket - nemükre való tekintet nélkül - az elemi után a polgári iskolába is beíratták. A csongrádi polgári megnyitása előtt a fiúgyermekeket Kecskemétre vagy Szegedre küldték tanulni. A

\footnotetext{
1167 Dudás 1985. 182.

1168 V.ö. Mohay 1992.
} 
motivációt az értelmiségi vagy köztisztviselői pályákról dédelgetett álmok és a földhiány adták. A hivatást apáról-fiúra öröklő külsővárosi harangozó családjában is nyilvánvaló volt, hogy a számos gyermek közül csupán egynek lesz biztos a megélhetése.

A legfényesebb pálya, amiről egy templomszolga édesapa álmodhatott, a papé volt. Ugyan Csongrádról jellemzően kevesen szánták rá magukat a nehéz stúdiumokra, az egyházi tisztségviselők gyermekei, unokái között mégis találunk papnövendékeket. 1904ben arról szerzünk tudomást, hogy Sohlya Antal Ilonka leányának és vejének Sándor nevü fiát a kispapok sorába vették fel. ${ }^{1169}$ Sándor tartalékos lelkészként szolgált az első világháborúban, majd miután egyházi elöljáróival összetüzésbe került, aposztatált. Öccse, János viszont kántortanító lett. 1894-ben a Csongrádi Közlöny Bába Szabó Imre papnövendék sikeres záróvizsgájáról tudósított. ${ }^{1170}$

Amint azt korábban már említettem, a csongrádi községháza alkalmazottai közt jellemzően pályahagyó iparosokat és a templomszolgák gyermekeit találjuk. Amennyiben Erdei Ferenc nyomán a nemzeti kispolgárság ernyőfogalma alá vesszük a köztisztviselőket és az „egyházak nem értelmiségi szolgálattevőit”, a községházán szolgáló leszármazottak nem meghaladták, csupán a világi hivatali szférába menekítették felmenőik életmintáját. ${ }^{1171}$

A több generációs kántortanító dinasztiák, mint a Mezey, Kmeth vagy Knapek arról tanúskodnak, hogy az egyházi éneklészek gyermekei szívesen folytatták édesapjuk hivatalát, jó eséllyel kerültek be a kántortanító-képző intézményekbe. Kmeth Lajos kántor fiai, József és István tanyai tanítók lettek Csongrád környékén. Keviczky Ferenc, az egykori harangozó és sekrestyés fia 1906-1910 táján a csongrádi Síp utcai elemi iskolában tanított. Testvére, Keviczky Andor egészen az iskolaigazgatói állásig vitte. ${ }^{1172}$

A tanítói és kántori hivatás mellett kellő szorgalommal magasabb világi pozíciók is elérhetővé váltak a kántorgyerekek számára. Tanulságos, hogy a kántori hagyomány fonalából kilépő, a politika világában kiteljesedő Sóhlya Gyula sosem szabadulhatott édesapja örökétől. Sosem szabadult - és tán nem is akart igazán: 1906-ban egy nosztalgikus hangvételü újságcikkben olvashatjuk, hogy a négy éve halott Sohlya Antal

\footnotetext{
${ }^{1169}$ Csongrádi Újság, 1904. július 10. II. évf. 28. szám, 2. old.

1170 Csongrádi Közlöny, 1894. június 24. I. évf. 15. szám, 2. old. Megjegyzendő, hogy Virter Lajos egykori csongrádi plébános apja is kántortanító volt. Vele együtt testvére is a papi hivatást választotta. Chobot I. 1917. 966.

${ }^{1171}$ Erdei 1980/a. 332.

1172 Csongrádi Lap, 1898. augusztus 28. VIII. évf. 35. szám, 3. old.
} 
főjegyzővé lett fia időnként orgonál és énekel a templomban. ${ }^{1173}$ Vele egy időben Keviczky György harangozó fia, Sándor ferences szerzetesből lett hivatali segédjegyző, később tömörkényi jegyző; testvére, Keviczky Endre pedig iktató és kiadó. ${ }^{1174}$ A plébániatemplom megmagasított tornyának toronygömbjébe Sándor fogalmazta a csongrádi helyi történelmet és közállapotokat áttekintő szöveget, 1886-ben. ${ }^{175}$ Magdics Gáspárné református szülésznő fia, Kázmér rostásból lett községi végrehajtó, Gáspár suszterként kereste kenyerét. Az 1890-es években már mindkét Magdics-fiú a községháza szolgálatában állt. ${ }^{1176}$

A Keviczky harangozó családban jellemző volt a több mesterség kitanulása. Öreg Keviczky György a harangozás mellett asztalosmesterséget űzött ${ }^{1177}$, Keviczky Katalinról tudjuk, hogy bábaasszonyként tevékenykedett ${ }^{1178}$, Ifjabb Keviczky György lakatosnak tanult majd többszörös lapszerkesztő lett, ám elsősorban iparosként tekintett magára. ${ }^{1179}$

Az utolsó Keviczky hivatali utódáról, Szőke Jánosról tudjuk, hogy földműves volt és búcsúvezető-előénekes. ${ }^{180}$ Palásti Lajos harangozó úgyszintén, ám János nevü fia már modern hentesüzletet nyitott Csongrádon. ${ }^{1181}$ A Palástit leváltó Hajdú János korábban gátőrként szolgált. Bába Szabó Rókus egyházfi származása szerint földművesnek vallotta magát. A 19. század első felében a kurátorok jellemzően az iparosok közül kerültek ki; lásd 1824-ből Szmatona Antal nevezetű cipészt (Belsőváros) vagy Mészáros Istvánt (Külsőváros), aki eredeti foglalkozását tekintve molnár volt. ${ }^{1182}$

Az adatokat látva kijelenthető, hogy a 19. század végére Csongrád közigazgatási hivatalaiban a templomszolgák és egyéb laikus egyházi asszisztencia gyermekei fontos

\footnotetext{
1173 „Sóhlya bátyánk örökébe azóta más lépett. Mégis olykor mintha az ő szavát, hangját hallanám, midőn a templomba tévedek, hogy lelkemen könnyítsék [...] Fent a khoruson hangzik az orgona fenségesen, szívhez szólóan. S aki énekel nem más, mint Sóhlya Gyula, Csongrád város főjegyzője. Ugyanaz a sajátos, kedves csengésü hang, mint hajdan, az orgonajáték pedig remekebb, müvésziesebb. [...] De az ö helyét nem ott jelölte ki a sors, ott van az idegölő munkában.” Csongrádi Újság, 1906. április 15. IV. évf. 16. szám, 3. old. ${ }^{1174}$ Csongrádi Lap, 1896. július 5. VI. évf. 27. szám, 2. old; Csongrádi Lap, 1896. július 5. VI. évf. 27. szám, 2. old.

${ }^{1175}$ MNL CsML CsL Képviselőtestületi iratok 1872-1949. A toronygombban elhelyezett szöveg 1886.

${ }^{1176}$ VPL Apar. Cs. Historia Domus, Hegyi Antal kitépett lapjai (144.-145 oldal). 1888.

1177 VPL APar. Cs. 1868. február 28. Keviczky György nyilatkozata. György az 1840-es évek derekán két éven keresztül vándorolt. 1852-ben példás magaviseletének igazolására kért bizonyítványt a városi elöljáróságtól. Forgó-Forgó 1987. 45.

1178 NPI Születési Anyakönyv, 1800. szeptember 2. Nagy András keresztségét Kevitzky Katalin szolgáltatta ki.

1179 VPL APriv. Hegyi Antal, 1892. március 19. Eszes Mátyás levele a hercegprímáshoz. 1891-ben egyetlen évfolyamot élt meg Ifjabb Keviczky György Közérdek nevet viselö hetilapja. Ennek egyik számában írja: „Minthogy pedig én a közép, vagyis iparos osztályhoz tartozom.” Közérdek 1891. augusztus 2. I. évf. 4. szám, 3. old. Ö szerkesztette korábban szintén rövid életű Csongrád hetilapot (1890).

${ }^{1180}$ VPL APriv. Hegyi Antal, 1898. augusztus 22-26. Szőke János vallomása.

1181 Tiszavidék, 1908. május 3. XIX. évf. 18. sz. 4. old.

1182 NPI Canonica Visitatio 1824.
} 
tényezőkké váltak. Közülük egyedül Sohlya Antal kántor fia volt valódi döntéshozói pozícióban, de az iktatói, ellenőrzői funkciók többségében csupa Keviczky és Magdics fiút találunk. Az egyházi és hivatali élet kulcspozícióit néhány helyi család és azok rokonsága tartotta kézben.

A folyamat már Hegyi Antal Csongrádra érkezése előtt elkezdődött, így mire a templomszolgák „lecserélésére” került a sor, a plébánosnak egy megerösödött, befolyásos leszármazotti körrel is meg kellett küzdenie. A tisztségviselő gyerekek szüleik védelmében egészen újfajta eszközökkel, elsősorban a nyomtatott sajtón keresztül igyekeztek a plébános ellen fordítani a közvéleményt. Magán kiadású röpiratok, nyílt levelek sora követte Keviczky György harangozó elbocsátását, Magdics szülésznő ügyét. A végeredményeket tekintve erőfeszítéseik nem jártak sikerrel, de jelentősen hátráltatták a plébánost szándékai megvalósításában (lásd. a harangozói lakból való kilakoltatás elhúzódása).

\section{Házassági kötelékek}

A csongrádi laikus templomszolgák egyöntetủen nagyra becsülték az iskolázottságot, így lehetőségeikhez mérten a legjobb iskolákba járatták gyermekeiket. A polgári végbizonyítvánnyal vagy végzett iparos mesterséggel felvértezve pedig kedvezőbb házasságkötésre nyílt lehetőség, így a templomszolgák gyermei már hivatalnokokhoz, tanárokhoz mentek feleségül, módos nagygazdák lányait kérték feleségül.

A templomszolgák családi körében mérsékelten ugyan, ám kimutatható egyfajta foglalkozási endogámia, illetve az úri középréteg felé terjeszkedő házassági kapcsolatrendszer. Az 1859-ben elhunyt Kmeth Lajos kántor első neje Bauersax Anna egyházpártoló, módos iparos leánya; második felesége a harangozó családjának tagja, Keviczky Márta volt. ${ }^{183}$ Sóhlya Gyula főjegyzőként Csongrád legmódosabb nagygazdájának lányát, Forgó Lucát vette feleségül. Sohlya Antal kántor Ilka nevü lánya a tehetséges kántortanító, későbbi polgári iskolai igazgató Farkas Béla felesége lett, míg Jolán az iparosnak tanult, majd helyettes kántorrá előlépett Hornyik Károlyhoz ment hozzá, aki egy neves kecskeméti értelmiségi família leszármazottja volt. 1891 Szent István ünnepén arról szerzünk tudomást, hogy a rózsafüzér társulati vezető Gyovai Döme István

\footnotetext{
1183 MNL CsML CsL Csongrád város 1865-1872-ig nagyközség tanácsának iratai. (1802) 1849-1871 (1872) V.B.42. Tanácsülési jegyzőkönyvek. 1859. november 7. jk. 288. sz.
} 
kisbirtokos leányát, Veronikát Blázsik Mihály tanító, későbbi elemi iskolai igazgató jegyezte el. ${ }^{1184}$

5. A laikus templomszolgák társadalmi szerepének változásairól

Értekezésünk szempontjából kiemelt fontosságú, hogy milyen változások történtek a 19. század második felében a laikus templomszolgák önképére, értékrendjére és társadalmi szerepére nézve.

A csongrádi kántornak határozott elképzelései voltak saját helyzetéről, a vele szemben tanúsított „méltányos magatartás” mibenlétéről. A csongrádi hívek képzetlen tömegéhez és a többi laikus templomszolgához képest vitathatatlanul rangosabbnak, befolyásosabbnak ismerte magát, problémát egyedül az alsópapsággal való kölcsönviszony letisztázása okozott. Mikor Sohlya Antal a plébánia falain belül próbálta meg letenni a művelt emberekhez méltó, egyenrangú, „polgárias” viszonyulásmód alapjait, kísérlete kudarcba fulladt. Alvinczy Ferenc plébános a papság tekintélyére nézve komoly veszélyforrásként értékelte a kántor újszerü szerepelképzelését, így gondolkodás nélkül a fegyelmezés eszköztárához nyúlt.

Ugyan a csongrádi harangozó és sekrestyés gyermekei már iparosok, községházi alkalmazottak, tanítók és lapszerkesztők voltak, az öreg harangozó életvitele, világnézete, ambíciói a 19. század végéhez közeledve mit sem változtak. Mivel meg volt elégedve ükapjától örökölt pozíciójával, hagyomány által megszabott feladatkörével, így Keviczky György kifogástalan hordozója és konzerválója volt saját társadalmi szerepének.

Sohlya Antal kántor és Bába Szabó Rókus egyházfi közös vonása a sokrétü közösségi-közéleti aktivitás volt. Az 1886 és 1900 között alig akad olyan világi egyesület vagy testület Csongrádon, melynek ne lettek volna tagja. Lehetett szó a Kaszinó vagy a Takarékpénztár megalakításáról, árvízi védegyletről, iskolaszéki tanácsról vagy 48-as Népkörről: bizonyos, hogy a laikus egyházi tisztségviselők valamelyikét ott találjuk a vezetőségi tagok között.

Az alsópapság és a laikus templomszolgák „kinyílása” a polgári egyesületek felé mutatja, hogy a plébániai személyzetnek fontos szerepe lehetett a paraszti polgárosulás útjára lépett csongrádi társadalom útkeresési kísérleteiben.

${ }^{1184}$ Közérdek 1891. augusztus 16. I. évf. 6. szám, 3. old. 


\section{SZEMÉLYEK ÉS SZEREPEK, ÉRTÉKRENDEK ÉS TÁRSADALMI RÉTEGEK}

Egy társadalmi szerep sikeres megtestesítői a tradicionális elvárások követésével újratermelik önmagukat, vagyis saját szerepüket; ezáltal az áthagyományozott normarendszert. ${ }^{1185}$ A végeredmény a rendszer megmerevedése, mely az újító kezdeményezésekre - legyen szó a szerepkör leszüküléséről vagy kitágításáról - egyaránt szankciókkal válaszol. Esettanulmányok sorozatán keresztül láthattuk, hogy Hegyi Antal plébános magatartása az intézményesült normarendszer konzerválása helyett saját társadalmi szerepének újrafogalmazása, kibővítése felé tartott. ${ }^{1186}$

Csongrád hivatali vezetői azt várták a mindenkori plébánostól, hogy mutasson példát állampolgári alázatból, szabálykövetésből, az elöljárók iránti tiszteletből; ő maga elégedjen meg a halhatatlan lelkek örök üdvösségre vezetésével, én ne merészkedjen a politika mezejére. Azáltal, hogy a csongrádi plébános közéleti szerepet vállalt és nyílt politizálásba kezdett, komoly érdekellentétek kereszttüzébe került. Politikai ellenfelei a közvélemény formálásával, a sajtó segítségével igyekezték visszaszorítani a plébánia falai közé. Hosszú cikkek sorozatában bírálták emberi természetét, panaszolták a lelkipásztori tekintély sérülésének következményeit. A plébános elleni hadjáratba a köztisztviselök mellett a zsidó értelmiségiek és az iparosok többsége is becsatlakozott, valamint mindazok, akik ellenszenvesnek találták Hegyi Antal hirtelen haragú és nehezen nyugvó természetét.

A csongrádi plébános társadalmi szerepe tehát a 19. század végére az egyre határozottabb közéleti-politikai szerepvállalással egészült ki. A változások megítélése rendkívül végletes volt. A sajtócikkek alapján úgy tünik, hogy Hegyi Antal bírálói a lelkipásztori eszmény sérülésétől tartottak; ám ez a félelem gyakran saját jól felfogott érdekeik védelmét rejtette magában. A nyilvánosság, a sajtó bevonása a „normaszegő” plébános ellenében alkalmazott szankciók új formájának tekinthető, mely esetenként röpiratokkal, nyílt levelekkel egészült ki. Hegyi Antal elkötelezett támogatóit ugyancsak változatos okok motiválták, amikor kiálltak sokat támadott plébánosuk védelmében.

A vezető réteg bizalmának elvesztésével a kis- és középparasztok, a politikai ellenzéket támogató nagygazdák valamint a vallási társulatokat betöltő földműves- és halászfeleségek váltak Hegyi Antal törzsbázisává. Néhány módos nagygazdától eltekintve széles, ám többnyire írástudatlan, politikai és döntéshozói befolyással alig rendelkező

\footnotetext{
${ }^{1185}$ Tomka 1997. 66.

${ }^{1186}$ Intézmény: a normák olyan rendszere, melynek saját léte van; valóság, amely külső, kényszerítő erejü tényként áll szemben az egyénnel. Tomka 1997. 26.
} 
rétegről van szó, melynek lenyügözésére, megragadására Hegyi plébános retorikája alkalmasnak bizonyult.

Hegyi Antal tisztában volt a közvetlenség erejével. A plébániai ügyeket személyesen tartotta kézben: a vallási társulatokat maga vezette ${ }^{1187}$, az új imádságokat is ö tanította be, a szentségimádásokon együtt imádkozott híveivel. Mindezek mellett vonzódott a díszes körmenetek, felszentelési ünnepségek iránt, melyeket sosem látott pompával, virágözönnel borított oltárok közt ültek meg. Ezek az erények a csongrádi középparasztok szemében valódi értéket képviseltek. A templom látványos szépülése, az óriási Jézus Szíve harang, az új bokrosparti kápolna és a magával ragadó vasárnapi szentbeszéd mellett a politikai korteskedés, az állandó pereskedés és a botrányos hírlapszerkesztés ténye „bocsánatos bünné” törpült. Igaz, hogy társadalmi szerepe szokatlan vonásokkal bővült, de papi elödeihez mérten nagyobb érzékkel ismerte fel, hatékonyabban elégítette ki az egyszerü nép vallási igényeit. Hegyi Antal politikai ambícióit mindezek tükrében vallásvédelmi offenzívaként értékelték. A hívek többsége támogatta Hock János képviselővé választását, ugyanakkor feltétel nélkül tagadta a polgári házasságkötés és anyakönyvezés létjogosultságát.

Összességében a csongrádi katolikus hívek szerepelvárásai változatlanok maradtak, viszont az egyes társadalmi (és érdek-) csoportok értékrendje, „,szemüvege”, a tettek megítélésének hangsúlyai eltolódtak. Így válhatott Hegyi Antal végletekig megosztó személyiséggé; míg a kis- és középparasztok a mindenre elszánt „lánglelkű papot” ünnepelték benne, Hegyi Antal a csongrádi „mívelt” ellentábor szemében csak egy manipulatív, keresztényietlenül pénzéhes érdekember maradt.

A társadalmi rétegek azonban nem statikus kategóriák, és hibás lenne azt állítani, hogy az egymáshoz közeli élethelyzetü, vagyoni állapotú emberek egységesen ítélték meg Hegyi Antal tevékenységét. A képet tovább árnyalja Hegyi plébános híresen kiszámíthatatlan természete. A tettlegességig fajuló összetüzések (templomi pofozkodások, lökdösődések, haragos kiabálások) miatt is közvetlen hivatali alkalmazottai, a megvert templomszolgák és a csalódott polgárok emeltek panaszt ellene. A körülbelül egy tucatnyi

\footnotetext{
${ }^{1187}$ A káplánok szerepköre a 19. század utolsó évtizedeire bizonyos szempontból leszükült, más területeken viszont kitágult. A csongrádi segédlelkészek ugyan már az 1860-70-es években is érdeklődést mutattak a közügyek és a politika iránt, csak Hegyi Antal politikai aktivizálódásával léptek határozottan a közéleti szerepvállalás útjára. Ez a „kinyílás” a plébános jól felfogott érdekében történt. Ugyancsak a plébános céljait szolgálta a káplánok kivonása a vallási társulatok szervezéséből, hisz egy másik „vezető személyiség” csak Hegyi Antal centralizációs törekvéseinek útjában állt volna.
} 
nyilvánosságra került esettel az ellenlábas sajtó több év távlatából is előhozakodott, míg a plébános táborában inkább jótékony hallgatás vagy hitetlen tagadás övezte a történteket.

Ha a paraszti polgárosulás perspektívájából szemléljük a 19. század utolsó csongrádi plébánosának tevékenységét, Hegyi Antal egyik legnagyobb érdeme a nép politizálási hajlamának növelése volt. ${ }^{1188}$ A kormány lépéseiről, az országgyülési képviselőjelöltek programjáról a plébános - kétségtelenül célzatos - templomi beszédeiből a legegyszerübb hívek is tudomást szereztek. Az ellenzék legális szervezeteiként müködő Olvasókörök megteltek kisbirtokos parasztgazdákkal, a kortes beszédeket hallatlan tömeg kísérte figyelemmel. Ez a fellángoló érdeklődés már csak azért is figyelemre méltó, mert a század végén Csongrád közel 20.000 lakosa közül mindössze 480 rendelkezett szavazati joggal. ${ }^{1189}$

Hegyi Antal másik érdeme a példamutató ránevelésben fogható meg: ő volt az első közéleti ember Csongrádon, aki határozott lépéseket tett a kulturált környezet, a tiszta, rendezett utcakép megvalósítása felé. Terve elképzelhetetlen lett volna a jószágaikat utcán legeltető, sáros csizmatalpukat a házak tövéhez verő lakosság együttműködése nélkül. A környezetére igényes polgárt jóformán a semmiből kellett megteremteni. A temető rendezését kísérő felháborodást nyomban a templomkert körbekerítése követte, ahol a plébános fegyverrel óvta a frissen ültetett facsemetéket a bekódorgó háziállatoktól. A helyi tisztségviselők kritikusan szemlélték a plébános intézkedéseit: előbb a „felbolygatott temető" tulajdonjogának kérdését firtatták, majd kiderítették, hogy a templomkert voltaképpen a településé, így Hegyi plébános faültetési mozgalma is jogtalan volt.

Hegyi Antal plébánosi karrierjének kudarca, titkos Amerikába menekülése azt mutatja, hogy az aktuális társadalmi igények és a Hegyi plébános által képviselt magatartásminta nem álltak szinkronban egymással. Ez a diszharmónia a századforduló tájékára a végletekig fokozódott. A számos felsorolt tényező mellett mégis mi lehetett Hegyi Antal bukásának fö oka?

1886-ban, az új plébános érkezésének idején már mozgásba lendült a korábbi

\footnotetext{
${ }^{1188}$ Kósa László megállapításai csongrádi viszonylatok között is érvényesek: „A volt telkes jobbágyból lett birtokos parasztság lassan közeledett a nemzethez tartozás gondolatához és még lassabban jutott el oda, hogy saját politikai és társadalmi eszméi legyenek, már pedig a nemzettel való azonosulás nélkül polgárosulásról beszélni nem lehet." Kósa 2002. 235.

1189 VPL APriv Hegyi Antal, 1892. január 14. Hegyi Antal levele a váci püspök felé. 1874-től a lakosok a jövedelemadó mértéke szerint válhattak jogosultra a szavazásra. Gyáni-Kövér 2006. 56.
} 
évszázadokban oly egyszerü, letisztult struktúrájú csongrádi társadalom. Ezek a változások főleg a föld nélküli rétegeket érintették. Az egykori zsellérekből kubikos vagy mezőgazdasági cseléd, a kereskedőkből hivatalnok, az iparosokból köztisztviselő vagy templomszolga lehetett. Az iskolázottság elterjedésének, egyre nagyobb megbecsültségének hála a laikus egyházi tisztségviselők gyermekeinek korábban sosem látott lehetőségei nyíltak a státuszemelkedésre, saját érdekeik érvényesítésére. A megváltozott és folyamatos változásban lévő társadalmi viszonyok, kapcsolatok és érdekeltségek között a század utolsó évtizedeiben már bajosan lehetett eligazodni.

Amint azt értekezésem elején is hangsúlyoztam: a társadalmi szerepekkel kapcsolatos normák, elvárások kisebb-nagyobb időbeli csúszással követik a strukturális változások ütemét. Igaz, hogy 1900-ban a csongrádi társadalom felépítése egészen más volt, mint fél évszázaddal korábban, a közösség értékrendjét, szerepelvárásait tekintve a rendiség korából örökölt minták továbbra is életképesek maradtak. Különösen érvényes mindez a plébános megítélésére.

Hegyi Antal kompromisszumokra képtelen természete sem könnyítette meg a dolgát, így sorsa csak a bukás lehetett. Emigrációjával egyházmegyéje, majd saját hazája is levette róla a kezét, majd kalandos visszatérése után mégis visszatalált a csongrádi néphez. A sors fintora, hogy Hegyi plébános egykori ellenfeleinek, köztük Sóhlya Gyula csongrádi főjegyző közbenjárásának köszönhette, hogy idő előtt szabadult a fogházból. A csongrádiak úgy vélték, egykori lelkipásztoruk megbünhődött minden vétkéért, így szelíden, megbocsátással várták vissza a településre. Visszatérte után Hegyi Antal a Keresztény Gőzmalom Rt vezérigazgatója lett, időnként a temetői kápolnában prédikált. Az idősödő egykori lelkipásztor élete alkonyán feladott a harccal és magányosan, szegénységben érte a halál.

Hogy a 19. század második felében élt plébánosok miként kezelték saját egyházközségükben a korszellem kihívásait, a paraszti polgárosulás felemás, torz jelenségeit, egyben a templomszolgák és az egyházközeli asszisztencia társadalmi helyzetének változásait, nos: ennek kiderítése a jövőbeli kutatások feladata marad. 


\section{SZAKIRODALOM}

ADORJÁNI Rudolf Károly

2006 Lukács Sándor ravai búcsúztatói 1930-1938 között. Kolozsvár, Kriza János Néprajzi Társaság.

ADRIÁNYI Gábor

1989

Az egyháztörténetírás mai igényei és módszertana. Magyar Egyháztörténeti Vázlatok, Regnum 1989/I. Budapest, METEM Munkaközösség. 325-335.

2009

A Bach-korszak egyházpolitikája 1849-1859. Budapest, Kairosz kiadó.

APOR Péter

2006

Történeti antropológia. In BóDY Zsombor - Ö. KoVÁCs József szerk. Bevezetés a társadalomtörténetbe. Hagyományok, irányzatok, módszerek. Budapest, Osiris Kiadó. 449-472.

BÁLINT Sándor

Népünk ünnepei. Az egyházi év néprajza. Budapest, Szent István Társulat.

1943 A szegedi népélet szakrális gyökerei. Regnum - Egyháztörténeti Évkönyv 1942-43. V. kötet, Budapest, Stephaneum kiadó. 51-69.

1974 Szeged-alsóvárosi vallásos társulatok és egyesületek. In HOFER Tamás - KisBÁN Eszter - KAPOSVÁRI Gyula szerk.: Paraszti társadalom és müveltség a 18-20. században II. Mezövárosok. Budapest, Magyar Néprajzi Társaság-Damjanich János Múzeum, Szolnok. 115-124.

1980 A szögedi nemzet. A szegedi nagytáj népélete. Harmadik rész. Szeged, A Móra Ferenc Múzeum Évkönyve, 1978/79. 2.

1981/a A népi hitvilág Tápé archaikus hagyományainak tükrében. In BÁLINT Sándor: A hagyomány szolgálatában. Összegyüjtött dolgozatok. Budapest, Magvető kiadó 7-35.

1981/b Liturgia és néphagyomány. In BÁLINT Sándor: A hagyomány szolgálatában. Összegyüjtött dolgozatok. Budapest, Magvető kiadó.

1983 Szeged - Alsóváros. Templom és társadalom. Budapest, Szent István 
társulat.

1987 A magyar vallásos népélet kutatása. In DANKÓ Imre - KÜLLŐs Imola szerk.: Vallási néprajz III. Módszerek és történeti adatok. Budapest. $8-65$.

1998 Karácsony, húsvét, pünkösd. Szeged, Mandala Kiadó Kft. Szegedi Kossuth Nyomda.

2009/a [1944] A magyar vallásos néprajz elmélete. In BÁLINT Sándor: Sacra Hungaria. Tanulmányok a magyar vallásos népélet köréböl. Budapest, Ős-kép kiadó. 143-148.

2009/b [1944] A népi kultusz. In BÁLINT Sándor: Sacra Hungaria. Tanulmányok a magyar vallásos népélet köréböl. Budapest, Ős-kép kiadó. 2009.

BALOGH János

1871

Halotti búcsúztatók. I. Szentes.

BÁNK József szerk.

1970

Váci Egyházmegyei Almanach. Szent István Milléneum évében. Vác, Váci Egyházmegyei Hatóság kiadása.

BÁRDOS Kornél

1990

Magyarország zenetörténete 1541-1686. II. Budapest, Akadémiai kiadó.

BARNA Gábor

1984 Katolikus egyházi népének, énekszerzők és a folklorizáció. A Mezey kántorok énekei a néphagyományban. In KISs Mária szerk.: Folklór és tradició I. A hagyományos műveltség továbbélése. Budapest, MTA Néprajzi Kutatócsoport, 123-133.

1990 Zur Erforschung des religiösen Volkslebens in Ungarn der Nachkriegszeit. In EBERHART, Helmut - HÖRANDNER, Edith PÖTTLER, Burkhard Hrsg.: Volksfrömmigkeit. Referate der Österreichischen Volkskundetagung 1989 in Graz. Wien, 91-105.

1996 A tállyai Fáklyás társulat dokumentumai. Devotio Hungarorum 3. Szeged, Néprajz Tanszék.

1998/a Parasztkántor, kántor, népének. Létünk. Társadalom, tudomány, kultúra. XXVIII. évf. 1998. 3-4. tematikus szám, [szerkeszti: Beszédes Valéria] 167-176. 
1998/b Az Élő Rózsafüzér kunszentmártoni társulatának jegyzőkönyvei (1851-1940). Devotio Hungarorum 5. Szeged, Néprajz Tanszék.

2000 "Az élőket hívom, a holtakat elsiratom, a villámokat megtöröm" In VISY Zsolt szerk.: Déli harangszó. Budapest, Mundus Magyar Egyetemi Kiadó. 129-184.

2002/a A barkai Skapuláré Társulat története. Devotio Hungarorum 8. Szeged, Néprajz Tanszék.

2009 A Mezey kántorcsalád és énekes könyvei a 19-20. századból. In BARNA Gábor szerk.: Istent dicsőitő egyházi énekkönyv. Mezeyénekek. Devotio Hungarorum 12. Szeged, Néprajzi és Kulturális Antropológiai Tanszék. 443-468.

2011 Az élő rózsafüzér társulata. Imádság és imaközösség a 19-21. századi vallási kultúrában. Budapest, Szent István Társulat, az Apostoli Szentszék Könyvkiadója.

BARTA László

1980

Az 1828. évi országos összeírás Csongrádon. In BÁLINT Gyula György szerk.: Mozaikok Csongrád Város történetéböl 1980. Szeged, Kiadja Csongrád Város Polgármesteri Hivatala müvelődési és ifjúsági irodája. 188-201.

BARTHA Elek

1980 A hitélet néprajzi vizsgálata egy zempléni faluban. Studia Folkloristica et Ethnographica, Debrecen.

1995 Halotti búcsúztatók a dél-gömöri falvak folklórjában I-II. Gömör néprajza XLVI. Debrecen.

BÁRTH Dániel

2003

Szokás és hatalom. Egyházi törekvés a szőlőőrzés bácskai rendszabályozására a XVIII. század közepén. Cumania 19. 2003, 85-120.

2005 Esküvő, keresztelö, avatás. Egyház és népi kultúra a kora újkori Magyarországon. Budapest, MTA-ELTE Folklór Szövegelemzési Kutatócsoport.

2013 Alsópapság és népi kultúra. Kutatási irányok, modellek és megközelítési lehetőségek. In BÁRTH Dániel szerk.: Alsópapság, 
lokális társadalom és népi kultúra a 18-20. századi Magyarországon. Budapest, ELTE BTK Folklore Tanszék. 9-43.

BÁRTH Dániel szerk.

2013

Alsópapság, lokális társadalom és népi kultúra a 18-20. századi Magyarországon. Budapest, ELTE BTK Folklore Tanszék.

BÁRTH János

1990 A katolikus magyarság vallásos életének néprajza. In DÖMÖTÖR Tekla főszerk.: Magyar. Néprajz VII. Népszokás, néphit, népi vallásosság. Budapest, Akadémiai Kiadó. 331-424.

2006 Jézus dicsértessék! A székelyvarsági hegyi tanyák népének vallási hagyományai. Kecskemét.

2012 Szentgyörgy megyéje Alcsíkban. Esettanulmány a katolikus székelység egyháztörténetéhez és társadalomnéprajzához. Kecskemét.

BAUMGARTNER, Jakob

1987 Der weg der religiösen Volkskunde in Ungarn. Schweizerisches Archiv für Volkskunde, 83. 1987. 215-221.

BECK, Rainer

1988 Der Pfarrer und das Dorf. Konformismus und Eigensinn im katolischen Bayern des 17/18. Jahrhunderts. In: Dülmen, Richard van Hrg.: Armut, Liebe, Ehre. Studien zur historischen Kulturforschung. Frankfurt am Main. 107-143.

1990 Népi vallásosság és társadalomtörténet. Megjegyzések egy kutatási koncepcióhoz kora újkori példán. In VÁRI András szerk.: A német társadalomtörténet új útjai. Tanulmányok. Gazdaság és társadalomtörténeti füzetek 1. Budapest. 38-57.

BENDA Gyula

2008 Zsellérböl polgár - Társadalmi változás egy dunántúli kisvárosban. Budapest, L’Harmattan Kiadó.

BEREZNAI Zsuzsanna 1989/a

Szentelmények az egyházi és a népi liturgiában. Csongrádi vallásos szokások és hiedelmek. In BÁLINT Gyula György szerk.: Mozaikok Csongrád város történetéböl. 1989. Csongrád, Kiadja Csongrád 
Város Polgármesteri Hivatala művelődési és ifjúsági irodája, Petőfi nyomda. 67-75.

1989/b A csongrádi adventisták. In BÁLINT Gyula György szerk.: Mozaikok Csongrád város történetéböl 1989. Csongrád, Kiadja Csongrád Város Polgármesteri Hivatala művelődési és ifjúsági irodája, Petőfi nyomda. 77-95.

BESZÉDES Valéria szerk.

1998 Létünk. Társadalom, tudomány, kultúra. XXVIII. évf. 1998. 3-4. tematikus szám.

BODNÁR József

1864 Csongrád szentegyházai. Katolikus Néplap, XVI. évf. 1864. 46.

BRÜCKNER, Wolfgang

Ungarische Studien zur Volksfrömmigkeit, Ikonographie und geistlischen Erzählliteratur beider Konfessionen. Bayerische Blätter für Volkskunde 14. (1987) 111-114.

BURKE, Peter

2000 Mi a történeti antropológia? In SEBÖK Marcell szerk.: Történeti antropológia. Módszertani írások és esettanulmányok. Budapest, Replika kör. 17-22.

CHILKÓ Sándor

1867 Gyász búcsú-hangok különféle temetési alkalmakra. Eger, Érseki Lyceum.

Сновот Ferenc

1915

A váczi egyházmegye történeti névtára I. Az intézmények története. Vác, Dercsényi Dezső vállalata, Pestvidéki Nyomda.

A váczi egyházmegye történeti névtára II. A papság életadatai. Vác, Dercsényi Dezső vállalata, Pestvidéki Nyomda.

CSIMA István

1895 Gyászmise-énekek. Régi és új énekekből összegyüjtötte és szabályos orgonakísérettel ellátta - Szt. István templomi fökántor $\mathrm{s}$ kiadótulajdonos, Kun-félegyházán.

CSORBA László

A katolikus egyházi értelmiség társadalmi gyökerei a polgári 
átalakulás korában. In KÖVÉR György szerk.: Magyarország társadalomtörténete a reformkortól az első világháborúig.I. Szöveggyüjtemény. Budapest, Nemzeti Tankönyvkiadó. 441-449.

DEÁKY Zita

1996 A bába a magyarországi népi társadalomban (18. század vége - 20. század közepe). Budapest, Centrál Európa Alapítvány.

DEÁKY Zita - KRÁSZ Lilla

2005 Minden dolgok kezdete. A születés kultúrtörténete Magyarországon (XVI-XX. század). Budapest, Századvég kiadó.

DELUMEAU, Jean

Le Catholicisme entre Luther et Voltaire. Paris, Presses Universitaires de France.

DÉNESI Tamás

2009

Plébániaszervezés Somogyban a 18. század első felében. In GŐZSY Zoltán - VARGA Szabolcs - VÉRTESI Lázár szerk.: Katolikus megújulás és a barokk Magyarországon, különös tekintettel a DélDunántúlra (1700-1740). Pécs, Pécsi Egyháztörténeti Intézet, Seria Historiae Dioecesis Quinqueecclesiensis VII. 197-223.

DIENES Dénes

2008

A reformáció. Vezérfonal az egyháztörténet tanulmányozásához. Sárospatak, Hernád Kiadó.

DOBSZAY László 1995 A magyar népének I. Veszprém, Veszprémi Egyetem.

DÓKA Klára

Segédanyag az egyházlátogatási jegyzőkönyvek feldolgozásához. II. kiadás, Budapest, Magyar Országos Levéltár.

2009 Áttekintés a magyarországi katolikus püspöki (érseki) levéltárakban őrzött egyházlátogatási jegyzőkönyvekről. In GőZSY Zoltán - VARGA Szabolcs - VÉRTESI Lázár szerk.: Katolikus megújulás és a barokk Magyarországon, különös tekintettel a Dél-Dunántúlra (1700-1740). Pécs, Pécsi Egyháztörténeti Intézet, Seria Historiae Dioecesis Quinqueecclesiensis VII. 293-306. 
DuboIs Henrik

1870

A gyakorlati lelkipásztor, vagyis mikép müködhetünk áldásosan községünkben? Magyarítá: a veszprémi növendékpapság Pázmányköre. Pest, Rudnyánszky A. nyomdája.

DudÁs Lajos

1980

Az októberi diplomától a kiegyezésig. Csongrád krónikája a provizórium korából 1860 októberétől 1867 végéig. II. rész. In BÁLINT Gyula György szerk.: Mozaikok Csongrád város történetéből, 1980. Csongrád, Kiadja Csongrád Városi Tanács V.B. Mủvelődésügyi Osztálya megbízásából a Csongrád megyei Lapkiadó Vállalat. 117-139.

1985 A csongrádi polgári fiúiskola története. In BÁLINT Gyula György szerk.: Mozaikok Csongrád város történetéböl, 1985. Csongrád, Kiadja Csongrád Város Polgármesteri Hivatala Müvelődési és ifjúsági irodája. 182-205.

1987 A csongrádi állami polgári leányiskola története. In BÁLINT Gyula György szerk.: Mozaikok Csongrád város történetéböl, 1987. Csongrád, Kiadja Csongrádi Városi Tanács V.B. Müvelődési, Egészségügyi és Sport Osztálya. 84-104.

1989 Csongrád város belterületének történeti és jelenkori (hely) névjegyzéke L-től ZS-ig. In BÁLINT Gyula György szerk.: Mozaikok Csongrád város történetéböl 1989. Csongrád, Kiadja Csongrád Város Polgármesteri Hivatala művelődési és ifjúsági irodája. 219238.

1996 Egyházi élet a hódoltsági területen. In GEORGIADES Ildikó SEBESTYÉN István szerk.: Oppidum Csongrád 1996. Csongrád, Oppidum Csongrád Alapítvány. 45-54.

1997 Csongrád és környékének szentegyházai az Árpádok korában. In GEORGIADES Ildikó - SEBESTYÉn István szerk.: Oppidum Csongrád 1997. Csongrád, Oppidum Csongrád Alapítvány. 5-18.

1998 Adatok a római katolikus egyház 19. századi Csongrádi müködéséről. In GEORGIADES Ildikó - SEBESTYÉN István szerk.: Oppidum Csongrád 1998. Csongrád, Oppidum Csongrád Alapítvány. 
99-119.

1999/a A római katolikus egyház megerösödése Csongrádon a 18. században. In GEORGIADES Ildikó - SEBESTYÉN István szerk.: Oppidum Csongrád 1999. Csongrád, Oppidum Csongrád Alapítvány. $7-28$.

1999/b Egy ismeretlen meghívólevél 1848 márciusából. In GEORGIADES Ildikó - SEBESTYÉN István szerk.: Oppidum Csongrád 1999. Csongrád, Oppidum Csongrád Alapítvány. 3-6.

1999-2000 A csongrádi Szent Józsefről elnevezett plébániatemplom szertartásainak rendje és szokásai 1936-1939 között. In Múzeumi kutatások Csongrád megyében. 1999/2000. Szeged, Móra Ferenc Múzeum. 83-98.

2000 A római katolikus egyház élete, tevékenysége Csongrádon a 20. század első felében. In GEORGIADES Ildikó - SEBESTYÉN István szerk.: Oppidum Csongrád 2000. Csongrád, Oppidum Csongrád Alapítvány. 82-113.

2001 Csongrád kántorai. In GeORGIADES Ildikó - SEBESTYÉN István szerk.: Oppidum Csongrád 2001. Csongrád, Oppidum Csongrád alapítvány. 67-88.

2003 Csongrád településtörténete a 16. századtól. In GEORGIADES Ildikó szerk.: Oppidum Csongrád 2003. Csongrád, Oppidum Csongrád Alapítvány. 95-98.

2004 Közoktatás és közművelődés Csongrádon (1850-1914). In GeOrgiades Ildikó szerk.: Oppidum Csongrád 2004. Csongrád, Oppidum Csongrád Alapítvány 7-26.

DudÁs Lajos - KÖHEGYI Mihály

2000 Csongrád régi és mai harangjai. A Móra Ferenc Múzeum Évkönyve 2000. Történeti Tanulmányok 3, Szeged. 387-401.

DÜLMEN, Richard von 1989 Volksfrömmigkeit und konfessionelles Christentum im 16. und 17. Jahrhundert. In DüLMEN, Richard van Hrg.: Religion und Gesellschaft. Beiträge zu einer Religionsgeschichte der Neuzeit. Frankfurt am Main, Socialwissenschaft Fischer. 50-69. 
ERDEI Ferenc

1980/a A magyar társadalom a két háború között. In ERDEI Ferenc: $A$ magyar társadalomról. Budapest, Akadémiai Kiadó. 293-346.

1980/b A magyar paraszttársadalom. In ERDEI Ferenc: A magyar társadalomról. Budapest, Akadémiai Kiadó. 83-252.

ERDÉLYI Péter

1993 Amerika a századelőn, ahogy egy csongrádi plébános látta. In LENGYEL András szerk.: Múzeumi Kutatások Csongrád Megyében 1992. Szeged, Móra Ferenc Múzeum. 93-98.

1998 Csongrád város rövid históriája. Múzeumi Füzetek, Csongrád 1. 318 .

ERDÉLYI Sándor

1887

Temetési énekek, népies búcsúztatók római kath. kántoroks az ezen pályára készülők használatára. Szeged, Endrényi testvérek nyomdája.

FARAGÓ Artur

1988

Mozaiktöredékek a 340 éves Központi Szeminárium történetéből. In KRÁNITZ Mihály szerk.: 340 éves a Központi Papnevelö Intézet 1648-1988. Budapest, A Budapesti Növendékpapság Magyar Egyházirodalmi Iskolája. 5-60.

FAZEKAS István

1993

A győri egyházmegye katolikus alsópapsága 1641-1714 között. Történelmi Szemle, az MTA Történettudományi Intézetének Értesítője. XXXV. évf. (1993) 1-2. szám, 101-131.

FEKETE Ferenc

1818

Utmutató kántorkönyv. Szeged, Grünn Orbán nyomdája.

FÉNYES Elek

1851 Magyarország Geographiai szótára, I. kötet. Pesten, Kozma Vazul.

FORGÓ Tilda-FORGÓ Ida

1987 Csongrád élete a szabadságharc bukása után. In BÁLINT Gyula György szerk.: Mozaikok Csongrád város történetéből, 1987. Csongrád, Csongrád Város Tanácsa. 29-80. 
FORRÓ Katalin

2000

A váci egyházmegye a 18-20. században. In ZOMBORKA Márta szerk.: A váci egyházmegye ezer esztendeje. Vác, Váci Múzeumért Közalapítvány. 22-37.

FREITAG, Werner

Volks-und Elitenfrömmigkeit in der frühen Neuzeit. Marienwallfahrten im Fürstbistum Münster. Paderborn, Ferdidand Schöningh.

1998

Pfarrer, Kirche und ländliche Gemeinschaft. Das Dekanat Vechta 1400-1803. Studien zur Regionalgeschichte 11. Bielefeld.

2002 Tridentinische Pfarrer und die Kirche im Dorf. Ein Plädoyer für die Beibehaltung der etatischen Perspektive. In HAAG, Norbert - HoLTZ, Sabine - ZIMMERMANN, Wolfgang in Verbindung mit BAUER, R. Dieter Hrsg.: Ländliche Frömmigkeit. Konfessionskulturen und Lebenswelten 1500-1850. Stuttgart, 83-114.

GACSÁRI KISS Sándor

1983 A csongrádi piroskavárosi templom története. In BÁLINT Gyula György szerk.: Mozaikok Csongrád város történetéből 1983. Csongrád, Csongrád Város Tanácsa. 92-120.

GAITH Rudolf - PATZNER István

Lelkipásztori lexikon rövid egybefoglalása a föbb lelkipásztori, plébánia-hivatali, liturgiai, egyház-és házasságjogi, adó- és pénzügyi teendöknek. A katholikus magyar lelkipásztorok használatára. Kiadja: Tokody Ödön új-pécsi plébános. Nyomtatott: csanád-egyházmegye könyvsajtón, Temesvár.

GARAY Alajos - SOHLYA Antal - ENGESZER Mátyás

1860

Temetési gyászénekek a szokásos egyházi imák- és sz. szertartásokkal. Pest, Emich Gusztáv Magy. Akad. Nyomdász kiadása.

GÁT László

1982 Csongrádi történelmi olvasókönyv. In BÁLINT Gyula György szerk.: Mozaikok Csongrád város történetéböl 1982. Csongrád, Kiadja a Csongrádi városi Tanács VB Mủvelődésügyi Osztálya. 5-224. 
2006 Csongrádi útikalauz. Szeged, Kiadja: Kálmán I.

GERENDÁS Ernő

1942

A céhek és a vallásos élet. Regnum - Egyháztörténeti Évkönyv, 1942/43. 371-199.

GERGELY Jenő

1999

A katolikus egyház története Magyarországon 1919-1945. Budapest, Pannonica kiadó

GERLEY Mátyás

1890 Gyászénekek, népies alkalmi búcsúztatók róm. Kath. kántorok és kántorjelöltek gyakorlati használatára. Esztergom, Buzárovits Gusztáv nyomdája.

GIESSWEIN Sándor

1914 A szociális kérdés és a keresztény szociálizmus. Népiratkák 294. Budapest, Szent István Társulat.

GóG Mihály

1984 A méltóságos nagykárolyi gróf Károlyi család tulajdonát képező csongrádi uradalom leírása. In BÁLINT Gyula György (szerk.) Mozaikok Csongrád város történetéböl 1984. Csongrád, Csongrád Város Tanácsa. 128-163.

GÖZSY Zoltán - VARGA Szabolcs

2009 A pécsi egyházmegye plébániahálózatának újjászervezése a 18. század első felében. In GöZSY Zoltán - VARGA Szabolcs - VÉRTESI Lázár szerk.: Katolikus megújulás és a barokk Magyarországon, különös tekintettel a Dél-Dunántúlra (1700-1740). Pécs, Pécsi Egyháztörténeti Intézet, Seria Historiae Dioecesis Quinqueecclesiensis VII. 225-264.

GuNDA Béla

1998 Az egyéniség- és személyiségkutatás kibontakozása a néprajztudományban. In BARNA Gábor szerk.: Szentemberek - a vallásos élet szervezö egyéniségei. Budapest, Néprajz Tanszék Szeged-Magyar Néprajzi Társaság. 13-25.

GYÁNI Gábor - KÖVÉR György

2006 Magyarország társadalomtörténete a reformkortól a második 
világháborúig. Budapest, Osiris Kiadó.

GYENIS András

1927

A mester nyomában. Gondolatok az egyházi pályáról. Budapest, Kiadja a Mária Kongregáció Kiadóhivatala. Kis Könyvtár Katholikus hívek számára 32. szám.

GyetVAi Péter

1987 Egyházi szervezés föleg az egykori déli magyar területeken és a bácskai Tisza mentén. Dissertationes Hungaricae ex Historia Ecclesiae VII. München, Görres Gesellschaft.

GYÖNGYÖSSY Orsolya

2008

„És a takarón megjelent az Úrjézus arca...” Krisztus-jelenések a csongrádi Nagyboldogasszony templomban. In Pócs Éva szerk.: Démonok, látók és szentek. Tanulmányok a transzcendensről IV. Budapest, Balassi kiadó. 503-533.

2009 A dualizmus-kori alföldi értelmiség világnézete egy Belicza-féle emlékkönyv alapján In TAMÁs Ágnes szerk.: Mozaikok a magyar történelemböl. Szeged, 25-32.

2010/a „Adom végbúcsúzásom, a legutolsó szólásom...” Knapek Dezsö halotti búcsúztatói, Csanytelek. Devotio Hungarorum 15. Szeged, Néprajzi és Kulturális Antropológiai Tanszék.

2010/b Foglalkozásokhoz, egzisztenciális élethelyzetekhez kötődő szentek tisztelete Csongrádon a 18-20. században. In ANTOS Balázs - TAMÁS Ágnes szerk.: Rajzolatok a magyar történelemröl. Szeged, 11-24.

2010/c Céhek és vallásos társulatok Csongrádon a 18-19. században. In MóD László - SiMON András szerk.: Olvasó. Tanulmányok a 60 esztendös Barna Gábor tiszteletére. Szeged, Gál Ferenc Hittudományi Főiskola, Gerhardus Kiadó, SZTE Néprajzi és Kulturális Antropológiai Tanszék. 429-438.

2010/d Ozsdolai népszokások. Libelli Transsilvanici 7. [Sorozatszerkesztő: Bárth János - Bárth Dániel.] Kecskemét.

2010/e Szívből szívbe csók az út" Egy 19. század végi csongrádi emlékkönyv képi megjelenítéseinek elemzése. Bácsország Vajdasági Honismereti Szemle, XV. évf. 55. sz. 2010/4. 91-96. 
2011/a Szent Vendel tisztelete Csongrádon a 19. században. Magyar Egyháztörténeti Vázlatok 2011/1-2. Szeged. 113-123.

2011/b The Cult of Saint Wendelin in Csongrád. Hereditas. Periodical of the „Bálint Sándor” Institue of the Study of Religion I. Szeged, Gerhardus kiadó. 81-92.

2013/a Historia Vexillorum. Céhzászlók a csongrádi Nagyboldogasszony templomban. In BOGÁR Judit szerk.: Az áhítat nem hivatalos alkalmai és formái az 1800 előtti Magyarországon. Lelkiségtörténeti tanulmányok 4. Piliscsaba, Pázmány Irodalmi Műhely. 71-79.

2013/b „Bába’ Mesternék” Csongrádon a 18-19. században. In GEORGIADES Ildikó szerk.: Oppidum Csongrád 2013. Csongrád, Oppidum Csongrád Alapítvány. 125-136.

2014/a Vallási társulatok - társadalmi folyamatok. A társulati élet változó dinamikája Csongrádon a 19. században. In BARNA Gábor KEREKES Ibolya szerk.: Vallás, egyén, társadalom. Szegedi Vallási Néprajzi Könyvtár 39; MTA-SZTE Vallási Kultúrakutató Csoport, a Vallási Kultúrakutatás Könyvei 7. Szeged, SZTE-BTK Néprajzi és Kulturális Antropológiai Tanszék. 31-48.

2014/b Hatások és emlékek. Segédlelkészek a csongrádi hívek perspektívájából. In BARNA Gábor - POVEDÁK Kinga szerk.: Lelkiségek és lelkiségi mozgalmak Magyarországon és Kelet-KözépEurópában. Szegedi Vallási Néprajzi Könyvtár 42; MTA-SZTE Vallási Kultúrakutató Csoport, a Vallási Kultúrakutatás Könyvei 10. Szeged, SZTE-BTK Néprajzi és Kulturális Antropológiai Tanszék. 129-136.

2014/C Adatok az izraelita bábaasszonyok keresztelési asszisztenciájának kérdéséhez. In GLÄSSER Norbert - ZIMA András szerk.: Hagyomány és modernitás. Szegedi Vallási Néprajzi Könyvtár 43; MTA-SZTE Vallási Kultúrakutató Csoport, a Vallási Kultúrakutatás Könyvei 11. Szeged, SZTE-BTK Néprajzi és Kulturális Antropológiai Tanszék. 2014. 119-128.

GYOVAI B. Lajos 1989

Szentek szobrai és keresztek. In BÁLINT Gyula György szerk.: 
Mozaikok Csongrád város történetéből 1989. Csongrád, Csongrád Városi Tanács. 183-196.

GYÜRKY Antal

1881

Napló töredékek egy falusi lelkész hátrahagyott irataiból. Vác, Nyomatott Serédy G. Siketn. Iparint. Könyvnyomdájában.

HANÁK Péter

1978 Magyarország társadalma a századforduló idején. In HANÁK Péter föszerk.: Magyarország története 1890-1918. (VII/1.) Budapest, Akadémiai Kiadó. 403-516.

HANAUER Á. István

Föpásztori körlevelek és intelmek 1919-1929. Rákospalota, Don Bosco nyomda.

HERCEG Mihály

1980 A Csongrád-vásárhelyi uradalom kialakulása (1709-1848). Tanulmányok Csongrád Megye történetéböl. Szeged, Csongrád Megyei Levéltár. Különnyomat.

HERMANn Egyed

A magyar katolikus papság az osztrák katonai diktatúra és az abszolutizmus idejében. Gödöllő.

HERMANN István

1998 Plosszer Ferenc káplán feljegyzései 1848-1849-röl a pápai Szent István Római Katolikus Plébánia Historia Domusában. Jókai füzetek 21. Pápa.

HOFER Tamás szerk.

1984

Történeti antropológia: Az 1983. április 18-19-én tartott tudományos ülésszak elöadásai. Budapest, MTA Néprajzi Kutatócsoport.

HoLl Béla

A váci egyházmegye alsópapságának és plébániáinak könyvei a XVIII. században. In MoNOK István - ZvAR Edina szerk.: Holl Béla: Laus Librorum. Válogatott tanulmányok. Budapest, Magyar Egyháztörténeti Enciklopédia Munkaközösség. 185-267. 
HORVÁTH Tibor

1993

METEM kutatás, plébániatörténet. Magyar Egyháztörténeti

Vázlatok, Regnum 1993./3-4. Budapest, METEM Munkaközösség. 125-198.

Hoss József

1948

A kaposvári plébánia története. A Veszprémi Egyházmegye Multjából 12. Veszprém.

HÖGYES Endre

1896 Emlékkönyv a Budapesti Királyi Magyar Tudomány Egyetem Orvosi Karának multjáról és jelenéröl. Budapest, Magyar Orvosi Könyvkiadó Társulat.

JÁNOSI MONIKA

1983 Egy öreg csongrádi orvos visszaemlékezései. Dr. Borsos Imre önéletírása (részlet). In BÁLINT Gyula György szerk.: Mozaikok Csongrád város történetéből 1983. Csongrád, Kiadja Csongrád Város Polgármesteri Hivatala müvelődési és ifjúsági irodája. 64-87.

JÁVOR Kata

2000 Az egyház és a vallásosság helye és szerepe a paraszti társadalomban. In PALÁDI-KovÁCs Attila föszerk.: Magyar Néprajz VIII. Társadalom. Budapest, Akadémiai Kiadó. 791-818.

JÓZSA László

2009 "Isten hajléka az emberek között" A kunszentmátroni római katolikus nagytemplom. Szegedi Vallási Néprajzi Könyvtár 21. Szeged, Néprajzi és Kulturális Antropológiai Tanszék.

JUHÁSZ Kálmán

1921 A licenciátusi intézmény Magyarországon. Budapest.

KARÁCSONYI János

1985 Magyarország egyháztörténete. Budapest, Könyvértékesítő Vállalat. KATOLIKUS LEXIKON (Kat. Lex.)

1931 II. kötet. BANGHA Béla szerk. Budapest, Magyar Kultúra kiadása.

1932 III. kötet. BANGHA Béla szerk. Budapest, Magyar Kultúra kiadása.

1933 IV.kötet. BANGHA Béla szerk. Budapest, Magyar Kultúra kiadása. 
KATONA Imre

1957

A magyar kubikosok élete. Budapest, Hazafias Népfront.

1976-77 Felgyő kertészközség elpusztításának koraeli verses krónikája. In Múzeumi kutatások Csongrád megyében 1976-77. Szeged, Móra Ferenc Múzeum. 163-170.

1996 A csongrádi kubikosság. Honismeret: A Honismereti Szövetség folyóirata, 24. évf. 1996/3. 68-71.

1997 Egy csongrádi betlehemes játék 1862-ből. In GEORGIADES Ildikó SEBESTYÉN István szerk.: Oppidum Csongrád 1997. Csongrád, Oppidum Csongrád Alapítvány. 63-72.

KATUS László

1994 A szegvári plébánia története. In SzÁNTó Konrád föszerk.: Magyar Egyháztörténeti Vázlatok, Regnum. Budapest, METEM Munkaközösség, 1994./1-2. 149-216.

KERSCHBAUMER Antal

1872 Paterfamilias. Lelkipásztorkodástan példákban, idösb $s$ ifjabb lelkészek számára. Fordította a Szt. Istvánról cimzett esztergomi ösrégi papnevelde magyar egyházirodalmi iskolája. Esztergom, Nyomatott Horák Egyednél.

KISHÁZI-KovÁCs László

2008 Egy híres szegedi plébános: Kreminger Antal (1804-1885). Deliberationes I. évf. 1. szám, 2008. 37-71.

KISS Réka

2011 Egyház és közösség a kora újkorban, a Küküllői Református Egyházmegye 17-18. századi iratainak tükrében. MTA Néprajzi Kutatóintézete, Budapest, Akadémiai Kiadó.

KOPPÁNY János

1985 Harangozók és harangozási szokások Tótkomlóson. In DANKÓ Imre - KÜLlŐs Imola szerk.: Vallási néprajz II. Protestáns egyházi források, kutatók, hagyományok. Budapest, ELTE Folklore Tanszék. $401-431$.

KóSA László

1998 Paraszti polgárosulás és a népi kultúra táji megoszlása 
Magyarországon 1880-1920. Budapest, Planétás kiadó.

2003

2011

KoudELA Géza

1936

KovÁCs Márk

1842

KovÁCSIK Antal

2010

KRÁsz Lilla

2003

KRIZA Ildikó

1993

KRUZSLICZ István

1988

1999

LABÁDI Lajos

2000

KUBINYI András
Nemesek, polgárok, parasztok. Budapest, Osiris kiadó.

Müvelödés, egyház, társadalom. Budapest, Akadémiai kiadó.

A magyar római katolikus egyház zenéje. In MoLNÁR Imre szerk.: A magyar muzsika könyve. Budapest, Merkantil nyomda. 14-25.

A' Keresztény Katolikai Isteni tiszteletnek minden ágaira ki-terjedö énekes könyv, négy részre fel-osztva és a' szükségesebb imádságokkal is el-látva. Áldozza Kovács Mark sz. benedek rendü. Pesten Esztergami Beimel Jósef sajátja 's áruja.

Katolikus társadalomszervezés Csongrádon az 1900-as évek elején: Porubszky József plébános müködése (1903-1911). In GEORGIADES Ildikó szerk.: Oppidum Csongrád 2010. Csongrád, Oppidum Csongrád Alapítvány. 115-164.

A bába történeti szerepváltozása a 18. századi Magyarországon. Budapest, Osiris Kiadó.

Felsőnyéki halotti búcsúztatók. Budapest, MTA Néprajzi Kutatóintézet.

Csongrád első kataszteri felmérése. In BÁLINT Gyula György szerk.: Mozaikok Csongrád Város történetéböl, 1988. Csongrád, Csongrád Város Tanácsa. 35-46. Vallásos társulatok a késő-középkori magyarországi városokban. In KUBINYI András: Főpapok, egyházi intézmények és vallásosság a középkori Magyarországon. METEM könyvek 22. Budapest. 341352.

Csongrád a szentesi lapokban (V.) (1883-1884) In GEORGIADES 
Ildikó - SEBESTYÉN István szerk.: Oppidum Csongrád 2000. Csongrád, Oppidum Csongrád Alapítvány. 114-146.

2004

Csongrád a szentesi lapokban (VIII.) (1887-1888) In GEORGIADES

Ildikó - SEBESTYÉN István szerk.: Oppidum Csongrád 2004.

Csongrád, Oppidum Csongrád Alapítvány. 67-128.

2006 Csongrád a szentesi lapokban (X.) (1891) In GEORGIADES Ildikó -

SEBESTYÉN István szerk.: Oppidum Csongrád 2006. Csongrád, Oppidum Csongrád Alapítvány. 75-110.

2007

Csongrád a szentesi lapokban (XI.) (1892.) In GEORGIADES Ildikó -

SEBESTYÉN István szerk.: Oppidum Csongrád 2007. Csongrád, Oppidum Csongrád Alapítvány. 67-123.

2008 Csongrád a szentesi lapokban. (XII.) (1893). In GEORGIADES Ildikó SEBESTYÉN István szerk.: Oppidum Csongrád 2008. Csongrád, Oppidum Csongrád Alapítvány. 71-112.

LICSICSÁNYI István

2011 Csongrád város kronológiája. Városunk múltja dióhéjban 895-1990.

Csongrád, Oppidum Csongrád Alapítvány.

LisZTÓCZKY László

2011

Az egyházi költészet Petőfije. In LISZTÓCZKY László: Az utolsó szalmaszál. Tanulmányok és alkalmi írások. Eger, Dsida Jenő Baráti Kör.

MACFARLANE, Alan D. J.

1970 The Family Life of Ralph Josselin; A Seventeenth-Century Clergyman. An Essay in Historical Anthropology. Cambridge, Cambridge University Press.

MAGRAW, Roger

1970 The Conflict in the Villages: Popular Anticlericalism in the Isère (1852-1870). In ZELDIN, Theodore ed. Conflicts in French Society: Anti-clericalism, Education, and Morals in the Nineteenth Century. Oxford, St. Anthony's Collage. 154-176.

MAGYAR KATOLIKUS LEXIKON (M. Kat. Lex)

2001 VI. kötet. Diós István főszerk. Budapest, Szent István Társulat.

2002 VII. kötet. Diós István föszerk. Budapest, Szent István Társulat. 
MÁLYUSz Elemér

2007

Egyházi társadalom a középkori Magyarországon. Budapest, Müszaki kiadó.

MÁRKUS István

1996 Polgárosuló parasztság. A magyar társadalomfejlödés egy faluszociológus szemével. Budapest, Dinasztia Kiadó.

MesZlÉnYi Antal

1928

A magyar katholikus egyház és állam 1848-49-ben. Szent István könyvek 58. Budapest, Szent István Társulat kiadása.

MEZEI Nepomuk János

1883 Istent dicsöítö egyházi énekkönyv. Szentes.

Mezősı Károly

1939

A váci egyházmegye a török hódoltság idején. Pongácz György báró püspök egykorú tájékoztatása alapján. Kiskunfélegyháza, Vesszősi József nyomdai müintézete.

MiHALIK Béla Vilmos

2012 Katolikus megújulás az egri egyházmegyben (1634-1746). In BAGI Zoltán Péter - HoRVÁTH Adrienn szerk.: Mozaikok a Magyar Királyság 16-17. századi történelméböl. Budapest, Históriaantik Kiadó. 159-160.

MiHÁlyfi Ákos

1896

A papnevelés története és elmélete I-II. Budapest, Kiadja a Szent István Társulat tudományos és irodalmi osztálya.

Az emberek megszentelése (szentségek és szentelmények). Egyetemi elöadások a lelkipásztorkodástan köréböl. Budapest, Stephaneum nyomda.

MóD László

2012

Adalékok az alföldi homoki szőlő- és borgazdálkodás modernizálásához: egy csongrádi szőlőbirtokos látogatása és 
tapasztalatai a kecskeméti Miklóstelepen. In GARACZI Imre szerk.: Érték és sors. Nemzetpolitika - kulturális örökség - identitás. Magyarságtudományi kutatások II. Veszprém, Veszprémi Humán Tudományokért Alapítvány. 247-256.

MoHAY Tamás

1992

Egy naplóiró parasztember élete és gazdálkodása a XX. század első felében Ipolynyéken. Kandidátusi értekezés tézisei. Budapest, Márton Áron kiadó.

MoHL Adolf

1909 Tata plébánia története. Győr, Győregyházmegye Könyvsajtója.

MolnÁR Antal

2001

2002

Adatok a váci püspökség török kori történetéhez. Egyháztörténeti Szemle, II. évf. 2. szám, 2001. 57-86.

Katolikus missziók a hódolt Magyarországon I. (1572-1647) Humanizmus és reformáció 26. [Sorozatszerkesztő: Jankovics József] Budapest, Balassi Kiadó.

2004/a Tanulmányok az alföldi katolicizmus török kori történetéhez. METEM könyvek 45. Budapest.

2004/b Egyház-és birtokigazgatás a váci püspökségben a török korban. In MOLNÁR Antal szerk.: Tanulmányok az alföldi katolicizmus török kori történetéhez. METEM könyvek 45. Budapest. 21-40.

2005 Mezöváros és katolicizmus. Katolikus egyház az egri püspökség hódoltsági területein a 17. sz.-ban. METEM könyvek 49. Budapest.

MOLNÁR István szerk.

1936 A magyar muzsika könyve. Budapest, Merkantil nyomda.

MunTAGNÉ TABAJDI Zsuzsanna

2013 Egy 18. századi romhányi plébános a protestáns közösségek hálójában. In BÁRTH Dániel szerk.: Alsópapság, lokális társadalom és népi kultúra a 18-20. századi Magyarországon. Budapest, ELTE BTK Folklore Tanszék. 143-153.

N. N.

1880 Tövisek és virágok. Töredékek a lelkészi életböl. Első füzet. Temesvár, Csanád-egyházmegyei könyvnyomda. 
PaLUGyay Imre

1855 Békés-Csanád, Csongrád és Honth vármegyék leirása. Pest, Heckenast Gusztáv sajátja.

PÁSZTOR Lajos

2000 A magyarság vallásos élete a Jagellók korában. Budapest, Magyar Egyháztörténeti Enciklopédia Munkaközösség kiadása.

PATKÓNÉ KÉRINGER Mária

1997 Váci Egyházmegye. Egyházlátogatási jegyzökönyvek katalógusa 2. Budapest, METEM munkacsoport kiadása.

PEROUAS, Louis

1964. Le diocése de La Rochelle de 1648-1724. Sociologie et pastorale. Paris, S.E.V.P.E.N.

PÉTERNÉ FEHÉR Mária

2009 A Ferences Rend Kecskeméten 1644-1950. Kecskemét, KalocsaKecskeméti Főegyházmegye.

POGONYI Bernát

1908 Sekrestyések és harangozók vezérkönyve. Írta: Pogonyi Bernát balatoni róm. kath. lelkész. Kiadja: Rétay Kálmán borsodsziráki róm. kath lelkész, az „egyházi müipar” és „egri népkönyvtár” szerkesztője. II. bővített kiadás, egri egyh. m. hatóság engedélyével. Budapest, Stephaneum Nyomda Rt.

POZSÁR István

1912

A Csongrád megyei céhek története. Csongrád, Bozó és Justin kiadása.

RAJZ Mihály

1943 Egyházmegyénk a török uralom végén. Vácegyházmegye multjából II. [sorozat szerk. Dr. Félegyházy József] Vác.

REMLING, Ludwig

1986 Bruderschaften in Franken Kirchen -und Sozialgeschichtliche Untersuchungen zum spätmittelalterlichen und frühneuzeitlichen Bruderschaftwesen. Würzburg, Kommissionsverlag F. Schöningh.

RÉVAI NAGY LEXIKONA

1914 XI. kötet. Révai Testvérek Irodalmi Intézet részvénytársaság, 
Budapest.

RICHÉ, Pierre

1973 La vie quotidienne dans l'empire carolingien. Paris, Hachette.

ROMSICS Ignác

2007 Magyarország története. Budapest, Akadémia kiadó.

ROOIJAKKERS, Gerard

1989 Ecclesiastical Power and Popular Culture. The attitude of the Catholic Church towards Youth-Culture in the Southern Netherlands 1560-1700. In Rihtman, Dunja - Auguštin - PovrZanovič, Maja eds.: Folklore and Historical Process. Zagreb, Institute of Folklore Research. 41-56.

Russo, Carla

1972 Studi recenti di storia sociale e religiosa in Francia: problemi e metodi. Rivista Storica Italiana 84. (1972) 625-682.

SÁRKÖZY Lajos

1915 A katholikus papság fegyelmének története Magyarországon. Veszprém, Veszprémi Egyházmegyei Nyomda.

SARNYAI Csaba Máté

2001

Állam és egyház a polgári átalakulás korában Magyarországon 1848-1918. METEM könyvek 29. Budapest.

2002 Polgári állam és katolikus egyház (1848. március-december) A katolikus autonómia-törekvések megjelenése. METEM könyvek 38. Budapest.

SÁVAI János

1997

Missziók, mesterek, licenciátusok. Documenta Missionaria II/I. Szeged, Agapé nyomda.

SCHÜCH Ignác A lelkipásztorkodástan kézikönyve II. Fordították a Györi nagyobb Papnevelő Intézet Szent Imre Egyesületének tagjai. Győr, Sauervin Géza könyvnyomdája.

SCHWARTZ Elemér

1928

Vallási néprajz. Ethnographia 39. (1928.) 165-168. 
SEBESTYÉN István

1998 Forradalom és népesedés. In GEORGIADES Ildikó - SEBESTYÉN István szerk.: Oppidum Csongrád 1998. Csongrád, Oppidum Csongrád Alapítvány. 77-98.

2002 Csongrád a XXI. század küszöbén. Budapest, Ceva kiadó.

2003 Néhány gondolat Csongrád nagyközség, illetve város 73 évének (1828-1901) demográfiai adataihoz. In GEORGIADES Ildikó szerk.: Oppidum Csongrád 2003. Csongrád, Oppidum Csongrád Alapítvány. 99-102.

SEBÖK Marcell

2000

Előszó. In Sebők Marcell szerk.: Történeti antropológia.

Módszertani írások és esettanulmányok. Budapest, Replika kör. 913.

SEBÖK Marcell szerk.

2000 Történeti antropológia. Módszertani írások és esettanulmányok. Budapest, Replika kör.

SHEILS, W. J. - WoOD, Diana

1989 The Ministry: Clerical and Lay. Studies in Church History, vol. 26. Ecclesiastical History Society, Oxford, B. Blackwell.

SINGER, Barnett

1983 Village Notables in the Nineteeth Century France. Priests, Mayors, Schoolmasters. Albany, State University of New York Press.

SOHLYA Antal

1876

Utmutató Kántorkönyv. A Római Katholika Szentegyház szertartásai szerént müködö magyar éneklészek számára a missale, rituálék és breviáriumok rubrikái szerént szerkesztette és bövitette Fekete Ferenc szab. kir. Szeged városának alsóvárosi kántora, ujra átdolgozta, bövitette és hangjegyezte Sohlya Antal csongrádi egyházi föéneklész s volt tanitóképezdei e szakmabeli oktató, m. kir. állami tanitóképezdei igazgató tanácsos. IV. kiadás. Szeged, Kiadja: Burger Zsigmond özvegye.

SPAETH, Donald A. 
1740. Cambridge, Cambridge University Press.

SzAKÁL Veronika

2011

Gelencei plébánosok feljegyzései időjárásról és természeti csapásokról. Libelli Transilvanici 9. Kecskemét.

SZÁNTÓ Konrád

1985

A katolikus egyház története a reformációtól napjainkig. II. kötet. Budapest, Ecclesia kiadó.

SZARKA Gyula

1947

A váci egyházmegye és püspökei a török hóditás korában.

Vácegyházmegye múltjából IV. [sorozat szerk. Félegyházy József] Vác.

SZEDLACSEK István

1924 Csongrád katholikus hitélete. Az Új Barázda naptára az 1925. közönséges évre. Összeállította az Új Barázda szerkesztősége. 5. évf. Budapest. 39-41.

SZÉKELY László

1995

Csíki áhítat. A csíki székelyek vallási néprajza. Budapest, Szent István Társulat.

SZELEPCSÉNYI György

1738

Cantus Catholici ex editione Szelepcseniana. Régi, és uj, deák, és magyar ájtatos egy-házi énekek, és litániák. Mellyekkel a' Keresztyének Esztendö által való Templomi Solennitásokban, Processiókban, és egyéb ájtatosságokban szoktak élni: Most újonnan, más több szép énekekkel megszaporittattak, és a' Keresztyéneknek Lelki épületekre, és vigasztalásokra ki-bocsáttattak. Nagy-Szombatban, Nyomtattatott az Akadémiai Bötükkel, Berger Leopold által.

SZENTI Tibor

1998 A bábák Hódmezővásárhelyen. In NovÁK László szerk.: Az Alföld társadalma. Az Arany János Múzeum Közleményei VIII. Nagykőrös, Arany János Múzeum. 533-602.

SZENTMIHÁLYI Mihály

1797-98 Egyházi énekes könyv I-IV. Eger. 
SZERDAHELYI János

1896

Népies búcsúztatók. Ó-Kanizsa, Bruck Pál nyomdája. [Sajtó alá rendezte: Ocskay Gyula]

SZÍJÁRTÓ M. István

2006

A mikrotörténelem. In BóDY Zsombor - Ö. KoVÁCS József szerk. Bevezetés a társadalomtörténetbe. Hagyományok, irányzatok, módszerek. Budapest, Osiris Kiadó. 500-520.

SzOKOLY István

1896

50 népies búcsúztató különböző alkalmakra. Esztergom, Buzárovits könyvnyomdája.

SzÜCS Judit

1986

„Az apám mëg az öregapám is itt születëtt”. In BÁLINT Gyula György szerk.: Mozaikok Csongrád város történetéböl 1986. Csongrád. 63-73.

1989 A paraszti polgárosulás kezdetei Csongrádon (A Szántai Kis család és Gulyás Mihály példáján). In BÁLINT Gyula György szerk.: Mozaikok Csongrád város történetéböl 1989. Csongrád. 125-135.

1993 Csongrádi cseregyerekek és cserelegények. In SzÜCS Judit szerk.: A Móra Ferenc Múzeum Évkönyve 1991/1992-1. Szeged, Móra Ferenc Múzeum. 145-152.

1995 A paraszti polgárosulás életstratégiái és megvalósulásuk Csongrádon a két világháború között. In SzüCs Judit szerk.: A Móra Ferenc Múzeum Évkönyve 1995. Studia Ethnographicae 1. Szeged, Móra Ferenc Múzeum. 49-63.

TACKETT, Timothy

Priest and Parish in Eighteenth-Century France. A Social and Political Study of the Curés in a Diocese of Dauphiné, 1750-1791. New Yersey, Princeton University Press, Princeton.

TÁNCZOS Roland 2006 Hegyi Antal, Csongrád harcos plébánosa. In GEORGIADES Ildikó szerk.: Oppidum Csongrád 2006. Szentes, Oppidum Csongrád Alapítvány. 59-74. 
TARI László

1977

Krónikák a régi Csongrádról 1704-1901. Szeged, Csongrád Megyei Könyvtári Füzetek 7. Somogyi Könyvtár.

TÁRKÁNYI Béla - ZsASSKOVSZKY Ferenc

1855

Katolikus Egyházi Énektár, Eger.

TÁRKÁNY SZÜCS Ernő

1981 Magyar jogi népszokások. Budapest, Gondolat kiadó.

THOMAs, Keith V.

1971

Religion and the Decline of Magic: Studies in Popular Beliefs in Sixteenth and Seventeenth Century England. London, Weidenfeld and Nicolson.

TOMISA Ilona

1992 Visitatio Canonica. Az Esztergomi föegyházmegye Barsi föesperességének egyházlátogatási jegyzőkönyvei 1647-1674. Budapest.

1997/a Visitatio Canonica. Egyházlátogatási jegyzőkönyvek Batthyány József esztergomi érsek idejéböl 1776-1779. Budapest.

1997/b A kánonjog és a népi jogszokás alakulása a XVII-XVIII. században egyházlátogatási jegyzőkönyvek alapján. In KUTI Klára szerk.: Morzsák. Tanulmányok Kisbán Eszter tiszteletére. MTA Néprajzi Kutatóintézete, Budapest. 171-176.

2000 Népi hitvilág. In SzENTPÉTERI József szerk.: Magyar Kódex III. Magyarország müvelödéstörténete 1526-1790. Budapest, Kossuth Könyvkiadó. 330-333.

2002 Katolikus egyház-látogatási jegyzőkönyvek, 16-17. század. Osiris Kiadó, Budapest.

2009 A plébános és a közösség viszonyának változása, a plébánosok anyagi helyzete a Dél-dunántúlon a 17-18. századi egyházi források alapján. In GÖZSY Zoltán - VARGA Szabolcs - VÉRTESI Lázár szerk.: Katolikus megújulás és a barokk Magyarországon, különös tekintettel a Dél-Dunántúlra (1700-1740). Pécs, Pécsi Egyháztörténeti Intézet, Seria Historiae Dioecesis Quinqueecclesiensis VII. 283-306. 
TOMKA Miklós

1997

Intézmény és karizma az egyházban. Vázlatok a katolikus egyház szociológiájához. Budapest, Országos Lelkipásztori Intézet, Márton Áron kiadó.

TOWER Vilmos

$1940 \quad$ Illemkódex papok és szerzetesek számára II. Budapest, Szerzői kiadás.

TÖRÖK József - LEGEZA László

$2001 \quad$ A váci püspökség évezrede. Budapest, Mikes kiadó.

TÜSKÉS Gábor szerk.

1981 „Mert ezt Isten hagyta...” tanulmányok a népi vallásosság köréböl.

Budapest, Magvető kiadó.

TÜSKÉs Gábor - KNAPP Éva

2001 Népi vallásosság Magyarországon a 17-18. században: források, formák közvetitök. Budapest, Osiris kiadó

UJVÁRY Péter

1929 Magyar Zsidó Lexikon. Budapest, Makkabi.

ULRICH Antal - ULRICH Béla

1897 Gyász Bucsuversek. Nagykőrös, Ottínger Ede nyomdája.

VALLÁSTÖRTÉNETI KISLEXIKON (Vall. Tört. Lex.)

1971 Gecse Gusztáv (szerk.) Budapest, Kossuth kiadó.

VANYÓ Tihamér

1937

$\mathrm{Az}$ egyházmegye-történetírásról. Regnum (Egyháztörténeti Évkönyv), 1937. Budapest, 3-19.

1940-41 A plébániatörténetírás módszertana. Regnum (Egyháztörténeti Évkönyv), 1940-1941. Budapest, 3-65.

VARGA János

1877 A babonák könyve. Arad, Nyomattatott Gyulai Istvánnál. Szerzői kiadás.

VARGA Lajos

1997 A váci egyházmegye történeti földrajza. Készült Sándor Frigyes középkori templomokról írott kéziratának felhasználásával. Vác, Váci Egyházmegyei Hatóság kiadása. 
VÁRY Gellért

1974 Emléklapok Csongorád múltjából. Szeged, Somogyi Károly Könyvtár.

VÁTZY János

1886 Gyászhangok temetkezéseknél és a halottas szent misék. Budapest, Dvorzsák János kiadója.

VEIT, Ludwig Andreas - LENHART, Ludwig

1956 Kirche und Volksfrömmigkeit im Zeitalter des Barock. Freiburg im Breisgau, Herder.

WIMMER Ede

$1856 A z$ énekmüvészet elemei. Röviden és érthetően elöadva s különös tekintettel a magyar koronaországi elemi iskolákra. Pest.

ZAKAR Péter

1999 A magyar hadsereg tábori lelkészei 1848-1849-ben. METEM könyvek 23. Budapest.

ZELDIN, Theodore (ed.)

1970 Conflicts in French Society: Anti-clericalism, Education, and Morals in the Nineteenth Century. Oxford, St. Anthony's Collage.

ZSASSKOVSZKY Ferenc

1853

Manuale Musico-Liturgicum. Eger.

ZSILINSZKY Mihály

1898 Csongrád vármegye története. Második rész. Budapest, Kiadja: Csongrád vármegye közönsége.

ZS.M.

1898 Népszokások - Csongrádban. Bába-Kalauz, A szülésznők lapja, A Magyar Bába-Egyesület hivatalos közlönye. V. évf. 1898. november 1. 11. szám, 161-166.

ZSÓTÉRNÉ NEMES Irén

1989 A csatát vívó Csatár a csongrádi közéletben. In BÁLINT Gyula György szerk.: Mozaikok Csongrád város történetéböl 1989. Csongrád, 35-48. 


\section{KÉZIRATOK}

BOROVICZÉNY Nándor

1906-1907 Lelkipásztorkodástani jegyzetek. Hallgatói számára írta: Dr. Boroviczény Nándor theologiai tanár Vácz. Váci Püspöki Könyvtár, kéziratok gyüjteménye.

DÉNESI Tamás

2006 Alsópapság, pasztoráció és egyházi irányitás a 18. századi veszprémi egyházmegyében. ELTE BTK Doktori disszertáció. Budapest.

Elérhetőség: http://doktori.btk.elte.hu/hist/denesitamas/diss.pdf

DudÁs Lajos

é. n.

Kül-és beltéri, köz-és magántulajdonban lévö, mindenki számára látható képzömüvészeti alkotások, emléktáblák, emlékmüvek Csongrádon. Kézirat a szerző tulajdonában.

1997 Csongrád harangjai. Csemegi Károly Könyvtár és Tari László Múzeum, Helyismereti gyüjtemény, D 93.

EKECSI Erzsébet

A Csongrádi Református Gyülekezet. Néprajzi és Kulturális Antropológiai Tanszék, Szeged. Szakdolgozat.

FÜZESI Péter

1960 Csongrád város krónikája. adatok Csongrád város történetéhez. Csemegi Károly Könyvtár és Tari László Múzeum, Történeti Adattár 67-2008.

é. n. Csongrádi arcképek. Csemegi Károly Könyvtár és Tari László Múzeum, Történeti Adattár 68-2008.

Ifj. SÓHLYA Antal

1900-1901 Debreceni Magyar Királyi Gazdasági Tanintézet - jegyzetek. Csemegi Károly Könyvtár és Tari László Múzeum, Csongrád, Néprajzi Adattár 144-2008.

JANES Zoltán

2012

A kegyúri intézmény kialakulása, virágzása és megszünése, különös tekintettel Kunszentmárton város egyházi életére 1850-töl 1950-ig. Pázmány Péter Katolikus Egyetem, Doktori disszertáció. Kézirat a 
szerző tulajdonában.

NAGY Géza Balázs

2008

A csongrádi Szent Rókus, Szent Sebestyén és Szent Rozália tiszteletére szentelt kápolna történeti dokumentációja Szentes. Magyar Nemzeti Levéltár Csongrád Megyei Levéltára Csongrádi Fióklevéltára, Helytörténeti Tanulmányok, kéziratok. 84. sz.

MAJZIK Zsanett

2009 A csongrádi zsidóság története 1949-ig. Kecskeméti Főiskola Tanítóképző Főiskolai Kar, Nevelés- és Társadalomtudományi Intézet. Szakdolgozat. Kézirat a szerző tulajdonában.

MóD László

2012 Sohlya Antal szerepe a csongrádi szőlö- és borgazdálkodás fejlesztésében. Megjelenés alatt lévő kézirat a szerző tulajdonában.

KATONÁNÉ SZABÓ Judit

2007

Harmat Artúr Szent vagy, Uram! Népénektár filológiai feldolgozása.

Doktori értekezés. Liszt Ferenc Zenemüvészeti Egyetem.

Elérhetőség:

http://docs.lfze.hu/netfolder/public/PublicNet/Doktori\%20dolgozato

k/katonane_szabo_judit/disszertacio.pdf

Kocsis Mária

2012 A laikus templomszolgák, avagy igy ministrálunk Mi. Néprajzi és KulturálisAntropológiai Tanszék, Szeged. Szakdolgozat.

KovÁCs Judit

2010 Laikus oltárszolgálat Maroslelén a 20. század második felétöl napjainkig. Néprajzi és Kulturális Antropológiai Tanszék, Szeged. Szakdolgozat.

SÁNDOR Antalné

1987

Csongrád-bokrosi hiedelmek. Csemegi Károly Könyvtár és Tari László Múzeum, Néprajzi Adattár 9-2005.

SOHLYA Antal

Kéziratos énekeskönyv. Csemegi Károly Könyvtár és Tari László Múzeum, Néprajzi Adattár 89-87.

1857 Egyházi ének és szent szertartás. Tanítóképezdei jegyzetek. 
Nagyvárad. Csemegi Károly Könyvtár és Tari László Múzeum, Néprajzi Adattár 91-87.

SÓHLYA Gyula

1870

Kéziratos énekeskönyv. Csemegi Károly Könyvtár és Tari László Múzeum, Néprajzi Adattár 90-87.

SOLYMOSI Jenő

é.n. $\quad$ Egy kápláni állomás. Váci Püspöki Könyvtár, Vaciensis gyüjtemény VPL V205.

SZÁNTAI KISS Mihály

Emlékek. Csemegi Károly Könyvtár és Tari László Múzeum, Néprajzi Adattár 83-87.

VARGA Lajos

2004 A váci szeminárium. Váci Püspöki Levéltár, Vaciensis gyüjtemény, Althann emlékkonferencia előadásai VPL V-3692.

\section{LEVÉLTÁRI FORRÁSOK}

CSEMEgI KÁROLY KÖNYVTÁR ÉS TARI LÁSZló MúZEUM, CsONGRÁD (CsKK TLM) Néprajzi Adattár (CsKK TLM NA)

Történeti Adattár (CsKK TLM TA)

Magyar NEMZETI LEVÉLTÁr CSONGRÁD MEGYEI LEVÉLTÁRA CSONGRÁdi FIÓKLEVÉLTÁRA (MNL CsML CsL)

XV. 33. Iratmásolatok XVIII-XX.sz. (MNL CsML CsL Iratmásolatok)

V.B.42. Csongrád Város, 1865-1872-ig Nagyközség Tanácsának iratai

a. Tanácsülési jegyzőkönyvek (MNL CsML CsL V.B. 42.a)

V.B.42. e. Végrendeletek (MNL CsML CsL V.B. 42.e)

V.B.49. Csongrád Város Községi Választmányának iratai (MNL CsML CsL V.B. 49.)

V.B.71. Csongrád Város, 1880-1923-ig Nagyközség Képviselötestületének iratai a. Közgyülési jegyzőkönyvek (MNL CsML CsL V.B. 71.)

V.B.72. Csongrád Város, 1880-1923-ig Nagyközség Tanácsának iratai (MNL CsML CsL V.B. 72.) 
V.B.79. Csongrád Város, 1865-1872-ig és 1880-1923-ig Nagyközség Községi Iskolaszékének, 1897-től Állami Elemi és Polgári Iskolai Gondnokságának iratai (MNL CsML CsL V.B. 79.)

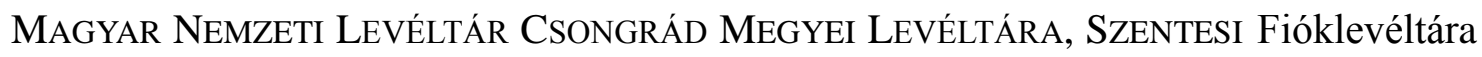
(MNL CsML SZL)

IV.B.427.c.V. Csongrád vármegye szervezési szabályrendeleteinek és egyesületi alapszabályainak levéltári gyüjteménye. Csongrád vármegyei egyesületi alapszabályok 1860-1951. A Csongrádi Kaszinó iratai. (MNL CsML SZL IV.B. 427.c.V.)

\section{Magyar NemZeti Levéltár Heves Megyei LeVÉLTÁRA, Eger (MNL HML)}

IV-416. Maklári anyakönyv másolata

\section{NAGYBOLDOGASSZONY PLÉBÁNIAHIVATAL IRATTÁRA, CSONGRÁD (NPI)}

Historia Domus - I. kötet

Anyakönyvek 1704-1900.

Vegyes iratok, levelezések

\section{VÁCI PÜSPÖKI ÉS KÁPTALANI LEVÉLTÁR (VPL)}

Acta Parochiarum Csongrád (VPL APar. Cs.)

Acta Privatorum Edelényi János (VPL APriv. Edelényi János)

Acta Privatorum Hegyi Antal (VPL APriv. Hegyi Antal)

Acta Privatorum Mátyus János (VPL APriv. Mátyus János)

Acta Privatorum Tóth Tamás (VPL APriv. Tóth Tamás)

Acta Privatorum Virter Lajos (VPL APriv. Virter Lajos)

Visitatio Paterna. Jegyzőkönyv az 1890. évi Szeptember havi főpásztori látogatás

eseményeiröl. (VPL Vis. Pat. 1890.)

Circulares 1782-1950. (VPL Circ.)

Synodus Dyocesana 1921. 


\section{SAJTÓANYAG}

\section{CSONGRÁDI KÖZLÖNY}

1894. március 4. I. évf. 1. szám, 1-2. old. 1894. április 22. I. évf. 6. szám, 3. old. 1894. május 6. I. évf. 8. szám, 4. old. 1894. május 27. I. évf. 11. szám, 4. old. 1894. június 24. I. évf. 15. szám, 2. old. 1894. július 15. I. évf. 18. szám, 1-2. old. 1894. augusztus 12. I. évf. 22. szám, 3. old. 1894. augusztus 19. I. évf. 23. szám, 3. old. 1894. szeptember 16. I. évf. 27. szám, 1. old. 1894. október 7. I. évf. 30. szám, 3. old. 1894. október 28. I. évf. 33. szám, 3. old. 1894. november 18. I. évf. 36. szám, 3. old. 1894. december 23. I. évf. 41. szám, 3. old. 1895. február 10. II. évf. 6. szám, 4. old. 1895. február 24. II. évf. 8. szám, 3. old. 1895. március 10. II. évf. 10. szám, 3. old. 1895. május 5. II. évf. 18. szám, 3. old. 1895. június 2. II. évf. 22. szám, 3. old. 1895. június 16. II. évf. 24. szám, 3. old. 1895. szeptember 1. II. évf. 35. szám, 4. old. 1895. szeptember 8. II. évf. 36. szám, 3. old. 1895. szeptember 15. II. évf. 37. szám, 3. old.
1895. szeptember 22. II. évf. 38. szám, 4. old. 1895. szeptember 29. II. évf. 39. szám, 3. old. 1895. október 13. II. évf. 41. szám, 3. old. 1895. október 20. II. évf. 42. szám, 4. old. 1895. november 16. II. évfolyam 51. szám, 3. old.

1895. december 29. II. évf. 53. szám, 2. old. 1896. január 5. III. évf. 1. szám 1. old. 1896. január 12. III. évf. 2. szám, 3. old. 1896. február 23. III. évf. 8. szám, 3. old. 1896. március 8. III. évf. 10. szám, 1. old. 1896. március 22. III. évf. 12. szám, 3. old. 1896. április 19. III. évf. 16. szám, 3. old. 1896. május 17. III. évf. 20. szám, 4. old. 1896. augusztus 30. III. évf. 35. szám, 3. old. 1896. szeptember 6. III. évf. 36. szám, 3. old. 1896. szeptember 20. III. évf. 38. szám, 4. old. 1896. szeptember 27. III. évf. 39. szám, 4. old. 1896. október 4. III. évf. 40. szám, 4. old. 1896. november 8. III. évf. 45. szám, 3. old. 1896. november 15. III. évf. 46. szám, 4. old. 1897. február 7. IV. évf. 6. szám, 4. old.

\section{CSONGRÁdi LAP}

1892. január 1. II. évf. 1. szám, 1. old. 1892. január 17. II. évf. 3. szám, 3. old. 1892. május 22. II. évf. 21. szám, 3. old. 1893. január 22. III. évf. 4. szám, 3. old. 1893. február 26. III. évf. 9. szám, 1-2. old. 1895. június 2. V. évf. 23. szám, 2. old. 1895. július 12. V. évf. 25. szám, 3. old.

1895. július 28. V. évf. 31. szám, 2. old. 1895. szeptember 22. V. évf. 39. szám, 3. old. 1895. október 27. V. évf. 44. szám, 3. old. 1895. december 15. V. évf. 51. szám, 1. old. 1895. december 22. V. évf. 52. szám, 2. old. 1896. január 6. VI. évf. 1. szám, 2. old. 1896. január 15. VI. évf. 3. szám, 1. old. 
1896. február 23. VI. évf. 8. szám, 1. old. 1896. március 1. VI. évf. 9. szám, 2. old. 1896. március 8. VI. évf. 10. szám, 3. old. 1896. március 15. VI. évf. 11. szám, 3. old. 1896. május 24. VI. évf. 21. szám, 2. old. 1896. június 28. VI. évf. 26. szám, 2. old. 1896. július 5. VI. évf. 27. szám, 2. old. 1896. november 8. VI. évf. 46. szám, 3. old. 1896. november 15. VI. évf. 47. sz. 3. old. 1897. május 9. VII. évf. 18. szám, 3. old. 1897. szeptember 4. VII. évf. 36. szám, 2-3. old. 1897. szeptember 26. VII. évf. 39. szám, 1. old. 1898. január 16. VIII. évf. 3. szám, 3. old. 1898. január 23. VIII. évf. 4. szám, 3. old. 1898. február 6. VII. évf. 6. szám, 3. old. 1898. február 13. VIII. évf. 7. szám, 3. old. 1898. március 11. VIII. évf. 11. szám, 2. old. 1898. március 27. VIII. évf. 13. szám, 2. old. 1898. április 10. VIII. évf. 15. szám, 3. old.

\section{CSONGRÁDI ÚJSÁG}

1903. október 25. I. évf. 1. szám, 1. old. 1903. november 8. I. évf. 3. szám, 2. old. 1903. december 20. I. évf. 9. szám, 3. old. 1904. február 28. II. évf. 9. szám, 1. old. 1904. március 13. II. évf. 9. szám, 2. old. 1904. július 10. II. évf. 28. szám, 4. old. 1904. július 17. II. évf. 29. szám, 3. old. 1904. augusztus 20. II. évf. 34. szám, 1. old.

\section{KÖZÉRDEK}

1891. augusztus 2. I. évf. 4. szám, 3. old
1898. május 29. VIII. évf. 22. szám, 2. old. 1898. június 12. VIII. évf. 24. szám, 2. old. 1898. július 10. VIII. évf. 28. szám, 3. old. 1898. július 24. VIII. évf. 30. szám, 3. old. 1898. augusztus 28. VIII. évf. 35. szám, 3. old. 1898. szeptember 18. VIII. évf. 38. szám, 2. old. 1898. szeptember 25. VIII. évf. 39. szám, 2. old. 1898. október 23. VIII. évf. 43. szám, 2. old. 1898. október 30. VIII. évf. 44. szám, 2. old. 1898. november 6. VIII. évf. 45. szám, 2. old. 1898. november 20. VIII. évf. 47. szám, 2. old. 1899. január 22. IX. évf. 4. szám, 3. old. 1899. március 5. IX. évf. 10. szám 2. old. 1899. június 11. IX. évf. 24. szám, 2. old. 1899. augusztus 6. IX. évf. 32. szám, 1-2. old. 1899. október 29. IX. évf. 44. szám, 3. old. 1901. február 4. XI. évf. 5. szám 2. old. 1901. február 26. XI. évf. 7. szám, 2. old.

1904. október 23. II. évf. 43. szám, 2. old. 1904. október 30. II. évf. 44. szám, 2. old. 1904. november 6. II. évf. 45. szám, 1. old. 1905. március 12. III. évf. 11. szám, 2. old. 1905. április 23. III. évf. 17. szám, 4. old. 1905. április 30. III. évf. 18. szám, 2. old. 1906. április 15. IV. évf. 16. szám, 3. old. 1911. január 15. IX. évf. 3. szám, 3. old.

1891. augusztus 16. I. évf. 6. szám, 3. old. 
1882. február 18. XII. évf. 7. szám, 3. old. 1884. augusztus 30. XIV. évf. 35. szám, 3. old. 1892. február 26. XX. évf. 21. szám, 4. old. 1892. március 25. XX. évf. 25. szám, 1-2. old.

\section{TISZAVIDÉK}

1890. március 2. I. évf. 1. szám, 3. old. 1890. március 22. I. évf. 12. szám, 3. old. 1890. május 11. I. évf. 11. szám, 3. old. 1890. október 26. I. évf. 35. szám, 3. old. 1893. január 8. IV. évf. 2. szám, 3. old. 1893. január 15. IV. évf. 3. szám, 3. old. 1893. január 22. IV. évf. 4. szám, 3. old. 1893. április 23. IV. évf. 17. szám, 3. old. 1893. június 25. IV. évf. 26. szám, 3. old. 1893. július 23. IV. évf. 30. szám, 3. old. 1893. július 30. IV. évf. 31. szám, 2. old. 1893. augusztus 6. IV. évf. 32. szám, 3. old. 1893. augusztus 13. IV. évf. 33. szám, 3. old. 1893. szeptember 3. IV. évf. 36. szám, 3. old.
1892. október 16. XX. évf. 121. szám, 2. old. 1893. július 30. XXIII. 90. szám, 2. old. 1898. május 6. XXVII. évf. 53. sz. 4. old. 1893. szeptember 17. IV. évf. 38. szám, 3. old. 1893. szeptember 24. IV. évf. 39. szám, 2. old. 1893. december 17. IV. évf. 51. szám, 3. old. 1894. január 21. V. évf. 3. szám, 3. old. 1894. március 11. V. évf. 10. szám, 3. old. 1894. október 28. V. évf. 43. szám, 3. old. 1894. november 11. V. évf. 45. szám, 3. old. 1894. december 16. V. évf. 50. szám, 3. old. 1897. január 17. VIII. évf. 3. szám, 3. old. 1897. március 28. VIII. évf. 13. szám, 3. old. 1902. január 26. XIII. évf. 4. sz. 3. old. 1902. február 9. XIII. évf. 6. szám, 3. old. 1908. április 12. XIX. évf. 15. szám, 3. old. 